January 2004 - NREL/SR-510-35212

\title{
State-Level Workshops on Ethanol for Transportation
}

\section{Final Report}

\author{
Angela Graf \\ BBI International \\ Cotopaxi, Colorado
}

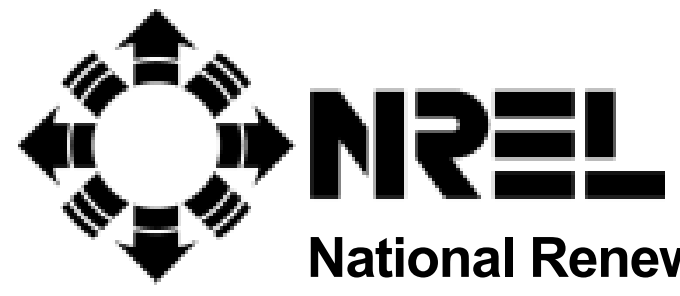

1617 Cole Boulevard

Golden, Colorado 80401-3393

NREL is a U.S. Department of Energy Laboratory Operated by Midwest Research Institute $\bullet$ Battelle

Contract No. DE-AC36-99-G010337 


\title{
State-Level Workshops on Ethanol for Transportation
}

Final Report

\author{
Angela Graf \\ $B B I$ International \\ Cotopaxi, Colorado
}

NREL Technical Monitor: H. Brown

Prepared under Subcontract No. ACO-2-32052-01

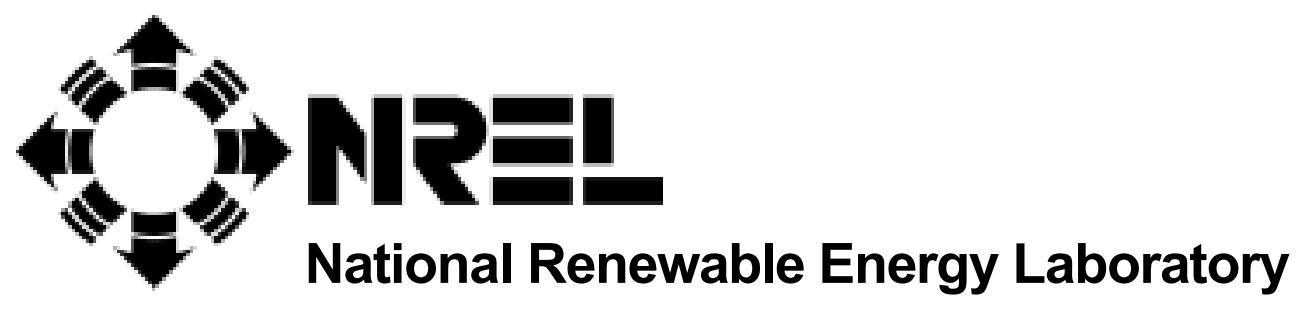

1617 Cole Boulevard

Golden, Colorado 80401-3393

NREL is a U.S. Department of Energy Laboratory

Operated by Midwest Research Institute $\bullet$ Battelle

Contract No. DE-AC36-99-G010337 
This publication was reproduced from the best available copy Submitted by the subcontractor and received no editorial review at NREL

\section{NOTICE}

This report was prepared as an account of work sponsored by an agency of the United States government. Neither the United States government nor any agency thereof, nor any of their employees, makes any warranty, express or implied, or assumes any legal liability or responsibility for the accuracy, completeness, or usefulness of any information, apparatus, product, or process disclosed, or represents that its use would not infringe privately owned rights. Reference herein to any specific commercial product, process, or service by trade name, trademark, manufacturer, or otherwise does not necessarily constitute or imply its endorsement, recommendation, or favoring by the United States government or any agency thereof. The views and opinions of authors expressed herein do not necessarily state or reflect those of the United States government or any agency thereof.

Available electronically at http://www.osti.gov/bridge

Available for a processing fee to U.S. Department of Energy and its contractors, in paper, from:

U.S. Department of Energy

Office of Scientific and Technical Information

P.O. Box 62

Oak Ridge, TN 37831-0062

phone: 865.576.8401

fax: 865.576 .5728

email: mailto:reports@adonis.osti.gov

Available for sale to the public, in paper, from:

U.S. Department of Commerce

National Technical Information Service

5285 Port Royal Road

Springfield, VA 22161

phone: 800.553 .6847

fax: 703.605.6900

email: orders@ntis.fedworld.gov

online ordering: http://www.ntis.gov/ordering.htm 


\section{Table of Contents:}

Introduction

Page \#

$\begin{array}{ll}\text { Background } & 1\end{array}$

2002/2003 Ethanol Workshop Series 2

State Selection and Workshop Coordination 4

$\begin{array}{ll}\text { Workshop Promotions } & 6\end{array}$

$\begin{array}{ll}\text { Conclusion and Recommendations } & 7\end{array}$

Appendix A: State Workshop Summaries and Highlights 8 Hawaii Ethanol Workshop $\quad 9$

Nevada Ethanol Workshop $\quad 11$

Kentucky Ethanol Workshop 13

$\begin{array}{ll}\text { California Ethanol Workshop } & 15\end{array}$

Appendix B: State Workshop Electronic Announcements and 17

Press Releases

Appendix C: Ethanol Workshop Media and Industry Coverage 28

- Links to Articles on the Internet

Appendix D: U.S. DOE Ethanol Workshop Series - State 31

Summaries

Appendix E: State Workshop Presentations 37 


\title{
Conduct State-Level Workshops on Ethanol for Transportation Subcontract \# ACO-2-32052-01 Task 3 - Final Report
}

\author{
Submitted by: \\ BBI International \\ Angela Graf, Project Manager \\ September 25, 2003
}

\section{INTRODUCTION}

In 2002/2003, under contract to the National Renewable Energy Laboratory, BBI International conducted state-level workshops ethanol in Hawaii, Nevada, Kentucky and California. These four workshops followed over 30 other workshops previous held under the Ethanol Workshop Series program sponsored by the U.S. Department of Energy. Two other workshops were conducted by BBI International during 2003, Oklahoma and Kansas, under contract to the Western Regional Biomass Energy Program.

The Ethanol Workshop Series (EWS) was intended to provide a forum for interest groups to gather and discuss what needs to be accomplished to facilitate ethanol production in-state using local biomass resources. In addition, the EWS was to provide a promotional and educational forum for policy makers, community leaders, media and potential stakeholders. It was recognized that to eventually achieve biomass-ethanol production, it was necessary to support grain-ethanol production as a bridge.

The long-term goal of the Workshops was to facilitate the development of biomass ethanol plants at a state-level. The near-term goal was to provide correct and positive information for education, promotion, production and use of fuel ethanol. The EWS drew from 65 to over 200 attendees and were deemed by the local organizers to have served the objectives set out by the U.S. Department of Energy.

\section{BACKGROUND}

The U.S. Department of Energy, Regional Biomass Energy Program, sponsored the first year of what became a five-year program to promote ethanol production from biomass feedstocks. The Ethanol Workshop Series (EWS) was a groundbreaking grassroots program that provided states with a forum to review and identify issues, resources and opportunities to develop a biomass-ethanol industry in their state.

As a subcontractor to the U.S. Department of Energy (U.S. DOE), BBI International coordinated and managed the EWS since its inception in 1999. Over 35 ethanol workshops in 27 states were held under this U.S. DOE sponsored program (including follow-up workshops in 8 states). 
The EWS began in 1999 with workshops in Alabama, Alaska, Maine, Michigan, Mississippi, South Dakota and Wisconsin. Recognizing the success and effectiveness of this program, another nine states were added in 2000 including, Colorado, Indiana, New York, Ohio, Oregon/Washington (joint workshop), Pennsylvania, South Carolina, and Texas. This was followed by another three years of workshops, plus follow-on workshops held by EWS states who wanted to build on their initial workshop.

\section{Participating States in the Ethanol Workshop Series:}

$\begin{array}{cccc}1999 & 2000 & 2001 & 2002 / 2003 \\ { }^{*} \text { Alabama+ } & { }^{*} \text { Colorado+ } & { }^{*} \text { Idaho } & { }^{*} \text { California } \\ \text { Alaska+ } & { }^{*} \text { Indiana } & { }^{*} \text { Iowa } & \text { Hawaii } \\ { }^{*} \text { Maine } & { }^{*} \text { New York } & { }^{*} \text { Maryland } & { }^{*} \text { Kansas } \\ { }^{*} \text { Michigan+ } & { }^{*} \text { Ohio } & { }^{*} \text { North Carolina^ } & { }^{*} \text { Kentucky } \\ \text { Mississippi } & { }^{*} \text { Oregon+ } & \text { Puerto Rico } & \text { "Nevada } \\ { }^{*} \text { South Dakota } & { }^{*} \text { Pennsylvania^ } & { }^{*} \text { Utah } & \text { Oklahoma } \\ { }^{*} \text { Wisconsin+ } & \text { South Carolina } & & \\ & \text { *Texas+ } & & \end{array}$

* denotes states that have new or expanding ethanol production or have projects seriously under consideration

+ denotes states that have had more than one EWS Workshop

${ }^{\wedge}$ denotes states that have had a related DOE agricultural ethanol workshop

Summary highlights from each state are included in Appendix D, "U.S. DOE Ethanol Workshop Series - State Summaries."

\section{2/2003 Ethanol Workshop Series}

Four Ethanol Workshops were conducted under sub-contract to the National Renewable Energy Laboratory and sponsored by the U.S. Department of Energy, Office of Biomass Program and Office of Energy Efficiency and Renewable Energy. Workshops were held in Hawaii, Nevada, Kentucky and California.

Hawaii - Honolulu, November 14, 2002, "Ethanol Fuel: Coming to a Car Near You" Nevada - Reno, January 9, 2003, "Developing a Pathway to Rural Economic Development Through Ethanol"

Kentucky - Frankfort, February 3, 2003, "Ethanol in Kentucky, A Growing Opportunity"

California - Sacramento, April 14-15, 2003, "Developing Ethanol's Role in California's Energy, Economic and Environmental Future" 
Appendix A contains State Workshop Summaries and Highlights.

Appendix B contains State Workshop Electronic Announcements and Press Releases.

Appendix C contains Ethanol Workshop Media and Industry Coverage - Links to Articles on the Internet.

Appendix D contains U.S. DOE Ethanol Workshop Series - State Summaries.

Appendix $E$ is included in the electronic version only

(www.nrel.gov/docs/fy04osti/35212.pdf). It contains the actual presentations from the workshops.

The purpose of the EWS was to provide a forum for policy makers, community leaders, media, and potential stakeholders and a catalyst for long-term cooperative action within the states. The goal was to educate potential users, government officials, and stakeholders about ethanol fuels in order to:

- create awareness of the benefits of ethanol

- create a positive image for ethanol

- support the widespread use of ethanol

- establish facilities for ethanol production

Ultimately, the objective was to lay out the pathway for development of an ethanol industry in the state by bringing together a coalition of people to address pertinent issues and exchange information. The attendance at each of these workshops ranged from 75 to over 200. Participants typically included representation from:

- State and Federal Energy Offices

- State and Federal Departments of Agriculture

- Local and State Economic Development Agencies

- State and Federal Departments of Forestry

- State Department of Air, Land and Water Resources

- Commodity Organizations, e.g., Corn, Wheat and Vegetable Growers Associations

- Public Utility Commissions

- State Legislatures and Governor's Offices

- Motor Vehicle Manufacturers and Fleets

- Universities and Trade Schools

- Environmental Organizations

- Ethanol Technology and Service Providers

- Ethanol Plant Developers

- Ethanol Producers

Each participating state felt that the EWS has been a very effective means to reach the established goal. It enabled interested groups to gather, in many cases for the first time, to discuss issues and actions needed to facilitate ethanol production and use. The following are just a couple of the many positive comments about the Workshops.

"Thanks to the US DOE Ethanol Workshop, interest and support of fuel ethanol in Hawaii went from zero to sixty in one week." - Maria Tome, Energy, Resources and Technology 
Division, Department of Business, Economic Development and Tourism, State of Hawaii (Workshop Planning Committee Chairperson)

“The Workshop gave Kentucky's agriculture leaders an opportunity to hear about how other states are benefiting from a growing market. [I] became even more convinced that ethanol production can help Kentucky farmers." - Senator Joey Pendleton, D-Hopkinsville, Kentucky (Workshop participant and speaker)

Not only did the EWS result in the opportunity to bring interest groups together, it encouraged participants to identify action steps and priorities to enable industry development. At the end of each workshop, a session "Where Do We Go from Here" was coordinated and lead by planning committee members. The outcome from this session included:

- Clearinghouse of Resources on Biomass and Ethanol - States provided resources to obtain more information on biomass and ethanol to interested individuals.

- Economic Impact Studies - Some states conducted an economic impact analysis to support the state and local benefits of ethanol production and use.

- Resource Assessments and Feasibility Studies on specific feedstocks or site-specific locations - Several states commissioned reports to gain more information about state resources and viability of ethanol production.

- State Ethanol Workgroups or Coalitions - Most states organized committees to continue discussions and action steps identified during the workshops, which now meet on a regular basis.

The EWS has also received national and international recognition at several industry events. Results and success stories from the EWS has been presented at the International Fuel Ethanol Workshop, National Ethanol Conference, World Summit on Ethanol for Transportation, Governors' Ethanol Coalition Meetings, and many other industry events.

\section{STATE SELECTION \& WORKSHOP COORDINATION}

Mid-2002 BBI International received recommendations from the U.S. Department of Energy headquarters on states which they'd like to have participate in the Ethanol Workshop Series. Under NREL Subcontract \#ACO-32052-01, workshops were conducted in four states: Hawaii, Kentucky, Nevada and California.

Hawaii - Honolulu, November 14, 2002 - Over 120 people attended the Hawaii Ethanol Workshop. The Workshop also included an add-on seminar for automotive mechanics to help educate them on the use of ethanol. The main Workshop addressed issues concerning ethanol production in the state. There are three proposed plants in the state that will use sugarcane as their primary feedstock. Legislation is pending requiring a $10 \%$ ethanol blend in gasoline, which will help to support ethanol. Since the Workshop, regular meetings are being held with key individuals to continue developing the support for ethanol state-wide. 
Nevada - Reno, January 9, 2003 - Biofuels in Nevada is highly supported by the state, including the Governor's Office. The state hopes to become energy exports within 10 years. As of recent, they've become energy importers. They see ethanol as a means to help reach that goal with the neighboring California market being a major driver. A feasibility study was commissioned to review specific sites and feedstock considerations for building an ethanol plant.

Kentucky - Frankfort, February 3, 2003 - A groundbreaking ceremony was held in Kentucky around the time of the workshop so much interest in ethanol was developing in the state. It also attracted much needed political support, in fact, a state legislator emcee'd the workshop. An ethanol task force was organized as a result of the workshop consisting of the Kentucky Energy Division, Kentucky Corn Growers, Farm Bureau, and Clean Cities Program. The goal of the committee is to increase the use of ethanol in the state, becoming a marketplace for their current and future production.

California - Sacramento, April 14-15, 2003 - The California Ethanol Workshop attracted the largest gathering of the EWS, over 210 participants. Several challenges to ethanol industry development were address, but the consensus was that California had enormous opportunities for ethanol production. It is currently the largest ethanol market in the country with nearly every major gasoline marketer switching to ethanol.

A complete summary for each of the four workshops - Hawaii, Kentucky, Nevada and California - can be found in Appendix A.

Once a state had been selected, BBI International began coordination activities with the State Bioenergy Coordinator. Each state has a designated Bioenergy Coordinator usually through the State Energy Office. The Bioenergy Coordinator provided guidance, direction and planning assistance for the workshop. The Coordinator also recommended representatives to serve on the Workshop Planning Committee. Committee members included representatives from state agencies, stakeholders and other industry representatives who provided workshop planning, program development, promotion, and subsequent workshop follow-up activities.

The Planning Committees were essential for developing a program that addressed critical needs of the state and bringing together the right people to discuss these issues. Each state varies in their level of industry development and interests, therefore, state planning committees are required to produce a program that best suits the needs of their state and audience. BBI International worked with each planning committee to help develop a workshop program that presented the desired message for each workshop.

In addition to working on program development with the state planning committees, BBI International coordinated pre- and on-site registration, sponsorship program, promotional campaign, registration materials and handouts, local logistics, on-site technical production, all on-site management, and workshop follow-up activities. 
As part of the EWS outreach activities, BBI International distributed all workshop and reports to state planning committee members and U.S. Department of Energy and National Renewable Energy Laboratory bioenergy staff members, published articles summarizing the highlights and developments from each workshop in their industry trade magazine, Ethanol Producer Magazine, produced a newsletter, the EWS News, and produced and maintained all workshop information on the EWS website, www.bbiethanol.com/doe.

\section{WORSKHOP PROMOTIONS}

Each workshop was promoted in coordination with the workshop planning committee. The planning committee helped to define a target audience, which helped to meet the goals of their workshop. From this, BBI International developed a mailing list for distribution of printed and electronic announcements. The mailing list was developed through a combination $\mathrm{BBI}$ International's in-house industry database and in-state industry contacts provided by the planning committee.

The promotional activities for each state workshop:

- Produced, printed and mailed a postcard announcement

- Produced, printed and mailed tri-fold program brochure

- Produced and issued workshop electronic announcements

- Provided details for state planning committees to produce press releases

- Posted detailed information on the EWS website

- Contacted industry representatives who may have special interest in attending and supporting the workshop

- Produced and published article in industry magazine, Ethanol Producer Magazine

- Produced and distributed workshop newsletter, EWS News

Sample copies of each of the state workshop electronic announcements and press releases issued by the planning committee can found in Appendix B.

\section{Summary of 2002/2003 Workshop Outreach and Results (Attendance):}

\begin{tabular}{|l|c|c|c|}
\hline & \multicolumn{2}{|c|}{ Mailing List (\# of people) } & \\
\hline State & Print & Electronic & Attendance \\
\hline Hawaii & 1,254 & 283 & 120 \\
\hline Kentucky & 2,287 & 556 & 77 \\
\hline Nevada & 1,645 & 385 & 75 \\
\hline California & 2,600 & 1,472 & 210 \\
\hline Total Attendance & & & $\mathbf{4 8 2}$ \\
\hline
\end{tabular}

The EWS website explains the purpose and goals of the EWS and includes detailed information about each state that has participated in the EWS. Each state ethanol workshop web page includes complete information about the state's workshop including program 
agendas, speaker papers, workshop summaries and committee contact information; EWS calendar; and editions of the EWS News. The Ethanol Workshop Series website can be viewed at www.bbiethanol.com/doe.

The website has been a significant tool in sharing interesting and important information about the EWS to interested individuals. It has helped promote the series as well as present the outcome of each Workshop. The EWS web pages have received over 1,200 hits monthly. The EWS web pages will be posted indefinitely.

\title{
Specific Internet Links to the Ethanol Workshops:
}

\author{
Hawaii (http://www.bbiethanol.com/doe/conference.cgi?doeid=41) \\ Kentucky (http://www.bbiethanol.com/doe/conference.cgi?doeid=42) \\ Nevada (http://www.bbiethanol.com/doe/conference.cgi?doeid=43) \\ California (http://www.bbiethanol.com/doe/conference.cgi?doeid=45)
}

The EWS News is an electronic newsletter that served as a tool to keep planning committee members and workshop supporters abreast of activities occurring in participating EWS states. Copies of the EWS News can be found on the EWS website, www.bbiethanol.com/doe.

Several articles were written about the EWS, primarily from local media (who received workshop press releases and announcements) and industry organizations promoting the EWS. Appendix $\mathrm{C}$ lists several web links to articles about the individual state ethanol workshops in Hawaii, Kentucky, Nevada and California.

The workshops were also promoted through BBI International's monthly industry publication, Ethanol Producer Magazine. Ethanol Producer Magazine is distributed nationwide to all ethanol producers, agricultural and other feedstock organizations, government and private organizations, stakeholders, and other related industries.

\section{CONCLUSION \& RECOMMENDATIONS}

Due to the grassroots-level success of the EWS, BBI International highly recommends its continuation; not only in states that have not had the opportunity to host an Ethanol Workshop, but also follow-on Ethanol Workshops in states who are actively moving forward as a result of their first workshop.

The success was greatly due to the fact that the workshop agenda was not a template, but rather, it was focused on the specific needs of each state. The Workshops should continue focusing on educating state agencies, stakeholders, and other interested parties about the opportunities for cellulose-ethanol production and use but also further develop a path-forward for establishing and expanding an ethanol industry on a state level. 


\section{APPENDIX A}

State Workshop Summaries and Highlights

NREL Subcontract \# ACO-2-32052-01

2002/2003 


\section{Hawaii Ethanol Workshop}

November 14, 2002

Ala Moana Hotel

Honolulu, Hawaii

The first of the ethanol workshops was held in Honolulu, Hawaii. Approximately 120 participants attended, most from the island of Oahu with a few from the neighboring islands. The majority of the attendees worked in private industry with a handful from either government or academia.

The planning committee chose the theme, "Ethanol Fuel: Coming to a Car Near You," in hopes gain interest from both the production and use side of the industry. The planning committee [comprised of representatives from Hawaii Department of Business, Economic Development and Tourism (committee chair); City and County of Honolulu; Hawaii Department of Agriculture; Hawaii Department of Health; Hawaii Natural Energy Institute; JN Automotive Group; and Honolulu Clean Cities] felt that educating the audience on the use of ethanol as well as the production was necessary to gain acceptance of ethanol in the state.

Many of the Hawaii attendees were surprised to learn that today's cars are designed to use ethanol. Hawaii currently does not have any fuel ethanol production or use, although there are several incentives and an ethanol content requirement in Hawaii State law (pending promulgation of rules).

The morning half of the workshop was designed to give a broad overview of policies and legislation, funding options, economic impacts, and historical perspectives of the ethanol industry. Eileen Yoshinaka, Pacific Liaison, U.S. Department of Energy, gave an overview of the Department of Energy Biomass Energy Program, its goals and mission. She provided a background on both petroleum and ethanol production and reviewed opportunities the Program offers to foster bioproducts use and develop partnerships with industry partners.

Maurice Kaya, Administrator for Hawaii's Energy, Resources and Technology Division, stated the workshop's purpose:

- Provide a context; update on the current national status of ethanol

- Discuss the potential for fuel ethanol production in Hawaii

- Provide an opportunity for community input

- Build a foundation for future discussion, work and collaboration

"Ethanol offers a tremendous opportunity for Hawaii," summarized Doug Durante from the Clean Fuels Development Coalition, based in Washington, DC. His overview was a comprehensive snapshot of federal and state programs supporting ethanol, ethanol production history and current usage, current oxygenate requirements, and discussion about the Renewable Fuels Standard and pricing.

Mark Yancey from BBI International presented a preliminary review of an economic impact analysis underway on the costs and benefits of ethanol production in Hawaii. The Hawaii Department of Business, Economic Development and Tourism is analyzing the possibility of satisfying a portion of the state's future transportation energy demand through alternative fuels. The report evaluated three possible ethanol production projects: two to produce ethanol from molasses and one would use biomass. Preliminary results look favorable, although this was just an economic impact analysis and not a feasibility study. 
Warren Hall of EA Engineering, Science and Technology, Inc., based in Hawaii, discussed a historical perspective of ethanol in the state. Maurice Kaya covered the state energy policy, incentives and mandates.

After lunch (which included an outdoor exhibit of an alternative fueled vehicle), the subject matter turned to specifics of fuel ethanol production, distribution and uses. The first panel focused on different feedstocks, including cellulose, molasses, sugar cane and municipal solid wastes. Presenters included Rick Elander from the National Renewable Energy Laboratory (Golden, CO), Jayant Godbole from Praj Industries (a design/engineering firm with experience building molasses-to-ethanol plants), and Hawaiibased Bob Shleser from the Aina Institute who authored a 1994 report on the feasibility of ethanol production in Hawaii.

Under the topic of distribution, two petroleum representatives discussed ethanol blending options and issues. Barry Duffin of ConocoPhillips and Mike Allen of Allen Oil Company talked about their current experiences providing ethanol-blended gasoline.

Barry Duffin, Quality Control Specialist at ConocoPhillips, described the approach used to switch their California stations (over 1000 stations) to sell gasoline with ethanol rather than MTBE. The switch was completed in December of 2001. ConocoPhillips is the largest gasoline retailer in the U.S. Mike Allen, President of Allen Oil Company, said that the public wants fuel ethanol so offering fuel ethanol can build customer loyalty.

The final panel on fuel ethanol use focused on the practical applications of ethanol's use presently in cars, racing engines, fuel cells, and diesel engines. Maria Tome, organizer of the workshop, from the Energy, Resources, and Technology Division of the Hawaii Department of Business, Economic Development and Tourism applauded the audience's interest and participation and concluded that ethanol can contribute to the state (and national) economy... and Hawaii's energy future. She strongly encouraged people to see the workshop as just the beginning of continued emphasis toward ethanol in the state. She invited all to complete their surveys of the workshop and sign up to become part of an ongoing working group.

As with previous workshops in the DOE Ethanol Workshop Series, a participant survey was included in the materials distributed. There was a significant amount of feedback with positive, hopeful impressions of ethanol. A majority of the respondents would like to be included in a task force or committee to further pursue ethanol production and use in Hawaii.

\section{Future Action Needed to Move the Ethanol Industry Forward in Hawaii:}

- Support of the petroleum companies

- Government funding; both federal and state incentives; promulgation of mandates

- Private and public communication and cooperation

- 2-3 day detailed workshop

In addition to the ethanol workshop, an innovative set of 2-hour evening "mechanic seminars" were conducted in advance of the workshop to promote the use of the fuel to Hawaiian drivers. The content focus of the seminars was fuel specifications, vehicle performance, compatibility issues, manufacturers' warranties and applications. Larry Johnson of Delta-T Corporation and Joe Collette an ethanol fuels instructor were both presenters at the seminars. 


\section{Nevada Ethanol Workshop}

January 9, 2003

Atlantis Hotel

Reno, Nevada

The Nevada Ethanol Workshop took place on January 9, 2003, in Reno. There were 75 people in attendance, which was said to be significantly more than anticipated. Participants came from both northern and southern regions in Nevada, which showed a cooperative effort in the state for ethanol industry development and interests. There were also some participants from California and the Midwest states. Attendees represented government and private industries equally.

The workshop theme was "Developing a Pathway to Rural Economic Development through Ethanol." The planning committee (comprised of representatives from the Nevada Office of Energy; Nevada Association of Counties; Nevada Division of Environmental Protection; Clark County Department of Air Quality Management; Washoe District Health-Air Quality Management Division; and the Environmental Health \& Safety Department) placed a strong focus on ethanol as a means to improve rural communities around the state.

Biofuels development is highly supported by the Governor's office. Carl Linvill, Energy \& Economic Advisor, Office of the Governor, said that over $\$ 2$ billion (of the $\$ 4$ billion in total energy expenditures) are spent out-of-state on transportation fuels in Nevada annually. He addressed the impacts of energy security and dependency on imported energy, rolling blackouts, and fuel supply disruptions. The state's goal is to export energy in the next 10 years.

Pat Perez of the Office of Transportation Fuel Supply \& Demand, California Energy Commission, addressed the concern that MTBE contamination is rising. There's a huge market opportunity for ethanol in California as a result. Approximately 70-80 percent of the MTBE market in California has already converted to ethanol.

Jeff James, Bioenergy Program Manager, Seattle Regional Office, U.S. DOE, discussed US oil dependence (55\% from foreign sources) and the value of biomass feedstocks for ethanol production. DOE is supportive of an ethanol program and making biomass energy R\&D a national priority. Biomass R\&D Act of 2000 directs DOE and USDA to enhance and coordinate biomass R\&D efforts while Energy Title IX of the Farm Bill supports increased use of biomass energy and production through R\&D. DOE looks to continue development of biofuels and form partnerships for progress.

Neil Koehler, representing the Renewable Fuels Association, gave a historical perspective about how oil price spikes and supply instabilities became major drivers for renewable energy, followed by further support for the industry through the Clean Air Act Amendments of 1990. Currently, the interest in ethanol originates from rural areas. It is thought that climate change issues will be the next driver for ethanol and other renewable fuels. Right now, half of the US market for ethanol is for octane enhancement and as a fuel extender.

The final session Developing an Ethanol Industry in Nevada... Where Do We Go from Here? was an interactive discussion to lay a pathway for industry development in Nevada. Four major areas were identified for further discussion and action steps.

\section{Issues Surrounding Market Development:}

- What is the risk to the state from MTBE dumping?

- Storage implications: Is there enough storage space for separate tanks of ethanol and gasoline?

- Competition with other alternative fuels such as propane and compressed natural gas.

- How to further utilize flexible fuel market in fleet vehicles (11,000 vehicles in Nevada) 


\section{Support for Ethanol Production:}

- Commission feasibility study for siting an ethanol plant

- Need to develop partnerships with oil companies, economic development agencies, and others to find the best location for an ethanol plant

- Develop legislation for ethanol funding for production

- Research and assess the most sustainable feedstocks for ethanol production in state

- Evaluate the importing of corn for ethanol production

- Review the USDA loan guarantee funds available for ethanol production

\section{Air Quality:}

- Assess the state's ability to maintain air/environmental quality and meet federal requirements

- Conduct study on life cycle analysis of ethanol production and use in the state

\section{Developing Partnerships:}

- Promote and seek out cooperation with industry associations and commodity groups such as the National Corn Growers Association and others who can provide resources for industry development

- Form coalition with Workshop participants to continue communication on steps towards industry development 


\section{Kentucky Ethanol Workshop}

February 3, 2003

Holiday Inn Capital Plaza

Frankfort, Kentucky

The Kentucky Ethanol Workshop took place on February 3, 2003, in Frankfort. There were 77 in attendance, representing several agricultural organizations; industry associations; private industry; and state government officials (including 5 senators and representatives). In a state with virtually no ethanol sold, this number was far more than anticipated at this initial Workshop. Government agencies, eager to learn more about the possibilities of economic development for the state, constituted the majority of the audience, although private sector was well represented as well. The western part of the state had the higher interest in grain-based ethanol and the eastern part had greater interest in the eventual potential for biomass-ethanol.

The planning committee consisted of the Kentucky Farm Bureau, Kentucky Corn Growers Association, Kentucky Division of Energy, and the Clean Cities Program of Kentucky. The theme they chose, Ethanol in Kentucky - A Growing Opportunity, expressed the possibly tremendous potential that an ethanol industry could bring to Kentucky and that's what the committee wanted to share with the attendees.

It was the second time since 1999 that a legislator - in this case, Senator Joey Pendleton - took the center stage as Master of Ceremonies for an Ethanol Workshop. Following the initial overview of the big picture on ethanol, the presentation narrowed down to be more Kentucky specific with a review of the ethanol industry's past and present status in the state.

One ethanol plant has been in production in Louisville since 1991 using waste liquids such as beer, orange juice and sodas as feedstock. It recycles the containers as part of the overall program. The newest ethanol producer in Kentucky is Commonwealth Agri-Energy, LLC, who broke ground on January $22^{\text {nd }}$ in Hopkinsville, which is in the western part of the state.

At lunch, two more legislators participated. Roger Thomas and Ernie Harris, Chairmen of the House and Senate Agriculture Committees respectively, expressed their support for the benefits of ethanol. The Luncheon Keynote, Bob Dinneen, President and CEO of the ethanol industry's trade organization, the Renewable Fuels Association, provided insight on the energy bill and other factors that impact the growing ethanol industry nationwide.

The afternoon discussions included a panel on Minnesota's success stories, programs and lessons learned that helped to demonstrate how the ethanol experience in a Corn Belt state can bring significant agricultural, environmental, community and statewide rewards.

Using all of the tremendous background information provided during the day, Todd Barlow, Kentucky Corn Growers Association, and Brian Alvey, Kentucky Farm Bureau, led all of the participants through a brainstorming session to identify issues, possible solutions and action items to increase the development of the ethanol industry in the state.

Discussion highlights of the final wrap session were:

- Develop a certified quality program that includes cattle + ethanol + mass marketing effort.

- Get refineries involved, including out-of-state refineries and also get to know your near-by terminal and encourage dedicated common storage.

- Seek the buy-in of various groups such as the beef industry by addressing the misunderstanding of ethanol being good for corn farmers and bad for feeders.

- Create methods for educating both legislators and consumers.

- Develop an in-state source for answers on ethanol. 
- Consider an innovative type of incentive like an "off-road use" gasoline tax of $1 / 2$-cent per gallon.

- Form an ethanol task force, or work group, to lead these efforts, that meets on a regular basis and embraces all sectors. 


\section{California Ethanol Workshop}

April 14-15, 2003

Embassy Suites Hotel

Sacramento, California

The Ethanol Workshop in California, April 14-15, became the largest contingency that has ever gathered to discuss ethanol in California. Over 210 people gathered to discuss the opportunities and barriers to the development of a prosperous ethanol industry in the state. The rural economy and agriculture became the focus of the workshop bringing together farmer organizations, energy and environmental groups, policy makers and stakeholders to discuss the steps needed to support ethanol production.

California is the leading agriculture state in the country as well as the most diverse in the world. It is also the leading dairy state, offering a significant market for ethanol coproducts. The California Department of Food \& Agriculture supports ethanol because it provides a value-added industry to help boost the rural economy by providing new products and new jobs.

"Ethanol would be a huge benefit to areas experiencing high unemployment rates, which is as high as $42 \%$ in the San Joaquin Valley," said to Dr. Ellen Burnes, California State University-Fresno. "A 40 mmgy plant would generate 41 full time jobs, 300 local jobs, and adds $\$ 8$ billion to the local economy," said Burnes.

According to the California Energy Commission (CEC), California became the largest market for ethanol this year, replacing MTBE, which will be banned by the end of the year. Fred Keeley, Executive Director of the Planning and Conservation League, expressed that ethanol will help improve air quality in the state and stimulate the economy, which are important reasons why California should support an ethanol industry.

Bill Jones, Former Secretary of State, supported ethanol as a means to reduce the state dependency on petroleum. California's fuel demand has grown 3\% of the past year, twice the projection. Biorefineries can produce ethanol and other bio-based products, which can be located in every region in the state, utilizing a variety of feedstocks. CEC estimates the demand for ethanol could reach 760-900 mmgy in 2004. As of April 2003, 70\% of California's gasoline contains ethanol. BP, Shell, ExxonMobil, ChevronTexaco, and Valero have all switched to ethanol to meet CARBOB standards.

Dave Smith, Director of Regulatory Issues at BP, said that BP is very close to becoming MTBE-free. They have contracted with 6 ethanol producers to supply ethanol. Their refineries are being upgraded to produce CARBOB using ethanol. They are working on improving the infrastructure for ethanol use in California. Challenges include the RVP, permitting with terminals, and fuel quality.

Ethanol has the potential to grow in other markets, such as E85 (FFV's). Mike McCormack from CEC's office of Transportation Fuel Supply \& Demand said that 175,000 vehicles in the state can operation on E85, equaling close to $100 \mathrm{mmgy}$ in potential demand for ethanol. Jerry Esper, Senior Manager for Fuel Economy Planning, DaimlerChrysler, said there are 3 million E85 vehicles on the road (1 million manufactured by DaimlerChysler) largely due to CAFÉ credits and fleet requirements. One billion barrels of gasoline could be saved if E85 was used to its maximum capacity. He had also discussed the challenges with ethanol-diesel blends and fuel cells.

Bill Maloney from ED\&F MAN Alcohol described the sources of ethanol being supplied to California. Approximately $98.7 \%$ of US ethanol production comes from the Midwest. Sources of alcohol outside the country come primarily from Carriabean Basin and Brazil. Various grades of alcohol are shipped in and 
distilled to anhydrous for export to the US through the Carribean Basin Initiative. Other sources for potential ethanol supplies are developing from emerging ethanol programs in Central and South America.

There are numerous feedstocks available for ethanol production within the state including corn, sorghum, sugar cane, cheese whey, food and beverage wastes, various biomass feedstocks such as forestry residue and rice straw. Potential production from agriculture resources total $595 \mathrm{bdt}$, forestry $966 \mathrm{bdt}$, and urban sources 914 bdt. The CEC assumes 50-70 gallons per bdt (bone dry ton).

Jack King, California Farm Bureau Federation, and Lee Swenson, Community Alliance with Family Farmers, expressed the opportunities for California agriculture to produce ethanol for the state's ethanol market; addressed the fact that food is an infrastructure problem, not a supply issue which addresses the fuel vs. food issue; and new feedstock opportunities such as hull-less barley.

A number of representatives from ethanol development projects discussed the status of projects in the central valley including Yolo County (corn), Imperial Valley (sugar cane and sugar beets), and San Joaquin Valley (fruits). These projects all aim to boost the farming community by providing new jobs and economic development.

The day ended with a session on a discussion of the framework needed to policies forward in California that support ethanol. From waste streams alone, California has the potential to produce $2-4 \%$ of their fuel demand from ethanol. Numerous studies have been conducted by CARB, CEC and other agencies to evaluate the impact of the state's dependence on petroleum, the affects of changes in gasoline on fuel prices, and establishing a strategic fuel reserve. It is apparent that California has the right market, the right feedstocks, the right resources and a public that is receptive to renewable energy. The interest for ethanol development in the state was very high. The hurdle seems to be a consensus among decision makers on what is needed to move the industry forward.

Over 150 people attended the second day of the workshop, which featured a special half-day session on Biomass Ethanol Potential in California. This session provided an opportunity for cellulose-ethanol project developments to give an update on their projects and technology and how it could apply to efforts in the state. Presentations included an overview of cellulose-ethanol production technology and challenges, the history of California's efforts to build a cellulose-ethanol industry, potential for forest residue collection for ethanol production to help reduce the risk of forest fires, case studies on lignocellulosic feedstocks and technological options for ethanol production and remaining steps to achieving commercial biomass-ethanol production. 


\section{APPENDIX B}

\section{State Workshop}

\section{Electronic Announcements and Press Releases}




\title{
HAWAII
}

(A second, more detailed announcement, was distributed by the planning committee chairperson)

Please Forward to Others Who May be Interested!

\section{Plan To Attend!}

\author{
November 14, 2002 \\ Ethanol Workshop 8:00 am - 4:30 pm \\ Ala Moana Hotel \\ Honolulu, $\mathrm{HI}$ \\ Cost: $\mathbf{2 0}$ (includes continental breakfast and lunch)
}

\section{“Ethanol Fuel: Coming Soon to a Car Near You”}

Fuel ethanol production in America has reached historic levels. In some states, fuel ethanol production supports rural economies. In others, fuel ethanol reduces air pollution. All across the U.S., it reduces dependence on imported oil and provides consumers with energy diversification and added fuel choice. Could Hawaii tap its own resources to produce some of its own transportation fuel? What would be involved? What would be the costs and benefits? The workshop will address technical as well as policy issues.

\section{Topics:}

- Fuel cost and vehicle performance

- Environmental issues

- Fuel distribution \& infrastructure

- Incentives

- Hawaii's ethanol content requirement law

Emerging markets for ethanol

\section{Who Should Attend:}

Fuel producers, distributors, retailers, and consumers; regulators; decision-makers; financiers; automotive service technicians; salespeople; vehicle enthusiasts; environmentalists; media; and the general public. 
Free Evening Classes (6:00-8:30pm):

Free evening classes for automotive service technicians are being scheduled for Kahului and Kona on November 11; Hilo and Lihue on November 12; and Honolulu on November 13. The ethanol fuels classes will cover fuel specifications; how changes in gasoline composition affect vehicle performance, fuel system materials compatibility; auto manufacturers' warranties; alternative fuels and vehicles; and oxygenated fuels in non-automotive applications. For more information, call Maria Tome at (808) 587-3809.

\section{Sponsored by:}

U.S. Department of Energy, Office of Fuels Development; Western Regional Biomass Energy Program; City and County of Honolulu; Hawaii Department of Agriculture; Hawaii Department of Business, Economic Development \& Tourism; Hawaii Department of Health; Hawaii Natural Energy Institute; Honolulu Clean Cities; JN Automotive Group

For program information, contact:

Maria Tome, Alternate Energy Engineer,

Energy, Resources, and Technology Division, Hawaii Dept. of Business, Economic

Development, and Tourism, phone: (808) 587-3809

e-mail: mtome@dbedt.hawaii.gov

For registration information, please use the attached document, or contact:

Anne Wester, BBI International, Workshop Coordinator, phone: 800-567-6411,e-mail:

anne@bbiethanol.com

For the agenda, registration form and additional details

Please visit www.bbiethanol.com/doe

\section{Please Circulate!}




\title{
KENTUCKY
}

Please Forward to Others Who May be Interested!

\section{Plan To Attend!}

\author{
February 3, 2003 \\ Kentucky-Ethanol Workshop 9:00 am - 4:00 pm \\ Holiday Inn Capital Plaza - Frankfort, Kentucky
}

Cost: $\$ 20$ (includes meals and materials)

\section{Ethanol in Kentucky-A Growing Opportunity}

Senator Joey Pendleton will be the Master of Ceremonies for this exciting workshop. Please join us in learning more about the benefits of ethanol in the state of Kentucky. Also in attendance will be the Chairman of the House Agriculture and Small Business Committee, Robert Thomas, and the Chairman of the Senate Agriculture and Natural Resources Committee, Ernie Harris. These two chairmen will introduce our dynamic keynote speaker, Bob Dinneen, President of the Renewable Fuels Association in Washington D.C. There will also be two flex-fuel vehicles on display, which use an $85 \%$ blend of ethanol with gasoline (E-85).

\section{Topics:}

Ethanol in the Bluegrass and Beyond

Ethanol 101 - Knowing the Facts

Ethanol and the Three E's:

Energy Security

Economics

Environment

An Interactive Discussion Between Presenters and Attendees-Where To Go From Here

\section{Who Should Attend:}

Fuel producers, distributors, retailers, and consumers; regulators; decision-makers; financiers; automotive service technicians; vehicle enthusiasts; environmentalists; media; and the general public

\section{Sponsored by:}

U.S. Department of Energy;

Kentucky Corn Growers Association

Kentucky Farm Bureau Federation

Hosted by:

Kentucky Division of Energy

Kentucky Clean Fuels Coalition 
For program information, contact:

Todd Barlow, Executive Director, Kentucky Corn Growers Association

Phone: 502-243-4150

E-mail: toddbarlow@compuserve.com

For registration information, use the attached registration form or contact:

Anne Wester, BBI International, Workshop Coordinator, phone: 800-567-6411,e-mail:

anne@bbiethanol.com

Holiday Inn Capital Plaza

405 Wilkinson Boulevard, Frankfort, Kentucky

Reservations: 502-227-5100

Reference: Ethanol Workshop for special room rates of $\$ 72$ single/double

Must call by January 20 to guarantee this price

For the agenda, registration form and additional details

Please visit www.bbiethanol.com/doe

\section{Please Circulate!}




\section{U.S. Department of Energy}

Kentucky Ethanol Workshop

February 4, 2003

\section{Kentucky-produced ethanol could boost state's farm economy, Pendleton says}

FRANKFORT - Sen. Joey Pendleton, D-Hopkinsville, put a spotlight on the future of Kentuckyproduced ethanol and its potential to boost the state's agricultural market during the Kentucky Ethanol Workshop, which was held in Frankfort yesterday.

"We've got a promising fuel source that could really help improve our state's agricultural economy if we do all we can to promote and expand the ethanol market," said Pendleton, who served as moderator of the workshop. "It's important for state leaders to recognize this is a key to diversifying our state's agricultural interests."

The workshop was one in a series of ethanol workshops the U.S. Department of Energy is sponsoring throughout the nation.

During the workshop, agriculture leaders discussed ways to expand the ethanol market, use ethanol by-products, promote ethanol as a value-added product for Kentucky farmers, and highlight its potential to help maintain a cleaner environment. Pendleton also noted that ethanol could help break the nation's dependency on foreign oil.

The workshop also gave Kentucky's agricultural leaders an opportunity to hear about how other states, such as Minnesota, are benefiting from a growing ethanol market.

Pendleton said he became even more convinced that ethanol production could help Kentucky farmers in recent years as he worked to establish a new ethanol plant in Hopkinsville. A groundbreaking ceremony for the plant was held last month. Once the plant is up and running, it will be capable of producing 20 million gallons of ethanol each year. 


\title{
NEVADA
}

Please Forward to Others Who May be Interested!

\author{
Plan To Attend! \\ January 9, 2003 \\ Nevada-Ethanol Workshop \\ 9:00 am - 4:30 pm \\ Atlantis Hotel \\ Reno, Nevada
}

Cost: $\$ 20$ (includes breakfast, lunch, and materials)

\section{"Developing a Pathway to Rural Economic Development through Ethanol”}

Fuel ethanol production in America has reached historic levels. In some states, fuel ethanol production supports rural economies. In others, fuel ethanol reduces air pollution. All across the U.S. ethanol reduces dependence on imported oil and provides consumers with energy diversification and added fuel choice. Could Nevada tap its own resources to produce some of its own transportation fuel? What would be involved? What would be the costs and benefits? The workshop will address these questions and others.

\section{Topics:}

- A National and Nevada-Specific Overview on Ethanol

- An Overview of Ethanol in California

- How Ethanol Impacts Energy Security, Environmental Improvements, and the Economy

- How Ethanol is Made

- Developing a Market in Nevada for Ethanol

- An Interactive Group Discussion to Create a Path Forward

\section{Who Should Attend:}

Fuel producers, distributors, retailers, and consumers; regulators; decision-makers; financiers; Automotive service technicians; vehicle enthusiasts; environmentalists; media; and the general public.

\section{Sponsored by:}

U.S. Department of Energy

Nevada State Energy Office

Nevada Association of Counties

University of Nevada-Environmental Health \& Safety

Department Bureau of Air Quality Planning

Washoe District Health-Air Quality Management 
Clark County Department of Air Quality Management

Ford Motor Company

U.S. Department of Agriculture

Truckee Meadows Clean Cities Coalition

Nevada State Motor Pool

Las Vegas Regional Clean Cities Coalition

University of Nevada-Environmental Health \& Safety

Nevada Department of Agriculture

Nevada Department of Environmental Protection

Nevada Commission on Economic Development

Nevada State Parks

For program and registration information, contact:

Anne Wester, BBI International, Workshop Coordinator, phone: (800) 567-6411, e-mail:

anne@bbiethanol.com

Registration form in PDF format attached. If unable to open, or for further information, see http://www.bbiethanol.com/doe/conference.cgi?doeid=43.

\section{Atlantis Hotel}

3800 South Virginia Street, Reno, Nevada 89502

Reservations: (800) 723-6500, Reference: Ethanol Workshop for room rates of $\$ 55$

single/double. Must call by December 25, 2002

For the agenda, registration form and additional details

Please visit www.bbiethanol.com/doe

\section{Please Circulate!}




\section{Ethanol Workshop}

\section{Set for JANUARY 9th in RENO, NEVADA}

\section{For Immediate Release Reno, Nevada}

\section{For Media Information Contact: Pete Konesky (775) 684-8735}

Can increased ethanol production create new markets for Nevada farmers, create new jobs and further help America's national energy independence?

Yes, say energy experts from around the country who will gather in Reno on January $9^{\text {th }}$ for an ethanol workshop that is part of a U.S Department of Energy series that has taken place in over 25 other states.

This one-day workshop, titled "Developing a Pathway to Rural Economic Development through Ethanol", will include panels of experts who will cover a wide range of ethanol related topics with special emphasis on Nevada. The workshop will be held at the Atlantis Hotel in Reno from 9:00 am to 4:30 pm.

The morning session will start with an overview of ethanol in the United States, with emphasis on Nevada and our neighbor, California. The Federal Biofuels Initiative will also be addressed. There will be three panels during the late morning and afternoon sessions. The first panel will focus on The Three E's of Ethanol: Energy Security, Environmental Improvements, and Economic Impact. The second and third panels will discuss How Ethanol is Made, and How Ethanol is Used, respectively. There will be an update presented on the proposed ethanol project in Winnemucca. During lunch there will be 2 flex-fuel vehicles on display. To wrap up the general session there will be discussion about the steps that need to be taken to develop an ethanol industry in Nevada.

This workshop is open to the public at a cost of $\$ 20$, which includes an ethanol information packet and lunch.

For more information about the workshop please contact Pete Konesky (775) 684-8735 or go to the Workshop website, www.bbiethanol.com/doe and click on Nevada. The workshop will be held in facilities that meet the accessibility requirements of the Americans with Disabilities Act. If you require special accommodations to attend, participate in or understand the workshop, please let Konesky know in advance so arrangements can be made. 


\section{CALIFORNIA}

(This was the $3^{\text {rd }}$ announcement that included a complete program agenda and was also distributed to state legislators)

\section{California Ethanol Workshop \\ Developing Ethanol's Role in California's Energy, Economic \& Environmental Future}

\section{Embassy Suites - Sacramento, California April 14-15, 2003}

\section{Seating is limited and filling fast. Register soon! \\ www.bbiethanol.com - Cost: $\$ 25$ (includes meals and materials) \\ (Legislators receive a complimentary registration)}

The California Ethanol Workshop is part of a workshop series sponsored by the U.S.

Department of Energy Office of Biomass Programs and Office of Energy Efficiency and Renewable Energy. Over 30 states have been a host to the Ethanol Workshop Series, with each focusing on steps towards industry development, impacts of ethanol production and use, and opportunities for biomass-to-ethanol production.

California presents one of the largest market opportunities in the country. With the phase-out of MTBE, rising energy prices, increasing dependency on imported energy, and the need for new agriculture uses and markets to boost the rural economy, ethanol has become an important topic for decision makers and stakeholders in California.

Top-level officials from state government and industry will discuss the latest issues, hurdles and opportunities towards ethanol industry development in the state. Please join us for an engaging and informative event.

\section{Preliminary Agenda \\ (see Appendix E)}

\section{Who Should Attend:}

Public officials; regulators; agricultural communities; financiers; potential and current producers; distributors, retailers, and consumers; transportation and automobile industry; media and other interested stakeholders.

\section{Sponsored by:}

U.S. Department of Energy, Office of Biomass Programs and Office of Energy Efficiency and Renewable Energy 
With Support from: California Energy Commission, California Department of Food \& Agriculture, California Renewable Fuels Partnership and California State University-Fresno

For program and registration information, contact:

Anne Wester, BBI International, Workshop Coordinator

Phone: 800-567-6411, E-mail: anne@bbiethanol.com

Accommodations:

Embassy Suites Sacramento

100 Capitol Mall, Sacramento, California 95814

Reservations: 916-326-5006, Reference "Ethanol Workshop"

For program updates please visit www.bbiethanol.com/doe

Please Circulate! 


\section{APPENDIX C}

Ethanol Workshop Media and Industry Coverage Links to Articles on the Internet 


\section{Partial List of Links to Articles, Announcements and Industry Coverage of EWS}

Hawaii

http://www.state.hi.us/dbedt/ert/ewg/

http://www.hawaii.gov/dbedt/ert/archive/wksp-e02.html

George Nitta's Radio show - http://www.georgenitta.com/Radio.htm (click on 11/9/02)

Honolulu Advertiser - http://the.honoluluadvertiser.com/article/2002/Nov/10/ln/ln25a.html

http://www.hawaiimotorcycle.org/2002_November_Newsletter.htm

Pacific Business News - http://www.bizjournals.com/pacific/stories/2002/11/04/daily1.html

http://www.bbiethanol.com/doe/conference.cgi?doeid=41

\section{Nevada}

The Nevada Rancher - http://nevadarancher.com/news/2003/feb03a.htm

http://gov.state.nv.us/pr/2003/01-03ETHANOL.htm

http://www.energy.ca.gov/ethanol/documents/

http://www.ethanolrfa.org/ereports/er112602.html

http://www.bbiethanol.com/doe/conference.cgi?doeid=43

\section{Kentucky}

http://www.kycorn.org/ethanolworkshop.html

http://www.joeypendleton.com/eth/eth.htm

http://www.environment.ky.gov/nrepc/landairwater/summer03/ethanol.htm

http://www.kyfb.com/federation/News Publications/kfbnews/2003/mar 03/pg8-9b.htm

http://www.bbiethanol.com/doe/conference.cgi?doeid=42 


\section{California}

http://www.valleyvoicenewspaper.com/valleyvoicearchive/april162003.htm

http://www.bbiethanol.com/doe/conference.cgi?doeid=45

http://www.ncga.com/news/CC/volume10/ccVol10n16.html

http://www.cfbf.com/agalert/2002/aa-041702b.htm

http://www.ccities.doe.gov/pdfs/ccnews_mar2003.pdf

http://www.renewingindia.org/newsletters/ethanol/current/news_vol1_12.htm 


\section{APPENDIX D}

\section{U.S. DOE Ethanol Workshop Series}

State Summaries

1999-2003 


\section{U.S. Department of Energy Ethanol Workshop Series Highlights and Success Stories 1999-2003}

(as of September 2003)

$\underline{2003}$

California (Sacramento) - "Developing Ethanol's Role in California's Energy, Economic and Environmental Future." This was the largest gathering about ethanol to take place in the state. Several challenges to industry developments were addressed, but the consensus was that California has an abundance of feedstocks and economic and environmental incentives to foster ethanol production. As of this year, it holds the largest market for ethanol in the country and is expected to more than double in the next several years. Nearly every gasoline marketer has made the transition to ethanol (MTBE ban is in effect December 31, 2003). Legislation is being proposed to support renewables including ethanol in the state. Support for ethanol came from all sectors, including CARB, several agriculture associations, and environmental groups. There are more than three active development projects in the state that will utilize corn, sugar cane/sugar beets and/or fruit.

Kansas (Topeka) - "Ethanol: Fueling Opportunities in Kansas Focusing on Utilization and Production." Kansas has five ethanol plants currently in production, some of which are the most unique in the country. One plant processes seed corn into ethanol; another uses its $\mathrm{CO}_{2}$ to force residual oil from oil fields; while another plant internalizes all of its distillers wet grains for use in its own feed lot. Several legislators participated in the workshop confirming their continued support of the state ethanol incentive legislation and the growth of the industry. Representatives from all proposed plants in the state attended the workshop, one of which has since begun their equity drive. One of the proposed projects is examining the option of corn stover as a feedstock, but the balance of the proposed projects are corn and sorghum based. An ethanol task force is being formed as a result of the workshop.

Kentucky (Frankfort) - "Ethanol in Kentucky, A Growing Opportunity." Around the time of the workshop, a groundbreaking was held for an ethanol plant in western Kentucky. This allowed for very good, positive media coverage. Excellent political support was shown during the workshop, as well as recognition of a great deal of interest in cellulose ethanol in eastern Kentucky. An ethanol task force or work group is being formed under the leadership of the planning committee; Kentucky Energy Division, Kentucky Corn Growers, Farm Bureau, and Clean Cities Program. The goal is to increase use of ethanol in the state and become a marketplace for their current and future production.

Nevada (Reno) - "Developing a Pathway to Rural Economic Development through Ethanol." Biofuels in Nevada are strongly supported by the state. In fact, the Governor's office has set a goal to become energy exporters (in recent years, they've become net importers). They view California as a major driver and source for new industry development in the state and a means to support the agriculture economy. A development group proposing an ethanol plant made a presentation on a preliminary economic impact study. The attendees, during the wrap-up session, recommended that a feasibility study be commissioned to locate an ethanol plant in the state with an evaluation of the economics of shipping in corn to help supplement the feedstock supply. That study has been completed and options are being evaluated. 
Oklahoma (Tulsa) - "Setting the Stage for Ethanol in Oklahoma." A state legislator was the emcee for the workshop, signaling the growing legislative support for an ethanol industry in Oklahoma. A presentation on the favorable results of a feasibility study for a proposed ethanol plant using grain sorghum and eventually hull-less barley was part of the agenda. Since the workshop, legislation was passed in Oklahoma that allows a generous tax credit for ethanol plants. Funding is already in place for this legislation. At least one project is moving along quickly, while two to three more are still being evaluated. The Farmers Union, Sorghum Association and Department of Agriculture are instrumental organizations for keeping the momentum going in the state.

\section{$\underline{2002}$}

Hawaii (Honolulu) - "Ethanol Fuel: Coming to a Car Near You." In 1996, legislation was passed in Hawaii requiring $10 \%$ ethanol in all gasoline in the state. No action was taken at that time because there was no ethanol produced in the state. Now, however, there are three proposed plants - all of which want to have the rule promulgated as soon as possible to create a market for their production. During the three days prior to the workshop, mechanics seminars were held in various locations throughout the state to address any misconceptions on performance that still lingered. The results of those seminars were part of the workshop. The leaders in Hawaii were very happy to have such a visible, high-caliber workshop held that helped position ethanol among key agencies, organizations and businesses. A task force is being formed and efforts are underway to make the proposed incentive a reality.

\section{$\underline{2001}$}

Alaska (Ketchikan) - "A Discussion of Issues and Opportunities Associated with Using Local Residues to Make Fuel Grade Ethanol in Southeast Alaska." Alaska held a second, follow-on workshop to discuss in more detail the availability and viability of producing ethanol from wood residues from the milling and forestry industry in southeast Alaska. A feasibility study was conducted as a result of this workshop. Alaska is still evaluating the potential of building a cellulose-ethanol plant, perhaps using gasification technology

Idaho (Boise) - "Ethanol and Idaho: Partners for the Future." Maintaining the momentum after the workshop, several regional workshops were held to examine the needs of each proposed region. Experienced people from Minnesota were brought in to testify before the Idaho legislature. Three proposed ethanol plant projects have had studies done and a statewide assessment has been completed. One of the projects proposed for Idaho has moved to Oregon because more enticing incentives were offered locally.

lowa (Des Moines) - "Ethanol, Fueling lowa's Economy." Despite lowa being such an advanced state for ethanol, they welcomed the opportunity to hold a workshop. It helped them in their quest to become the largest ethanol state in the country. They recognized there is never too much awareness and understanding. There are now upwards of 12 ethanol plants in various stages of development. Three new plants have come on line since the workshop and several are under construction. lowa has an ethanol development council and a Renewable Fuels Association.

Maryland (Baltimore) - "A Dialogue on the Potential for the Production and Use of Fuel Ethanol in Maryland." Their workshop was held in October 2001. A statewide study was commissioned to determine the best location(s) in the state for an ethanol plant. Although they originally intended to have a barley plant of their own, they now have a joint project with Pennsylvania. 
North Carolina (Raleigh) - "Ethanol, Driving North Carolina's Energy, Economic and Environmental Future." An effort was made to involve in the program all key state agencies that will play a role in the development of an ethanol industry in the state. The panel of primary importance was the legislative panel that was comprised of two state representatives and two senators. Strong support was expressed and innovative ideas to help set the groundwork for a new ethanol industry were expressed. The workshop set the stage to revitalize one proposed project on the eastern coast of North Carolina. Increasing the marketplace for ethanol was one of the more immediate goals.

Oregon (Eugene) - "The Oregon Ethanol Forum: A Closer Look at Fuel Ethanol." Oregon held a second, follow-on workshop to the one held in conjunction with the state of Washington in 2000. The purpose of this workshop was to clear up some of the issues and myths about ethanol in order to gain further support for biomass-ethanol. A study commissioned by the Oregon Office of Energy was released at this workshop. The study was a resource assessment of cellulosic biomass feedstocks in the state for ethanol production. It also included a preliminary economic analysis of an ethanol facility using various feedstocks available in the state. Oregon has one grain-ethanol project actively underway and studies are still being done for a proposed biomass-ethanol plant.

Puerto Rico (San Juan) - "A New Frontier: Benefits \& Opportunities for Ethanol Production \& Use." Puerto Rico is considering the possibility of using alternative energy sources, and the Puerto Rico Power Authority is beginning to become interested in technologies such as ethanol production. Oil is the major power source for energy production, all of which is imported. Furthermore, all gasoline is blended with MTBE. The local sugar cane producers and related industries have great interest in resurrecting their feedstock for ethanol production, utilizing sugar and cellulose as feedstocks.

Utah (Salt Lake City) - "Biofuels in Utah's Future: A Dialogue." The backdrop for the Utah Ethanol Workshop was Governor Mike Leavitt's announcement of the state's new Energy Policy. The Energy Policy supports and enforces the state's goal to become energy reliable, affordable, sustainable and clean. The purpose of the Workshop was to educate key people about how biomass ethanol meets the goals of the new Energy Policy. The result was a highly useful presentation and discussion about the benefits of ethanol's use and production as a reliable, sustainable source of energy for the state. Utah has since been reviewing potential sites for an ethanol plant and a proposed plant in the western part of the state intends to help fulfill California's need for ethanol.

\section{$\underline{2000}$}

Colorado (Yuma) - "Fuel Ethanol Production in Colorado: It's Potential and History." The first DOE Ethanol Workshop was held in Denver in 2000. The Colorado Action Group for Ethanol (CAGE) was established and that has kept the momentum going. The group decided to hold a second workshop in 2001 that educated rural Colorado about what's involved in building an ethanol plant. There are three projects conducting feasibility studies right now. The plant proposed for northeast Colorado, an area with tremendous feedlots, will most likely be built. A smaller plant is planned for southeast Colorado. And the third plant is located in central Colorado and may use potatoes and railed-in corn.

Indiana (Indianapolis) - "Ethanol: Growing Renewable Energy and Economic Development." During February following the workshop, a series of Renewable Motor Fuels Workgroup meetings were held to discuss the primary difficulties in increasing ethanol (and biodiesel) consumption and potential means of further improving that consumption. The group met three times at one-month intervals and included state and city government, the corn and soybean growers, ethanol and biodiesel producers, the petroleum marketers association, and petroleum industry representatives. Although they have no state producer incentive, they set the stage to welcome a second ethanol plant. That plant is now under construction in Rensellear, Indiana. 
New York (Albany) - "Ethanol in New York: Today and Tomorrow." Prior to the workshop, the general feeling was that ethanol wasn't an option for the Empire State. Two grain-ethanol plants are proposed for New York. One has completed its feasibility study and is seeking equity; the second completed a prefeasibility study and will soon continue with a full study followed by a business plan. New York is also the home of the most imminent MSW-to-ethanol plant in the country - located in Middleton. That project has spent two years in regulations and mitigation because it is the first of its kind in the country.

Ohio (Columbus) - "Exploring Fuel Ethanol, Climate Change, Energy, and Other Sustainability Issues." Taking advantage of the enthusiasm and interest generated by the workshop, legislation for ethanol was introduced shortly afterward. The following year, an incentive in the form of tax benefits for the investors was passed. There are several proposed grain-ethanol projects quite far along, plus a proposed MSWethanol plant.

Oregon/Washington (Portland) - "A Conversation about Ethanol in the Northwest: Exploring Fuel Ethanol, Climate Change, Energy, and Other Sustainability Issues." Oregon and Washington held a joint workshop in conjunction with Transportation 2000. Since then, Oregon and Washington have both make strides to keep the momentum going by scheduling meetings in potential locations for ethanol production facilities to educate local communities and interest groups. Oregon, as reported, held a second workshop and Washington folded their further workshop efforts into the "Harvesting Clean Energy" conferences held annually in Washington by the organization, Climate Solutions.

Pennsylvania (Grantville) - "Ethanol, for a Cleaner, More Prosperous Pennsylvania." Pennsylvania also was a state that initially seemed unlikely for an ethanol industry. The workshop brought together key people within state government who previously hadn't worked together on biofuels. They continued their efforts and now a plant, Penn Mar LLC, will be breaking ground soon and one is also under consideration in western Pennsylvania.

Texas (Austin) - "Renewable Fuels for Rural Economic Development \& Clean Air in Texas - A RuralUrban Partnership." Prior to the workshop, ethanol only had a profile at Baylor University where testing was underway on ethanol as an aviation fuel. The workshop was attended by the Texas Ethanol Champion, Representative David Swinford from the panhandle area of Texas. He introduced legislation following the workshop, which after constant vigilance and persistence, passed in May 2001. There are three projects that have since conducted feasibility studies and all are planning to move forward

\section{9}

Alaska (Fairbanks) - "Meeting Mandates and Receiving Benefits from the Production and Use of Ethanol-Based Fuels in Alaska." This was the first of two workshops that were held in Alaska. The purpose was to educate key people and correct some misinformation on performance issues especially in light of the ethanol program in place in Anchorage. A second workshop, as reported, was held in Ketchikan in 2000 to introduce the concept of a pilot plant for biomass ethanol. A pilot plant is currently under construction for producing ethanol from forest residues using gasification technology.

Maine (Waterville) - "Ethanol Production Potential in Maine...We Can Get There from Here." - There is a great deal of interest in developing an ethanol industry in the state using potatoes and forest residues. A steering committee was formed that met several times to investigate the potential and feasibility of ethanol production in the state. In February 2000, a follow-on seminar was held in Augusta to further expand the knowledge base of the key individuals in preparation for their support of ethanol production in the state. A statewide study was conducted following the workshop that determined that Maine may need to wait until cellulosic ethanol is commercially viable before developing an ethanol industry. When that occurs, many key elements are already in place in the state to move the development of the industry along expeditiously. 
Michigan (Lansing) - "Driving Michigan's Ethanol Future." The first workshop in 1999 was so successful that Michigan chose to hold a second in 2000 and a third Ethanol Workshop was held in September 2001. Legislation that provided a $\$ 5,000,000$ grant for the first ethanol plant was passed during the workshop. Resultantly, a 40-mmgy ethanol plant was constructed and is in production in Caro, Michigan. An Ethanol Work Group has been established which meets once every month and publishes an Ethanol Update newsletter. Another plant is currently conducting a feasibility study in southern Michigan

Mississippi (Raymond) - "Renewable Energy for Mississippi: Developing Indigenous Supply Options." The workshop in 1999 was the first time anyone had spoken about the remote possibility of an ethanol industry in Mississippi. It had, previously, seemed very unlikely. The core organizing group, via the Mississippi Biomass Council, continued meeting and kept the interest and possibility alive. In the fall of 2002, legislation was passed that provides an incentive for ethanol production. There are currently three projects in planning stages.

South Dakota (Rapid City) - The workshop helped elevate the understanding of the farmer-owned cooperative and the LLC. Beyond the three original ethanol plants that already were in the state, four new plants have come on line since the workshop and approximately three are under construction. Interest in cellulosic ethanol is still alive in the Black Hills region. A plant is proposed for the Wyoming Black Hills area by a group who met during the workshop.

Wisconsin (Madison) - "An Ethanol Production Plant: A Doorway of Opportunity in Wisconsin." Following the workshop in 1999, the level of interest increased tremendously. A second workshop was held in 2000. In 2000 legislation was written and then passed in 2001 that provides a $20 \phi$ direct to the producer payment. Today there are three plants in production, one under construction and several on the drawing board. 
Appendix E: Workshop Presentations

\section{Hawaii Workshop}

1. National Energy and Fuels Policy, Eileen Yoshinaka, Pacific Liasion-Honolulu, U.S. Department of Energy

2. Workshop Purpose and Objective, Maurice Kaya, P.E., Administrator, State of Hawaii, Energy, Resources and Technology Division

3. Ethanol Fuel: Coming Soon to a Car Near You, Doug Durante, Executive Director, Clean Fuels Development Coalition

4. Ethanol: An Important Role in Global Transportation Fuels, Gary Herwick, Director, Transportation Fuels, General Motors Corporation

5. Biofuels for Sustainable Transportation, Larry Schafer, Legislative Counsel, Renewable Fuels Association

6. Economic Impact Assessment for Ethanol Production and Use in Hawaii: An Interim Report, Mark Yancey, Director of Consulting Services, BBI International

7. Fuel Ethanol in Hawaii: A Historical Perspective, Warren Hall, Hawaii Manager, EA Engineering, Science and Technology

8. Ethanol Fuel for Hawaii: State Policy, Incentives, and Mandate, Maurice Kaya, Energy Program Administrator, Hawaii State Energy Office

9. Ethanol From Cellulosic Materials, Rick Elander, National Renewable Energy Laboratory

10. Ethanol from Cane Molasses, Jayant Godbole, Praj Industries Ltd.

11. Waste - Our Most Sustainable Resource, Bob Schleser, Aina Institute

12. Steps to Building an Ethanol Plant, Larry Johnson, Delta-T Corporation

13. California Ethanol Project Overview, Barry Duffin, Quality Control Specialist, ConocoPhillips

14. Mike Allen, Allen Oil

15. Larry Johnson, Delta-T Corporation

16. Biofuels for Sustainable Transportation: Ethanol and Fuel Cells, Larry Schafer, Legislative Counsel, Renewable Fuels Association

17. E-Diesel and Biodiesel: A Status Report to the Industry, Doug Vind, Regent International

\section{Nevada Workshop}

1. The United States Bioenergy Initiative-A Good Plan for the Country, Jeff James, Bioenergy Program Manager, Seattle Regional Office, U.S. Department of Energy

2. National Overview on Ethanol-Why this Industry is Growing, Neil Koehler, Renewable Fuels Association

3. Ethanol in California-What our Neighbors in the West are Experiencing, Pat Perez, Office Manager, Office of Transportation Fuel Supply and Demand, California Energy Commission

4. Ethanol in Nevada-Historic, Current, and Future, Andy Goodrich, Director, Washoe District Health-Air Quality Management Division

5. E85 and Nevada's Alternative Fuels in Fleets Program, Sigurd Jaunarajs, Environments Scientist, Nevada Division of Environmental Protection

6. Environmental Aspects of Ethanol as a Motor Fuel, David Andress, President, David Andress and Associates

7. Economic Impact for the Rural Economy, Dave Kolsrud, Agri-Energy LLC

8. Considerations and Steps to Take when Building an Ethanol Plant, Mark Yancey, BBI International

9. E10, E85 and Fuel Cells, Doug Vind, Regent International

10. E-Diesel: A Status Report to Industry, James Peeples, Vice President, AAE Technologies, Inc. 


\section{Kentucky Workshop}

1. The Federal Bioenergy Initiative, David Waldrop, Division Director for the Atlanta Regional Office's Federal Programs, Transportation and Power Division

2. How Ethanol is Made: Grain and Cellulosic, Tim S. Morris, Fagen, Inc.

3. Ethanol Markets: E10, E85, E-Diesel, Fuel Cells, Fairman Thompson, Parallel Products, division of U.S. Liquids

4. Distillers Grains: A Top-Notch Feed, Pearse Lyons, Altech, Inc.

5. Does the Impact Enjoyed in Minnesota Relate to Kentucky? Ralph Groschen, Minnesota Department of Agriculture

6. Ethanol-Blended Fuels and Minnesota's Environment, Tim Gerlach, American Lung Association of Minnesota

\section{California Workshop}

1. Welcoming Remarks, Steve Shaffer, Director, Office of Agriculture and Environmental Stewardship, California Department of Food and Agriculture

2. Overview of Program, Kim Penfold, Project Manager, Seattle Regional Office, U.S. Department of Energy

3. California's Transition from MTBE to Ethanol and Beyond, Mike McCormack, Office of Transportation Fuel Supply and Demand, California Energy Commission

4. Future of Ethanol Use in California's Gasoline Under Different Scenarios/Fuel Blends, Dave Smith, Director, Regulatory Fuel Issues, BP

5. Outlook for E85, Fuel Cells and Other Ethanol Markets in California, Jerry Esper, Senior Manager, Fuel Economy Planning, Daimler Chrysler Corporation

6. Fuel-Cycle Energy and Emission Impacts of Fuel Ethanol, Michael Wang, Environmental Analyst, Argonne National Laboratory

7. California's Ethanol Supply Options, William Maloney, Director of Business Development, ED\&F MAN Alcohol

8. Status Report on Opportunities Fostering a California Ethanol Industry, Neil Koehler, Director, California Renewable Fuels Partnership

9. The Investment Climate for Ethanol Production in California, Mark Yancey, Director of Consulting Services, BBI International

10. Overview of Ethanol's Prospective Contribution to California Agriculture, Matt Summers, Air Resources Engineer, California Department of Food and Agriculture

11. Corn-to-Ethanol Project in Colusa County, Phil Cherry, Harvest Biofuels

12. Sweet Sorghum and Sugar Cane to Ethanol in Imperial County, Carson Kalin, Partner, Imperial Bioresources

13. San Joaquin Valley Ethanol Outlook, Ellen Burnes, Professor, California State University, Fresno

14. Next Steps for Ethanol in California, Scott Matthews, Director, Transportation Energy Division, California Energy

15. The Hard Realities of Commercializing Biomass to Ethanol in California, George Simons, PIER Renewable Program Manager, California Energy Commission

16. Biomass-to-Ethanol Process Technology Options, Jim McMillan, Senior Biochemical Engineer, National Renewable Energy Laboratory

17. Biomass Ethanol as a Potential Tool for Forest Fire Hazard Reduction, Doug Wickizer, California Department of Forestry and Fire Protection

Active Process Developers' Approaches and Progress to Date

18. Bob Walker, SWAN Biomass Company

19. Michael Fatigati, Arkenol Fuels, Inc.

20. Gene Jackson, Power Energy Fuels, Inc.

21. Solid Waste Stream to Ethanol in California, Greg Shipley, Genahol, Inc. 
22. Dilute Nitric Acid Hydrolysis, Lee MacLean, HFTA, University of California Forest Products Lab

23. Biomass Ethanol Status, Daniel Musgrove, Universal Entech

24. Case Studies on Lignocellulosic Feedstocks and Technological Developments and Options for Ethanol Production, Fran Ferraro, Senior Technical Specialist, Merrick and Company

25. Remaining Steps to Achieving Commercial Biomass-to-Ethanol Process Technology, Bryan Jenkins, Professor, University of California - Davis, and Executive Director, California Biomass Collaboration 


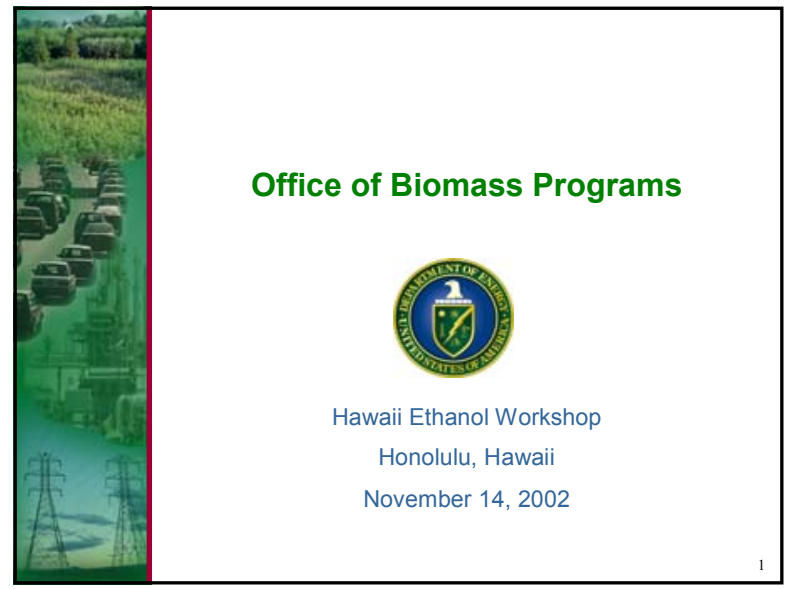

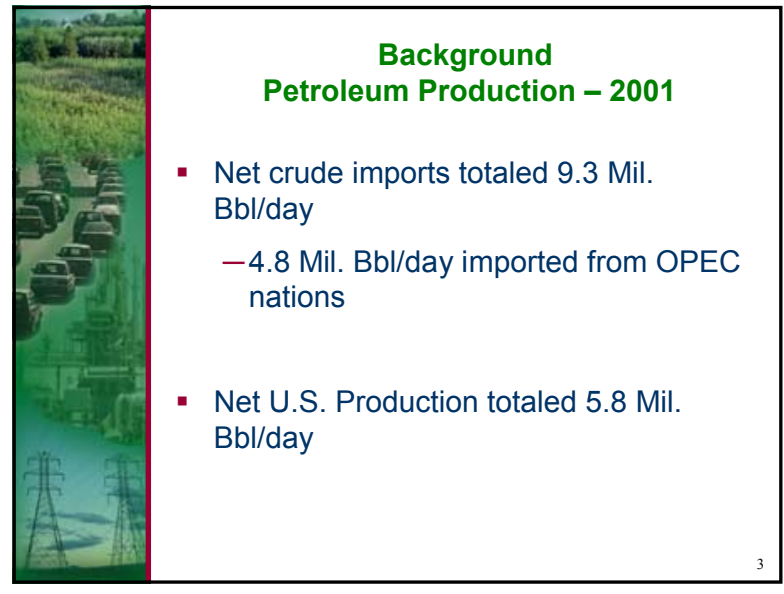

\begin{tabular}{|c|c|}
$\begin{array}{c}\text { Background (cont.) } \\
\text { Ethanol Production - 2001 }\end{array}$ \\
- $\begin{array}{l}1.77 \text { billion gallons of ethanol were produced } \\
\text { in the U.S. }\end{array}$ \\
- 2002 estimates exceed 2 billion gallons \\
- $\begin{array}{l}90 \% \text { ethanol produced from the starch portion } \\
\text { of the corn kernal }\end{array}$
\end{tabular}

\begin{tabular}{|l|l|} 
- Background \\
- Program Mission and Goals \\
- Office of Biomass Programs R\&D Focus Areas \\
- Opportunities
\end{tabular}

Background (cont.)
Petroleum Consumption - 2001
$\begin{aligned} & \text { - Imports are a large and growing share of U.S. } \\ & \text { petroleum consumption } \\ & -19.6 \text { Mil. Bbl/day consumption } \\ & -10.9 \text { Mil. Bbl/day net imports } \\ & -25 \% \text { of these imports come from OPEC nations } \\ & \end{aligned}$
$\begin{aligned} & \text { Petroleum product consumption in the } \\ & \text { transportation sector was approx. } 14.9 \text { Mil. } \\ & \text { Bbl/day } \\ & - \text { Motor gasoline: } 8.61 \text { Mil. Bbl/day }\end{aligned}$

\begin{tabular}{|l|c|} 
Program Goals \\
Goals \\
- Reduce U.S. dependence upon foreign \\
- $\begin{array}{c}\text { Sources of petroleum } \\
\text { Support development of Industrial Biorefinery } \\
\text { The term 'biorefinery' means equipment and } \\
\text { processes that: } \\
\text { Convert biomass into fuels and } \\
\text { chemicals; and }\end{array}$ \\
- May produce electricity
\end{tabular}




\begin{tabular}{ll|}
\multicolumn{1}{c}{ Program Mission } \\
Mission \\
-To foster research and development on \\
advanced technologies to transform our \\
abundant biomass resources into clean, \\
affordable, and domestically-produced \\
biofuels, biopower, and high-value \\
bioproducts for improving the economic \\
development and enhancing the energy \\
supply options of the U.S.
\end{tabular}

Opportunities
On the horizon
- Develop and integrate bioproducts to
enable deployment of biofuels
- Develop strong partnerships with industry
leaders committed to technology
deployment
- Coordinate with USDA
- Provide Americans with a stronger
economy, healthier environment, and more
secure future
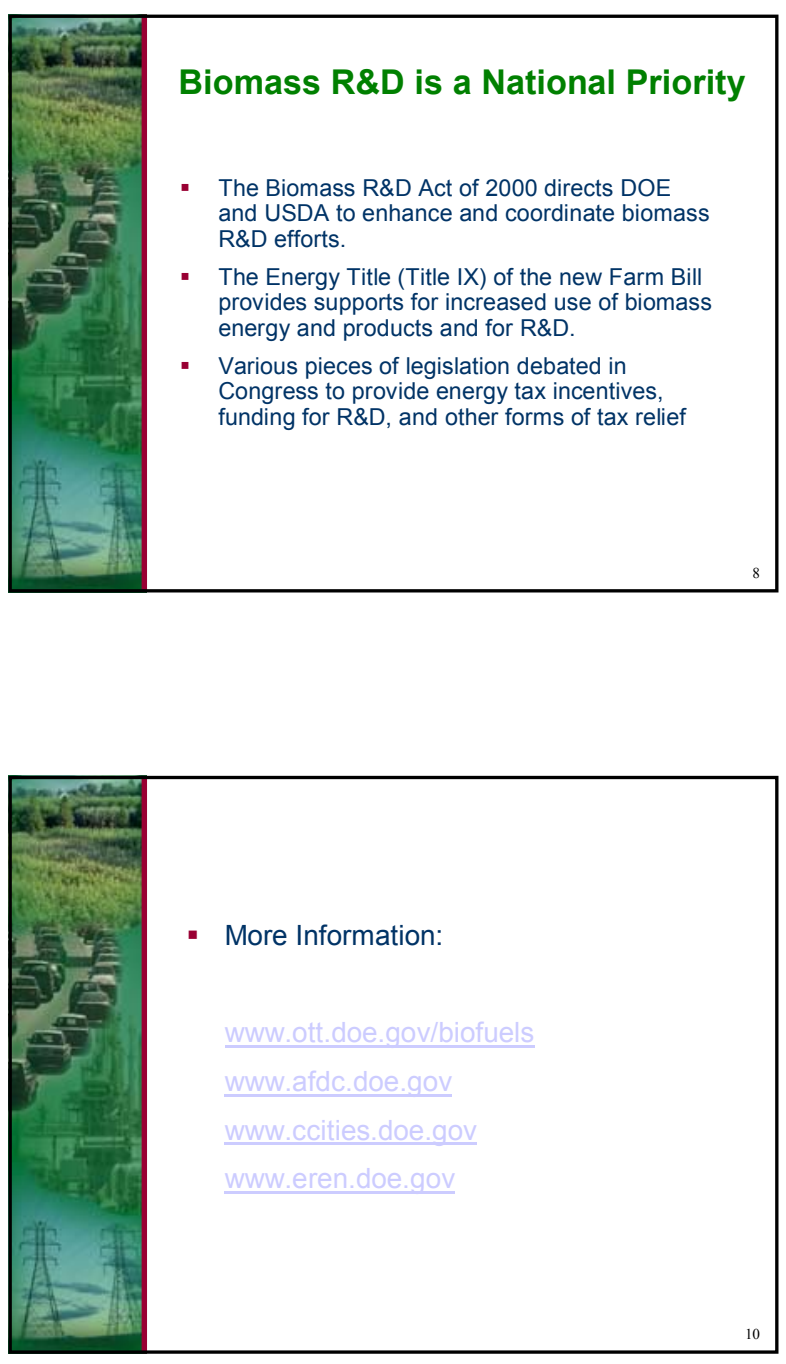


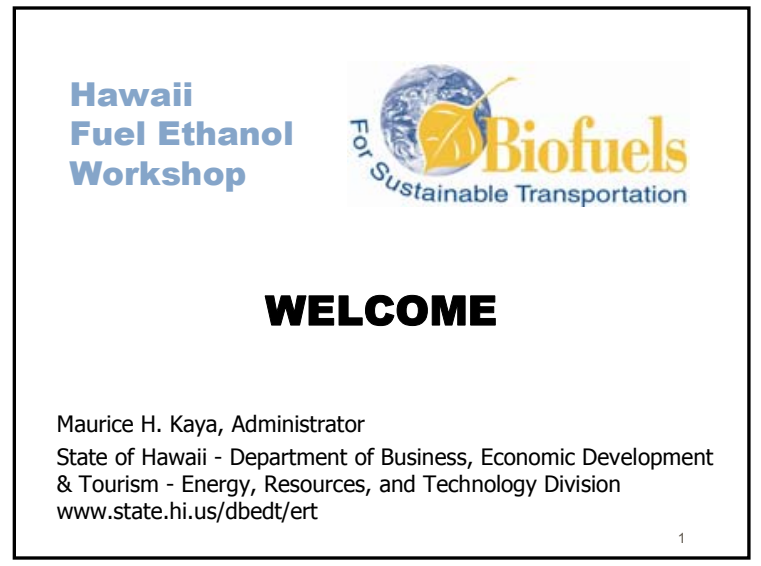

\section{Working Group}

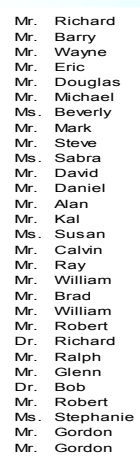

Akana
Ching
Condit Darmstaedter
Durante Durante
Edward Harbin
Hepburn
Holaday Holaday
Kauka Keith
Kenknigh Kenknight
Kennett
Kobayash Kobayas
Kusunoki Lee Levinso Maloney
Nicolai Nierpoi
Primiano
Primo Primiano
Rochelea
Saito Saito Shlese Tam
Whalen
Wong Wong
Yorke
Akana Petroleum Inc State Department of Health
Shell Oil Products Us WEG-Kauai LLC Sustainable Kauai
Saument Coalition Chamber of Commerce of Hawal Hawaiian Commercial and Sugar Garden Island RC\&D Oloha Petroleum, Ltd. Gay and Robinson State Department of Agriculture S. Postal Service Pacific Area Operation N Automotive State Department of Agriculture Hawaii Natural Energy Institute Leeward Petroleum Inc. The 'Aina Institute State Department of Health Hawaii Agriculture Research Center Hawaiian Commercial and Sugar Tesoro Hawaii Corporation

\section{Sponsors}

- U.S. Department of Energy, Office of Fuels Development

- Pacific Regional Biomass Energy Program

- City and County of Honolulu

- ED\&F Man Alcohols

- Hawaii Department of Agriculture

- Hawaii Department of Business, Economic Development \& Tourism

- Hawaii Department of Health

- Hawaii Natural Energy Institute

- Hawaiian Commercial and Sugar Company

- Honolulu Clean Cities

- JN Automotive Group

\section{Workshop Purpose and Objective}

- Provide context

- Present information on current status of fuel ethanol nationally

- Present information on potential for production and use of fuel ethanol in Hawaii

- Provide an opportunity for community input

- Build a foundation for future discussion, work and collaboration in this area

\section{Why Fuel Ethanol?}

- Cars can use it.

- Consumers will benefit.

- Our economy will be stronger.

- Our air will be cleaner. 

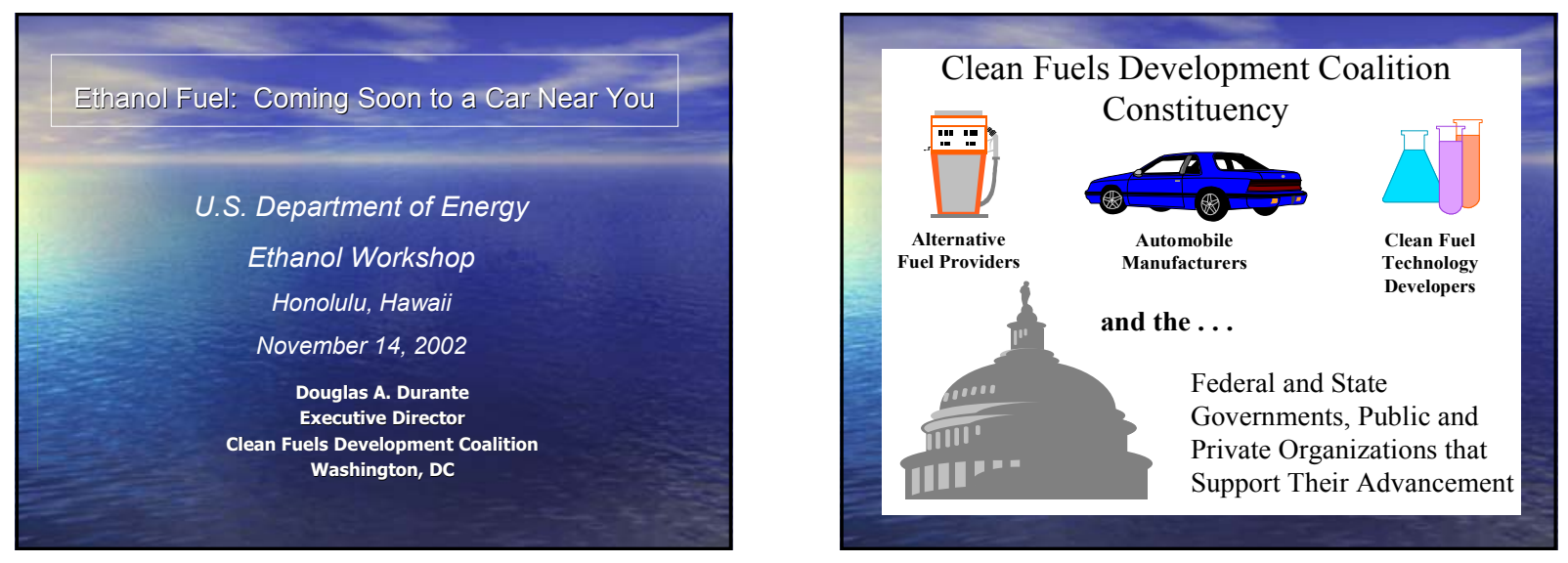

\section{Ethanol has a Long History of Bipartisan Support}

Jnergy Security Act of 1978

JEnergy Tax Act of 1980

Alternative Motor Fuels Act of 1988

JClean Air Act of 1990

Energy Policy Act of 1992

Energy Act of 2002??

All Identify Ethanol as a Way to Achieve a Variety of Public Policy Goals

Ethanol Supported by a Variety of Federal and State Programs

, Increasing Ethanol Use:

Federal Tax Incentives

Clean Air \& Control of Fuel Properties

Fleet Requirements

E-85 and Alt Fuel Credit Program

- Increasing Ethanol Production:

Financial Assistance

Commodity Programs

State and Local Incentives

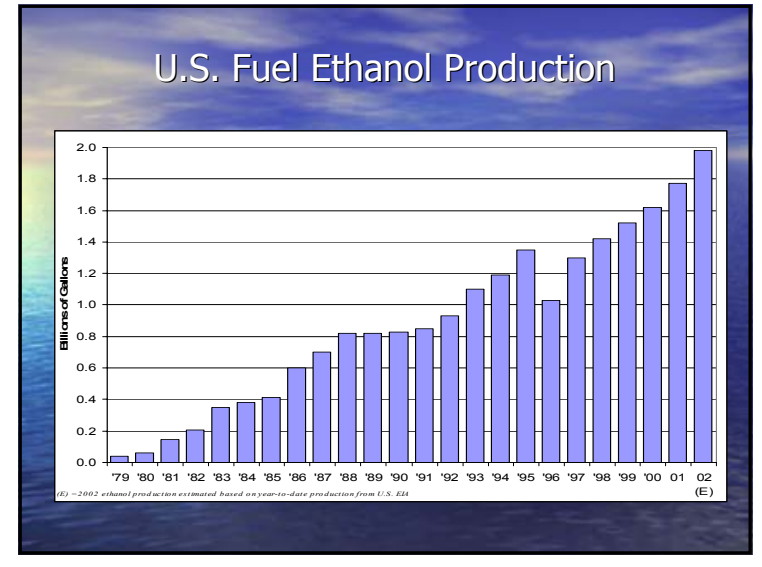


Ethanol Represents Small Sliver of U.S. Petroleum Pie
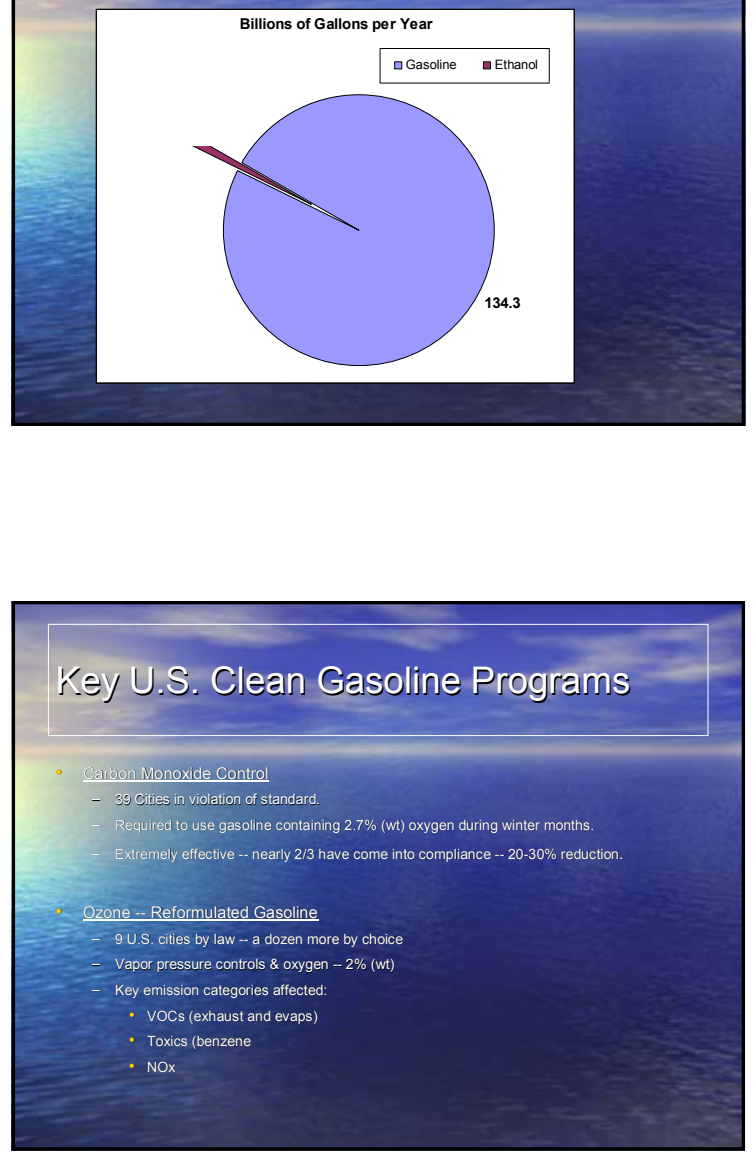

Possible Banning of MTBE

- 4.5 billion gallons used in the U.S.

Proposed to be banned Nationwide

- California

Scheduled for elimination in 2004

- Most refiners already moving away from MTBE

- Other States are also Banning

- Arizona (2003)

- Connecticut (2003)

Minnesota (2005)

- Nebraska (use limited)

- New York (2004)

- South Dakota (use limited)

- More to follow when state legislatures begin work in January
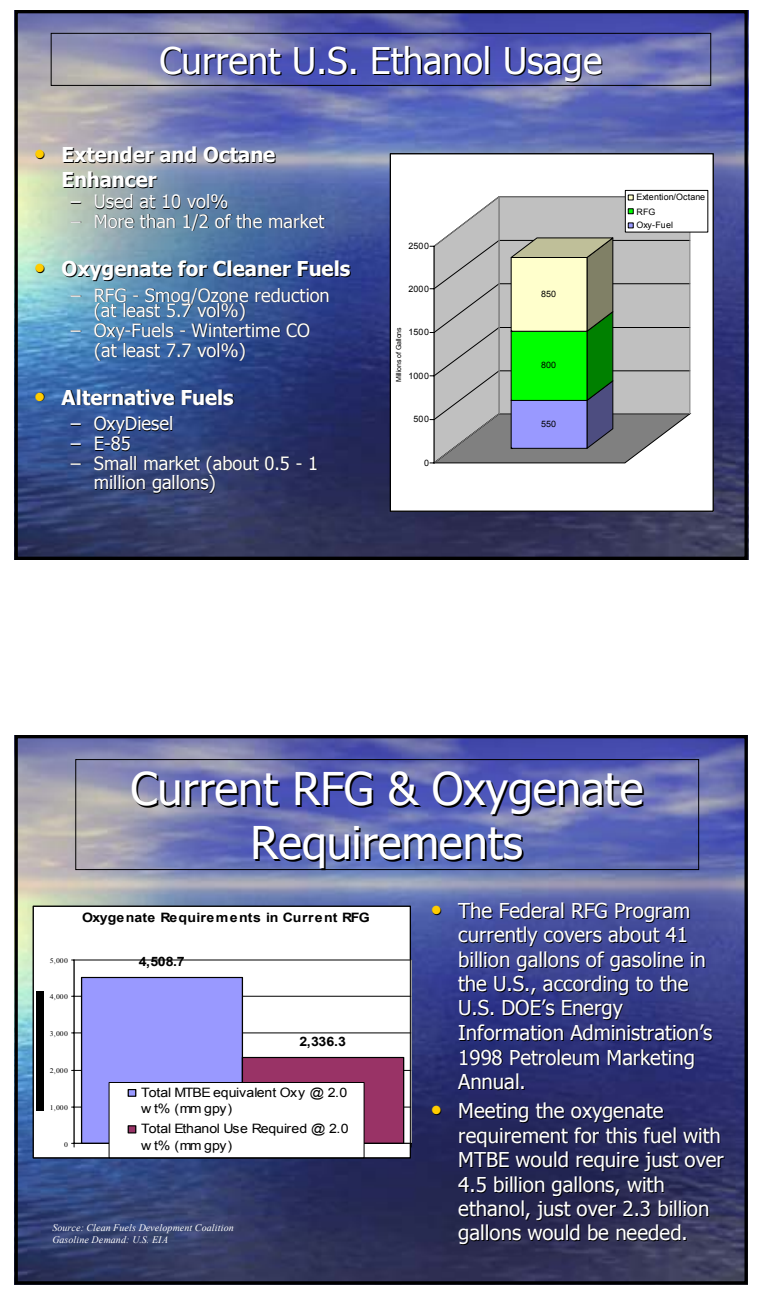

\section{U.S. Clean Fuel Requjrements}

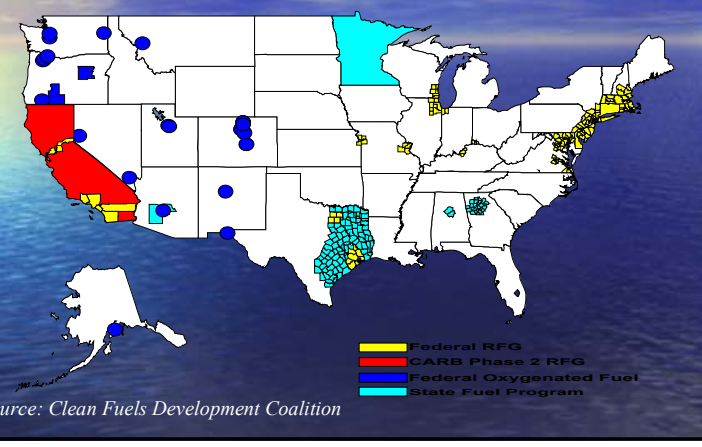



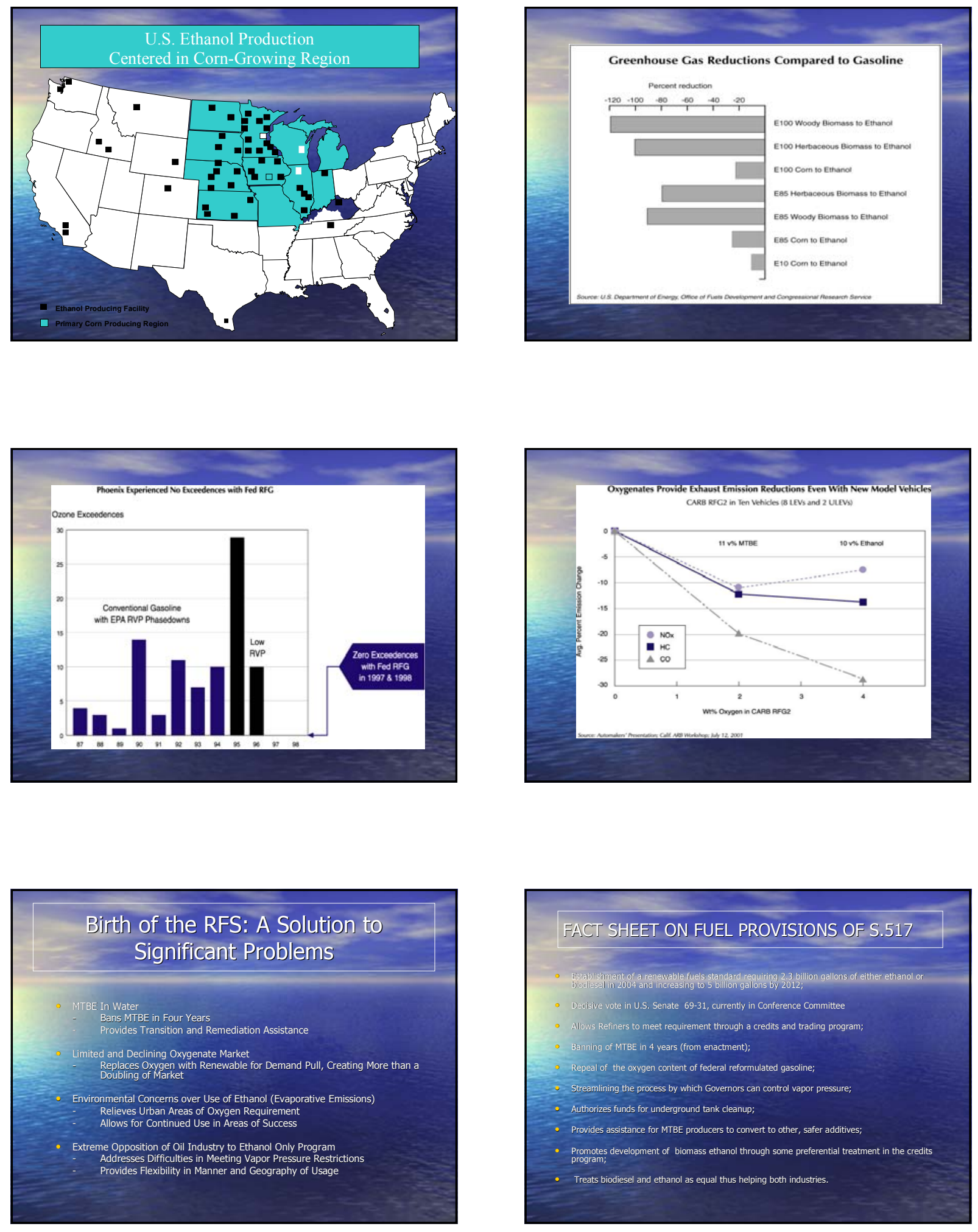

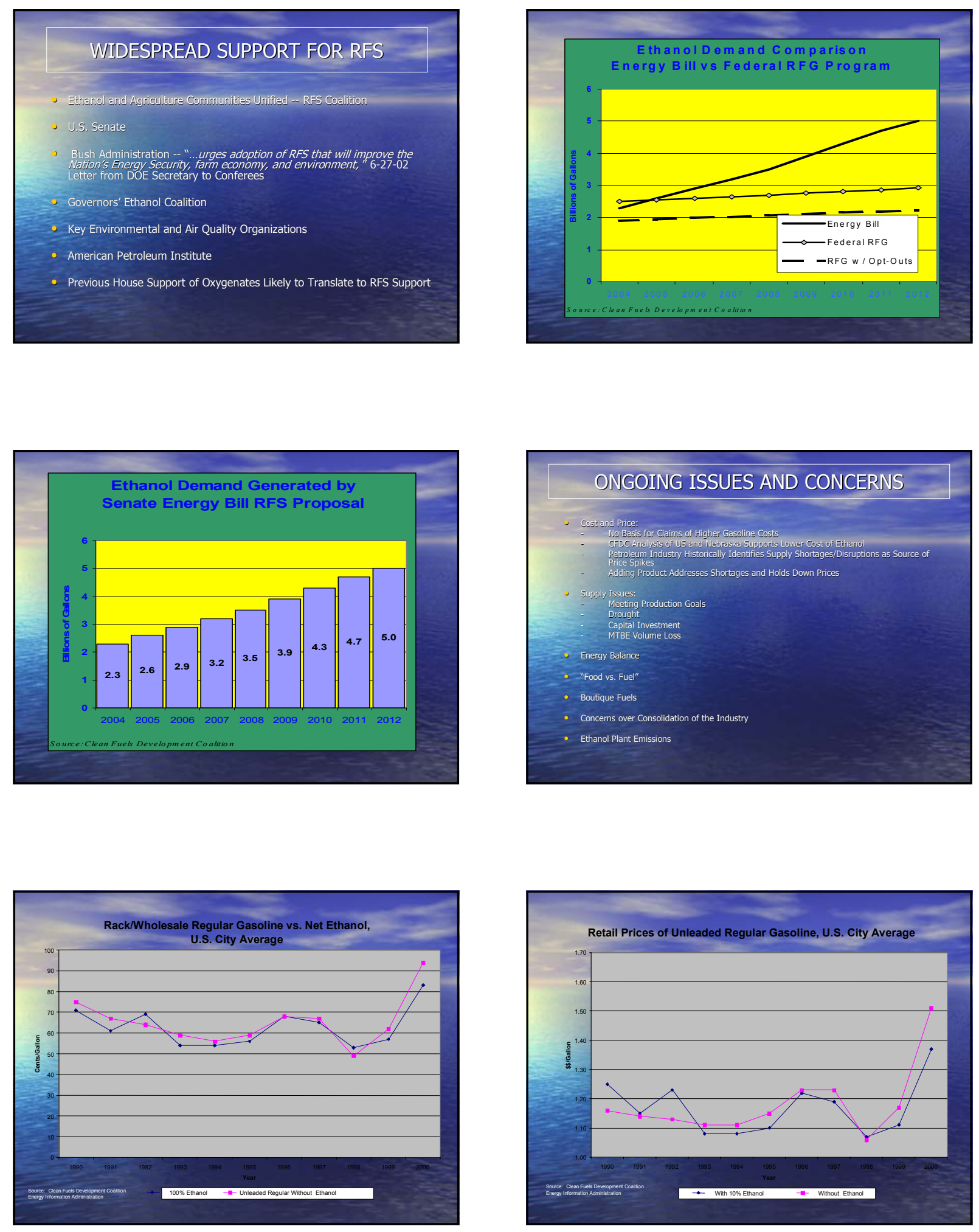

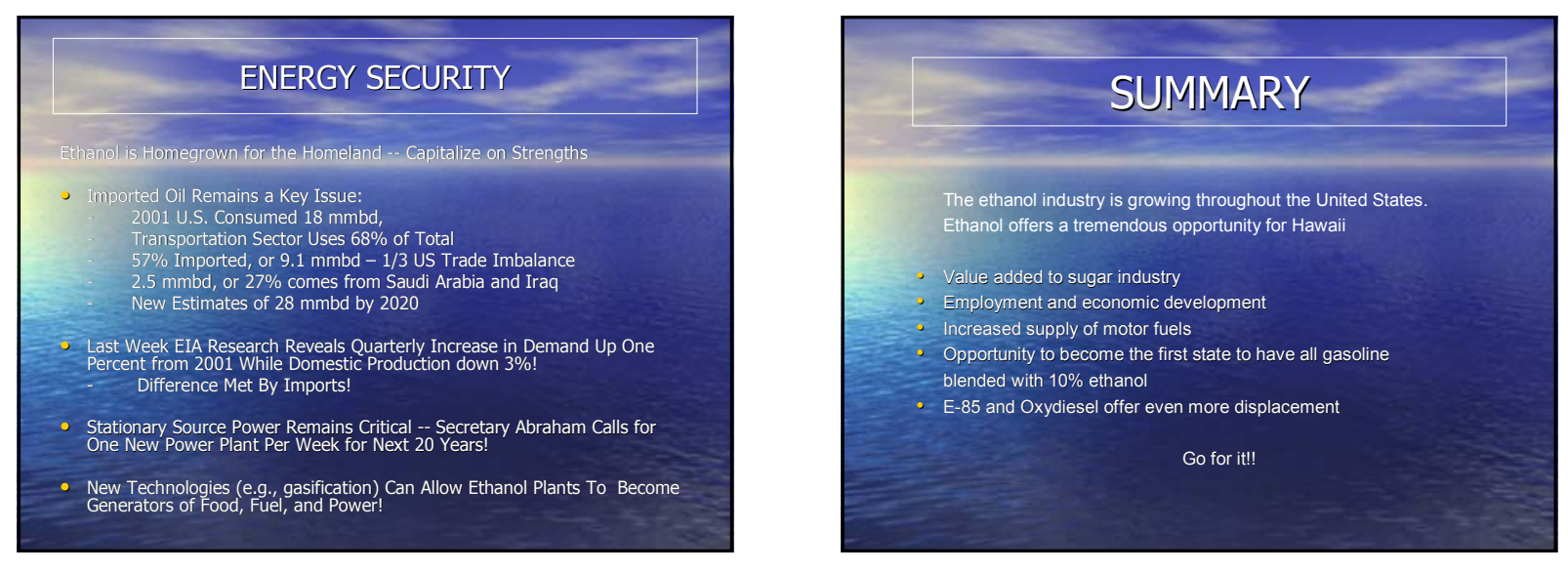


\section{Transportation Fuel Quality}

\section{Ethanol: An Important Role in} Global Transportation Fuels

\section{Hawaif - U.S. DOE Ethanol Workshop}

Honolulu, Hawaif

November 14, 2002

Gary Herwick

General Motors Corporation
Fuel quality affects emissions, fuel economy, durability/, driveability

- Vehicles and fuels must be considered a "system"

- Ability to meet stringent global emission requirements increasingly dependent on fuel quality

- Insure lowest emissions

- Enable emission control technolog

- World-Wide Fuel Charter Category 4 (Tier 2/LEV II/Euro IV) - $<10 \mathrm{ppm}$ sulfu

Dith all specifications

- Address energy use and greenhouse gas emissions concerns

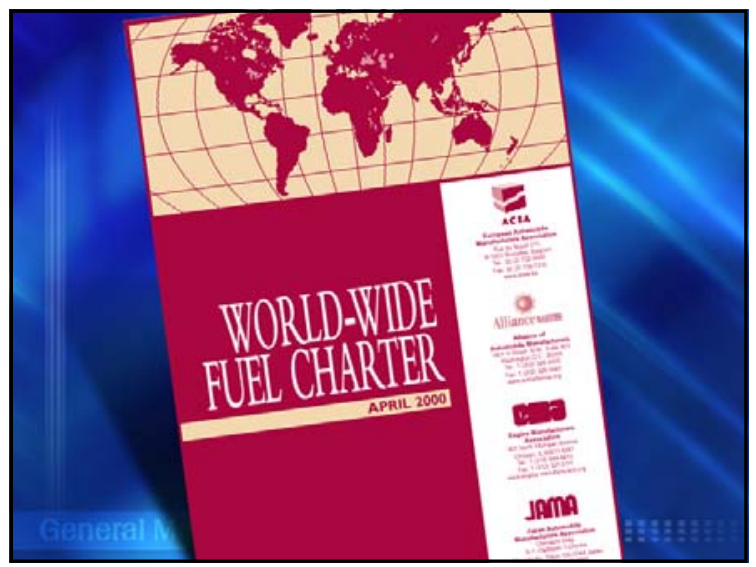

General Motors Promotes the Use of Ethanol in Transportation Fuel

- Approved the use of $10 \%$ ethanol blended gasoline in all $\mathrm{GM}$ products for 20 years

- Owners manuals recommend the use of clean fuels containing oxygenates

- Largest producer of E85 Flexible Fuel vehicles

- Tahoe, Suburban, Yukon, Yukon XL SUV

- S10, Sonoma, Silverado, Sierra Pickup

- Strategic transportation fuels initiative

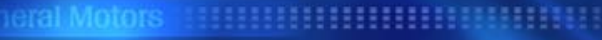
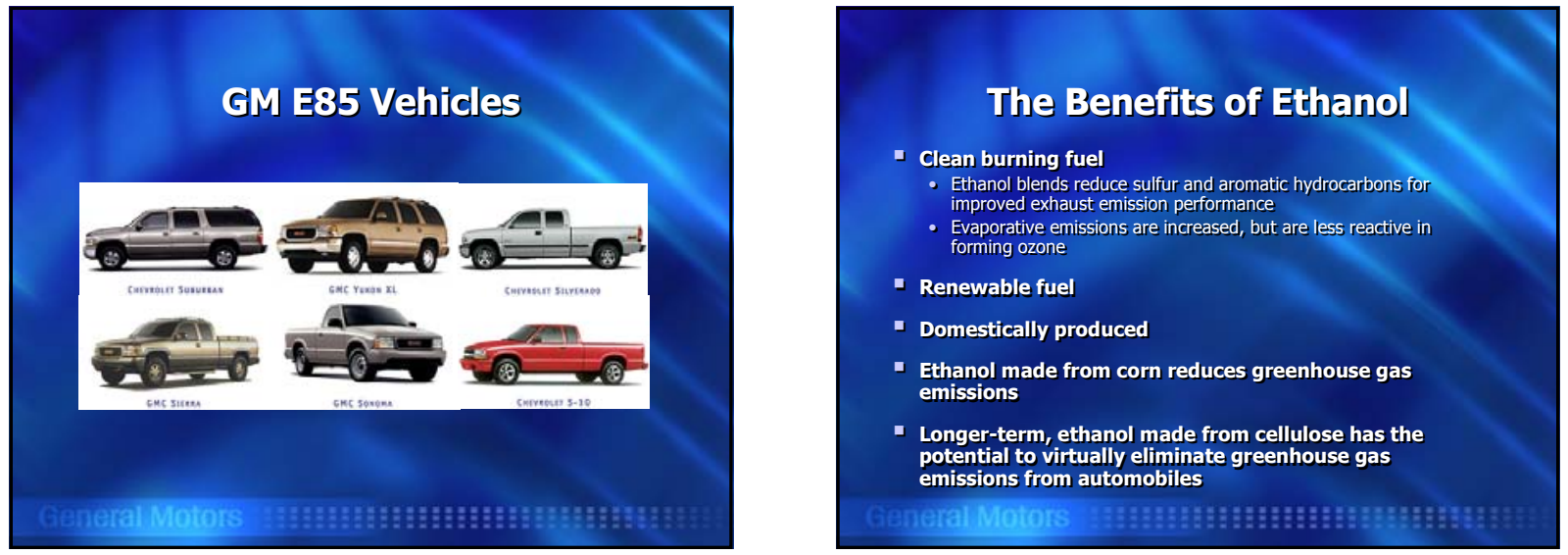


\section{Strategic Initiative}

Promote the use of E85 as a renewable alternative fuel and as a means of addressing $\mathrm{CO}_{2}$ emission concerns Support the development of ethanol from cellulose

- GM commissioned Well-to-Wheels life cycle analysis of energy use and greenhouse gas emissions

- Compares 15 propulsion technologies and 75 different fue "pathways"

- Ethanol (E85) reduces greenhouse gas emissions more than any other alternative fuel

- "The alternative fuel that makes sense."

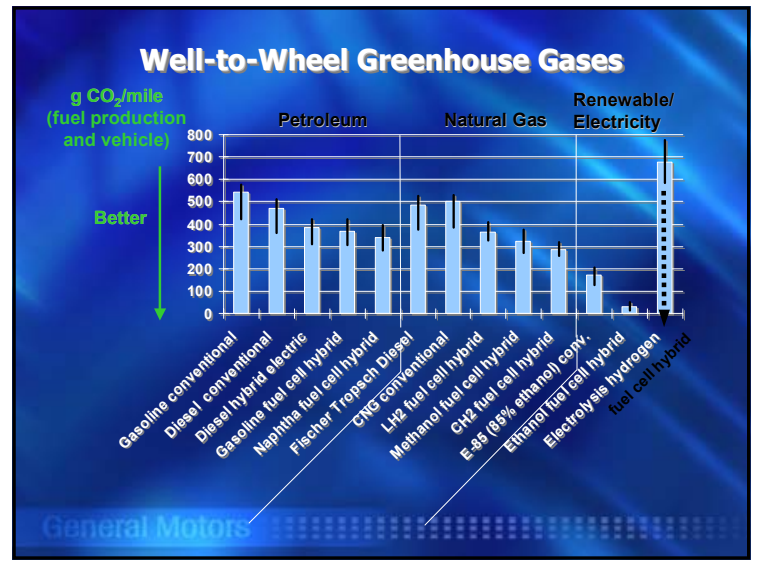

\section{Gasoline DI Limit}

A DI limit enhances the opportunity for ethanol blended fuels

- DI limit applies to the HC blendstock

- Mitigates impact of ethanol on cold start HC emissions

- Renewable Fuel Standard and a DI limit go together

- CRC test programs will quantify effects on LEV vehicles

- Mitigation strategies are needed

whoral Morors

\section{Ongoing GM Support}

Research on the development of ethanol from bio-mass

- Development of E85 fueling infrastructure

- Partnership with BP to provide E85 fueling capability for GM

company vehicle fleet in Southeast Michigan

- Additional infrastructure and education project plans

- Membership in CFDC, NEVC

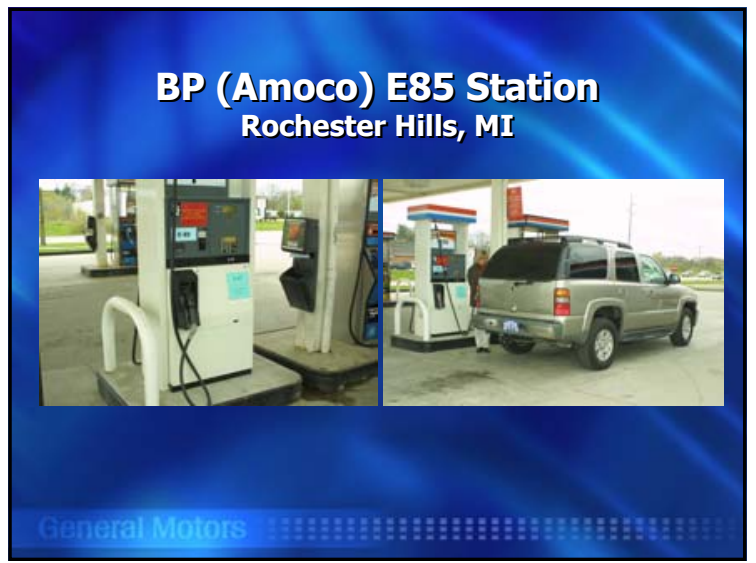




\section{Summary}

- Transportation fuels must address energy use and greenhouse gas emissions concerns.

- General Motors has supported the use of ethanol in transportation fuels for many years.

- $\mathbf{G M}$ is the largest producer of E85 Flexible Fuel vehicles.

- GM will continue to support increased use of ethanol through research and infrastructure development.

- A DI limit on US gasoline enhances the opportunity for ethanol, mitigates emissions impact of ethanol. 

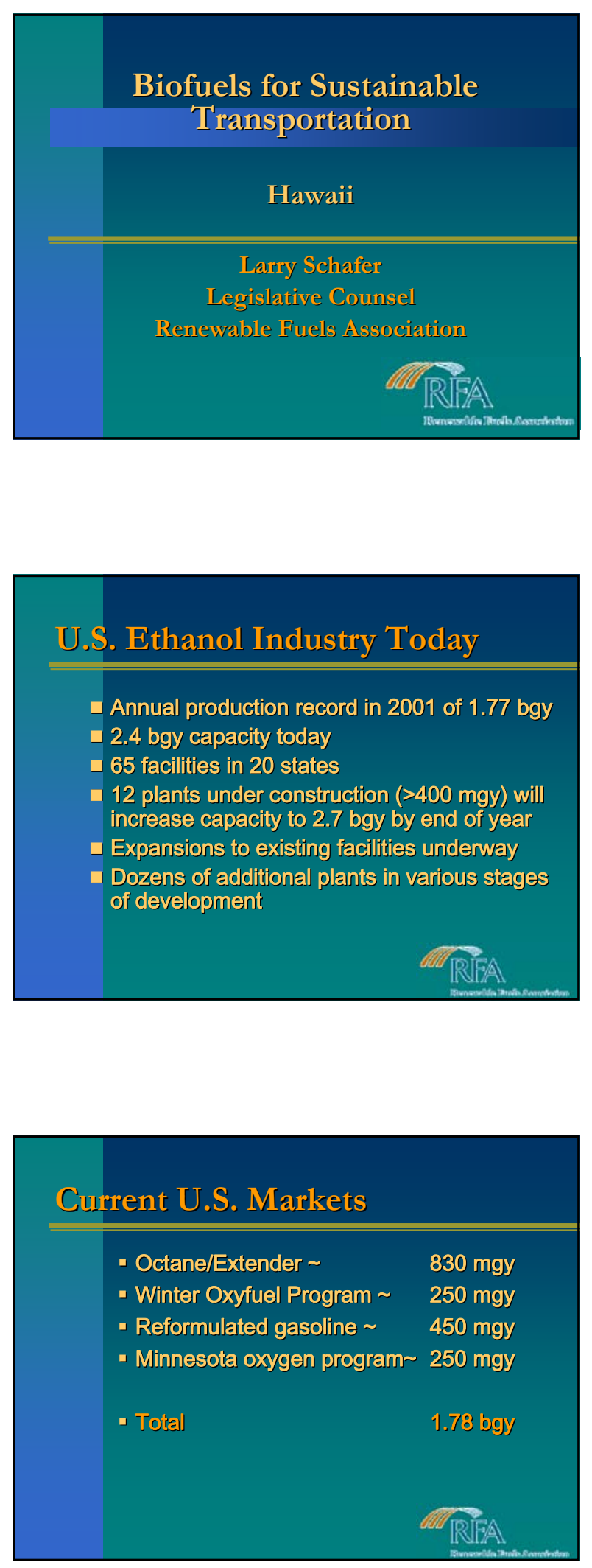
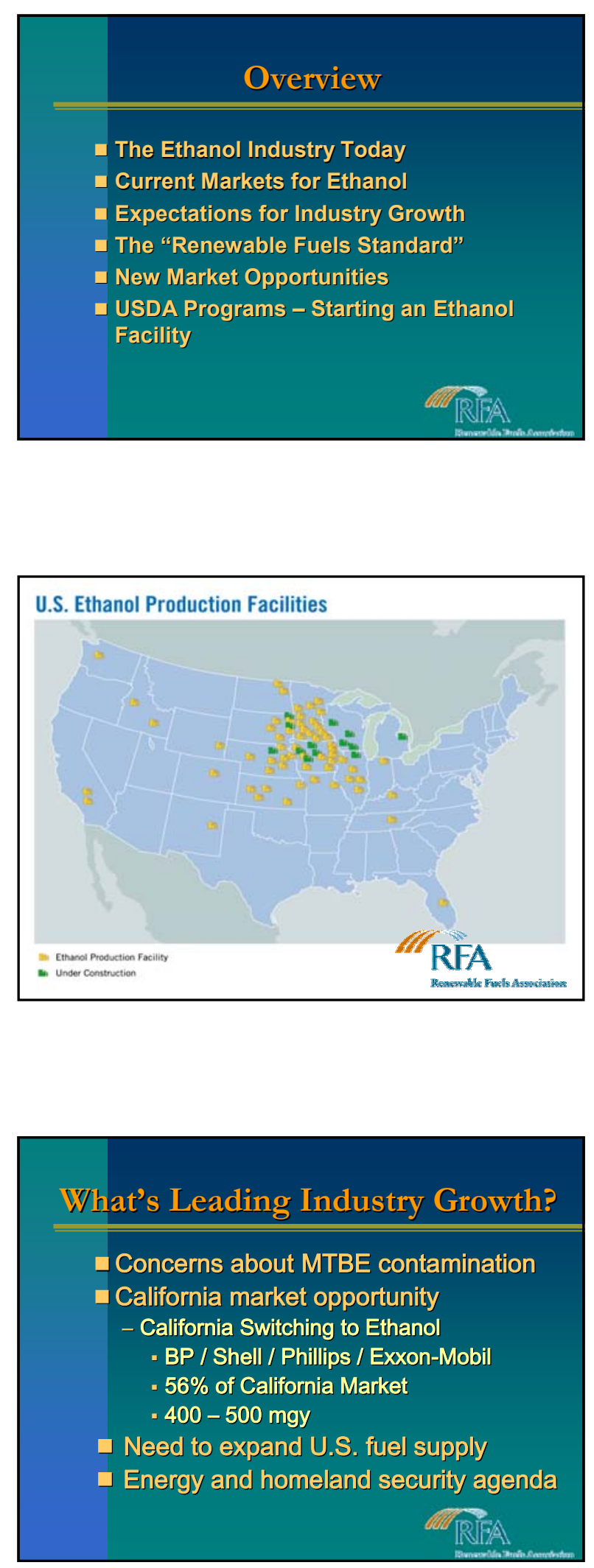

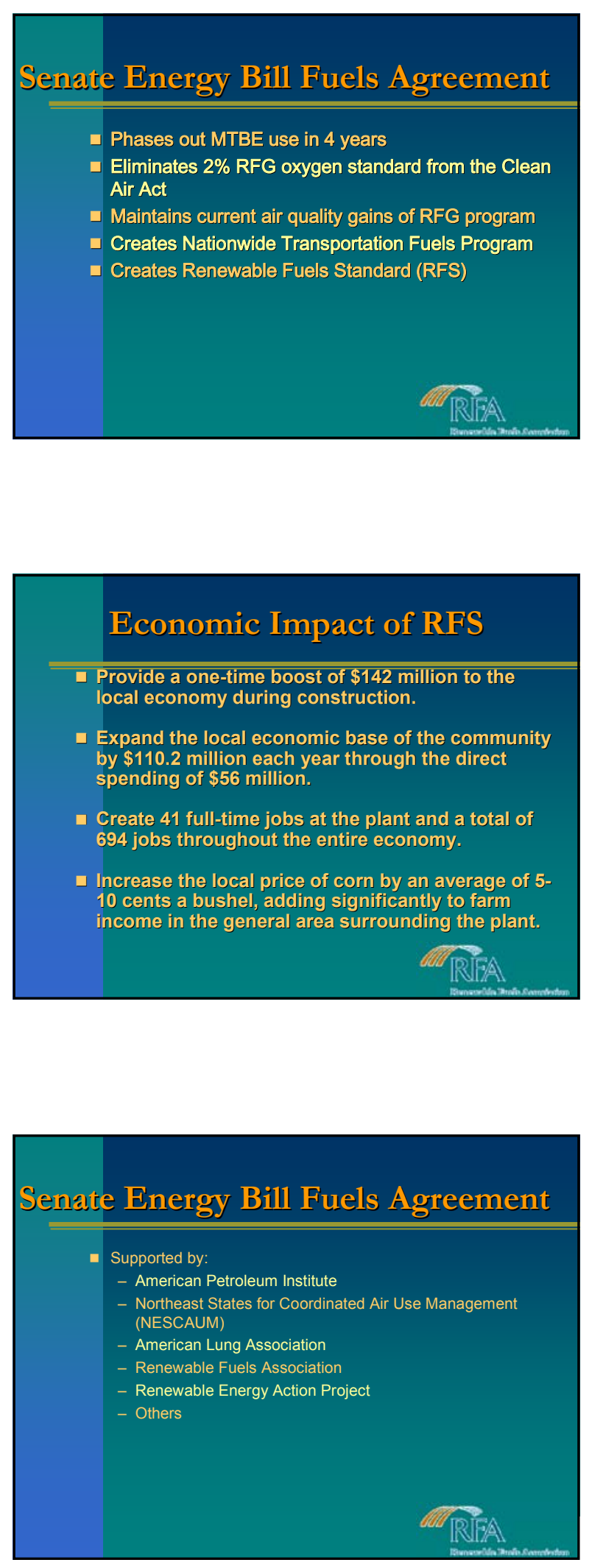
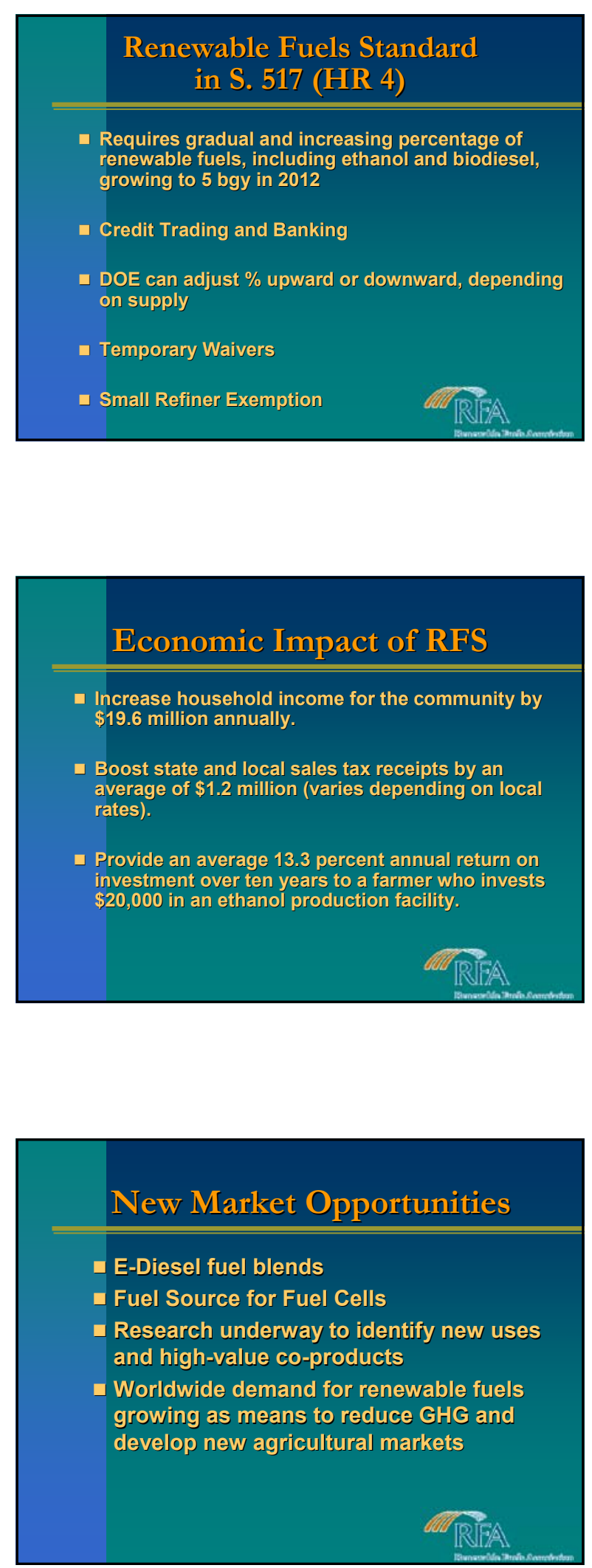

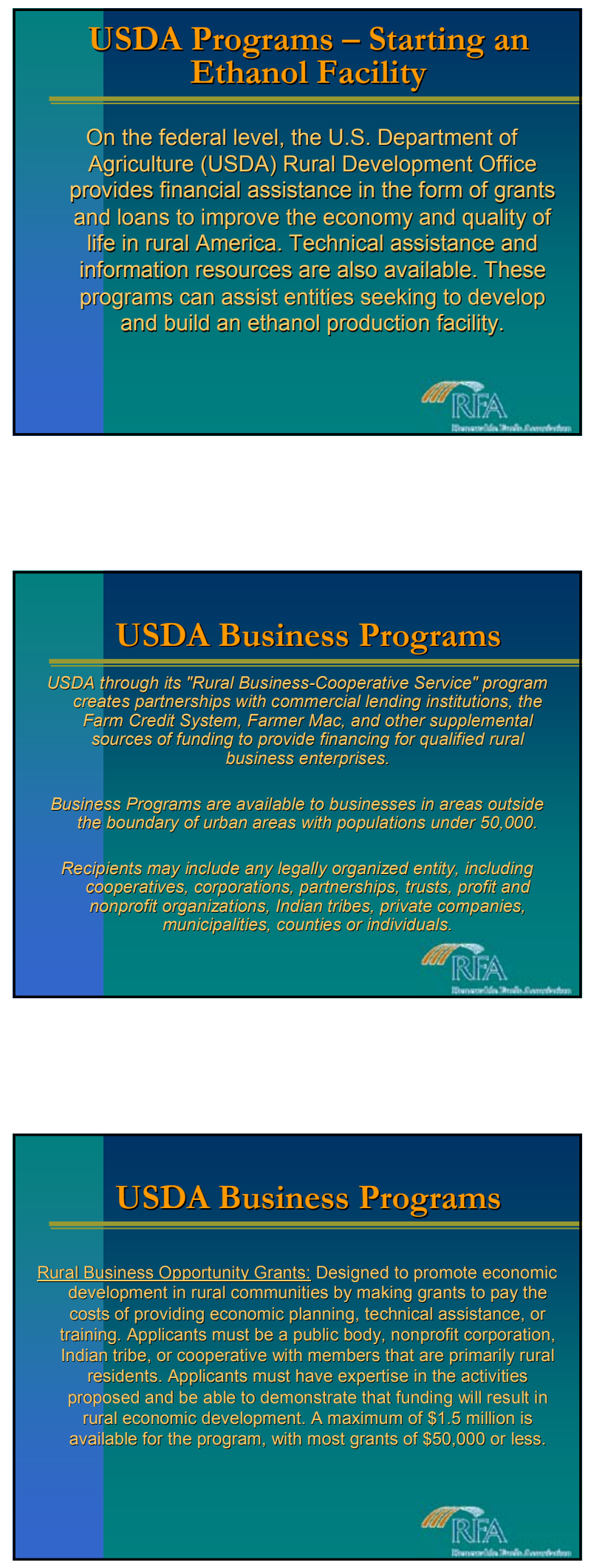
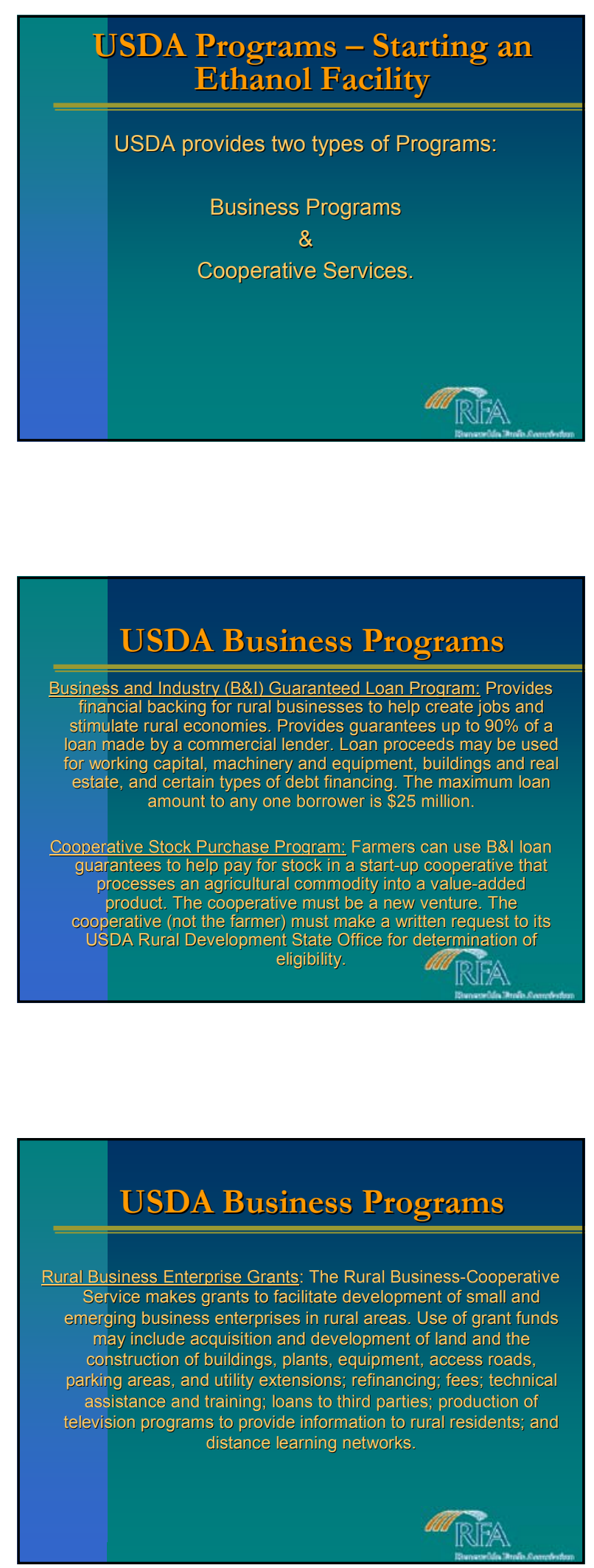


\section{USDA Business Programs}

Intermediary Relending Program: The purpose of the Intermediary Relending Program (IRP) is to finance business facilities and community development projects in rural areas. This is achieved through loans made by the Rural Business-Cooperative Service (RBS) to intermediaries. Intermediaries re-lend funds to ultimate recipients for business facilities or community development. Intermediaries establish revolving loan funds so collections from

loans made to ultimate recipients in excess of necessary

operating expenses and debt payments will be used for more loans to ultimate recipients.

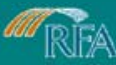

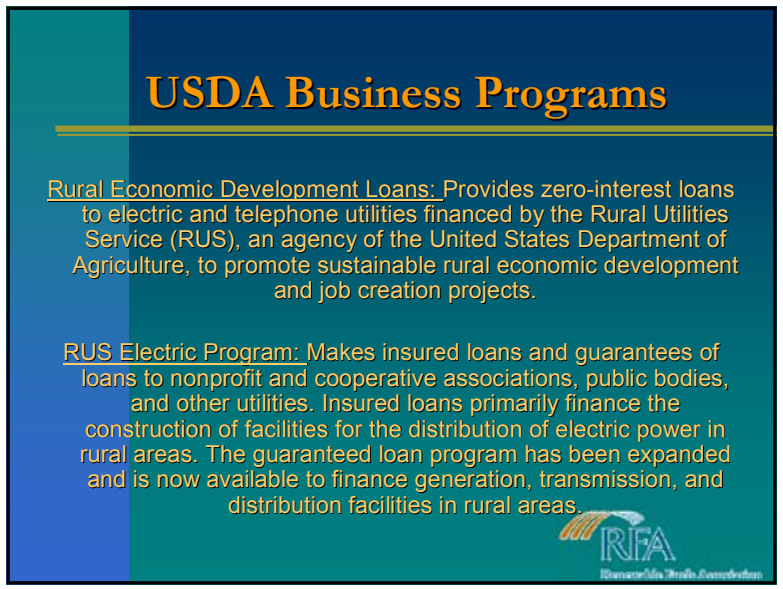
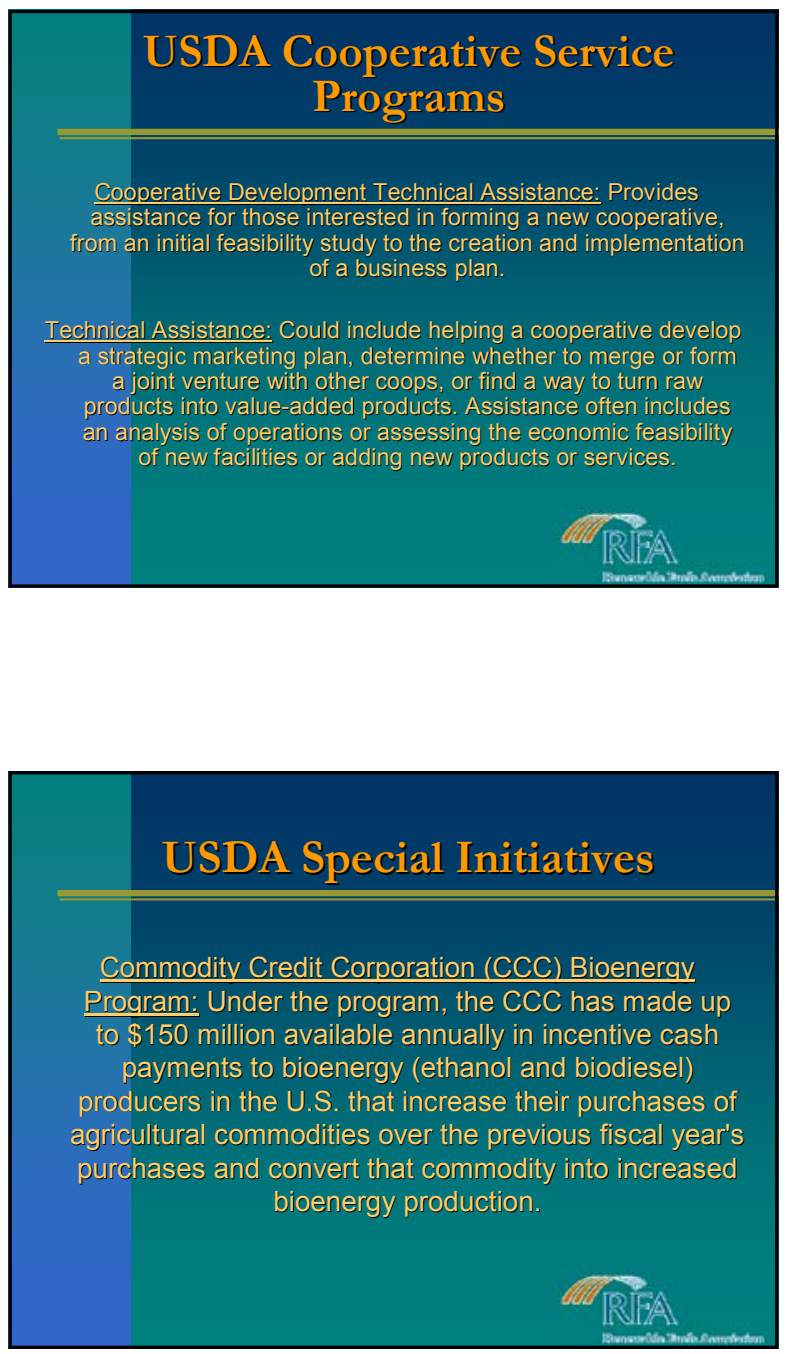

\section{USDA Cooperative Service Programs}

Cooperative Development Technical Assistance: Provides assistance for those interested in forming a new cooperative from an initial feasibility study to the creation and implementation of a business plan.

chnical Assistance: Could include helping a cooperative develop a strategic marketing plan, determine whether to merge or form oint venture with other coops, or find a way to turn rav of new facilities or adding new products or services.

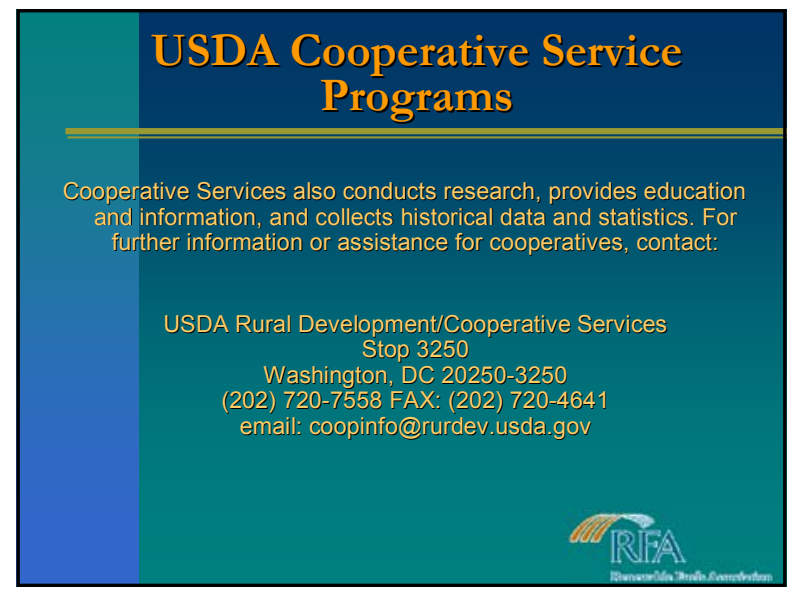

Promotes understanding and use of the cooperative as a viable organizational option for marketing and distributing agricultural products. Helps rural residents form new cooperative businesses and improve the operations of existing cooperatives.

Value-Added Agricultural Product Market Development Grants Independent Producers: This grant program seeks to encourag independent agricultural producers to further refine their products for value-added benefits. These grants will facilitate greater participation by farmers in markets for value-added agricultural commodities and facilitate the opening of new markets for value-added products. The proposed project must change the form of an agricultural product, such as processing grain into ethanol, wheat into flour, etc

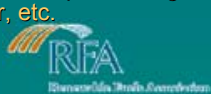




\section{USDA Special Initiatives}

Rural Cooperative Development Grants: USDA grants are

available for establishing and operating centers for cooperative

development to improve rural economies through the

development of new cooperatives and to improve the operations of existing coops.

Biobased Products and Bioenergy Program: This program seeks to promote national economic interests through the conversion of renewable farm and forestry resources to affordable fuel (i.e.

ethanol and biodiesel), chemicals, electricity, pharmaceuticals,

and other materials in cost- competitive manner. Loans are

eligible for financing under the Business and Industry

Guaranteed and Direct Loan Programs (see above)

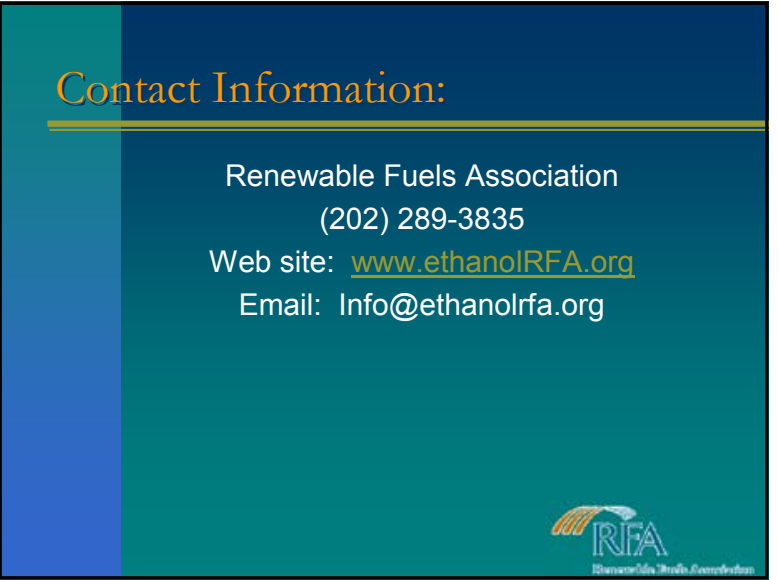




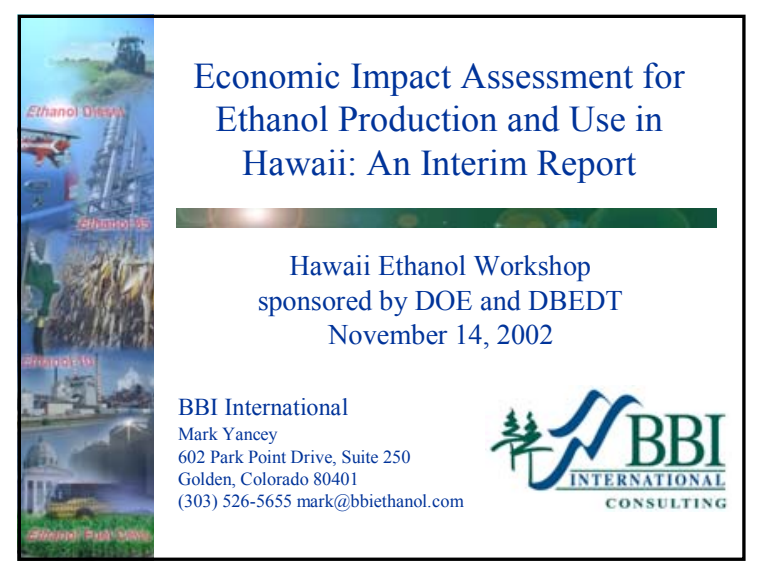

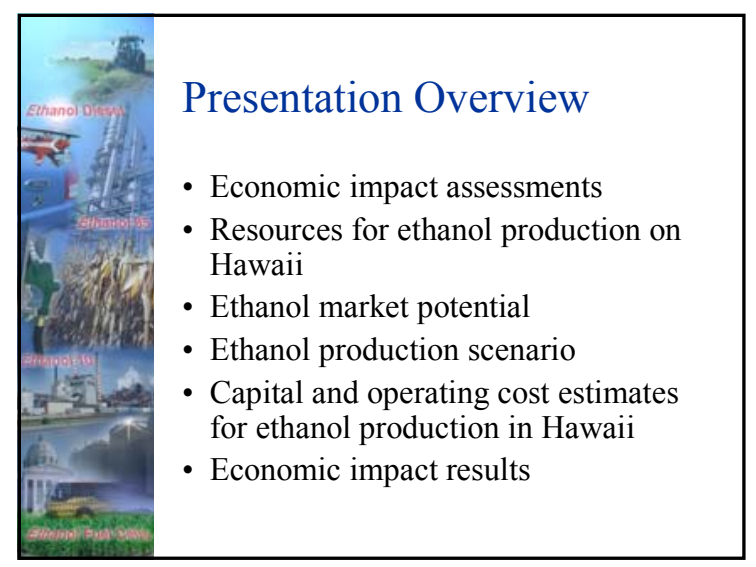

\begin{tabular}{|l|l|}
\hline & Hawaii's Resources for \\
& Ethanol Production \\
& Ethanol is typically produce by \\
& fermentation of sugars by yeast \\
- & All plants contain sugar, starch or \\
& cellulose - all can be used to make \\
& ethanol \\
- & Hawaii has sugar and cellulose \\
& feedstocks and few starch crops \\
- & MSW (garbage) can also be used \\
&
\end{tabular}

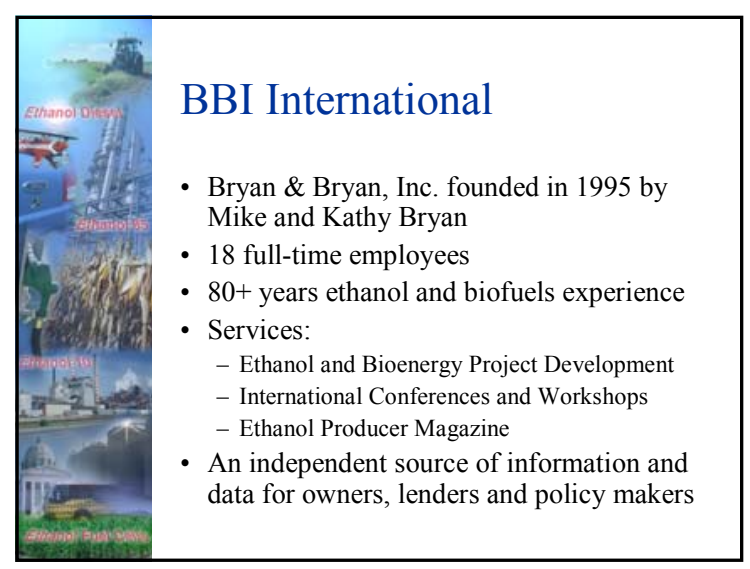

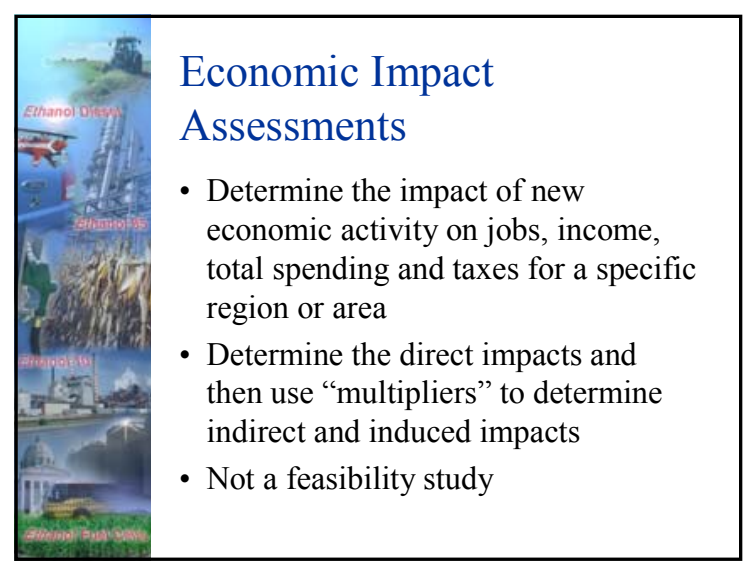




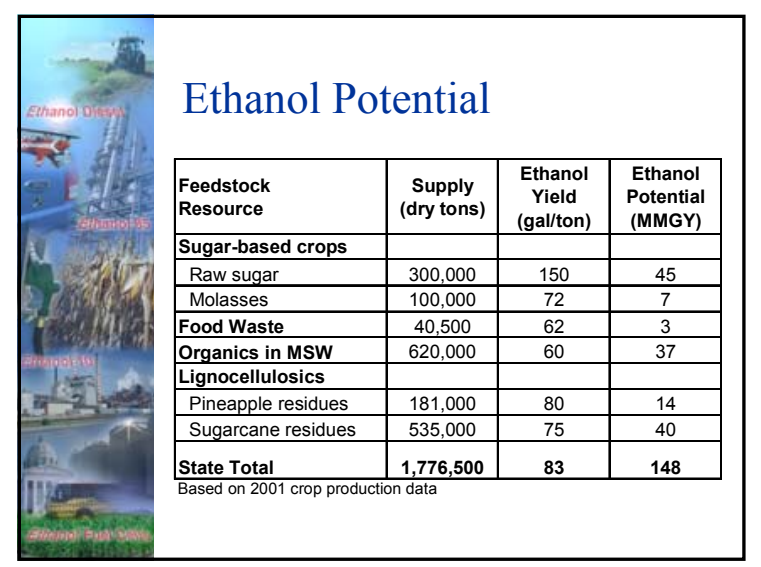

\begin{tabular}{|l|l|}
\hline & Ethanol Production Scenario \\
& There are many possible scenarios for \\
ethanol production in Hawaii \\
- After considering many different \\
scenarios, BBI selected: \\
$15 \mathrm{MMGY}$ on Oahu from MSW \\
$15 \mathrm{MMGY}$ on Maui from Molasses \\
$10 \mathrm{MMGY}$ on Kauai from Molasses
\end{tabular}

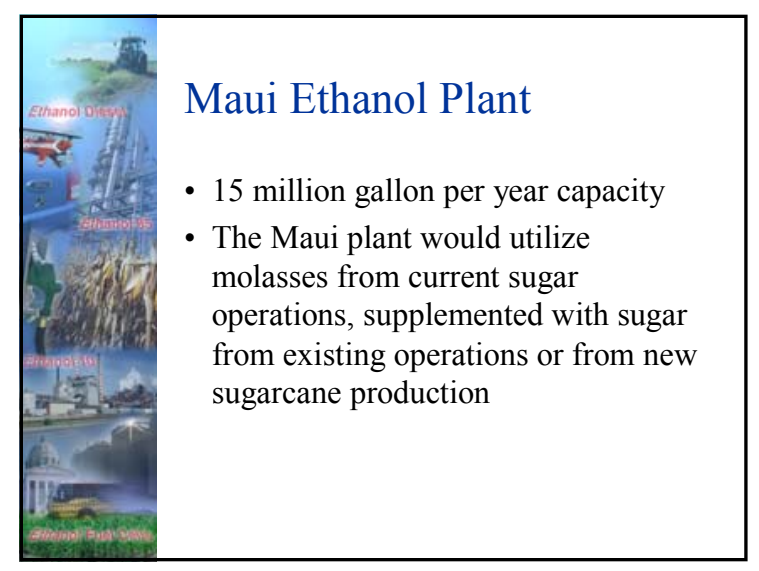

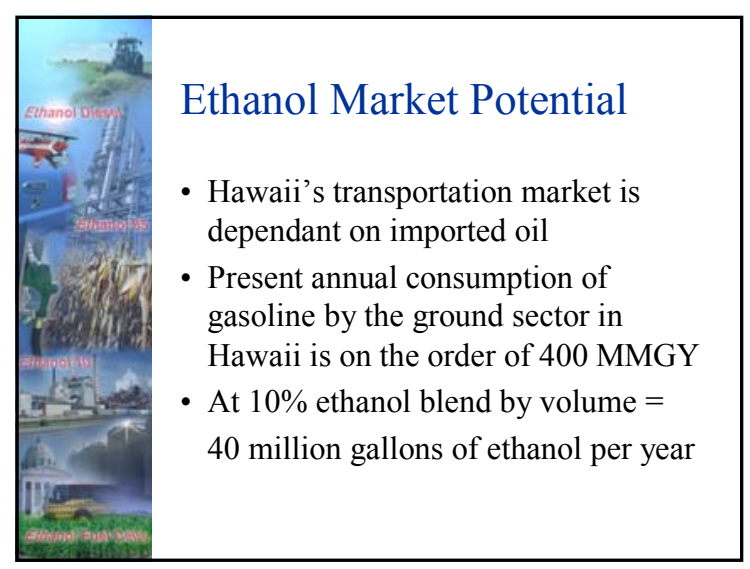

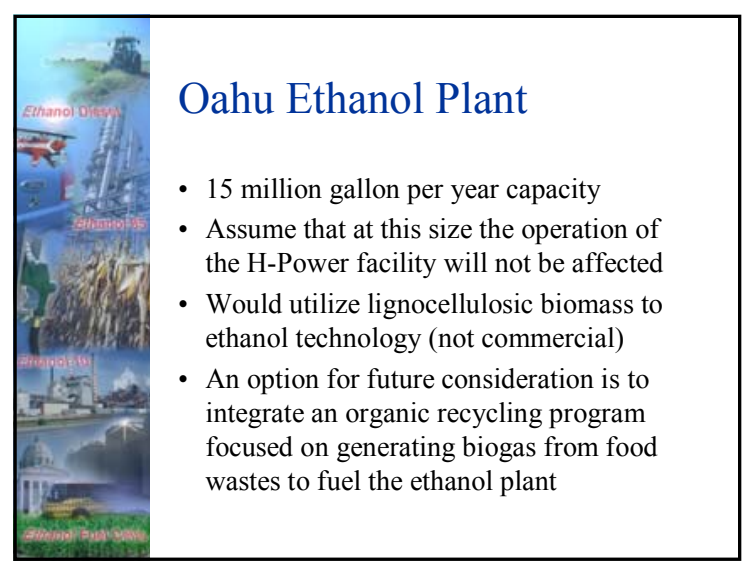




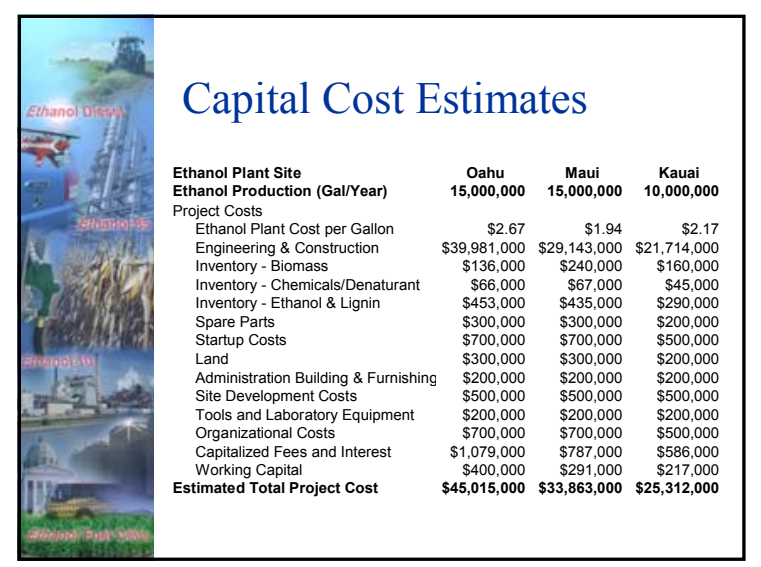

\section{Economic Impacts}

- The expenditures of the ethanol plants will become the income of other businesses or individuals, which in turn is re-spent in the economy to provide income for others

- The initial economic activity has a multiplier effect that ripples through the economy

- Economic impact analysis is an analytical method that provides a measure of the economic effects of an activity within a specified region

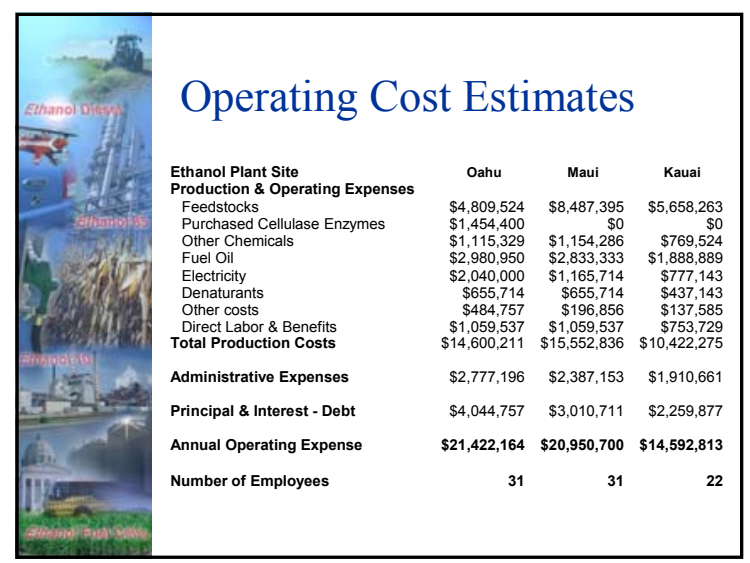

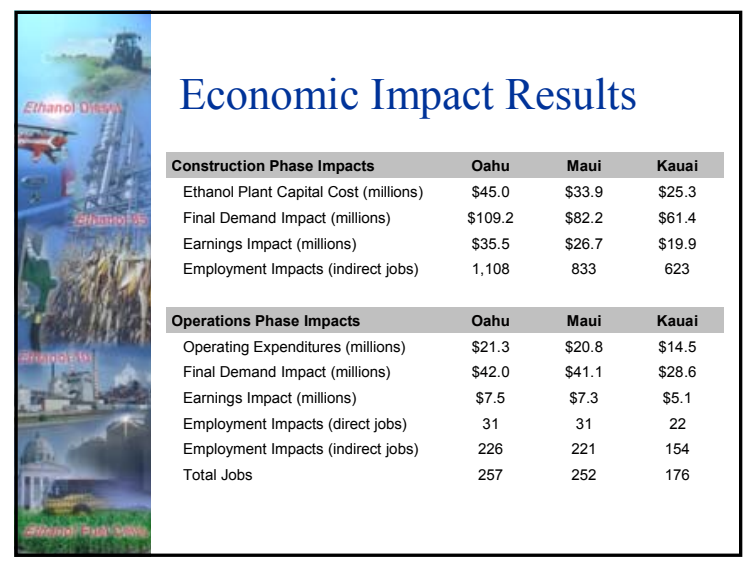

\section{Tax Impacts}

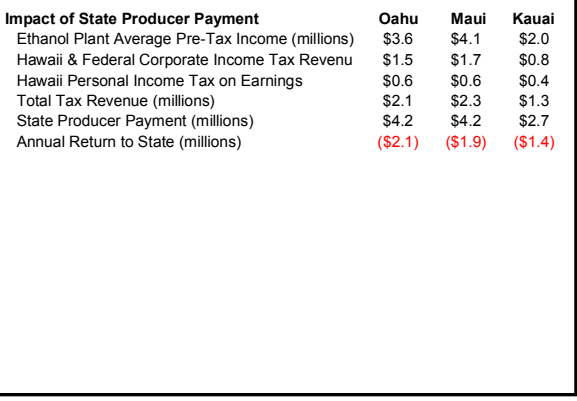

\section{Impacts to Fuel Refining and} Distribution Systems

- Dr. Joseph Masin conducted a study to determine the capital and operating cost impacts of blending fuel grade ethanol with gasoline in Hawaii

- Ethanol is assumed to be manufactured in Hawaii and blended with gasoline at $10 \%$ by volume 

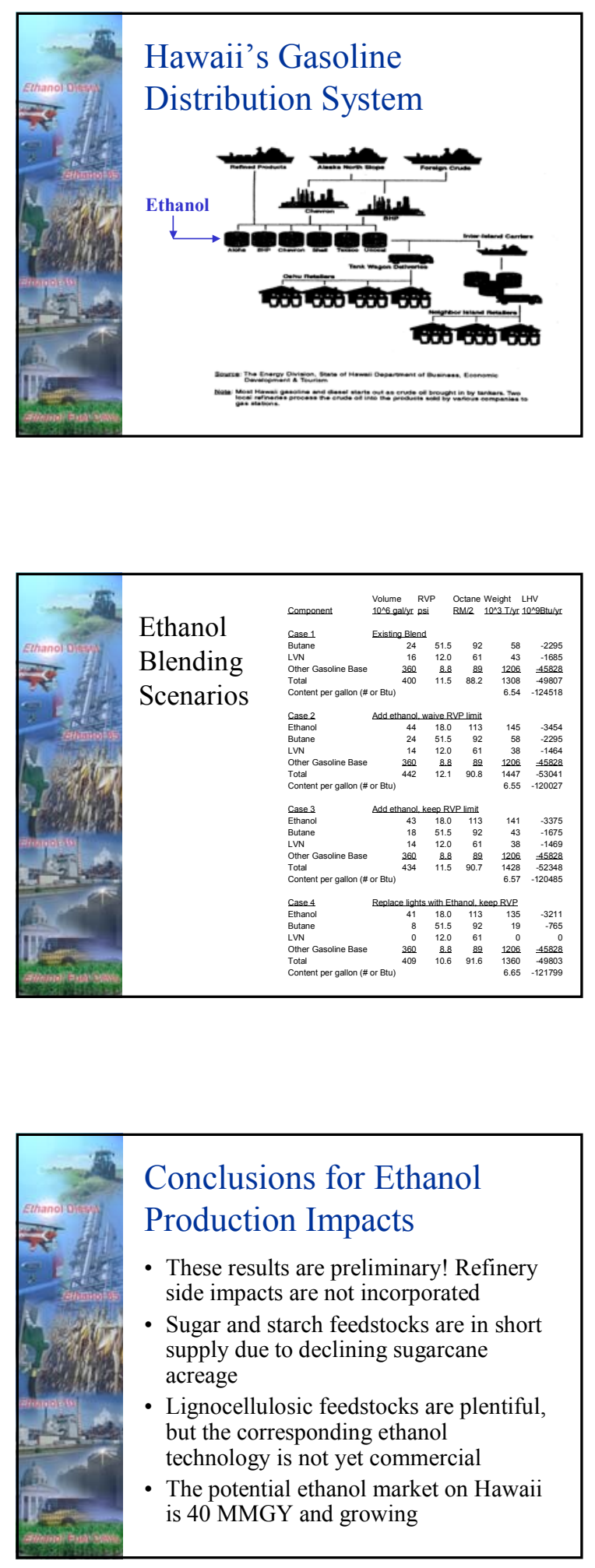

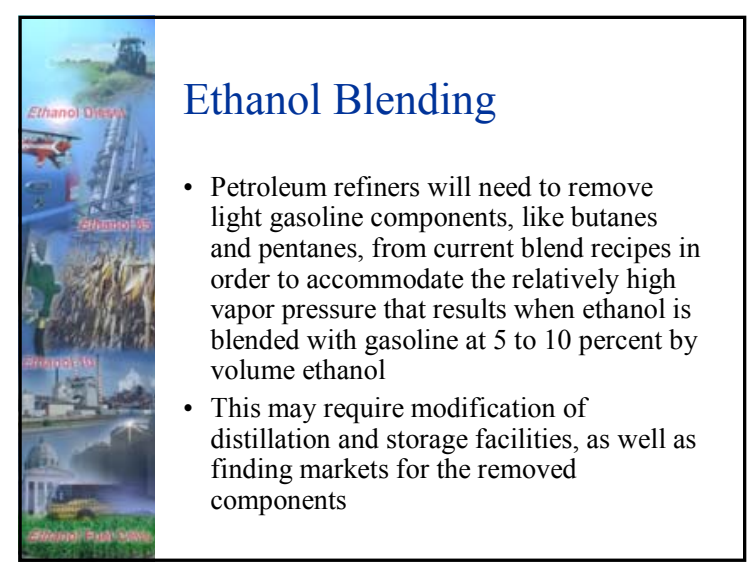

\begin{tabular}{|c|c|c|c|c|}
\hline Ehano of of & \multicolumn{4}{|c|}{$\begin{array}{l}\text { Summary of Refinery and } \\
\text { Fuel Distribution Impacts }\end{array}$} \\
\hline (3) & $\begin{array}{l}\text { Ethanol Blending } \\
\text { Description } \\
\text { Vapor Pressure (psi) * } \\
\text { Refiner's Capital Costs (\$MM) } \\
\text { Additional Labor (FTE) } \\
\text { Net Refiner Revenue (\$/gal) } \\
\text { Net Decrease in Energy (\$/gal) } \\
\text { Net Savings with Ethanol (\$/gal) }\end{array}$ & 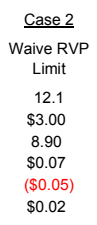 & $\begin{array}{c}\underset{\text { Case 3 }}{\text { Keep RVP }} \\
\text { Limit } \\
11.5 \\
\$ 4.30 \\
8.30 \\
\$ 0.06 \\
(\$ 0.05) \\
\$ 0.01\end{array}$ & $\begin{array}{c}\text { Case } 4 \\
\text { Replace } \\
\text { Lights with } \\
\text { Ethanol } \\
10.6 \\
\$ 5.70 \\
8.60 \\
\$ 0.02 \\
(\$ 0.03) \\
(\$ 0.01)\end{array}$ \\
\hline & Vapor pressure limit for gasoline in & aii is $11.5 \mathrm{psi}$ & & \\
\hline
\end{tabular}




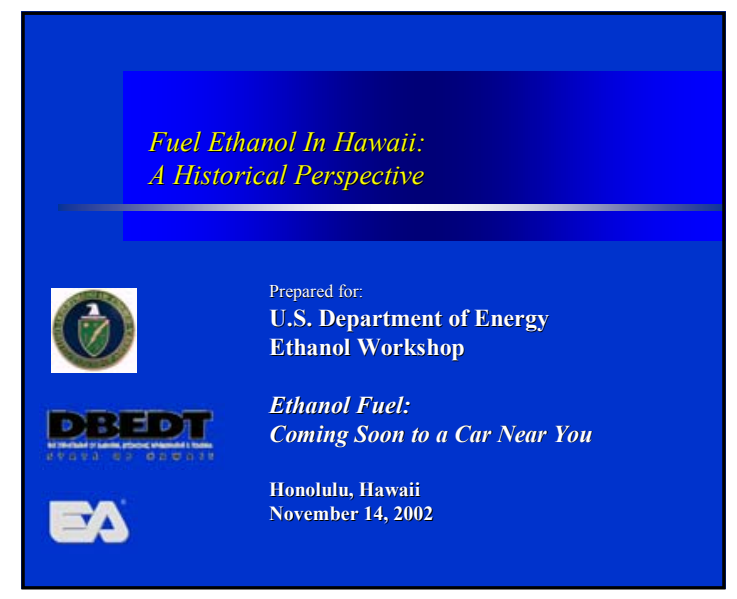

\section{Historical Perspective}

- Early ethanol fuel use

- Notable non-fuel uses

- Chronology of ethanol fuel use

- Past problems experienced in Hawaii

- Typical types of problems reported

- Possible causes and solutions

- Simple steps to eliminate problems

\section{Early Ethanol Fuel Use}

- Maui Agriculture Co. (Paia mill) built the first distillery in U.S. to produce ethanol from molasses for fuel use in 1917 !

- Ethanol used to operate cars, trucks, and camp stoves during WWI.

- Continued to use ethanol fuel until 1922(?) when gasoline and kerosene supplies became cheaper and more consistent.

\section{Chronology of Ethanol Fuel Use}

- Worldwide oil shortages causes gasoline prices to skyrocket in 1970 s.

- Midwestern farmers focus on using corn to produce ethanol as a gasoline "extender."

- Various studies in Hawaii focus on using ethanol from molasses to accomplish same thing.

- Local sugar industry is optimistic and invests heavily into research in this area.

- HSPA (now HARC) studies indicate profitability of producing ethanol from molasses will rely heavily on government incentives.

\section{Notable Non-Fuel Uses}

- Seagram's constructs a distillery at HC\&S Puunene (Maui) to produce rum in 1963. Rum is sold under the Leilani brand.

- Distillery closes in 1969.

- A\&B acquires distillery in 1976.

- A\&B sells facility to Maui Distillers in 1980 to produce "Hana Bay" and "Whaler's" brand rum.

- Closed in 1986.

- Hawaiian brand rums still exist today.

\section{Chronology of Ethanol Fuel Use}

- Aloha Petroleum imports ethanol to blend with gasoline and begins marketing "gasohol" in 1979.

- Hawaii is a national leader by being one of the first locations to offer gasohol to the general public.

- Customer problems attributed to gasohol arise immediately. (Discussed in more detail later)

- In 1979, A\&B and Maui Distillers agree to reopen Maui distillery to produce ethanol for both fuel and alcoholic beverages. 


\section{Chronology of Ethanol Fuel Use}

- In 1980 , the legislature contemplates a $\$ 0.06$ per gallon tax to underwrite construction of a $\$ 40$ million fuel ethanol plant. Proposal goes nowhere.

- C. Brewer (now BEI) completes a feasibility study in March 1981 to build an 11.4 million gallon per year molasses to ethanol plant on Big Island.

Plans to build the facility continue to move ahead

- Nationally, average retail gasoline prices peak at $\$ 1.94$ per gallon in 1981

\section{Chronology of Ethanol Fuel Use}

- State demonstrates a $10 \%$ ethanol blend in DAGS fleet in early 1981.

- Conducted between February and May 198

- Involved 127 vehicles (1972 to 1980 model years)

- Over 348,000 miles

- No unusual problems noted

- Average national gasoline prices begin to drop in 1982.

\section{Chronology of Ethanol Fuel Use}

- Aloha Petroleum discontinues their 2.5 year-old gasohol program in 1982.

- Weak demand and less overall interest spur decision

- Overall program was not doing well financially.

- By 1984, the average national gasoline price had dropped over $22 \%$ from the 1981 peak.

- C. Brewer decides to cancel plans to build Big Island ethanol plant in 1984.

- Unable to finalize long-term ethanol purchase agreement with local refineries

- Unable to justify investment since they do not directly market gasoline

\section{Chronology of Ethanol Fuel Use}

- Pacific Ethanol Products builds a small ethanol production facility on Oahu in 1985.

- Molasses obtained from Oahu Sugar.

- Completed by end of 1985 to obtain federal tax credits.

- Nationally, U.S. EPA mandated phase-down of lead levels in gasoline reaches 0.1 gram per gallon. Alternative octane enhancers, including ethanol, gain favor.

- In 1986, Aloha Petroleum imports ethanol to blend and market an "ethanol-enhanced" unleaded fuel.

\section{Chronology of Ethanol Fuel Use}

- State again demonstrates a $10 \%$ ethanol blend in the DAGS fleet in late 1986

- Uses only Hawaii-produced, molasses-derived ethanol from Pacific Ethanol Products.

- Problems with vapor lock on about $1 \%$ of fleet every week

- Vapor pressure of blend was found to be excessive. Can be corrected with proper blending.

- By 1987, national average gasoline price had dropped to $\$ 1.10$ per gallon.

\section{Chronology of Ethanol Fuel Use}

- By the late 1980s, Pacific Ethanol Products was the only entity offering ethanol for fuel blending in state.

- Many of the economic incentives driving the production of ethanol in Hawaii were gone.

- Due to naturally clean air, Hawaii was no mandated to reduce $\mathrm{CO}$ emissions through use of oxygenates (e.g., ethanol, MTBE)

- National average gasoline price was under $\$ 1.06$ per gallon by 1993 
Past Problems Experienced in Hawaii

- There were problems reported by automotive service technicians believed to be related to the use of gasoline blended with ethanol.

- Mostly anecdotal.

- Controlled studies showed few of these same problems (e.g., State DAGS fleet, 1981).

- Very few problems ever reported regarding engine power, mileage, or performance.

- Similar problems were initially seen in other U.S. mainland locations and have been overcome.

\section{Possible Causes and Solutions}

- Deterioration of rubber components in carburetors, fuel lines, and fuel pumps.

- Appeared to only affect certain makes and models of vehicles.

- Components in newer vehicles have been updated and are fully compatible.

- All vehicle warranties now cover use of ethanol blended fuel.

- Most older cars have already had these parts replaced with newer materials.

\section{-}

\section{Typical Types of Problems Reported}

- Deterioration of rubber components in carburetors, fuel lines, and fuel pumps.

- Fuel filter plugged with debris.

- Vapor lock.

- Water in fuel line

\section{Possible Causes and Solutions}

- Fuel filter plugged with debris.

- No evidence that ethanol contained debris

- Ethanol has inherent solvent and detergent qualities. If any system is dirty (i.e., vehicle fuel system, UST at dispensing location, transport truck, etc.), the addition of ethanol may loosen and suspend this debris

- Fuel systems on newer vehicles very clean

- More detergents being used in gasoline now than previously.

- Filter is doing its job.

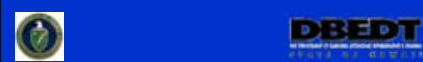

\section{Possible Causes and Solutions}

- Vapor lock.

- Can be caused by high vapor pressure or a high vapor/liquid ratio of the fuel.

- Ethanol has a high vapor pressure and raises the vapor pressure of the blended fuel.

- Current formulation of gasoline refined in Hawaii has a vapor pressure too high to allow direct blending with ethanol without exceeding the U.S. EPA maximum vapor pressure parameter.

- Blending ethanol with gasoline refined in Hawaii would necessitate refiners to reformulate the vapor pressure or their gasoline.

\section{Possible Causes and Solutions}

- Water in vehicle fuel line

- Water may have come from vehicle's fuel tank or the gasoline UST.

- Water in vehicle's fuel tank Extremely rare to have water in fuel system in newer vehicle.

If older vehicle has water in fuel tank, addition of ethanol may move water into fuel line. 


\section{Possible Causes and Solutions}

- Water in vehicle fuel line (continued)

- Water in gasoline UST

Older gasoline USTs may have contained water. This water

may have mixed with the ethanol and caused water to be

transferred to vehicle.

Hawaii Department of Health UST program became

the much higher degree than before.

Critical that USTS must be free of water before ethanol blends are added. However, once UST is free of water ethanol blend will keep UST water free.

Normal practice now to place a filter on dispensing pump to prevent transfer of any free water in UST to vehicle. This was not a common practice previously.

\section{Ethanol In Perspective...}

Then and Now

THEN

- Used as a gasoline "extender"

- Octane boost came from lead

- Very few concerns of gasoline's effect on air quality

- Very little experience with ethanol blends

- Vehicle manufacturers generally not supportive

\section{Simple Steps to Eliminate Problems}

- Be certain that gasoline USTs are free of any free water before being used for ethanol blends.

- Work with refiners to obtain gasoline with the correct vapor pressure so that ethanol can be blended without exceeding U.S. EPA maximums.

- Install filters on dispensing pumps to remove free water.

- Be prepared to replace some rubber seals, etc. on older and vintage vehicles.

Ethanol In Perspective..

Then and Now

NOW

- Used as a gasoline extender, oxygenate, and octane booster

- Used in more than 40 states

- ALL automobile manufacturers approve of use of E10

- Strong Federal and State support for reasons of economic and energy security

- Clearly defined handling and storage standards based on "real world" experience 


\section{Ethanol Fuel \\ for Hawait: \\ State Policy, \\ Incentives, and Mandate}

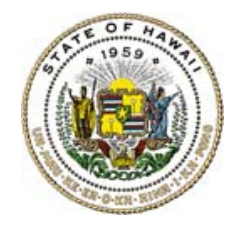

State of Hawaii

Department of Business, Economic Development \& Tourism

Energy, Resources, and Technology Division

www.state.hi.us/dbedt/ert

Maurice H. Kaya, Administrator

\section{State Laws Supporting Fuel Ethanol}

- Ethanol production credit

- Exemption from $4 \%$ state excise tax on retail sales

- Reduced highway taxes on E85

- Ethanol content requirement

\section{State Tax Credit for Investment in} Ethanol Production Facilities

- Equivalent to 30 cents per gallon of fuel-grade ethanol produced

- Credit for up to 15 million gallons / year / facility

- Available up to 8 years if investment was less than $\$ 50$ million; up to 10 years for investment greater than $\$ 50$ million

- Facility must be in Hawaii and in production before January 1, 2012.

- www.state.hi.us/dbedt/ert/ethanol-incentive.html

\section{Exemption from $4 \%$ state excise tax on retail sales for alcohol fuels}

- Fuel mixture consisting of at least $10 \%$ biomass-derived alcohol

- Applies to E10 and E85

- Exemption terminates on December 31, 2006

- www.capitol.hawaii.gov

(find Hawaii Revised Statutes section 237-27.1)

\section{Reduced Rate of State Highway Tax}

- Alternative fuels are subject to one-half the effective state highway tax rate of diesel fuel

- Applies to E85

- Does not apply to E10 or oxydiesel

- www.state.hi.us/dbedt/ert/fueltax-act143.html

\begin{tabular}{|l|cc|cr|cr|rr|}
\hline \multicolumn{6}{|c|}{ State plus County taxes for on-highway use of alternative fuels: } \\
\hline & Honolulu & \multicolumn{2}{c|}{ Maui } & Hawaii & \multicolumn{2}{c|}{ Kauai } \\
\hline Ethanol (E100) & $\$$ & 0.094 & $\$$ & 0.084 & $\$$ & 0.072 & $\$$ & 0.084 \\
\hline Gasoline & $\$$ & 0.325 & $\$$ & 0.290 & $\$$ & 0.248 & $\$$ & 0.290 \\
\hline
\end{tabular}

States with 10 or more years of fuel ethanol use

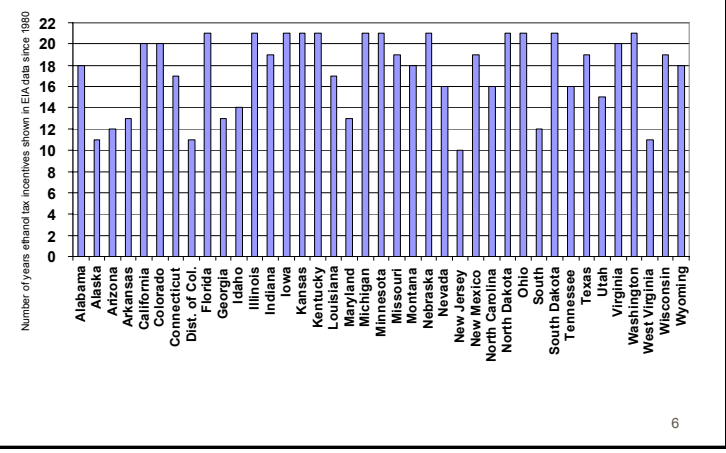




\section{Fuel ethanol on the Mainland}

- On the Mainland, "independent" gasoline stations were the first to offer E10.

- Adding $10 \%$ ethanol to gasoline:

- raises octane 3 points

- raises vapor pressure (RVP) 1 pound / sq. in. (psi)

- EPA imposed summertime volatility limits of 7.0-9.0 psi in all areas of the U.S. - except Alaska and Hawaii

- EPA allows a 1.0 psi "volatility waiver" for gasoline ethanol blends - but it does not apply in Hawaii

\section{Summertime vapor pressure limits *}

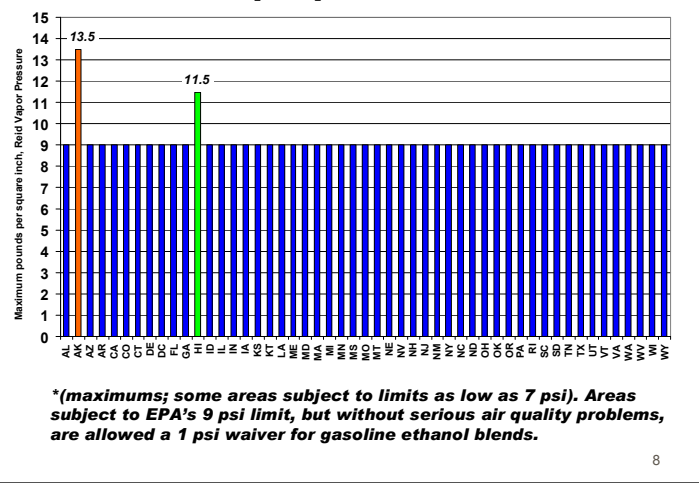

\section{Why no fuel ethanol in Hawait?}

- According to ASTM specification D4814, Hawaii is volatility class " $C$ " all year: gasoline may not have a RVP (Reid vapor pressure) greater than 11.5 pounds per sq.in.

- Gasoline testing report in 1989 showed that vapor pressures ranged from 9.7 to $11.4 \mathrm{psi}$.

- Adding ethanol to gasoline near the 11.5 psi limit would result in out-of-spec fuel

- To blend ethanol in Hawaii, refiners would have to produce a suitable blendstock

- Bottom line: in Hawaii, refiner participation is necessary.

\footnotetext{
Hawaii Ethanol History (abridged)

1984 C. Brewer cancels plans to construct an ethanol plant on the Big Island. According to their press release, " ... we cannot invest $\$ 15$ million in capital to produce a product we cannot be assured of marketing ....

1991 "Ethanol blending letter" sent to refiners \& gasoline retailers asking: "for ethanol/gasoline blends to becould have to be

1992 Meeting of energy \& agriculture people to see if there are ethanol \& electricity opportunities at Hamakua.

994 Numerous articles on "ethanol will (or won't) help save sugar."

1994 Ethanol Content Requirement signed into law. The law states: "DBEDT shall adopt rules ... to require that gasoline ... contain $10 \%$ ethanol... " National Energy Policy Act requires centrally-fueled State fleets on Oahu to

purchase alternative fuel vehicles.
"Transportation Energy Strategy" completed. Various approaches considered. E10 recommended as cost-effective approach

Oil company representatives say "we're energy companies," will blend ethano if the price is right, mandate is not necessary.

Ethanol production incentive signed into law. Incentive is 30 cents per gallon of fuel grade ethanol.

2002 Several ethanol producers are ready to start construction of ethano production facilities in Hawaii. Ethanol production expected in 2004
}

\section{\$486J-10 (a) - Ethanol Content Requirement}

- The commissioner shall adopt rules ... to require that gasoline sold in the State for use in motor vehicles contain ten per cent ethanol by volume.

- The amounts of gasoline sold in the State containing ten per cent ethanol shall be in accordance with rules as the commissioner may deem appropriate.

- The commissioner may authorize the sale of gasoline that does not meet these requirements as provided in subsection (d).

\section{$\S 486 \mathrm{~J}-10$ (b) and (c)}

(b) Gasoline blended with an ethanol-based product, such as ethyl tertiary butyl ether, shall be considered to be in conformance with this section if the quantity of ethanol used in the manufacture of the ethanol-based product represents ten per cent, by volume, of the finished motor fuel.

(c) Ethanol used in the manufacture of ethanol-based gasoline additives, such as ethyl tertiary butyl ether, may be considered to contribute to the distributor's conformance with this section; provided that the total quantity of ethanol used by the distributor is an amount equal to or greater than the amount of ethanol required under this section. 


\section{\$486J-10 (d) - Ethanol Content Requirement}

(d) The commissioner may authorize the sale of gasoline that does not meet the provisions of this section:

(1) To the extent that sufficient quantities of competitively-priced ethanol are not available to meet the minimum requirements of this section; or

(2) In the event of any other circumstances for which the commissioner determines compliance with this section would cause undue hardship.

\section{\$486J-10 (e) - Ethanol Content Requirement}

(e) Each distributor, at such reporting dates as the commissioner may establish, shall file with the commissioner, on forms prescribed, prepared, and furnished by the commissioner, a certified statement showing:

(1) The price and amount of ethanol available;

(2) The amount of ethanol-blended fuel sold by the distributor;

(3) The amount of non-ethanol-blended gasoline sold by the distributor; and

(4) Any other information the commissioner shall require for the purposes of compliance with this section.

\section{$\S 486 \mathrm{~J}-10$ (f), (g) and (h)}

(f) Provisions with respect to confidentiality of information shall be the same as provided in section 486J-7.

(g) Any distributor or any other person violating the requirements of this section shall be subject to a fine of not less than $\$ 2$ per gallon of nonconforming fuel, up to a maximum of $\$ 10,000$ per infraction.

(h) The commissioner, in accordance with chapter 91 , shall adopt rules for the administration and enforcement of this section.

\section{\$486J-1 - Definitions}

"Competitively priced" means fuel-grade ethanol for which the wholesale price, minus the value of all applicable federal, state, and county tax credits and exemptions, is not more than the average posted rack price of unleaded gasoline of comparable grade published in the State.

\section{\$486J-1 - Definitions}

"Distributor" means and includes:

(1) Every person who refines, manufactures, produces, or compounds fuel in the State, and sells it at wholesale or at retail, or who utilizes it directly in the manufacture of products or for the generation of power;

(2) Every person who imports or causes to be imported into the State or exports or causes to be exported from the State, any fuel; and

(3) Every person who acquires fuel through exchanges with another distributor.

\section{\$486J-1 - Definitions}

"Petroleum commissioner" or "commissioner" means the administrator of the energy, resources, and technology division of the department of business, economic development, and tourism. 


\section{Ethanol Content Requirement}

- Rules have not been finalized.

- Rulemaking takes several months.

- There is an opportunity for public input.

- If private companies can reach agreements that result in local production and availability of fuel ethanol, regulation may not be necessary.

\section{Summary}

- Incentives and mandates are in place to support the local production and use of fuel ethanol.

- Fuel ethanol is not currently available in Hawaii.

- We expect it to be available in 2004.

- Working together, we can make it happen.

- Thank you

Websites with More Information

- Hawaii State Energy Office: www.hawaii.gov/dbedt/ert

- Hawaii State Department of Taxation: www.hawaii.gov/tax

- Hawaii State Legislature: www.capitol.hawaii.gov 

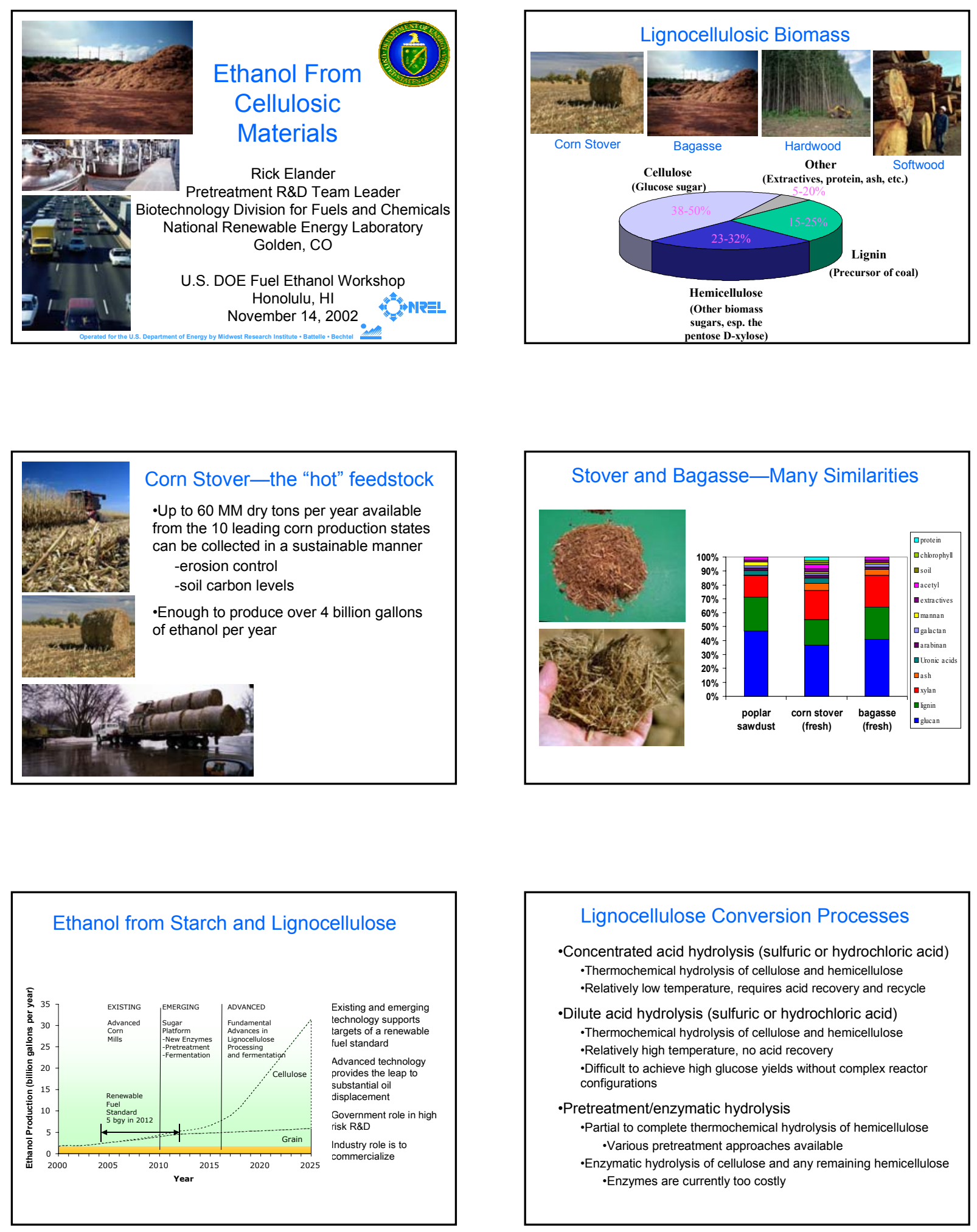

\section{Lignocellulose Conversion Processes}

- Concentrated acid hydrolysis (sulfuric or hydrochloric acid) -Thermochemical hydrolysis of cellulose and hemicellulose -Relatively low temperature, requires acid recovery and recycle

-Dilute acid hydrolysis (sulfuric or hydrochloric acid) -Thermochemical hydrolysis of cellulose and hemicellulose - Relatively high temperature, no acid recovery

-Difficult to achieve high glucose yields without complex reactor configurations

-Pretreatment/enzymatic hydrolysis

-Partial to complete thermochemical hydrolysis of hemicellulose -Various pretreatment approaches available

-Enzymatic hydrolysis of cellulose and any remaining hemicellulose -Enzymes are currently too costly 

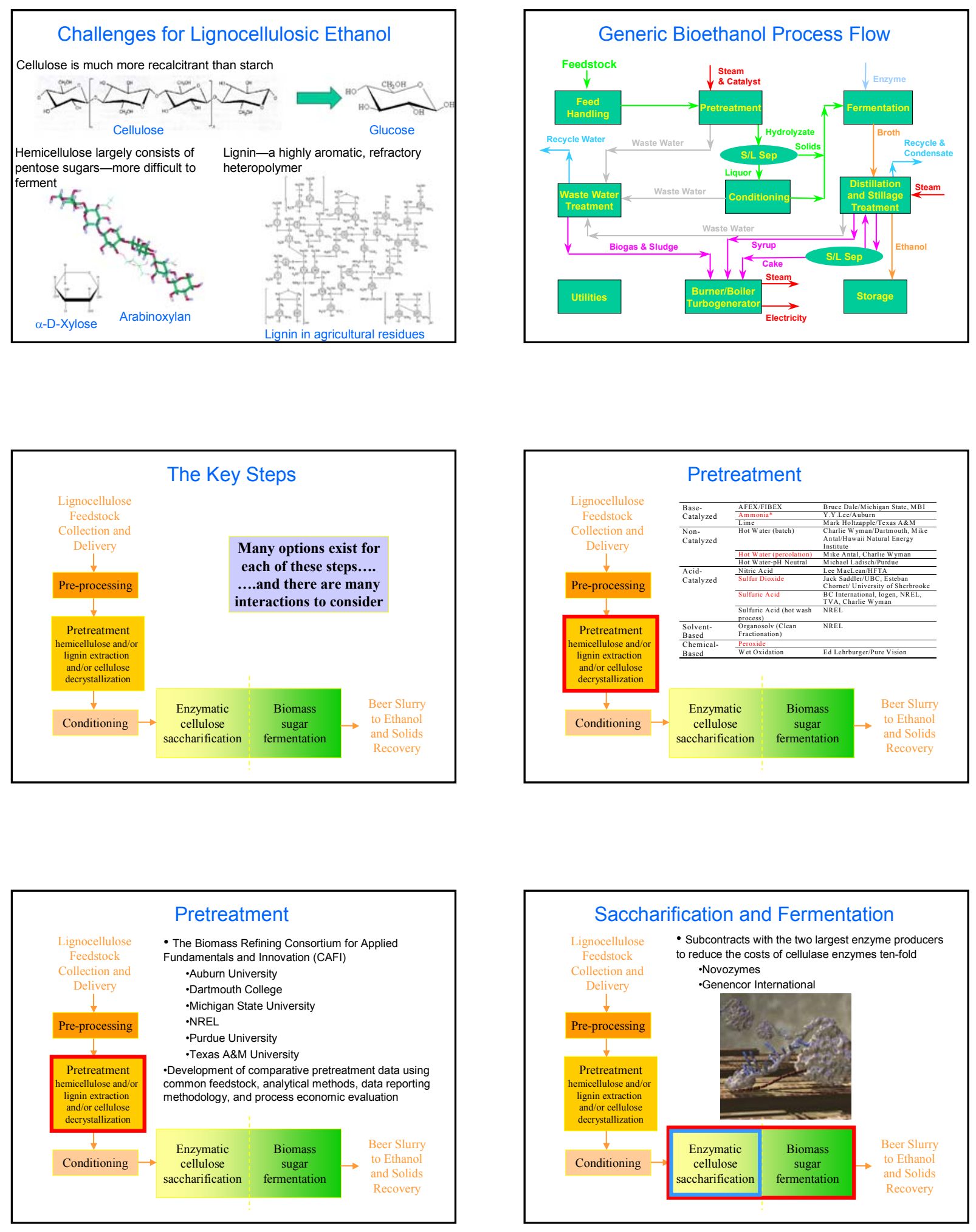

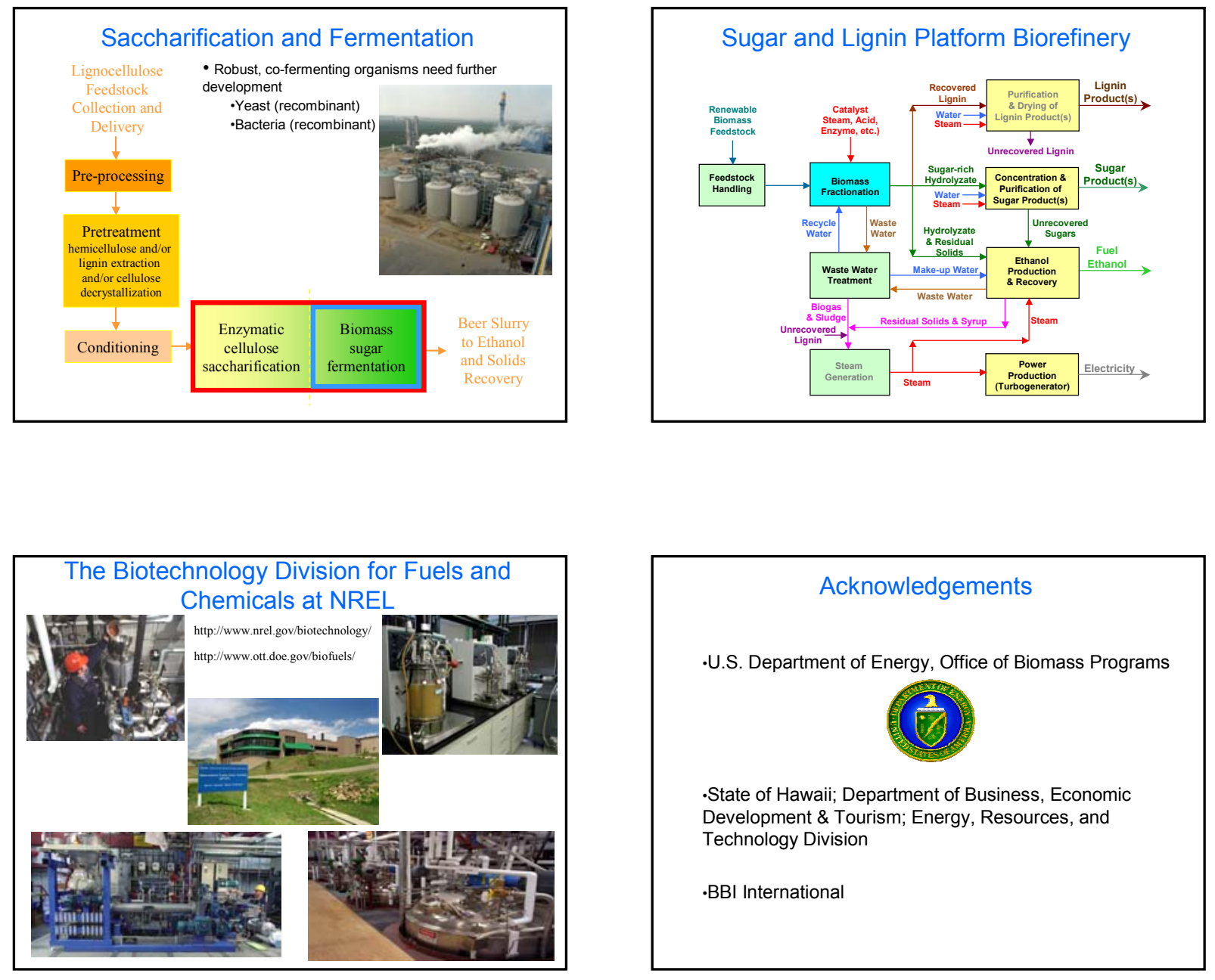

\section{Acknowledgements}

.U.S. Department of Energy, Office of Biomass Programs

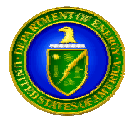

-State of Hawaii; Department of Business, Economic Development \& Tourism; Energy, Resources, and Technology Division

$\cdot \mathrm{BB}$ International 


\section{Ethanol from \\ Cane Molasses}

Jayant Godbole

PRAJ INDUSTRIES LTD.

PUNE, INDIA

DOE+BBI Hawaii Ethanol Workshop, November 14, 2002 Honolulu, Hawaii.

\begin{tabular}{|c|c|}
\hline PRA & PRAJ - Background \\
\hline • & Over 250 customers around the world. \\
\hline • & Over 60 distilleries attached to sugar mills. \\
\hline ' & $\begin{array}{l}\text { Fermentation process using cane molasses, syrup } \\
\text { of sugarcane juice or mixture, grains, cassava etc. }\end{array}$ \\
\hline • & $\begin{array}{l}\text { Has mapped molasses characteristics by analyzing } \\
\text { more than } 1500 \text { cane molasses samples across the } \\
\text { world. }\end{array}$ \\
\hline www.pra.net & DOE+BBl: Hawail Ethanol Workshop, November 14, 2002, Honolulu \\
\hline
\end{tabular}

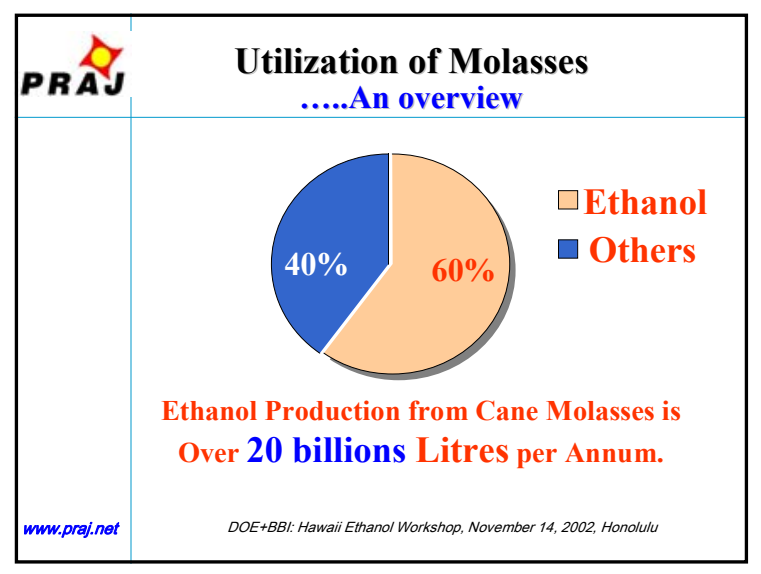

\begin{tabular}{|c|c|}
\hline PRAJ & Availability of Molasses \\
\hline www.praj.net & $\begin{array}{l}\text { Tropical Climatic Conditions Influence Many } \\
\text { Technical Aspects of Molasses to Ethanol } \\
\text { Fermentation. } \\
\text { Majority of Molasses to Ethanol Plants are } \\
\text { Concentrated in Tropical \& Sub-tropical } \\
\text { Regions. } \\
\text { India has more than } 200 \text { distilleries using cane } \\
\text { molasses. Other major producers od ethanol } \\
\text { from cane molasses are Thailand, Indonesia, } \\
\text { Philippines, Brazil, Guatemala, Mexico etc. } \\
\\
\text { DOE+BBl: Hawaii Ethanol Workshop, November 14, 2002, Honolulu }\end{array}$ \\
\hline
\end{tabular}




\begin{tabular}{|c|c|}
\hline PRA & $\begin{array}{c}\text { Factors Affecting } \\
\text { Composition of Molasses }\end{array}$ \\
\hline & $\begin{array}{l}>\text { Variety of cane } \\
>\text { Composition of soil } \\
>\text { Climatic conditions } \\
>\text { Harvesting practices } \\
>\text { Sugar manufacturing process } \\
>\text { Handling and storage }\end{array}$ \\
\hline www.praj.net & DOE+BBl: Hawail Ethanol Workshop, November 14, 2002, Honolulu \\
\hline
\end{tabular}

\begin{tabular}{|c|c|c|}
\hline PRAJ & \multicolumn{2}{|c|}{ Typical Composition of Molasses } \\
\hline & $\begin{array}{l}\text { - Total Solids } \\
\text { - Total reducing sugars } \\
\text { - Unfermentable Sugars } \\
\text { - Fermentable Sugars } \\
\text { - Total Inorganics } \\
\text { - Settlable dry sludge } \\
\text { - Specific Gravity } \\
\text { - Titrable volatile acidity } \\
\text { - pH at } 40 \text { deg. Diluion } \\
\text { - Caramel(OD) }\end{array}$ & $\begin{array}{l}: 75 \text { to } 88 \% \mathrm{Wt} \text {. } \\
: 44 \text { to } 60 \% \mathrm{Wt} \text {. } \\
: 4 \text { to } 5 \% \mathrm{Wt} \text {. } \\
: 40 \text { to } 55 \% \mathrm{Wt} \text {. } \\
: 8 \text { to } 12 \% \mathrm{Wt} . \\
:<3.5 \% \mathrm{Wt} . \\
: 1.38 \text { to } 1.52 \\
: 3000-20,000 \mathrm{ppm} \\
: 4.5 \text { to } 5.6 \\
: 0.2 \text { to } 0.6\end{array}$ \\
\hline www.praj.net & \multicolumn{2}{|c|}{ DOE+BBl: Hawail Ethanol Workshop, November 14, 2002, Honolulu } \\
\hline
\end{tabular}

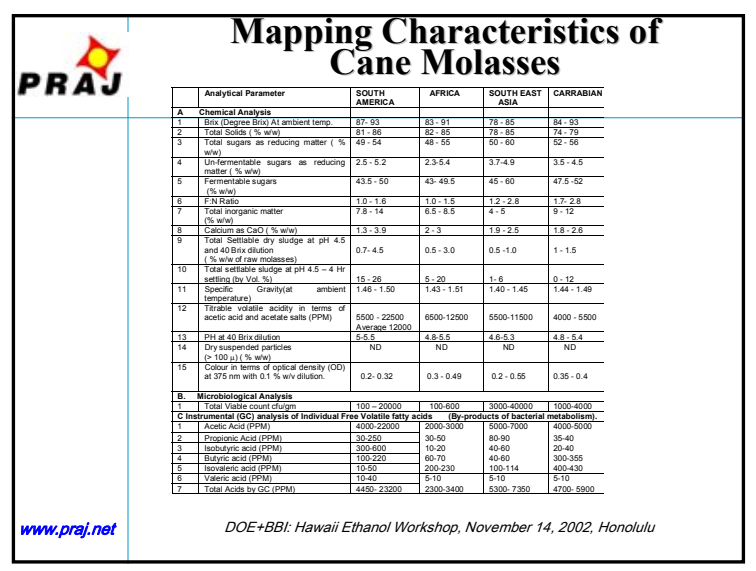

\begin{tabular}{|c|c|}
\hline \multicolumn{1}{|c|}{ R A J } & General observations about Cane \\
Molasses
\end{tabular}

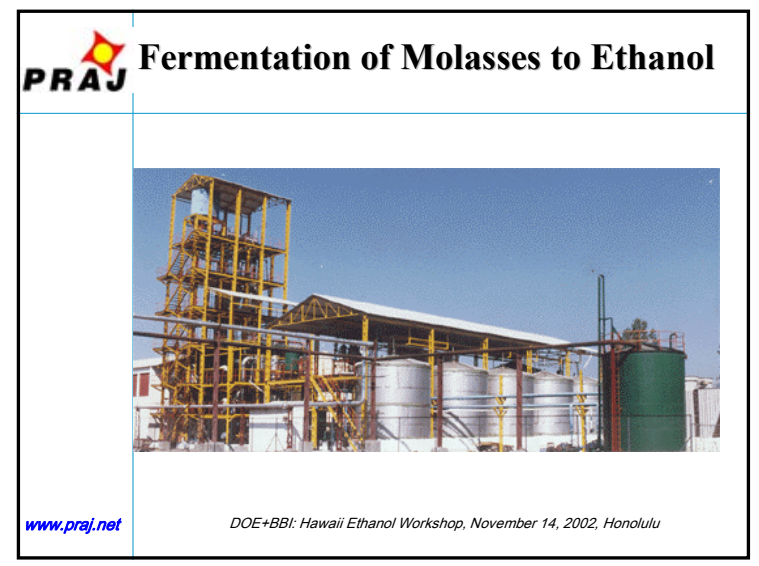

\begin{tabular}{|c|c|}
\hline PRAJ & What is Fermentation? \\
\hline whw.praj.net & $\begin{array}{l}\text { Fermentation of Sugar. } \\
\text { Fermentable sugar gets converted in to ethanol } \\
\text { with yeast as catalyst. } \\
\text { Reaction: } \\
\text { Di-saccharide -------------> Mono-saccharide } \\
\text { Mono-saccharide ----------> Ethanol + } \mathrm{CO}_{2} \\
\quad \text { Yeast } \\
\qquad O E+B B \text { : Hawail Ethanol Workshop, November } 14,2002 \text {, Honolulu }\end{array}$ \\
\hline
\end{tabular}




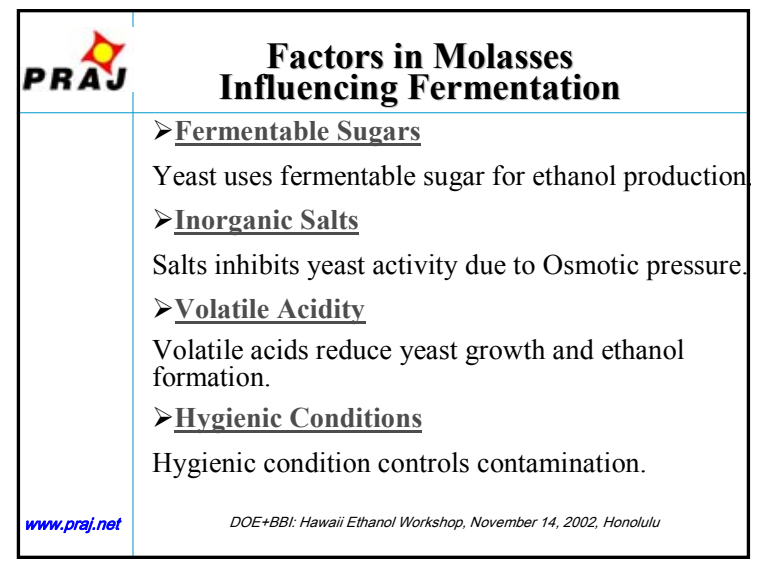

\begin{tabular}{|c|c|}
\hline PRA & $\begin{array}{c}\text { Composition of Molasses \& Effects } \\
\text { on Fermentation Kinetics }\end{array}$ \\
\hline www.praj.net & $\begin{array}{l}>\text { F:N ratio }<0.9 \text { retards fermentation rate by } \\
\text { average } 15-20 \% \\
>\text { Ash content above } 10 \% \text { can retard the rate of } \\
\text { fermentation by } 5-10 \% \text {. } \\
>\text { Extent of caramelization : (Measured as color } \\
\text { in OD units at } 375 \mathrm{~nm} \text { of } 0.1 \% \text { molasses } \\
\text { solution) }>0.40 \text { OD retards fermentation rate } \\
\text { by } 20-25 \% \text {. Reaction ceases beyond } 0.65 \text {. } \\
>\text { Volatile acids in mash }>2500 \text { ppm reduce the } \\
\text { rate of fermentation and yeast growth. } \\
\text { Volatile acids in mash }>5000 \text { ppm reduce } \\
\text { fermentation rate by } 30-40 \% \text {. } \\
\text { Volatile acids in mash }>7000 \text { ppm can kill } \\
\text { the yeast reducing viability up to } 40-50 \% \text {. } \\
\\
\text { DOE }\end{array}$ \\
\hline
\end{tabular}

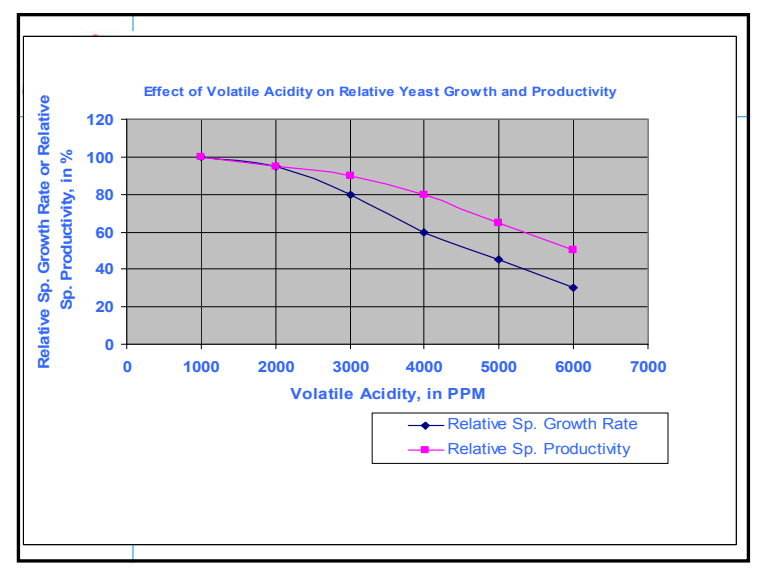

\begin{tabular}{|c|c|}
\hline PRA & Parameters For Fermentation \\
\hline & $\begin{array}{l}\text { Alcohol concentration in Mash. } \\
\text { Sugar \& Yeast Concentration in Mash. } \\
\text { Temperature \& pH of Mash. } \\
\text { Volatile acidity in Mash. } \\
\text { Residence Time In Fermentors. } \\
\text { Fermentation Efficiency. }\end{array}$ \\
\hline www.praj.net & DOE+BBl: Hawail Ethanol Workshop, November 14, 2002, Honolulu \\
\hline
\end{tabular}

\begin{tabular}{|c|c|}
\hline PRA & Fermentation Plant \\
\hline & $\begin{array}{l}\text { Main Sections: } \\
\text { Yeast Propagation. } \\
\text { Fermentation. } \\
\text { Yeast Separation and Recycle. } \\
\text { Sludge Separation. } \\
\text { Auxiliary Sections: } \\
\text { Handling \& distribution of Inputs. } \\
\text { Cooling System. } \\
\text { Acid, Nutrients, Antifoam Supply. } \\
\text { Cleaning in Place System. }\end{array}$ \\
\hline www.praj.net & DOE+BBl: Hawail Ethanol Workshop, November 14, 2002, Honolulu \\
\hline
\end{tabular}

\begin{tabular}{|c|c|}
\hline PRA & Continuous Fermentation.... \\
\hline www.praj.net & 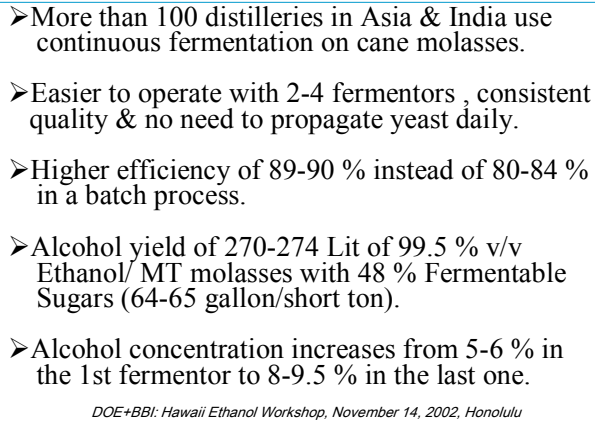 \\
\hline
\end{tabular}



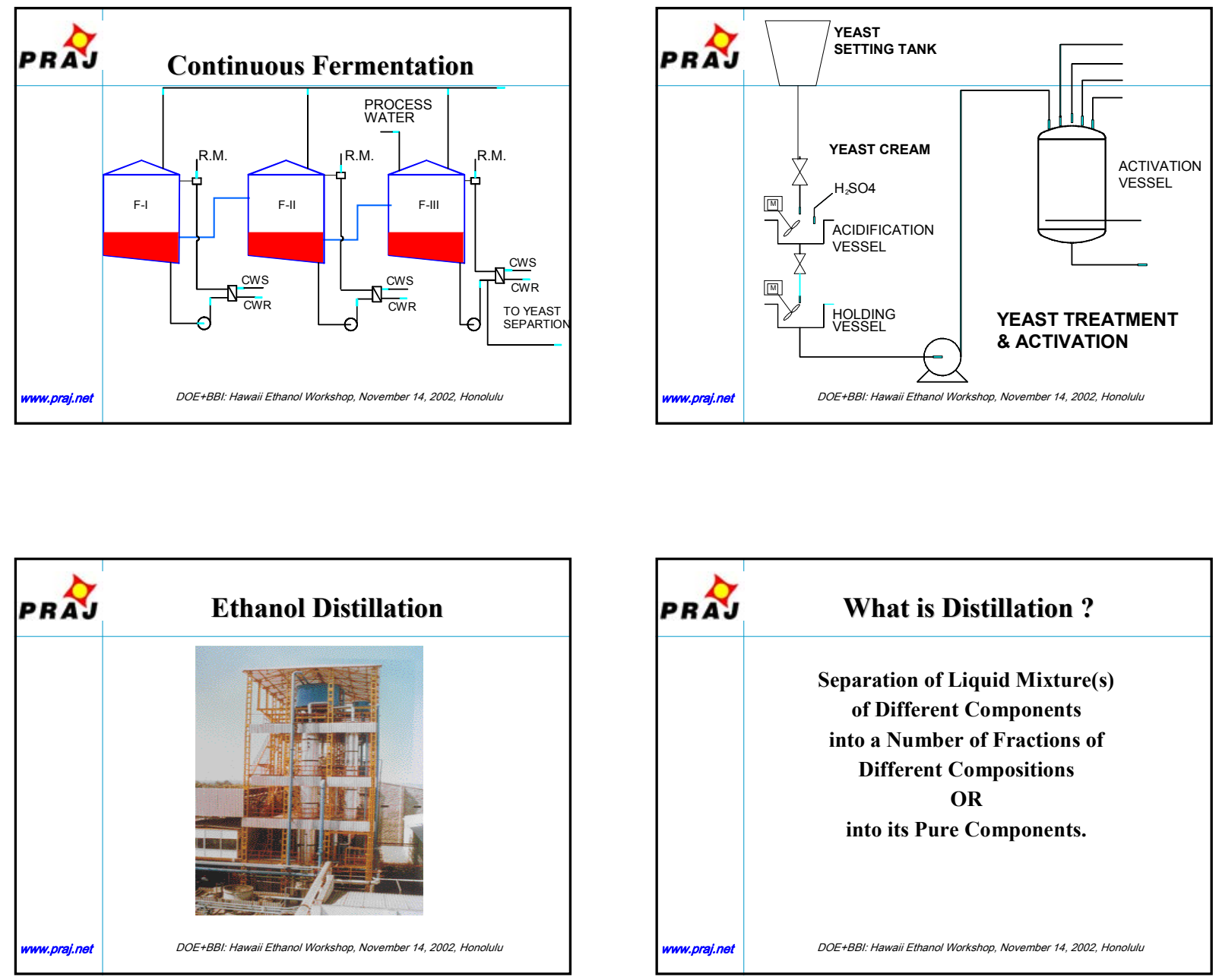

\begin{tabular}{|c|c|}
\hline $\boldsymbol{P R}$ AJ & What is Distillation ? \\
\hline & $\begin{array}{c}\text { Separation of Liquid Mixture(s) } \\
\text { of Different Components } \\
\text { into a Number of Fractions of } \\
\text { Different Compositions } \\
\text { OR }\end{array}$ \\
into its Pure Components. \\
wnw.pra.net
\end{tabular}

\begin{tabular}{|c|c|}
\hline PRA & Objective of Distillation \\
\hline & $\begin{array}{l}\text { Stripping of alcohol from Fermented Mash. } \\
\text { Concentration of stripped alcohol to } 95 \text { - } 96.5 \% \mathrm{v} / \mathrm{v} \\
\text { for industrial alcohol \& further concentration to } \\
99.5-99.8 \% \mathrm{v} / \mathrm{v} \text { in dehydration plant for ethanol. } \\
\text { Concentration of stripped Ethanol to } 96-96.5 \% \mathrm{v} / \mathrm{v} \\
\text { for Potable application. Separation of impurities } \\
\text { become prime importance. Achieved by controlling } \\
\text { Dilution \& Extraction } \\
\text { Temperature. } \\
\text { DOE+BBl: Hawail Ethanol Workshop, November 14, 2002, Honolulu }\end{array}$ \\
\hline
\end{tabular}

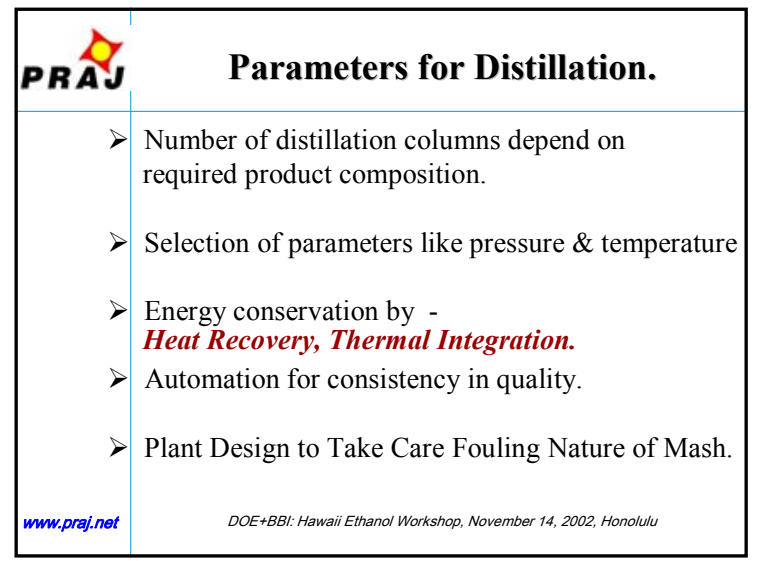




\begin{tabular}{|c|c|}
\hline PRAJ & Distillation Scheme Selection \\
\hline$>$ & $\begin{array}{l}\text { Energy cost being a significant potion of } \\
\text { operating cost, configuration is designed to } \\
\text { minimize energy. }\end{array}$ \\
\hline$>$ & Use of re-boilers to minimize volume of effluent. \\
\hline$>$ & $\begin{array}{l}\text { Using cascading pressure for integration of heat \& } \\
\text { saving in energy. }\end{array}$ \\
\hline$>$ & Automation to get consistent quality product. \\
\hline www.praj.net & DOE+BBl: Hawail Ethanol Workshop, November 14, 2002, Honolulu \\
\hline
\end{tabular}

\begin{tabular}{|c|c|}
\hline$P R \bar{A} \boldsymbol{J}$ & Effluent Treatment \\
\hline & $\begin{array}{c}\text { AN OVERVIEW OF } \\
\text { TECHNOLOGIES FOR TREATMENT OF } \\
\text { VINASSE FROM } \\
\text { CANE MOLASSDES DISTILLERIES }\end{array}$ \\
\hline www.praj.net & DOE+BBl: Hawail Ethanol Workshop, Novermber 14, 2002, Honolulu \\
\hline
\end{tabular}

\begin{tabular}{|c|c|}
\hline PRAJ & Multi-pressure Vacuum Distillation \\
\hline$>$ & Lower consumption of steam \\
\hline$>$ & $\begin{array}{l}\text { Multi-pressure vacuum configuration } \\
\text { eliminates problems of scaling in mash column }\end{array}$ \\
\hline$>$ & Consistently high quality of product \\
\hline$>$ & Higher degree of instrumentation and automation \\
\hline www.praj.net & DOE+BBl: Hawail Ethanol Workshop, November 14, 2002, Honolulu \\
\hline
\end{tabular}

\begin{tabular}{|c|c|}
\hline PRA & Objective For Effluent Treatment \\
\hline & $\begin{array}{l}\text { To ensure safe treatment of the organic part } \\
\text { of the effluent } \\
\text { To ensure safe and proper disposal of the } \\
\text { treated effluent. }\end{array}$ \\
\hline www.praj.net & DOE+BB: Hawail Ethanol Workshop, November 14, 2002, Honolulu \\
\hline
\end{tabular}

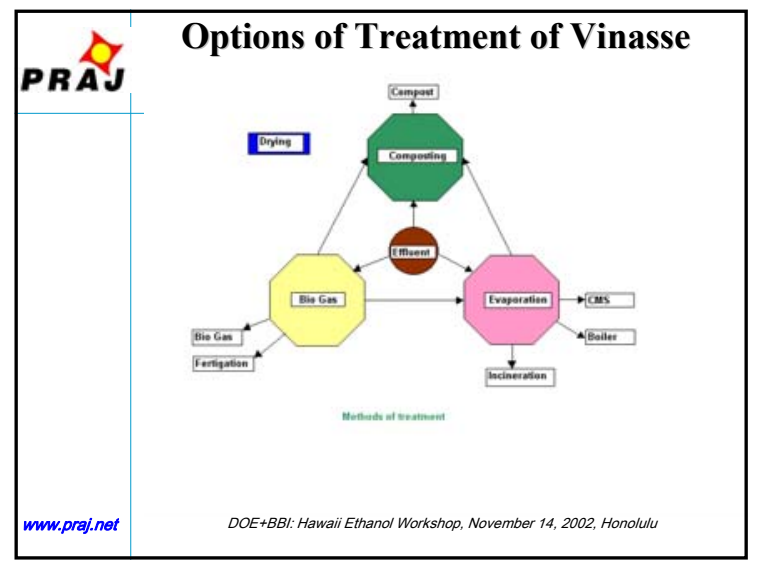




\begin{tabular}{|c|c|}
\hline PRAJ & Options / Schemes \\
\hline$\vec{\nu}$ & $\begin{array}{l}\text { Anaerobic Bio-Methanation followed by aerobic, } \\
\text { activated sludge treatment: almost } 80 \% \text { of the } \\
\text { energy requirement can be derived from vinasse. } \\
\text { Aerobic, Biological Composting. } \\
\text { Concentration and usage in Animal Feed (CMS). } \\
\text { Concentration and Incineration, with and without } \\
\text { Steam Generation. } \\
\text { Ferti - Irrigation with bio-methanated or with } \\
\text { partially evaporated vinasse. } \\
\text { Disposal in water bodies like river,lake or sea. }\end{array}$ \\
\hline www.praj.net & DOE+BBl: Hawail Ethanol Workshop, November 14, 2002, Honolulu \\
\hline
\end{tabular}

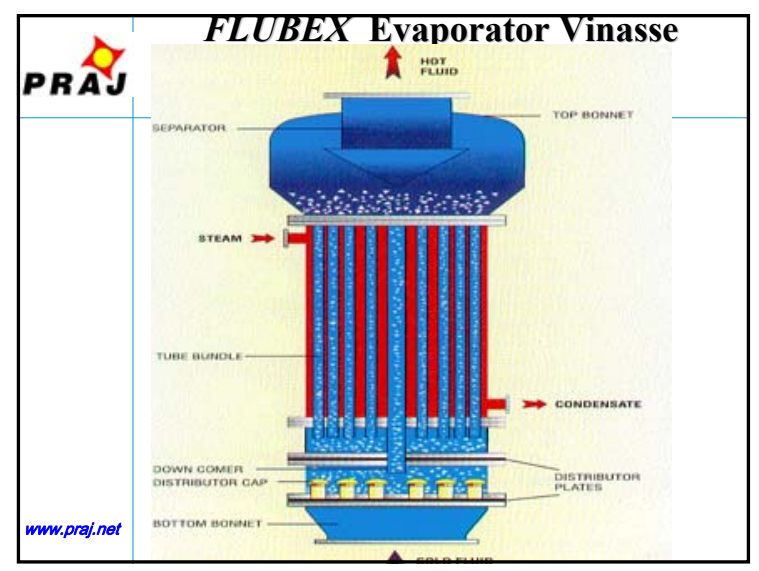

\begin{tabular}{|c|c|}
\hline PRAJ & Recycle of Vinasse \\
\hline www.praj.net & $\begin{array}{l}\text { When using cane molasses or juice syrup, up to } 50 \\
\% \text { of vinasse can be recycled. } \\
\text { Vinasse gets concentrated to } 25-30 \% \text { solids. } \\
\text { Careful process design required to avoid excessive } \\
\text { build-up of bacterial contamination. } \\
\begin{array}{l}\text { Aspects like content of calcium \& inorganic ash and } \\
\text { content of bacteria \& volatile acids need to be } \\
\text { considered carefully. }\end{array} \\
\text { DOE+BB: Hawail Ethanol Workshop, November } 14,2002, \text { Honolulu }\end{array}$ \\
\hline
\end{tabular}

\begin{tabular}{|c|c|}
\hline PRA & $\begin{array}{c}\text { Integration of } F L U B E X \text { Evaporator } \\
\text { with Distillation }\end{array}$ \\
\hline an rein & $\begin{array}{l}\text { Evaporation of Mash before distillation to } \\
\text { produce high wine } \\
\text { Vinasse gets concentrated to } 50 \% \text { solids } \\
\text { Use of vapors from Rectifier column under high } \\
\text { pressure to heat the evaporator } \\
\text { Steam consumption of }<3.7 \mathrm{~kg} / \text { lit }(31 \mathrm{lb} / \text { gallon) of } \\
\text { alcohol for evaporation }+ \text { distillation } \\
\text { System eliminates use of Mash column and thus } \\
\text { avoids related problems of scaling. }\end{array}$ \\
\hline www.praj.net & DOE+BBl: Hawail Ethanol Workshop, November 14, 2002, Honolulu \\
\hline
\end{tabular}

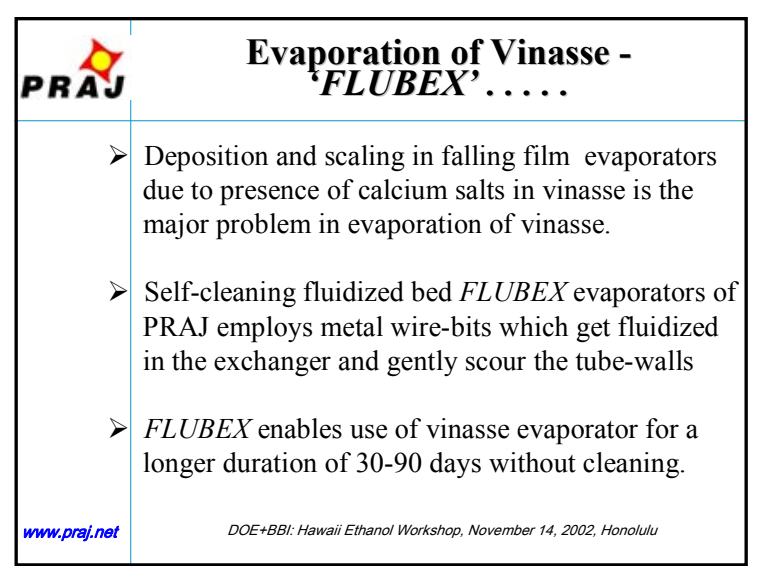

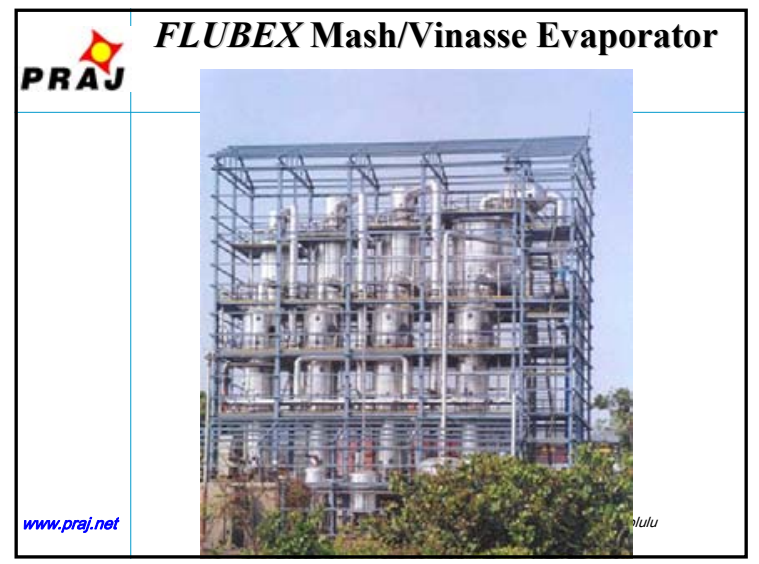



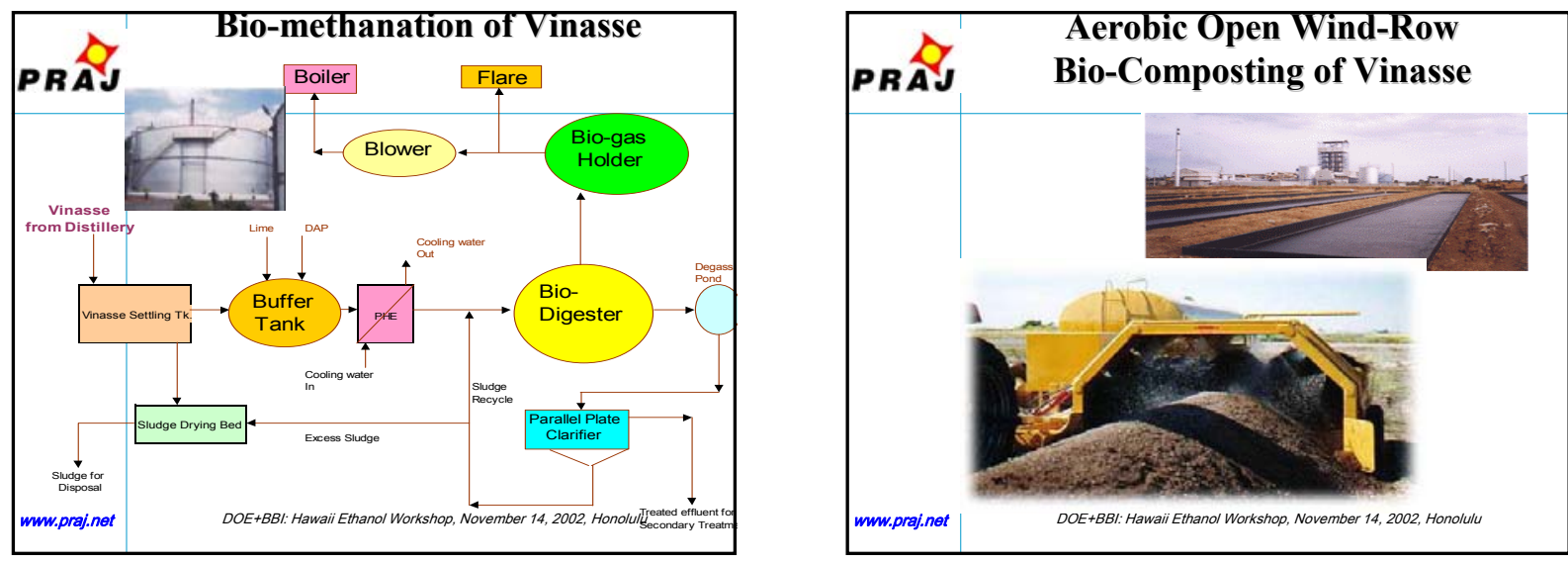

\begin{tabular}{|r|l|}
\hline \multicolumn{1}{|c|}{ Conclusions } \\
\hline$>$ & $\begin{array}{l}\text { Appropriate technologies at affordable project } \\
\text { investment are available for production of } \\
\text { ethanol from cane molasses. }\end{array}$ \\
& $\begin{array}{l}\text { Valuable energy and organic soil conditioner } \\
\text { compost can be produced by treatment of } \\
\text { vinasse. }\end{array}$ \\
\hline www.pra.net & $\begin{array}{l}\text { Variable cost of production will is between } \\
\text { US Cents 75-95/gallon, depending upon factors } \\
\text { like cost of molasses, technology used and the } \\
\text { choice of vinasse treatment. } \\
\text { DOE+BBl: Hawaii Ethanol Workshop, November 14, 2002, Honolulu }\end{array}$ \\
\hline
\end{tabular}

\begin{tabular}{|l|l|}
\hline INDUSTRIES \\
www. praj.net
\end{tabular}




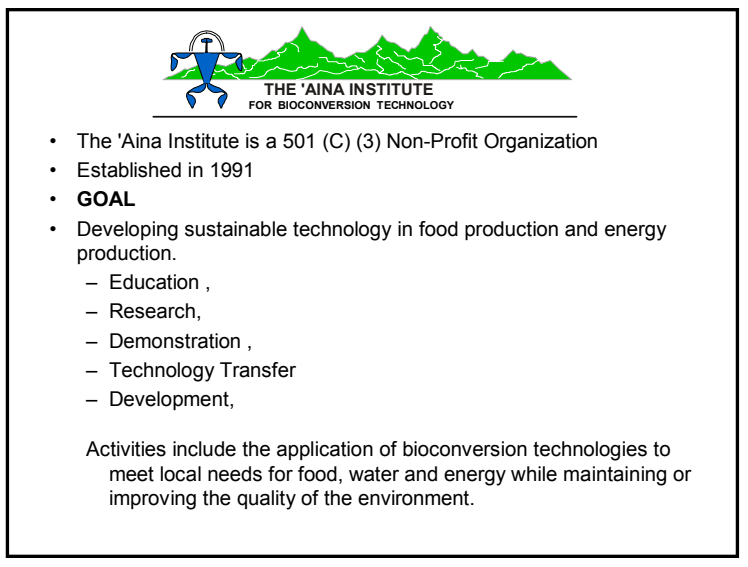

BIOMASS - ETHANOL BACKGROUND

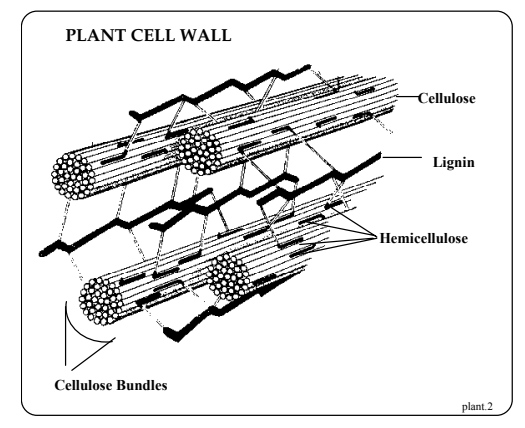

This is a discussion about:

ETHANOL TECHNOLOGY

\&

"Waste Our Most Sustainable Resource"

Wasting Waste is Wasteful !

\section{BIOMASS - ETHANOL BACKGROUND}

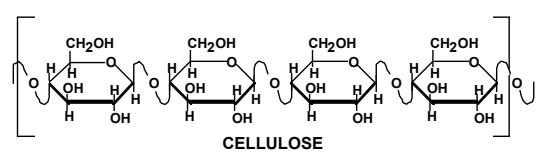

HYDROLYSIS

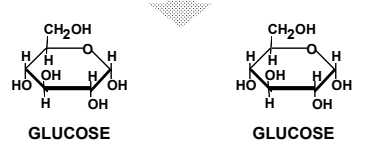

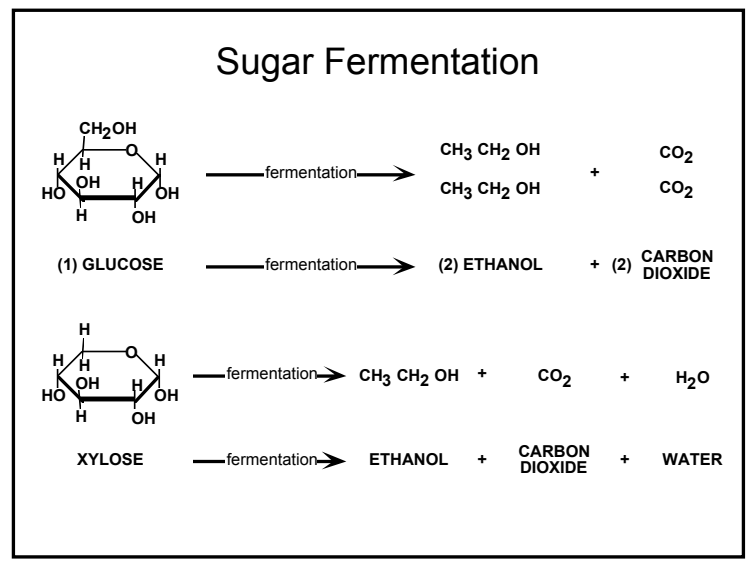

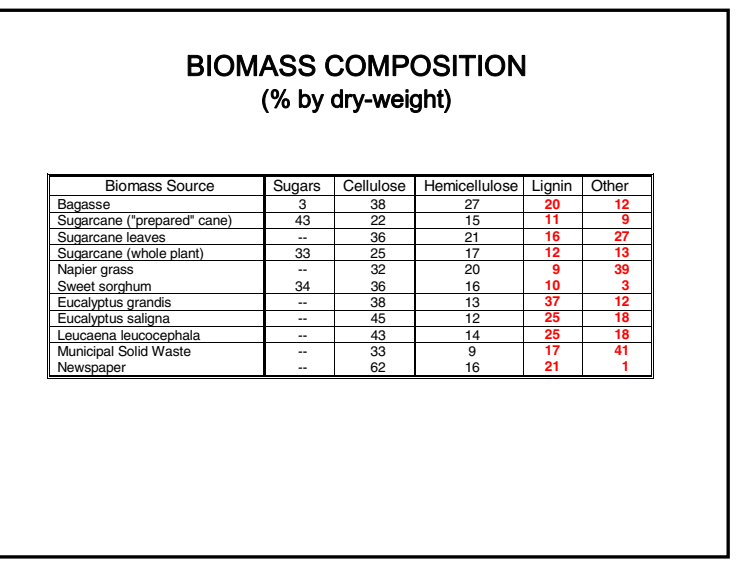



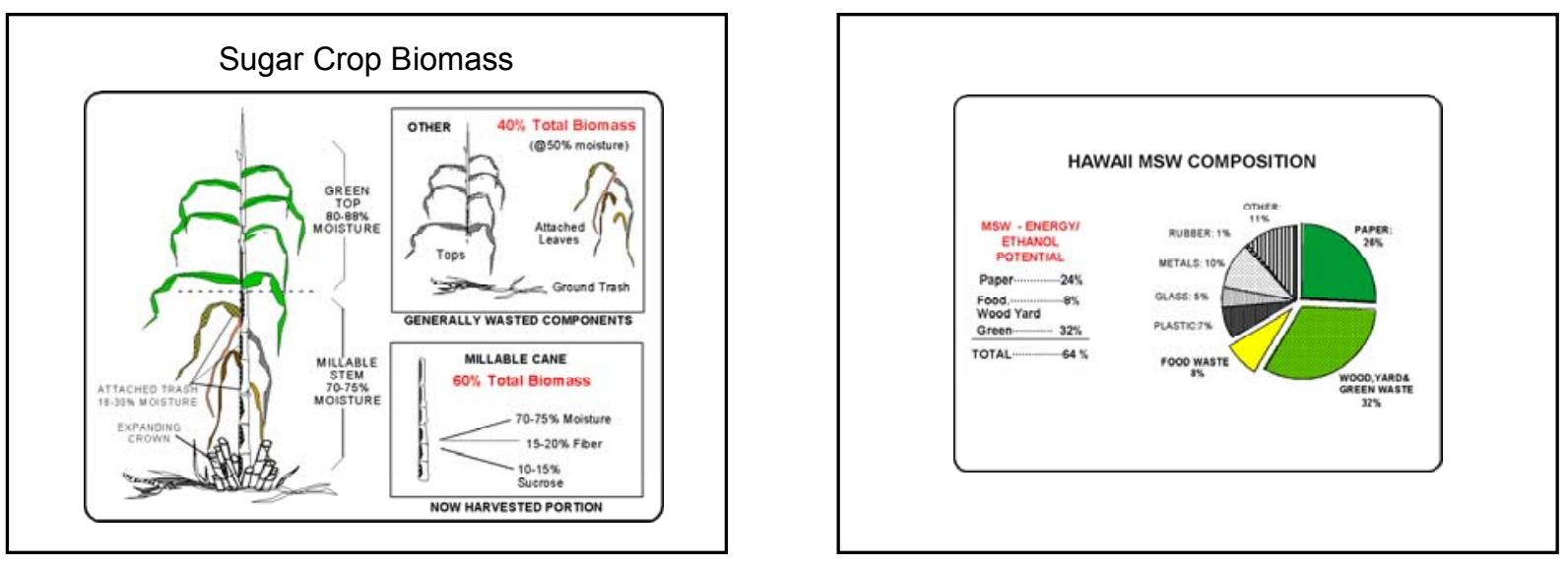

There are major opportunities to produce biomass from waste

\section{Hawaii Paper \&Green Waste}

- Producing Ethanol from sugar limits opportunities

- Producing Ethanol from corn seed alone limits opportunities

- Substantial research has focused on producing ethanol from biomass and wastes

- $\mathrm{CO}_{2}$ loss in fermentation reduces yields

- Enzyme cost and performance must be considered.

- Process costs and reliability are still major issues

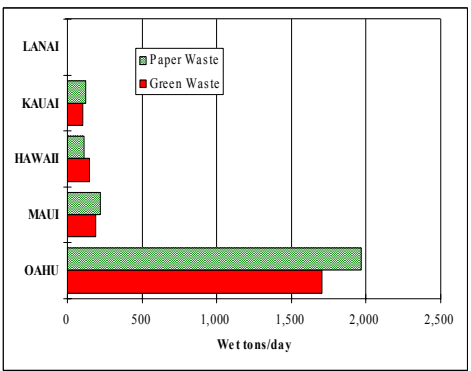

\section{TECHNOLOGY REVIEW}

- A Brief Survey of Biomass-Ethanol Technologies

- A Look at Present and Future Opportunities

SIMULTANEOUS SACCHARIFICATION and FERMENTATION

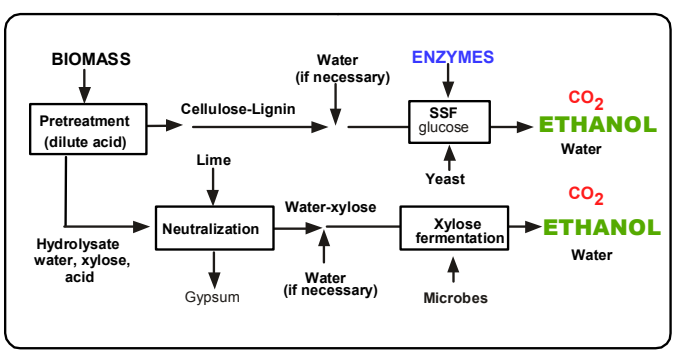


CONCENTRATED ACID HYDROLYSIS NUTRALIZATION \& FERMENTATION

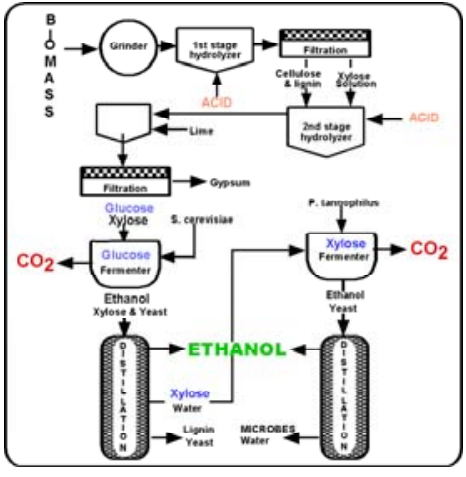

AMMONIA DISRUPTION HYDROLYSIS \& FERMENTATION

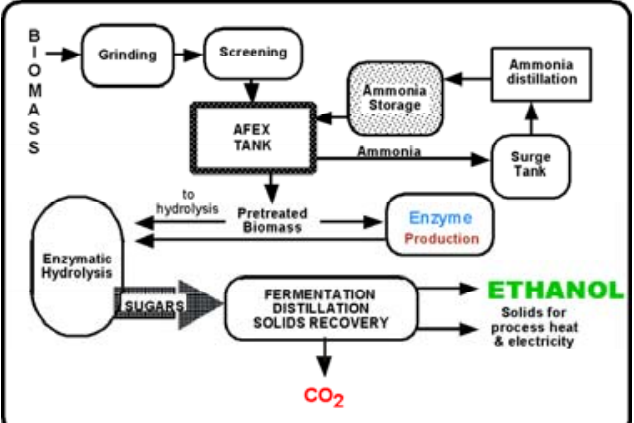

STEAM DISRUPTION HYDROLYSIS FERMENTATION
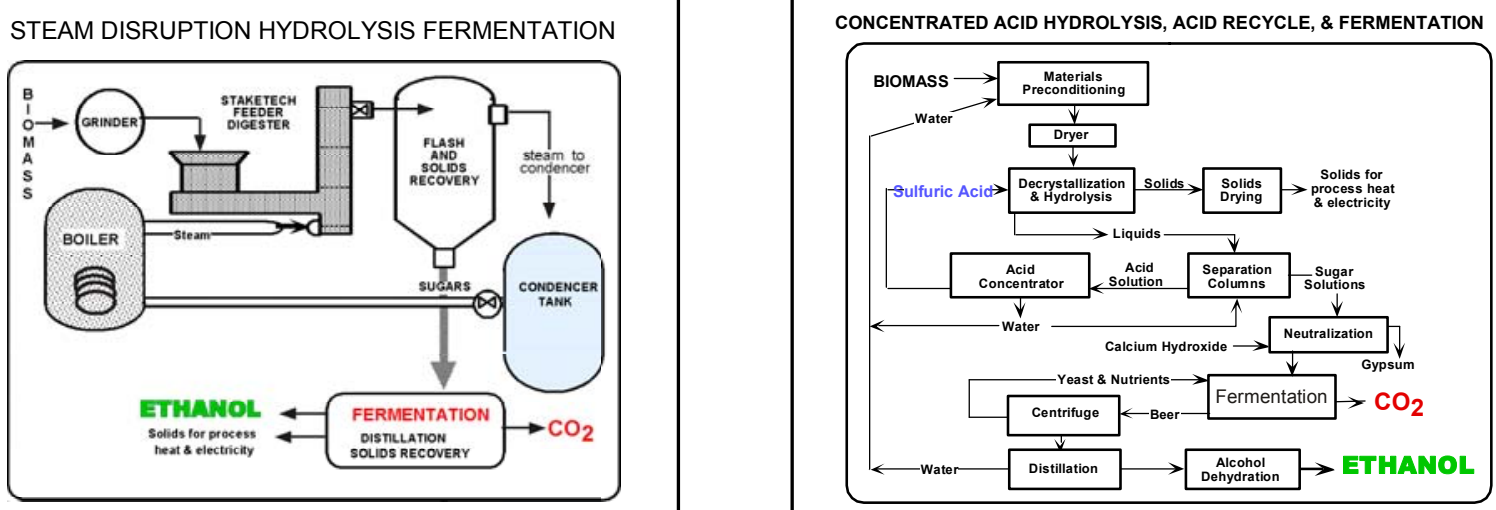

ACIDIFIED ACETONE EXTRACTION HYDROLYSIS \& FERMENTATION

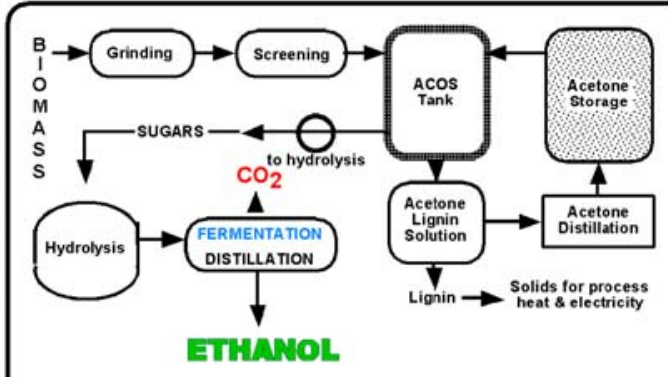

ACID DISRUPTION AND TRANSGENIC MICROORGANISM FERMENTATION

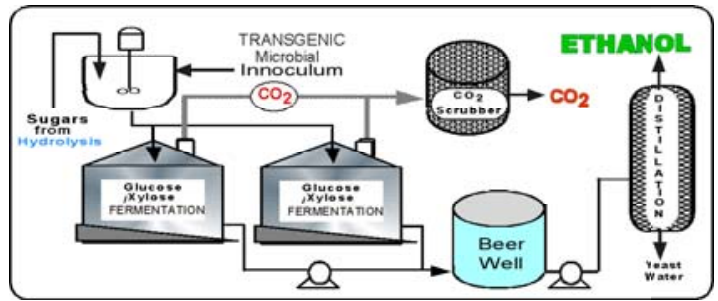



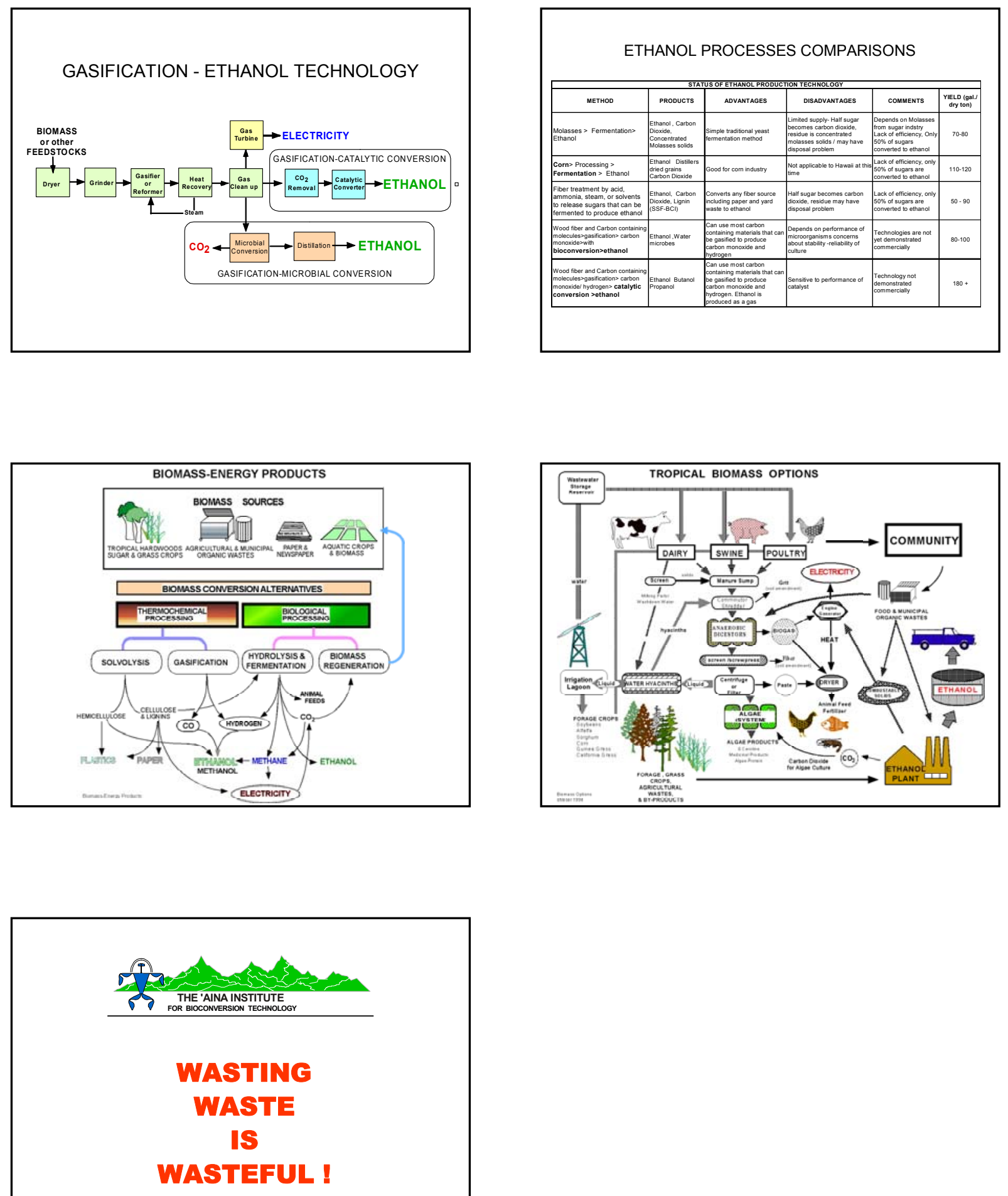


\section{ODeltar}

Unconventional solutions, unrivaled results.
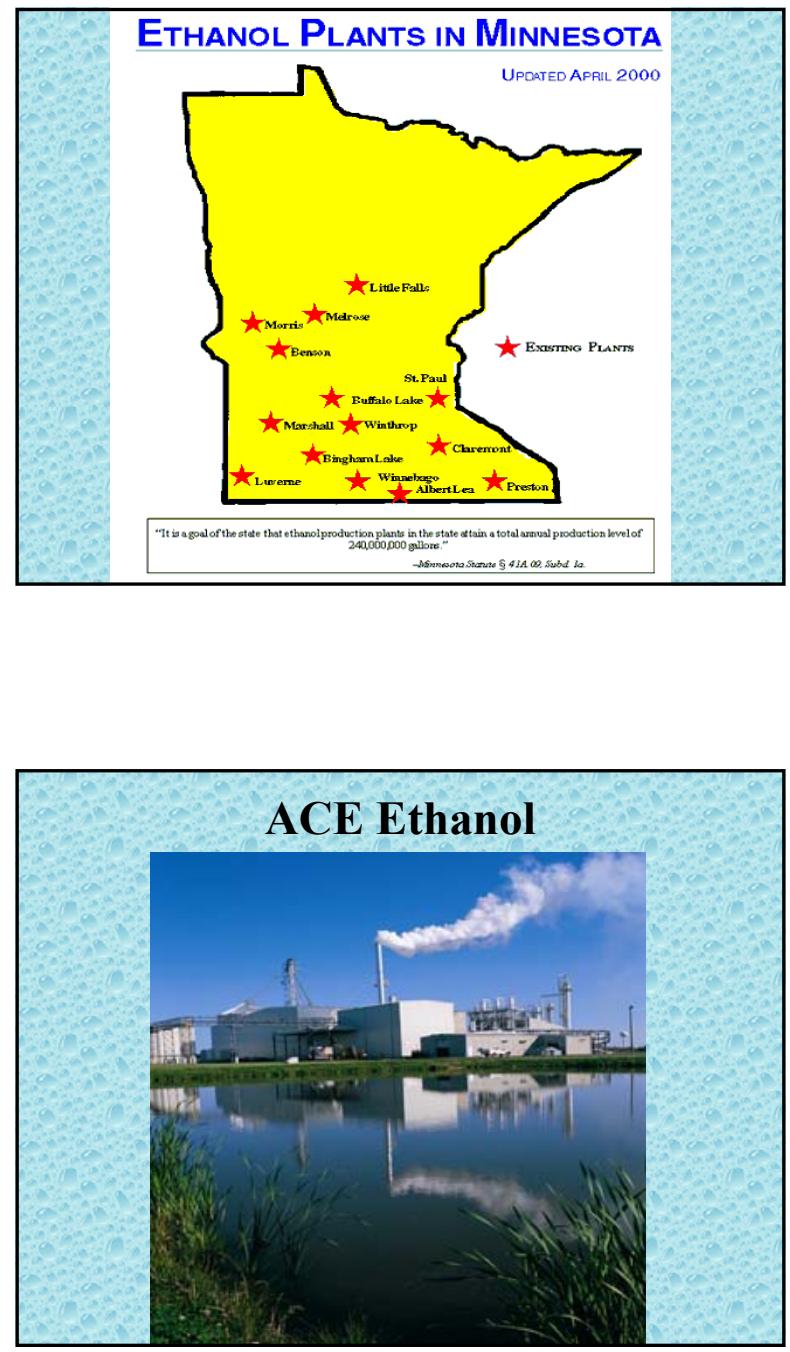

\section{Larry Johnson}

- 25 years Production Agriculture.

- 15 years Ethanol Consultant

- 3 years Delta-T Corporation

Business Development Manager
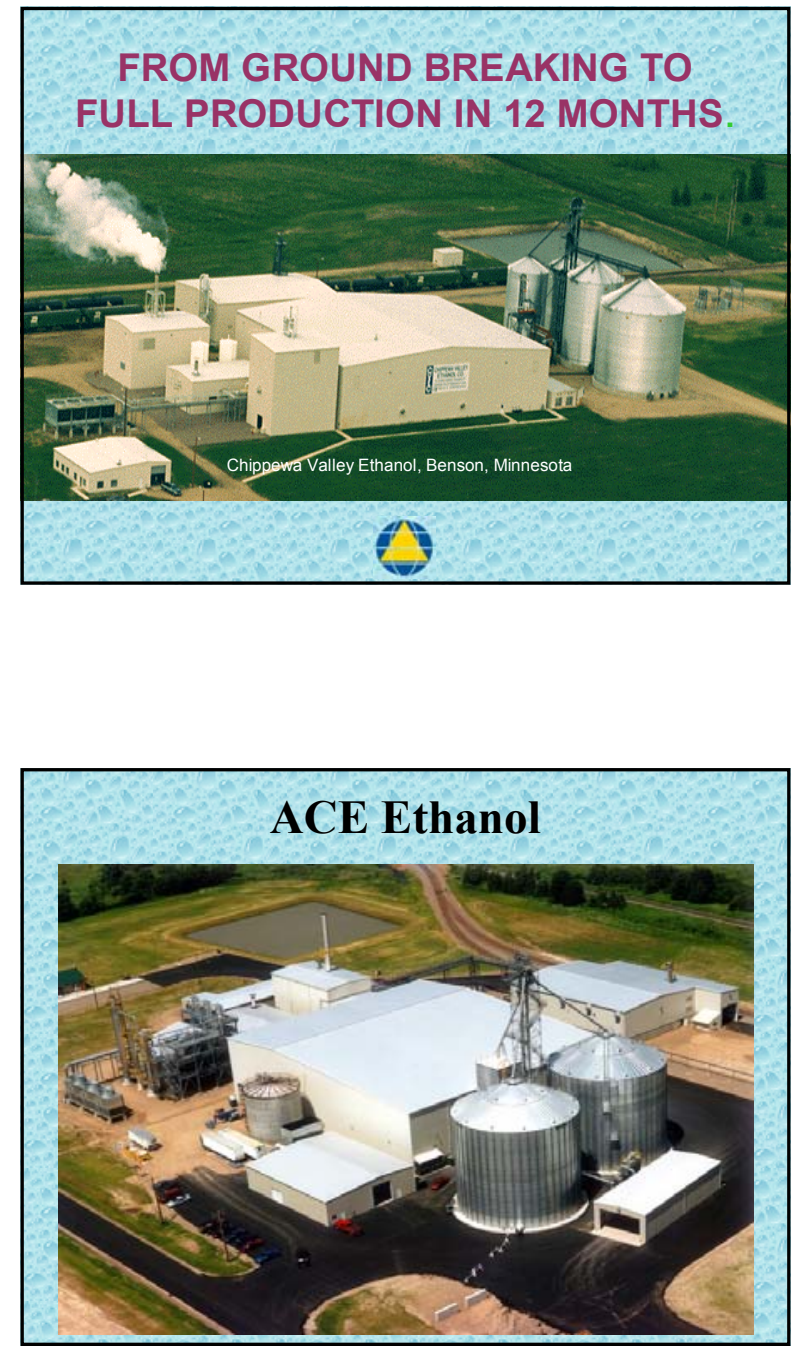


\section{WHAT'S DRIVING ETHANOL DEMAND?}

-World energy demand and high crude oil prices - The Clean Air Act Amendments of 1990

-Unprecedented U.S. gasoline demand

-The phase-out of MTBE from U.S. gasoline

- Continued demand for gasoline octane

-U.S. oil refineries are operating at capacity

-A general movement toward renewable energy

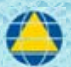

\section{Ethanol Plant Requirements}

1. SITE QUALIFICATIONS

2. BUSINESS ECONOMICS

3. PROJECT FINANCING
WHAT MISTAKES WERE MADE PREVIOUSLY BY ETHANOL

\section{PLANTS?}

- Inadequate Technology

- Inefficient Plant Design

- Inaccessible Markets

- Under Capitalization

- Poor Management

\section{Site Qualifications}

-Rail

-Roads

-Water

- Boiler Fuel

-Electricity

-Permits

-Community Acceptance

\section{Business Economics}

- Feedstocks

-Markets

- Costs and Efficiencies

-Livestock

\section{Project Financing}

-Grants

-In-Kind

-Investor Equity

-Debt Finance 

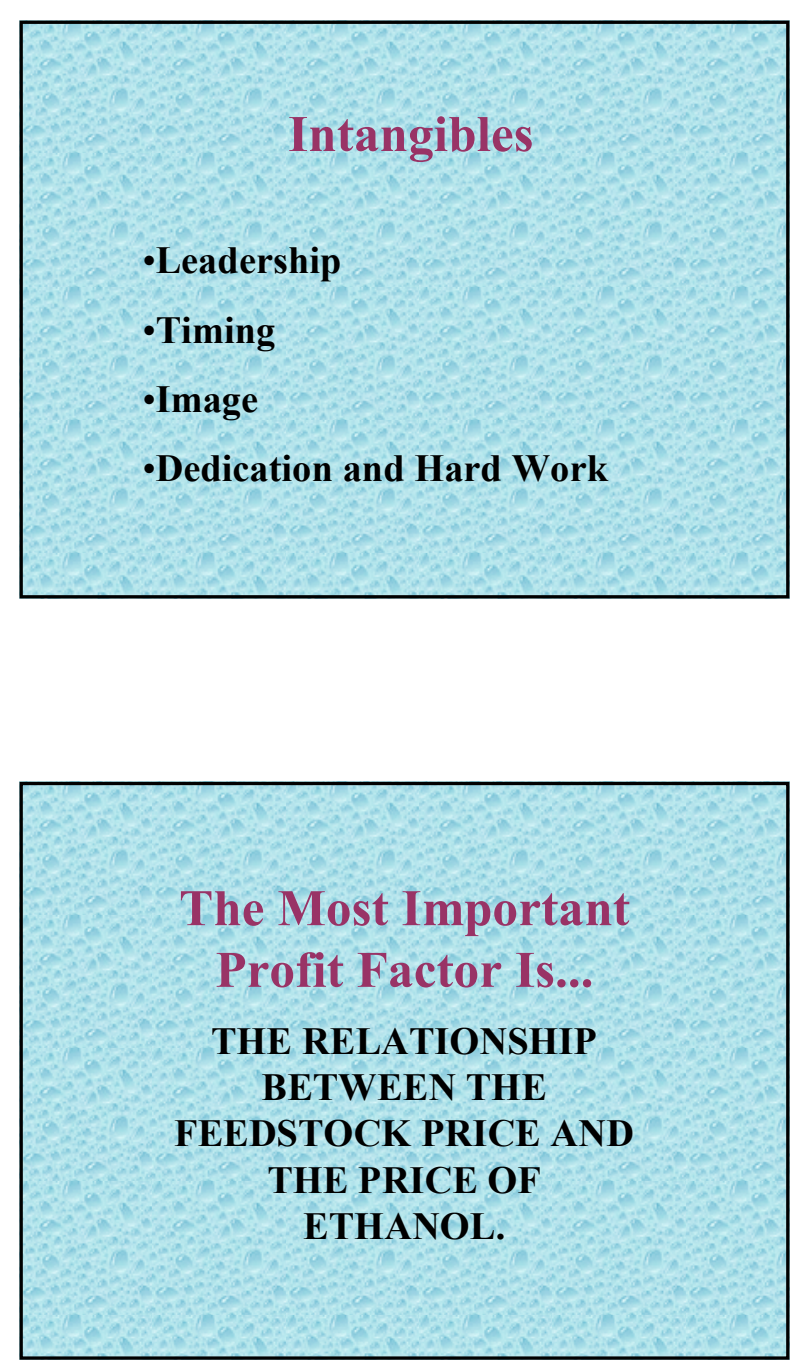

\section{The Correct Decision} Will Require Accurate Information, Good Planning, a Little Luck and Dedication...

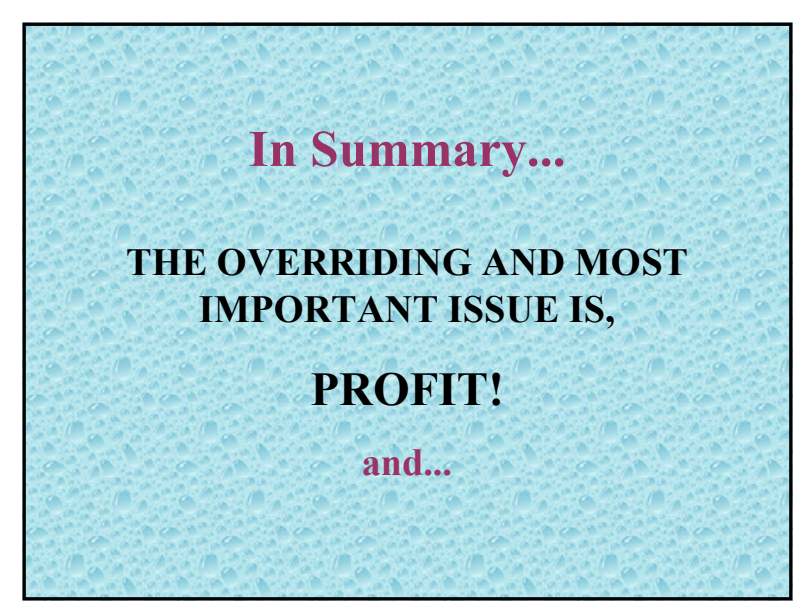

\section{What Level Profitability??}

-Ethanol will Definitely Add Value!

-Energy up? Agriculture Down?

-Agriculture up? Energy Down?

\section{Hawaii Specific Considerations}

-Maintaining the Unique Island Character

-Enhancing and Diversifying State Economy

-Promoting Desirable Land Use

-Maintaining Clean Environment

-Providing a High Performance Fuel

-Considering Future Technology

-Insuring Energy Security

- Creating a Workable Public Policy Environment

-Serving the Hawaiian Citizens 

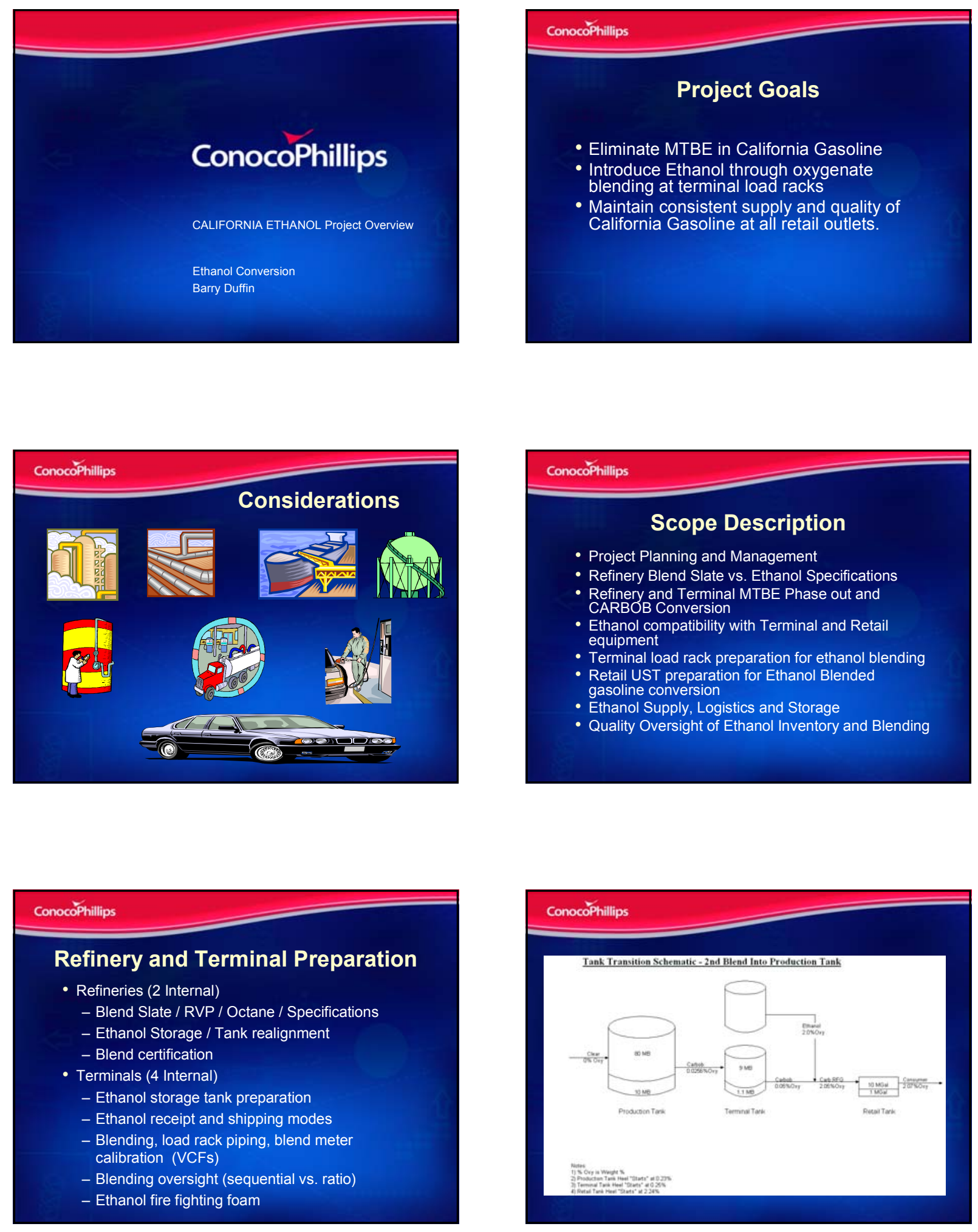

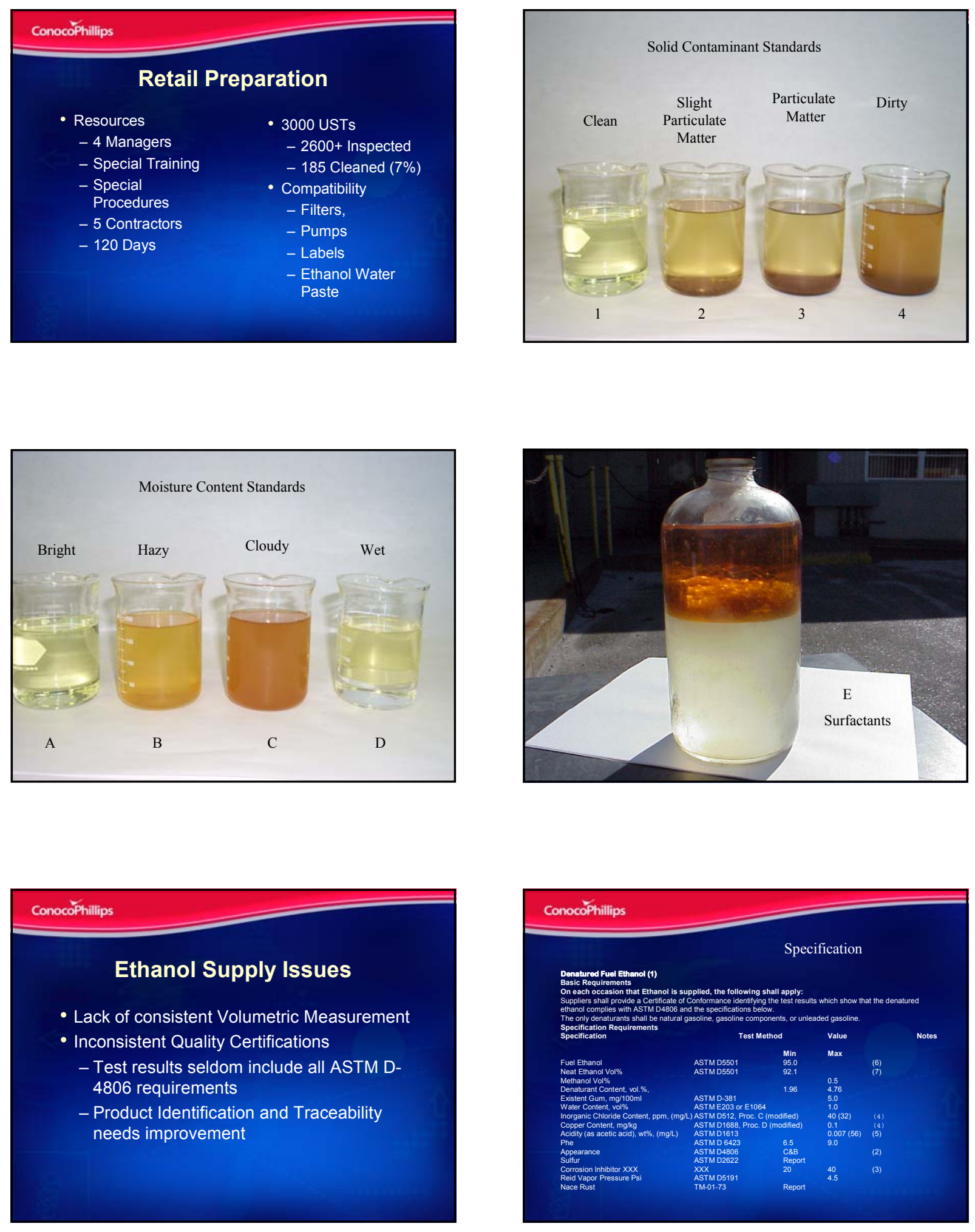


\section{Lessons Learned}

- Have a Tactical Implementation Plan - Monitor progress on a scheduled basis

- Volumetric measurement of ethanol should be performed using API Table 6C in place of Table 6B

- Require inspection and removal of any water bottoms from third party terminal tanks

- Inspect as many Retail outlet USTs as possible

- Train retail operators on proper housekeeping

- Plug overfill drains at retail outlets 

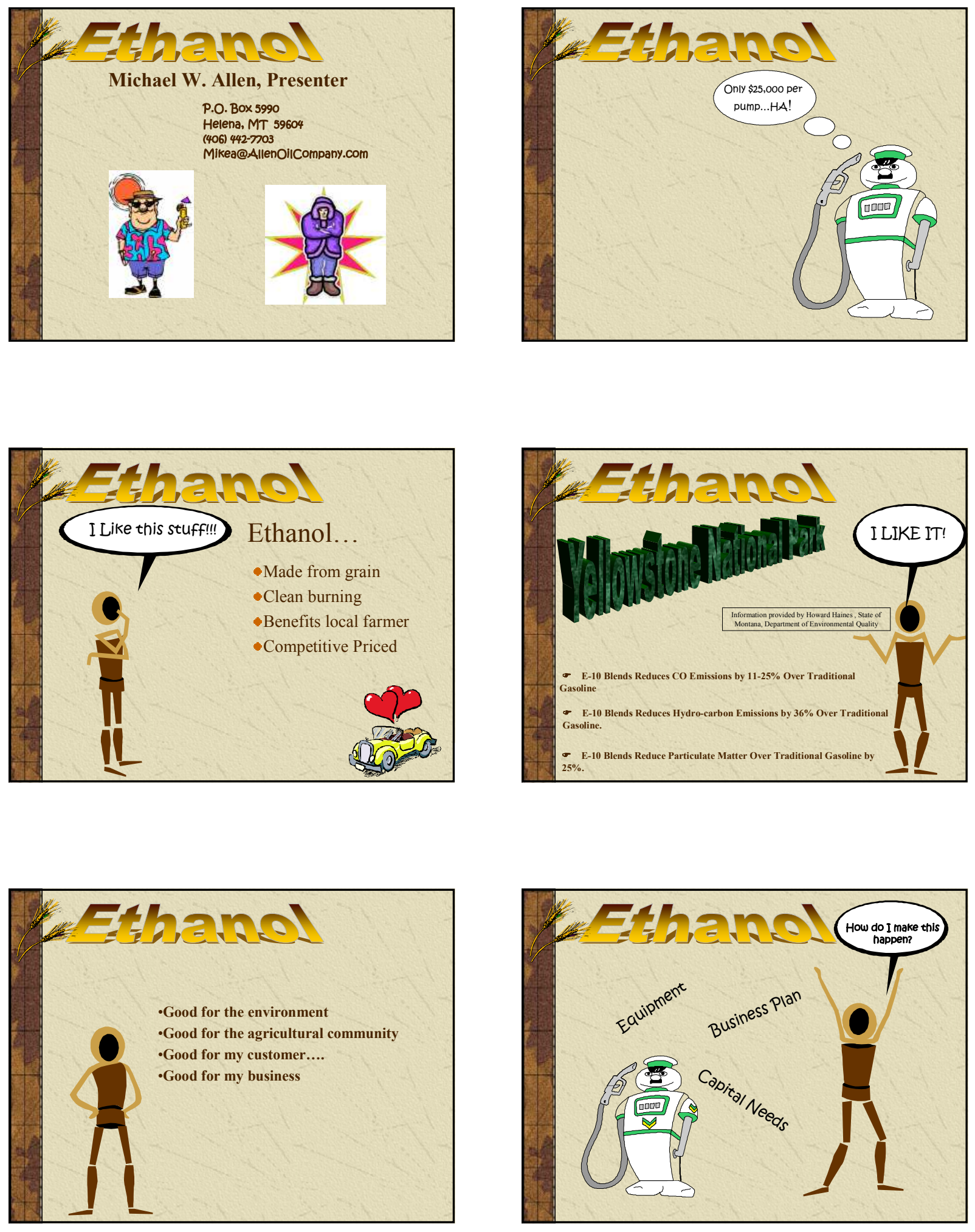

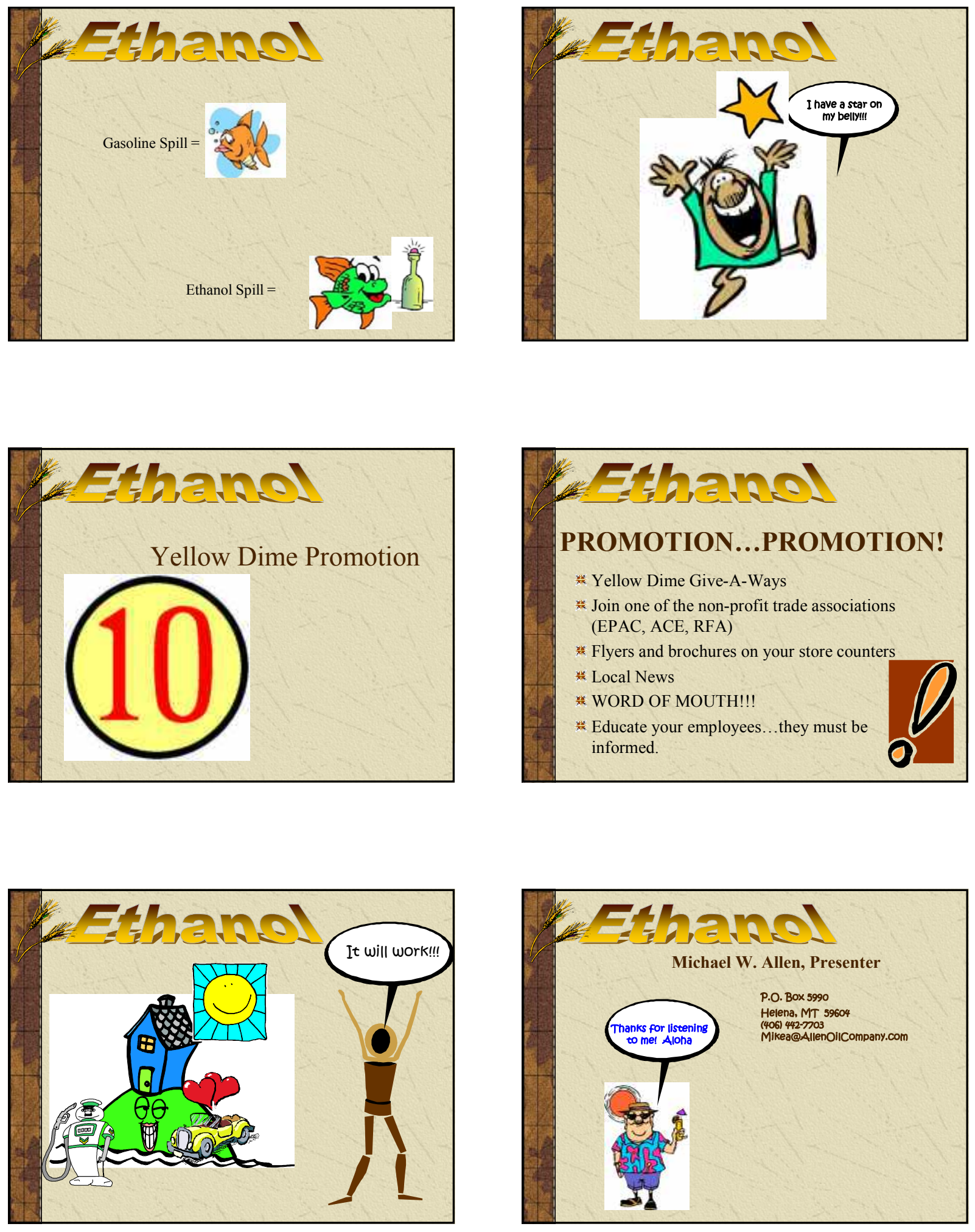


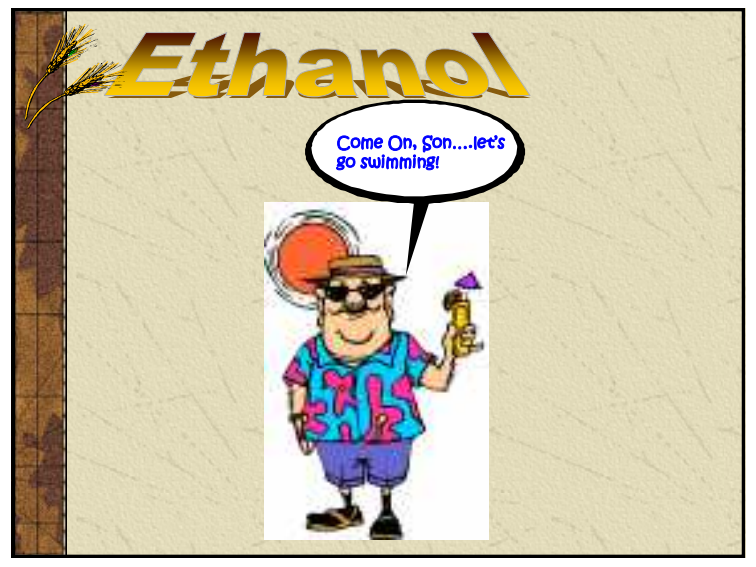




\section{ODeltat}

Unconventional solutions, unrivaled results.
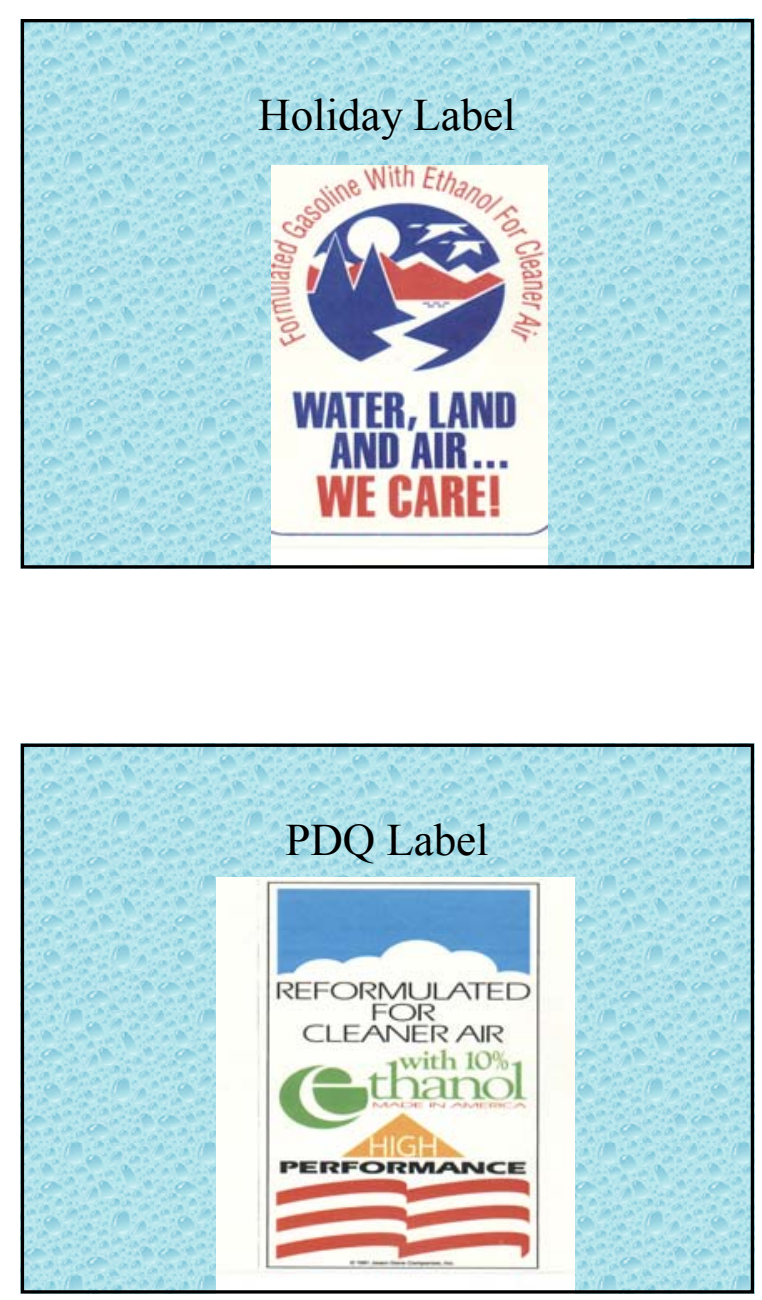

\section{Larry Johnson}

Delta-T 25 years Production Ag.

15 years Ethanol Consultant

3 years Delta-T Corporation

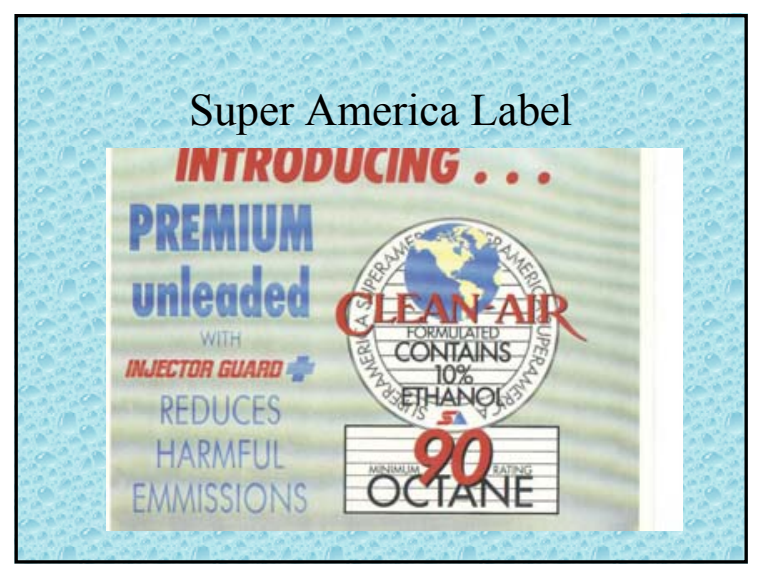

Why Ethanol - The Discussion Agenda and History Initially Politically Driven - Today also Market Driven

$>$ Agriculture - Historic

1900 s and 1930s

> Energy - Iranian Revolution

1979

$>$ Octane - CAA Lead Phase-out

1985

$>$ Energy - Gulf War

1991

$>$ Air Quality - CAAA Oxy and RFG

$>$ Refinery Demand - At Capacity

2000

$>$ Renewable Energy - All of the Above

TODAY 


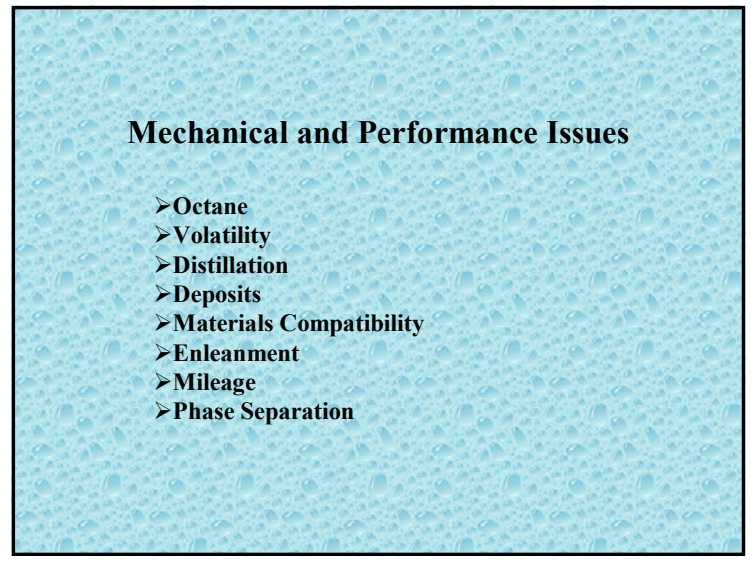




\section{Biofuels for \\ Sustainable Transportation}

Ethanol and Fuel Cells

The Future is Now!

November 14, 2002 - Honolulu, HI

\section{What is a Fuel Cell?}

Fuel cells work by combining hydrogen and oxygen in a chemical reaction to create electricity, without the noise and pollution of conventional engines.

In principle, a fuel cell works like a battery.

Unlike a battery, however, a fuel cell does not run down or require recharging.

It will produce energy in the form of electricity as long as fuel is supplied.

\section{Ethanol $\mathrm{C}_{2} \mathrm{H}_{5} \mathrm{OH}$}

Why does ethanol have a future as the fuel source for fuel cells?

Ethanol is a hydrogen-rich liquid, which overcomes both the storage and infrastructure challenges of hydrogen for fuel cell applications.

\section{Why Ethanol?}

- Ethanol promotes fuel flexibility/diversity

- Coexists with Gasoline, Natural Gas

- Ethanol will leverage existing investments

- Ethanol production/distribution infrastructure

- Fuel Cell R\&D- Government and Commercial

- 3 market areas- with different timing

- Stationary powe

- Ethanol-Hydrogen refueling stations

- Ethanol/Gasoline fuel cell vehicles

- Ethanol will continue to receive government focus because of it's high societal benefits

- Economic, Energy Security, Environmental.

\section{Societal Benefits are High}

- Improved air quality,

- Increased energy security,

- Economic opportunities for farmers and fuel distributors.

- Production from cellulosic biomass feedstocks, such as corn stover, rice straw, and forestry residues.

- Spills or leaks will not pollute groundwater

\section{The Societal Benefits of Ethanol} are High

Ethanol and fuel cells together create significant synergy, reaching markets and bringing benefits that are not achievable with any other fuel or with any other power technology.

Ethanol is a renewable resource that is playing an increasingly important role in assuring the nation's air quality, improving the economic security of America's farming communities, and addressing the challenges of homeland energy security. 


\section{Ethanol \& Fuel Cells - The Power of 2.}

-Ethanol blends seamlessly with gasoline fuels to create an improved, fuel cell fuel that is easily stored and dispensed. These blends can be varied over time, providing fuel source flexibility.

-Ethanol, a renewable fuel, used in fuel cell vehicles or for stationary power plants generates far fewer greenhouse gases than conventional fuels such as gasoline or natural gas.

-Fuel cells are extremely efficient powerplants, reducing the importance of fuel cost and leveling the playing field vs. fossil fuels.

-Ethanol's distribution infrastructure is complete to the terminal level, meaning that only very limited investment in local distribution could enable ethanol to power fuel cells for remote residences and cell towers far from the electric grid.

- Unlike other fuel cell alternative fuels like hydrogen or methanol, ethanol has a very positive environmental, health, and safety footprint with no major uncertainties or hazards.

-The technology to use ethanol in fuel cells already exists and has been demonstrated. Only minor changes are required to existing systems to introduce ethanol as a fuel cell fuel.

\section{Driving On Ethanol}

- An ethanol fuel cell vehicle (FCV) will emit about $13 \%$ of the tailpipe pollutants compared with a gasoline vehicle and less than half the pollutants of even a gasoline hybrid vehicle.

- Greenhouse gas emissions from an ethanol FCV would be substantially less than even an advanced vehicle using a gasoline internal combustion engine. The ethanol FCV contributions to greenhouse gases could be close to zero if cellulosic biomass is used for the ethanol feedstock.

- Unlike hydrogen and methanol, ethanol poses no unique or potentially "show-stopping"health and safety hazards.

- Unlike other fuel cell alternative fuels like hydrogen or methanol, ethanol has a very positive environmental, health, and safety footprint with no major uncertainties or hazards.

\section{Ethanol is Already Widely Available}
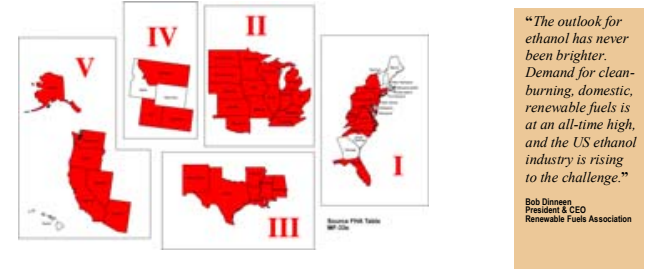

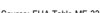

The ethanol infrastructure is second only to gasoline as a passenger car fuel.

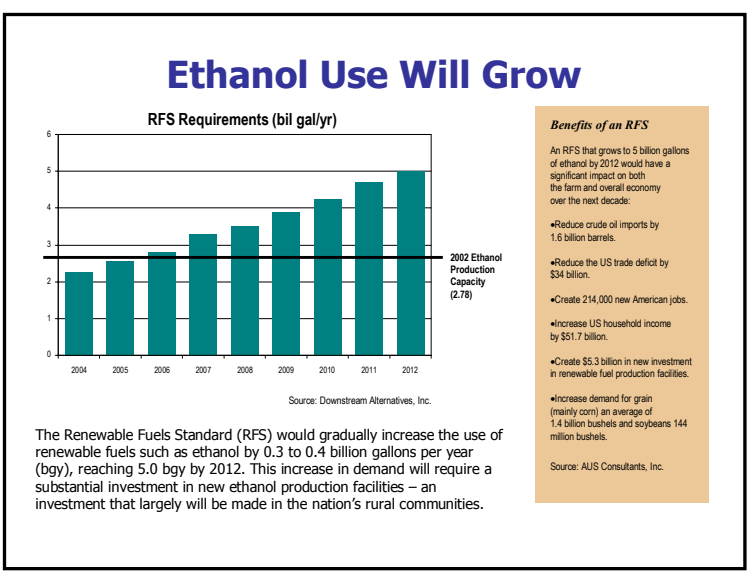

\section{Market Areas}

Hydrogen Fueling Stations- Ethanol converted to hydrogen at a service station site. Would support early vehicle demonstrations.

Stationary Power- Ethanol can be used to make power locally. Cost competitiveness depends on:

- FC cost \& efficiency improvements

- Ethanol pricing vs. propane and natural gas

- State/federal incentives for renewables

Fuel Cell Vehicle Fuel- Ethanol (or blend) used in "gasoline" fuel cell vehicles. 


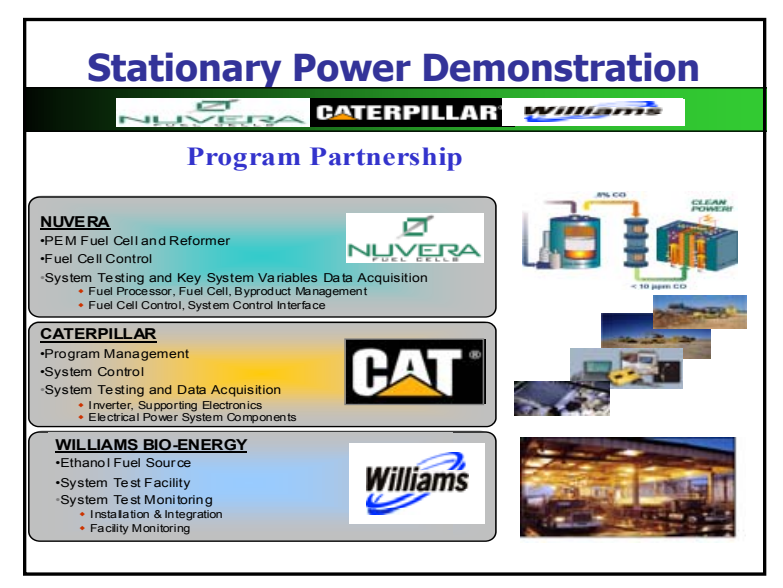

\section{Ethanol Around The World}

Brazil-Volkswagen plans to produce 100,000 ethanol-fueled cars in Brazil, exchanging the finance for Kyoto carbon credits with the Brazilian government.

India- August 142002 The Indian government ordered the compulsory sale of ethanol-blended gasoline from January 2003 in 13 of the country's states and territories.

China- In November 2001 started to construct its first ethanol plant in Jilin province.

France- bio-ethanol is "a boon to... Agriculture! Bio-Fuels produce some unsuspecting benefits for the environment Notably in agriculture where once fallow fields are again in use, and jobs are created in rural areas. Even better, increased plant growth reduces $\mathrm{CO} 2$ in the air, as the growing plants "trap" it by photosynthesis." -Oxygen, Peugeot Citroen Magazine

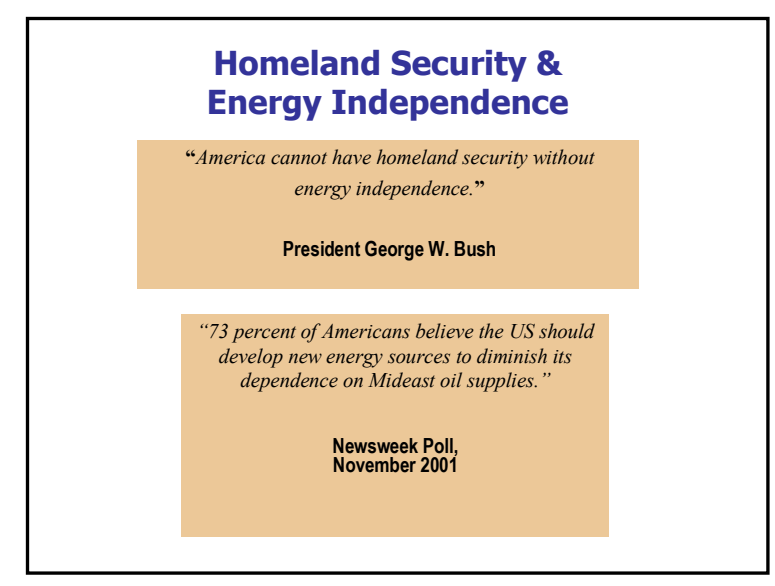

\section{Near Term Actions Awareness and Engagement}

1. Raise stakeholder awareness

- Economic analyses to define competitive markets

- Ethanol supply, and infrastructure development status

- Conference presentations

2. Identify Fuel Cell companies willing to include ethanol in market development.

3. Evaluate technical and economic feasibility of building an ethanol-hydrogen fueling station.

4. Engage the automotive industry to gain further acceptance of ethanol

5. Work with the DOE to tailor existing technology programs to the use of ethanol.

6. Work with state and local governments to define ethanol role in renewable power programs.

\begin{tabular}{|c|c|}
\hline \multirow{2}{*}{\multicolumn{2}{|c|}{ 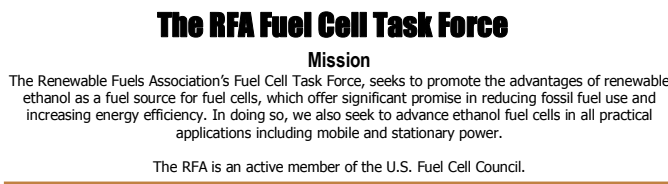 }} \\
\hline & \\
\hline $\begin{array}{l}\text { Fuel Cell Tas } \\
\text {-Jeff Oestmann, Cargill Inc. } \\
\text { - Randall Doyal, Al-Corn Clean Fuel } \\
\text {-Charles Corr, Archer Daniels Midland } \\
\text {-Jacki Fee, Cargill Inc. } \\
\text { - Robert Reynolds, Downstream Alternatives Inc. } \\
\text { - Glenn Kenreck, GE Betz } \\
\text { - Jeff Roskam, ICM, Inc. } \\
\text {-Philip Shane, Illinois Corn Growers Association }\end{array}$ & $\begin{array}{l}\text {-David Loos, llinois Department of Commerce } \\
\text { and Community Affairs } \\
\text {-Neil Koehler, Kinergy, LLC } \\
\text {-Duane Adams, Minnesota Corn Growers } \\
\text { Association } \\
\text {-Jon Doggett, National Corn Growers Association } \\
\text {-Todd Allsop, New Energy Corp. } \\
\text {-Gary Welch, Williams Bio-Energy } \\
\text {-Mary Giglio, Renewable Fuels Association }\end{array}$ \\
\hline
\end{tabular}




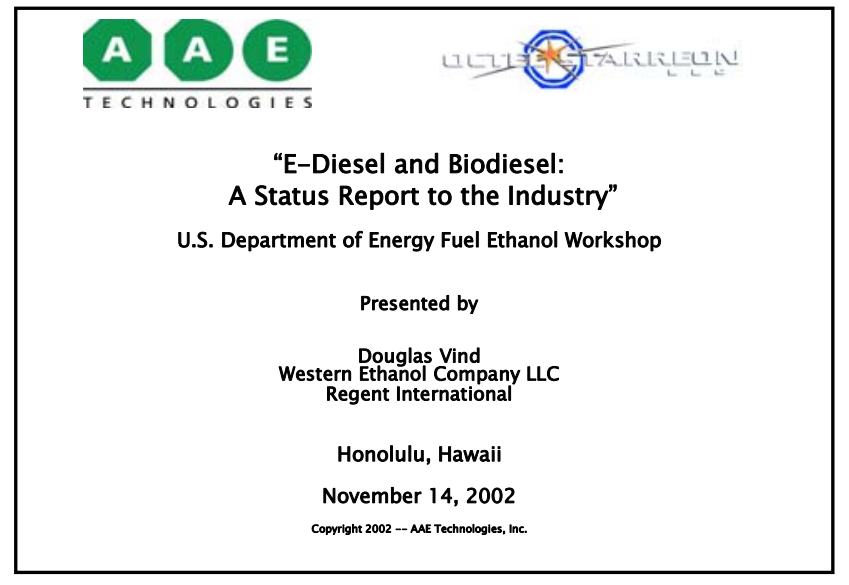

\section{A A E \\ TECHNOLOGIES

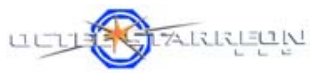

Introduction (continued)

\section{Western Ethanol Company LLC Regent International}

- 20 years as an ethanol producer and distributor, both domestic and international.

- Detailed experience in shipping, storing, and delivering fuel ethanol throughout Europe and North America.

- Committed to identifying and developing new uses and markets for ethanol fuels.

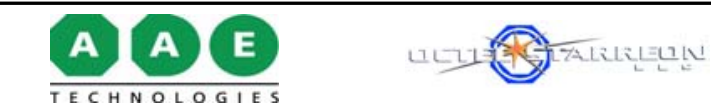 \\ Introduction \\ AAE TECHNOLOGIES, INC. \\ - Established in 1997, holder of numerous worldwide patents for fuel additive technologies \\ - O²Diesel ${ }^{\mathrm{TM}}$ efforts in U.S. underway since 1998 - focused \\ on cost-effective, commercially viable products \\ OCTEL STARREON, LLC \\ - Over 60 years as a leading world fuel additive supplier \\ - Leading manufacturer and supplier of diesel additives \\ - North American sales and distribution network for Performance \& Petroleum Specialty Chemicals}

\section{A A E \\ TECHNOLOGIES}

\section{Diesel Market Overview}

- Diesel emissions under scrutiny on a global level

- Global policies challenge operators, refiners and marketers

- Targeted emissions from diesel: NOx, CO, PM and air toxics

- Other solutions such as CNG, catalysts \& DPFs are costly, some still untested, and many require major infrastructure changes

- Fleets affected include: urban transit vehicles, delivery \& service fleets, construction and other off-road equipment

- U.S. market: $~ 50$ billion gallons and growing (highly segmented)

\section{A A E \\ $\overline{\text { TECHNOLOGIES }}$}

\section{What is E-Diesel?}

A diesel fuel containing conventional diesel blendstock(s) with:

- Up to 15 vol\% Anhydrous Ethanol

- Stabilized with $~ 1.0$ - 5.0 vol\% proprietary additive(s), and

- Cetane enhancement where required

The AAE-Octel Starreon Octimax ${ }^{T M} 4931$ (includes cetane improver) makes commercially viable $\mathrm{O}^{2}$ Diese $^{\mathrm{TM}}$ at $<1.0$ vol\% additive treat rate

- Premium Diesel performance - lubricity, stability, conductivity

- Little or no infrastructure or engine changes required

- Can be used in heavy-duty on- $\&$ off-road $\mathrm{Cl}$ engines now!

\section{A A E \\ $\overline{\text { TECHNOLOGIES }}$}

What is E-Diesel? (continued)

Why Ethanol is an Ideal Diesel Oxygenate

- Benefits:

- Renewable, domestic replacement for imported petroleum

- No significant environmental side-effects

- Widely proven as a gasoline oxygenate in world markets including USA, Canada \& Brazil

- Supply \& infrastructure already exists in key global markets

- Greenhouse gas reduction impacts

However, historically unable to 'blend' ethanol with diesel largely due to ethanol's hygroscopic nature -- UNTIL NOW! 


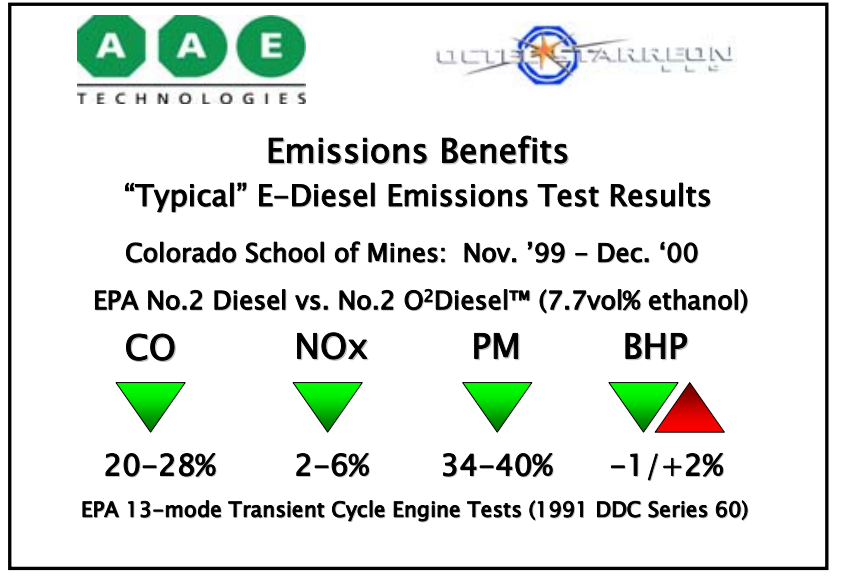

\section{A A E \\ TECHNOLOGIES}

\section{Summary: $\mathrm{O}^{2}$ Diesel ${ }^{\mathrm{TM}}$ Fleet Testing}

- Nevada Ready Mix (Las Vegas, NV): Feb. 2000 - July 2001 (quarry trucks)

- Lincoln StarTran (Lincoln, NE): August, 2000 - current (urban buses)

- Pepsi-Cola (The Bronx, NY): Nov. 2000 - current ( $>200$ delivery trucks)

- Zachry Const. (San Antonio, TX): Mar. 2001 - current (const. equipment)

- Pearl City Co-op (Pearl City, IL): June 2000 - current (fuel delivery trucks)

- Winnipeg Transit (Winnipeg, Manitoba): Oct. 2001- Aug. 2002 (20 buses)

- Citizen Area Transit (Las Vegas, NV): Started Nov. 2002 (17 urban buses)

Also:

- OCTranspo (Ottawa, Ontario): Starts 1st Qtr. 2003 (20 urban buses)

- 5 Municipalities (So. Calif.): Starts 1st Qtr. 2003 (120 diesel engines)

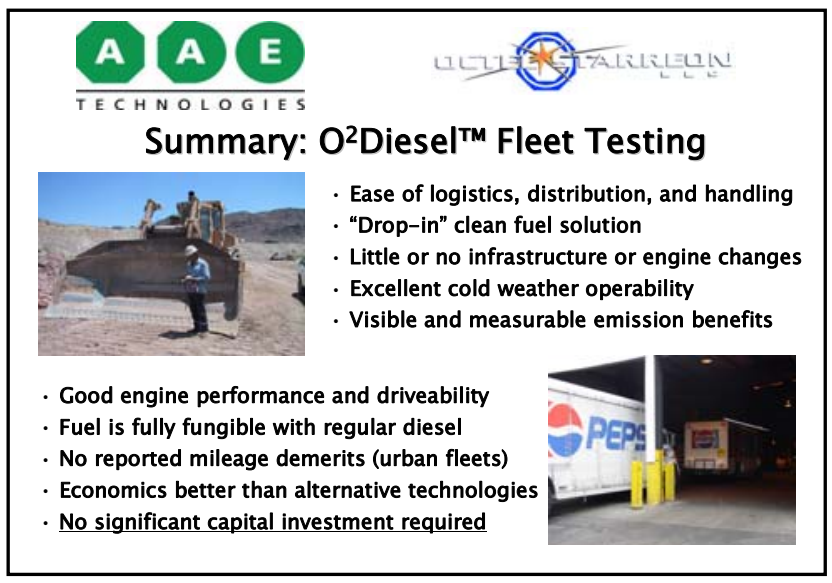

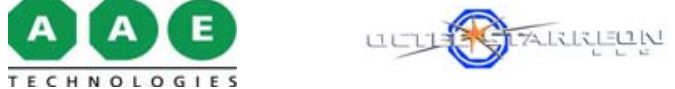

\section{E-Diesel Technical Agenda: 2002}

"Ethanol-Blended Diesel Fuel Handbook" -- initiated Summer, 2001 and to be completed Fall, 2002 (Argonne Nat'l. Labs)

- Uniform Safety and Handling procedures -- Evaluation underway in $2001 / 02$ at Southwest Research Institute

- Greenhouse gas impact analysis -- initiated Summer, 2001 by Argonne Nat'l. Labs (Michael Wang, et al)

- Health effects testing req'd. per Section 211(b) of the Clean Air Act

- John Deere cooperative test program ( $\$ 2$ million +2 years)

\section{A A E \\ $\overline{\text { TECHNOLOGIES }}$

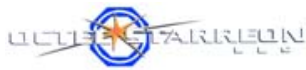

E-Diesel Consortium: Organization

- Draft Consortium Charter approved Dec. 4, 2001

- Established under the Renewable Fuels Foundation

- Consortium began work in early 2002

- Significant technical \& regulatory agenda (2002 - 03)

- Broad industry/government participation anticipated

\section{A A E \\ TECHNOLOGIES}

E-Diesel Consortium: Participants

- State of Illinois "Core Group" (original E-Diesel Task Force)

- Additive Suppliers (AAE Technologies/Octel Starreon, Akzo Nobel, GE/Betz, Lubrizol, Pure Energy Corp., etc.)

- Engine Manufacturers (John Deere, etc.)

- US Dept. of Energy (including NREL, Argonne National Lab)

- Renewable Fuels Association (U.S. and Canada)

- National Corn Growers Association (and state chapters)

- State and local, public \& private groups (e.g., Nebaska Ethanol Board) 


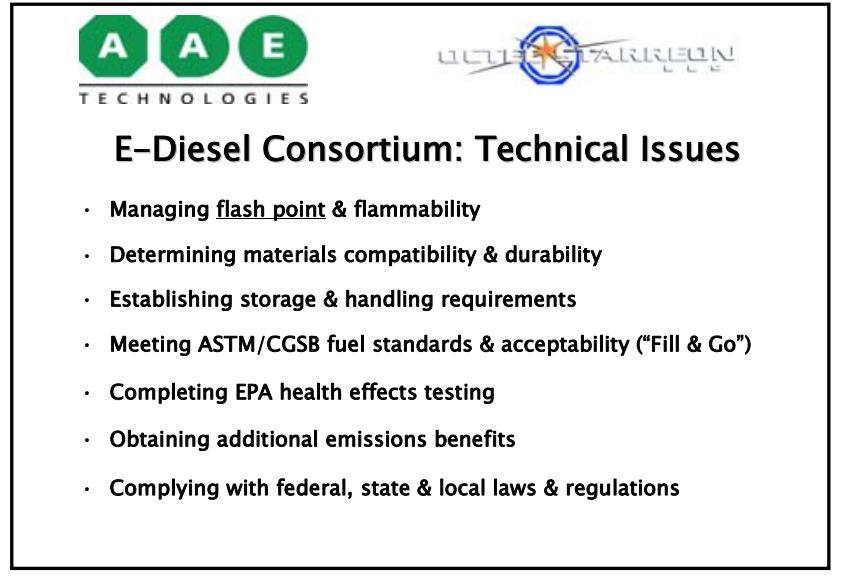

\section{A A E \\ TECHNOLOGIES}

\section{Biodiesel Overview}

- What is Biodiesel?

- How is Biodiesel made?

- Biodiesel market

- Benefits of Biodiesel

- Biodiesel Challenges

- Ethanol and Biodiesel

\section{A A E \\ $\overline{\text { TECHNOLOGIES }}$}

Challenges:

\section{Conclusions}

- E-Diesel faces a substantial technical \& regulatory agenda

- Tax incentive issues must be addressed for full commercialization

- Meaningful public \& private support for E-Diesel needed

- Major competition from other new diesel fuels \& technologies expected

- OEM skepticism will be significant for a while to come

\section{But E-Diesel has Momentum.}

- E-Diesel Consortium is now in place to address all outstanding issues

- E-Diesel will be "ready for prime time" well before $2006-07$ !

\section{A A E \\ TECHNOLOGIES \\ What is Biodiesel? \\ Biodiesel (fatty acid alkyl esters) is a cleaner-burning diesel replacement fuel. \\ - Made from natural, renewable sources such as new \& recycled vegetable oils and animal fats. \\ - Just like petroleum diesel, biodiesel operates in combustion-ignition engines. \\ - Blends of up to $20 \mathrm{vol} \%$ biodiesel $+80 \mathrm{vol} \%$ petroleum diesel fuels (B20) can be used in nearly all diesel equipment and are compatible with most storage and distribution equipment. \\ - Higher blends, even neat biodiesel (B100), can be used in many engines built since 1994 with little or no modification.}

\section{A A E \\ TECHNOLOGIES}

\section{How is Biodiesel Made?}

- Biodiesel fuel can be made from "virgin" or recycled vegetable oils and animal fats, which are non-toxic, biodegradable, renewable resources.

- Fats and oils are chemically reacted with an alcohol (typically methanol, but ethanol is also used) and a catalyst to produce fatty acid methyl (or ethyl) esters and glycerine co-products.

- Biodiesel can be produced by a variety of esterification technologies.

- Approximately $50 \%$ of the U.S. biodiesel industry can use any fat or oil feedstock, including recycled cooking grease. The other half is limited to vegetable oils, the least expensive of which is soybean oil.

\section{A A E \\ $\overline{\text { TECHNOLOGIES }}$

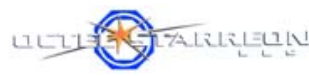

\section{Biodiesel Fuel Market}

The use of biodiesel has grown dramatically in the United State during the last few years. (Currently about 25 mil. gallons per year).

The Energy Policy Act (EPACT) was amended in 1998 to include biodiesel fuel use as a way for federal, state, and public utility fleets to meet requirements for using alternative fuels.

Biodiesel users include the U.S. Postal Service and the U.S. Departments of Energy and Agriculture. In addition, many school districts, transit authorities, national parks, public utility companies, and garbage and recycling companies also use the fuel.

- With sufficient government incentives, biodiesel sales could reach about 2 billion gallons per year, or about $8 \%$ of highway diesel consumption. 


\section{A A E \\ TECHNOLOGIES

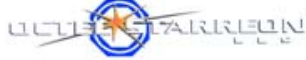

\section{Benefits of Biodiesel}

- Every gallon of biodiesel displaces 0.95 gallons of petroleum-based diesel over its life cycle.

- Biodiesel reduces the amount of carbon dioxide ( $\mathrm{CO} 2)$ being released into the atmosphere.

- Biodiesel is nontoxic and biodegradable.

- Biodiesel can provide substantial lubricity benefits to premium diesel fuels.

Biodiesel is an oxygenated fuel, so it contributes to a more complete fuel burn and a greatly improved emissions profile.

- Biodiesel reduces air toxics that are associated with petroleum diesel exhaust and are suspected of causing cancer and other human health problems.

\section{A A E \\ TECHNOLOGIES \\ Challenges for Biodiesel}

- Biodiesel currently costs between $\$ 1$ and $\$ 2$ per gallon to produce.

- Fats and greases cost less and produce less expensive biodiesel but feedstock costs alone are at least $\$ 1.50$ per gallon of soybean oilbased biodiesel.

- According to the National Renewable Energy Laboratory (NREL), there is only enough U.S. feedstock to supply 1.9 billion gals. of biodiesel.

- Biodiesel's fuel economy, torque, and power are somewhat less than diesel ( $8 \%$ to $15 \%$ ) because of its lower energy content.

- Biodiesel derived from some feedstocks tends to increase NOX emissions.

- In colder weather, tank heaters or agitators may be required.

\section{A A E \\ TECHNOLOGIES}

\section{Ethanol and Biodiesel}

Ethanol can be utilized to produce derived from using methanol).

- Ethyl esters can have lower smoke opacity, exhaust temperatures and pour point temperatures than methyl esters.

- Ethyl esters meet the same ASTM standard specification for biodiesel as methyl esters (D6751)

- Ethanol is a preferred process alcohol compared to methanol because it is renewable and more environmentally benign.

- In Hawaii, recycled vegetable oils \& ethanol represent the most promising biodiesel (ethyl ester) feedstocks due to their availability.

- For more Biodiesel information contact the National Renewable Energy Laboratory (NREL)

\section{A A E}

$\overline{\text { TECHNOLOGIES }}$

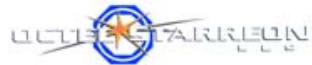

For more information contact:

AAE Technologies, Inc. 200 Executive Drive Newark, Delaware 19702 USA

Western Ethanol Company LLC Regent International
1075 Yorba Place, Suite 101

(302) 266-6000 (office) (302) 266-7076 (fax) www.aaetech.com

(714) 854-1333 (office) (714) 854-1330 (fax) www.regentinternational.com

Octel Starreon, LLC

Fuel Additives

$8375 \mathrm{~S}$. Willow Street

Littleton, Colorado 80124 USA

(303) 566-0530 (office)

(303) 792-5668 (fax) 

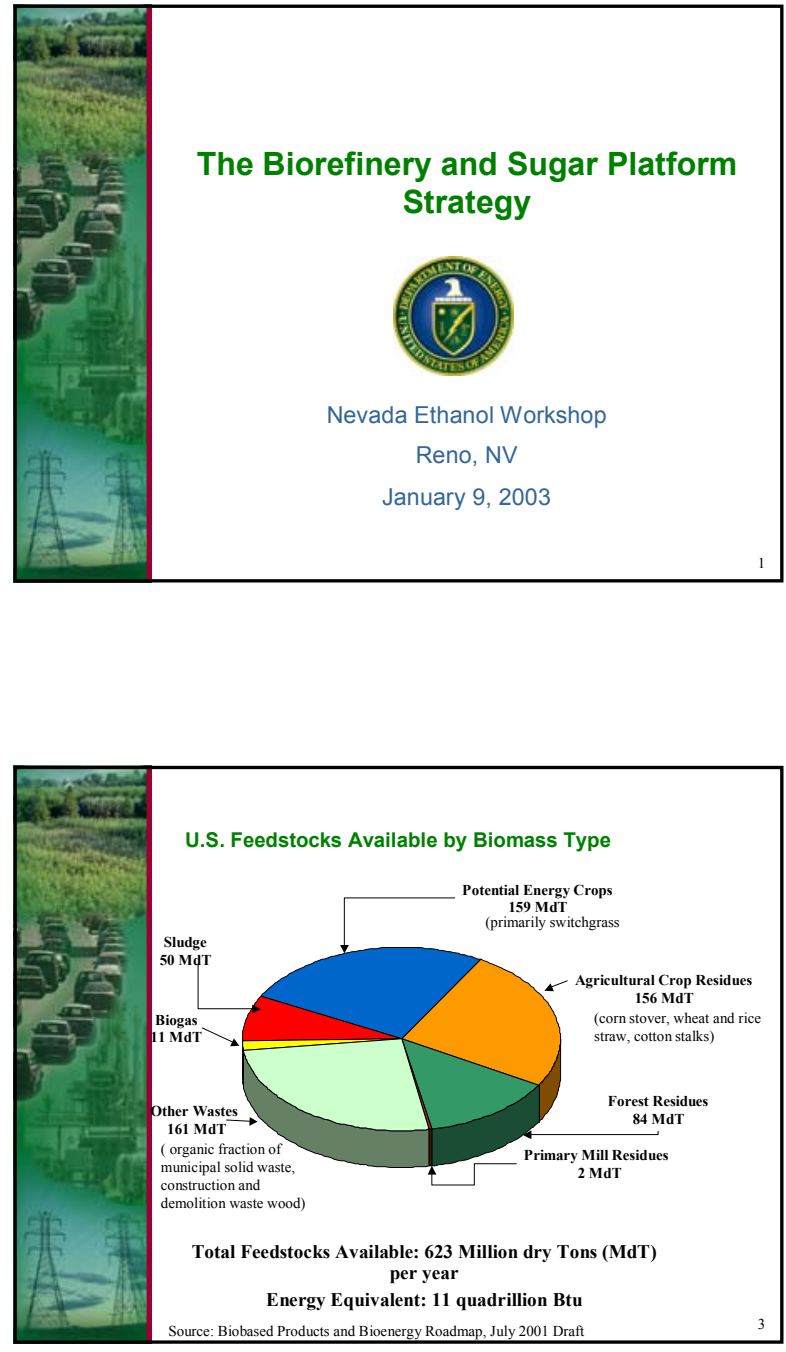

\begin{tabular}{|c|c|}
\hline 50 bete & $\begin{array}{l}\text { Restructuring Biomass } \\
\text { Program - } 2002\end{array}$ \\
\hline & - Major restructuring of EERE \\
\hline & $\begin{array}{l}\text { - Previous focus on biofuels, biopower } \\
\text { and bioproducts }\end{array}$ \\
\hline & $\begin{array}{l}\text { - Current focus biorefinery and } \\
\text { technology development pathways for } \\
\text { fuels, power, and bioproducts }\end{array}$ \\
\hline & \\
\hline
\end{tabular}

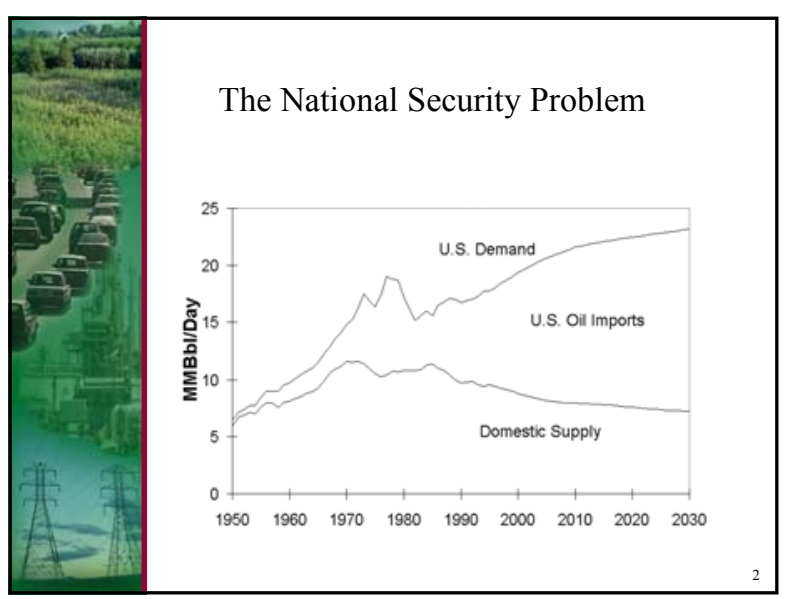

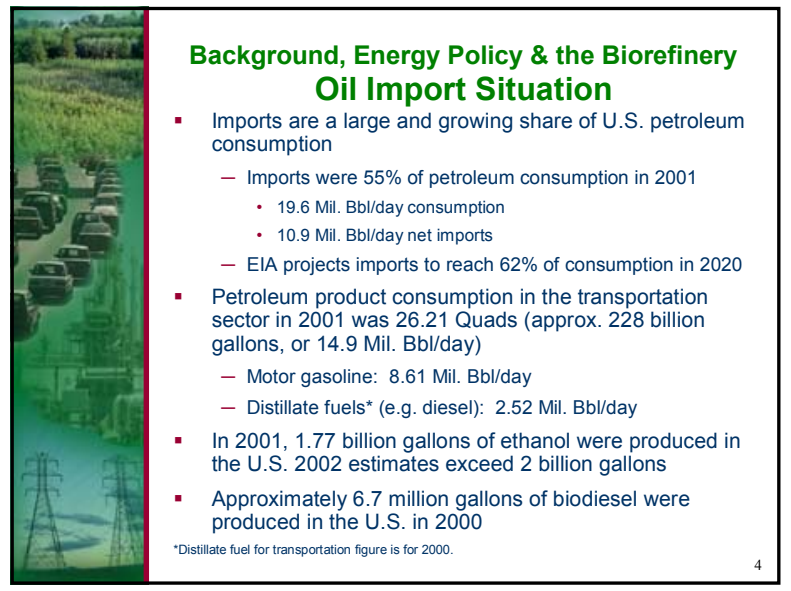




Background, Energy Policy \& the Biorefinery
Program Mission and Goals

$\begin{aligned} & \text { Background, Energy Policy \& the Biorefinery } \\ & \text { Biorefinery Concept }\end{aligned}$
$\begin{aligned} & \text { - Thermochemical and/or biochemical } \\ & \text { processes } \\ & \text { - Multiple product capability (some } \\ & \text { combination of ethanol, hydrogen, } \\ & \text { electricity, sugars, syngas, and specialty } \\ & \text { chemical products) } \\ & \text { - Multiple feedstock capability }\end{aligned}$

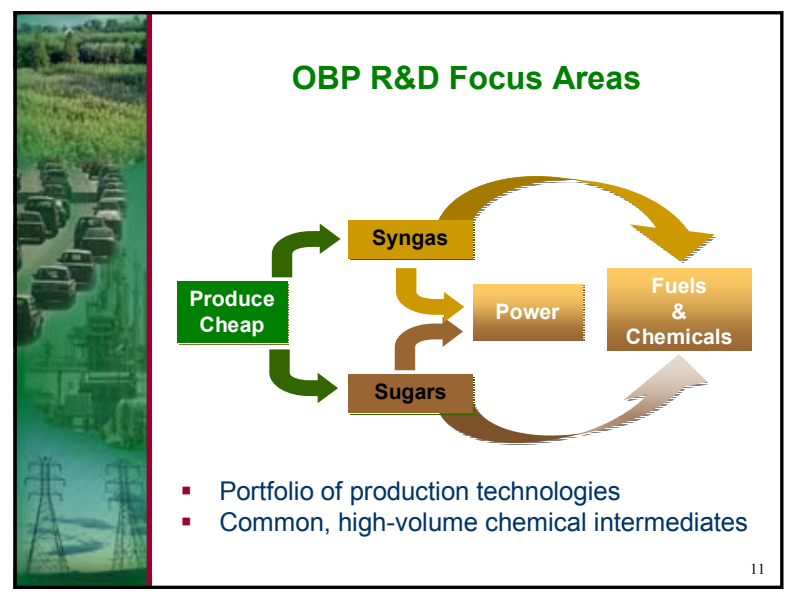

\begin{tabular}{|l|}
$\begin{array}{l}\text { Background, Energy Policy \& the Biorefinery } \\
\text { What is a Biorefinery? }\end{array}$ \\
$\begin{array}{l}\text { According to the } 2002 \text { Farm Bill, "The } \\
\text { term 'biorefinery' means equipment } \\
\text { and processes that: } \\
\text { - Convert biomass into fuels and } \\
\text { chemicals; and } \\
\text { - May produce electricity }\end{array}$ \\
\end{tabular}

\begin{tabular}{|c|c|}
\hline $\begin{array}{c}\text { Background, Energy Policy \& the Biorefinery } \\
\text { Biolndustry Challenges }\end{array}$ \\
- Market Competition \\
- Feedstock Infrastructure \\
- Sustainability \\
- $\begin{array}{l}\text { Policy - internalizing externalities, carbon, } \\
\text { thinnings, ethanol tax credit, PURPA, } \\
\text { Renewable portfolio standards } \\
\text { - Adoption of Technology by Industry }\end{array}$ \\
\end{tabular}




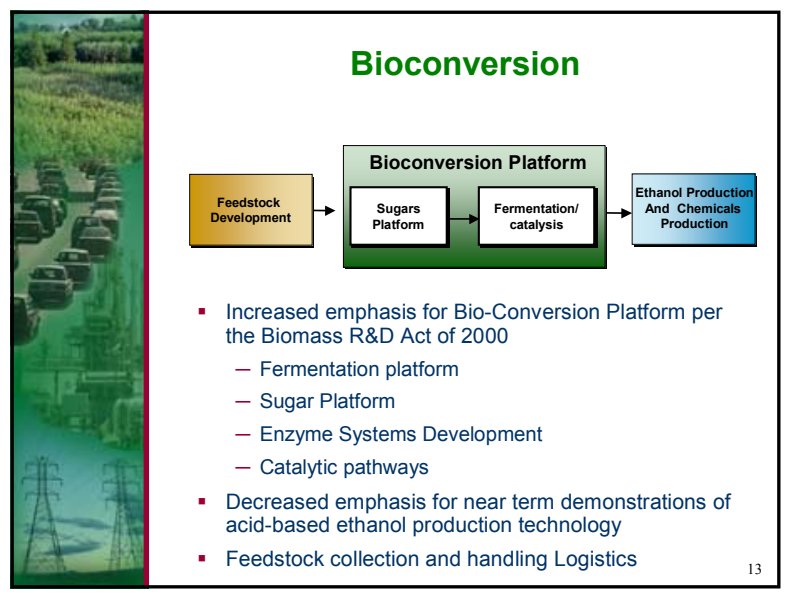

Opportunities
On the horizon
- Develop and integrate bioproducts to enable
deployment of biofuels
- Develop strong partnerships with industry
leaders committed to technology deployment
- Coordinate with USDA
- Demonstrate utilization of corn stover in
existing dry mills for fuel and co-products
- Improve profitability of existing wet \& dry
mills



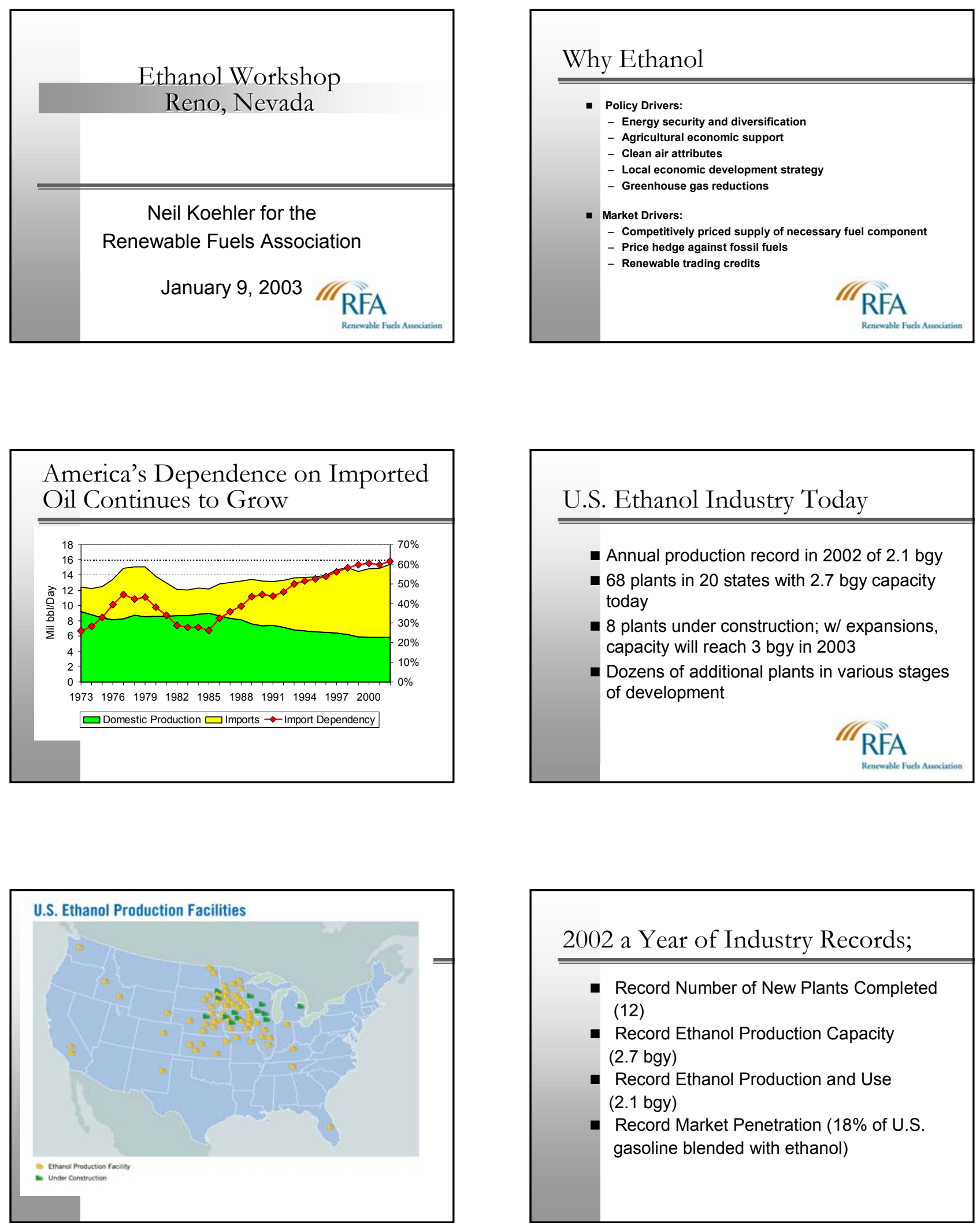

\section{2 a Year of Industry Records;}

- Record Number of New Plants Completed (12)

- Record Ethanol Production Capacity (2.7 bgy)

- Record Ethanol Production and Use (2.1 bgy)

- Record Market Penetration (18\% of U.S. gasoline blended with ethanol) 

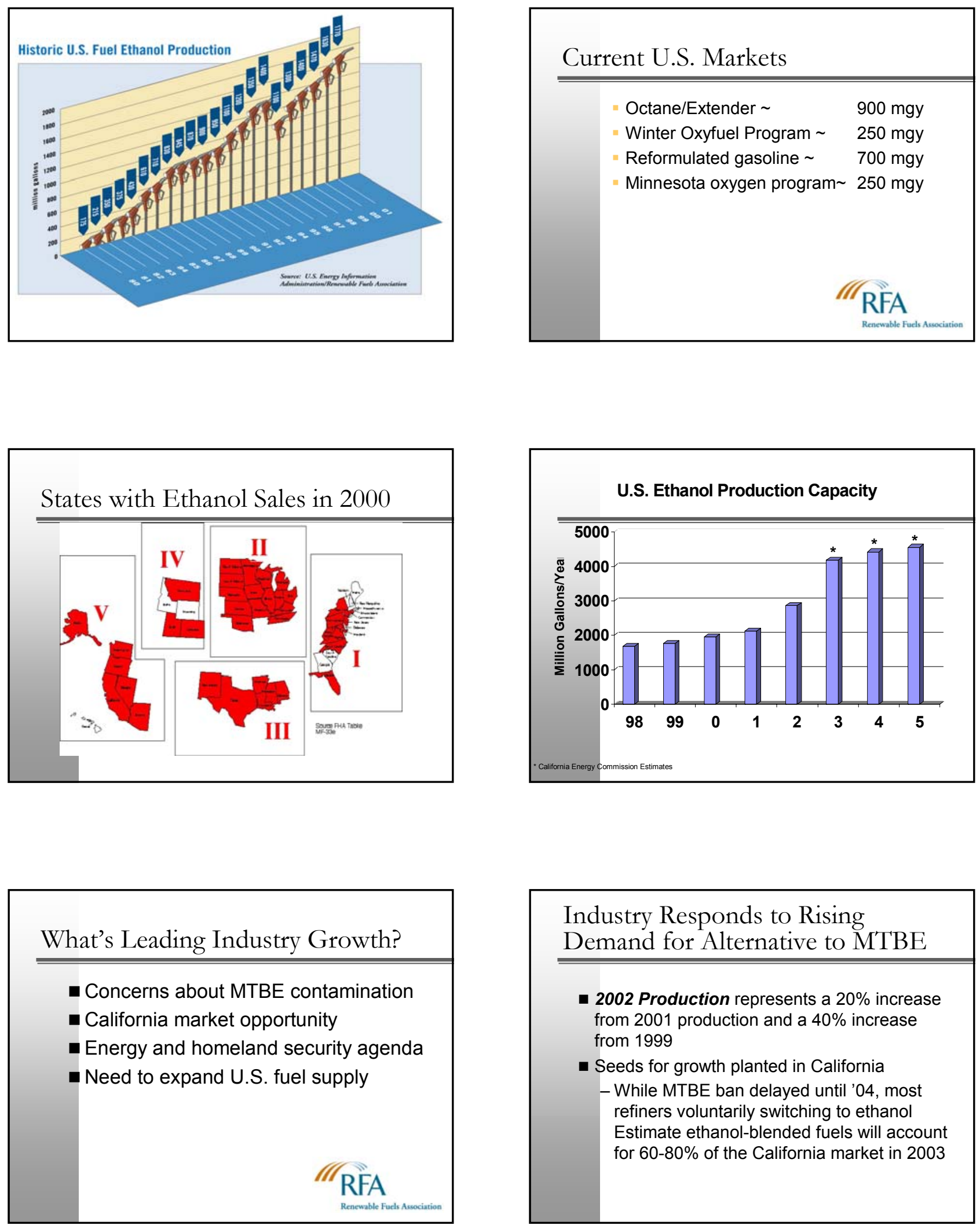

Industry Responds to Rising Demand for Alternative to MTBE

- 2002 Production represents a $20 \%$ increase from 2001 production and a $40 \%$ increase from 1999

- Seeds for growth planted in California

- While MTBE ban delayed until '04, most refiners voluntarily switching to ethanol Estimate ethanol-blended fuels will account for $60-80 \%$ of the California market in 2003 
Farmers Leading the Fight for Energy Independence

- 27 of the 68 current ethanol plants are owned by farmers

- 6 out of 8 ethanol plants under construction are farmer-owned

Majority of ethanol plants under development are farmer-driven projects
Historic Fuels Agreement Debated in last Congress

- Phases out MTBE use in 4 years

- Eliminates RFG oxygen standard

- Increases flexibility in fuels marketplace

- Maintains air quality gains of RFG program

- Creates Renewable Fuels Standard (RFS)

- Supported by petroleum, agriculture and environmental interests

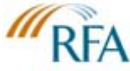

Renewable Fuels Anociation

\section{Renewable Fuels Standard}

- Provides for gradual and increasing phase-in of the use of renewable fuels, such as ethanol and biodiesel, growing to 5 bgy in 2012

- Provides for orderly transition allowing renewable fuel capacity expansion and infrastructure modifications

- Doesn't require renewable fuels to be used in any particular state or region, ensuring renewable fuels will be used where most economical and cost-effective
Cont.

- Allows for Credit Trading and Banking

- Temporary Waivers

- Small Refiner Exemption

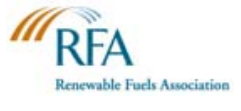

\section{Benefits of the RFS}

- Reduce crude oil imports by 1.6 billion barrels

- Reduce the U.S. trade deficit by $\$ 34$ billion

- Create 214,000 new American jobs

- Increase U.S. household income by $\$ 51.7$ billion

- Create $\$ 5.3$ billion in new investment in renewable fuel production facilities

- Increase demand for grain (mainly corn) an average of 1.4 billion bushels and soybeans 144 million bushels per year.

\section{Logistics of Nationwide RFS}

- Ethanol is transported cost-effectively nationwide via barge, railcar and oceangoing vessel

- According to DOE, "no major infrastructure barriers exist" to achieving 5 bgy market, and logistics modifications needed can be achieved cost-effectively

- EIA states consumer price impact of the RFS <one cent/gal; expects price to fall due to positive impact of banking and trading credits

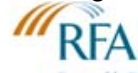




\begin{tabular}{|l|} 
Nationwide Economic Benefits of \\
Ethanol Demand \\
\hline \hline Increases net farm income by $\$ 4.5$ bil \\
- Boosts total employment 195,200 jobs \\
Adds over $\$ 450$ mil to state tax receipts \\
- Improves U.S. trade balance by $\$ 2$ bil \\
- Saves Treasury more than $\$ 3.6$ bil \\
100 mgy plant creates 2,250 local jobs \\
for a community (USDA)
\end{tabular}

Ethanol's Environmental Benefits

- Reduces emissions of CO, VOCs, NOx and particulates

- Replaces water contaminating MTBE

- Displaces toxics - benzene, toluene

- Renewable - reduces greenhouse gas emissions

Displaces fossil energy use
Local Economic Benefits of a 40 mgy facility

- Provide a one-time boost of $\$ 142$ million during construction

- Expand the local economic base $\$ 110.2$ million each year

through the direct spending of $\$ 56$ million

- Create 41 full-time jobs at the plant and 694 jobs throughout the entire economy

- Increase local price of corn by an average of 5-10 cents a bushel

- Increase household income for the community by $\$ 19.6$ million annually

Boost state and local sales tax receipts by an average of $\$ 1.2$ million (varies depending on local rates)

- Provide an average $13.3 \%$ annual return on investment over 10 years to a farmer who invests $\$ 20,000$ Source: "Ethanol and the Local Community," John Urbanchuk, AUS Consultants and Jeff Kapell, SJH \&
Energy Security Benefits

- 2/3 known oil reserves in Mideast

- Use of ethanol displaces imported oil (23.3 gallons of ethanol = 1 barrel of oil)

- Today $97 \%$ of transportation energy comes from petroleum, of which $61 \%$ is imported - U.S. energy imports to grow from $57 \%$ in 2002 to $68 \%$ in 2025

A dispersed energy infrastructure is less vulnerable to terrorist attack

The Future is Bright

- Ethanol and diesel fuel blends

- Fuel Source for Fuel Cells

- Research underway to identify new uses and highvalue co-products

- Commercialization of cellulose to ethanol technology

- Worldwide demand for renewable fuels growing as means to reduce greenhouse gases and develop new agricultural markets 


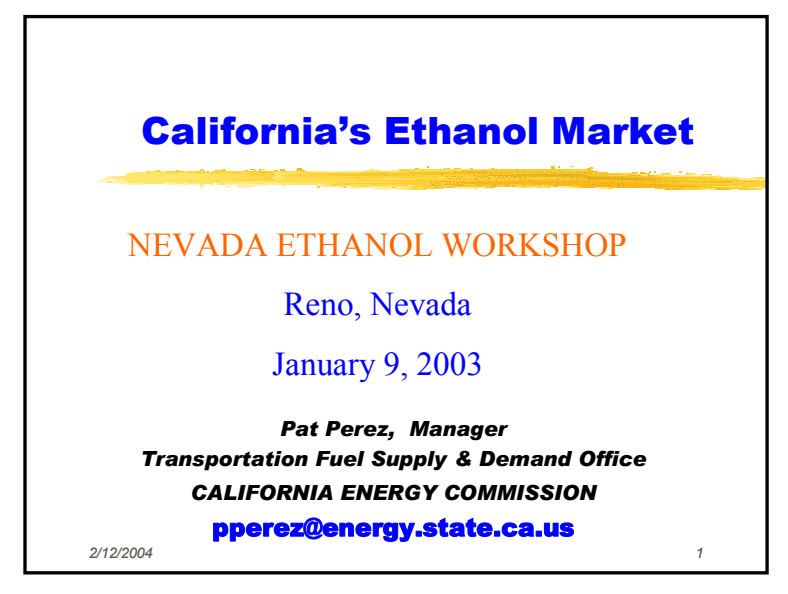

\section{Research \& Development Efforts - 1980s}

- Commercial Scale Ethanol Production Feasibility Studies 1980s - CEC

I Selma (CA) Demonstration Project - 8 mgy capacity

- Alcohol Vehicle Fleets - CEC

- Alcohol Fuel Plant Design Competition CDFA

I. Parallel Products Facility Begins Operation

\section{Presentation Topics}

Research and Development Programs

Ethanol Demand \& Supply Outlook

MTBE Phaseout

- Challenges and Opportunities

\section{Research \& Development Efforts - 1990s to Present}

I Gridley Project in Butte County - Collins Pine Project in Plumas County

- 20 conventional based ethanol projects are in some stage of evaluation or planning today

I Corn based projects in Northern and Central California

I Sugarcane -based projects in Imperial Valley

\section{MTBE Phaseout and Ethanol Substitution}

|1 Governor's 1999 Executive Order...

I Orders end of MTBE use by 2003 (later extended to 2004)

II Directs studies of ethanol use as a replacement for MTBE

I Directs evaluation of the potential for an in-state ethanol industry

IEnvironmental Policy Council determines (2000)
Ethanol Demand Scenarios

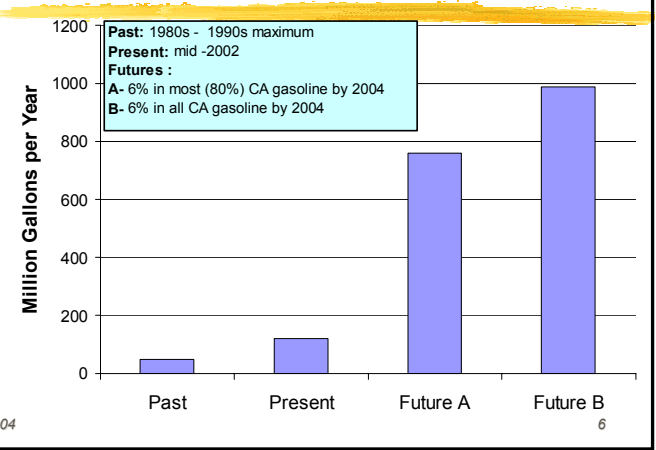




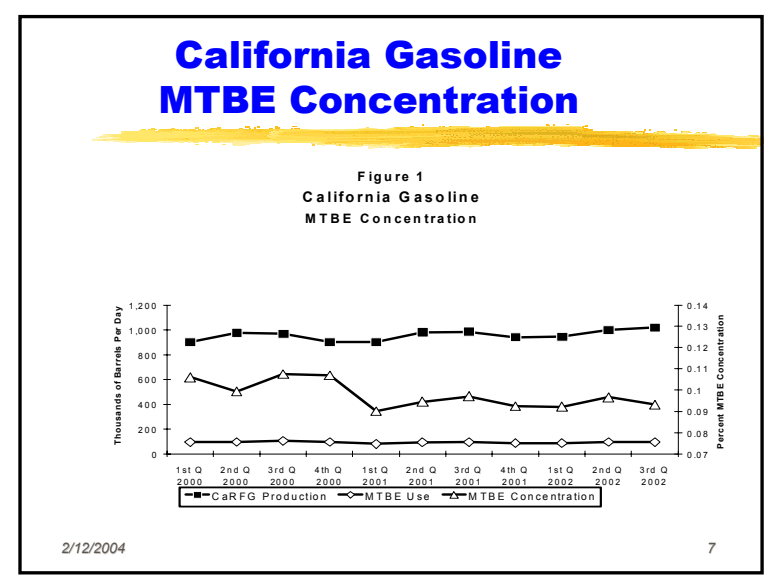

\section{Public Announcements to Replace} MTBE With Ethanol in Early 2003

Phillips-Conoco - Completed

British Petroleum -Amoco

Shell Oil

Exxon-Mobil

Others California Refiners are Considering

\section{California's Supply Sources}

Domestic U.S. Sources

Foreign Sources

California

| Current

I Projected

Energy Commission Proprietary Survey Results

U.S. Ethanol Production Capacity @End of Year - MGY

20012002200320042005

Existing Plants

Existing Plat Expansions

$\begin{array}{lllll}2219 & 2967 & 2967 & 2967 & 2967\end{array}$

NewPlants Plamed

$\begin{array}{lll}147 & 242 \quad 320\end{array}$

NewPlants Under Construction

$\begin{array}{llll}40 & 1190 & 1354\end{array}$

\begin{tabular}{|c|c|}
\hline vew Hants Under Constuction & $502 \quad 542$ \\
\hline Totd & 221929673416490151 \\
\hline
\end{tabular}
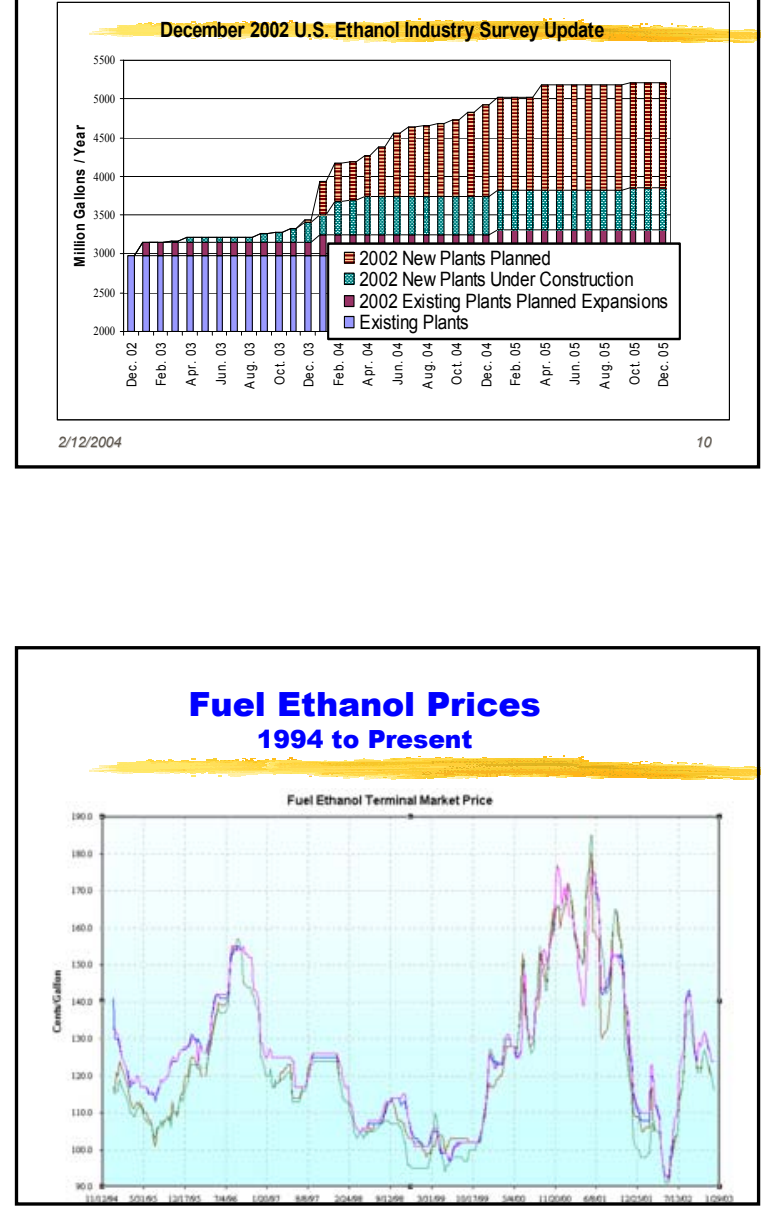


\section{Ethanol Challenges}

- Uncertainty in California Ethanol Market

Difficulty in Securing Project Financing

Status of Federal Energy Legislation

- Lack of Commercially Demonstrated Technology

- Uncertain Economics

- Siting/Environmental and Permitting Issues 2/12/2004

\section{Ethanol Opportunities}

Growing transportation fuel market

- Large agricultural sources as well as cellulosic wastes and residues.

E-10 Blends - up to 600 MGY

E-85 Market

- Fuel Cell Applications

Ethanol/Diesel Blends

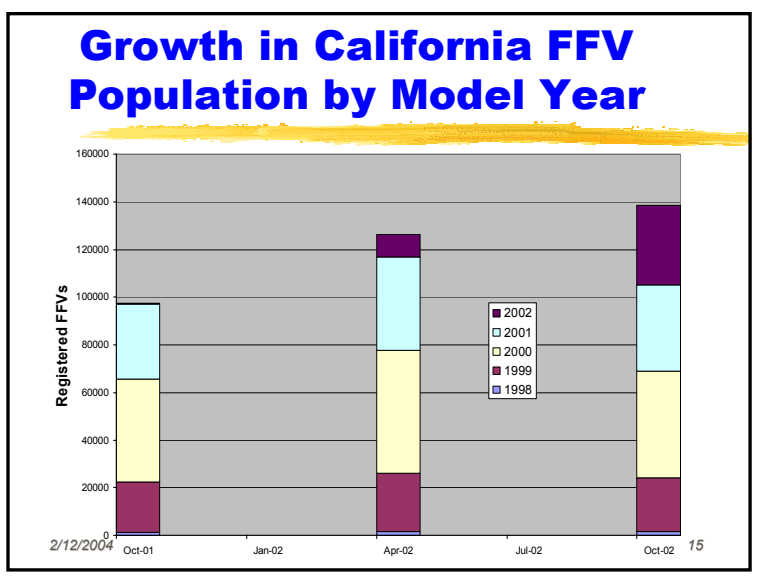

\section{For More Information}

About Ethanol Activities...

1 Visit California Energy Commission's Web Site at: www.energy.ca.gov/ethanol

I Other Websites:

I CARB: www.arb.ca.gov/cbg/ethanol

I Imperial Bioresources LLC: www.imperialbioresources.com

I Northern CA Ethanol LLC: www.northerncaliforniaethanol.com

I Lawrence Livermore Natl Lab: www.erd2/12/2004llnl.gov/ethanol 


\section{$\mathrm{CO}$ and Ethanol as an Oxygenate}

January 9, 2003

Andrew C. Goodrich

Washoe District Health Air Quality Management Division

\section{Air Quality in the Truckee Meadows}

- Non-attainment for CO, Ozone, PM10.

- Eight (8) air quality monitoring sites throughout southern Washoe County.

- Regulations for fireplaces, wood stoves, and oxygenated gasoline.
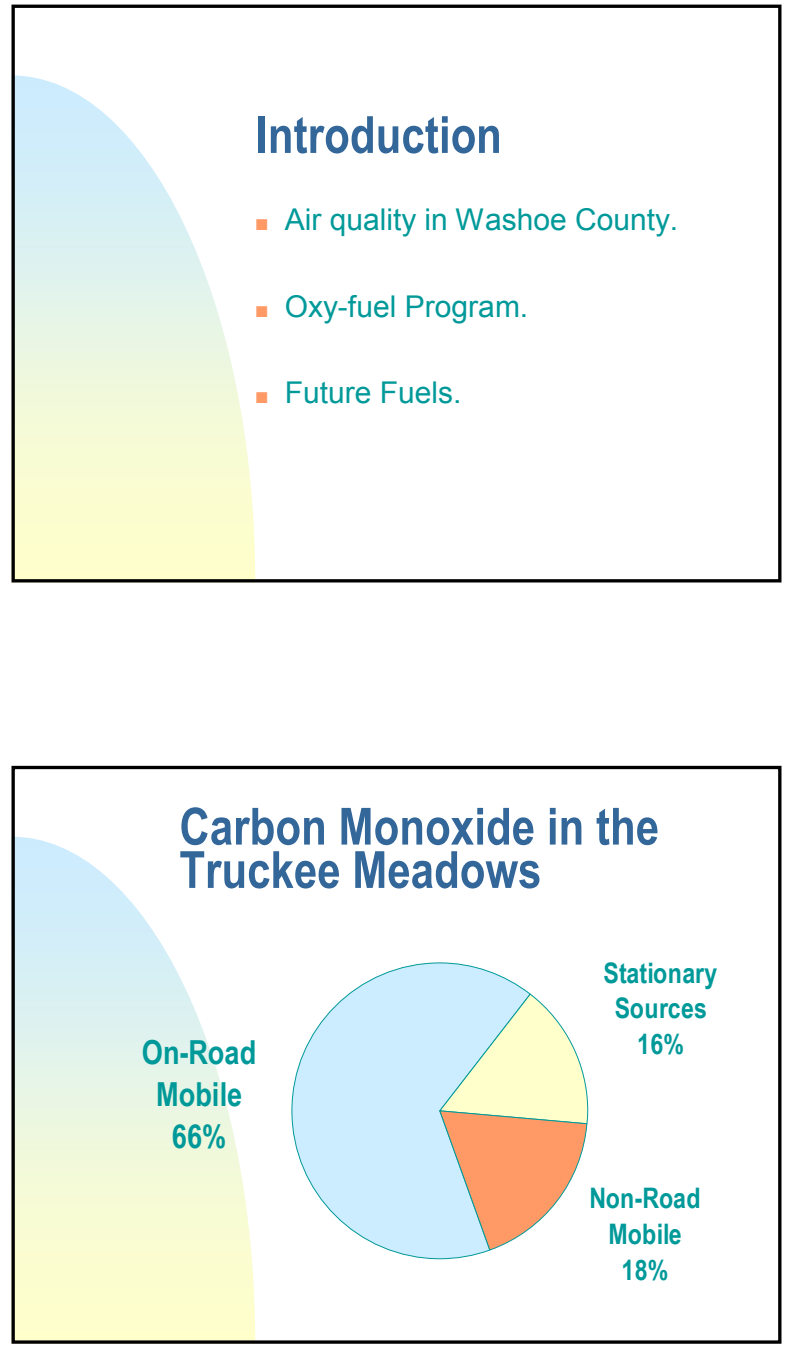

\section{Oxygenated Fuel Regulation}

- Originally adopted in 1989, revisions in 1992, 2000.

- Simple - 1/2 page rule, sets $\mathrm{O} 2$ minimum.

- MTBE Prohibition tied to CA

\section{Oxygenated Fuel}

Minimum O2

- First two years $\mathrm{O} 2$ set at 2.0 percent by weight

- Since 1991; O2 set at 2.7\% weight

Market Share

- First 6 years: 85-90 \% MTBE

- Since 1995: 95-100 \% Etoh 

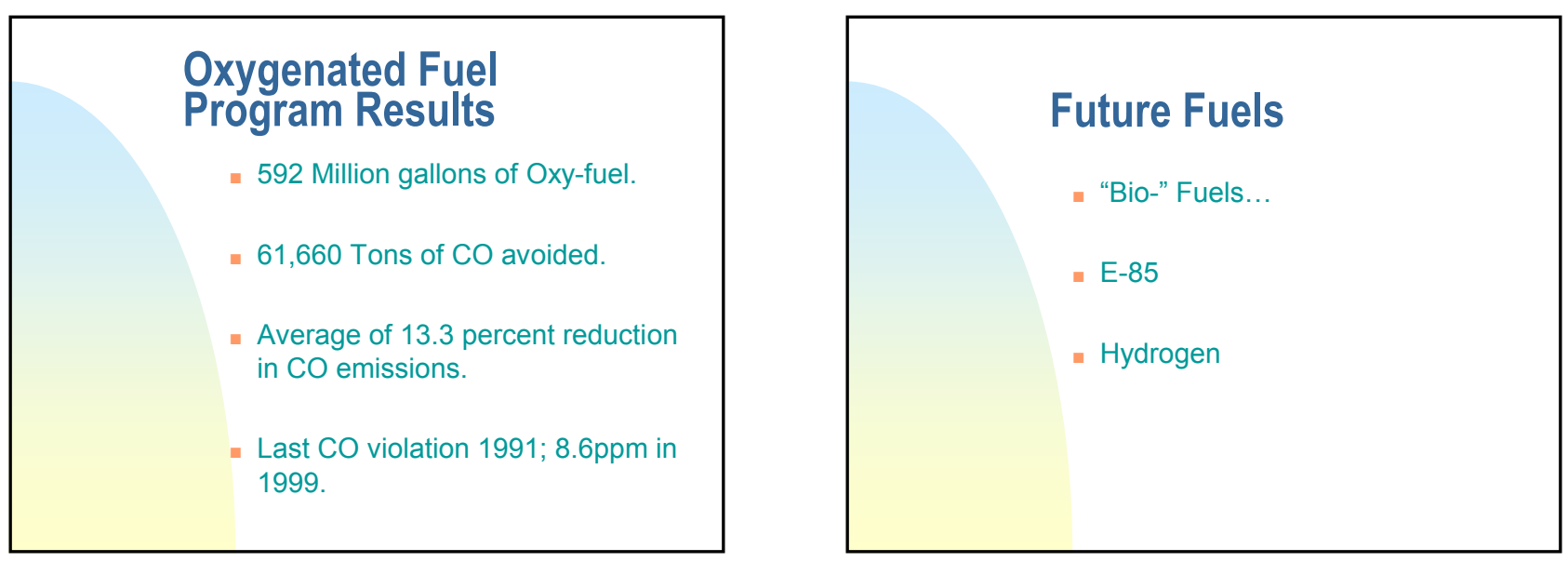


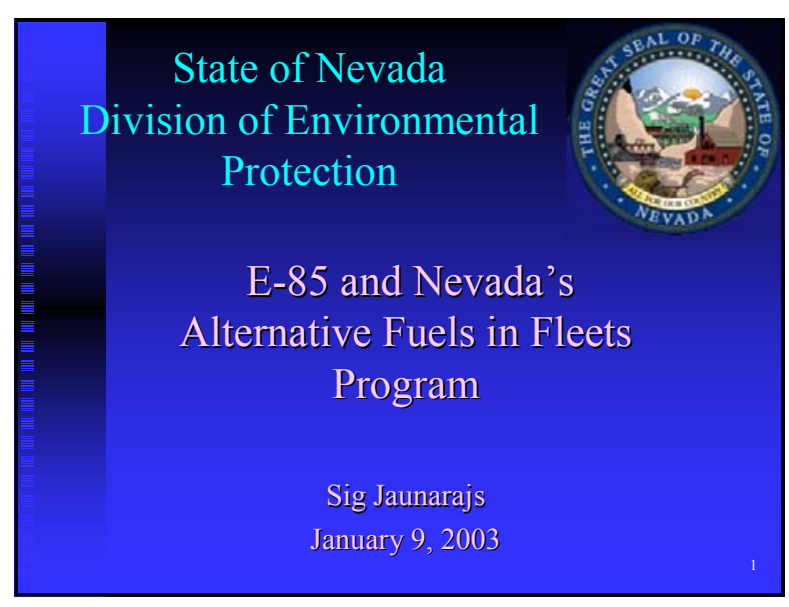

\section{Vehicles that can use E-85}

- Only specially-equipped vehicles may run on E-85, however, you may be driving one and not even know it

- Fuel system materials must be compatible with an alcohol; vehicle's computer adjusted to optimize performance with E-85

- Flexible-Fuel (Flex-Fuel) vehicles can burn either unleaded gasoline, E-85 or any combination of both
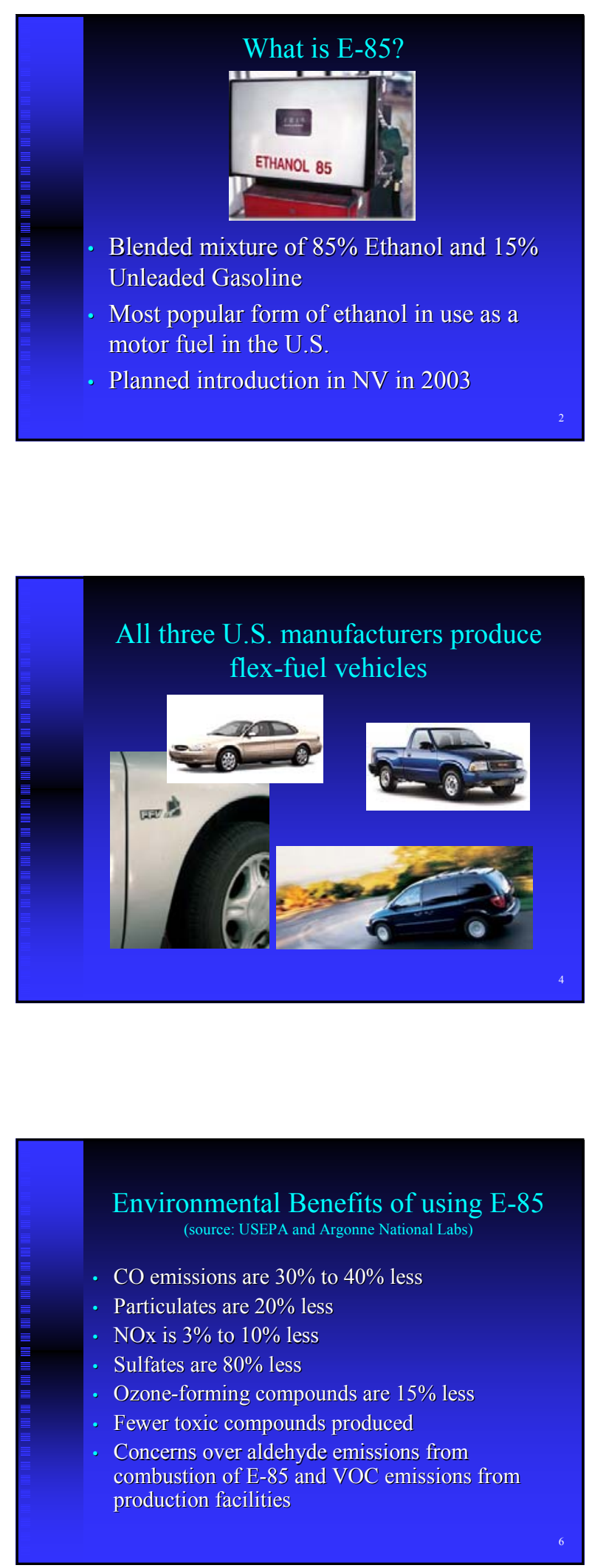


\section{Ethanol Use in NV}

- Limited experience with ethanol; E-10 used as a wintertime oxygenated fuel

- Closed production facility at Wabuska

Nevada's First E-85

Dispenser - NV State

Motor Pool facility at

Reno/Tahoe Airport -

Opening soon!

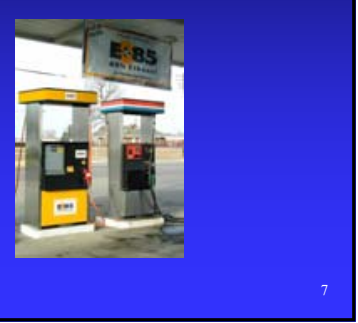

Nevada's Alternative Fuels in Fleets Program

- Requires that city, state, and county fleets acquire and use alternative fuel vehicles in Washoe and Clark counties

- E-85 is a listed alternative fuel

- Public fleets will likely be the first significant consumers of E-85

Ethanol is perhaps not the perfect fuel, but is an environmentally responsible alternative for Nevada 


Environmental Aspects
of Ethanol as a Motor
Fuel

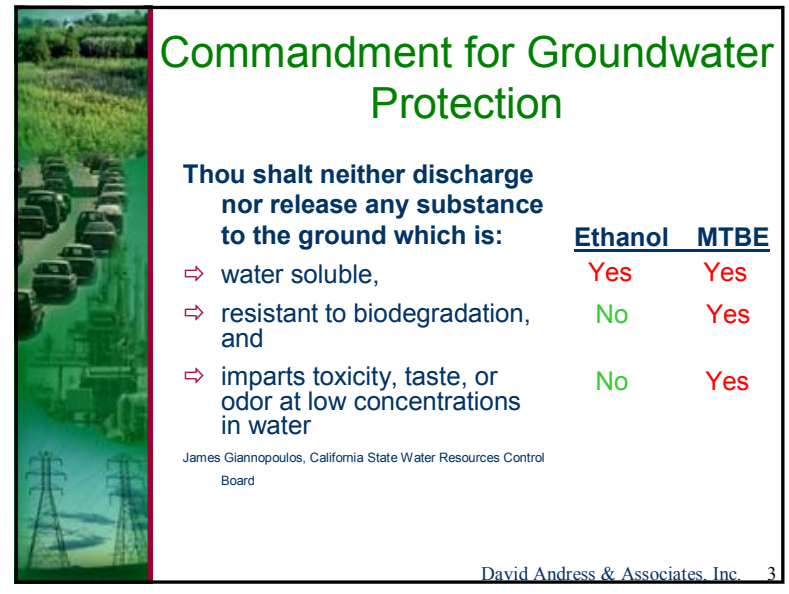

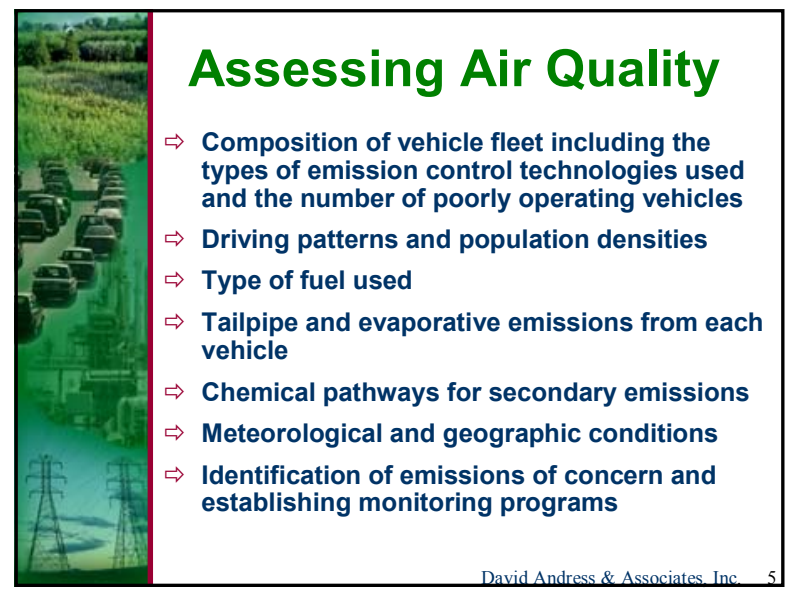

Recent Developments
$\Rightarrow$ The potential expansion in ethanol due
to restrictions on MTBE has
heightened public interest in the air
and water quality impacts of using
ethanol fuels
$\Rightarrow$ Major concerns for air quality are:
- voc and NOx emissions
- Acetaldehyde and PAN emissions

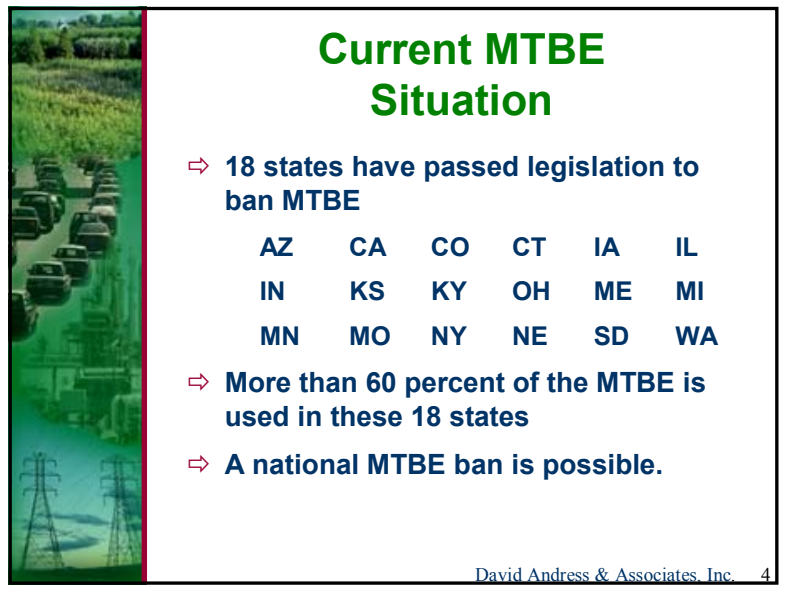




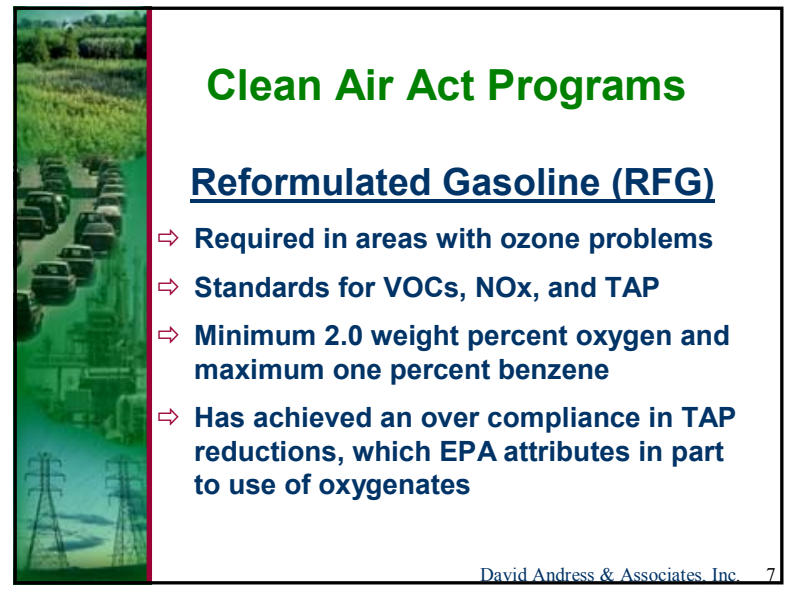

\begin{tabular}{|l|l|}
\hline \multicolumn{2}{|c|}{$\begin{array}{l}\text { Refinery Blending and } \\
\text { Ethanol Properties }\end{array}$} \\
$\qquad$\begin{tabular}{|l|l|}
\hline $\begin{array}{l}\text { Gasoline } \\
\text { Volume }\end{array}$ & $\begin{array}{l}\text { Ethanol provides volume (loss of MTBE } \\
\text { presents volume problems) }\end{array}$ \\
\hline $\begin{array}{l}\text { RFG } \\
\text { Emissions }\end{array}$ & $\begin{array}{l}\text { Ethanol reduces most toxic air pollutants } \\
\text { (except acetaldehyde) through dilution, but } \\
\text { increases evaporative VOC emissions } \\
\text { (summer issue) and perhaps NOx }\end{array}$ \\
\hline Octane & $\begin{array}{l}\text { Ethanol (like MTBE) is a high-octane } \\
\text { blendstock }\end{array}$ \\
\hline RVP in CG & $\begin{array}{l}\text { Ethanol increases RVP (summer issue), but } \\
\text { most CG containing 10\% has one psi waiver }\end{array}$ \\
\hline $\begin{array}{l}\text { Oxygen and } \\
\text { CO }\end{array}$ & $\begin{array}{l}\text { Emanol is an oxygenate, reduces CO } \\
\text { emissions, EPA/CA now give an ozone- } \\
\text { related VOC credit for CO reductions }\end{array}$ \\
\hline Sulfur & Ethanol reduces sulfur through dilution \\
\hline
\end{tabular} \\
\hline
\end{tabular}

\begin{tabular}{|c|c|c|c|}
\hline \multirow{6}{*}{$\begin{array}{c}\text { Directional } \\
\text { Changes in } \\
\text { Emissions When } \\
\text { Ethanol Is } \\
\text { Blended with } \\
\text { Conventional } \\
\text { Gasoline and } \\
\text { RFG }\end{array}$} & & $\begin{array}{l}\text { Conventional } \\
\text { Gasoline }\end{array}$ & RFG \\
\hline & \multicolumn{3}{|l|}{ Toxic air pollutants } \\
\hline & \begin{tabular}{|l|} 
Acetaldehyde \\
Benzene \\
1,3-butadiene \\
Formaldehyde \\
\end{tabular} & $\begin{array}{l}\text { increase } \\
\text { decrease } \\
\text { decrease }^{1} \\
\text { increase }^{1}\end{array}$ & $\begin{array}{l}\text { increase }^{2} \\
\text { decrease } \\
\text { decrease } \\
\text { decrease }\end{array}$ \\
\hline & \multicolumn{3}{|l|}{ Criteria air pollutants } \\
\hline & \begin{tabular}{|l|} 
CO \\
NOx \\
Tailpipe VOC \\
Evaporative VOC \\
Total VOC \\
Particulate matter \\
\end{tabular} & $\begin{array}{l}\text { decrease } \\
\text { increase } \\
\text { decrease } \\
\text { increase } \\
\text { increase } \\
\text { decrease }\end{array}$ & $\begin{array}{c}\text { decrease } \\
\text { no change } \\
\text { no change } \\
\text { no change } \\
\text { no change } \\
\text { decrease }\end{array}$ \\
\hline & \multicolumn{3}{|l|}{\begin{tabular}{|l|} 
Other \\
\end{tabular}} \\
\hline \multirow{2}{*}{$\begin{array}{l}\text { The Directional Changes } \\
\text { Refer to Changes When } \\
\text { Comparing Conventional } \\
\text { Gasoline Containing Ethanol } \\
\text { with Ethanol-Free } \\
\text { Conventional Gasoline and } \\
\text { RFG Containing Ethanol } \\
\text { with RFG Containing MTBE }\end{array}$} & \begin{tabular}{|l|} 
PAN \\
Isobutene \\
Toluene \\
Xylene
\end{tabular} & $\begin{array}{l}\text { increase } \\
\text { decrease } \\
\text { decrease } \\
\text { decrease }\end{array}$ & $\begin{array}{l}\text { increase }^{2} \\
\text { decrease } \\
\text { decrease } \\
\text { decrease }\end{array}$ \\
\hline & \multicolumn{3}{|c|}{ 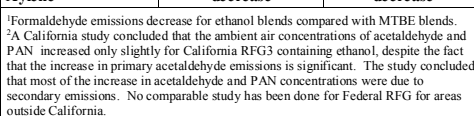 } \\
\hline
\end{tabular}
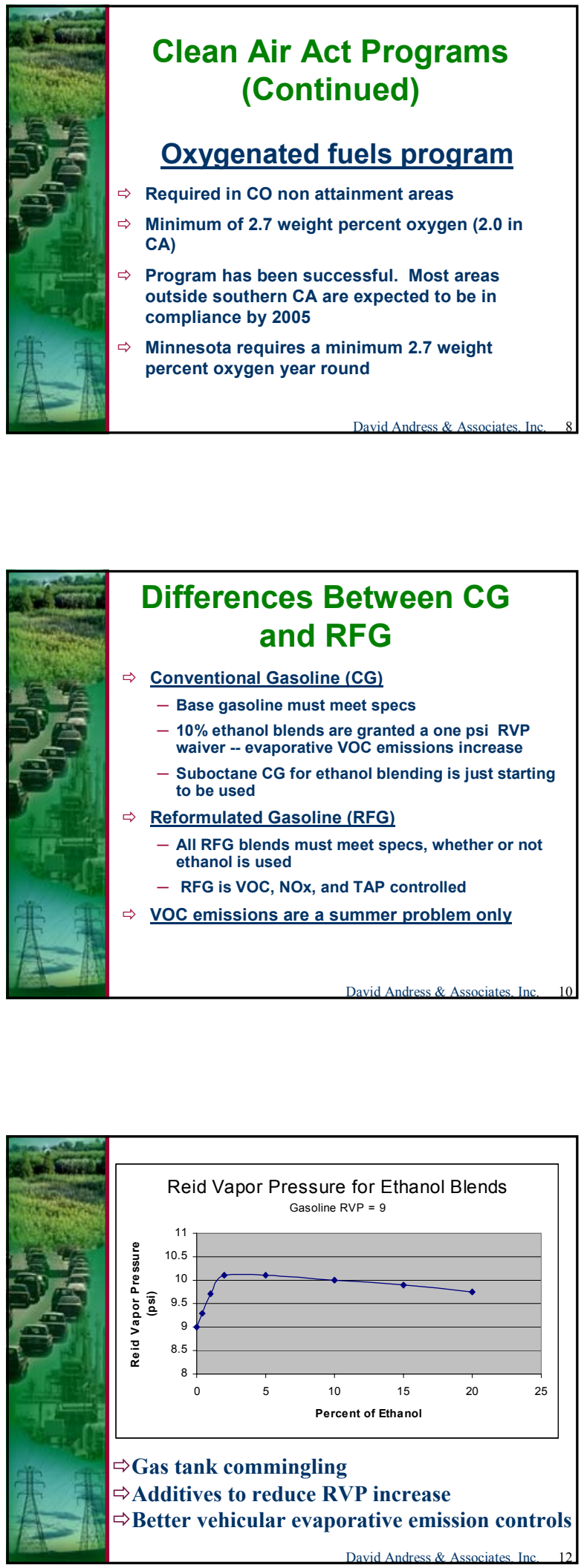


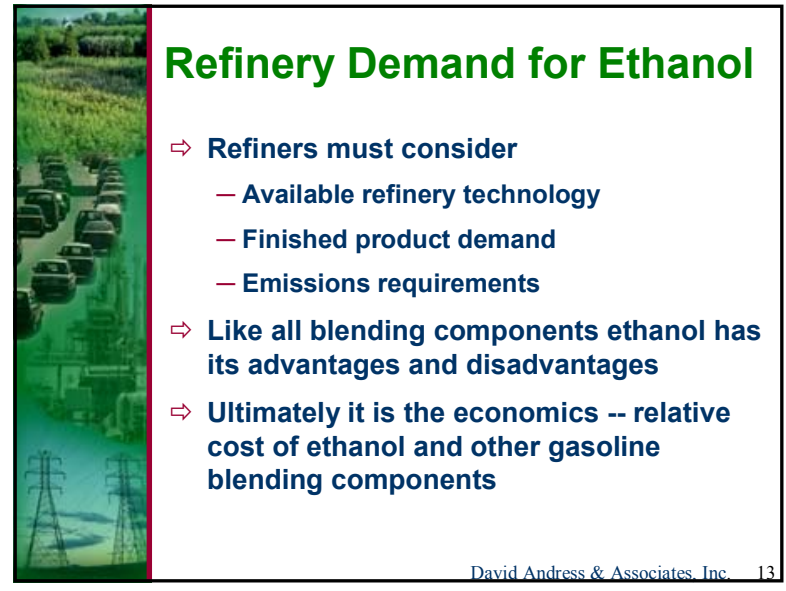

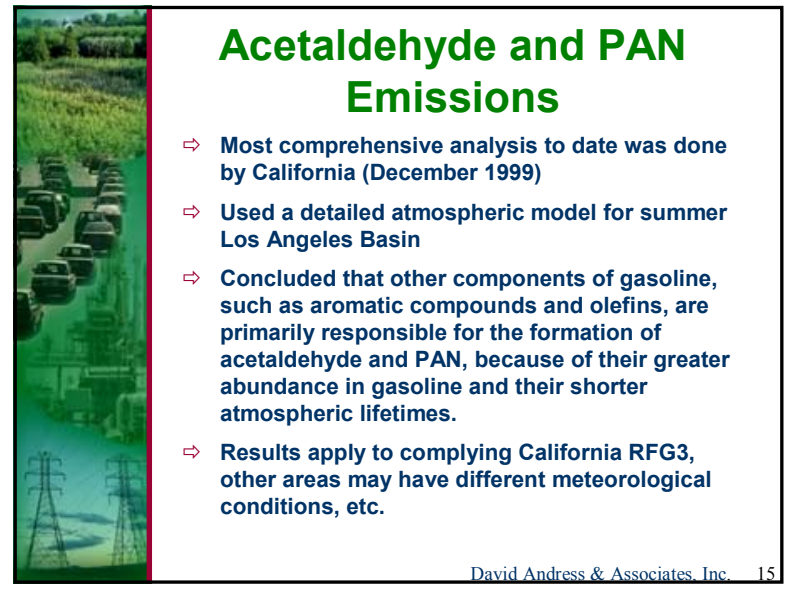

\section{Acetaldehyde Emissions and Air Quality Impacts (continued)}

Comparison of Modeled Air Quality Changes from 1997

\begin{tabular}{|c|c|c|c|c|}
\hline Compound & $\begin{array}{c}2003 \\
\text { MTBE }\end{array}$ & $\begin{array}{c}2003 \\
\text { Et2.0\% }\end{array}$ & $\begin{array}{c}2003 \\
\text { Et3.5\% }\end{array}$ & $\begin{array}{c}2003 \\
\text { NonOxy }\end{array}$ \\
\hline Acetaldehyde (Total) & $-13 \%$ & $-13 \%$ & $-10 \%$ & $-14 \%$ \\
\hline Acetaldehyde (Primary) & $-25 \%$ & $-23 \%$ & $4 \%$ & $-26 \%$ \\
\hline Acetaldehyde (Secondary) & $-12 \%$ & $-12 \%$ & $-11 \%$ & $-13 \%$ \\
\hline
\end{tabular}

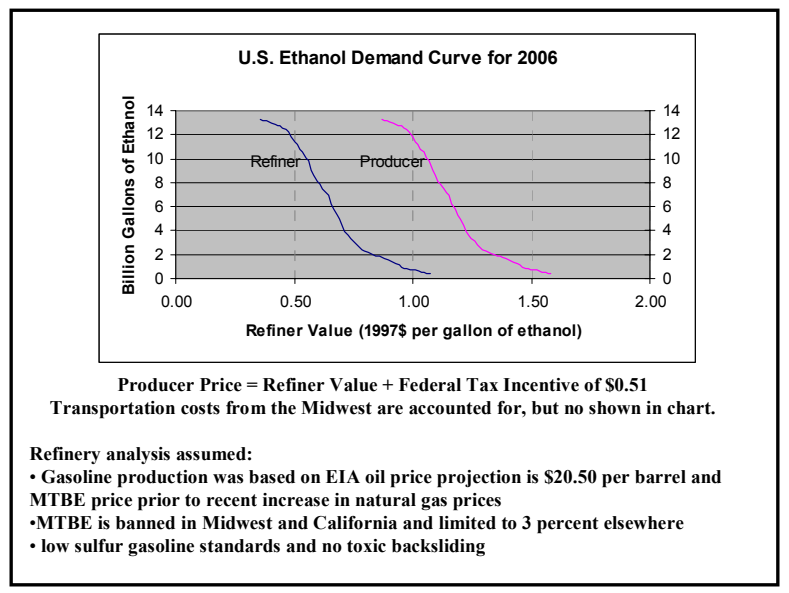

\begin{tabular}{|c|c|c|c|}
\hline \multicolumn{4}{|c|}{$\begin{array}{l}\text { Acetaldehyde Emissions and } \\
\text { Air Quality Impacts } \\
\text { Changes in Vehicular Primary Acetaldehyde Emissions } \\
\text { Relative to } 2003 \text { MTBE Baseline Gasoline }\end{array}$} \\
\hline Scenario / Type of & Change & \multicolumn{2}{|c|}{ Percent Change } \\
\hline 2003 Ethanol at $2.0 \mathrm{wt} \%$ & Oxygen & \multicolumn{2}{|c|}{$27 \%$} \\
\hline 2003 Ethanol at $3.5 \mathrm{wt} \%$ & Oxygen & \multicolumn{2}{|l|}{$132 \%$} \\
\hline 2003 Non-Oxygenate & & \multicolumn{2}{|c|}{$-5 \%$} \\
\hline \multicolumn{4}{|c|}{$\begin{array}{c}\text { Comparison of Modeled Air Quality Changes from } 2003 \\
\text { MTBE Baseline }\end{array}$} \\
\hline Compound & 2003 Et2.0\% & 2003 Et3.5\% & 2003 NonOxy \\
\hline Acetaldehyde (Total) & $\mathbf{0} \%$ & $4 \%$ & $-1 \%$ \\
\hline Acetaldehyde (Primary) & $4 \%$ & $39 \%$ & $-1 \%$ \\
\hline Acetaldehyde (Secondary) & $0 \%$ & $2 \%$ & $-1 \%$ \\
\hline
\end{tabular}

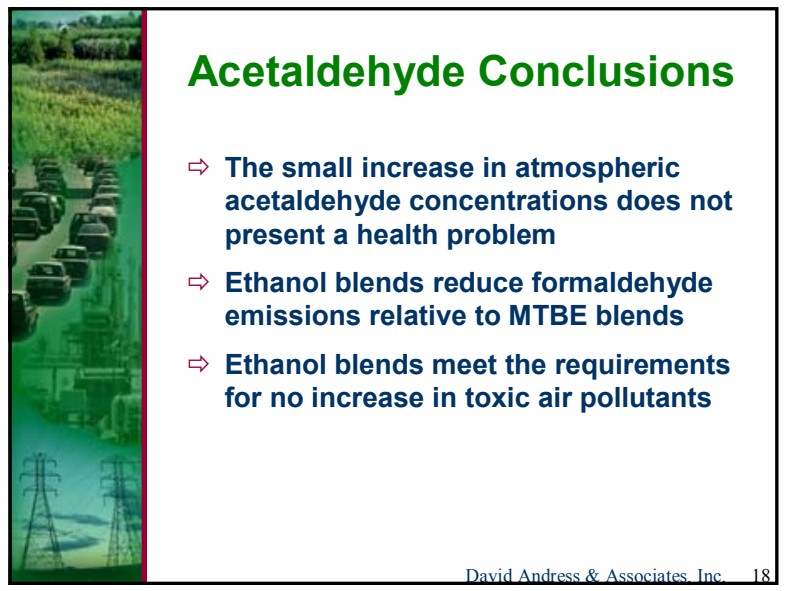



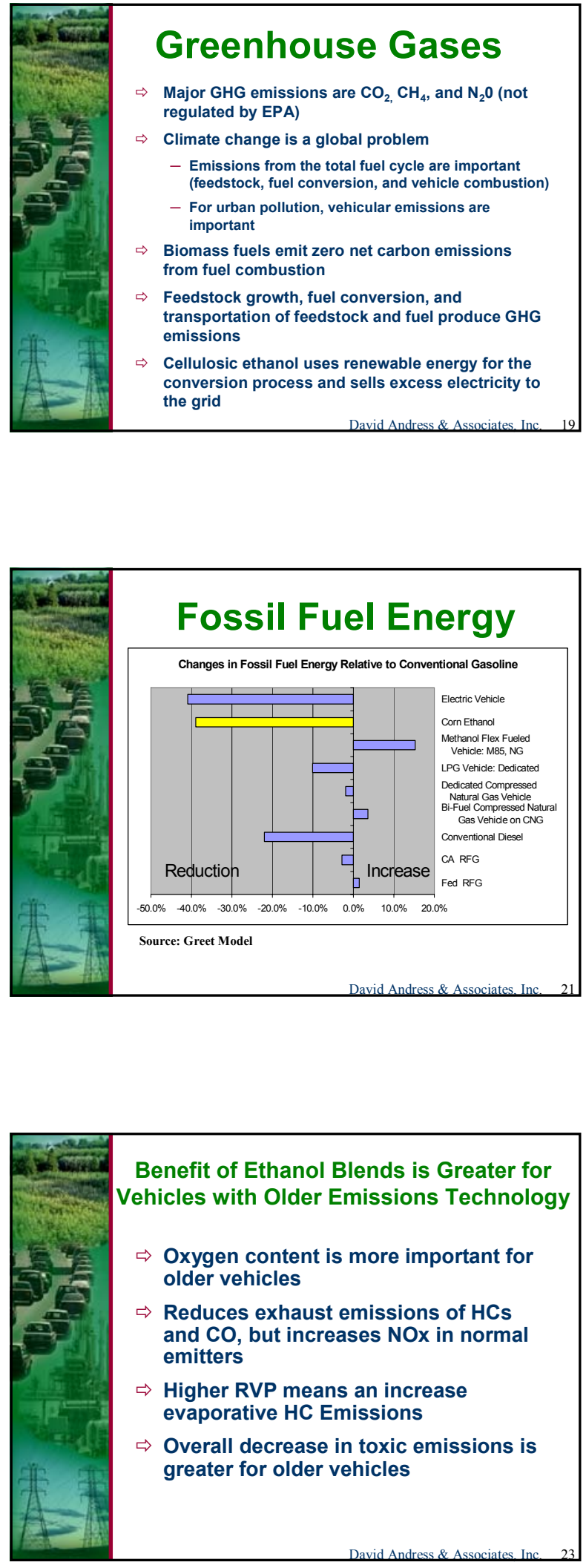
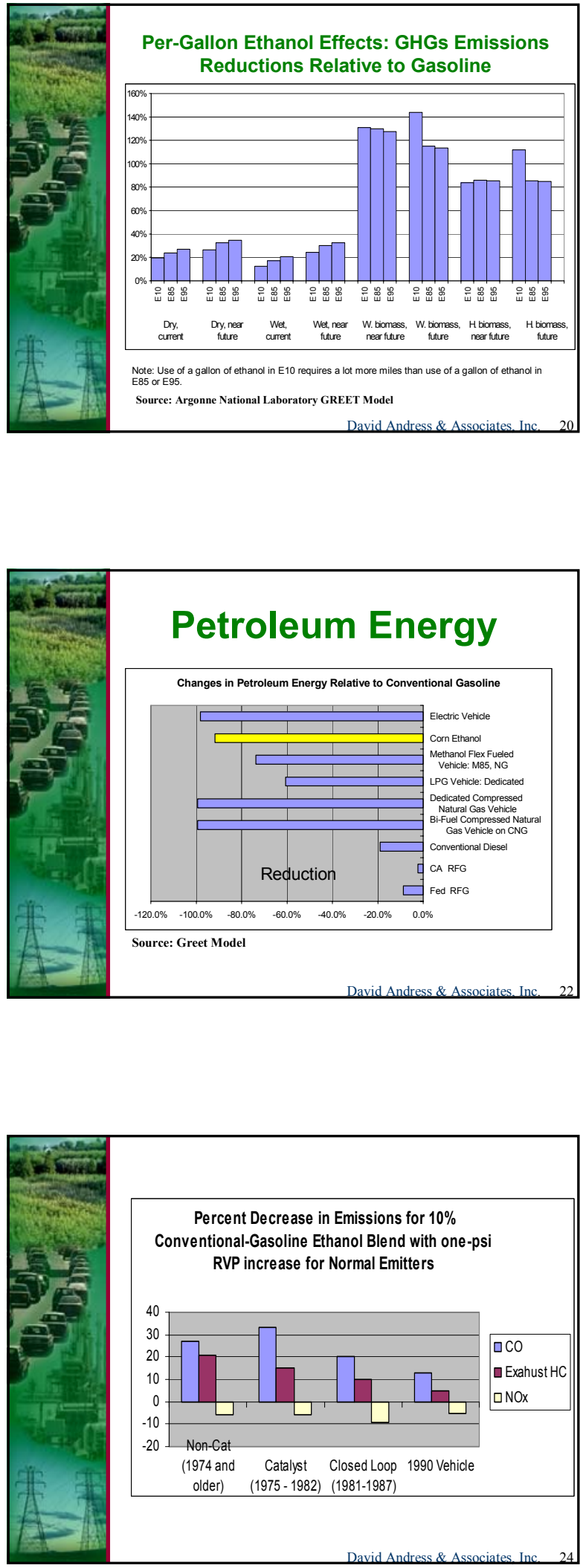


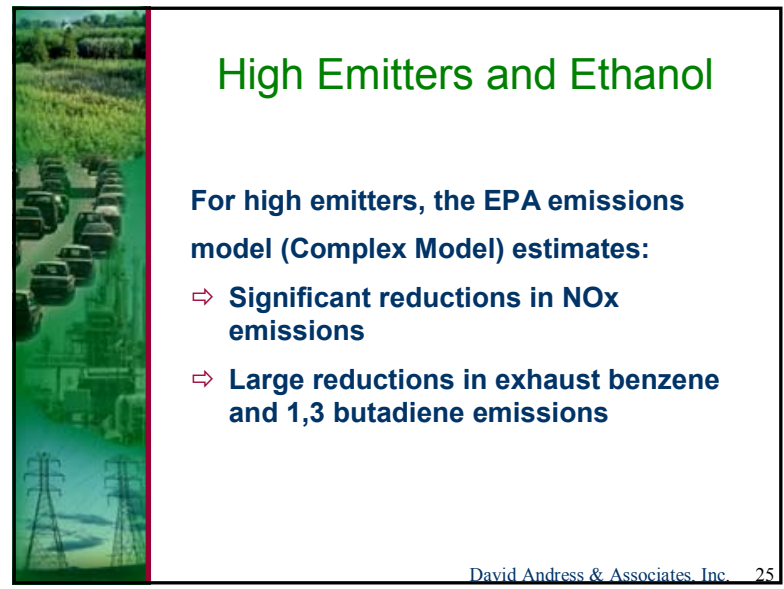
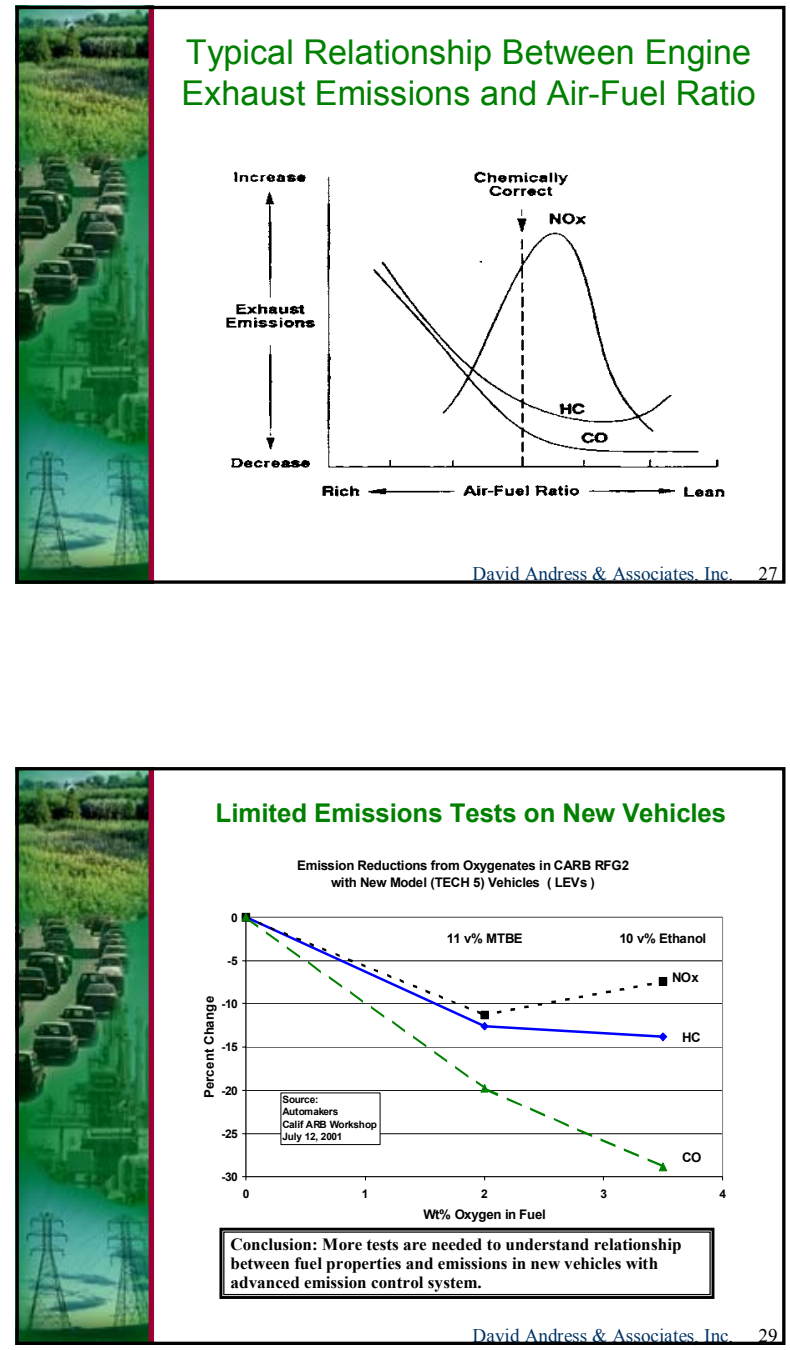

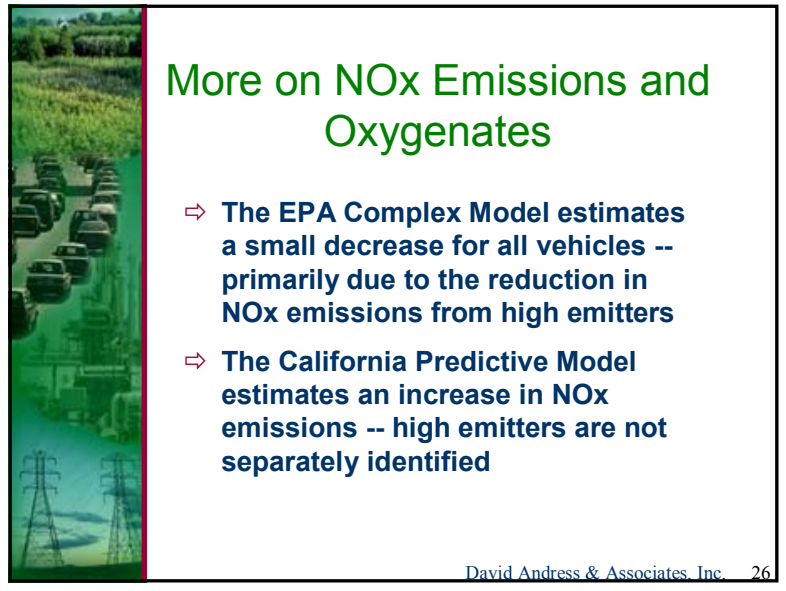

Future Fuel Trends
$\Rightarrow$ With modern control systems that
dynamically adjust the air-to-fuel ratio, the
effect of oxygen in the fuel will diminish
$\Rightarrow$ Ethanol will be valued more for:
- toxic emission reductions
- high octane
- virtually no sulfur
$\Rightarrow$ These properties will become more
important with the elimination of MTBE
$\Rightarrow$ Ethanol's major disadvantage is the RVP
increase




\begin{tabular}{|c|c|c|c|c|c|c|}
\hline$\frac{18 \operatorname{sen}}{5+20}$ & \multicolumn{6}{|c|}{$\begin{array}{l}\text { Mass and Potency Weighted } \\
\text { Exhaust Toxic Emissions }\end{array}$} \\
\hline \multirow{7}{*}{$\frac{5}{5}$} & & & \multicolumn{2}{|c|}{$\begin{array}{c}\text { Mass Em issions } \\
(\mathrm{mg} / \mathrm{m} \text { ile })\end{array}$} & \multicolumn{2}{|c|}{ 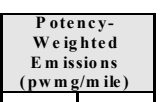 } \\
\hline & & \begin{tabular}{|l} 
Potency \\
Weighting
\end{tabular} & & & & \\
\hline & Benzene & $\frac{T \text { Factors }}{0.170}$ & $\begin{array}{r}8 \times 6.90 \\
8.90 \\
\end{array}$ & \begin{tabular}{|l|l|}
1.83 \\
\end{tabular} & \begin{tabular}{|c|}
$\frac{a k F}{1.51}$ \\
\end{tabular} & \begin{tabular}{|c|c|}
0.31 \\
\end{tabular} \\
\hline & 1,3-B - utadiene & 1.000 & \begin{tabular}{|l|}
0.87 \\
\end{tabular} & \begin{tabular}{|l|}
0.17 \\
\end{tabular} & \begin{tabular}{|l|}
0.87 \\
\end{tabular} & $\begin{array}{l}0.17 \\
\end{array}$ \\
\hline & Formalde hyde & 0.035 & 2.79 & \begin{tabular}{|l|}
3.36 \\
\end{tabular} & 0.10 & 0.12 \\
\hline & Acetalde hyde & 0.016 & \begin{tabular}{|r|}
0.84 \\
\end{tabular} & \begin{tabular}{|l|}
17.21 \\
\end{tabular} & 0.01 & 0.28 \\
\hline & Total & & $\begin{array}{l}13.40 \\
\end{array}$ & \begin{tabular}{|l|}
19.25 \\
\end{tabular} & 2.49 & 0.88 \\
\hline & \multicolumn{6}{|c|}{ Ethanol also reduces evaporative benzene emissions } \\
\hline & & & & & & \\
\hline
\end{tabular}




Environmental Aspects
of Ethanol as a Motor
Fuel

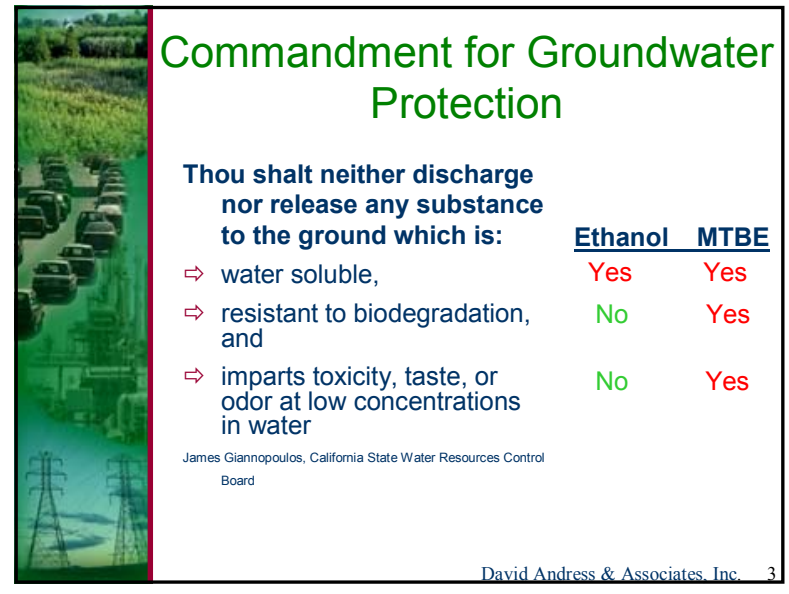

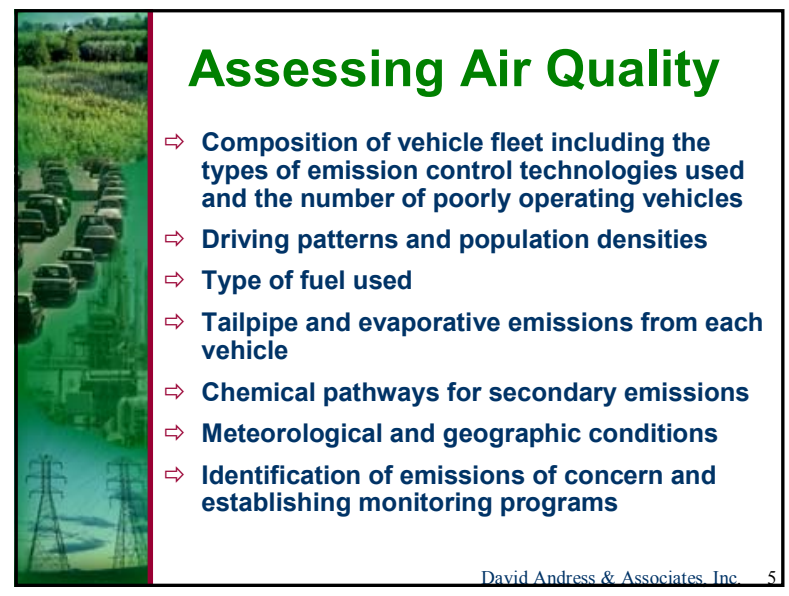

Recent Developments
$\Rightarrow$ The potential expansion in ethanol due
to restrictions on MTBE has
heightened public interest in the air
and water quality impacts of using
ethanol fuels
$\Rightarrow$ Major concerns for air quality are:
- voc and NOx emissions
- Acetaldehyde and PAN emissions

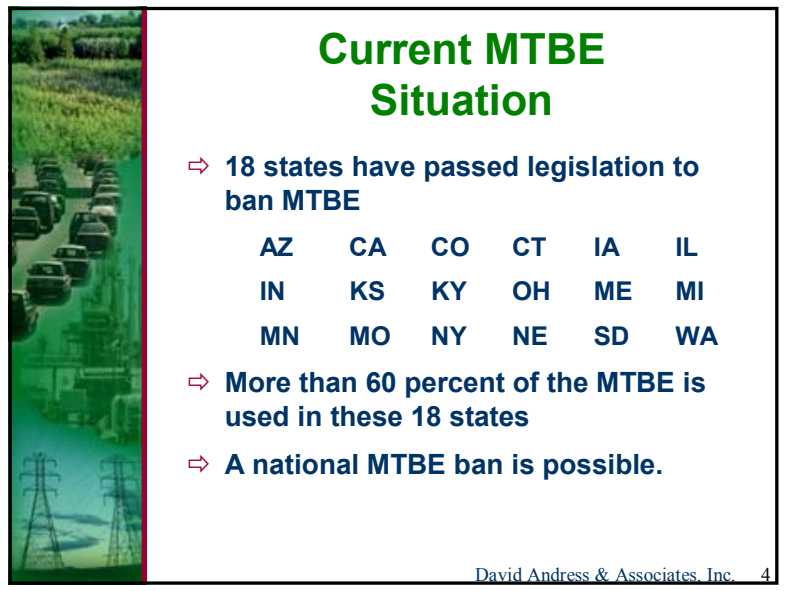




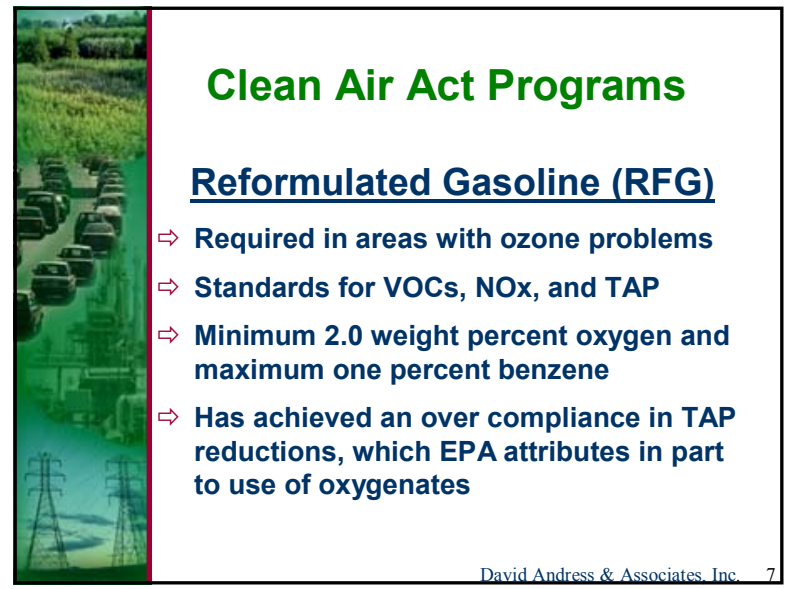

\begin{tabular}{|l|l|}
\hline \multicolumn{2}{|c|}{$\begin{array}{l}\text { Refinery Blending and } \\
\text { Ethanol Properties }\end{array}$} \\
$\qquad$\begin{tabular}{|l|l|}
\hline $\begin{array}{l}\text { Gasoline } \\
\text { Volume }\end{array}$ & $\begin{array}{l}\text { Ethanol provides volume (loss of MTBE } \\
\text { presents volume problems) }\end{array}$ \\
\hline $\begin{array}{l}\text { RFG } \\
\text { Emissions }\end{array}$ & $\begin{array}{l}\text { Ethanol reduces most toxic air pollutants } \\
\text { (except acetaldehyde) through dilution, but } \\
\text { increases evaporative VOC emissions } \\
\text { (summer issue) and perhaps NOx }\end{array}$ \\
\hline Octane & $\begin{array}{l}\text { Ethanol (like MTBE) is a high-octane } \\
\text { blendstock }\end{array}$ \\
\hline RVP in CG & $\begin{array}{l}\text { Ethanol increases RVP (summer issue), but } \\
\text { most CG containing 10\% has one psi waiver }\end{array}$ \\
\hline $\begin{array}{l}\text { Oxygen and } \\
\text { CO }\end{array}$ & $\begin{array}{l}\text { Emanol is an oxygenate, reduces CO } \\
\text { emissions, EPA/CA now give an ozone- } \\
\text { related VOC credit for CO reductions }\end{array}$ \\
\hline Sulfur & Ethanol reduces sulfur through dilution \\
\hline
\end{tabular} \\
\hline
\end{tabular}

\begin{tabular}{|c|c|c|c|}
\hline \multirow{6}{*}{$\begin{array}{c}\text { Directional } \\
\text { Changes in } \\
\text { Emissions When } \\
\text { Ethanol Is } \\
\text { Blended with } \\
\text { Conventional } \\
\text { Gasoline and } \\
\text { RFG }\end{array}$} & & $\begin{array}{l}\text { Conventional } \\
\text { Gasoline }\end{array}$ & RFG \\
\hline & \multicolumn{3}{|l|}{ Toxic air pollutants } \\
\hline & \begin{tabular}{|l|} 
Acetaldehyde \\
Benzene \\
1,3-butadiene \\
Formaldehyde \\
\end{tabular} & $\begin{array}{l}\text { increase } \\
\text { decrease } \\
\text { decrease }^{1} \\
\text { increase }^{1}\end{array}$ & $\begin{array}{l}\text { increase }^{2} \\
\text { decrease } \\
\text { decrease } \\
\text { decrease }\end{array}$ \\
\hline & \multicolumn{3}{|l|}{ Criteria air pollutants } \\
\hline & \begin{tabular}{|l|} 
CO \\
NOx \\
Tailpipe VOC \\
Evaporative VOC \\
Total VOC \\
Particulate matter \\
\end{tabular} & $\begin{array}{l}\text { decrease } \\
\text { increase } \\
\text { decrease } \\
\text { increase } \\
\text { increase } \\
\text { decrease }\end{array}$ & $\begin{array}{c}\text { decrease } \\
\text { no change } \\
\text { no change } \\
\text { no change } \\
\text { no change } \\
\text { decrease }\end{array}$ \\
\hline & \multicolumn{3}{|l|}{\begin{tabular}{|l|} 
Other \\
\end{tabular}} \\
\hline \multirow{2}{*}{$\begin{array}{l}\text { The Directional Changes } \\
\text { Refer to Changes When } \\
\text { Comparing Conventional } \\
\text { Gasoline Containing Ethanol } \\
\text { with Ethanol-Free } \\
\text { Conventional Gasoline and } \\
\text { RFG Containing Ethanol } \\
\text { with RFG Containing MTBE }\end{array}$} & \begin{tabular}{|l|} 
PAN \\
Isobutene \\
Toluene \\
Xylene
\end{tabular} & $\begin{array}{l}\text { increase } \\
\text { decrease } \\
\text { decrease } \\
\text { decrease }\end{array}$ & $\begin{array}{l}\text { increase }^{2} \\
\text { decrease } \\
\text { decrease } \\
\text { decrease }\end{array}$ \\
\hline & \multicolumn{3}{|c|}{ 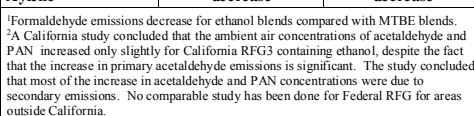 } \\
\hline
\end{tabular}
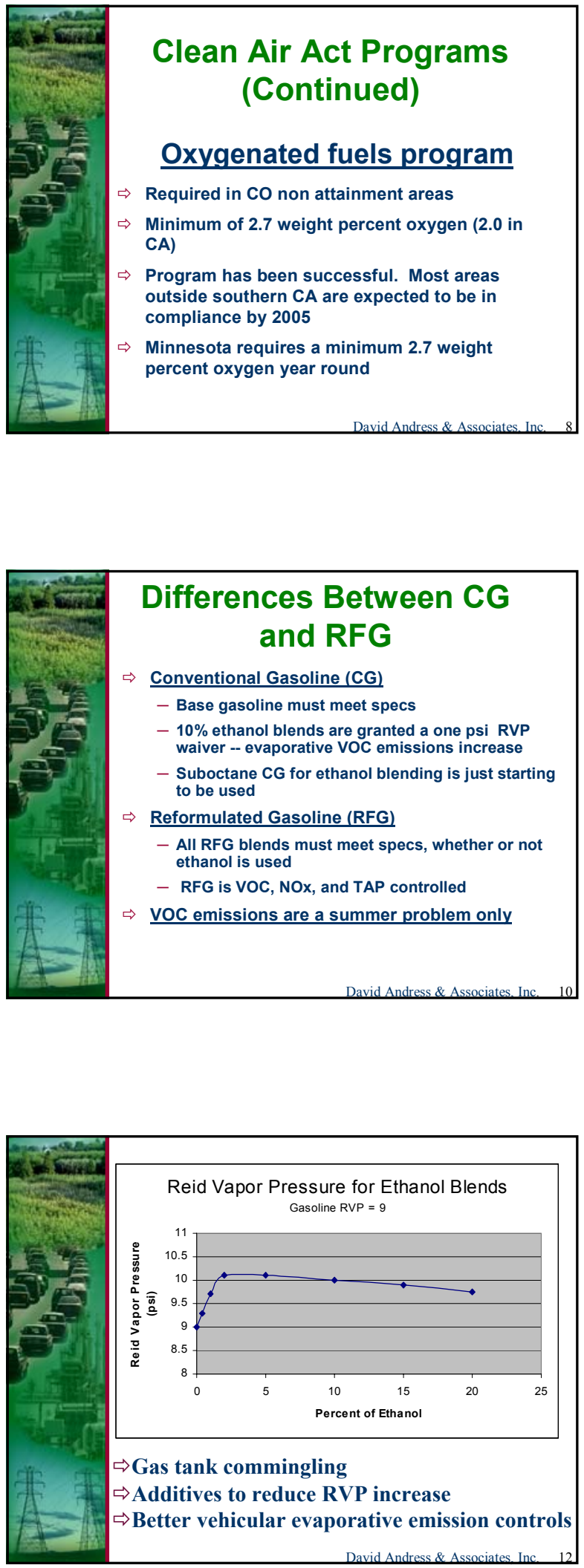


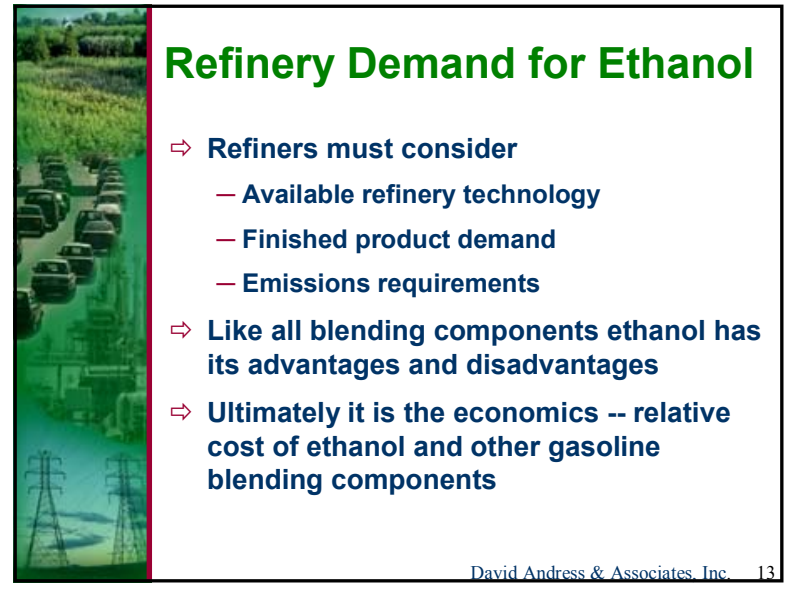

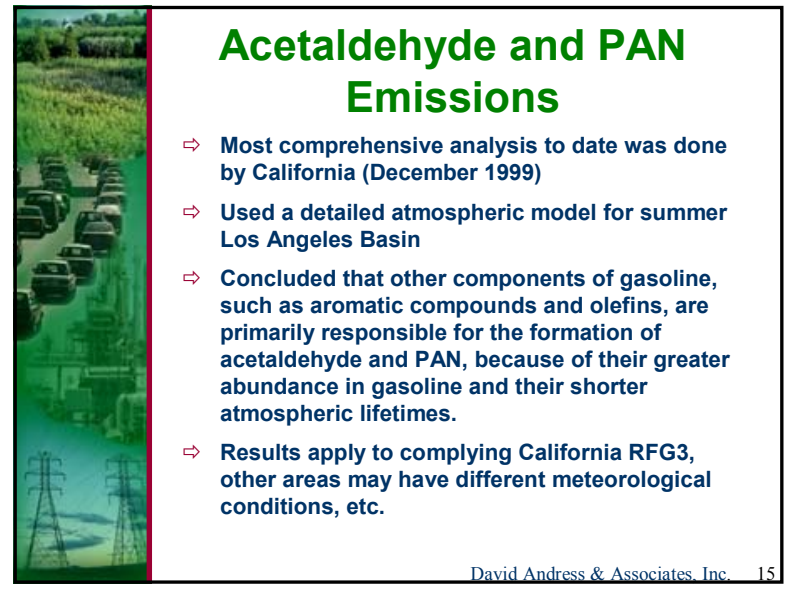

\section{Acetaldehyde Emissions and Air Quality Impacts (continued)}

Comparison of Modeled Air Quality Changes from 1997

\begin{tabular}{|c|c|c|c|c|}
\hline Compound & $\begin{array}{c}2003 \\
\text { MTBE }\end{array}$ & $\begin{array}{c}2003 \\
\text { Et2.0\% }\end{array}$ & $\begin{array}{c}2003 \\
\text { Et3.5\% }\end{array}$ & $\begin{array}{c}2003 \\
\text { NonOxy }\end{array}$ \\
\hline Acetaldehyde (Total) & $-13 \%$ & $-13 \%$ & $-10 \%$ & $-14 \%$ \\
\hline Acetaldehyde (Primary) & $-25 \%$ & $-23 \%$ & $4 \%$ & $-26 \%$ \\
\hline Acetaldehyde (Secondary) & $-12 \%$ & $-12 \%$ & $-11 \%$ & $-13 \%$ \\
\hline
\end{tabular}

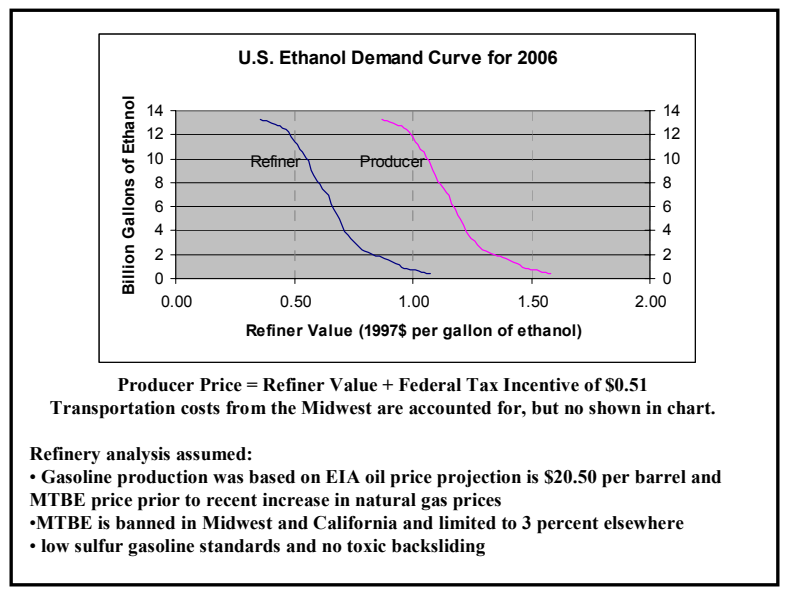

\begin{tabular}{|c|c|c|c|}
\hline \multicolumn{4}{|c|}{$\begin{array}{l}\text { Acetaldehyde Emissions and } \\
\text { Air Quality Impacts } \\
\text { Changes in Vehicular Primary Acetaldehyde Emissions } \\
\text { Relative to } 2003 \text { MTBE Baseline Gasoline }\end{array}$} \\
\hline Scenario / Type of & Change & \multicolumn{2}{|c|}{ Percent Change } \\
\hline 2003 Ethanol at $2.0 \mathrm{wt} \%$ & Oxygen & \multicolumn{2}{|c|}{$27 \%$} \\
\hline 2003 Ethanol at $3.5 \mathrm{wt} \%$ & Oxygen & \multicolumn{2}{|l|}{$132 \%$} \\
\hline 2003 Non-Oxygenate & & \multicolumn{2}{|c|}{$-5 \%$} \\
\hline \multicolumn{4}{|c|}{$\begin{array}{c}\text { Comparison of Modeled Air Quality Changes from } 2003 \\
\text { MTBE Baseline }\end{array}$} \\
\hline Compound & 2003 Et2.0\% & 2003 Et3.5\% & 2003 NonOxy \\
\hline Acetaldehyde (Total) & $\mathbf{0} \%$ & $4 \%$ & $-1 \%$ \\
\hline Acetaldehyde (Primary) & $4 \%$ & $39 \%$ & $-1 \%$ \\
\hline Acetaldehyde (Secondary) & $0 \%$ & $2 \%$ & $-1 \%$ \\
\hline
\end{tabular}

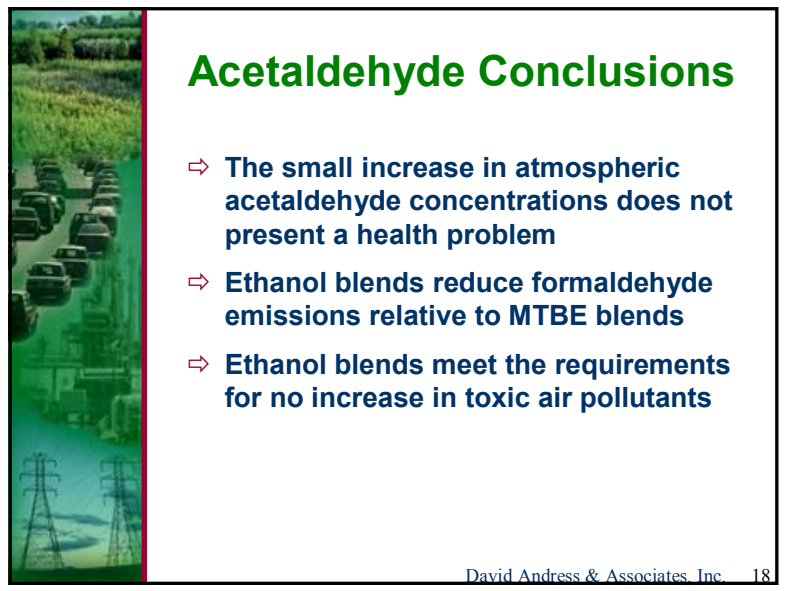



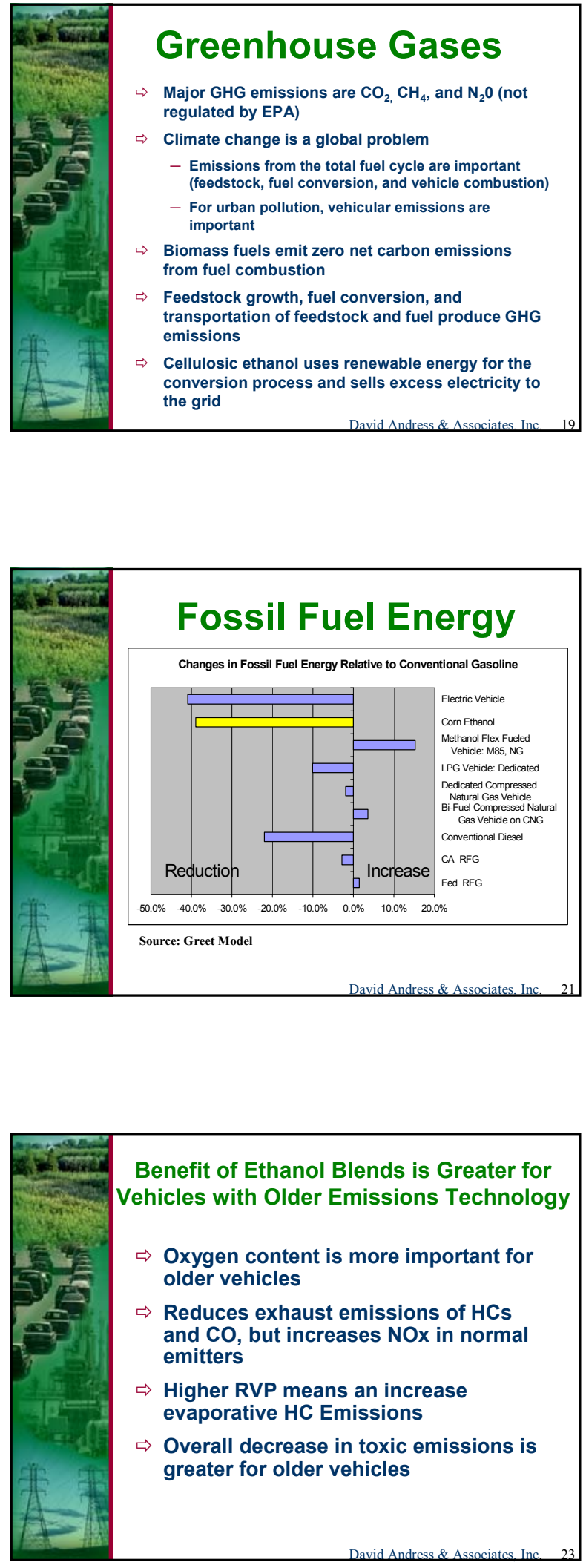
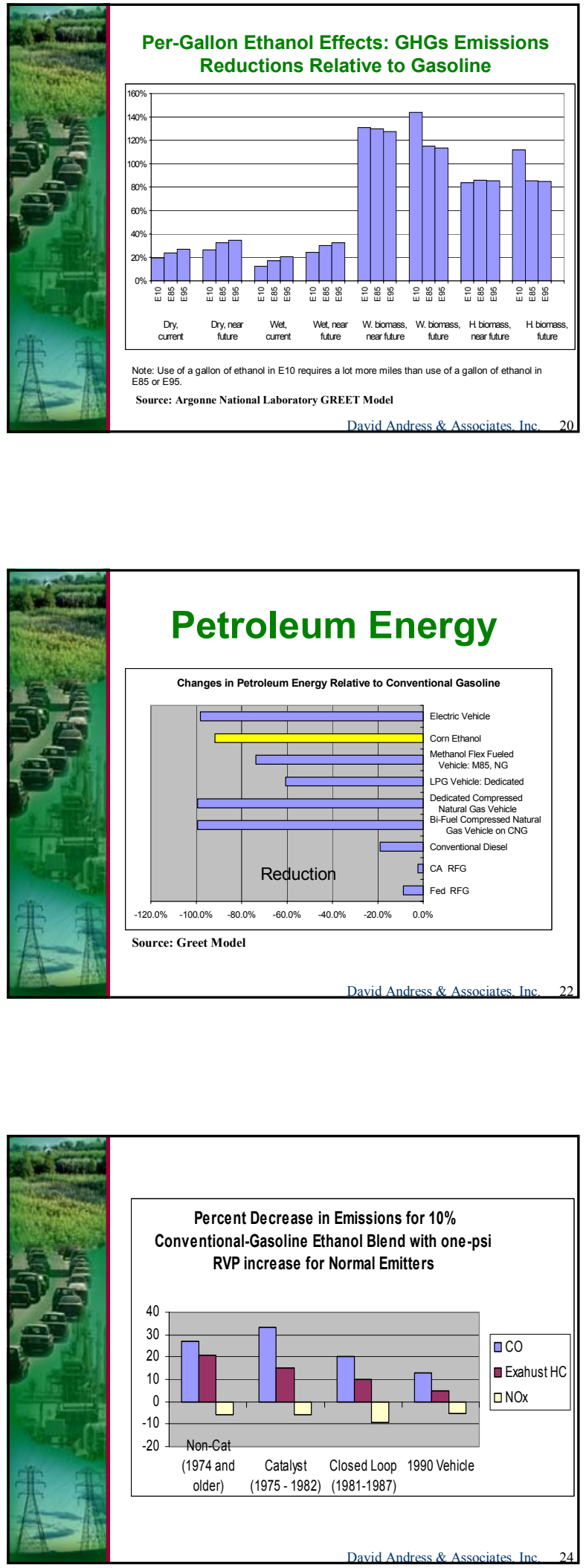


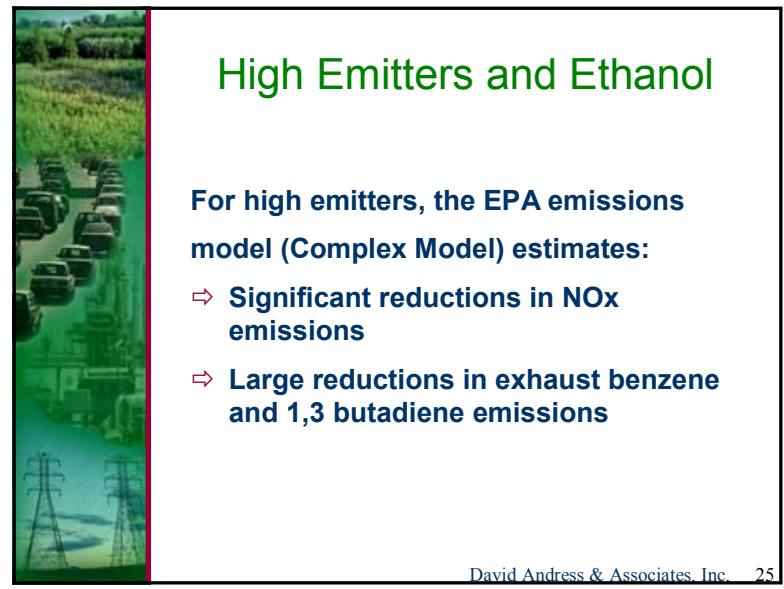
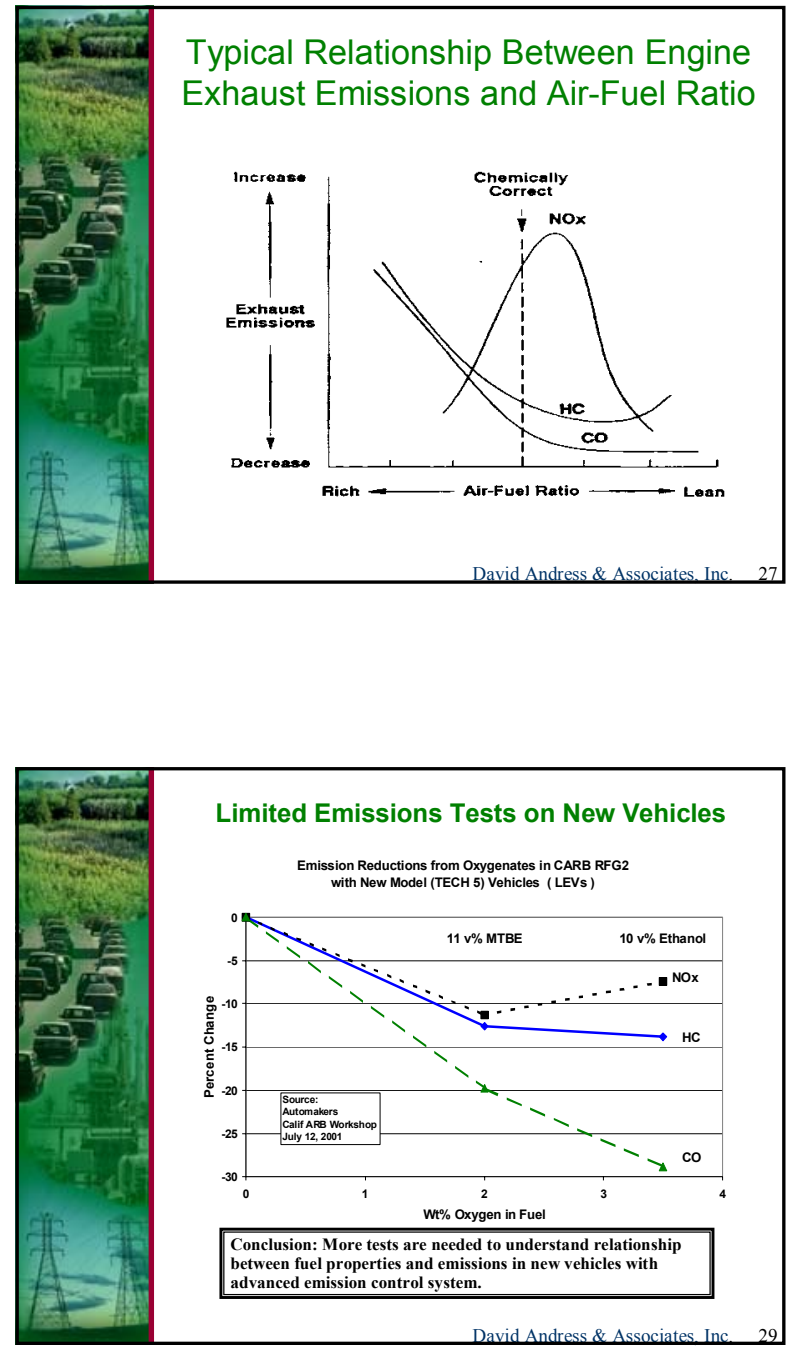

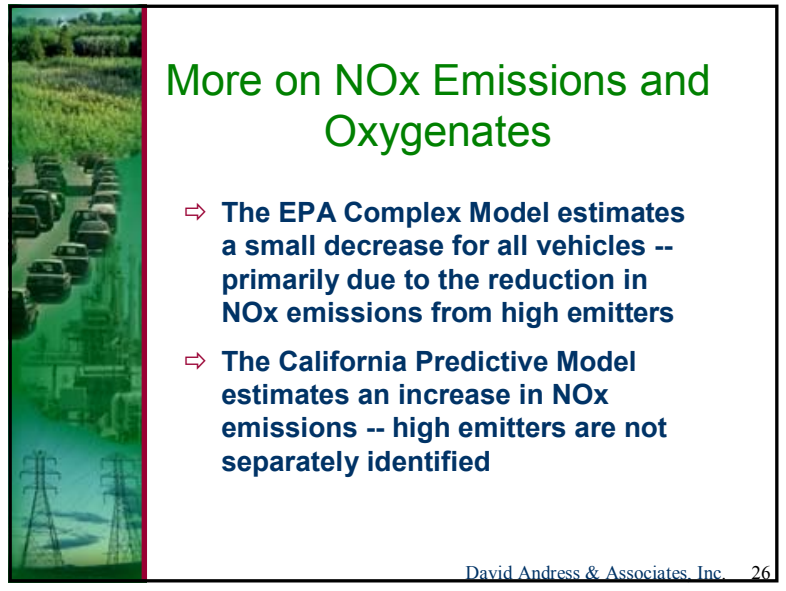

Future Fuel Trends
$\Rightarrow$ With modern control systems that
dynamically adjust the air-to-fuel ratio, the
effect of oxygen in the fuel will diminish
$\Rightarrow$ Ethanol will be valued more for:
- toxic emission reductions
- high octane
- virtually no sulfur
$\Rightarrow$ These properties will become more
important with the elimination of MTBE
$\Rightarrow$ Ethanol's major disadvantage is the RVP
increase




\begin{tabular}{|c|c|c|c|c|c|c|}
\hline$\frac{18 \operatorname{sen}}{5+20}$ & \multicolumn{6}{|c|}{$\begin{array}{l}\text { Mass and Potency Weighted } \\
\text { Exhaust Toxic Emissions }\end{array}$} \\
\hline \multirow{7}{*}{$\frac{5}{5}$} & & & \multicolumn{2}{|c|}{$\begin{array}{c}\text { Mass Em issions } \\
(\mathrm{mg} / \mathrm{m} \text { ile })\end{array}$} & \multicolumn{2}{|c|}{ 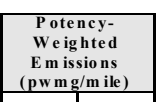 } \\
\hline & & \begin{tabular}{|l} 
Potency \\
Weighting
\end{tabular} & & & & \\
\hline & Benzene & $\frac{T \text { Factors }}{0.170}$ & $\begin{array}{r}8 \times 6.90 \\
8.90 \\
\end{array}$ & \begin{tabular}{|l|l|}
1.83 \\
\end{tabular} & \begin{tabular}{|c|}
$\frac{a k F}{1.51}$ \\
\end{tabular} & \begin{tabular}{|c|c|}
0.31 \\
\end{tabular} \\
\hline & 1,3-B - utadiene & 1.000 & \begin{tabular}{|l|}
0.87 \\
\end{tabular} & \begin{tabular}{|l|}
0.17 \\
\end{tabular} & \begin{tabular}{|l|}
0.87 \\
\end{tabular} & $\begin{array}{l}0.17 \\
\end{array}$ \\
\hline & Formalde hyde & 0.035 & 2.79 & \begin{tabular}{|l|}
3.36 \\
\end{tabular} & 0.10 & 0.12 \\
\hline & Acetalde hyde & 0.016 & \begin{tabular}{|r|}
0.84 \\
\end{tabular} & \begin{tabular}{|l|}
17.21 \\
\end{tabular} & 0.01 & 0.28 \\
\hline & Total & & $\begin{array}{l}13.40 \\
\end{array}$ & \begin{tabular}{|l|}
19.25 \\
\end{tabular} & 2.49 & 0.88 \\
\hline & \multicolumn{6}{|c|}{ Ethanol also reduces evaporative benzene emissions } \\
\hline & & & & & & \\
\hline
\end{tabular}



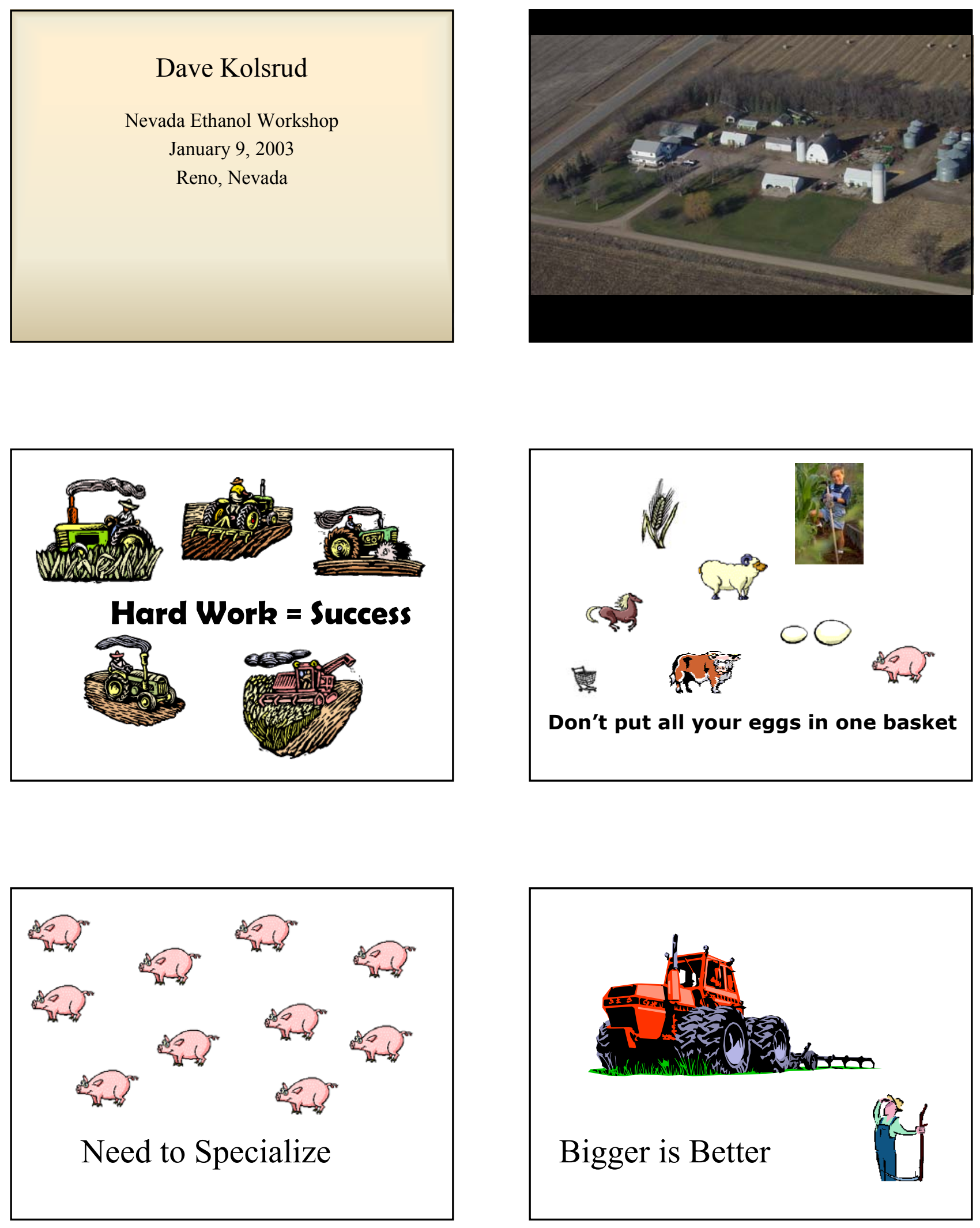

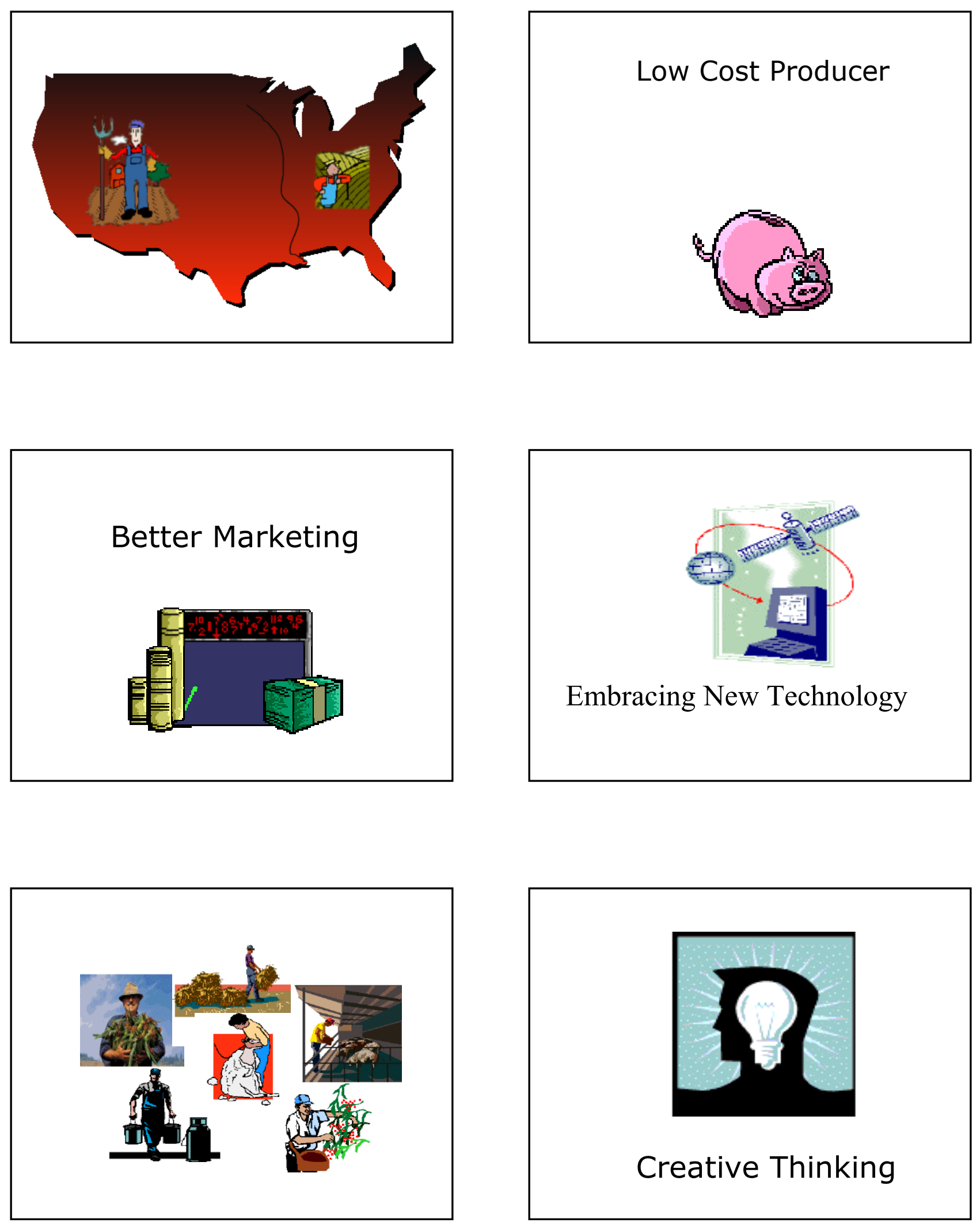

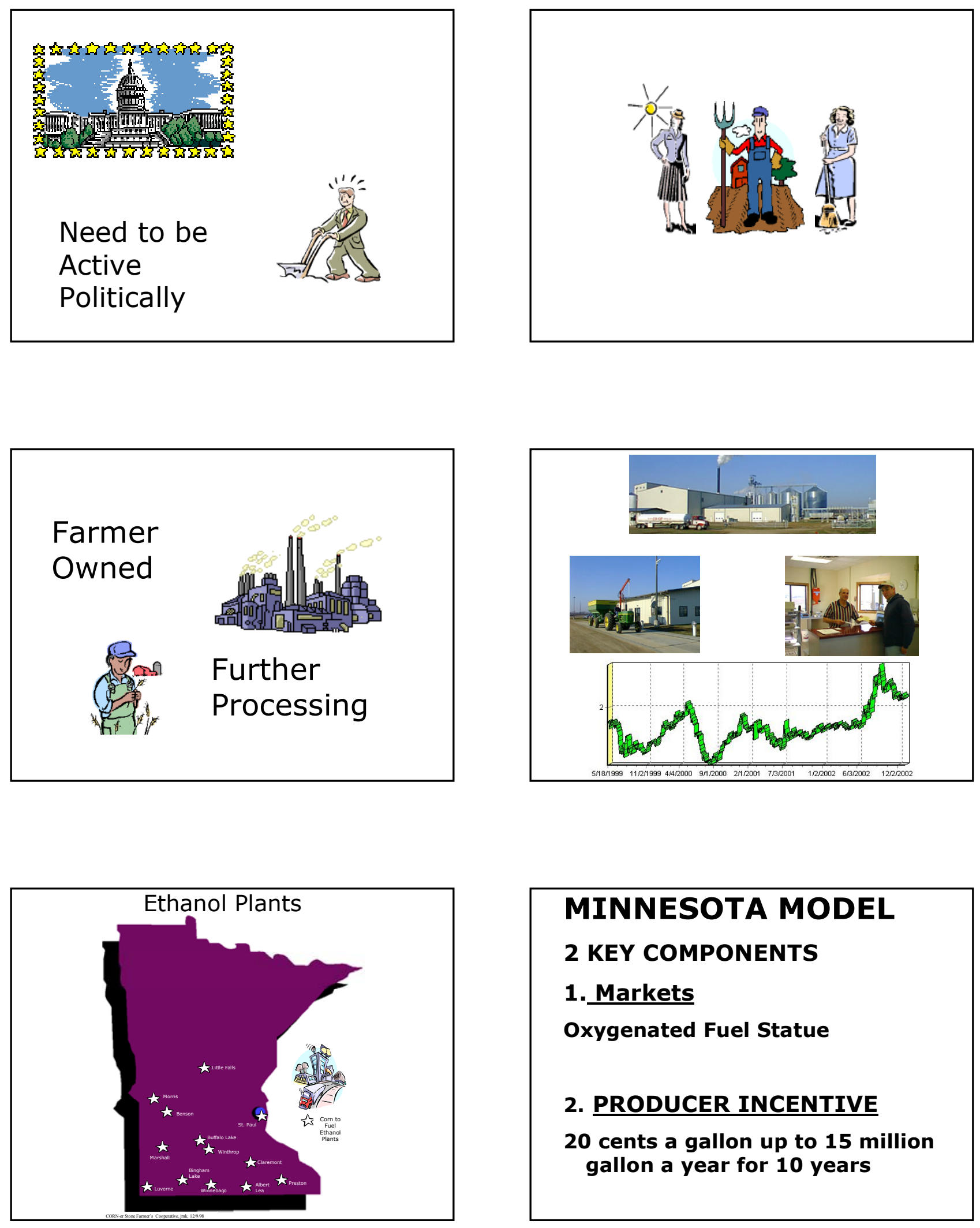

\section{MINNESOTA MODEL}

\section{KEY COMPONENTS}

\section{Markets}

Oxygenated Fuel Statue

\section{PRODUCER INCENTIVE}

20 cents a gallon up to 15 million gallon a year for 10 years 


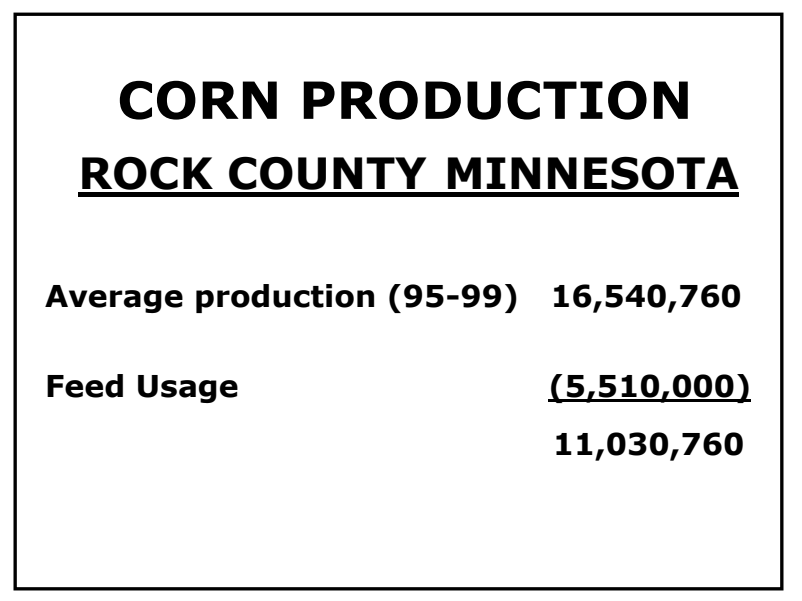

\section{Bushel Corn Equals}

2.6 Gal. Ethanol 17 \# DDGS

$\underline{X \$ 1.20}$

X 3.5 cents/lb.

$\$ 3.12$

59.5 cents

$\$ 3.12$

$+.60$

$\$ 3.72$

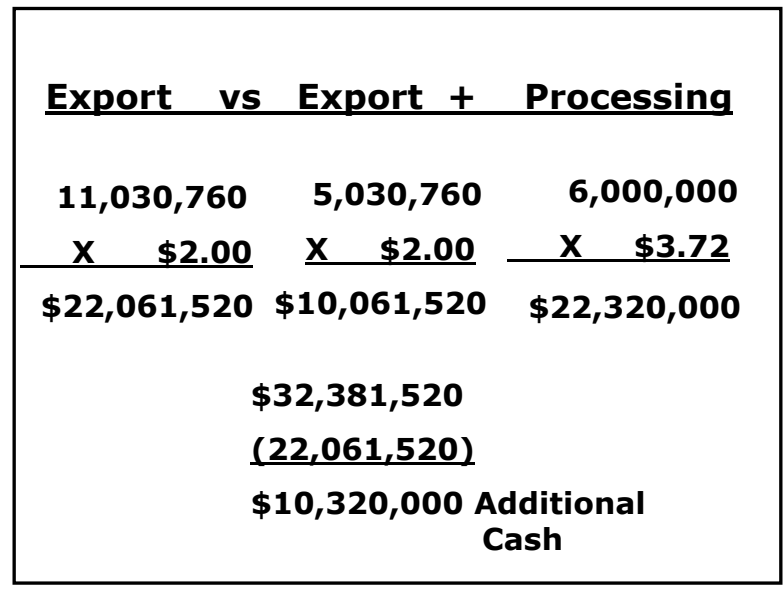
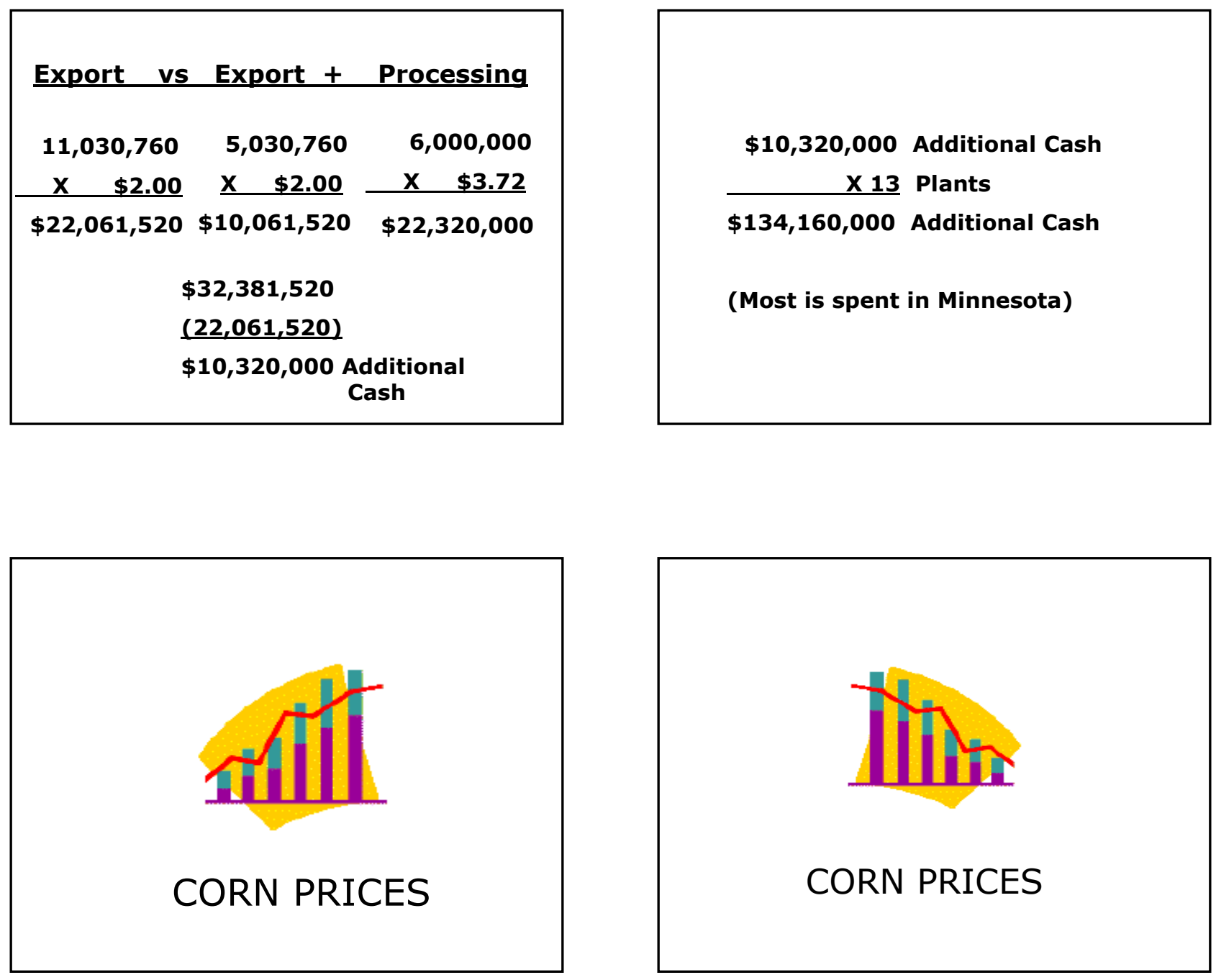

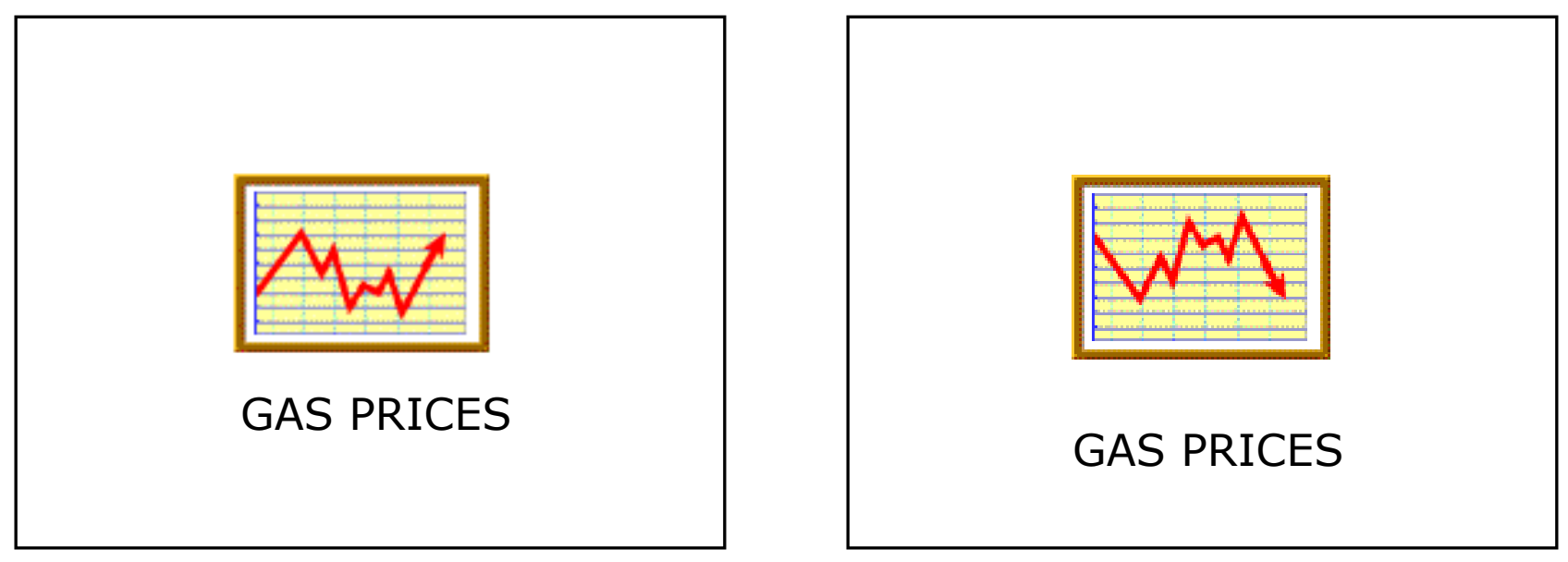

Farmer Owned Wind Towers

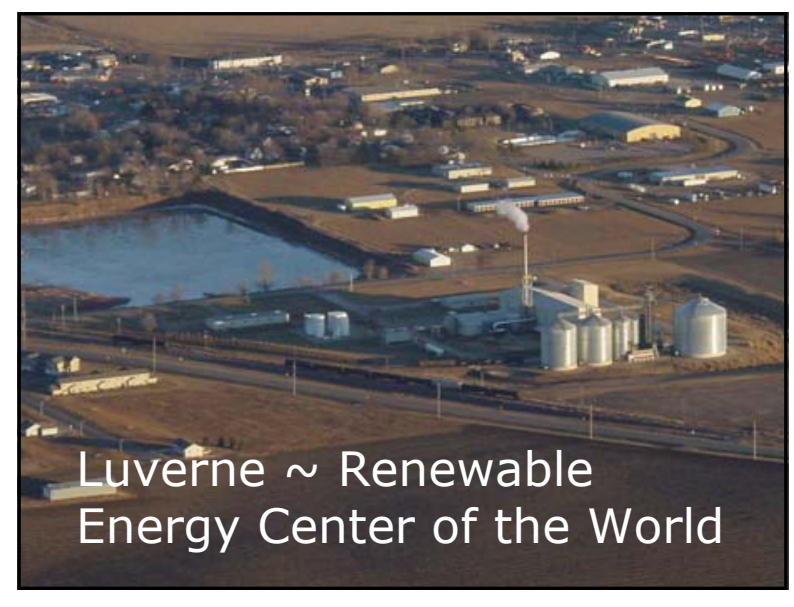



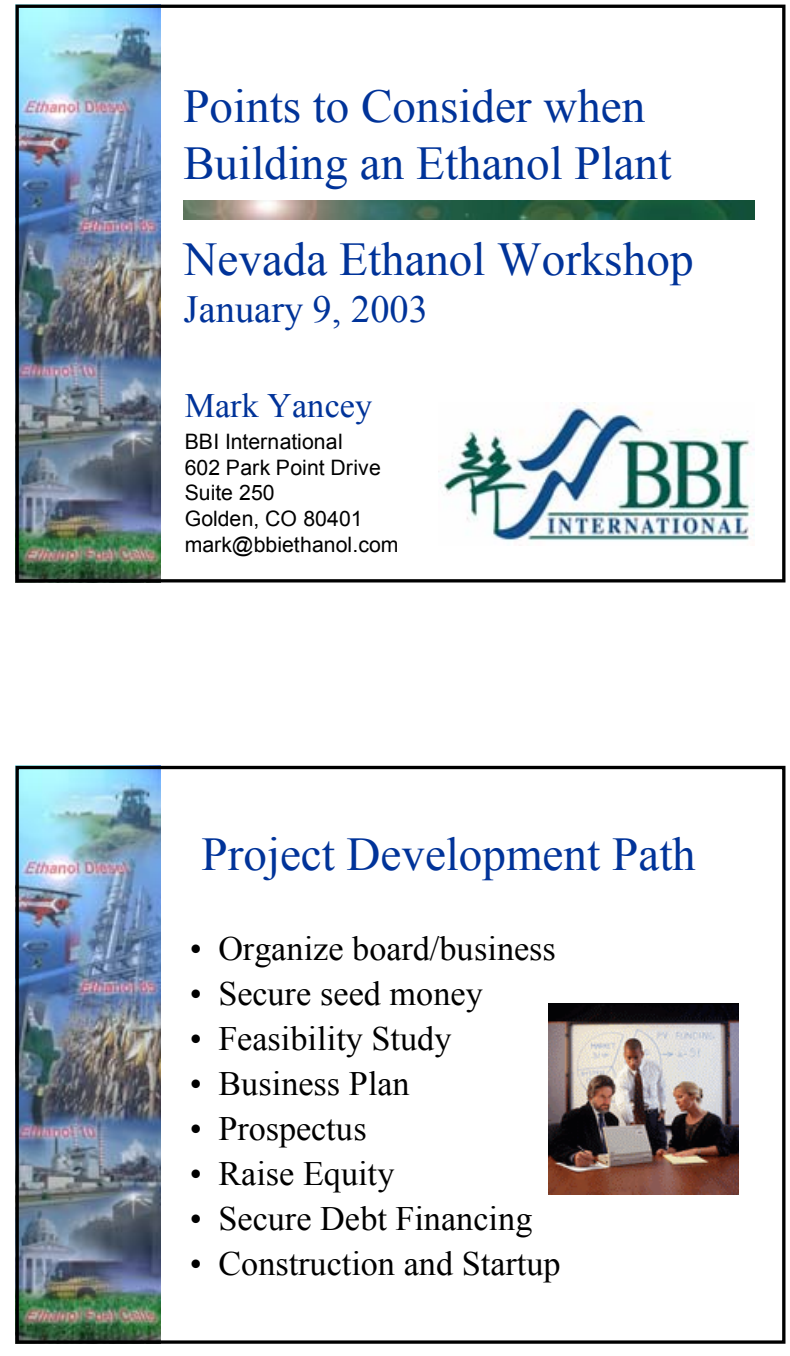

\section{Site Selection}

- Typically 20 to 40 acres in a rural area with:

- Low cost feedstock (typically corn)

- Good rail access

- Good road access

- Adequate utilities at reasonable cost

- Close proximity to co-product markets

- Access to ethanol markets

- Access to labor

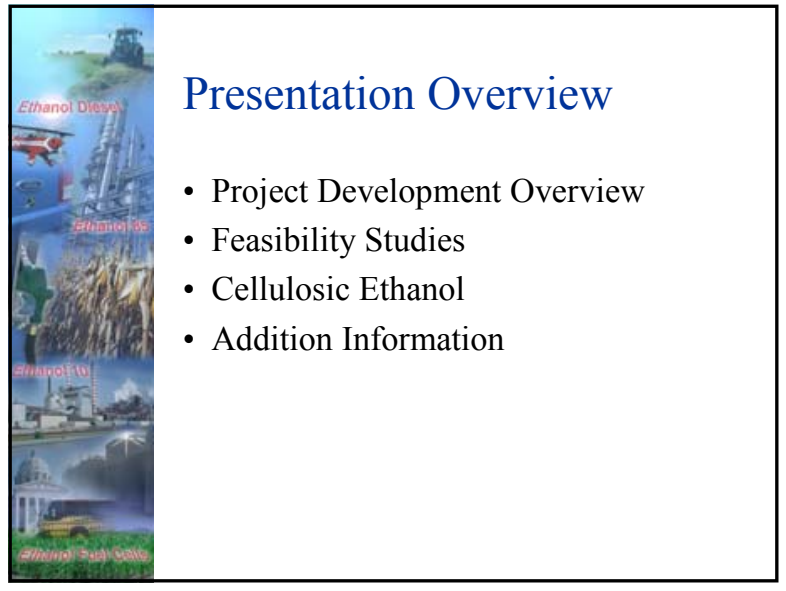

\begin{tabular}{|c|}
\hline $\begin{array}{l}\text { Key Elements of an } \\
\text { Ethanol Feasibility Study } \\
\text { - Site selection } \\
\text { - Feedstock analysis } \\
\text { - Fuel ethanol, DDGS \& CO2 markets } \\
\text { - Financial analysis } \\
\text { - Construction costs } \\
\text { - Owner's costs } \\
\text { - Operating costs } \\
\text { - Sensitivity studies }\end{array}$ \\
\hline
\end{tabular}

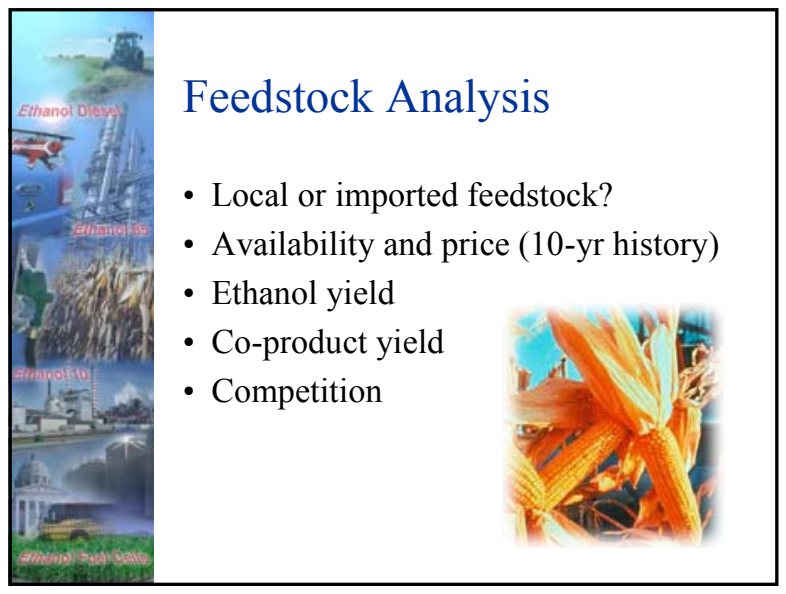



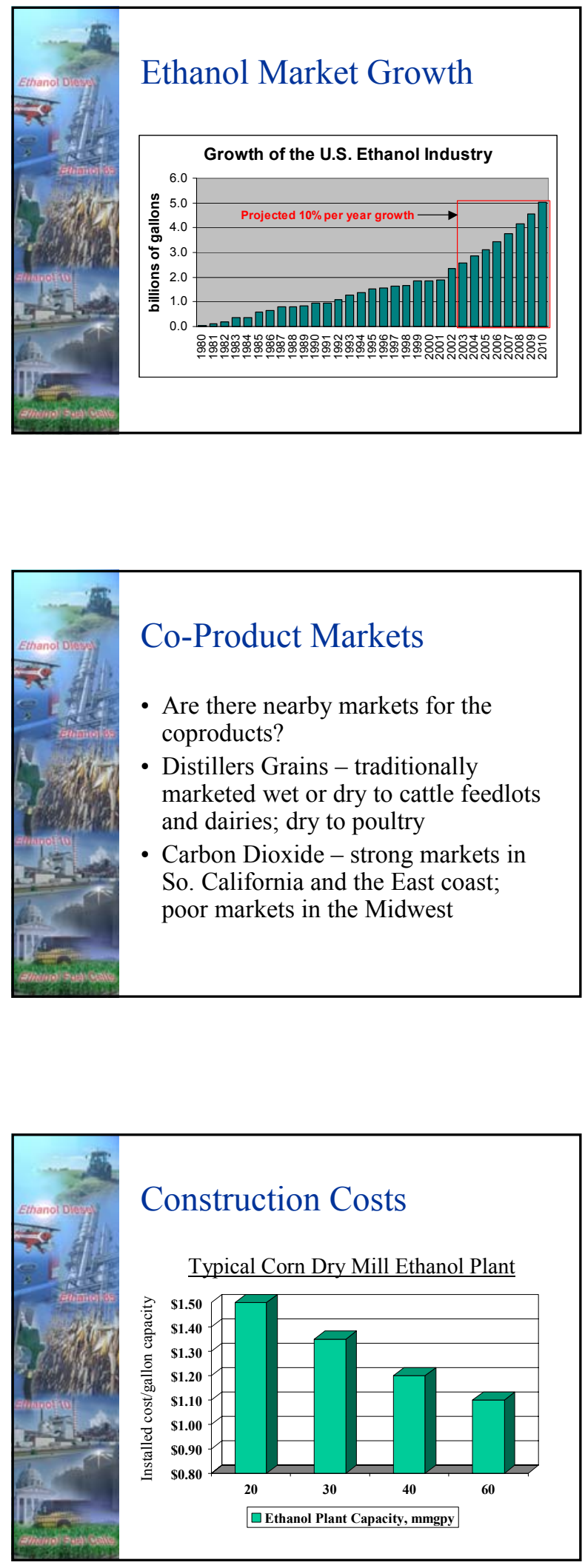
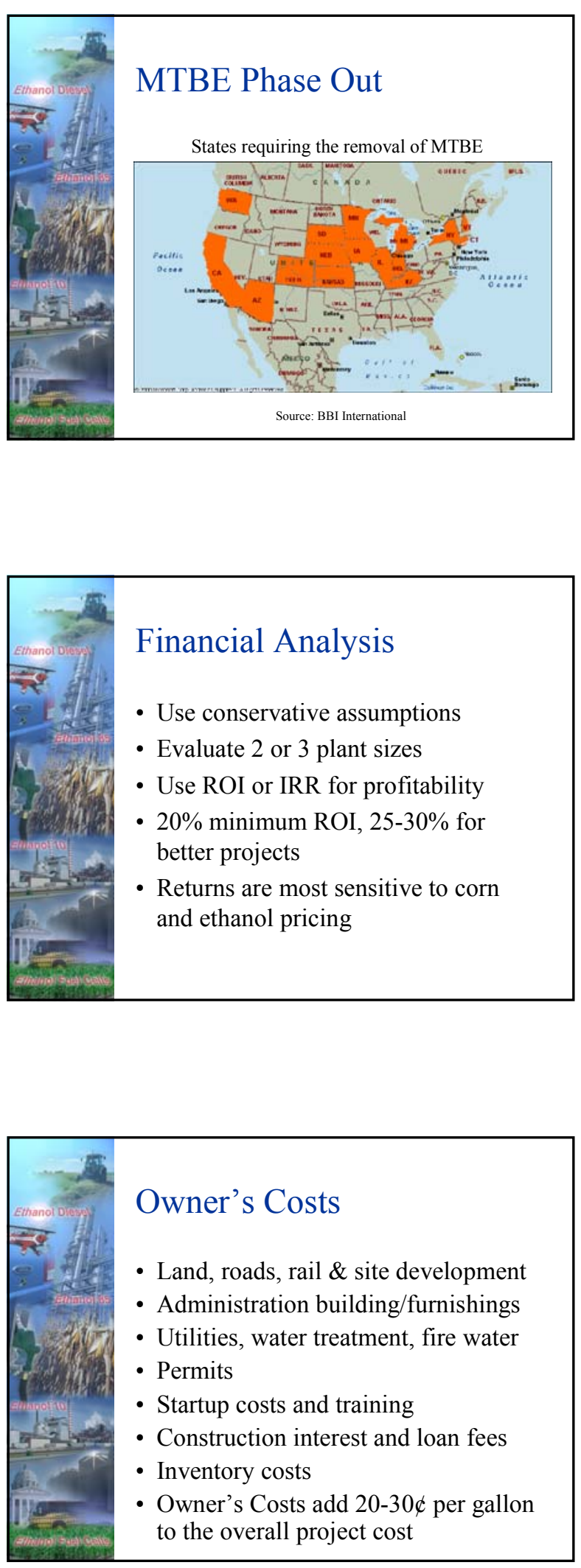


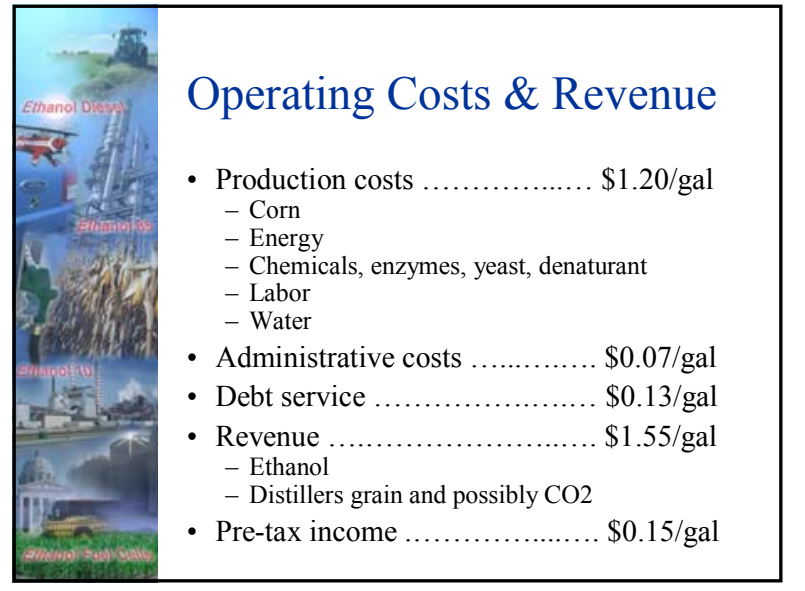

\begin{tabular}{|l|l|}
\hline & After the Feasibility Study \\
& $\begin{array}{l}\text { - Obtain commitment for the site } \\
\text { - Select process design company and begin } \\
\text { preliminary engineering work } \\
\text { - Begin discussions with lenders } \\
\text { - Complete a business plan } \\
\text { - Complete prospectus for stock offering } \\
\text { - Obtain required permits } \\
\text { - Secure equity and debt financing } \\
\text { - Hire a project coordinator } \\
\text { - Begin construction }\end{array}$ \\
\hline
\end{tabular}

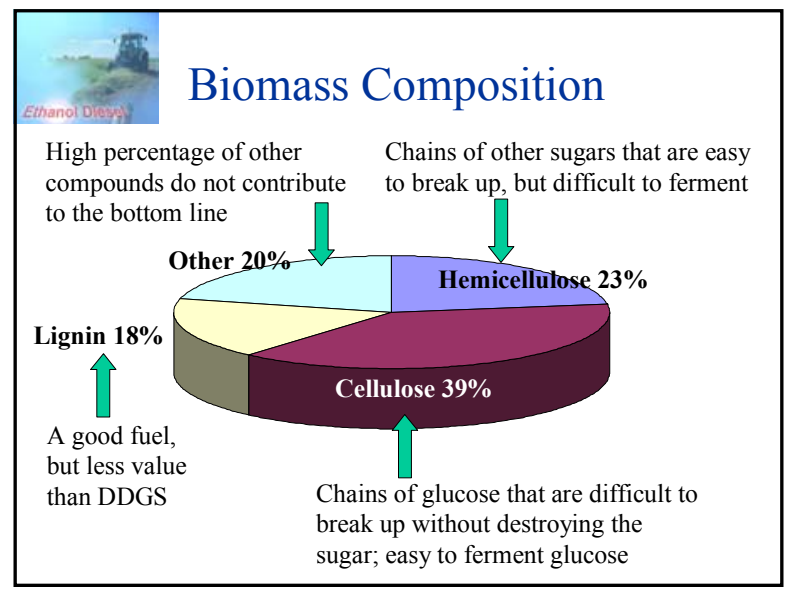

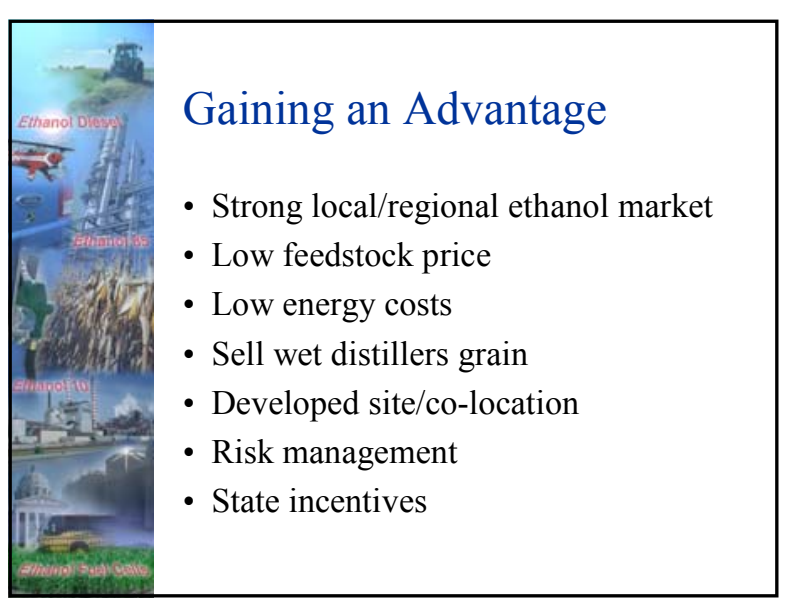

Cellulosic Ethanol
Ethanol can be produced from
"biomass" - agricultural and forest
residues, garbage, energy crops, etc.
- All plants are made up of various
types of sugars - primarily cellulose
and hemicellulose - plus lignin which
is the "glue" that holds the plant
together

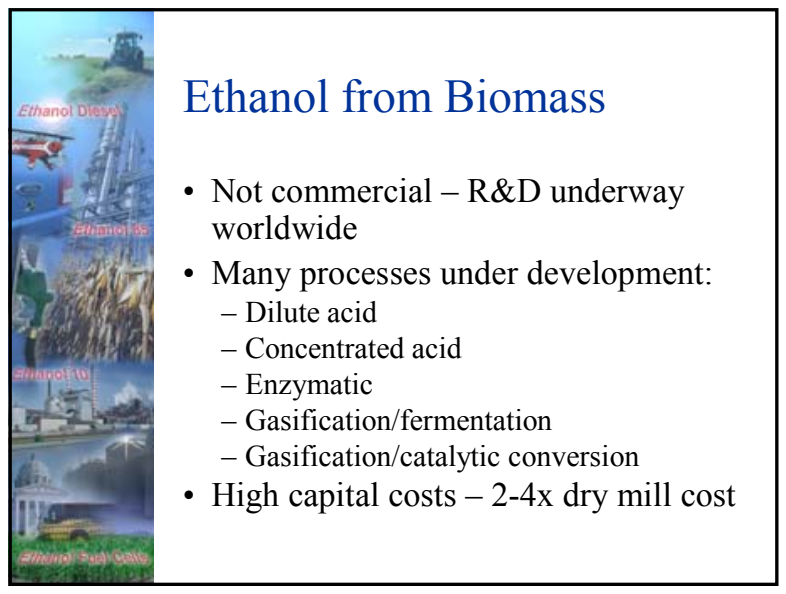




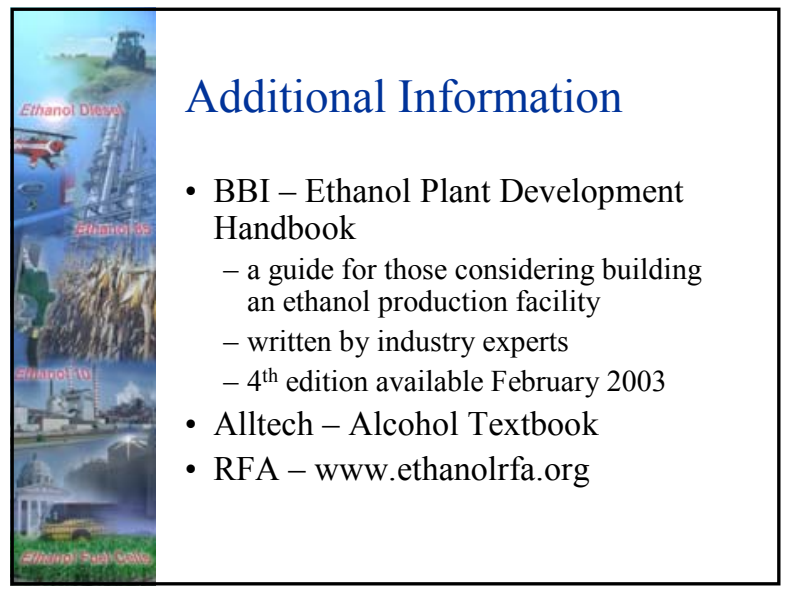

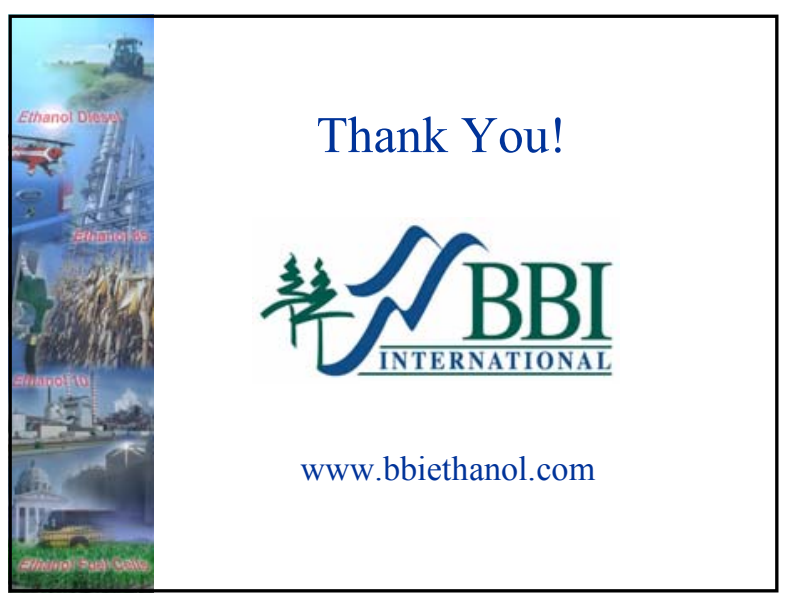




\section{Commercial Uses for Ethanol}

\section{Markets for Ethanol}

• E-10 Unleaded Gasoline

- E-85

Presented by Doug Vind President

Western Ethanol Company Regent International

\section{What is $\mathrm{E}-10$ ?}

- 10vol $\%$ denatured motor fuel grade ethanol in a mixture with $90 \mathrm{vol} \%$ unleaded gasoline.

- ASTM specifications have typically defined the quality parameters for denatured ethanol.

- CARB has set separate specifications for denatured ethanol.

- Ethanol industry continues to review and evaluate implementing additional, voluntary controls on specific quality issues.

\section{E-10 in the US (a chronology)}

- Product Extender

- Margin Improver

- Octane Enhancer

- Carbon Monoxide non-attainment strategy

- Carbon Monoxide attainment maintenance

- Federal Reformulated Gasoline

- CARB Cleaner Burning Gasoline

- MTBE Phase-Out (replacement oxygenate)

- Federal Renewable Fuels Standard?

\section{E - 10 in Nevada (a chronology)}

- Margin Improver

- Carbon Monoxide attainment (maintenance strategy)

- Clark County Cleaner Burning Gasoline Program

- Octane Enhancer (sub-octane pipeline grades of gasoline shipped from California)

- MTBE Phase-Out

- Federal Renewable Fuels Standard?

\section{CO Control Strategy}

- Clark County and Washoe County have benefited from aggressive and tailored Oxygenated Fuels Programs to achieve compliance with Federal CO attainment standards.

- The continued mandatory use of oxygen is a cornerstone in maintaining $\mathrm{CO}$ compliance in view of projected strong growth in local population and vehicle miles traveled. 


\section{Ethanol's Cost/Value}

- Historically ethanol has been utilized to improve the gross margin (per gallon) of the blender or retailer by creating a higher octane grade of gasoline at a reduced cost.

- During the mandatory wintertime oxygenated fuels season, refiners have taken advantage of the increased octane blending value of ethanol and have shipped sub-octane base gasoline via common pipeline.

\section{Ethanol's Cost/Value (cont.)}

- Starting this month, ethanol will be utilized by most refiners as a replacement oxygenate to MTBE throughout Southern and Northern California

- Relative to other available blending component choices, ethanol will provide California refiners with a cost effective solution to replace the lost octane resulting from the removal of MTBE.

\section{Ethanol's Cost/Value (cont.)}

- Because the majority of California refiners have elected to remove MTBE at nearly the same time, the transition to ethanol is expected to be well coordinated and will result in establishing a uniform California base gasoline blend-stock for ethanol blending (CARBOB).

- CARBOB will, within the Oil Companies proprietary pipeline distribution networks, replace CARB gasoline.

- Ethanol will be treated as an additive and in-line/rack blended. This practice is consistent with other additive "packages" currently a part of proprietary Oil Company branded gasoline.

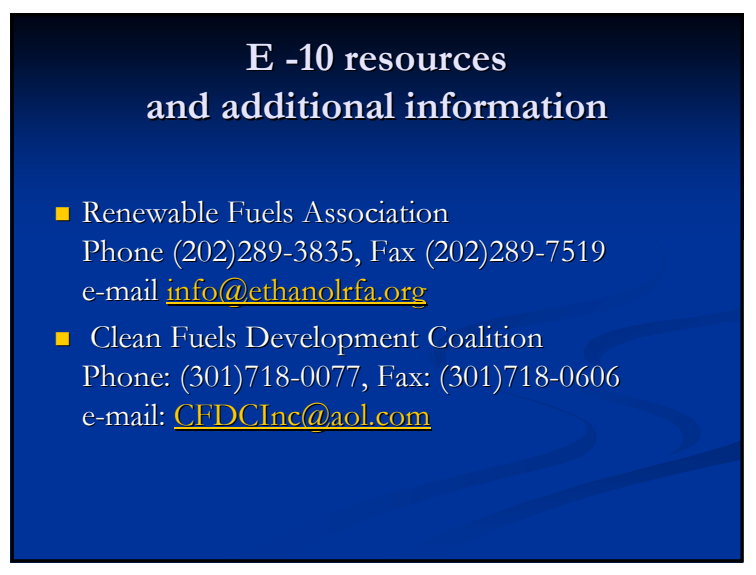

\section{E85 Vehicles}

- Currently over two million E85 Flexible Fuel vehicles on America's roads today.

- DaimlerChrysler, Ford and General Motors provide the flexible fuel engine as standard on several models, including mid-size cars, minivans and trucks.

- The Energy Policy Act of 1992 requires federal agencies to buy vehicles that run on alternative fuels. 
What are the latest types of Flexible Fuel Vehicles?

- Ford

- 2002-2003 4.0L Explorers (4-door)

- 3.0L Taurus LX, SE and SES

sedan and wagon

- 3.0L 4x2 Ranger pickup

- 2001 3.0L 4x2 Ranger

- 3.0L Taurus LX, SE and SES sedan

1999-2000 3.0L Ranger pickup

4WD \& 2WD

- 3.0L Taurus LX, SE and SES

sedan

- (Many 1995-98 Taurus 3.0L Seda are also FFVs
- DaimlerChrysler

- 2003 2.7L Dodge Stratus Sedan

- $2.7 \mathrm{~L}$ Chrysler Sebring Sedan \& Convertible

- 3.3L Dodge Cargo Minivan

- 2000-2003 3.3L Chrysler Voyager

- 3.3L Dodge Caravan Minivan

- 3.3L Chrysler Town \& Countr

- 1998-1999 3.3L Plymouth Voyage

- 3.3L Dodge Caravan Minivan

- 3.3L Chrysler Town \& Country

\section{E85 Fueling}

- Compatible with existing retail gasoline storage tanks and dispensing equipment.

- Can be splash blended at the terminal and delivered via conventional gasoline tank truck.

- Government sponsored programs available to assist in cost of installing E85 fueling stations.
What are the latest types of

Flexible Fuel Vehicles? (cont.)

- General Motor

- 2002-2003 5.3L V-8 engine Chevy Silverado \& GMC Sierra half-ton pickups

- 5.3L Vortec-engine Suburban, Tahoe, Yukon, and Yukon XI

- 2000-2001 2.2L Chevrolet S-10 pickups \& 2002 2.2L Sonoma pickups

- Isuzu

- 2000-2001 Isuzu 2.2L Hombre pickup

- Mazda

- 1999-2001 Selected Mazda 3.0L B3000 pickups

- Mercury

- 2002-2003 4.0L Selected Mountaineers

- 2001 3.0L Selected Sables (look for the "Road \& Leaf" symbol

\section{E85 Opportunities}

- Flexible Fuel Vehicles can be used to meet EPACT requirements.

- Increasing commitment from Auto Manufactures to produce Flexible Fuel Vehicles.

- Growing commitment by some Fleets to consistently purchase E85 fuel.

- State and Federal tax incentives exist for E85.

- Pricing can be competitive with unleaded gasoline.

\section{E85 Challenges}

- Fueling Infrastructure

- Volume

- Lack of clear requirement to use the fuel in Flexible Fuel Vehicles

- Price

\section{E85 Resources and additional information}

- Call the National Ethanol Vehicle Coalition at (573) 635-8445, toll-free at (877) 485-8595 or via e-mail at nevc@e85fuel.com.

- National Alternative Fuels Hotline (800)423-1DOE 


\section{What is a Fuel Cell?}

- A fuel cell is an electrochemical energy conversion device that converts hydrogen and oxygen into electricity and heat.

- Operates like a battery but does not run down or require recharging.

- Relies on chemistry, not combustion.

- Emissions consist primarily of water and steam.

\section{How a Fuel Cell works}

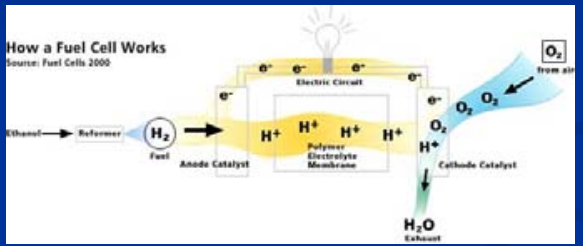

\section{Why use ethanol in fuel cells?}

- Renewable and domestically produced hydrogen-rich liquid.

- Ethanol is widely available today throughout the U.S. as a transportation fuel.

- Ethanol infrastructure is second only to gasoline.

- Ethanol production capacity continues to expand.

- Cost of production continues to decline.

\section{Ethanol in Fuel Cell Advantages}

- Automotive

- Ethanol is compatible with gasoline reformer technology.

- Flexible and can be optimized regionally.

- Ethanol reformer simpler, more reliable and less costly than a gasoline/multi-fuel reformer.

\section{Ethanol in Fuel Cell \\ Advantages}

\section{口Distributed Power}

- Low emissions, noise and environmental footprint.

- Local ethanol production creates regions of energy self-sufficiency.

- Local ethanol production will expand the economic base of the local economy and create jobs and tax revenue.
Fuel Cell resources and additional information

- RFA publication "Ethanol and Fuel Cells: Converging Paths of Opportunity" available at www.ethanolrfa.org

- California Fuel Cell Partnership www.fuelcellpartnership.org 


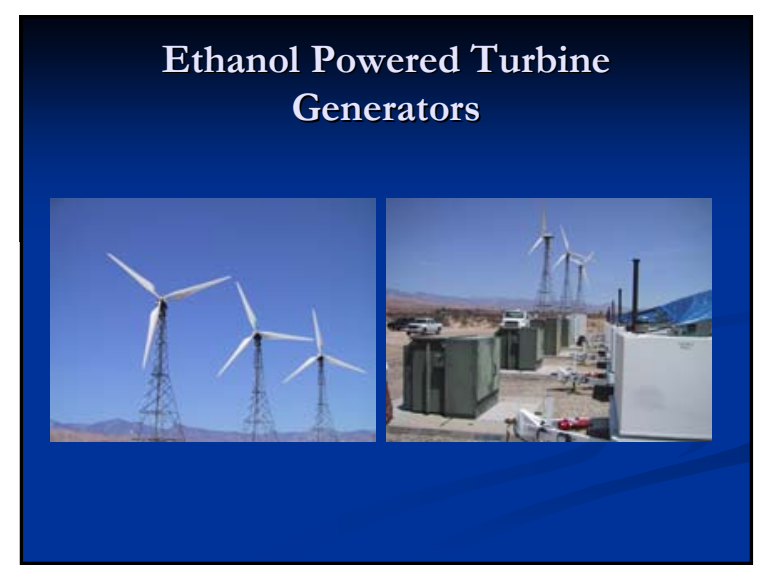

\section{"Green Electricity"}

- Small $150 \mathrm{kw}$ to $450 \mathrm{kw}$ turbines create "dispatchable" power.

- Available to supplement existing intermittent renewable power sources (wind)

- "Peak Load" renewable power supply.

- Utilizes existing turbine generator technology.

- Expands local/regional renewable electricity generating capacity.

\section{For more information on ethanol powered turbines}

Please contact:

Doug Vind at

dbv@regentinternationl.com

\section{Commercial Uses} for Ethanol

Presented by Doug Vind President

Western Ethanol Company

Regent International 

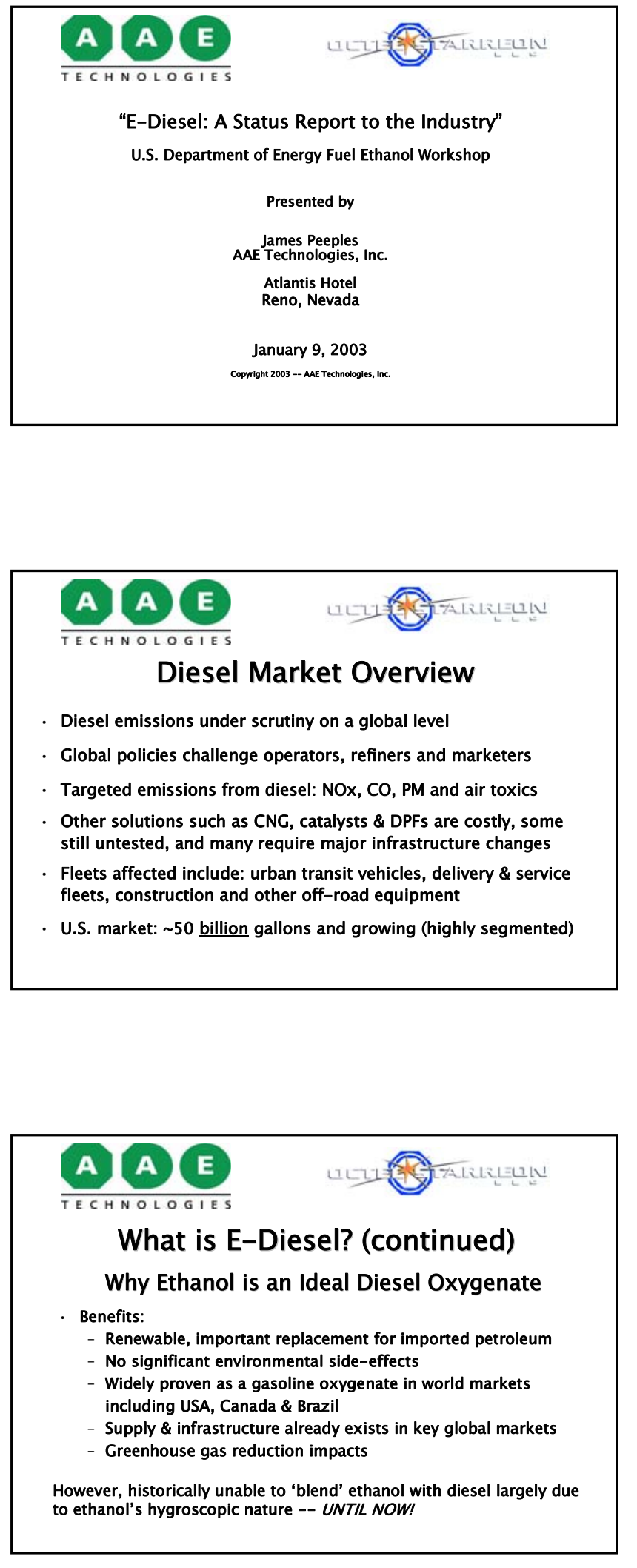

Introduction
AAE TECHNOLOGIES, INC.
- Established in 1997, developer and holder of numerous
worldwide patents for fuel additive technologies
- O'Diesel
On cost-effectse in U.S. underway since 1998: focused
OCTEL STARREON, LLC
- Over 60 years as a leading world fuel additive supplier
- Leading manufacturer and supplier of diesel additives
- North American sales and distribution network for
Performance \& Petroleum Specialty Chemicals

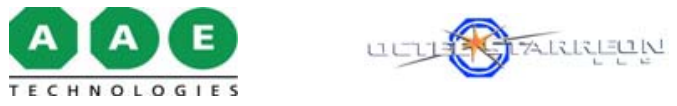

\section{What is E-Diesel $\left(\mathrm{O}^{2}\right.$ Diesel $\left.^{\mathrm{TM}}\right)$ ?}

A diesel fuel containing conventional diesel blendstock(s) with:

- Up to 15 vol\% Anhydrous Ethanol,

- Stabilized with $\sim 1.0$ - 5.0vol\% proprietary additive(s), and

- Cetane enhancement where required

The AAE-Octel Starreon Octimax ${ }^{T M} 4931$ (includes cetane improver) makes commercially viable $\mathrm{O}^{2} \mathrm{Diese}^{\mathrm{TM}}$ at $<1.0 \mathrm{vol} \%$ additive treat rate

- Premium Diesel performance: lubricity, stability, conductivity

- Little or no infrastructure or engine changes required

- Can be used in heavy-duty on- \& off-road $\mathrm{Cl}$ engines now!

\section{A A E \\ $\overline{\text { TECHNOLOGIES }}$ \\ $\mathrm{O}^{2}$ Diesel $^{\mathrm{TM}}$ Emissions Benefits \\ "Typical" E-Diesel Emissions Test Results}

Colorado School of Mines: Nov. '99 - Dec. '00

EPA No.2 Diesel vs. No.2 O²Diesel ${ }^{\mathrm{TM}}$ (7.7vol\% ethanol)

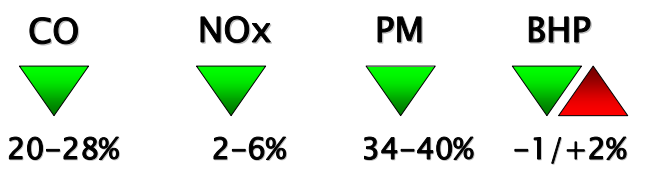

EPA 13-mode Transient Cycle Engine Tests (1991 DDC Series 60) 


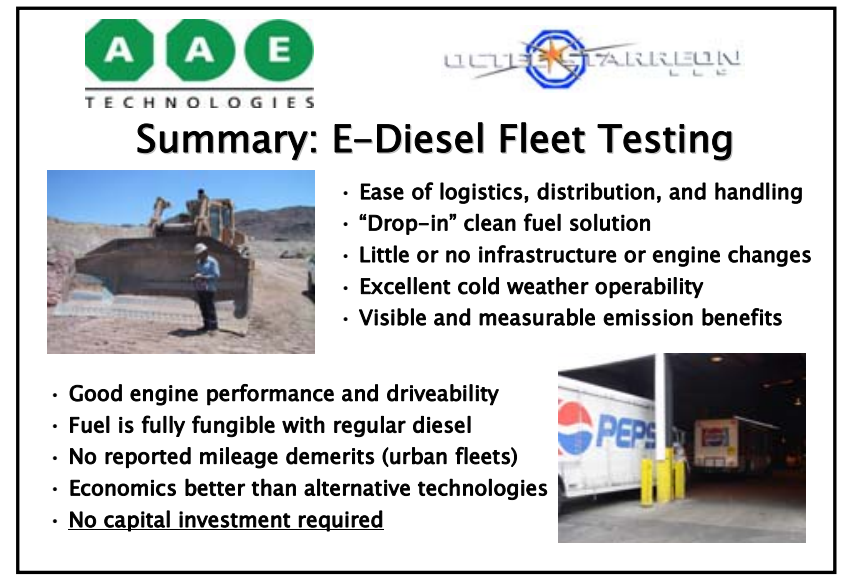

\section{A A E \\ TECHNOLOGIES}

$\mathrm{O}^{2}$ Diesel ${ }^{\mathrm{TM}}$ Fleet Testing: Nevada

- Project Participants: DOE/NREL, CE-CERT (Riverside, CA), AAE

Technologies, RTC/ATC (Las Vegas Transit), SwRI, Clark County

(NV), Rebel Oil Co, Western Ethanol/Regent International

- Fleet: 17 out-of-warranty DDC transit buses (Series $50 \& 6 \mathrm{~V} 92$ engines)

- Length of demonstration: $10-12$ months (starts January 9, 2003)

- Real-world, in-use emissions testing planned (an e-diesel first)

- Full demonstration of fuel delivery systems, handling \& logistics

- Detailed analysis of fuel effects on engines and fuel system components

\section{A A E}

TECHNOLOGIES

\section{Summary: $\mathrm{O}^{2}$ Diesel $^{\mathrm{TM}}$ Fleet Testing}

- Nevada Ready Mix (Las Vegas, NV): Feb. 2000 - July 2001 (quarry trucks)

- Lincoln StarTran (Lincoln, NE): August, 2000 - current (urban buses)

- Pepsi-Cola (The Bronx, NY): Nov. 2000 - current ( 150 delivery trucks)

- Zachry Const. (San Antonio, TX): Mar. 2001 - current (const. equipment)

- Pearl City Co-op (Pearl City, IL): June 2000 - current (fuel delivery trucks)

- Winnipeg Transit (Winnipeg, Manitoba): Oct. 2001- Aug. 2002 (20 buses)

- Denny Wessels Transport (Buffalo Center, IA): Nov. 2001 - May 2002

Also:

- OCTranspo (Ottawa, Ontario): Starts $1^{\text {st }}$ Qtr. 2003 (20 urban buses)

- 5 Municipalities (So. Calif.): Starts $1^{\text {st }}$ Qtr. 2003 (120 diesel engines)

\section{A A E \\ TECHNOLOGIES}

\section{E-Diesel Technical Agenda: 2003}

"Ethanol-Blended Diesel Fuel Handbook" -- initiated Summer, 2001 and to be completed Fall, 2002 (Argonne Nat'l. Labs)

- Uniform Safety and Handling procedures -- Evaluation begun in $2001 / 02$ at Southwest Research Institute (SwRI)

- Greenhouse gas impact analysis -- initiated Summer, 2001 by Argonne National Labs (Michael Wang, et al)

- Health effects testing req'd. per Section 211 (b) of the Clean Air Act

- John Deere cooperative test program ( $\$ 2$ million +2 years)

\section{A A E \\ TECHNOLOGIES}

\section{E-Diesel Consortium: Organization}

- Draft Consortium Charter approved Dec. 4, 2001

- Established under aegis of the Renewable Fuels Foundation

- Consortium began work in early 2002

- Significant technical \& regulatory agenda (2002 - 04)

- Broad industry/government participation anticipated

\section{A A E \\ TECHNOLOGIES}

E-Diesel Consortium: Participants

- State of Illinois "Core Group" (original E-Diesel Task Force)

- Major U.S. ethanol producers (ADM, Cargill, Williams)

- Additive Suppliers (AAE Technologies/Octel Starreon, Akzo Nobel, GE/Betz, Lubrizol, Pure Energy Corp., etc.)

- Engine Manufacturers (John Deere, etc.)

- US Dept. of Energy (including NREL, Argonne National Laboratory)

- Renewable Fuels Association (U.S. and Canada)

- National Corn Growers Association (and state chapters)

- State and local, public \& private groups (e.g., Nebaska Ethanol Board) 


\section{A A E}

TECHNOLOGIES

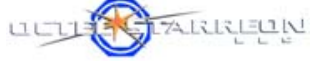

\section{E-Diesel Consortium: Technical Issues}

- Managing flash point \& flammability

- Determining materials compatibility \& durability

- Establishing storage $\&$ handling requirements

- Meeting ASTM/CGSB fuel standards \& acceptability ("Fill \& Go")

- Completing EPA health effects testing

- Obtaining additional emissions benefits

- Complying with federal, state $\&$ local laws $\&$ regulations

\section{A A E \\ TECHNOLOGIES}

\section{Conclusions}

- E-Diesel faces large technical \& regulatory challenges

- Tax incentive issues must be addressed for full commercialization

- Meaningful public \& private support for E-Diesel will get results

- Major competition from other new diesel(s) expected

- OEM skepticism will be significant for a while to come

- E-Diesel Consortium is now in place to address all issues

- E-Diesel will be "ready for prime time" well before $2006-07$ !

\section{A A E \\ TECHNOLOGIES \\ AAE Technologies, Inc. 200 Executive Drive Newark, Delaware 19702 USA \\ (302) 266-6000 (office)
(302) 266-7076 (fax) \\ www.aaetech.com \\ Octel Starreon, LLC \\ Refinery \& Performance Fuel Additives \\ \&37 Willow Street \\ Littleton, Colorado 80124 USA \\ (303) 566-0530 (office) \\ (303) 792-5668 (fax)}

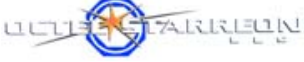



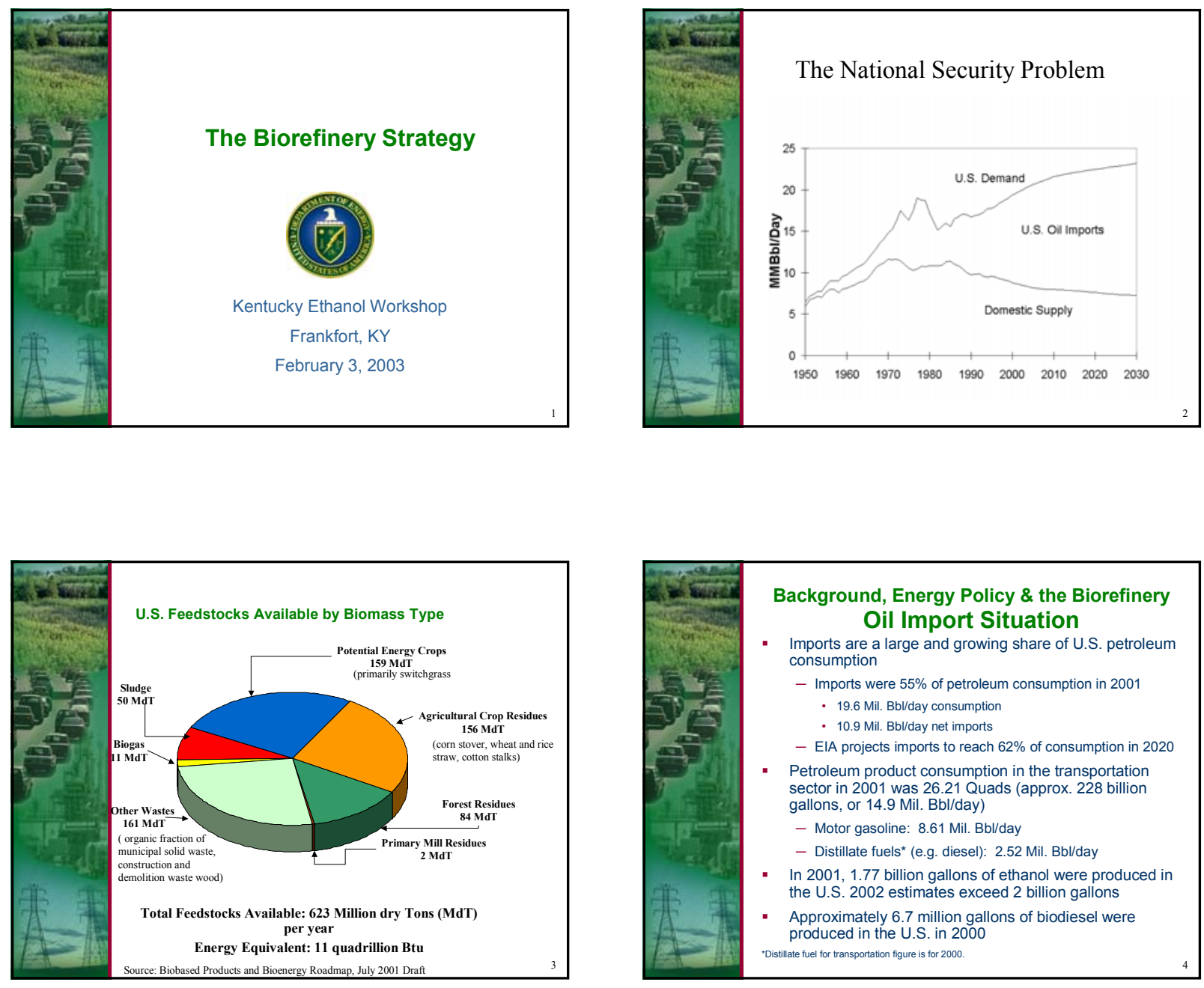

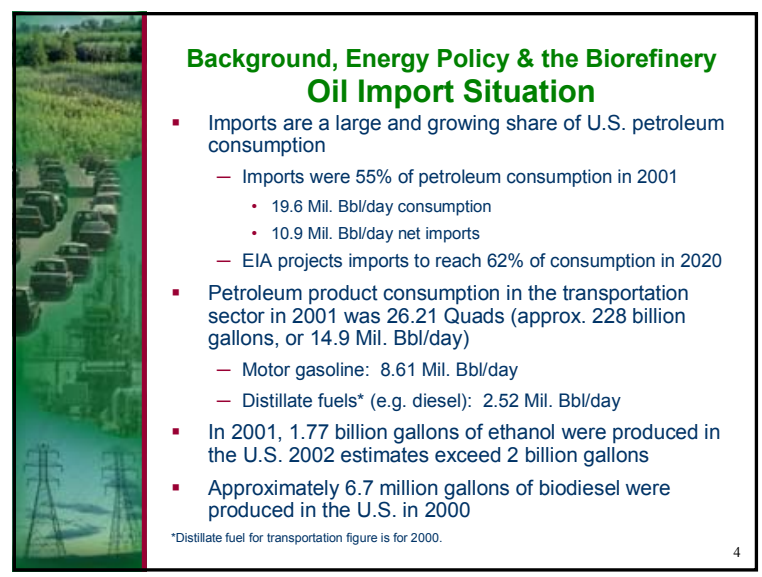

\begin{tabular}{|l|}
\multicolumn{1}{|c|}{$\begin{array}{c}\text { Restructuring Biomass } \\
\text { Program - 2002 }\end{array}$} \\
- Major restructuring of EERE \\
- $\begin{array}{l}\text { Previous focus on biofuels, biopower } \\
\text { and bioproducts } \\
\text { - Current focus biorefinery and } \\
\text { technology development pathways for } \\
\text { fuels, power, and bioproducts }\end{array}$ \\
\end{tabular}

Background, Energy Policy \& the Biorefinery
Biomass RD\&D is a National Priority
- The President's National Energy Policy
includes multiple recommendations that
support Bioenergy.
The Biomass R\&D Act of 2000 directs DOE
and USDA to enhance and coordinate biomass
R\&D efforts.
The Energy Title (Title IX) of the new Farm Bill
provides supports for increased use of biomass
energy and products and for R\&D.
The comprehensive energy bill now pending in
Congress contains provisions to encourage
expansion of biomass utilization, including a
Renewable Fuels Standard for transportation
fuels.




Background, Energy Policy \& the Biorefinery
Program Mission and Goals

\begin{tabular}{|l}
$\begin{array}{c}\text { Background, Energy Policy \& the Biorefinery } \\
\text { Biorefinery Concept }\end{array}$ \\
$\begin{array}{l}\text { - Thermochemical and/or biochemical } \\
\text { processes }\end{array}$ \\
- Multiple product capability (some \\
combination of ethanol, hydrogen, \\
electricity, sugars, syngas, and specialty \\
chemical products) \\
- Multiple feedstock capability
\end{tabular}

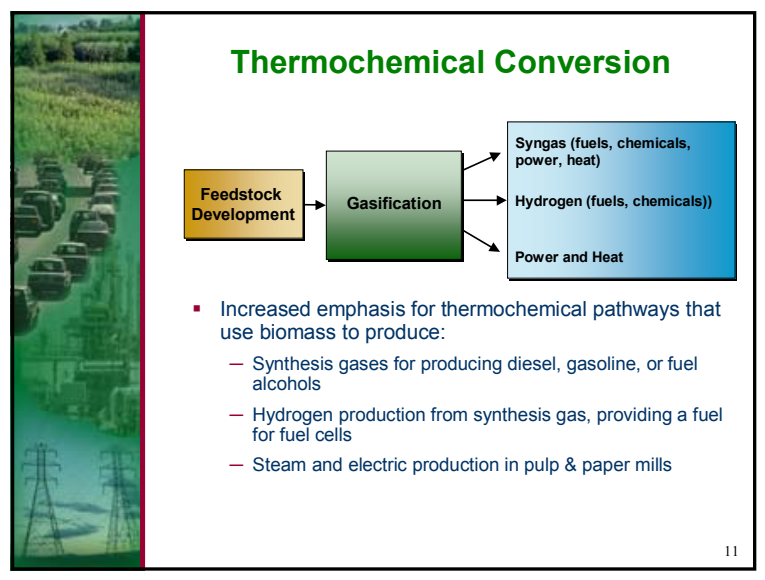

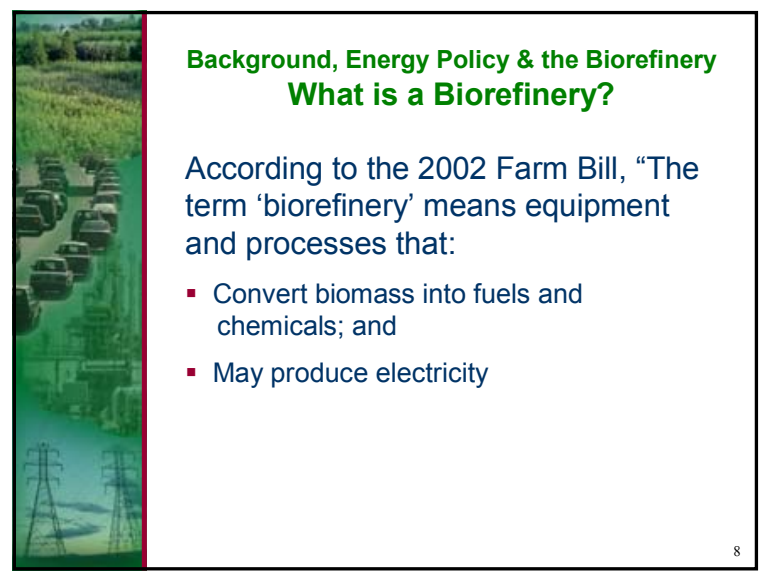
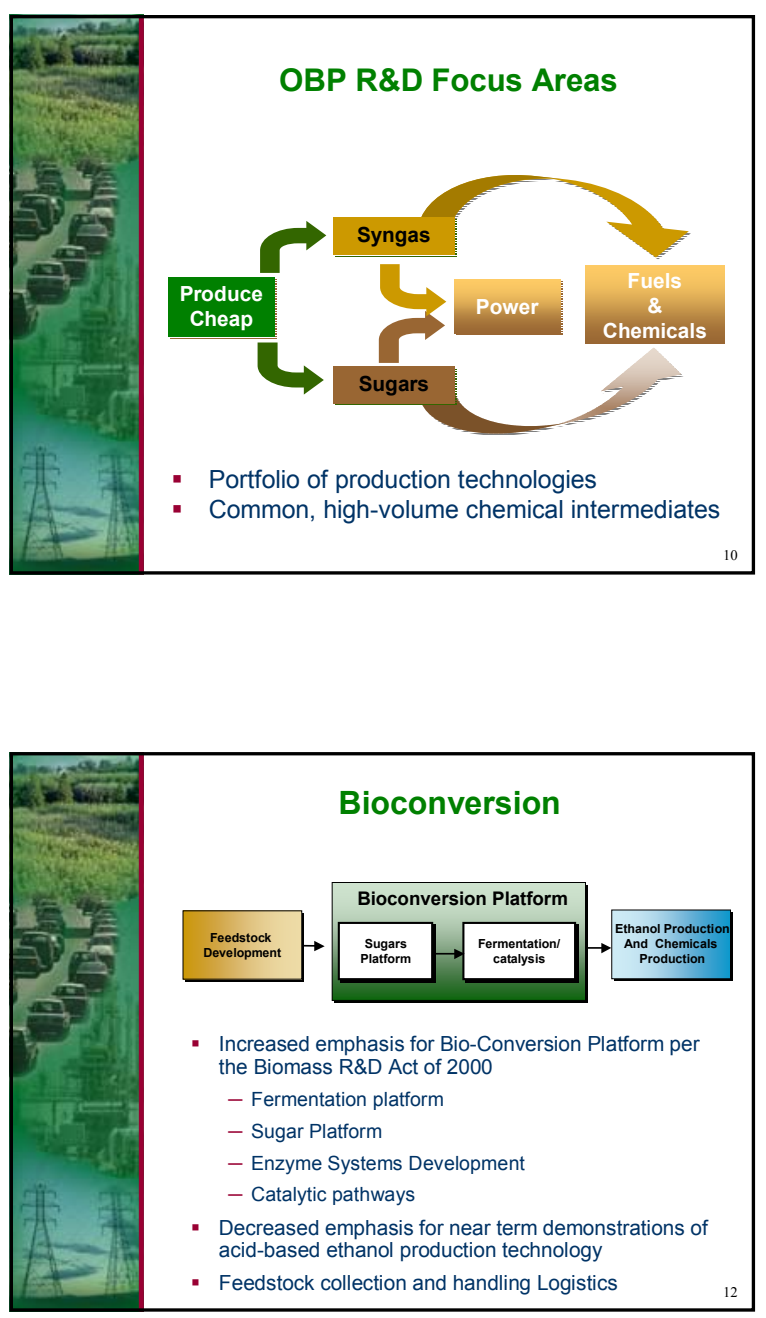


Opportunities
On the horizon
- Develop and integrate bioproducts to
enable deployment of biofuels
- Develop strong partnerships with industry
leaders committed to technology
deployment
- Coordinate with USDA
- Demonstrate utilization of corn stover in
existing dry mills for fuel and co-products
- Improve profitability of existing wet \& dry
mills



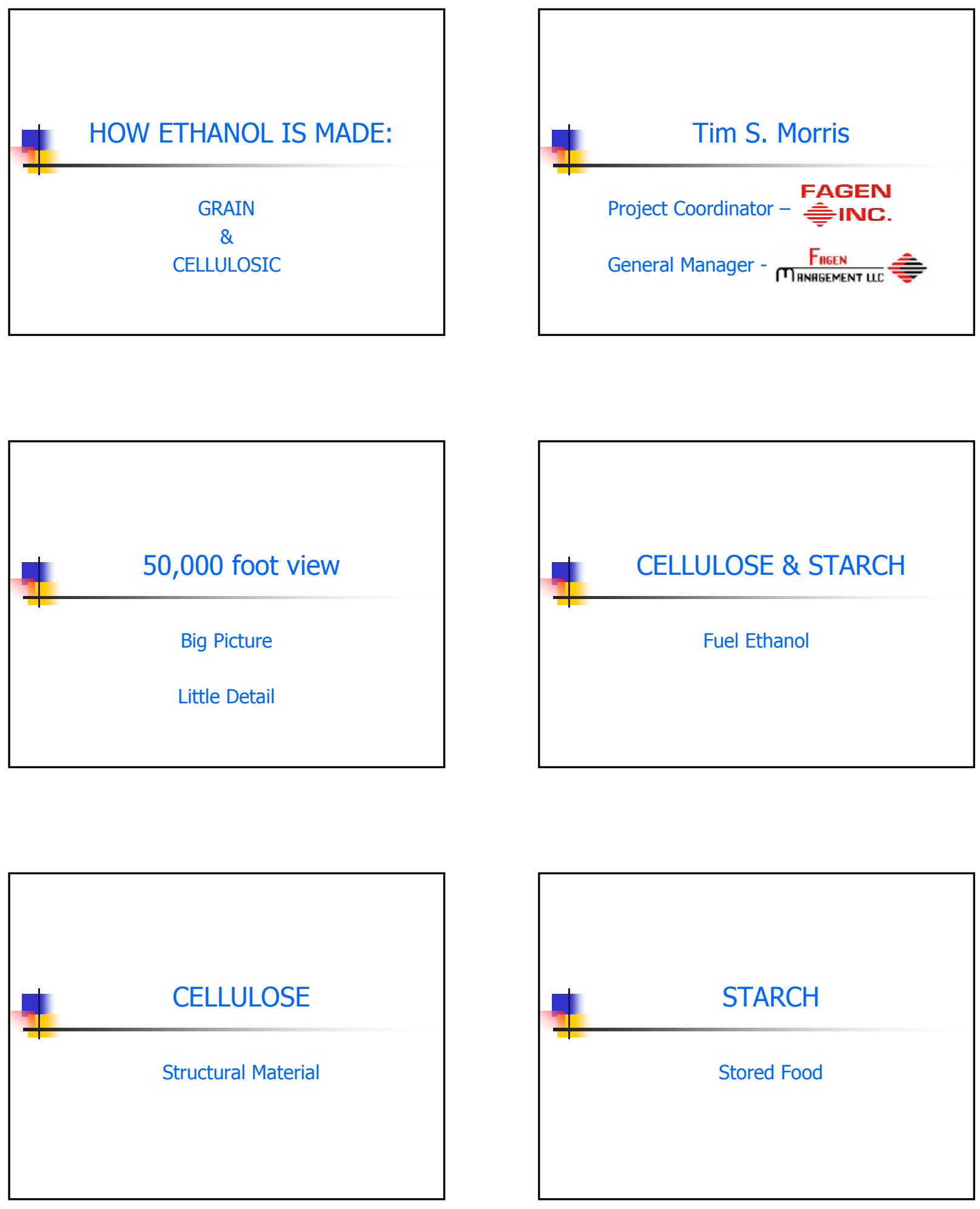

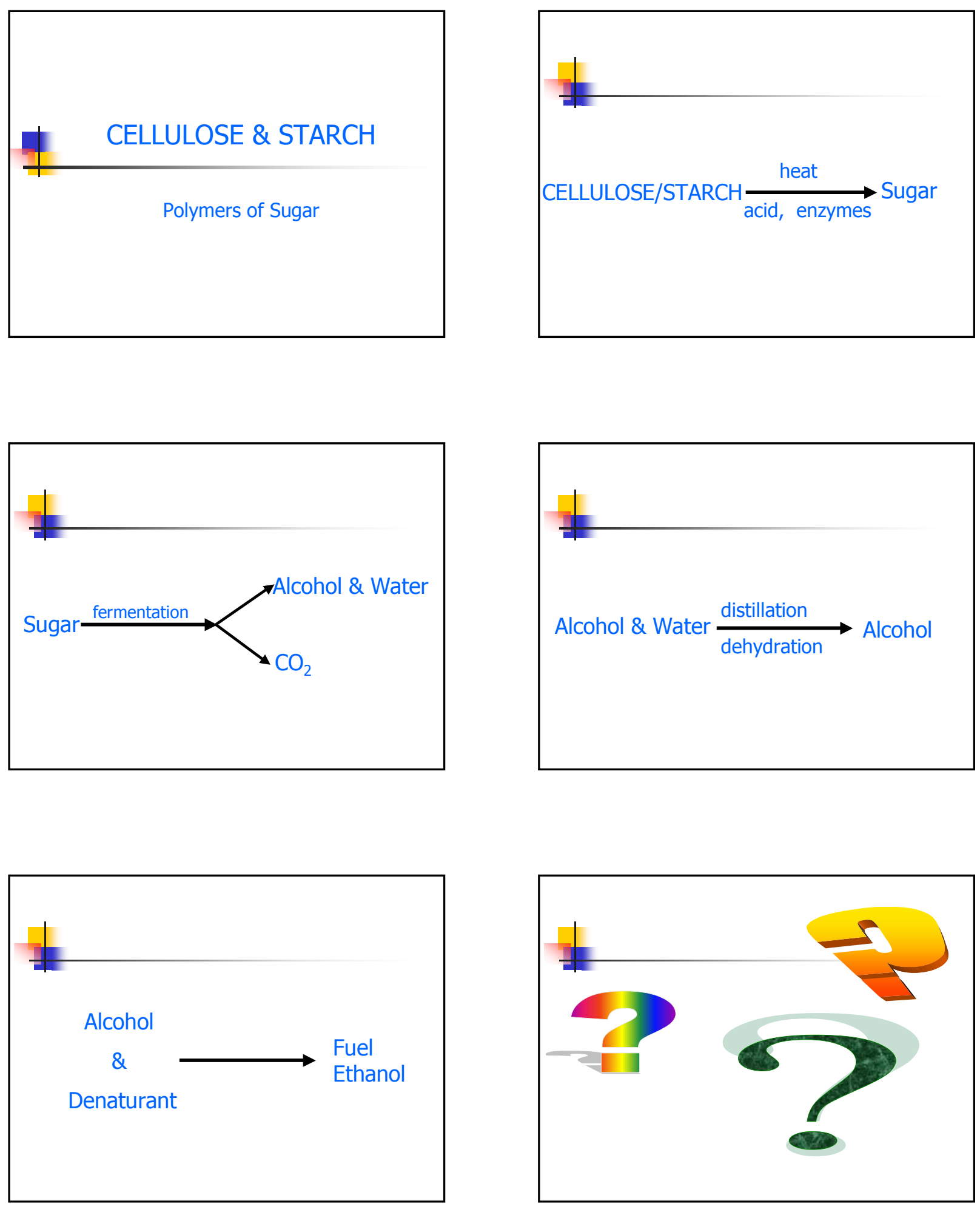


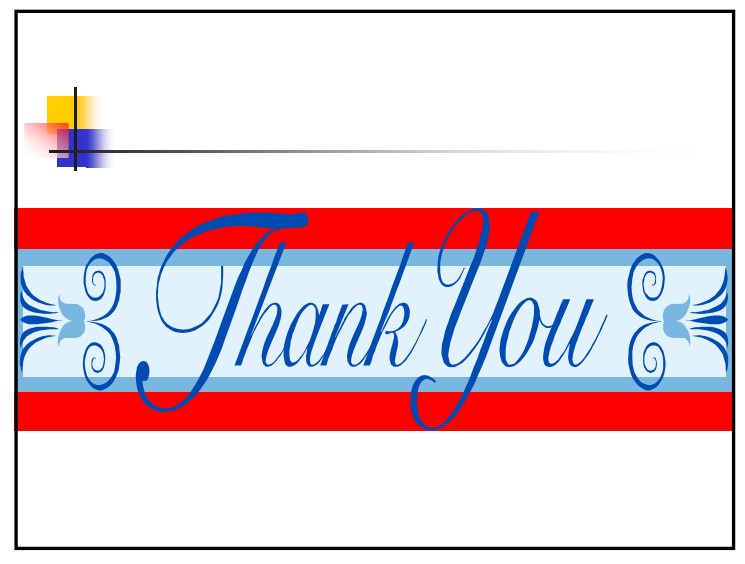




\section{ETHANOL 101 - KY}

- E 10

- E 85

- E Diesel

- FUEL CELLS

\section{Kentucky ethanol production} 5 million gallons per year

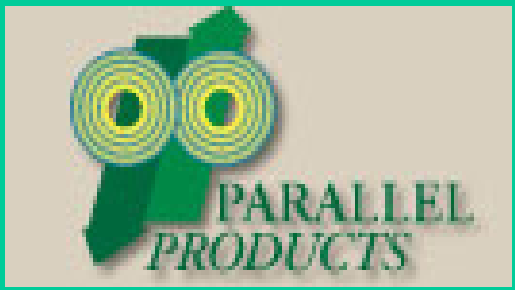

Ethanol Demand in Kentucky 81 million gallons per year

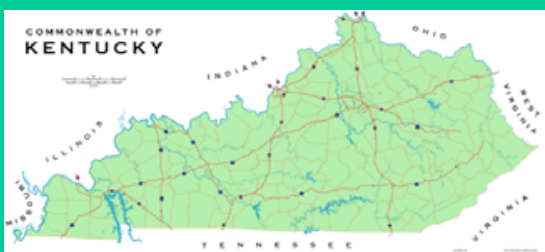

\section{E 85}

- University of Kentucky, Lexington

- City of Lexington

- State Fleet Frankfort

- Murray State University, Murray

- Mammoth Cave State Park

- CECIL'S SERVICE 447 South $8^{\text {th }}$ St. Louisville (Chevron)

\section{Ethanol Demand in Kentucky}

Location

Monthly Volume

Catlettsburg, Ky.

Covington, Ky.

Lexington, Ky.

Louisville, Ky.

Paducah, Ky.

Somerset, Ky.

Evansville, In.

Cape Girardeau, Mo.

500,000
$1,000,000$
500,000
$4,500,000$
75,000
130,000
20,000
10,000

\section{E DIESEL}

PRO

- PARTICULATE IMISSIONS

SUBSTANTIALLY

IMPROVED

- CONTAINS UP TO $15 \%$ ETHANOL
CON

- CLASS 1

FALMMABLE LIQUID

- LOWER BTU CONTENT REDUCES FUEL ECONOMY 


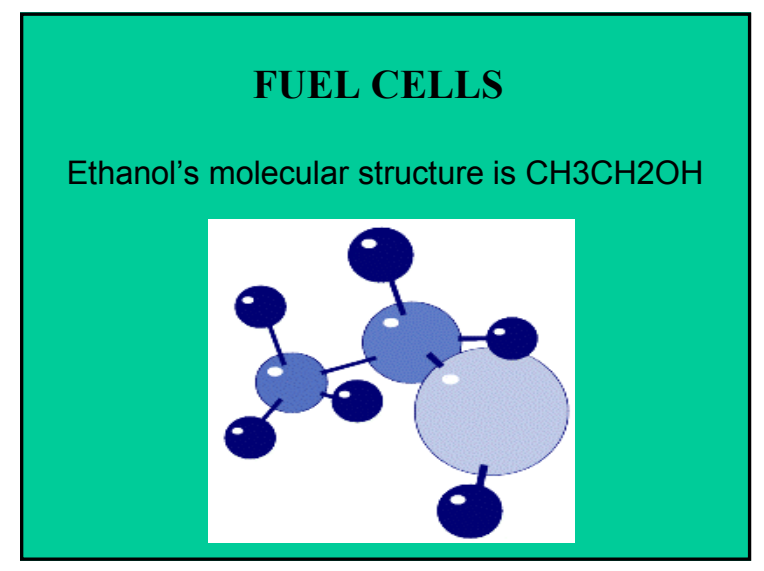


The Key to a Distillery's Success:

How it designs its process with Distillers Grains in mind

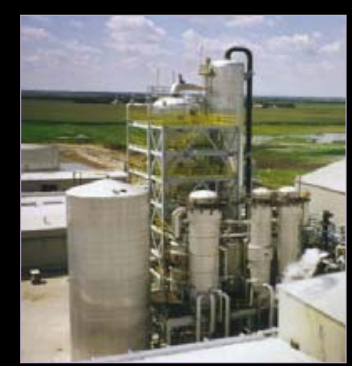

Altech
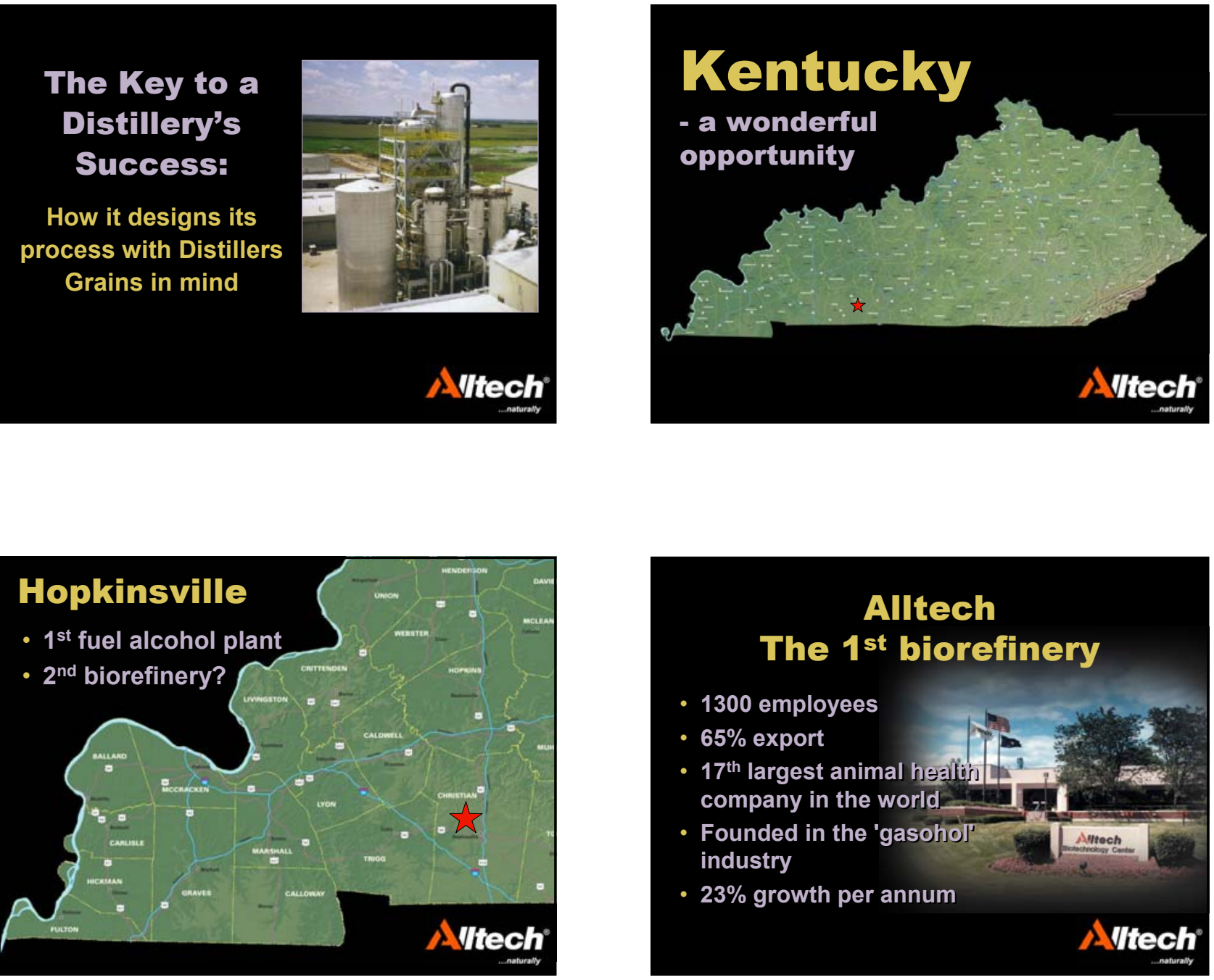

\section{Alltech}

The $1^{\text {st }}$ biorefinery

- 1300 employees

- $65 \%$ export

- $17^{\text {th }}$ largest animal hesilors company in the world = 2.

- Founded in the 'gasohoj' industry

- $23 \%$ growth per annum

Altech

The Challenge

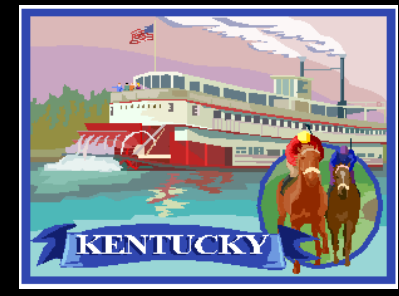

- Add value to agricultural products

- Replace tobacco revenue

\section{Solution}

- Fuel ethanol? --- NO

- Add value? --- YES!

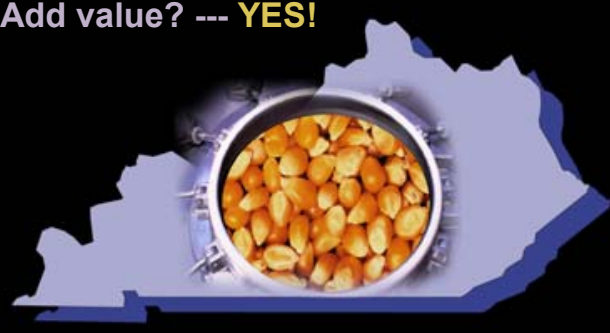




\section{A few misconceptions...}

- Our DDGS (fuel alcohol) is better than beverage plant DDGS

- Our technology is better than beverage plants

\section{The Key}

- Maximize alcohol production (yield)

- Thus minimize DDGS production

- Lower DDGS production costs

- Ass vajueto.DDGS

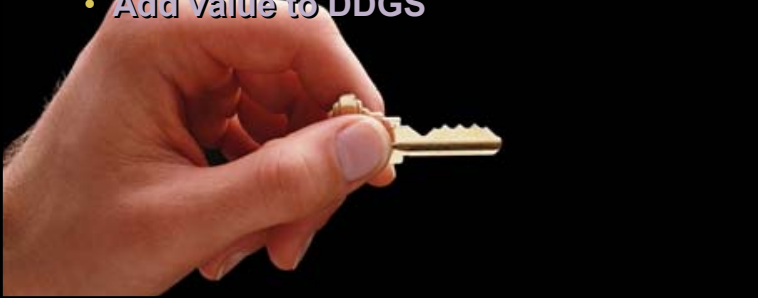

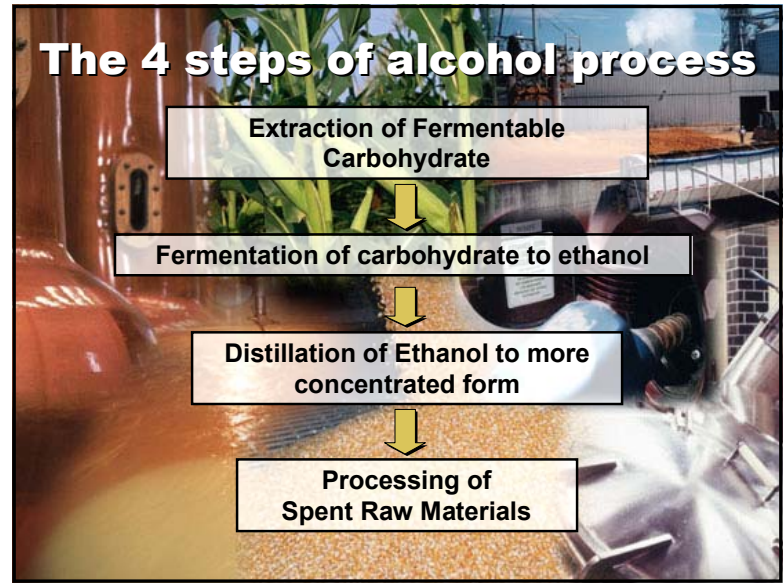

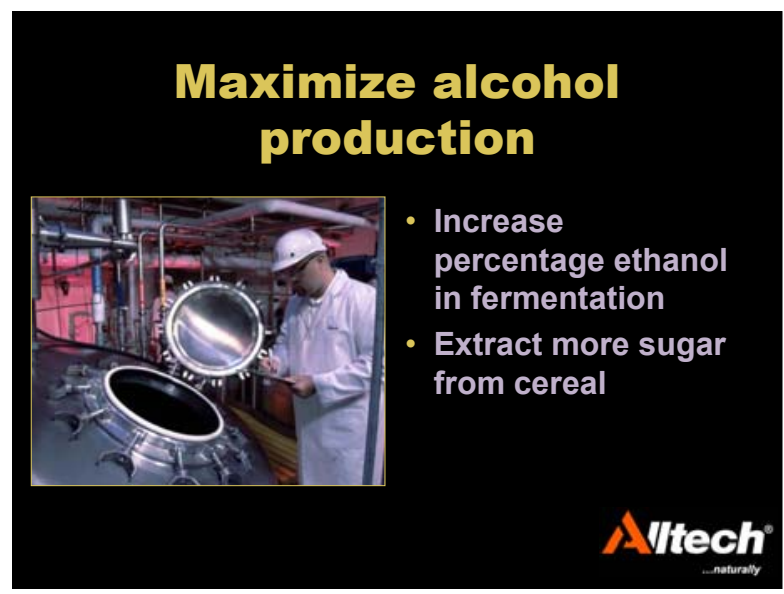

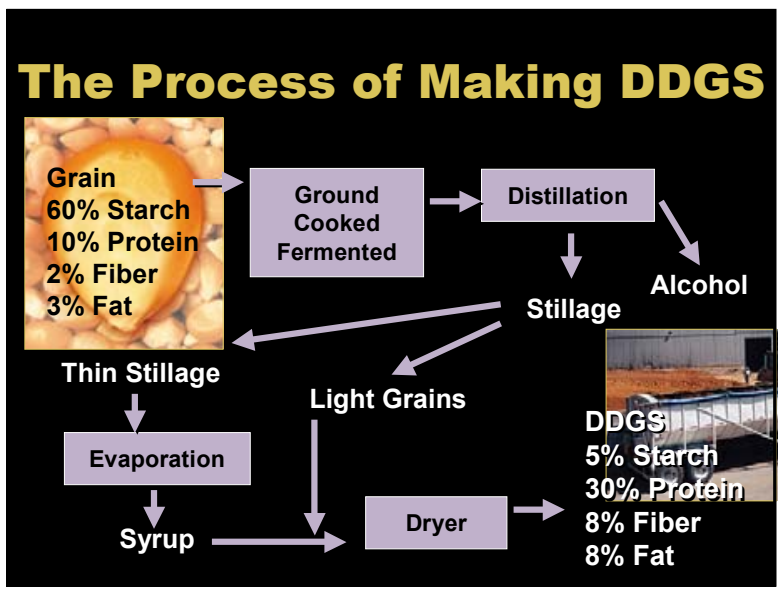

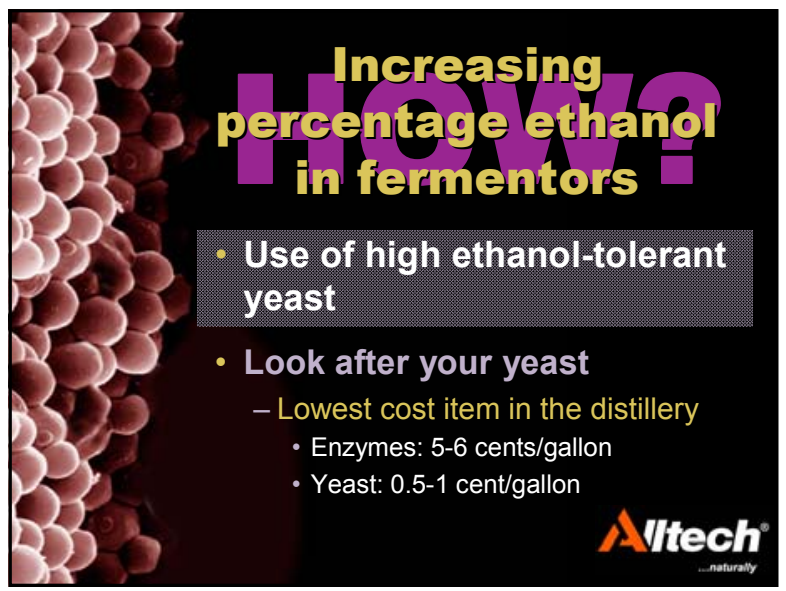




\section{Extract more ethanol from cereal}

- A combination of "conventional" enzymes and Rhizozyme

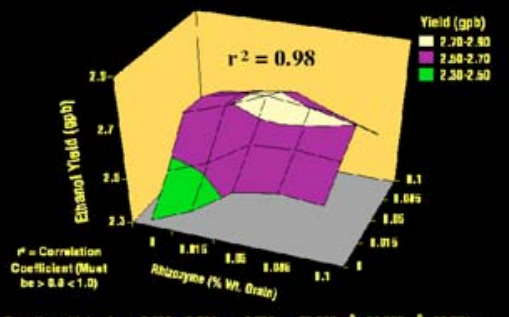

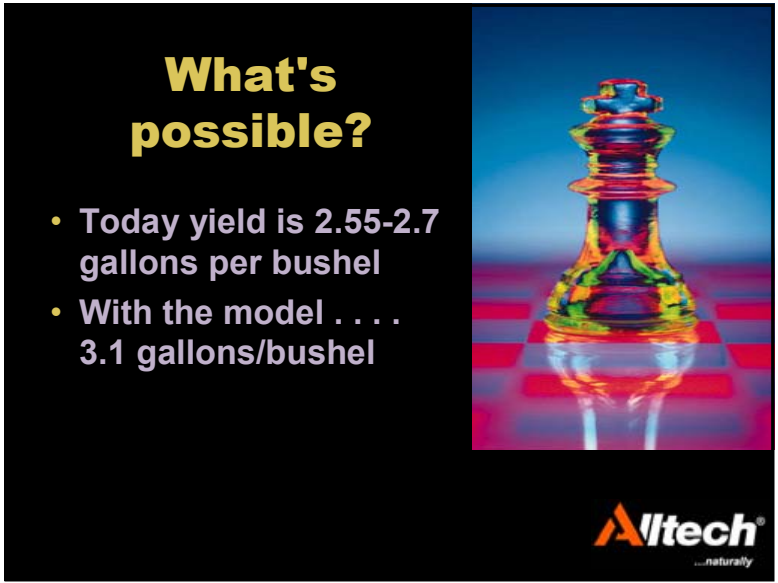

\section{Can it be done?}

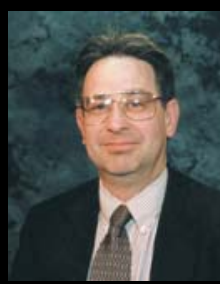

Karl Dawson

University of Kentucky Altech Inc.
- 3.1 gallons/bushel is now possible

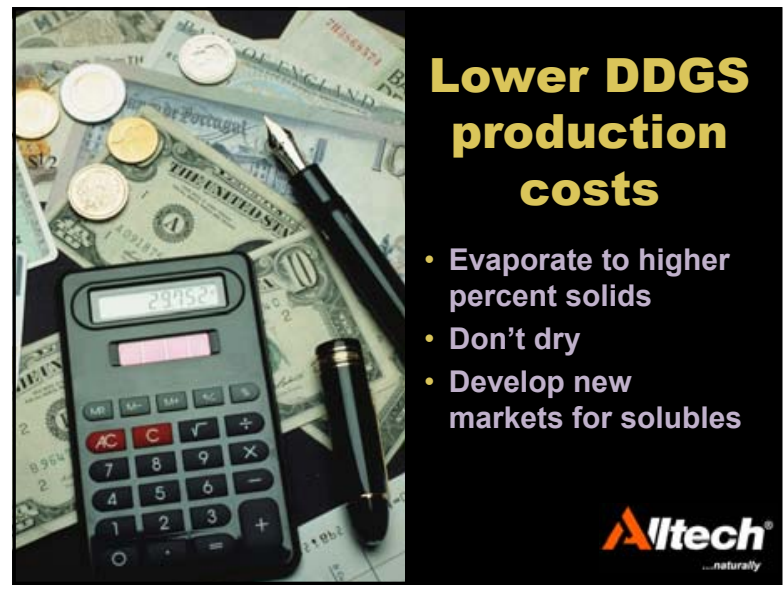

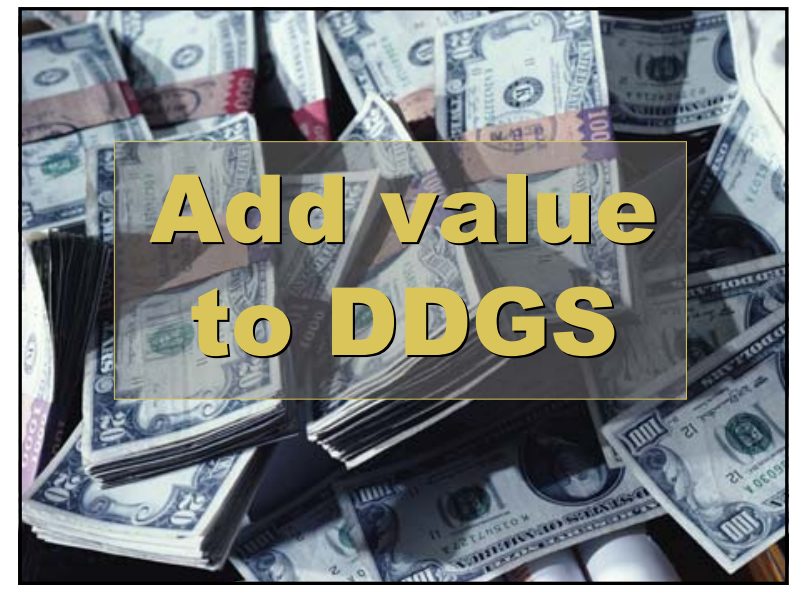

\section{For Hopkinsville:} 20 million gallons

\begin{tabular}{|c|c|c|}
\hline Yield & 2.65 & 3.1 \\
\hline $\begin{array}{l}\text { Corn required } \\
\text { Bushels, m }\end{array}$ & 7.54 & 6.54 \\
\hline Tons & 211,000 & 180,000 \\
\hline Savings, m & & $\$ 200,000+$ \\
\hline $\begin{array}{l}\text { *Corn: } \$ 2.50 / \text { bu } \\
\text { *Allowance less DDGS }\end{array}$ & & \\
\hline
\end{tabular}

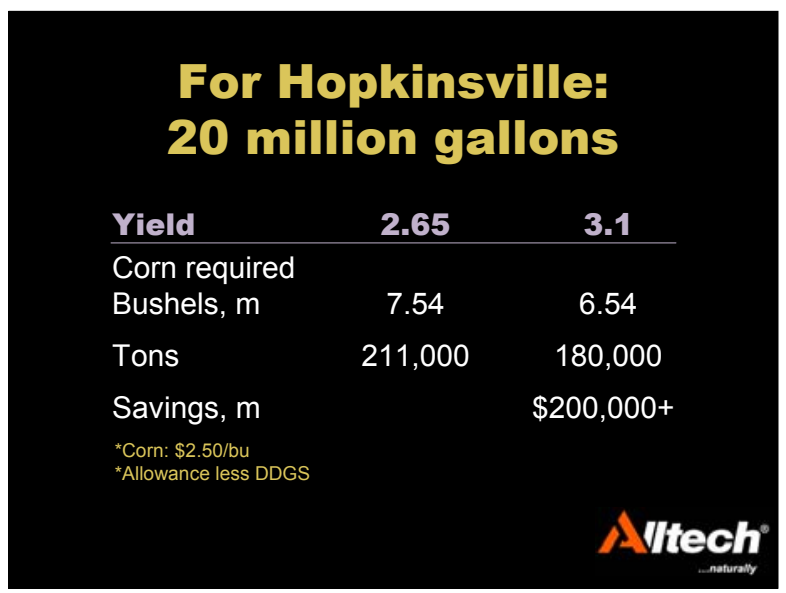




\section{The Process of Making DDGs}

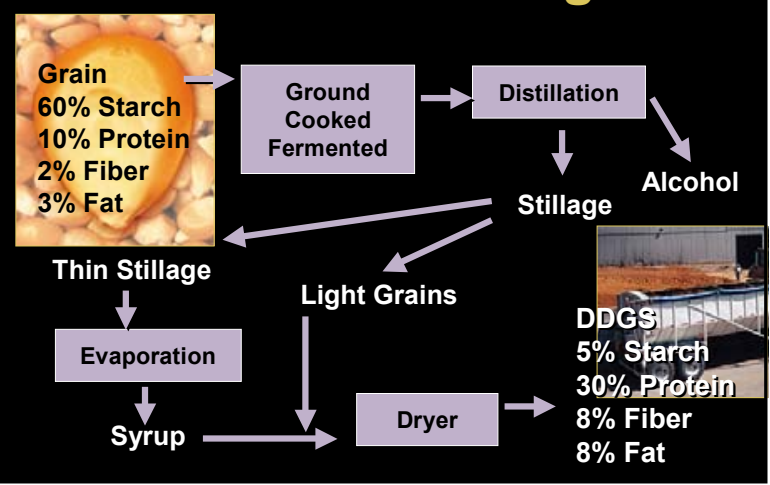

\section{So What is the} DDGS Problem

- Recognized as a commodity

- Used as a feed material for ruminants - High fiber content (poorly used by monogastics)

- Sold on the basis of its protein content not as value

- Sold via brokers

- Whose concept is more meaningless price

- NO attempt to brand

\section{The Future?}

More, More, More DDGS

Less, Less, Less Price

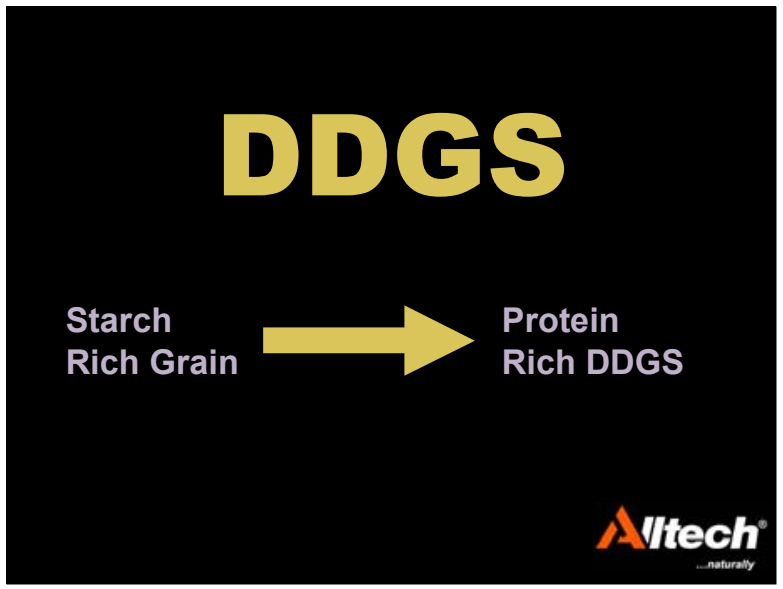

The Problem Will Get Worse

By 2012

- An extra 4.5 million tons of DDGS . . . USA as production goes to 5 billion gallons

- An extra 7 million tons of DDGS ... Europe as European alcohol production starts

- Total . . . . 11.5 million additional

tons DDGS expected by 2012 - 3-fold increase!!!!

- No allowance for Austrailia China, India

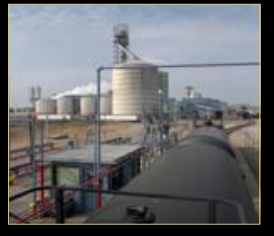

\section{Economics of Ethanol} Production $1000 \mathrm{~kg}$ of Grain $\$ 80.00$

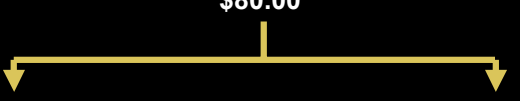

100 gallons of alcohol* $\quad 330$ kg DDGS* $\$ 100.00$ $\$ 26.00$

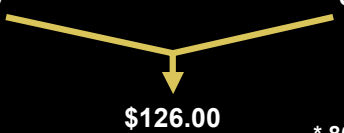

*1.00/gal

$\$ 126.00$

* 80 USD/ton 
Potential Economics of Ethanol Production if DDGS was \$166/ton
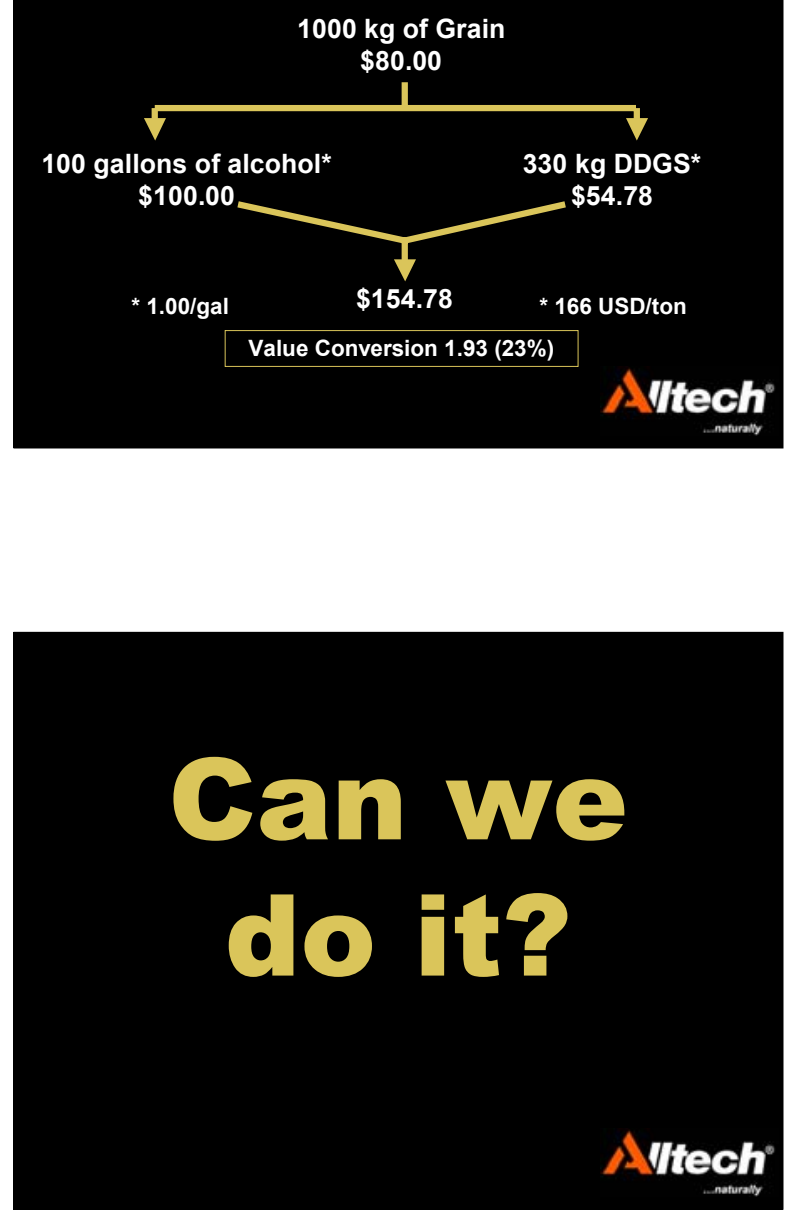

\section{What is VA $101 ?$}

- A DDGS where an additional step gave additional value

- A product developed by Alltech

\section{Is it Possible?}

- DDGS: \$166 USD per ton

- Additional revenue \$32 USD per ton processed

- 82 cents/bushel

- 32 cents/gallon

- Value Added $\$ 320,000$ per million gallons

\section{Altech}

\section{VA 101}

A successful story of how to add value to a by-product
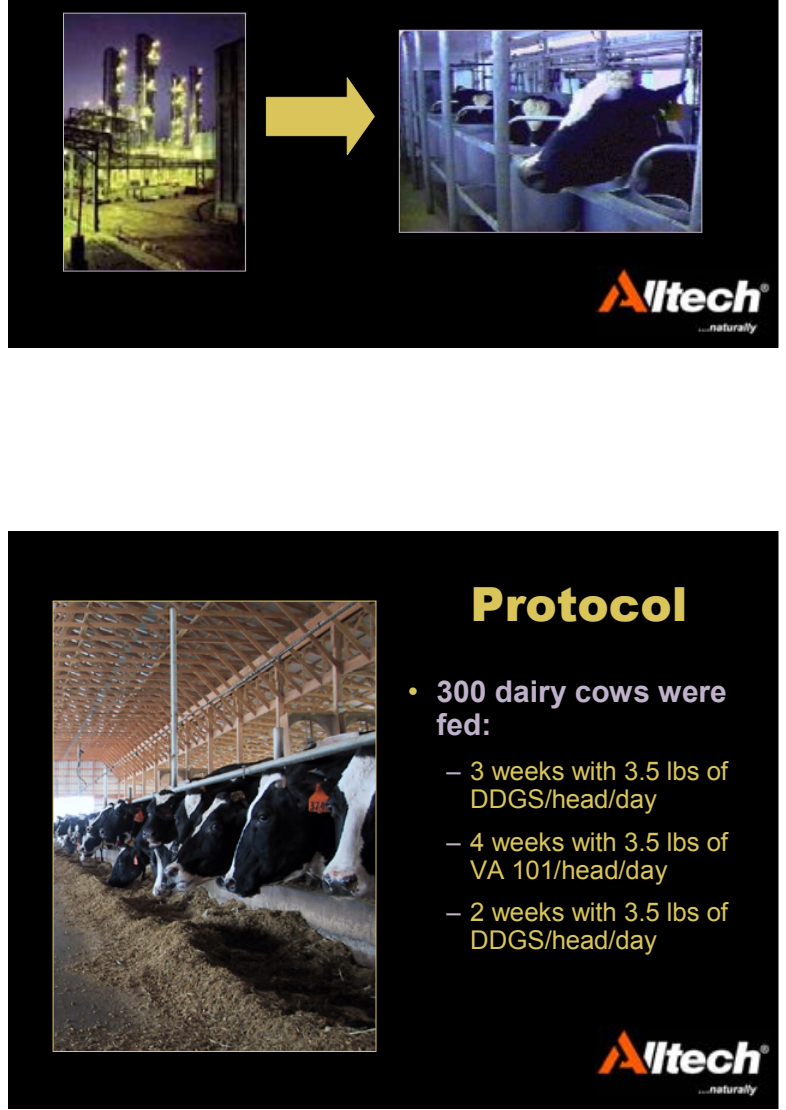


\section{Milk Production}

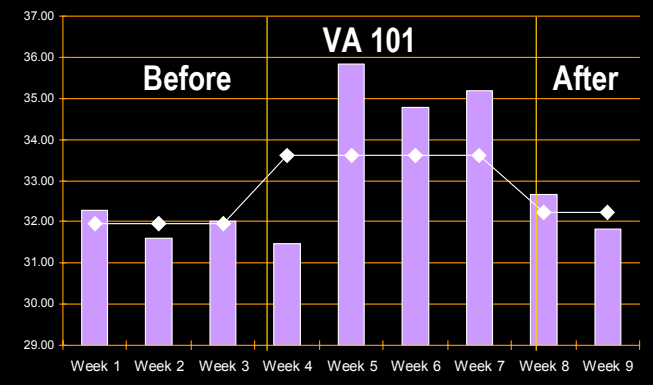

Milk Production Liters/ head / day $\multimap-$ Average Liters/ head / day

\section{Facts behind success}

\section{Economics:}

- 3.65 more Ibs milk per head per day

- Price of milk $=\$ 0.12 / \mathrm{lb}$

- Extra milk income $=\$ 0.44$ per head per day

- More protein in the milk, in this case $4.45 \%$, gives a premium price:
- Or $\$ 0.03$ per head per day - Total $=\$ 0.47$ per head per day

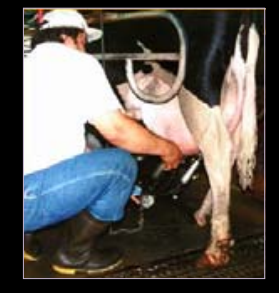

\section{Facts behind success Return $=\$ 0.47 /$ head $/$ day}

Cost of Adding Value

1. VA $101=\$ 0.05 / \mathrm{hd} / \mathrm{d}$

2. Margin $=\$ 0.10 / \mathrm{hd} / \mathrm{d}$

3. Total $=\$ 0.15 / h d / d$

Return on extra outlay

$=3.1: 1$ for producer

$\$ 80.00 /$ ton DDGS

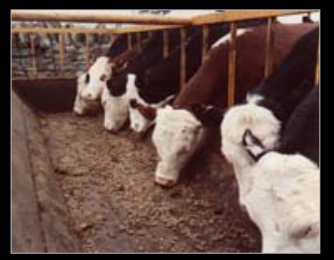

$+\$ 86.00$ / ton DDGS converted to VA $101+$ margin

$\$ 166.00 /$ ton DDGS converted to VA 101

AVtech"

\section{Milk Protein}

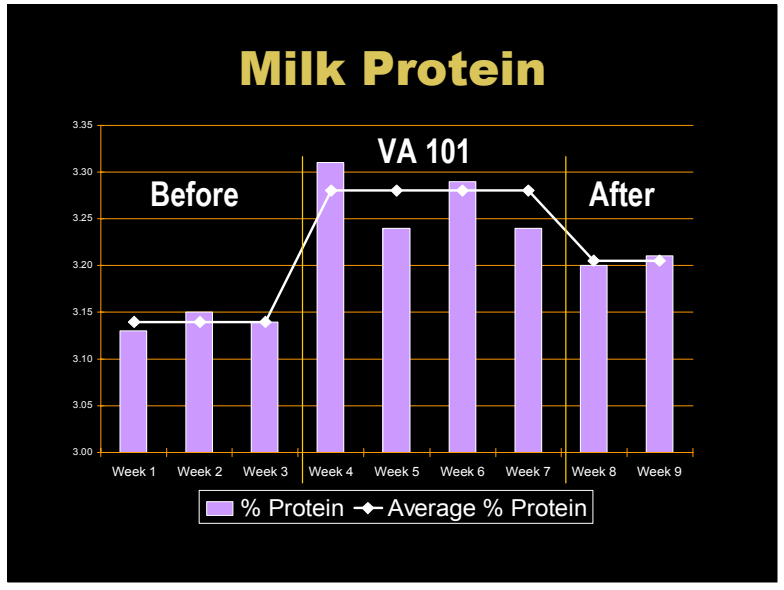

\section{Farmers need 3:1 ratio}
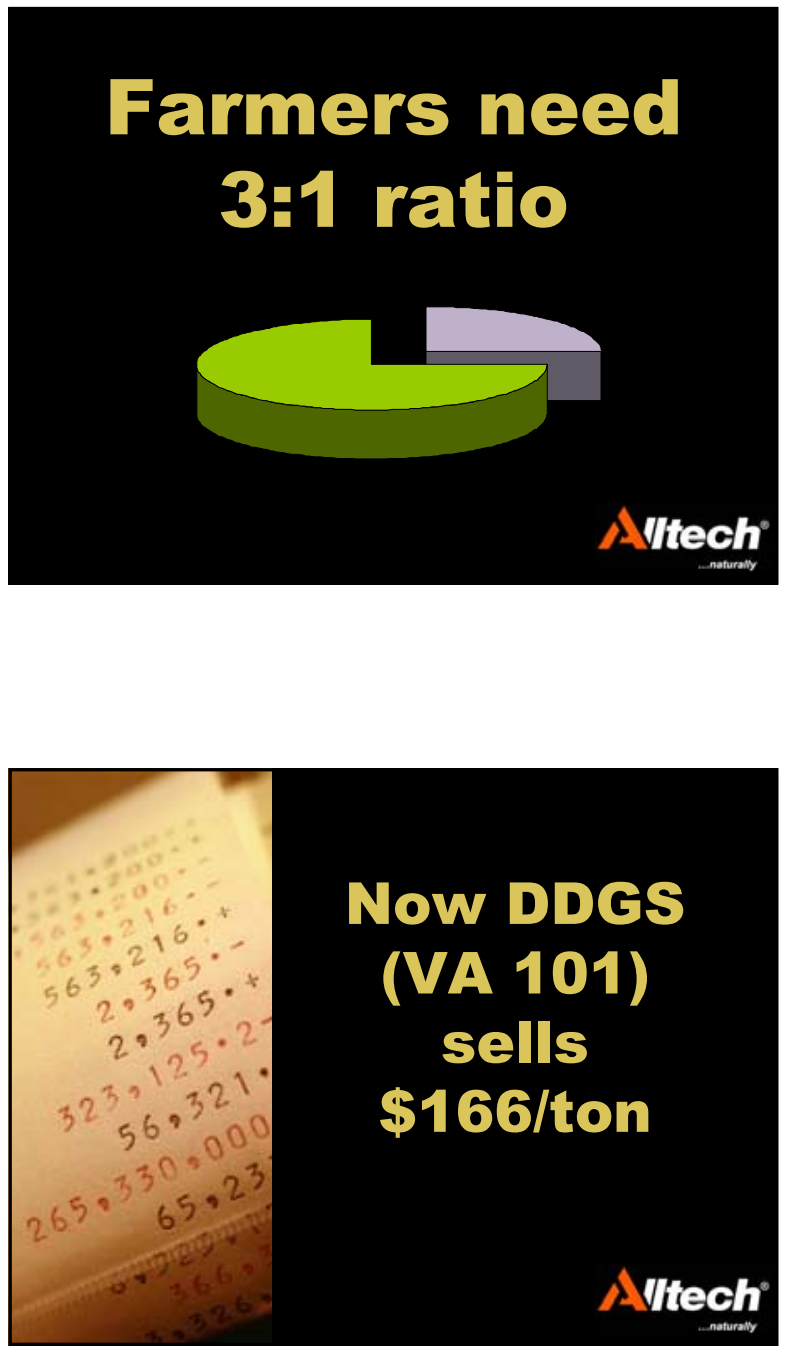
The new economics

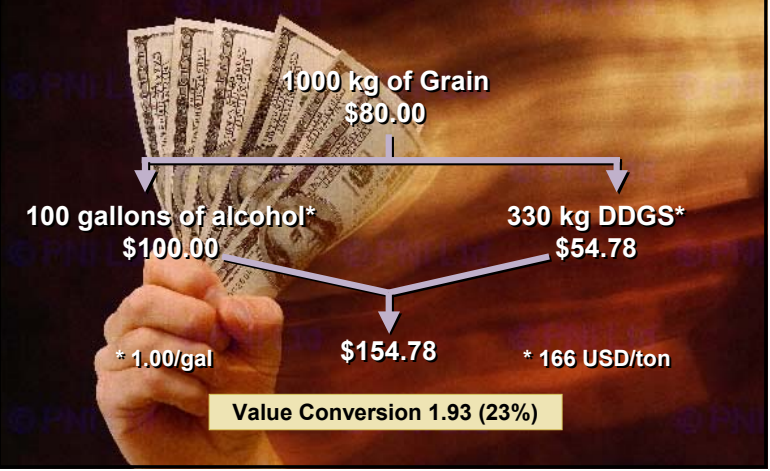

\section{Commitment to market}

- A corporate commitment must be made by the distillery to

- Value-added production

- Sell and market that value

- Build and maintain markets

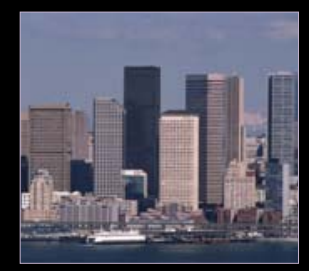

Altech

\section{However, for VA 101 to work we need. . .}

Altech

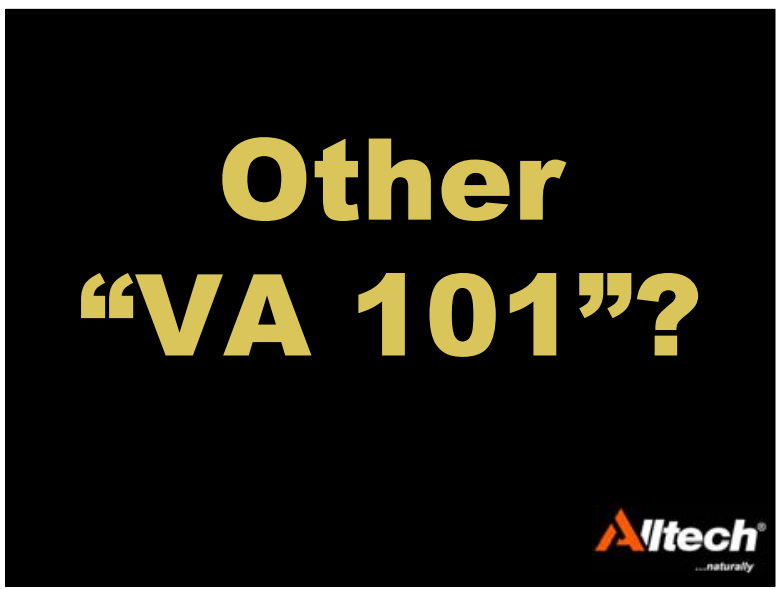

\section{Can we help?}

\section{Non-Ruminant} Market

- Less than $4 \%$ of DDGS goes to swine, poultry and agriculture

- If every broiler got $7 \mathrm{~g} / \mathrm{head} / \mathrm{day}$ all DDGS gone in USA

- If every pig got $1 / 3 \mathrm{lbs} / \mathrm{day}$ - all DDGS gone in USA

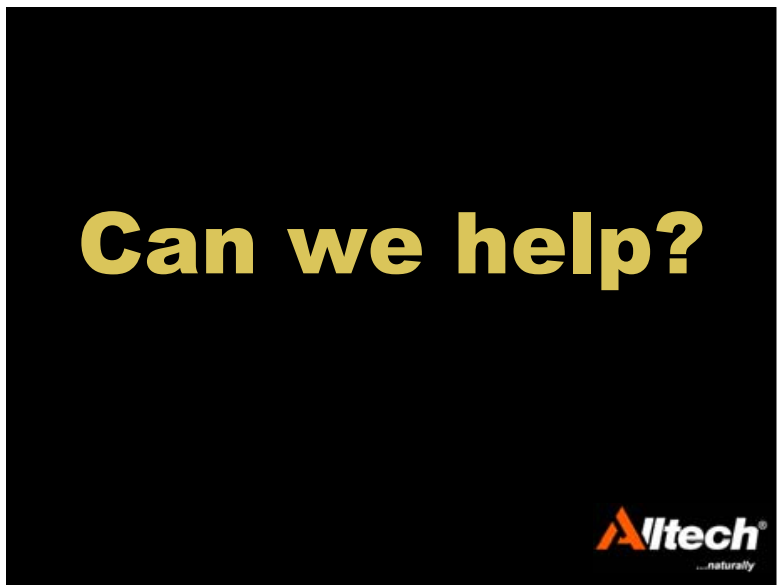




\section{Think outside the box}
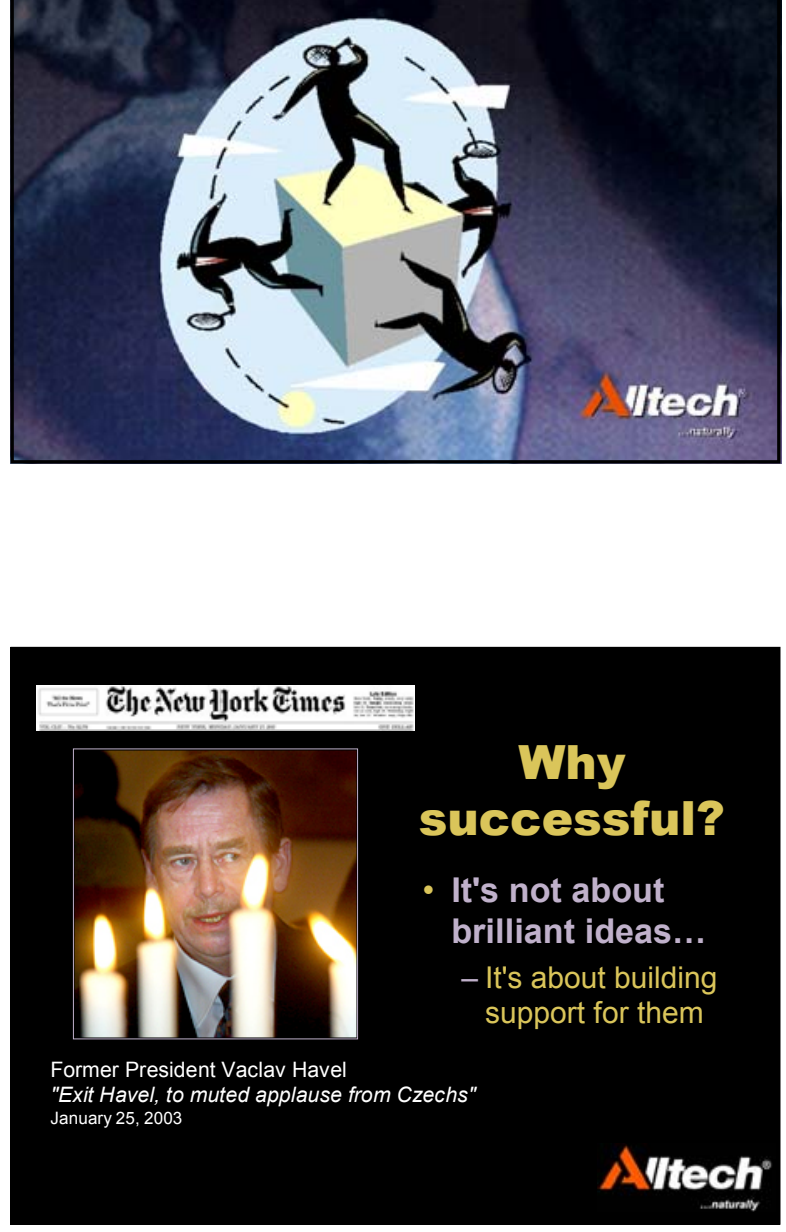

\section{The coffee commodity}

Reinventing a 900 year old

commodity product

into a great coffee experience

The Starbuck Story:

Rewarding every cly suomsents

Reference: A new brand world, Scott Bedlbury, 2002

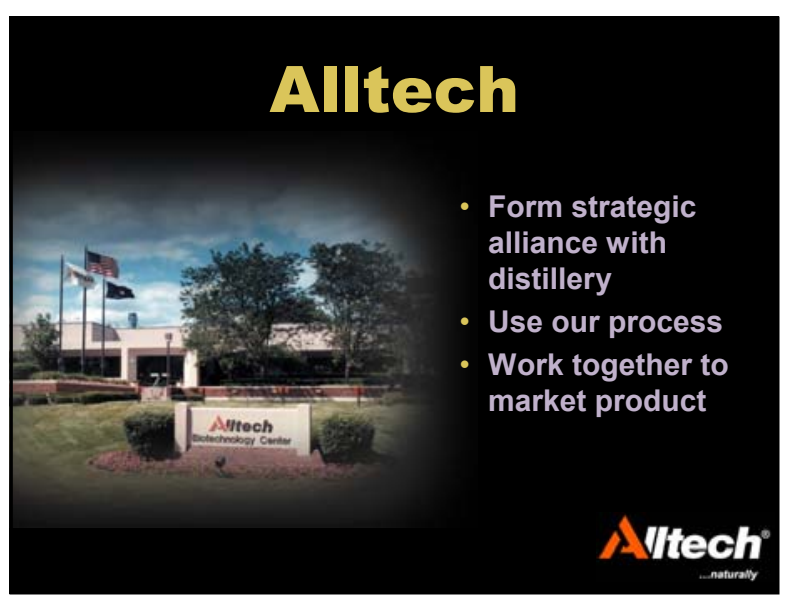

We mijst build a branded value-added product

- We must form strategje alljiances

- Technology

- Marketing

Altech

Altech 


\section{Minnesota’s Ethanol Program}

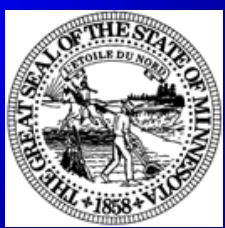

Ralph Groschen

Minnesota Department of Agriculture

\section{Minnesota's Ethanol Program}

- Historical program goals:

- Boost farm and rural economy

- Reduce reliance on foreign energy sources

- Clean up environment by reducing toxic auto emissions
Minnesota's Ethanol Program

- The situation in 1979:

- OPEC oil embargo leads to long lines and high prices at gas pumps

- Concerns grow about U.S. dependence on imported oil

- Federal legislation bans leaded gasoline

\section{Minnesota's Ethanol Program}

- Minnesota responds:

- 1980 State Legislature creates “Blender's Credit"

- Blenders get tax credit of 4 cents/gallon for gas blended with 10 percent ethanol

- Leads to increased use of ethanol-blended fuels
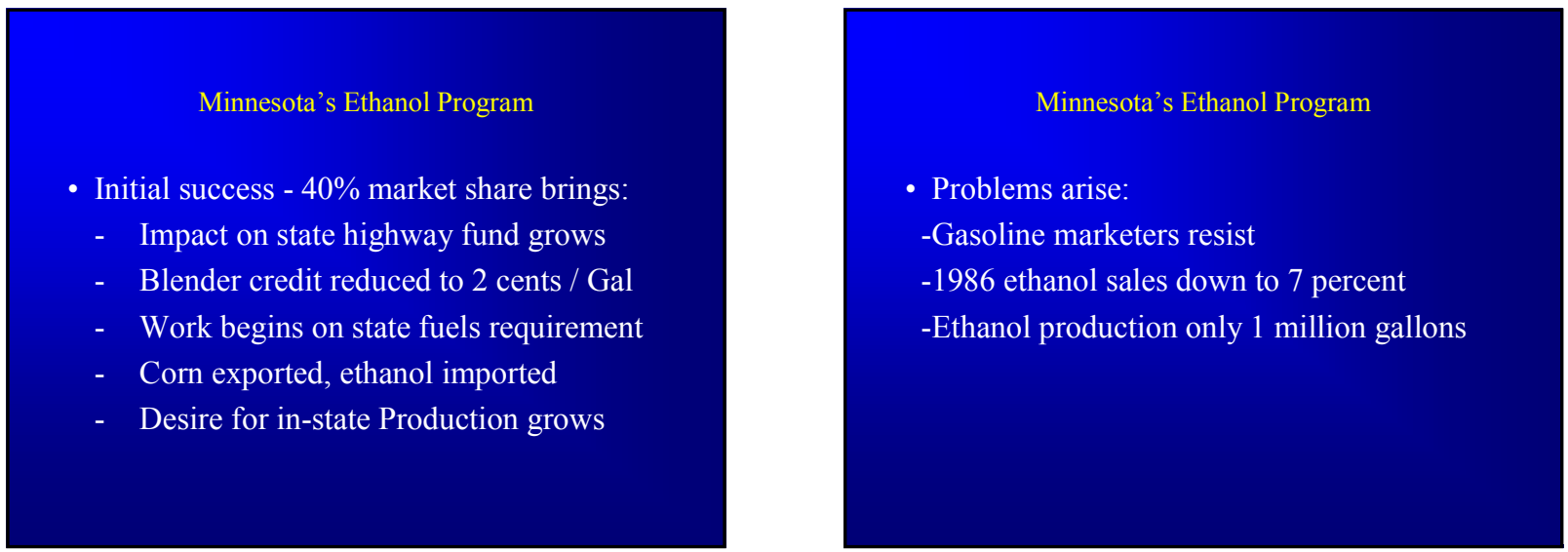
- 1980s Farm crisis gives ethanol new life:

- Minnesota loses 8,000 farms between 1984 and 1986

- Two-thirds of corn crop exported as raw commodity

- Virtually no industrial processing of corn
- MDA sets goals for revitalized program:

- Increase market share for ethanol blends

- Educate consumers about ethanol facts

- Build ethanol production capacity and infrastructure

- Revitalize rural communities through farmerowned, value-added processing
Minnesota's Ethanol Program

- Air quality emerges as third driver:

- Clean Air Act requires Minneapolis-St. Paul to include 2.7\% oxygen in all gas sold from October 1 to February 1

- Expanded to year-round in 1995

- Expanded statewide in 1997

\section{Minnesota's Ethanol Program}

- Minnesota's Ethanol Dream Team:

- Farm organizations

- Commodity Groups

- Rural electrification associations

- Governor's Office

- State Attorney General's Office

- Department of Agriculture and other agencies

- Legislature
Minnesota's Ethanol Program

The MDA's Role:

- Public education

- Help increased ethanol production

- Encourage farmer-owned developments

\section{Minnesota's Ethanol Program}

1. Public education:

- Educational materials

- Public and private presentations

- Respond to media and policy queries

- Sponsorships, technical experts, spokespeople

- Oxy-fuel Hotline

- Troubleshooting performance problems 
2. Increasing Production:

- Statutory Goal:

- Production of 240 million gallons in MN

- Key elements

- 20-cent per gallon producer incentive

- Financial, technical \& organizational support

- Local market development
3. Assist local developers/ farmer investors: - Financial

- $\$ 500,000$ loans to developers

- Stock loan program helps farmers buy into co-ops

- Technical and organizational

- MDA staff help draft project work plans, schedules

- MDA staff help conduct organizational meetings

- Liaison with state and federal agencies

- MDA staff review marketing, business plans
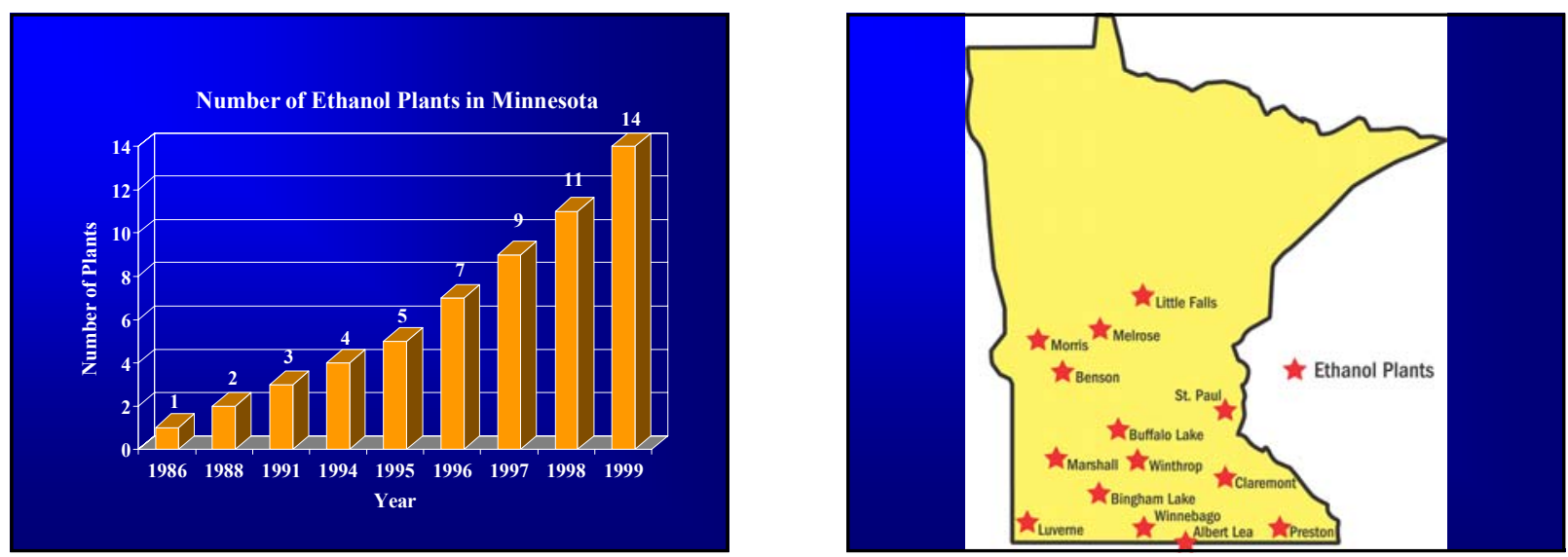

Ethanol Production vs. Market Penetration

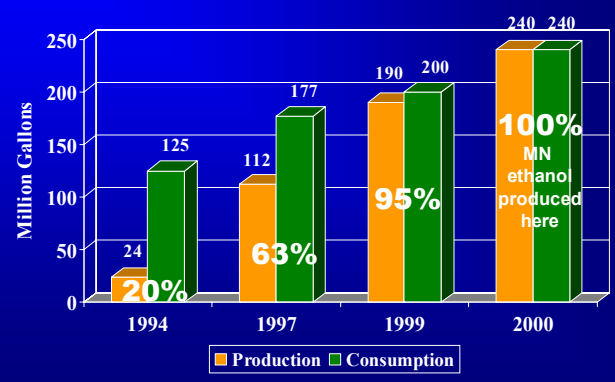

\% Ethanol Market Share in Minnesota 1986 Thru 1997

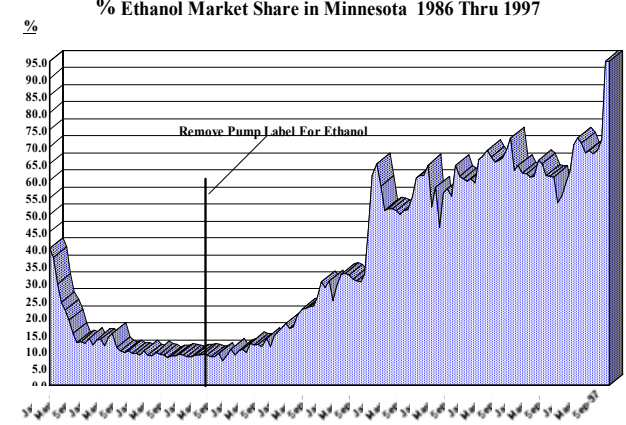


Minnesota Ethanol:

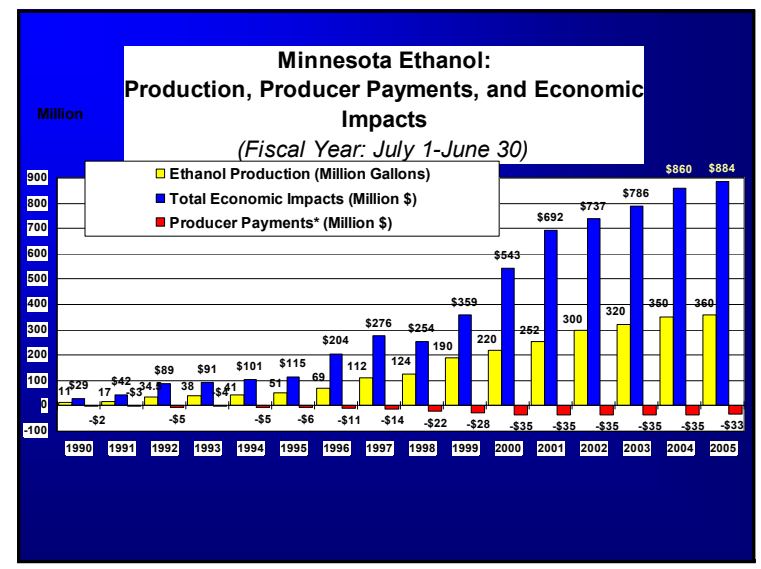

Minnesota's Ethanol Program

- For 2001 production year

- Based on IMPLAN economic Impact model

- \$1 producer payment returns $\$ 20$ economic benefit to the state.

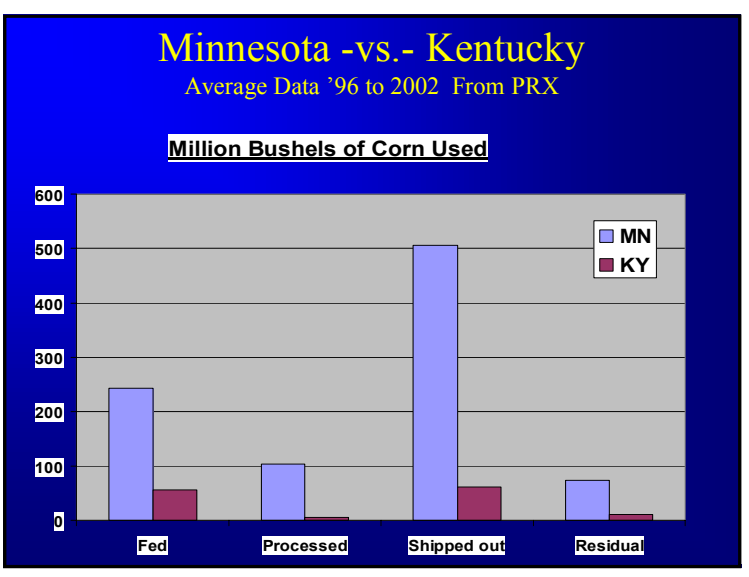

MN Corn Use 1995 -vs- 2001

\% Corn Usage $\mathrm{MN}$-vs.- KY

Average Data '96 - 2002 From PRX
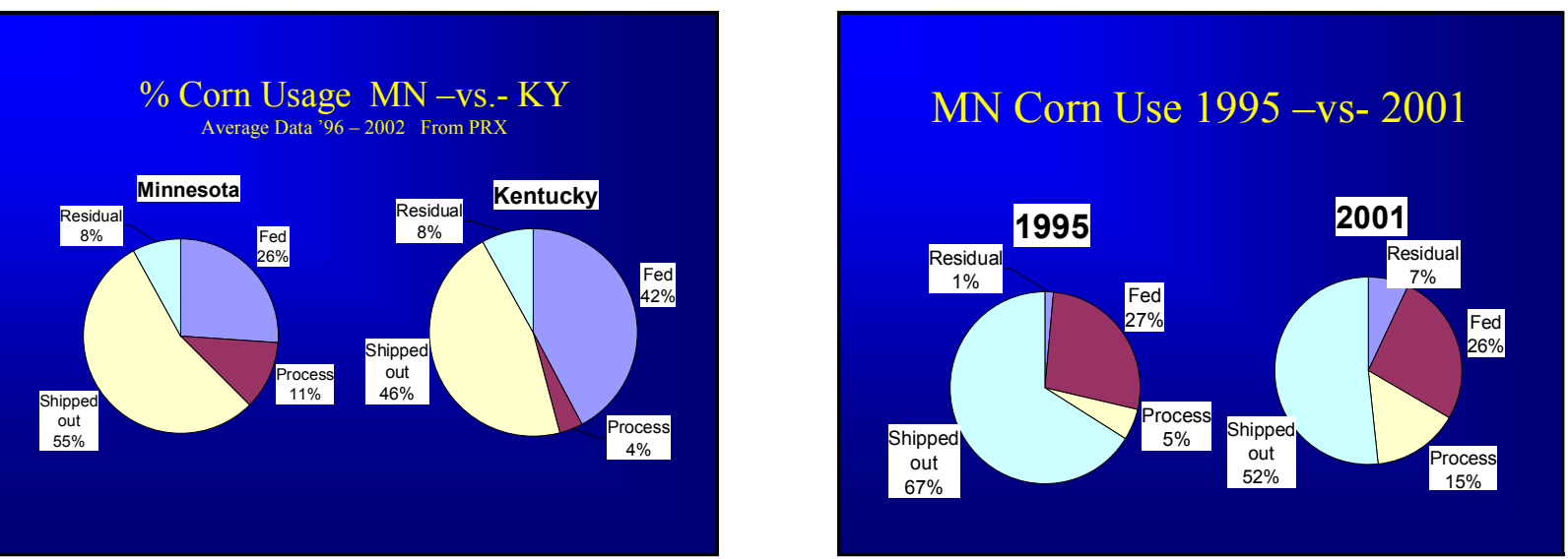
- The results:

- 14 ethanol plants, 11 owned by farmers

- Production capacity surpasses $\mathbf{2 4 0}$ million gallons by August 2000, now 360 million.

- $17 \%$ of corn crop used for industrial processing - \$200 million in value added to commodities

- 750 new jobs in the plants

- 4,000 external jobs supported by plants

- 25-35 good jobs or more per plant
- Impacts of farmer-owned processing: - Corn-to-ethanol adds $\$ 2$ to $\$ 2.50$ in value per bushel

- Each 15-million gallon plant adds up to $\$ 14$ million in value to 5.5 million bushels of corn each year

- Money pumped into local communities
Minnesota's Ethanol Program

- Ethanol as a Farmer Investment:

- Hedge on traditional corn market prices

- Farmers to capture more of total profit

- Farmers diversify, smoothing out peaks and valleys in farm income

\section{Minnesota's Ethanol Program}

- Goals achieved:

- Boost farm and rural economy $\checkmark$

- Value added on 17 percent of corn crop

- 12 farmer-owned value-added cooperatives

- Reduce reliance on foreign energy $\checkmark$

- Utilizes abundant natural gas to convert corn into ethanol "that can replace petroleum by a factor of 7 to 1 ,"

- Clean up environment $\checkmark$

- Twin Cities in attainment for carbon monoxide

\begin{tabular}{|l|c|c|}
\hline \multicolumn{3}{|c|}{ Value of Corn } \\
\hline \multicolumn{2}{|c|}{ Raw Commodity vs. Value-Added } \\
\hline \multicolumn{2}{|c|}{ (per bushel of corn) } \\
\hline Octobe r 1996 Pric s & \\
\hline & Corn & Value-Added \\
\hline & & Dry-Milling \\
\hline Products & Price & DDG \\
\hline Corn & $\$ 2.82$ & \\
\hline Ethanol & & $\$ 3.77$ \\
\hline DDG & & $\$ 1.26$ \\
\hline Total Value & $\$ 2.82$ & $\$ 5.03$ \\
\hline
\end{tabular}

\begin{tabular}{|c|c|c|}
\hline \multicolumn{3}{|c|}{ Value of Corn } \\
\hline \multicolumn{3}{|c|}{ Raw Commodity vs. Value-Added } \\
\hline \multicolumn{3}{|c|}{ (per bus he l of corn) } \\
\hline \multicolumn{3}{|c|}{ July 1996 Prices } \\
\hline & Corn & Value-Added \\
\hline & & Dry-Milling \\
\hline & Raw & Ethanol \& \\
\hline Products & Commodity & DDG \\
\hline Corn & $\$ 5.18$ & \\
\hline Ethanol & & $\$ 3.76$ \\
\hline DDG & & $\$ 1.45$ \\
\hline Total Value & $\$ 5.18$ & $\$ 5.20$ \\
\hline
\end{tabular}




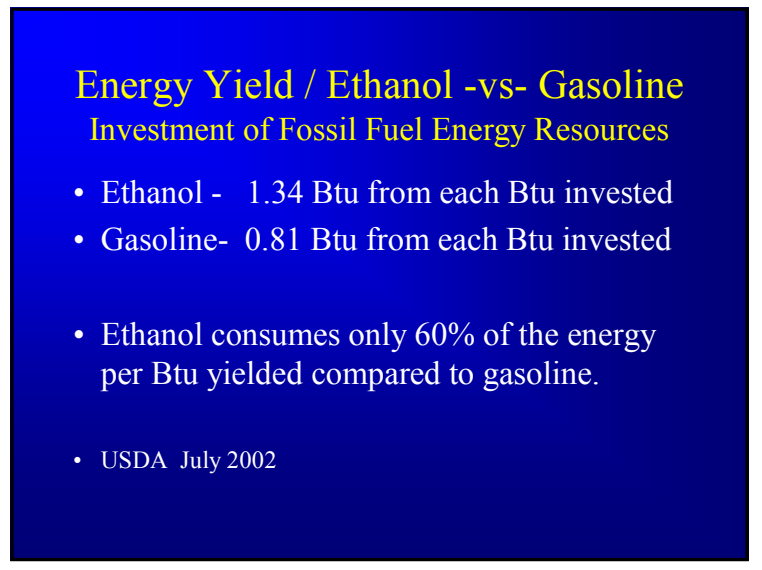


What's Up Your Tailpipe?

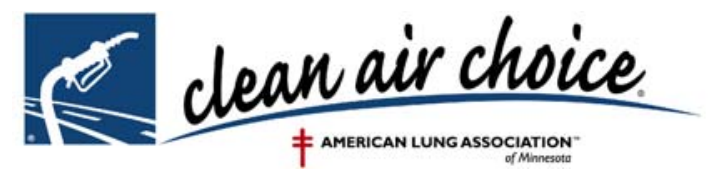

Kentucky Ethanol Workshop February 3, 2003

American Lung Association of Minnesota Outdoor Air Programs
Today's Discussion:

- ALAMN Mission

- MN Air Quality

- AQ \& Motor Vehicles

- Fuel Ethanol

- E10

- E85

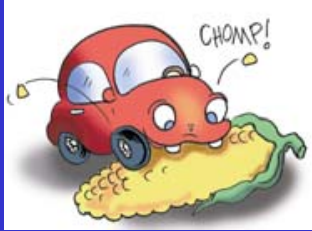

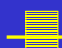

"What? Minnesota? Isn't that the land of clean air and sky blue waters?"

Trends?

- 2002: JAMA - Lung cancer deaths $+\mathbf{8} \%$ for every $10 \mu \mathrm{g} / \mathrm{m}^{3}$ increase of fine particulates. PCA concern PM2.5 non-attainment may be of more immediate concern than $\mathrm{O}_{3}$

- 2001: Worst $\mathrm{MN} \mathrm{O}_{3}$ season in 30 years.

-1999: 10 air toxics exceed health benchmarks. $61 \%$ of excess cancer risk associated with motorized vehicles.

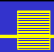

"Traditional? Alternatives? I just gotta get the kids to hockey practice!"

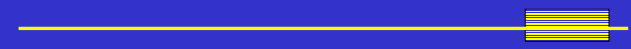

- Nearly $90 \%$ of respondents claimed ALAMN 'recognition' would be important in choosing a fuel.

- Hundreds of millions of 'impressions' via earned media and consumer education in 1999-2002.

- ALAMN national recognition for MN cleaner fuels efforts (USEPA; USDOE \& even Gov. Jesse).

$\neq$ AMERICAN LUNG ASSOCIATION。 f AMERICAN LUNG ASSOCIATION 
Ethanol-blended or "oxygenated" is one tool Minnesota uses to fight vehicle pollution.

"Oxygenated" gasoline is part of the state implementation plan for reducing carbon monoxide. EPA has granted MN

"maintenance" status for CO.
- Renewable resource.

- GHG reduction tool

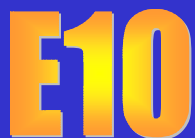

- Clean octane - reduces ozone-formers and air toxics by diluting/displacing benzene, olefins, aromatics, and sulfur. $\quad$ (EPA, 1999a

- Favorably alters fuel distillation index to reduce cold-start emissions.

- $18 \%$ less CO with California vehicles using fuel with $2.1 \mathrm{wt} \%$ oxygen. (Johnson et al., 1998)

- Less CO and HC emissions compared to non-ethanol blend.

(Knapp et al., 1998)

\section{Twin Cities Gasoline Survey \& Comparison}

- Partner with UND EERC fuels lab

- Random at-the-pump samples

- Top-selling 87-octane brands

(BP Amoco, SuperAmerica, Holiday)

- Composition (all E10)

- On-road vehicle testing (non-FTP)

- EPA MOBILE6.2 emissions modeling
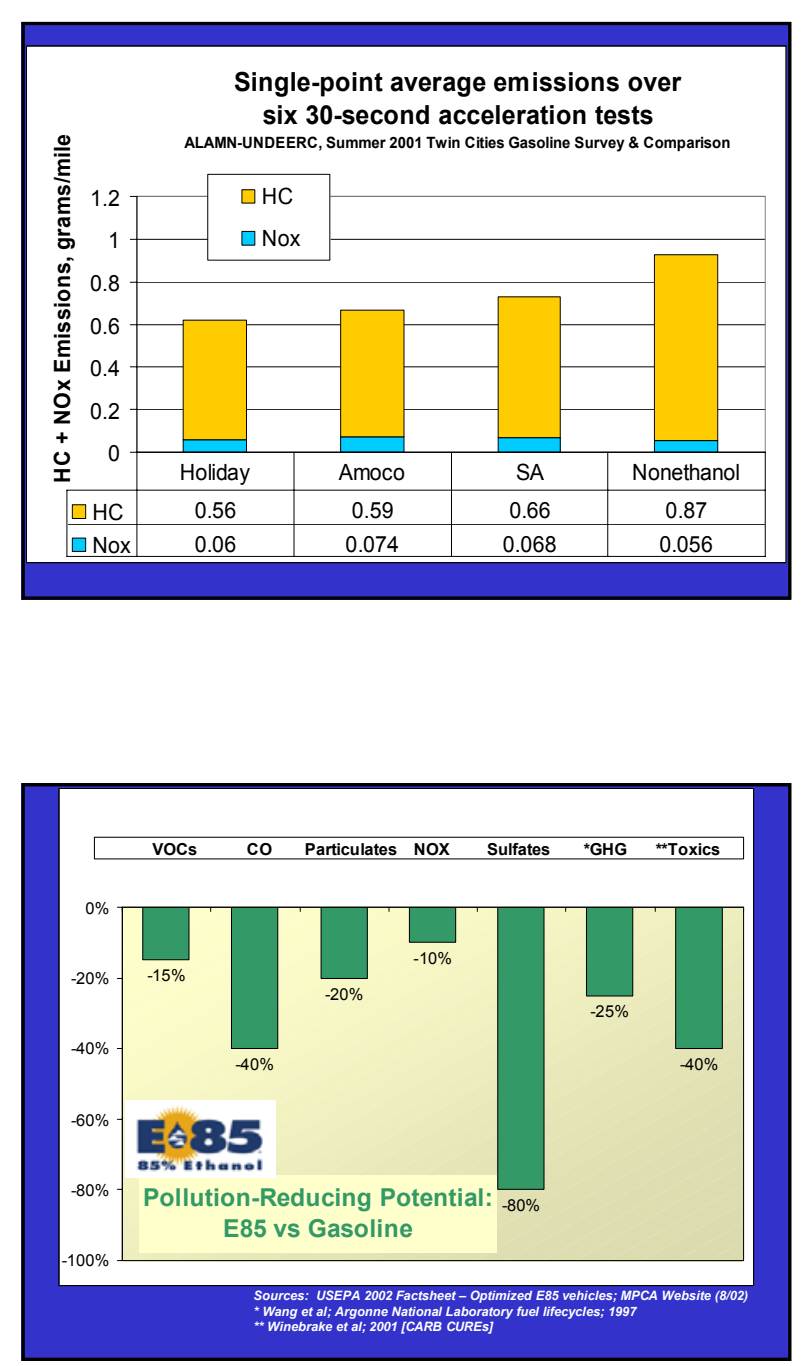

01 [CARB CURES]

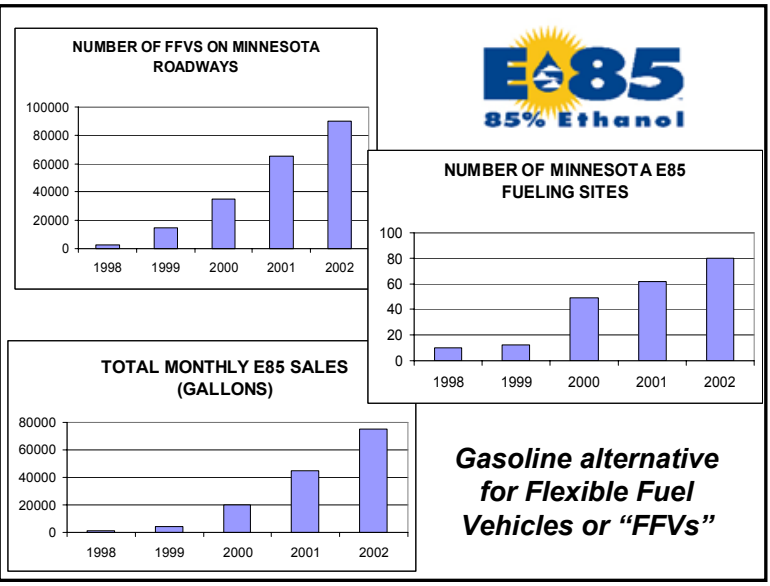



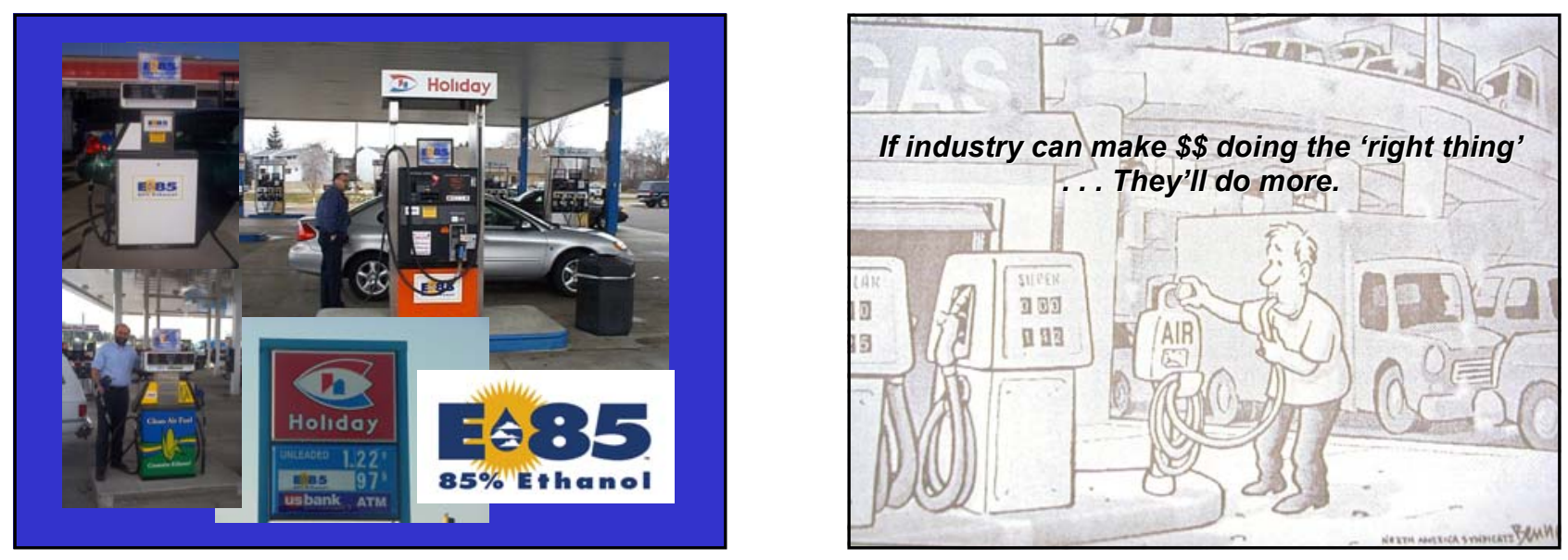
Welcoming Speech

Ethanol in California workshop

April 14, 2003

8:30 a.m.

Embassy Suites Hotel, Sacramento

- It is my pleasure to welcome you to the Ethanol in California Workshop.

- I would like to thank US Department of Energy, BBI International, the CEC and my staff for putting together a most informative agenda to highlight the opportunities and benefits of an agrifuels industry in California.

- I am pleased to have CDFA participate along with our sister agencies, the California Air Resources Board in CalEPA, the California Energy Commission and the California Department of Forestry and Fire Protection.

- As many of you know, California is the leading agricultural state in the Nation. It has been for more than 50 years.

- California farmers are the most diverse and innovative in the world. They have an ability to respond effectively and efficiently to new markets.

- California is the leading dairy state, and as such is the largest market for high protein corn residuals. It has been for nearly a decade.

- However, nearly every commodity we produce is suffering from record low market prices at the same time that inputs costs continue to rise and environmental regulatory pressures increase. 
- One of the primary reasons CDFA supports efforts to develop a California agrifuels industry is that it presents a significant opportunity for growers to diversify into new, profitable value-added products that provide many environmental and energy security benefits.

- We at CDFA also view fuel ethanol production as one tool in the technology toolbox that can assist growers in meeting future air quality and water quality regulatory challenges in an economically feasible and environmental beneficial manner.

- Early this year, California became the largest consumer of fuel ethanol in the United States as MTBE is successfully phased out of our gasoline. It is likely this market for "agrifuels" will continue to grow.

- Yet, less than 10 million gallons of the 600 million gallons of fuel ethanol currently required is produced in the state. As I see it, there now exists a great opportunity for an agriculture based industry to develop in California to meet these new market demands. This afternoon we will hear from several project proponents who expect to take advantage of the opportunity.

- The key to successful development of an in-state production industry is a positive business and investment climate based on reasonable market assurances. We at CDFA recognize this need.

- The potential benefits of an in-state fuel ethanol production industry are far-reaching. 
- First and foremost, the industry can provide valuable economic development and job creation especially in economically depressed rural communities.

- Investments in ethanol production provide huge local economic development benefits in plant construction, operation and maintenance, transportation, farm production and support services.

- Every dollar spent on imported gasoline supplies is a dollar that leaves the California economy. Every dollar spent on fuel ethanol produced in California is a dollar that recycles through the economy two or three times.

- California ethanol production will add to energy supplies while replacing fossil fuels and reducing greenhouse gases.

- The industry can supply a significant portion of the State's fuel needs, providing a price buffer to imported gasoline blend-stocks.

- Ethanol can and does provide significant environmental benefits, and is the only renewable transportation fuel currently available for light duty vehicles.

- Developing an ethanol production industry based on conventional feedstocks such as corn, sugar cane, sweet sorghum, cheese whey and other sugar and starch residuals will provide the economic and technical foundation to transition to cellulose based ethanol.

- Cellulose containing agricultural and forestry residues, and urban paper, wood and green waste can be converted to fuel ethanol resulting in conservation of landfill space, reduction of catastrophic wildfire potential and reduction of open field agricultural burning. 
- Finally, I want to emphasize the concept of ethanol as flexible fuel. Many of us are aware of the ability to use $85 \%$ ethanol (E-85) in hundreds of thousands of flexible fuel vehicles produced by the major automobile manufacturers. In fact, we at CDFA are developing an opportunity to refuel our fleet of more than $100 \mathrm{FFVs}$ on E-85 in partnership with InterState Oil Company and a US Department of Energy grant administered by the National Ethanol Vehicle Coalition.

- We are well aware of the current major market in reformulated gasoline. We should also explore opportunities to use ethanol in other applications including but not limited to $10 \%$ gasoline blends, hybrid FFVs, heavy duty engine applications and as a fuel cell feedstock.

- Thank you for your attention, and I look forward to supporting efforts to make a vibrant fuel ethanol production industry a reality in California. 


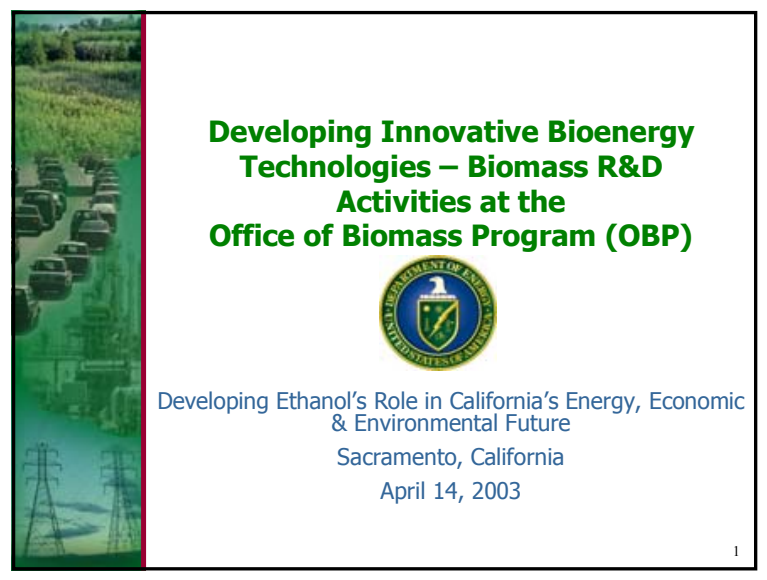

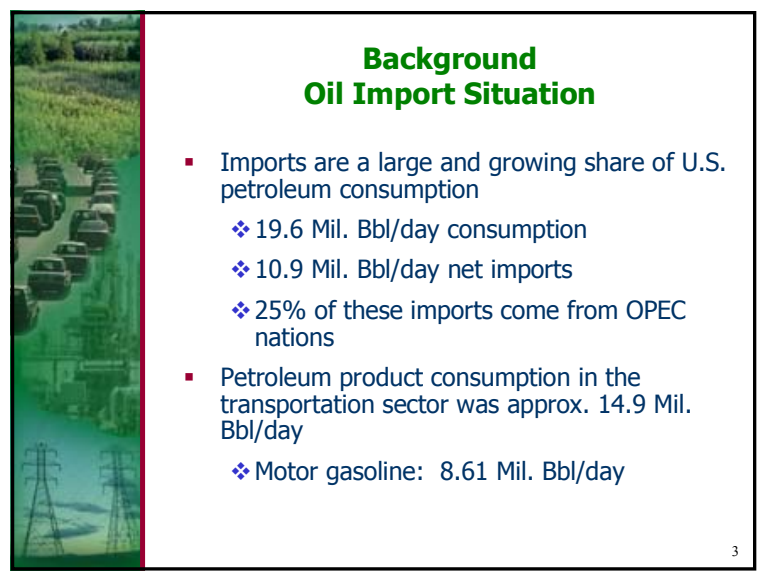

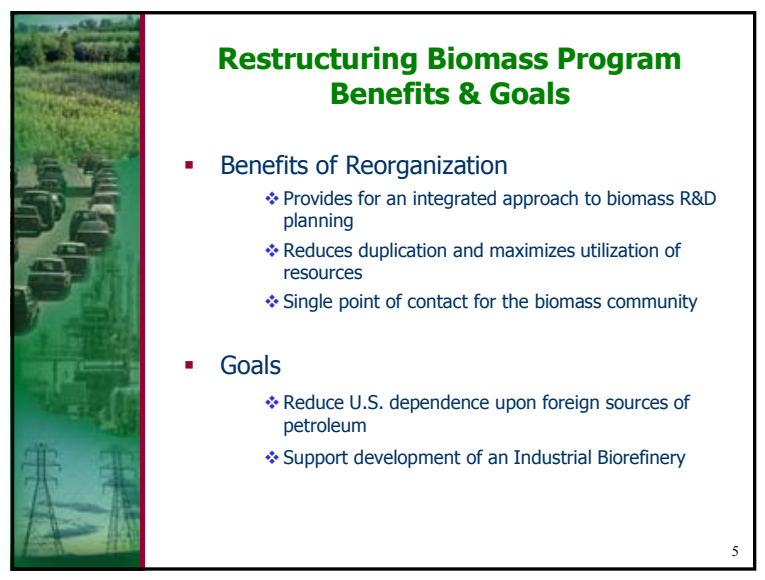

\begin{tabular}{|l|l|}
\multicolumn{1}{c|}{ Topics } \\
- Background \\
- Restructuring Biomass Program \\
- Biorefinery Concept \\
- Ongoing R\&D in Bioproducts \\
- Key Technical Barriers \\
- Challenges \\
- Opportunities \\
- Find Out More
\end{tabular}
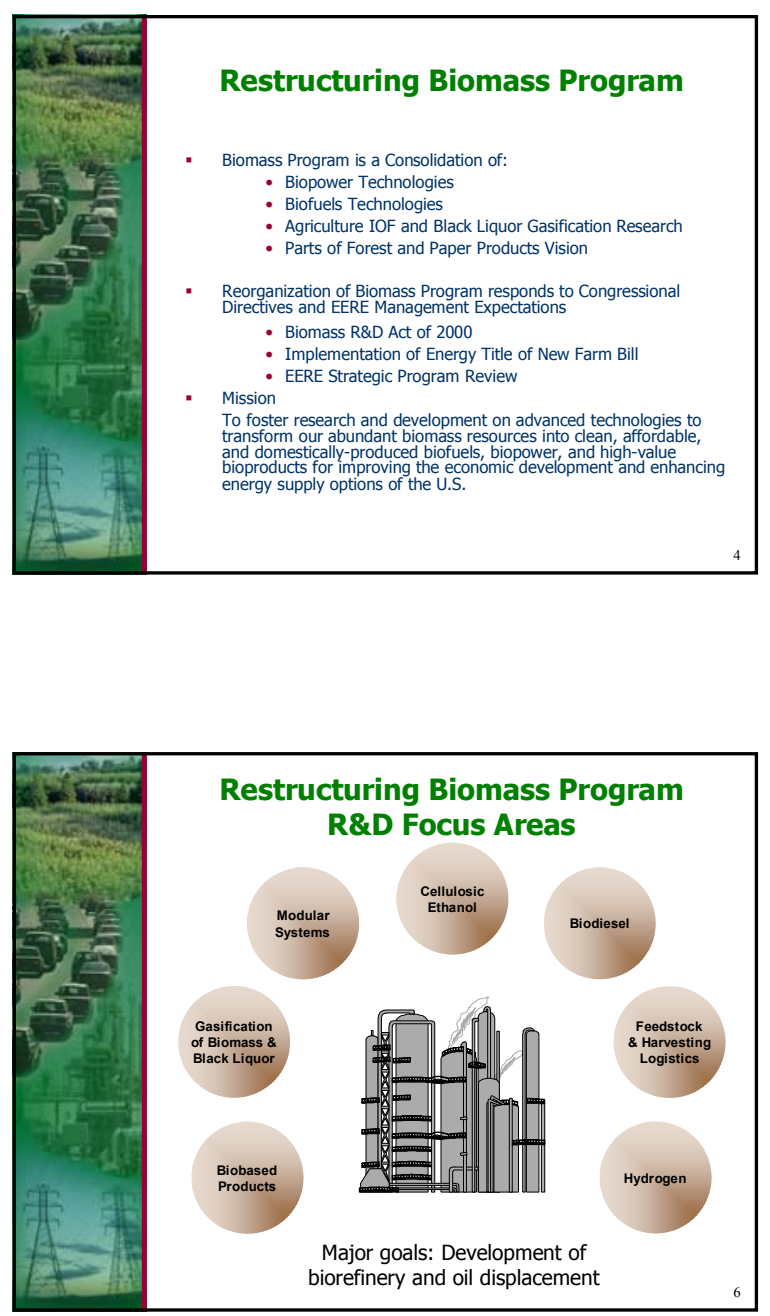

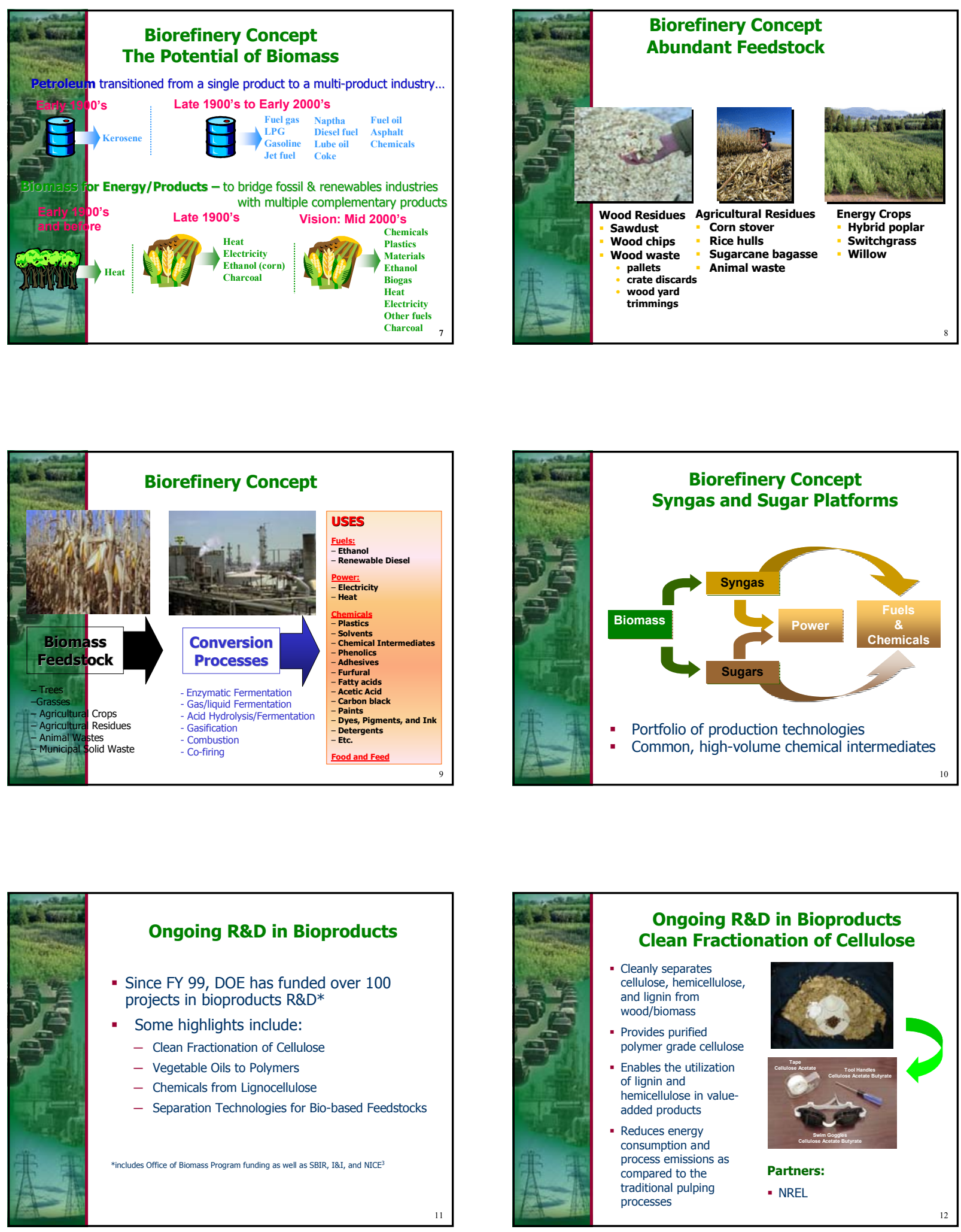

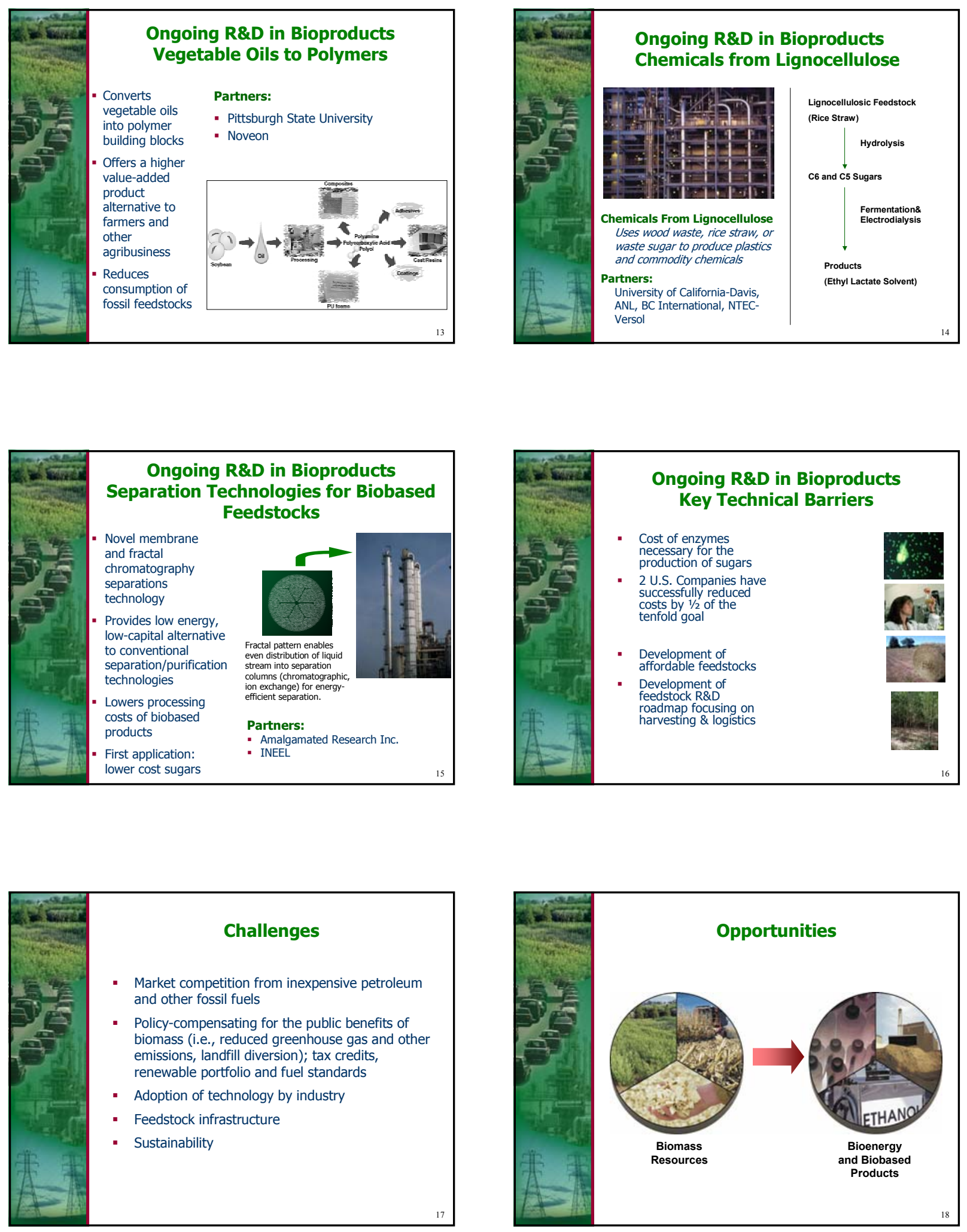


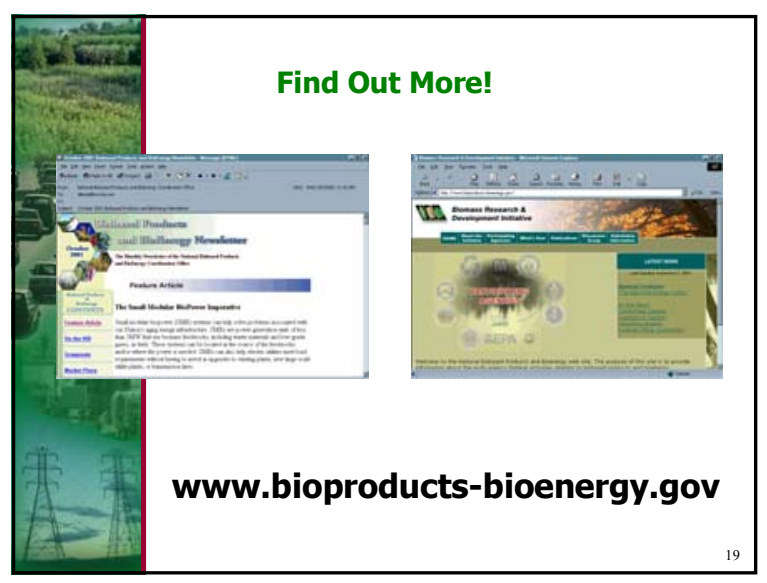

\begin{tabular}{ll|}
\multicolumn{1}{c|}{ Contact Information } \\
Kim Penfold \\
DOE Seattle Regional Office \\
Phone: (206) 553-2166 \\
Fax: (206) 553-2200 \\
Email: kim.penfold@ee.doe.gov \\
\end{tabular}




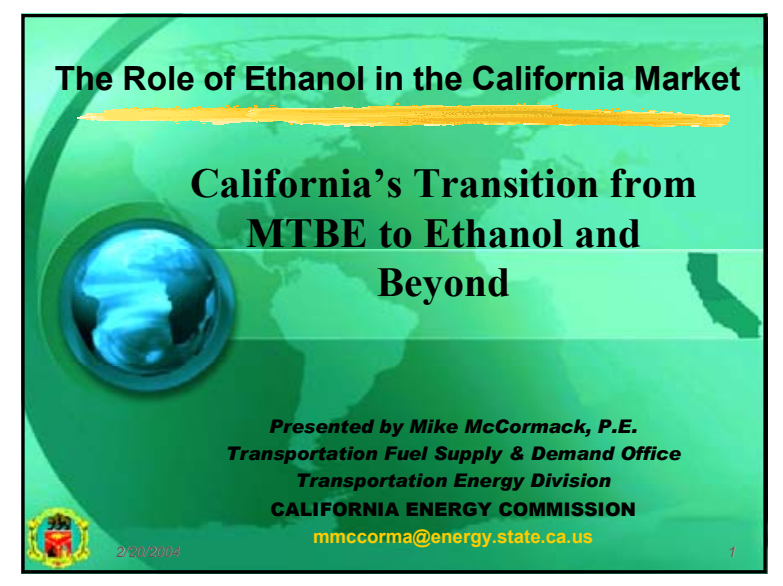

Background - MTBE Use

Required seasonal use beginning 1992

Federal winter oxygenated fuels program

Designed to reduce carbon monoxide emissions

Most refiners selected MTBE- some use of ethanol

MTBE blended at about 11 percent of gasoline volume in California

Mandated year-round use in 1995 \& 1996

Federal reformulated gasoline (RFG) program to control emissions of toxics and pollutants that contribute to the formation of photochemical smog

Federal law requires minimum use of oxygenates in all RFG regions ( 2 percent by weight)

California reformulated gasoline regulations permit discretionary use, but federal mandate applies to 80 percent of State

\section{Topics}

Background - History of MTBE use in California

Gasoline Demand and Supply/oxygenate use

Refinery Announcements / Phase-out schedule

Ethanol Demand Scenarios 2004 and 2012

Ethanol Supplies - California survey

Summary and Conclusions
Background-Gasoline Demand and Supply

California demand is nearly 12 percent of United States gasoline demand

Gasoline demand in California during 2003 estimated to be in the range of 15.6 to 16 billion gallons

13 refineries located in California produce the majority of gasoline for California, Nevada and Arizona (about 60 percent)

Imports of gasoline and blending components increase each year, while refinery capacity remains relatively flat (annual growth rate of 0.5 percent)

Demand expected to increase between 1.6 and 3 percent per year in the future (i.e., 250 to 480 million gallons in 2004)

\section{Fuel oxygenate use}

Types and quantities of fuel oxygenates

MTBE has been the oxygenate of choice

Blending properties like hydrocarbons

CaRFG (with MTBE) can be shipped by pipeline to gasoline terminals

1.4 billion gallons blended in California gasol Blending concentration of over 9 volume percent for entire gasoline pool

Ethanol use limited, but a long history in California

Blending properties less like hydrocarbons

alcohols cause gasoline vapor pressure to increase more than ethers

water absorption/phase separation - must dry-out storage tanks and pipelines

California's common carrier pipeline company does not plan to ship gasoline

anol at this time

million gallons blended during 2002

ConocoPhillips was first company to use ethanol in California
Public Announcements - Early MTBE Phase-out

ConocoPhillips - "76" - "Circle K"

British Petroleum - "ARCO"

Shell Oil - "Shell" - "Texaco"

ExxonMobil - "Exxon"

ChevronTexaco: MTBE-free in Southern California beginning January 2003; MTBE-free in Northern California later this year

1] Tesoro: Announced compliance by December 2003 and ability to market both MTBE-based (CaRFG"2") and ethanol-based (CaRFG"3") reformulated gasoline 

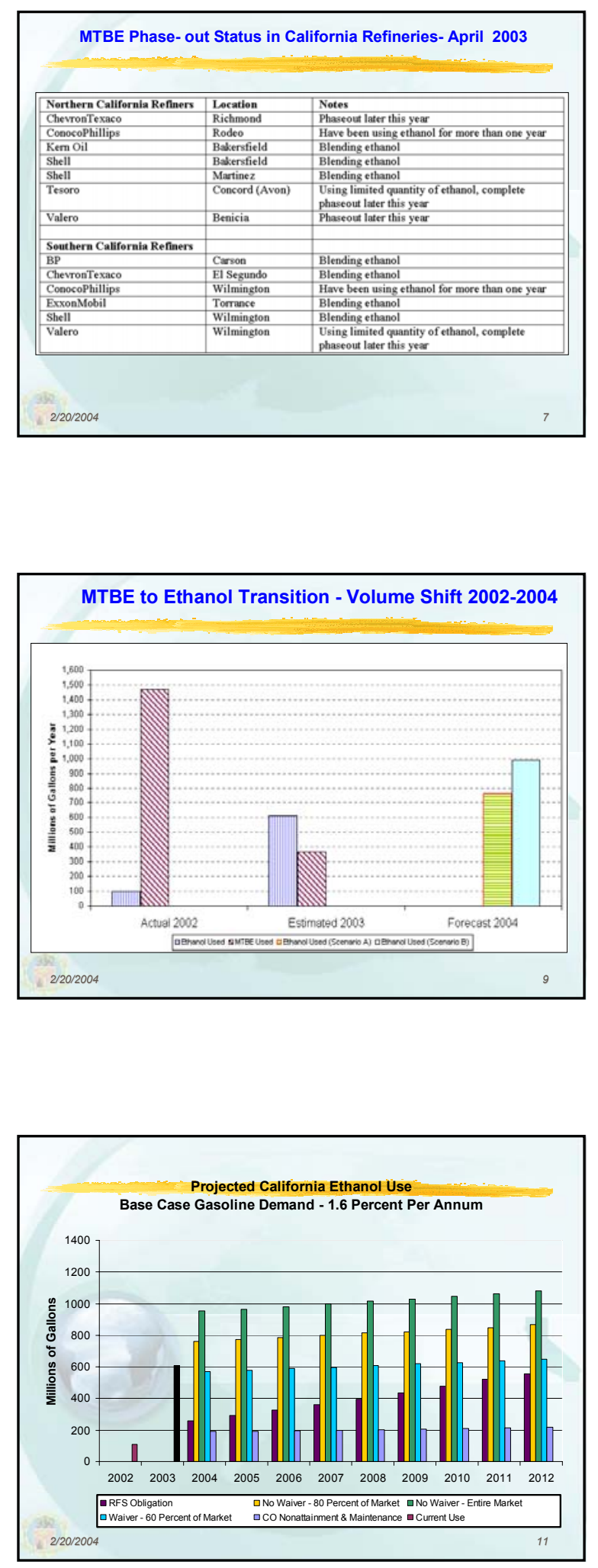

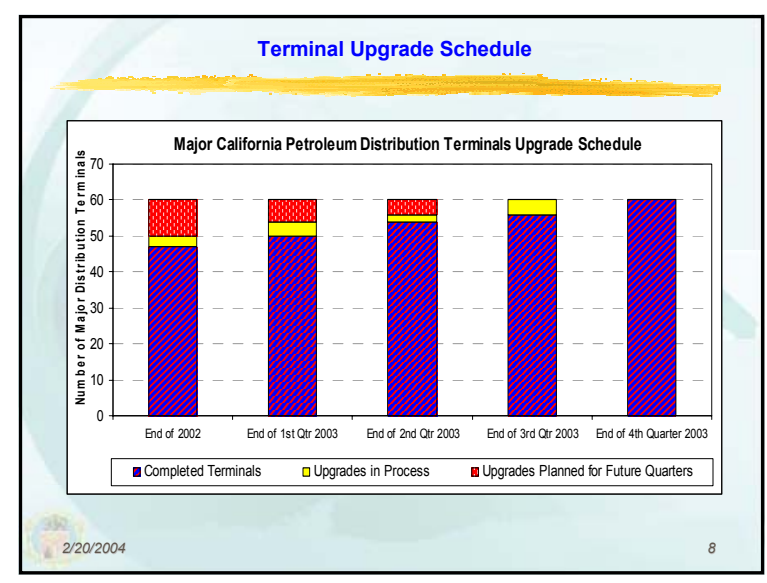

\begin{tabular}{|l|}
\hline $\begin{array}{c}\text { Summary of MTBE phase-out and CaRFG3 } \\
\text { Implementation }\end{array}$ \\
Progressing without significant problems or issues \\
Most terminals are able to store, blend, and distribute CaRFG3 with ethanol \\
I About $70 \%$ of California's gasoline contains ethanol (April 2003) \\
50 completed terminals, 4 upgrades in progress, 6 upgrades scheduled \\
Ethanol supplies now routinely delivered to all 50 (of 60 ) terminals \\
March switch to summer grade gasoline went relatively smoothly \\
Refiners were able to make low volatility CARBOB for ethanol blending \\
CARBOB moved through the Kinder Morgan Pipeline system to \\
terminals without major issues \\
Report to Governor on causes of recent gasoline price spikes completed in \\
March \\
2/20/2004
\end{tabular}

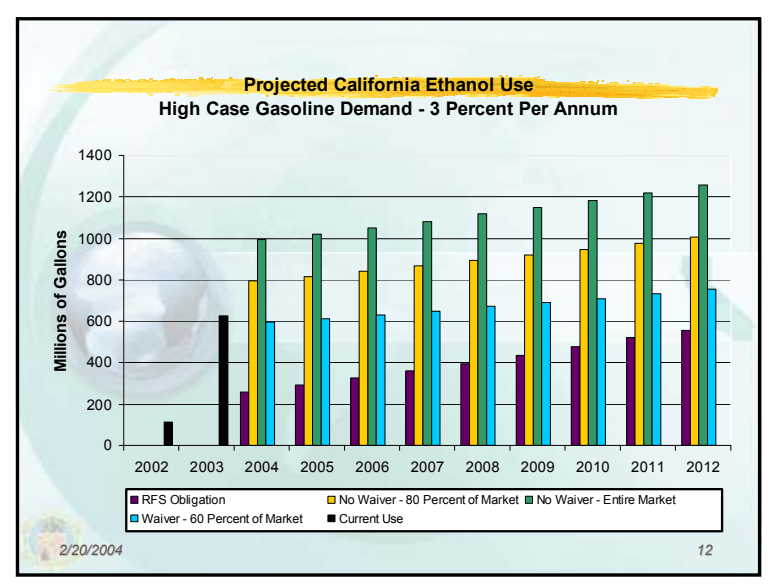




\section{Ethanol Demand Scenarios - CaRFG blending 2004-2012}

Ethanol demand follows gasoline demand growth (6\% blending case)

1.6 to $3 \%$ per annum growth to 2012 assumed

760 to 990 million gallons in 2004 (high certainty)

560 to 1258 million gallons in 2012 (less certain)

low end is RFS obligation - CAA oxy requirement waived

lower yet if RFS + regional RFS credit trading allowed

lowest demand as air quality $\mathrm{CO}$ maintenance measure in South

Coast Air Basin $=216 \mathrm{million}$ gal $/ \mathrm{yr}$

Future ethanol demand at 7.7 or $10 \%$ blending

710 to 1600 million gals in $2012(7.7 \%$ blending $)$

920 to 2100 million gals in 2012 ( $10 \%$ blending)

$\mathrm{AQ}$ maintenance volume(lowest case) - 360 million gal/yr

Currently limited by vehicle NOx emission considerations

Would require new CARBOB formulations/no emissions impacts

Multiple CARBOBs could be difficult to distribute; probably just one as 2/20/2004exists today

\section{EthanoI Demand Scenarios - E-85 use} 2004-2012

Fleet of E-85 Flexible fuel vehicles (FFVs) in California is growing 175,000 FFVs identified in DMV database - April 2003

Growth rate of 32,500 vehicles per year since 1999

$64 \%$ general public, $13 \%$ car rentals, $12.5 \%$ corporate, $5.6 \%$ government, $5.1 \%$ fleet leasing

2004 ethanol demand scenario

180 million gal/yr (full time use)

90 million gal/yr ( $1 / 2$ time use)

95 million gal/yr (fleets only)

2012 ethanol demand scenario(flat vehicle growth rate $-32,500 \mathrm{veh} / \mathrm{yr}$ ) 415 million gal/yr (full time use)

207 million gal/yr ( $1 / 2$ time use)

221 million gal/yr (fleets only)

2012 scenario - FFVs comprise $1.8 \%$ of the 2012 fleet

more aggressive scenario - yields $5 \%$ FFVs in 2012 and potential demand of 1.2 billion, 600 and 640 million gal/yr

Assumes AMFA dual-fuel CAFÉ incentives retained beyond the 2008 model year

\section{Ethanol Demand Scenarios- Summary}

Two possible future markets - ethanol blending in CaRFG and E-85 for use in Flexible Fuel Vehicles

2003/2004 all ethanol for blending in CaRFG

760 to 990 Million gal/year (2004) .....quite certain

None to some $\mathrm{E}-85$ if $\mathrm{FFV}$ fleet fueling facilities become reality

Upper limit if all fleets installed fueling capability - 95 million gal/yr

2012 combined demand is less certain, but potentially large

Depends on the price of ethanol relative to gasoline, outcome of federal energy legislation (RFS), CAA oxygenate waiver process, outcome of sta policy and actions, potential growth in ethanol supplies (in-state, U.S. ns, fuel distribution segregation capabilities and other factors

Low end - 440 million gal/yr -220 million gal/yr E-85 fleets / 220 million gal/yr for AQ maintenance (wintertime $\mathrm{CO}$ in Couth Coast), RFS obligation Callonia avoided the (Wh regione credit trading

High end - 1.6 to 2.5 billion gal/yr - 1 to 1.5 billion gal/yr for CaRFG blending, $1.6 \mathrm{co} 2.5$ bilion
U.S. Ethanol Production Capacity Survey Update

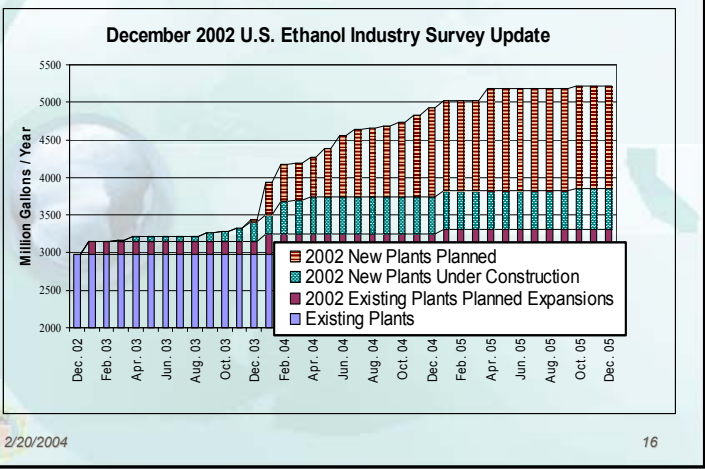

Summary and Conclusions
The phase-out of MTBE and its replacement with ethanol is
proceeding smoothly - $70 \%$ of California's gasoline now contains
ethanol
Terminal conversions to handle ethanol will be completed prior to
the December 31,2003 deadline for MTBE phase-out
Ethanol supplies are adequate to meet California's CaRFG3
blending needs in 2003 - staff will examine implications of the New
York and Connecticut MTBE phase-out plans, as well as a future
national MTBE ban
Future use of ethanol in California depends on many factors - some
of which were discussed today
Demand scenarios for 2012 indicate ethanol use in the range of 440
million to over 2 billion gallons per year
The population of E-85 Flexible Fuel Vehicles is growing and an
opportunity for supplying E-85 exists
2/20/2004




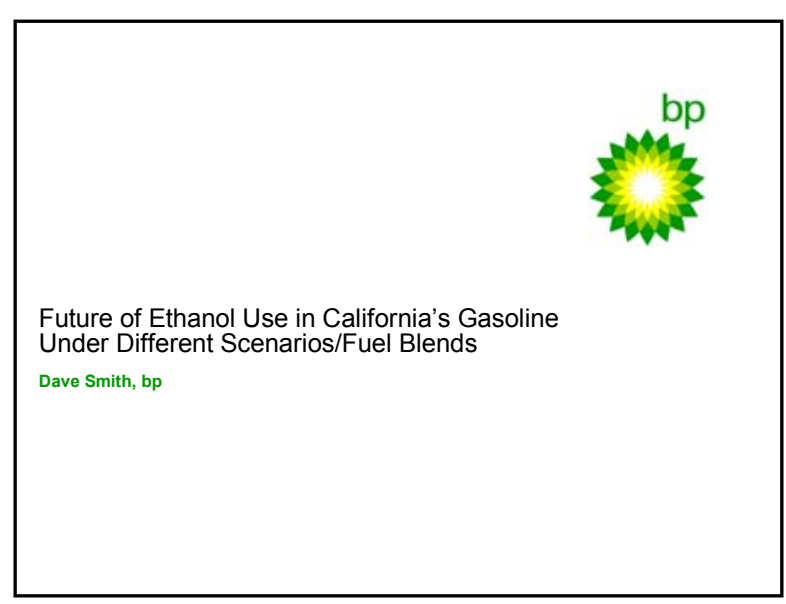

\section{Challenges with Current Transition}

- Ethanol Supply Contracts \& Logistics

- Major SC Refinery Turnaround Previously Scheduled

- Refinery and Terminal modifications

$$
\text { - S. Cal. Refinery }
$$$$
\text { - Proprietary Terminals }
$$

- Common Carrier Terminals

- Ca Retail Sites

- 1000+ ARCO Branded Service Stations

- Ca Summer RVP Season

- $80 \%$ of Cal. Gasoline must meet Federal RFG Oxy. Mandate

- CARB Phase 3 New Regulations

- New CARBOB Model

- EtOH Conc. Vs Emissions

- Unexpected Surprises

\begin{tabular}{l}
\hline May 2, 2002: Announced Early MTBE Phase-out \\
- MTBE Free - at Refinery - 1/1/03 Target \\
$\quad-$ MTBE Unit Shutdown Jan. 2 \\
- MTBE Out of Blender Jan. 3 \\
$-1^{\text {st }}$ CBOB into Proprietary P/L Jan 5-6 \\
$\quad-1^{\text {st } C B O B \text { into Kinder Morgan P/L Jan } 8}$ \\
$\quad-$ Arrive San Diego Jan 10 \\
- All Refinery production MTBE Free - late January \\
- All Terminals MTBE Free before March \\
- All Service Stations Expected MTBE Free before \\
April
\end{tabular}

\section{Ethanol Supply \& Logistics}

- Contracted with six ethanol suppliers by time of announcement

- No W. Coast Producers of ethanol

- Transportation costs may provide an opportunity for California

- Ethanol Storage Needs

- Converted existing tankage to ethanol storage

- Ethanol began arriving in late 2002

- Ethanol Terminal Strategy - So. Cal

- Third party marine terminal is the main Southern terminal. Extensive work required - rail, rack, tanks.

- San Diego: Will be supplied by truck from LA until rai

modifications are completed. Will have ability to load out by truck.

- S.Cal. Proprietary Terminals - In by truck. Will have ability to load out by truck as a contingency.

\section{Ethanol Terminal Strategy - NoCal}

- Sacramento:

- In by truck or rail, out by truck. Issues with the city delayed rail work supply by truck until resolved.

- Richmond \& Stockton:

- In by rail, out by truck.

- Kinder Morgan Terminals (Chico, Brisbane, San Jose, Fresno)

- Supplied from BP Terminals

\section{S. California Refinery Turn-Around}

- T/A started early January

- 6 Major Refinery units impacted

- Major gasoline producing units included

- Longest Unit T/A - 49 days

- Significant reduction in crude throughput and production 


\section{Supply Plans - Jan-Mar 2003}

- Supply Options during the turnaround \& Phaseout

- Maximize Carson Refinery production prior to T/A and Phaseout

- Component build plan in Nov-Dec

- Component import plan for Jan-Mar

- Other BP WC refinery to blend winter CARBOB

- Imported significant Barrels from BP refinery of Phase 2 CARBOB

- Storage Tank Challenges

- No significant problem at LA import facility - CARB assisted - CARBOB purchases

- Local

- Imports

- Voluntarily Reported Production and Imports to CEC
Shipping

- Products moved with Jones Act ships:

- Blend stocks and Products from PNW to LA

- Products to PNW and Canada

- Exports from Carson

- Gasoline from LA to Bay

- Component imports to LA from GC

- In addition, import/export gasoline and components and ship exports on foreign flag ships to other countries

\section{Future Use of Ethanol}

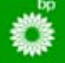

New infrastructure getting in Place for widespread use of Ethanol in California

- Experience with ethanol blending in California may effect future use.

- Pipelines only taking $\mathrm{CBOB}$ that requires $5.7 \mathrm{vol} . \% \mathrm{EtOH}$

- Provides fungibility

- Federal Renewable Oxygenate is adopted \& Fed. RFG Oxy Mandate Eliminated

- National refiners would likely maximize ethanol use close to the EtOH sources

- N. Cal. Refiners have produced non-oxygenated CARB gasoline

- No significant impact on volumes

- Ethanol use would continue as a blending component.

- Winter Oxygenate Season Eliminated in S. California

- Ethanol use would continue as a blending component.

- Similar experience in PNW.

- San Diego Could be Reclassified to Ozone Attainment

\section{Unexpected Challenges}

- Ethanol Logistics - SD, LA, SF

- Permitting Concerns @ terminals

- San Diego Terminal EtOH Blending Equipment Failure

- Blending computer failed to add ethanol to $\mathrm{CBOB}$ in truck

- 60 Stations delivered non-oxygenated CBOB in $\sim 12 \mathrm{hrs}$.

- Over a week to fix all the stations

- Pumped out UST's

- Deliver properly oxygenated $\mathrm{CBOB}$

- Returning oxygenated $\mathrm{CBOB}$ to Terminals

\section{Oxygen Impact Within CARB Model \\ - CARB Phase 3 Predictive Model \\ - Modeled increase of ethanol from 2.0 wt.\% to 3.5 wt.\%: \\ - At 2.0 wt. \% - NOx PM results: $-0.4 \%$ \\ - At 3.5 wt. $\%$ - NOx PM results: $+4.6 \%$ \\ - To accommodate NOx increase the following changes would needed to be made: \\ - Sulfur reduced by $15 \mathrm{ppm}$ (Compared to a ref. standard of $20 \mathrm{ppm}$ ) AND \\ - Olefins reduced by 7 vol. \% (Compared to a ref. standard of 6 vol.\%) \\ - Fungibility a major concern for varying ethanol concentration}

\section{Other EtOH Scenarios}

- Summer-time ethanol blending just beginning

- Increased imports of blend stocks \& finished products

- Low-RVP CARBOB reduces production volumes

- Drivability Index still an outstanding issue

- Impact of EtOH on Groundwater contamination may be an issue - whether real or otherwise.

- Results of ARB's EtOH permeation study could be an important factor for future use.

- Unexpected events...... 


\section{DAIMLERCHRYSLER}

\section{California Ethanol Workshop}

Gerald A. Esper, Senior Manager

Product Fuel Economy Planning

DaimlerChrysler Corporation

April 14, 2003

\section{Ready, Fire, Aim}

- Clear statement of the objective is critical:

$-\mathrm{CO}_{2}$ emission reductions?

- Independence from foreign oil?

- Agricultural policy?

- Replacement of petroleum as it is depleted worldwide?

- The target needs to be clearly defined, scientifically based, and achievable:

- Stabilize atmospheric $\mathrm{CO}_{2}$ at 500ppm? Preindustrial levels?

- Reduce U.S. imports to $40 \%$ ? ...20\%? ...0\%?

- Appropriate strategies, including transportation technologies, can then be appropriately judged.

\section{With Clear Goals, Engineers Will Deliver}

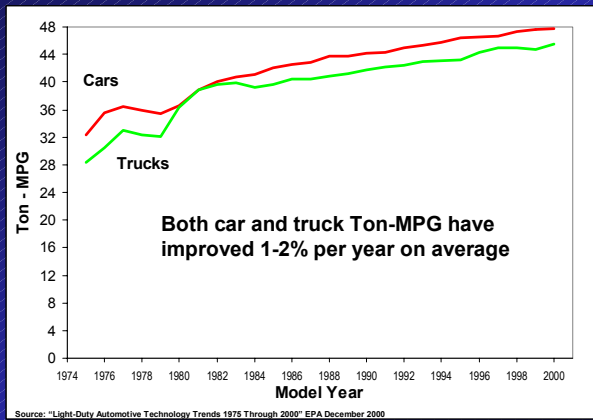

Large Car Utility and Performance at Sub-Compact Car Fuel Economy Levels

1978 Dodge Omni
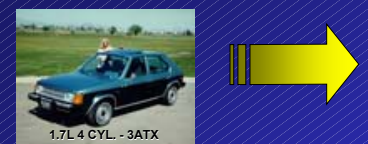

2003 Chrysler Concorde

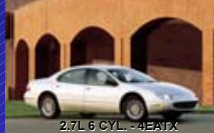

- Increased safety content (air bags, energy absorption..) - Emissions reduced 95\% (EPA75 to NLEV)

- Increased interior volume by $21 \%$

- Improved unadjusted combined fuel economy (Omni 26.2 MPG vs. Concorde 28.4 MPG)
Near-, Mid-, and Long-Term Technologies

- Vehicle Fuel Economy Technologies

- Near-term are generally incremental improvements on existing internal combustion engines, including diesels.

- Mid-term technologies deploy existing ICE technologies in new contexts the most publicized of these being hybrids.

- Alternative fuels, including ethanol, and bio-diesel present both short-, and midterm opportunities to reduce petroleum usage.

- Long-term technologies contemplate entirely new approaches to motive power - Electric Vehicles, Fuel Cells, the "Hydrogen Economy.

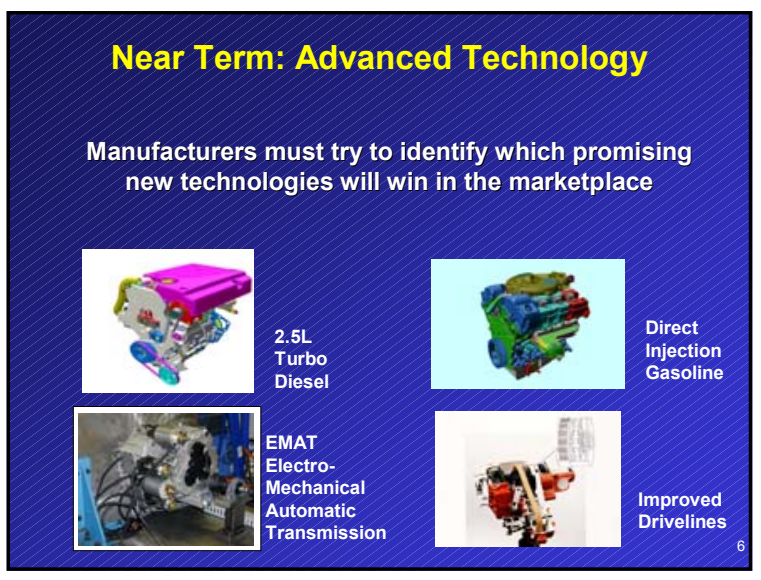




\section{Diesel Benefits and Obstacles}

- Modern diesel engines are very popular in Europe

- Diesels in the U.S. face serious challenges due to extremely strict NOx standards and poor U.S. fuel quality.

- This is a good example of conflicting societal goals: - Fuel economy vs. NOx reductions?

- A fundamental question, beyond fuel economy, and emissions, is: "Will the American public embrace the diesel?" Can we build a business case for volume production of diesel-powered light duty vehicles?

\section{DaimlerChrysler Advanced Diesel}

Jeep Liberty Diesel

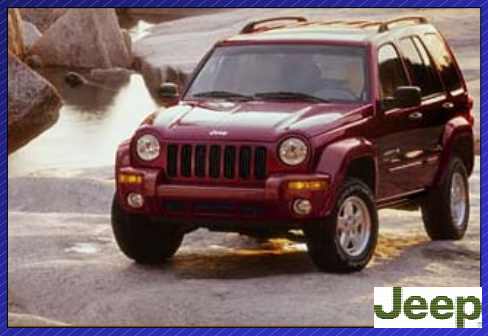

\section{Jeep Liberty Market Test}

- DaimlerChrysler will conduct a market test introduction of the Jeep Liberty with a 2.8L, 4cylinder diesel with high pressure, electronically controlled, common rail direct fuel injection.

- The vehicle is expected to achieve about 25$30 \%$ better fuel economy than a comparablyperforming 3.7L V-6 gasoline engine.

- The emissions performance is not yet finalized, but we will meet the EPA Tier 2 standards.

\section{Bio-Fuels (E-85)}

- DaimlerChrysler is a leader in the E-85 market: - About 3 million E-85 capable vehicles (FFVs) in operation, 1 million of those were produced by DaimlerChrysler.

- All DaimlerChrysler FFVs are "50 State" vehicles.

- The E-85 fuel infrastructure has not yet materialized.

- If these 3 million vehicles operated on E-85, over a billion gallons of gasoline could be saved per year, and over 10 billion pounds of $\mathrm{CO}_{2}$ emissions could be avoided.

- Now is not the time to abandon this program, but to strengthen it, and add additional incentives for the production and distribution of E-85.

- We expect NHTSA to extend the FFV CAFE credit program through the $2008 \mathrm{MY}$.

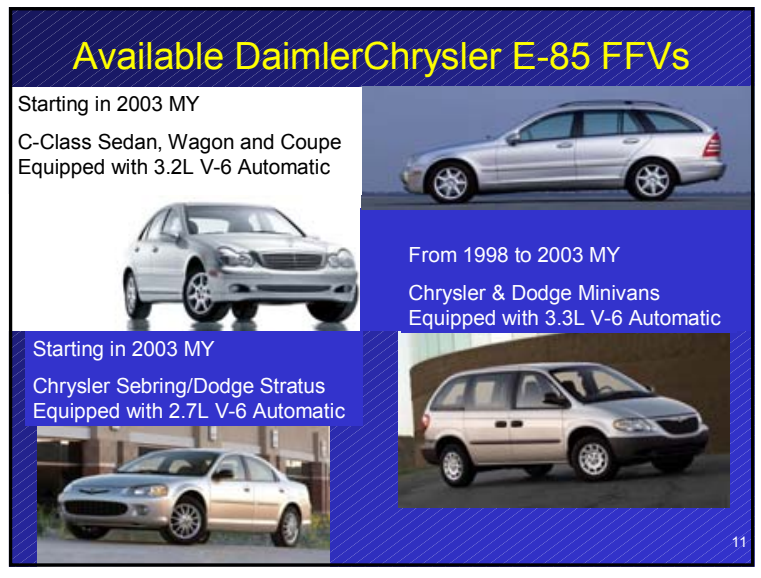

\section{Bio-Fuels (Bio-diesel)}

- Currently, DaimlerChrysler diesel vehicles are warranted for operation on bio-diesel only up to B-5 (5\% FAME in conventional diesel fuel).

- Given a stronger ASTM specification for B-20, and incentives for production of B-20, we could consider upgrading of engine materials to tolerate a higher level of bio-diesel.

- All bio-fuels should be subject to a rigorous life cycle analysis, to ensure that the programs are not just converting petroleum to a different liquid fuel, while incurring great costs to the taxpayer. 


\section{Ethanol and Diesel Fuel Don't Mix}

- DaimlerChrysler is very concerned about proposals to blend ethanol into diesel fuel.

- Even very small percentages of ethanol in diesel fuel lowers the flashpoint of the fuel mixture.

- This could create a flammable mixture in the fuel tank and presents a very serious safety concern.

- We do not support blending of ethanol with diesel fuel.

- Ethanol may have a role to play as the alcohol feedstock for the esterification of bio-diesel (Fatty Acid Ethyl Ester instead of Methyl Ester)
Medium Term: DaimlerChrysler HEVs

Dodge Ram Contractor Special

- Integrated starter-generator hybrid powertrain

- Achieves up to $10 \%$ better fuel economy

- Converts to a clean electric generator when parked

- A complete work-site or household can be powered from the electric outlet box
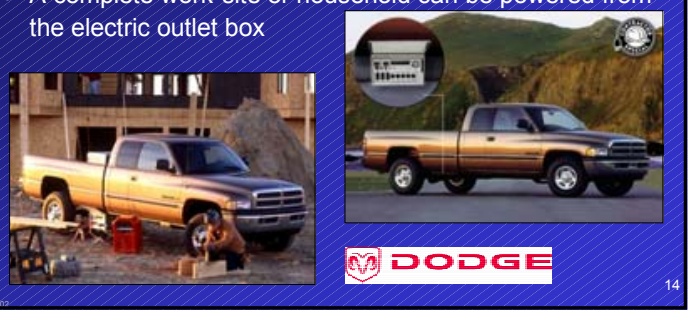

\section{Commercially Based Iactical Iruck - ComBaTT}

- Hybrid Electric Vehicle for the U.S. Military

- 4WD, 5.9 L Turbo-diesel, with integrated 35kW electric Traction Motor Generator provides up to 20 kW @ $60 \mathrm{~Hz} \mathrm{AC}$

Traction Assist, Regenerative Braking, Silent AC Power Generation, Improved Fue Economy, Enhanced off-Road and Structural Features

- Limited Range of "Stealth" operation on electric power

- Meets the DoD strategic target of utilization of a single battlefield fuel

- A positive business case exists, at least for limited production

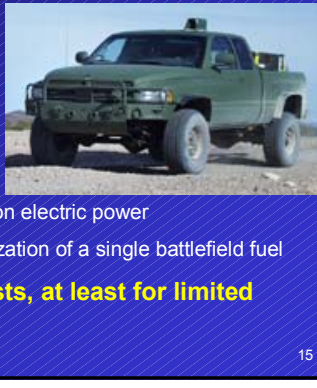

The biggest question regarding fuel cell vehicles is not the fuel cell, but the fuel

- Fuel Cells run on hydrogen.

- Choosing the source of the hydrogen will require a balance between distribution, on-board storage, and on-board processing.

- Several hydrogen sources have been evaluated:

- Pressurized or liquefied hydrogen stored on-board

- Methanol for on-board reforming

- Gasoline for on-board reforming

- DaimlerChrysler has shown that materials not normally considered as fuels can be used to generate hydrogen on board as demonstrated in the sodium borohydride powered Natrium Minivan.

\section{Long Term: Fuel Cell Vehicles (FCVs)}

- DaimlerChrysler has begun the deployment of 30 Fuel Cell powered city transit buses around the world.

- Beginning in 2003, DaimlerChrysler will market 60 A-Class based, compressed $\mathrm{H}_{2}$ "F-cell" vehicles.

- Volume production is at least ten years away, due to cost, complexity, and fuel infrastructure issues.

Compressed $\mathrm{H}_{2}$ Fuel Cell Bus

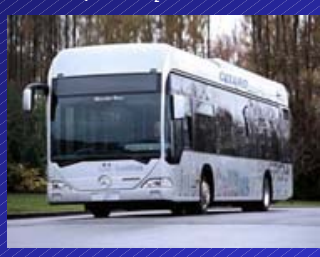

Cell Compressed $\mathrm{H}_{2}$ Fuel Cell Vehicle

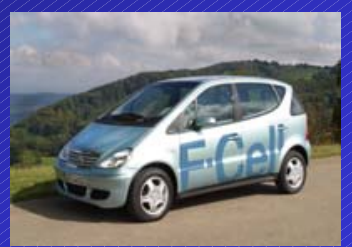

\section{Conclusions}

- Development of energy policy should be preceded by clear definition of objectives and targets.

- Energy objectives and targets will drive technology deployment.

- In the absence of clear objectives, resources will be wasted.

- Customer expectation cannot be ignored as a driving force in the automobile market.

- Enhanced use of bio-fuels can have a big impact on petroleum consumption in future vehicles, and also reduce petroleum usage in the existing fleet.

- The promise of technology is constrained by cost and conflicting requirements including regulatory standards. 


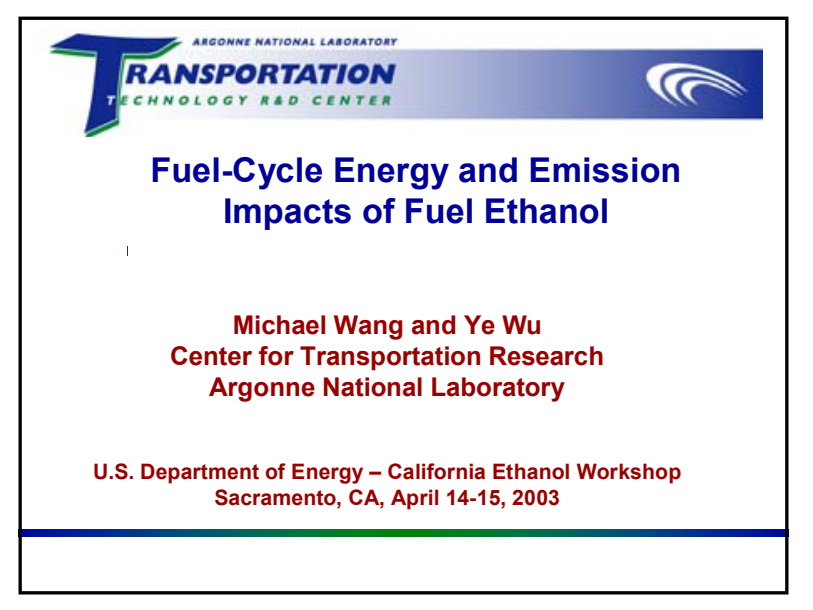

The GREET (Greenhouse gases,
use in Transportation) Model
Regulated Emissions, and Energy
$\square$ GREET includes emissions of greenhouse gases
- $\mathrm{CO}_{2}, \mathrm{CH}_{4}$, and $\mathrm{N}_{2} \mathrm{O}$
- $\mathrm{VOC}, \mathrm{CO}$, and $\mathrm{NO}_{\mathrm{x}}$ as optional GHGs
$\square$ GREET estimates emissions of five criteria pollutants
- VOC, CO, $\mathrm{NO}_{x}, \mathrm{PM}_{10}$, and $\mathrm{So}_{\mathrm{x}}$
- Total and urban emissions separately
GREET separates energy use into
- All energy sources
- Fossil fuels (petroleum, natural gas, and coal)
- Petroleum
The GREET model and Its documents are available at
http://greet.anl.gov; there are 790 registered GREET users

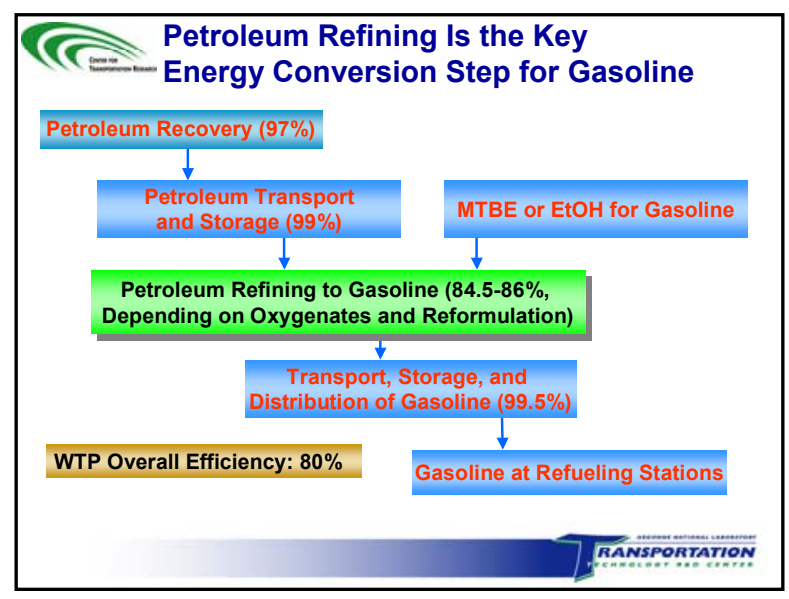

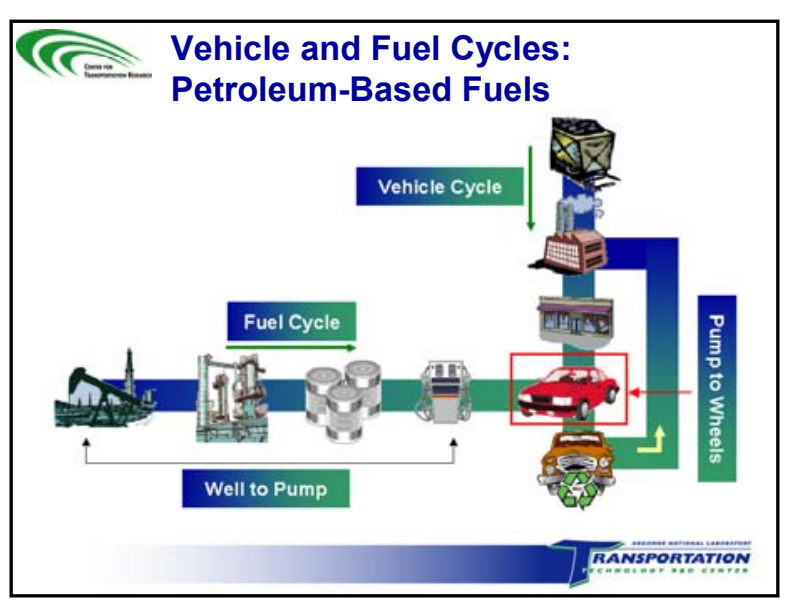

Energy Effects of Fuel Ethanol
Have Been Subject to Debate
Some studies, especially those completed between late
1970s and early 1990s, concluded negative energy
balance value of ethanol
Those past studies basically examined energy use of
producing ethanol
Though self evaluation of ethanol's energy balance is easy
to understand, it may not be useful to fully understand true
energy benefits of fuel ethanol
A more complete way is to compare fuel ethanol with the
fuels to be displaced by ethanol (i.e., gasoline)
The GREET model has been applied here to conduct a
comparative analysis between ethanol and gasoline

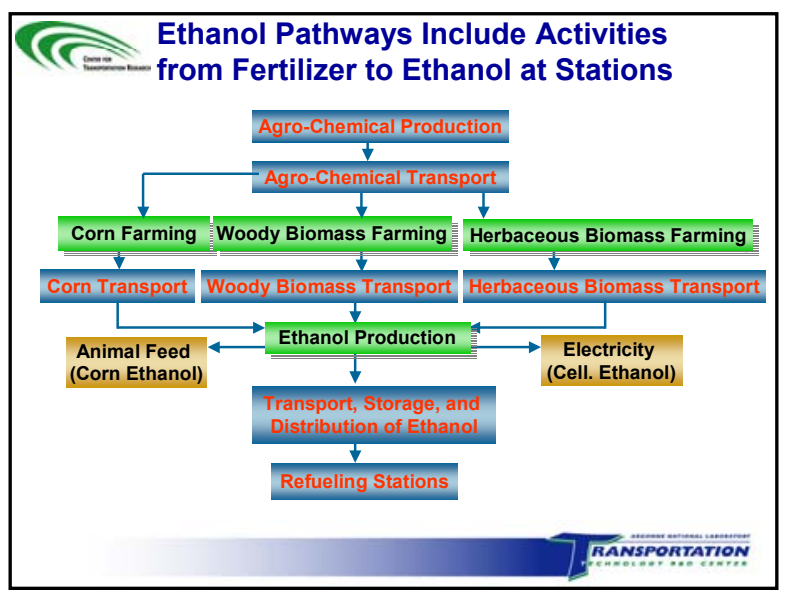



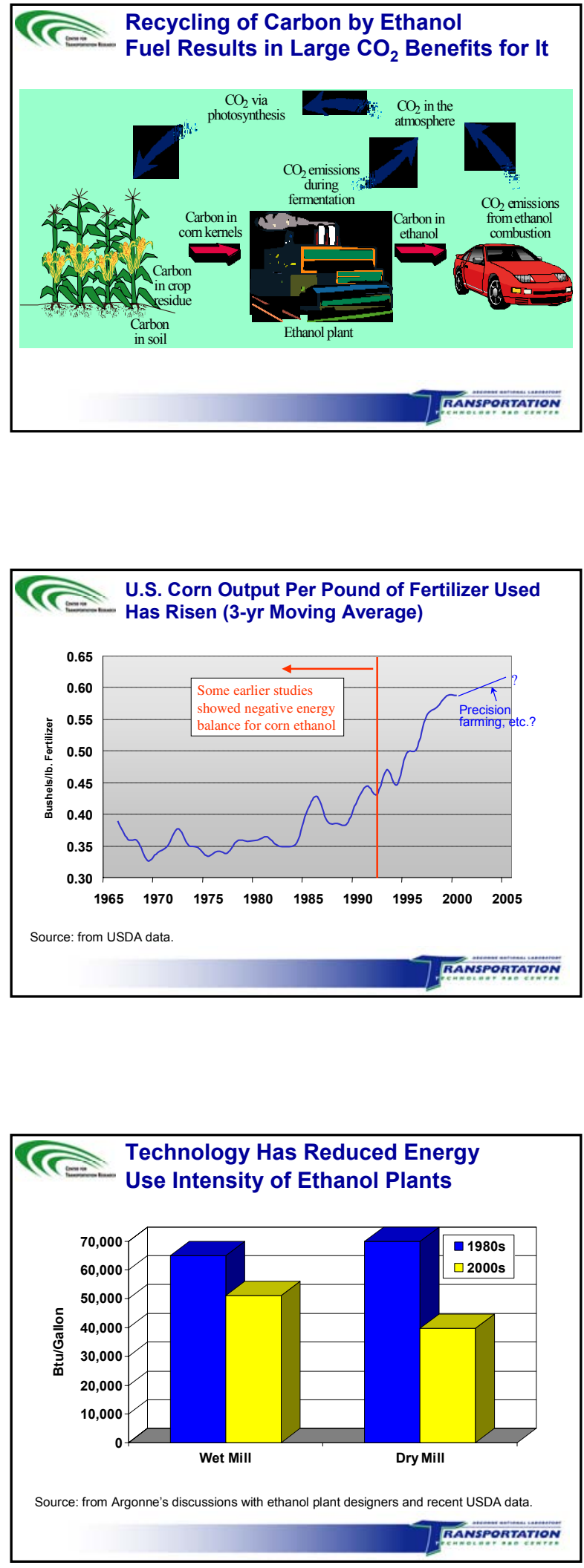
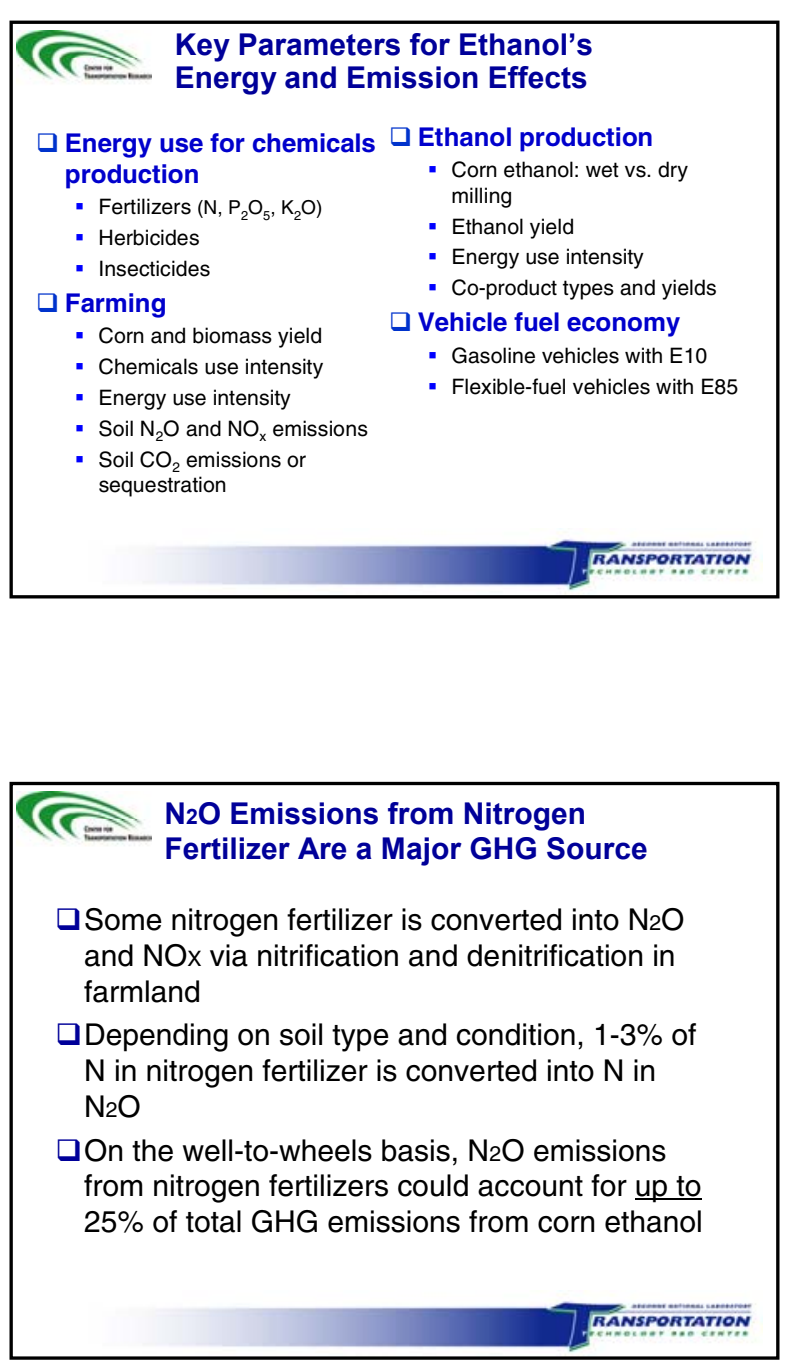

\begin{tabular}{|l|c|}
\hline \multicolumn{2}{|c|}{$\begin{array}{l}\text { Well-to-Gate Energy and } \\
\text { Emissions Allocated to Co-Products } \\
\text { (Animal Feed) Vary by Allocation Method }\end{array}$} \\
\begin{tabular}{|l|c|c|}
\hline Allocation Method & Wet milling & Dry milling \\
\hline Weight & $52 \%$ & $51 \%$ \\
\hline Energy content & $43 \%$ & $39 \%$ \\
\hline Process energy & $31 \%$ & $34 \%$ \\
\hline Market value & $30 \%$ & $24 \%$ \\
\hline Displacement & $\sim 16 \%$ & $\sim 20 \%$ \\
\hline \\
- Weight and energy methods no longer used \\
Some studies did not consider co-products at all
\end{tabular} \\
\hline
\end{tabular}



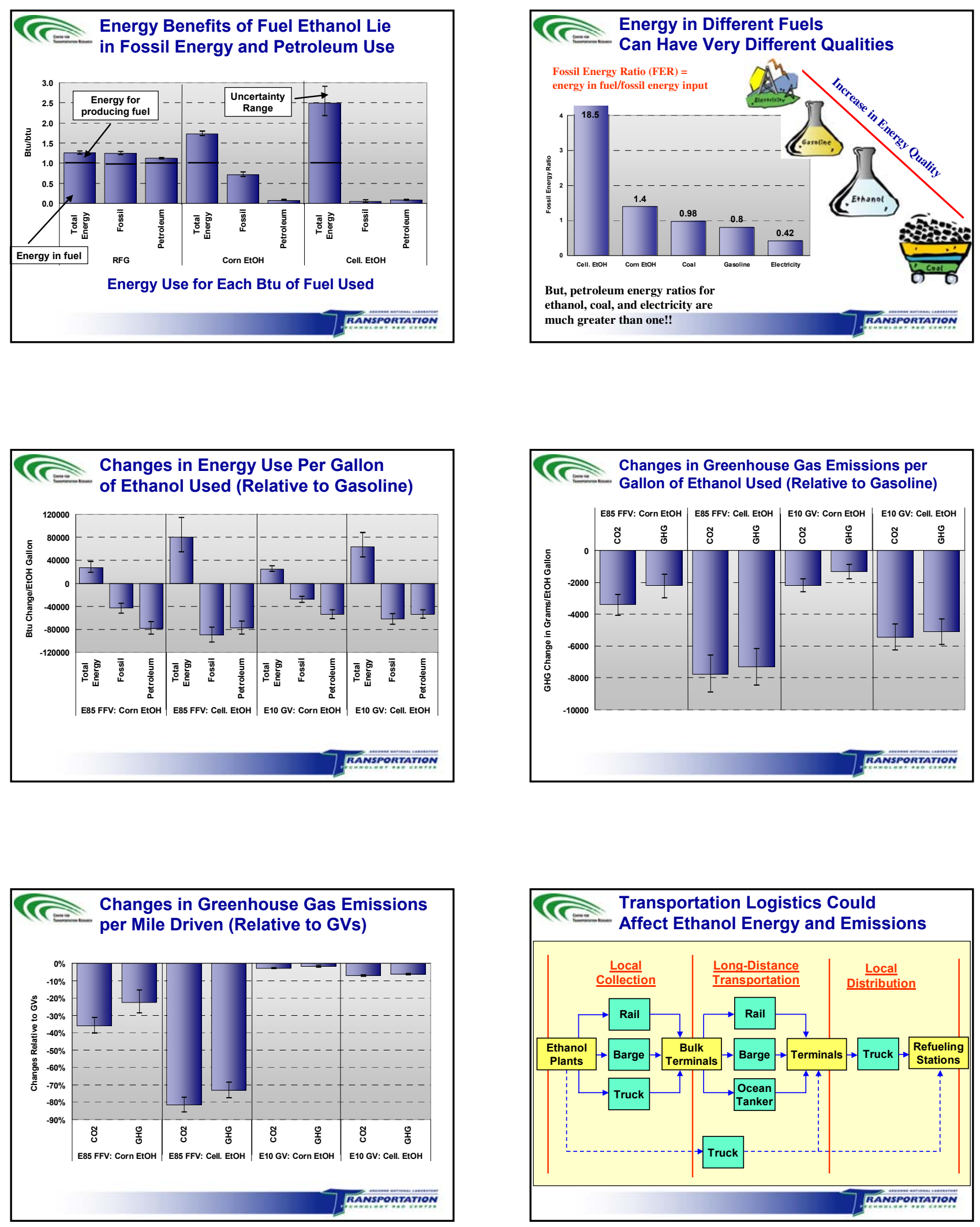

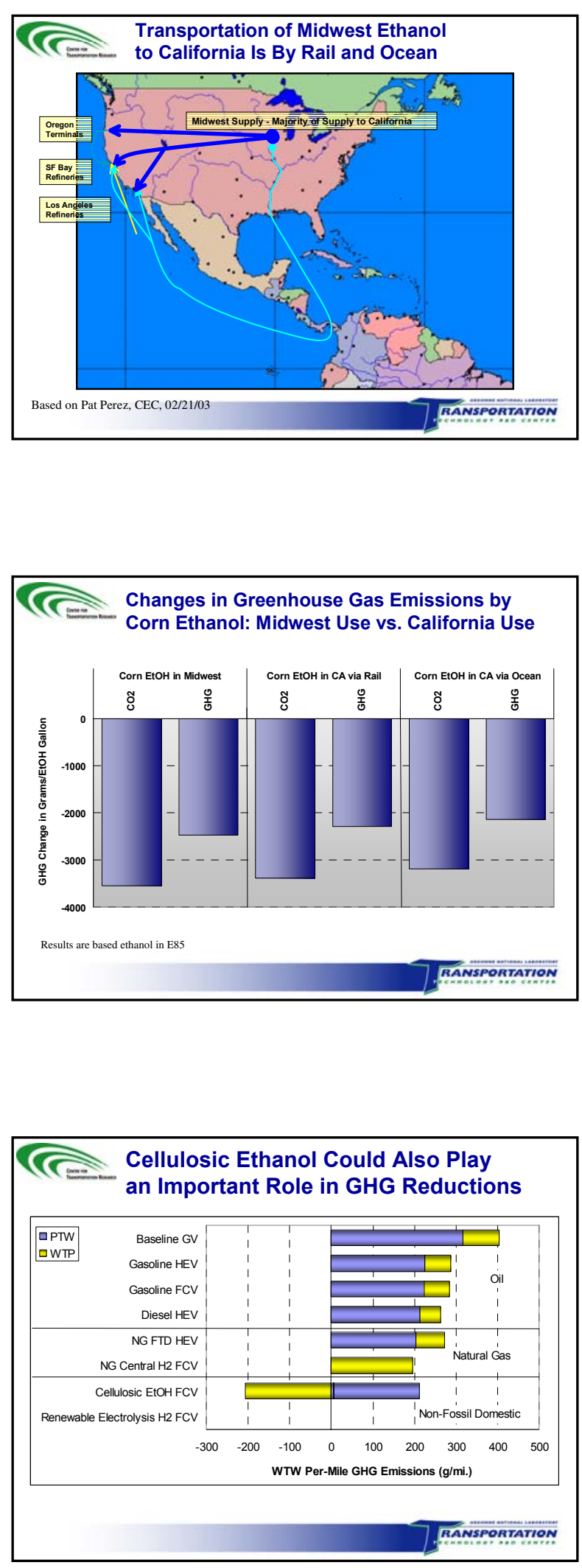
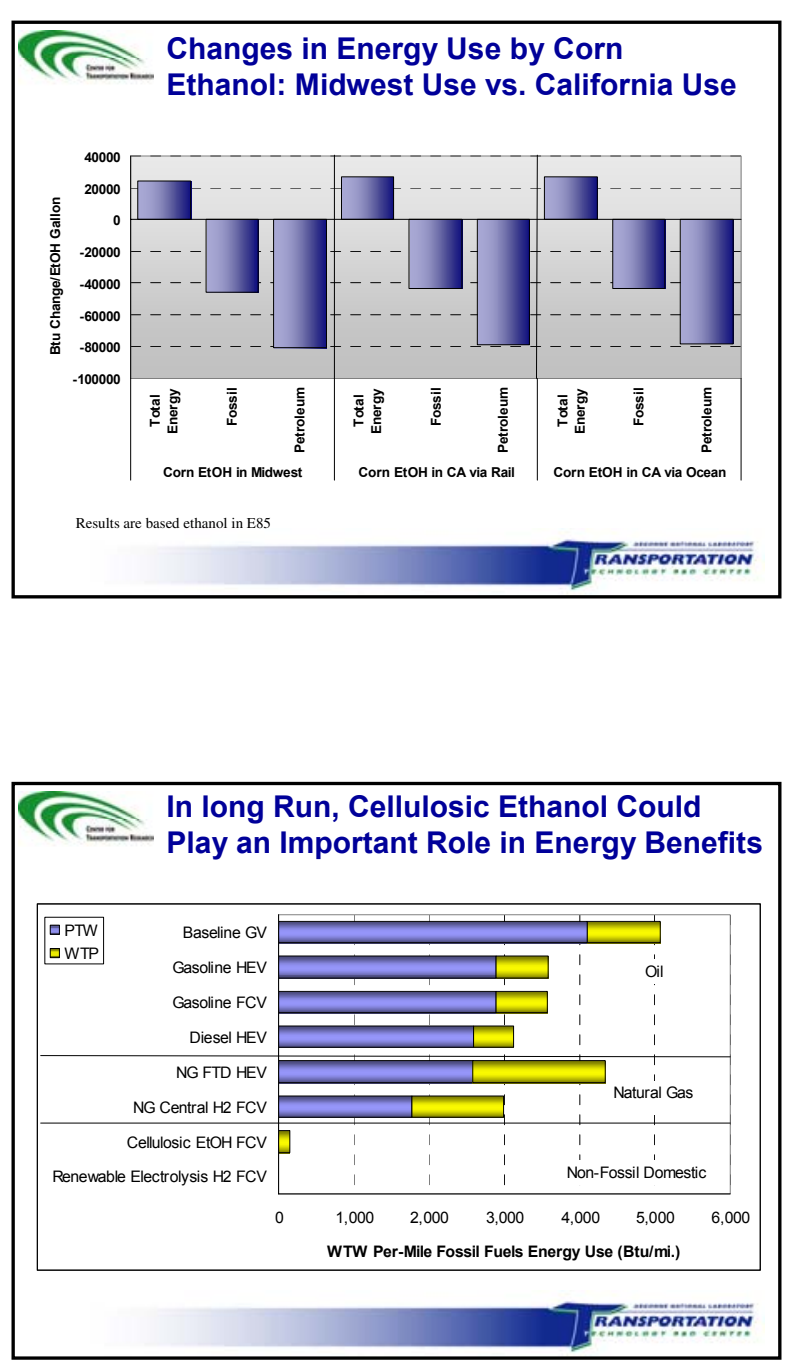

\section{लि Conclusions}

Any type of fuel ethanol helps substantially reduce transportation's fossil energy and petroleum use

- Ethanol's energy balance alone is not meaningful

- Corn-based fuel ethanol achieves moderate reductions in GHG emissions

- Cellulosic ethanol will achieve much greater energy and GHG benefits 


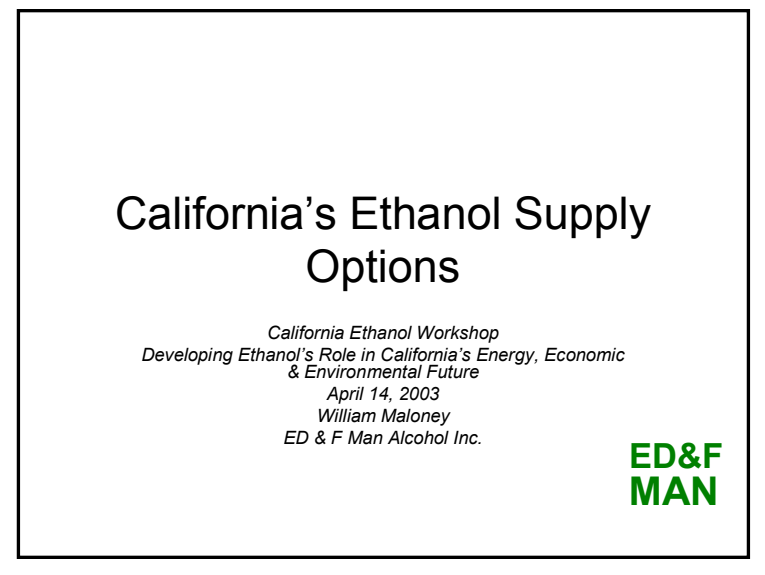

\section{California's Ethanol Supply Options}

- Domestic US Supply

- CBI Supply

- Other Foreign Supply

- Pacific Northwest Supply
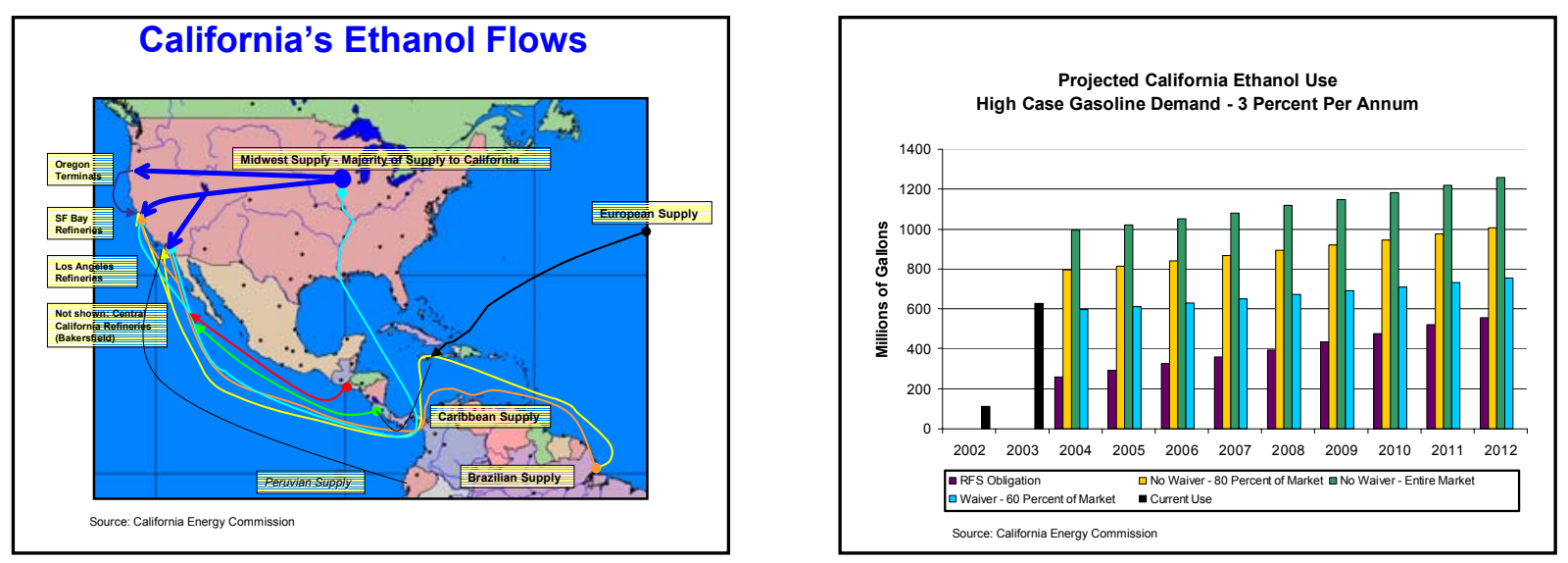

\section{US Domestic Production}

- $98.7 \%$ of US Ethanol Production is in PADD 2 (Midwest).

- PADD 2 Currently Supplies Approximately $92 \%$ of all ethanol to California.

- Major States Supplying CA are lowa, Illinois and Nebraska.

\section{Logistical Method of Supply}

- Oil Companies expressed desired method of delivery is $2 / 3$ via rail and $1 / 3$ via bulk marine.

- Current difficulties being experienced in Southern CA due to incomplete rail infrastructure (should be completed summer 2003).

- Some Southern CA delivered via barge from Northern CA. 


\section{Caribbean Basin Initiative}

What is the Caribbean Basin Initiative and how is it relevant to California fuel ethanol supplies?

The Caribbean Basin Initiative (CBI) is a Unilateral US trade agreement allows the export of ethanol into the United States tariff free.

The Fuel Ethanol tariff is US cents 54 per USG.

What are the rights for $\mathrm{CBI}$ ethanol dehydration plants?

A tariff quote allowed into the USA of $7 \%$ of US demand for fuel ethanol with 60 million USG minimum, $\mathbf{3 0} \%$ indigenous required to go above $7 \%$.

- No limit on volume produced from local feedstock.

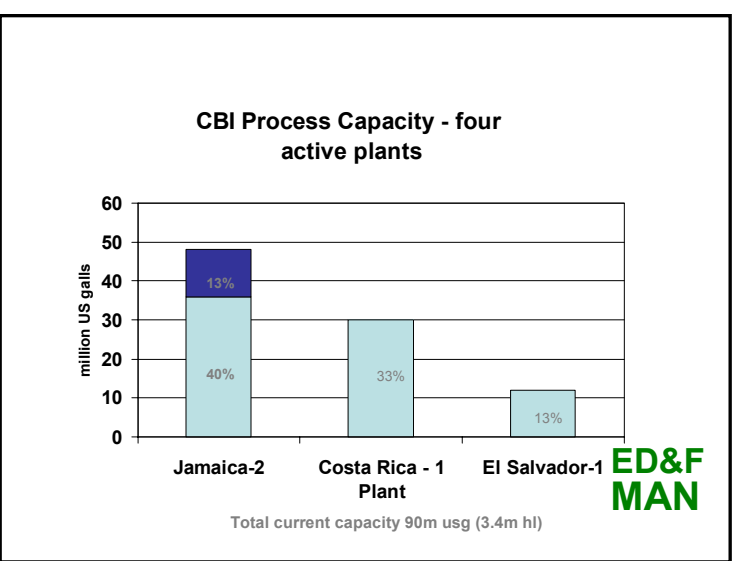

\section{CBI Feedstock Supply}

- European surplus wine ethanol from France, Italy, Spain.

- Brazilian sugar cane alcohol. 


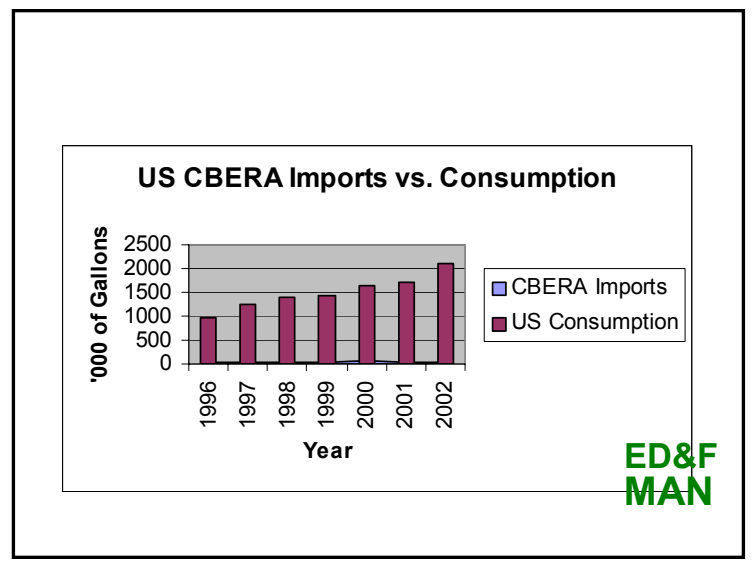

\section{Variables to CBI Imports}

- Fall off in availability of wine ethanol in Europe (WTO Restrictions).

- Brazilian internal \& external sugar \& ethanol prices vs. US fuel ethanol prices.

- Exposure to currency movements \& freight rates.

Make CBI a Relatively High Cost Producer, i.e., not in market in significant way if prices are below $\$ 1.25$.

CA Ethanol Demand \& CBI Supply - RFS

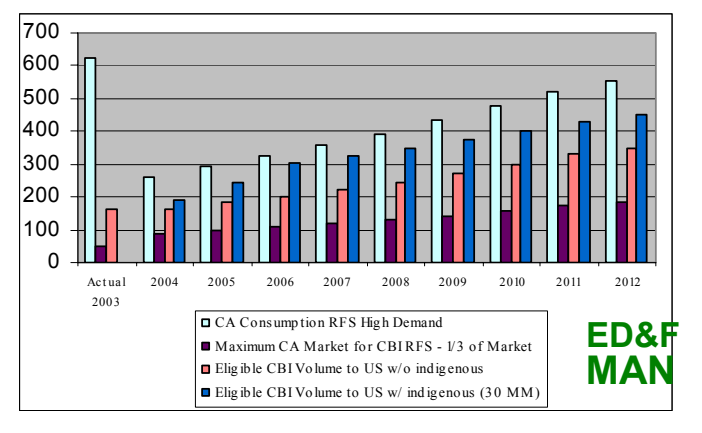

\section{Indigenous CBI Production}

- Guatemala - several projects, $20 \mathrm{MM+}$ gallons per annum potential.

- Nicaragua - project 10 MM gallons per annum potential.

- Dominican Republic - Potential, but more likely to East Coast.

\section{Indigenous CBI Production}

- Has to be fermentation.

- No limit to volume allowed under CBI for full fermentation process ethanol.

- Driven by molasses prices or very low sugar prices.

- Opportunity price of molasses in rum and animal feeds.

- Land available in certain CBI countries, but insufficient returns to spur sugar cane planting for ethanol.

\section{Other Potential Int'I Suppliers}

- Andean Pact - Peru, Bolivia, Colombia, Venezuela \& Ecuador.

- Peru Project - Plan for 200 million gallons per annum from sugar cane (PetroPeru).

Much publicized, but uncertain at this time. 


\section{Other Potential Int'I Suppliers}

- Brazil Directly - Possible under FTA (Free Trade of the Americas)

- Current \$0.54 Duty plus Transport, need \$1.40's + Prices

- Expect Strong US Producer Led Political Resistance to duty-free imports

- Mexico (Under NAFTA)

- No Current Projects, but potential exists for moderate quantities (e.g., $20 \mathrm{MM}$ gallons).

- Canada (Under NAFTA)

- Target markets internal to Canada.

\section{New Western US Suppliers?}

- Pac Northwest Projects Target California

- Oregon, 130 MM Annual Production

- Washington, 40 MM Annual Production

- Idaho, 15 MM Annual Production

- Montana, 100 MM Annual Production

Pac NW Market - Approximately 120 MM

ED\&F

MAN

\section{Conclusions}

- Midwest will continue to supply most CA ethanol demand.

- CBI Suppliers (mostly Brazil feedstock) have opportunity to supply $1 / 3$ of demand (under RFS). Capability limited by Brazilian commitment to market.

- Some potential for new int'l suppliers, e.g., Peru.

- Pac NW suppliers look to CA, but may be a very competitive market.

- Local CA production possible, but will have to compete with efficient low-cost Midwest producers. 


\section{STATUS REPORT ON OPPORTUNITIES FOSTERING A CALIFORNIA ETHANOL INDUSTRY}

\section{Neil Koehler}

California Renewable Fuels Partnership

\section{CALIFORNIA ETHANOL WORKSHOP}

Sacramento, California

April 14, 2003

\section{CALIFORNIA RENEWABLE FUELS PARTNERSHIP}

- Coalition of Agricultural, Environmental, Local Government, and Ethanol groups giving a voice to the California ethanol opportunity

- Creating a California Brand Ethanol Industry

\section{CALIFORNIA RENEWABLE FUELS PARTNERSHIP MEMBERS}

\section{California Farm Bureau}

Bluewater Network

Community Alliance With Family Farmers

Californians Against Waste

Sacramento Area Council of

Silicon Valley Toxics Coalition

Imperial County Community Economic Development

Ventura County (Solid Waste Department)

Nevada County

Arkenol Inc.

Harvest Biofuels LLC

Imperial Bioresource

Masada Resource Group

Northern California Ethano

Pacific Ethano

Plumas Corporation
THE CALIFORNIA ETHANOL PRODUCTION OPPORTUNITY

- Exploding ethanol market demand - Minimum 750 million gallon market in 2004 with only 8 million gallons of production

- Growing gasoline demand with no new refineries to be built in state

- Intersection of the nation's largest fuel and dairy feed markets

- Large and diverse raw material supply - Primary and waste

- Sugar, starch and cellulose

- Rural and Urban opportunities

\section{RAPID NATIONAL ETHANOL INDUSTRY EXPANSION}

- MTBE Phaseout

- Strong Policy Support

- Agricultural Economic Development

- Energy Security Concerns

- Air Quality Regulations

- Climate Change Issues

- Dominated by Midwest Corn Ethanol Industry

- New Market Growth Outside of Midwest

\section{BENEFITS OF A CALIFORNIA ETHANOL INDUSTRY}

- New supplies of Renewable Transportation Fuel

- Cost Effective Source of Octane and Dilution of Toxic components of gasoline

- Production of High Protein Feed for the California Dairy Industry

- Reduction in Petroleum Dependence

- New source of Economic Development

- CO2 Reductions

- 6.4 million tons on $\mathrm{CO} 2$ reductions with ten percent ethanol blends and current ethanol production technology 

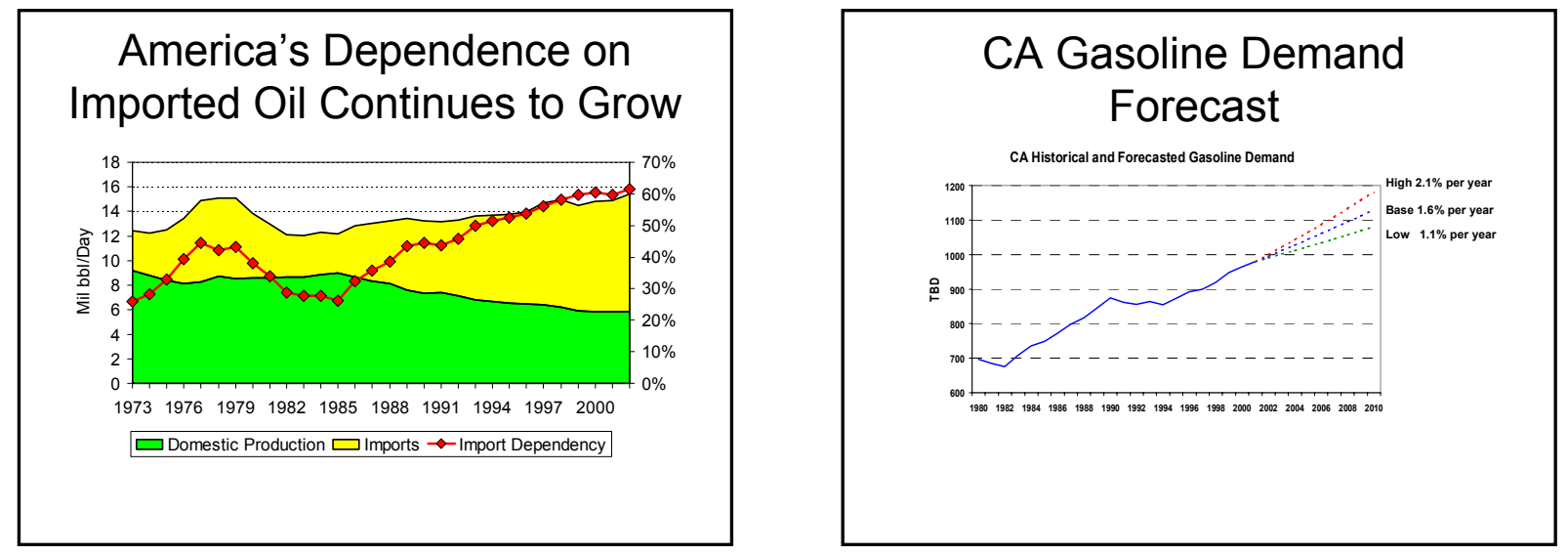

\section{CA Petroleum Import Trends}
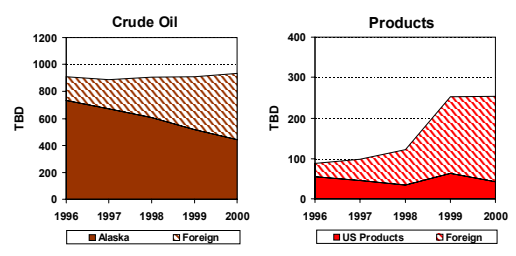

LOCAL ECONOMIC BENEFITS OF A 40 MILLION GALLON PER YEAR ETHANOL FACILITY

Provide a one-time boost of $\$ 142$ million during construction Expand the local economic base $\$ 110.2$ million each year through
the direct spending of $\$ 56$ million

Create 41 full-time jobs at the plant and 694 jobs throughout the

Increase local price of corn by an average of 5-10 cents a bushel Increase household income for the community by $\$ 19.6$ million annually

Boost state and local sales tax receipts by an average of $\$ 1.2$

million (varies depending on local rates)

Source: "Ethanol and the Local Community," John Urbanchuk, AUS Consultants and Jeff Kapell, SJH \& Company,
June 2002 ,

\section{CALIFORNIA ETHANOL CHALLENGES}

- Competition from Existing Industry

- Market Uncertainty

- Technology Risks for Cellulose Conversion

- Lack of Coherent State Policy Support 


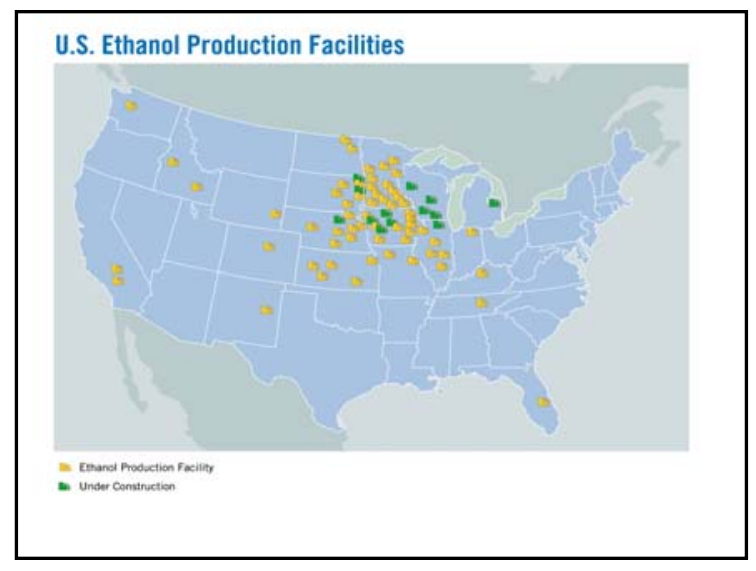

\section{CALIFORNIA ETHANOL MARKET}

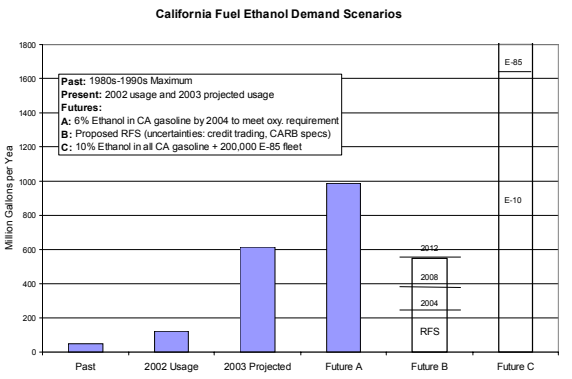

\section{CALIFORNIA ETHANOL STRATEGY}

- Integration with local markets for raw materials and products

- Develop 5 to 10 Conventional Ethanol Facilities in near term with 300 to 400 million gallons of annual production

- First Round of development platform for Cellulose Conversion

- Focused Public/Private Partnership

\section{CALIFORNIA ETHANOL POLICY NEEDS}

- State Renewable Fuels Standard

- Extra Credit for Cellulose

- Recalibrate CARB Predictive Model

- Effective implementation of new $\mathrm{CO} 2$ reduction law (AB1493) to maximize the cost effective use of renewable fuels

- Loan guarantees (cellulose)

- Production Incentives

\section{CURRENT PROGRESS}

- Companies in Northern, Central and Southern California have secured sites, seed capital and announced development plans

- Significant progress on cellulose conversion technologies

- 2003 California Legislative bills SB 820 (Denham) and SB671 (Florez) promoting ethanol production and use

- $\mathrm{AB} 1493 \mathrm{CO} 2$ regulatory implementation and $\mathrm{CEC} A \mathrm{AB}$ 2076 Petroleum Dependence process supporting coherent Renewable Fuels Policy in California

- Smooth transition from MTBE to ethanol in California securing the market

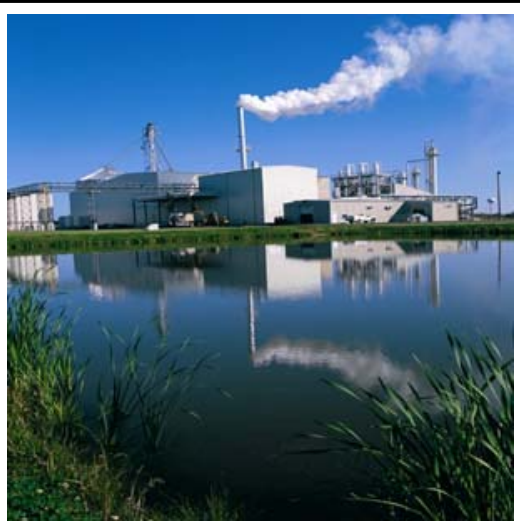




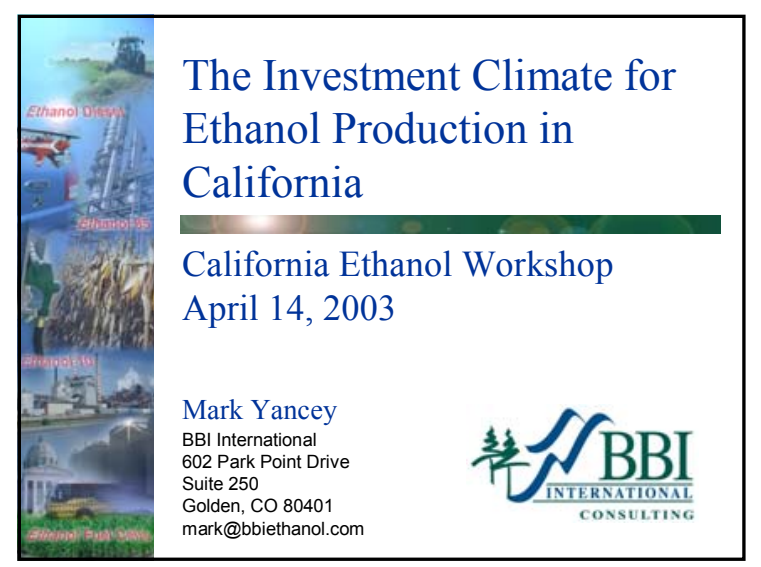

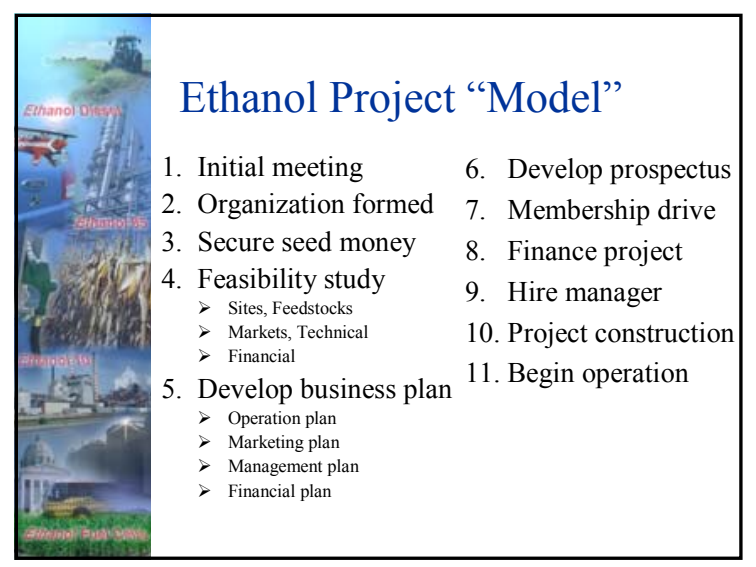

\section{Equity Investment}

- Based upon historic corn and ethanol pricing and current fixed ethanol production cost estimates, investors should receive a $25 \%$ - $30 \%$ annual return on investment

- At times of low corn prices and high ethanol prices (2000 and 2001), investors have received up to $75 \%$ annual return on investment

- 1998 and 1999 - \$1.00 to \$1.10/gal

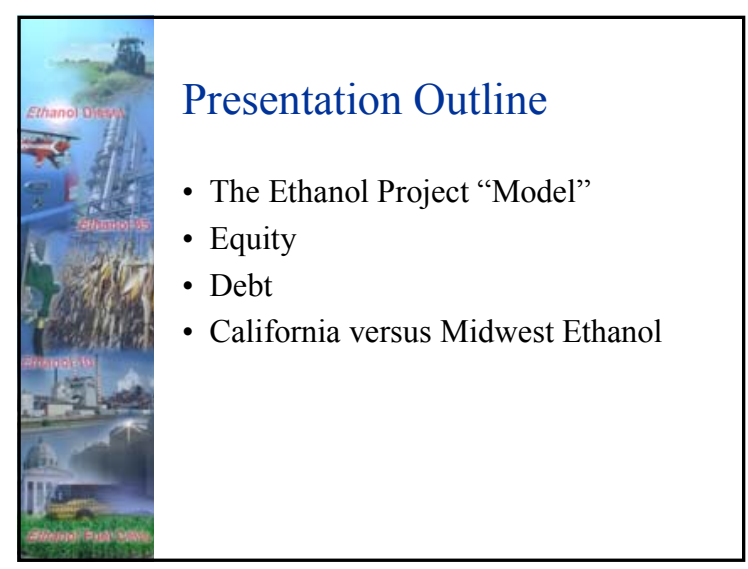

\begin{tabular}{|c|c|}
\hline 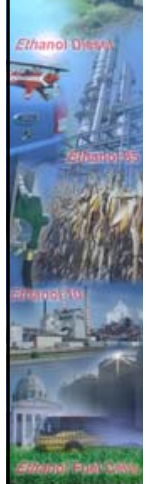 & $\begin{array}{l}\text { Project Equity } \\
\text { - Plan to have } 40-50 \% \text { equity } \\
\text { - Subordinated debt and grants count as } \\
\text { equity } \\
\text { - A } 40 \text { million gallon per year dry } \\
\text { mill ethanol plant should cost } \\
\text { approx. } \$ 55 \text { million } \\
\text { - Equity required is } \$ 22 \text { to } \$ 28 \\
\text { million }\end{array}$ \\
\hline
\end{tabular}

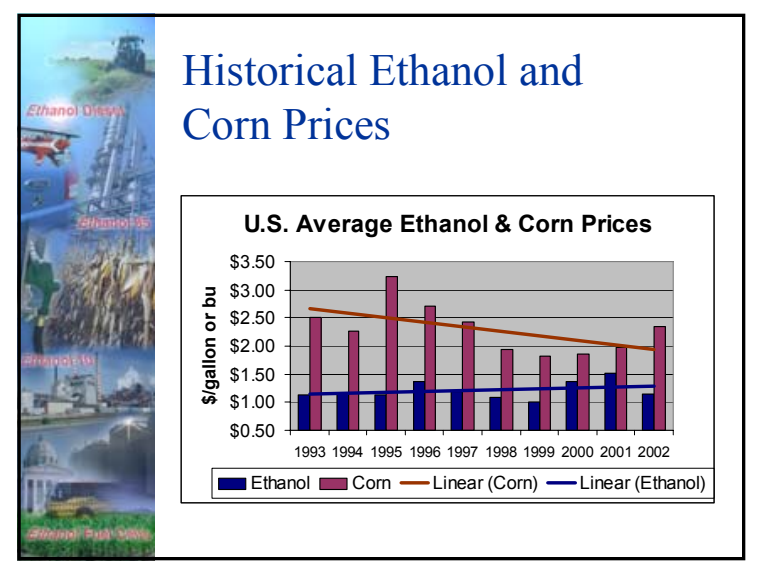




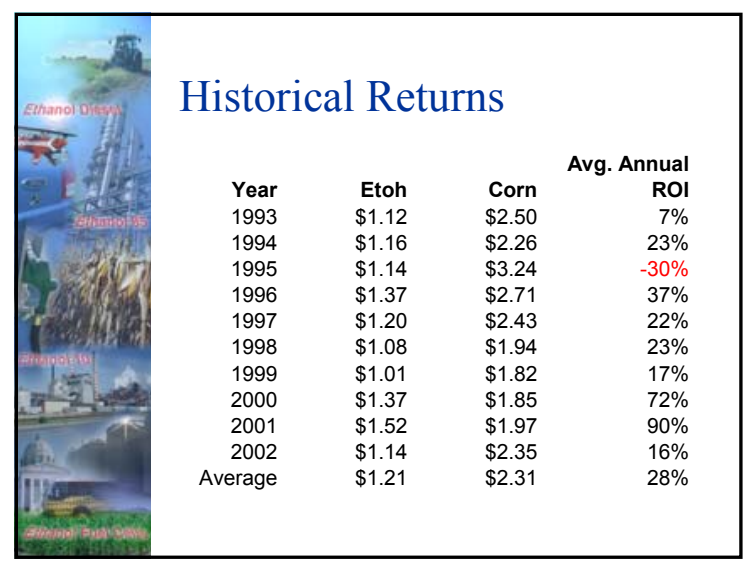

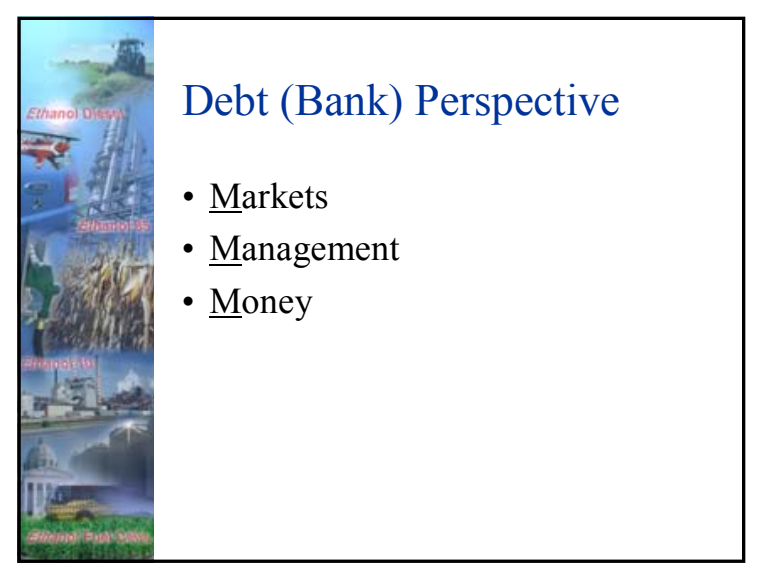

\begin{tabular}{|l|l|}
\hline & Marketing Plan \\
& $\begin{array}{l}\text { - Ethanol Marketing Alliance } \\
\text { - Market Development Plan } \\
\text { - Customers } \\
\text { - Distribution channels to your customers } \\
\text { - Competitors } \\
\text { - Your advantage? } \\
\text { - Ethanol Supply and Demand } \\
\text { - Difficult for new lenders to understand }\end{array}$ \\
\hline
\end{tabular}

\begin{tabular}{|c|c|}
\hline सं & $\begin{array}{l}\text { Management Plan } \\
\text { - Management Team } \\
\text { - Board of Directors } \\
\text { - Officers } \\
\text { - Design/Build "Partner" } \\
\text { - Legal Council and Project Consultants } \\
\text { - Management Team Experience } \\
\text { - Startup and Operating Plans } \\
\text { - Risk Management Plan }\end{array}$ \\
\hline
\end{tabular}

\begin{tabular}{|l|l|}
\hline & Financial Plan \\
& $\begin{array}{l}\text { - Projected Return on Investment } \\
\text { - Strong Cash Flow } \\
\text { - Adequate Working Capital } \\
\text { - Source of Funds } \\
\text { - Use of Funds } \\
\text { - Guarantees } \\
\text { - Cost and performance of plant; startup } \\
\text { date }\end{array}$ \\
\end{tabular}

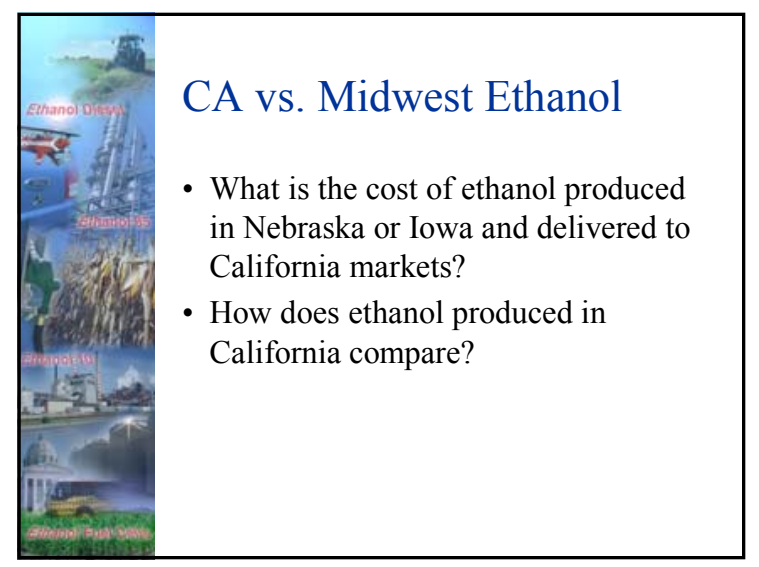



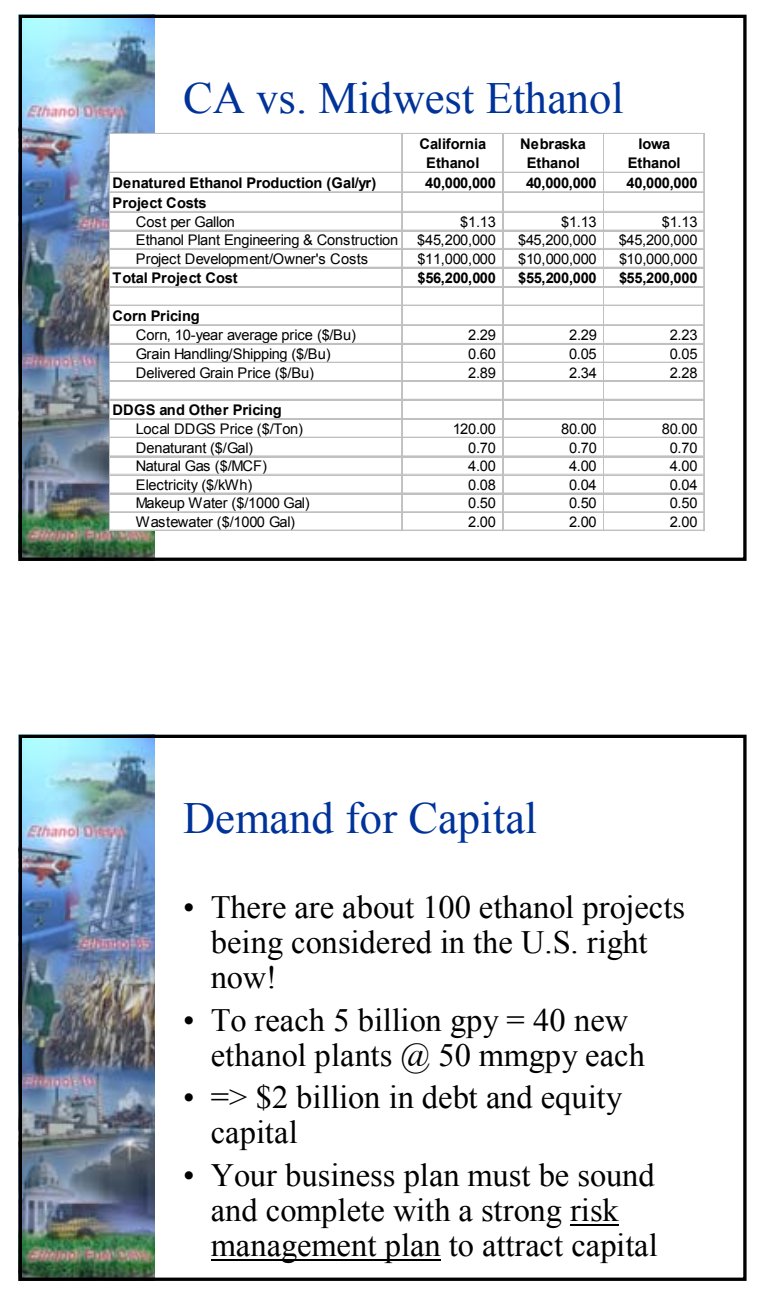
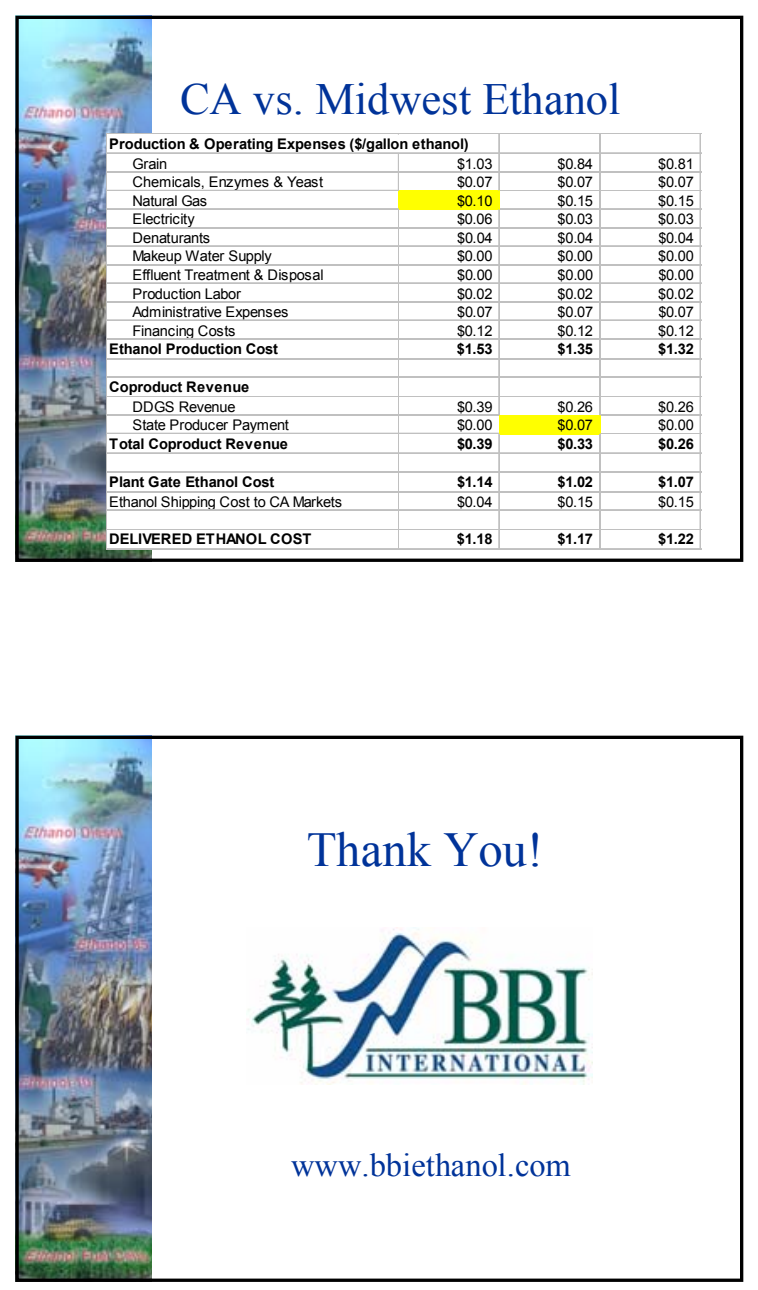


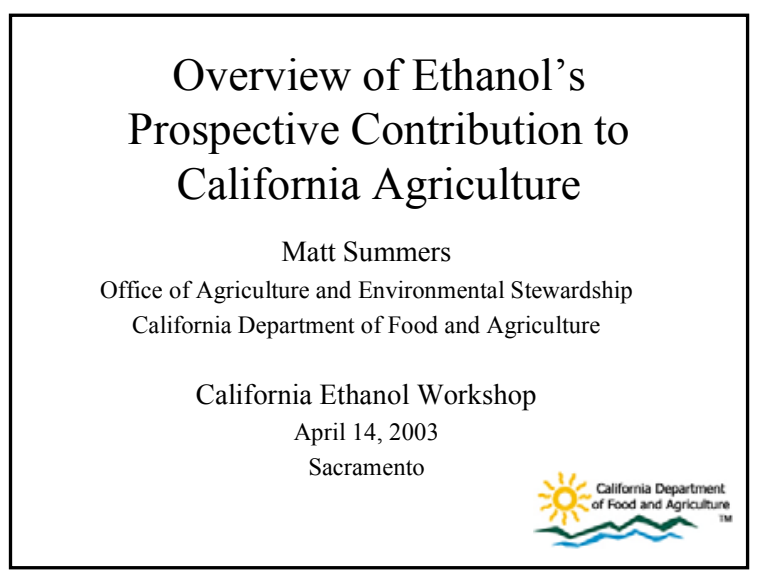

\section{Overview}

- California Ethanol Market

- Feedstock and Production Opportunities

- California Production Potential

- Challenges

- Fuel Applications

- Important Messages and Considerations

\section{California Ethanol Market}

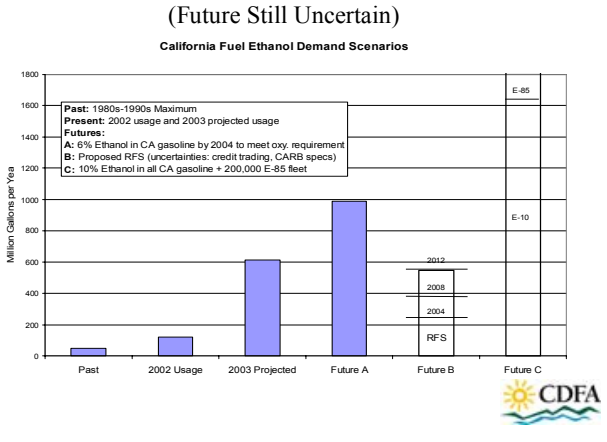

Back to the future?

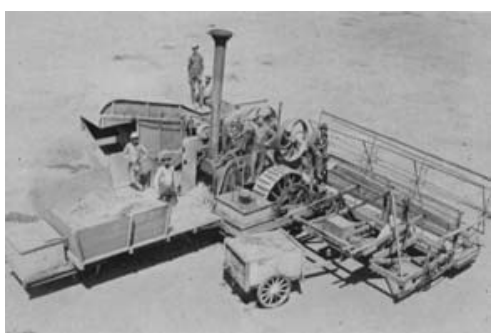

The first self-propelled combine used straw as fuel!! The Berry Combine, Lindsey, California 1886

\section{Current CA Ethanol Production Opportunities}

- Butte County

- Yolo, Colusa County

- San Joaquin County

- Fresno, Kern, Kings, Tulare Counties

- Imperial County

- Ventura County
Conventional Feedstock

- Sugar Cane

- Food and Beverage Wastes

- Ample resources (agriculture, forest, urban) 


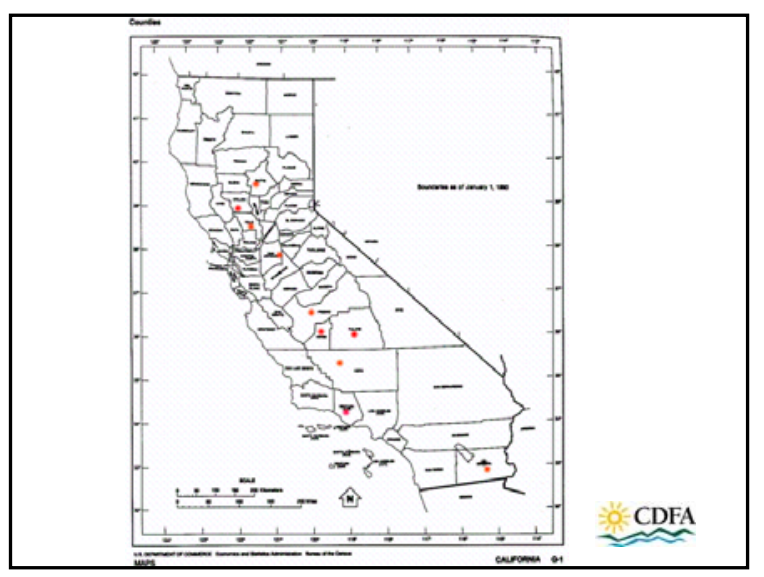

\section{CA Production Potential: Conventional Feedstock}

- Agriculture (in millions gallons ethanol)

- Protein - 280

- Crop shift - $\quad 233$

- By-products - $\quad 61$

TOTAL - 574

- Assumptions

- Protein - All feed protein provided by corn byproducts, 600,000 acres of corn required.

- Crop shift of 245,000 acres to non-corn feedstock (sugar cane, etc.)

CA Production Potential: Biomass Feedstock

- Agriculture

- Biomass -

- Manure -

TOTAL -

- Forestry

- Mill Waste - 385

- Slash -

- Thinings -

TOTAL -
- Urban

- Paper -

- Wood -

609

- Yard -

- Assumptions

- CEC biomass data

- 50 to 70 gallons of ethanol per BDT

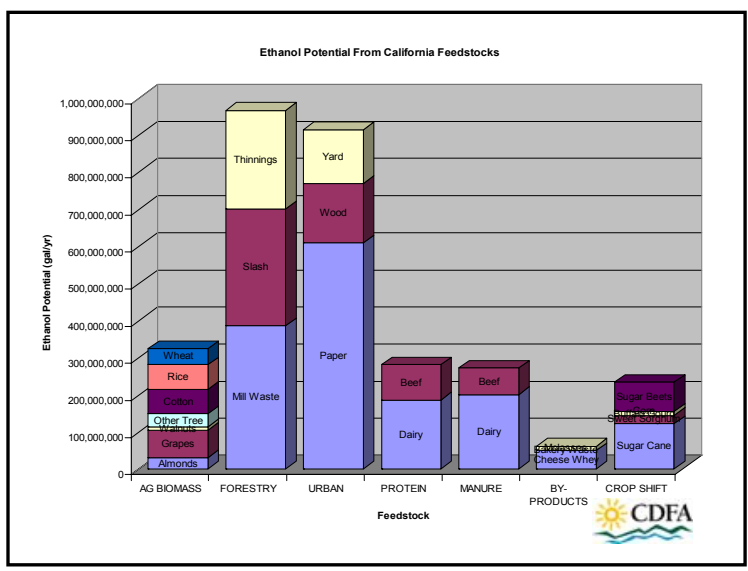

\section{California Production} Advantages

- Proximity to large/growing ethanol market

- Proximity to large/growing feed market

- Growing season and variety of feedstock

- Large underutilized biomass resources

- Hotbed of innovation

\section{California Production Challenges}

- Uncertainty in future demand for product

- Availability of feedstock if changes in cropping are required

- Cost of feedstock and energy inputs

- Regional regulatory requirements

- Conversion technology and acquisition costs not established for biomass 


\section{Corn Ethanol Production in California vs. Midwest}

- Higher per acre yields

- Higher per acre inputs

- Irrigation is required

- Field drying of grain is typical

- Opportunities for feeding wet protein

\section{Ethanol Energy Ratio Sensitivity}

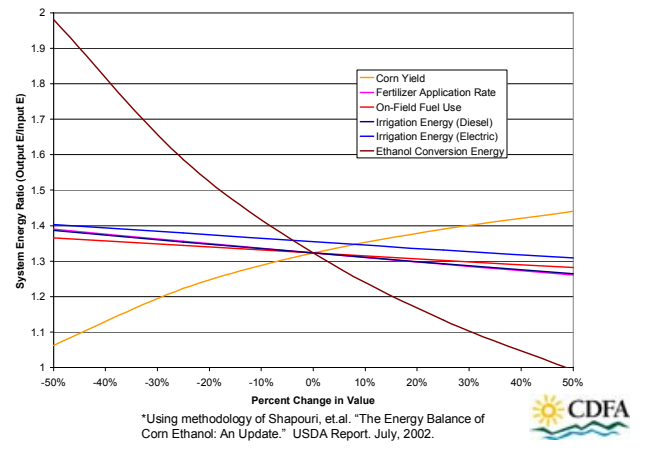

\section{Messages To Policy Makers} about Ethanol in California

- Ethanol reduces CA dependence on imported fossil fuels and delivers environmental benefits

- Ethanol can help temper volatility in fuel prices

- Signals of future stability in CA ethanol market essential for establishing CA production

- The Minnesota Model works! Production incentive can be a cost-effective jump-start to industry, diversifies and strengthens the rural economy-creates jobs and markets

- Consider a renewable portfolio standard for transportation fuels (as exists for electricity) CDFA
Energy Inputs for Ethanol Production

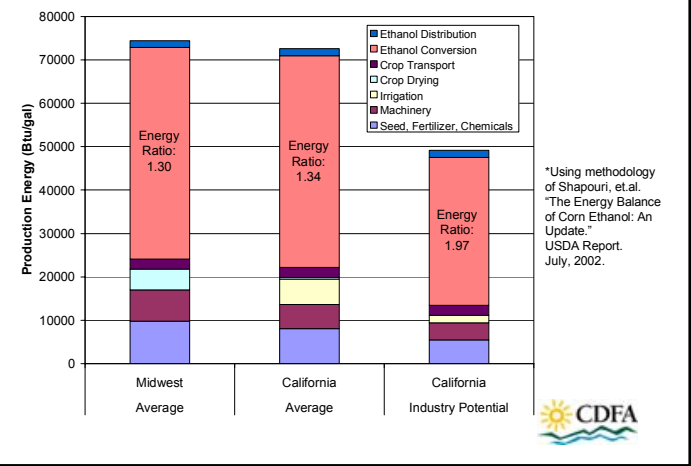

\section{The Flexible Fuel}

- Reformulated gasoline - up to E-10?

- E-85 (over 150,000 FFV's and growing in CA)

- Heavy duty applications

- E-Diesel and Biodiesel

- E-95 and E-100

- E-22 - E-24

- Flex-fueled hybrids

- Fuel cells

\section{California Policy and Ethanol}

- California policy makers have prioritized reduction of greenhouse gasses from transportation (AB1493) and reduced dependence on petroleum (AB 2076)

- Jobs a major concern, particularly in the current economy in some regions 


\section{Key Considerations}

- California agriculture is a significant feature of the existing environment

- California agriculture's strengths are in its diversity, favorable climate, and high technology, which should be further exploited

- New markets and products can enhance the agricultural and rural economy of California

- Strategic partnerships will be required to fully exploit these opportunities

\section{Contact Information}

Matthew D. Summers, P.E.

California Department of Food and Agriculture

1220 N. Street

Sacramento, CA 95814

916-651-7178

msummers@cdfa.ca.gov

\section{Data Sources}

- CDFA Crop Statistics - 2001 (for 2000)

- CEC Report - Evaluation of Biomass-toEthanol Fuel Potential in California, December, 1999

- Dr. Paul Sebesta, UC Riverside (sugar cane)

- Ethanol Conversion factors - The Energy Balance of Corn Ethanol: An Update, USDA, 2002 . 
CORN-TO-ETHANOL PROJECT IN COLUSA COUNTY

Phil Cherry

California Biofuels Development Group, LLC

U.S. DOE - California Ethanol Workshop April 14, 2003

\section{Why Corn-to-Ethanol in California?}

* Develop In-state Industry to Meet New Demand Before Midwest Captures Market

* Technology/Process is Proven and Commercialized

* Large Dairy Market for Co-product

* Greater Chance of Success

\section{Why Sacramento Area?}

* Local Corn Grown / Can Be Grown

* Closure of Sugar Beet and Tomato Processing Plants

* Agricultural / Industrial Area

* Proximity to Gasoline Terminals, Feed Markets, and State Government
California Biofuels Development Group, LLC

\section{Initial Activities}

* Contact Made with Yolo County Farm Bureau in March 2001

* Yolo County Farm Bureau Sponsored Three Ethanol Forums

- May 2001

- August 2001

- April 2002

* Yolo County Ethanol Task Force Formed in August 2001

\section{Yolo County Ethanol Task Force}

* Supervisor Rosenberg Appointed a Blue-Ribbon Panel to Explore the Benefits and Constraints of Siting a Facility in the Area

* 20-Member Team Composed of Local Government, Universities, Industry, and Growers

* Consisted of Four Sub-committees - Economics / Financing / Marketing

- Environmental Issues

- Infrastructure / Potential Sites

- Raw Material Supply / Transportation / Technology

California Bioficels Development Group, LLC

\section{Yolo County Ethanol Task Force}

* Concluded That Ethanol Production was Feasible and the County Provided a Viable Location for Development of the Industry

* Report Submitted to and Approved by Economic Development Council in January 2002

* Board of Supervisors Unanimously Endorsed Local Efforts to Bring Ethanol Facility to the County in February 2002 


\section{Early Project Development}

* Ethanol Company Formed

* Potential Sites Evaluated

* Engineering and Construction Firms Assessed and Midwest Plants Toured

* Grain Suppliers and Product Marketers Interviewed

* Preliminary Meetings with Permitting Agencies Califorma Bioficls Deveclopment Group, LLC

\section{Project Description}

\& 20 Million Gallons per Year Facility

- Utilize Dry-Mill Process Technology

- Require 210,000 tons of Corn

- Produce 64,000 tons DDGS as Co-product

- Incorporate CHP System to Supply Energy

- Designed for Expansion to 40 MGPY

* Located in Colusa County Near Arbuckle

- Site of The Adams Group, Inc. Headquarters, Trucking Company, and Specialty Oils Plant

alifornia Biofuels Development Group, LLC

\section{Project Advantages}

* Located Near Sacramento Area Ethanol Market - 57 million gallons per year

* Industrial Zoned Property with Existing Infrastructure

\& Reduced Capital and Operating Costs

* Local Community and Agency Support

\section{Project Milestones}

* Property Selected, Land Surveyed, and Site Plan Completed

* Contract with Design - Build Firm and Preliminary Facility Layout Completed

* Agreements in Place for Grain Supply, Ethanol Marketing, and DDGS Sales

* Business Plan Developed
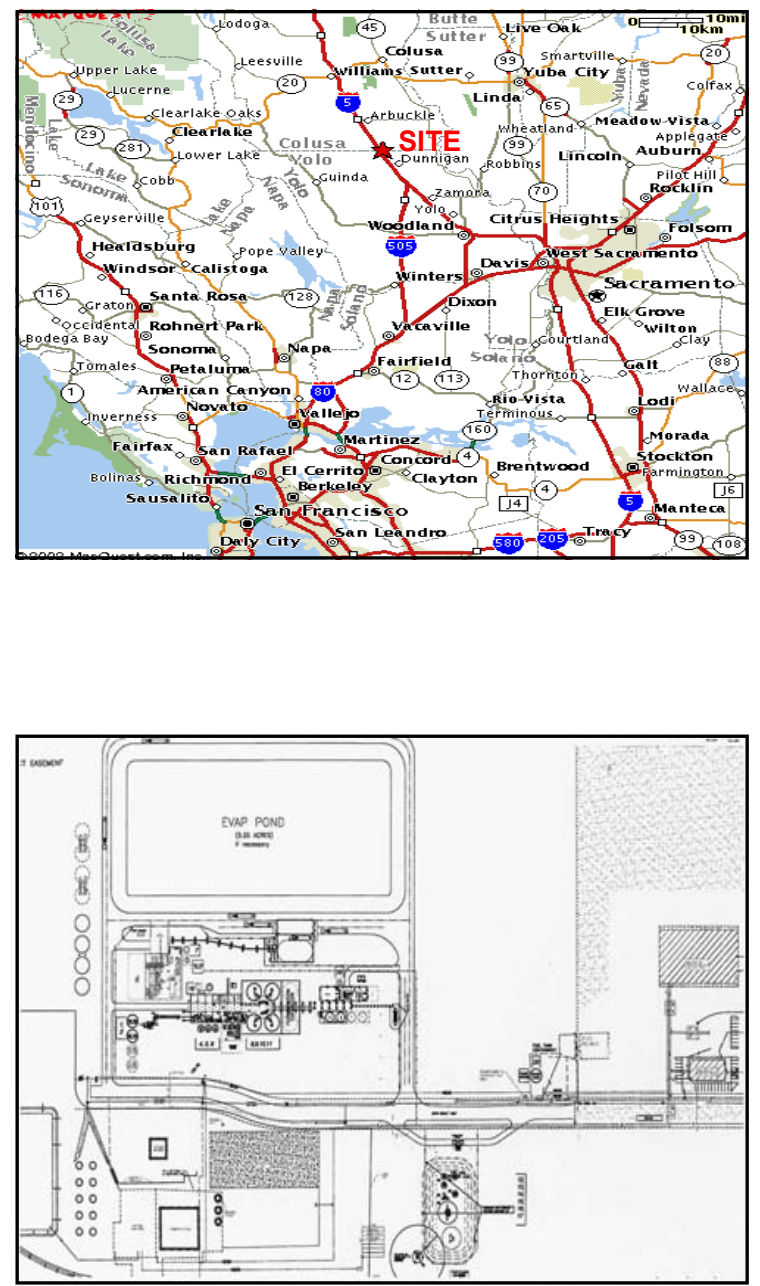

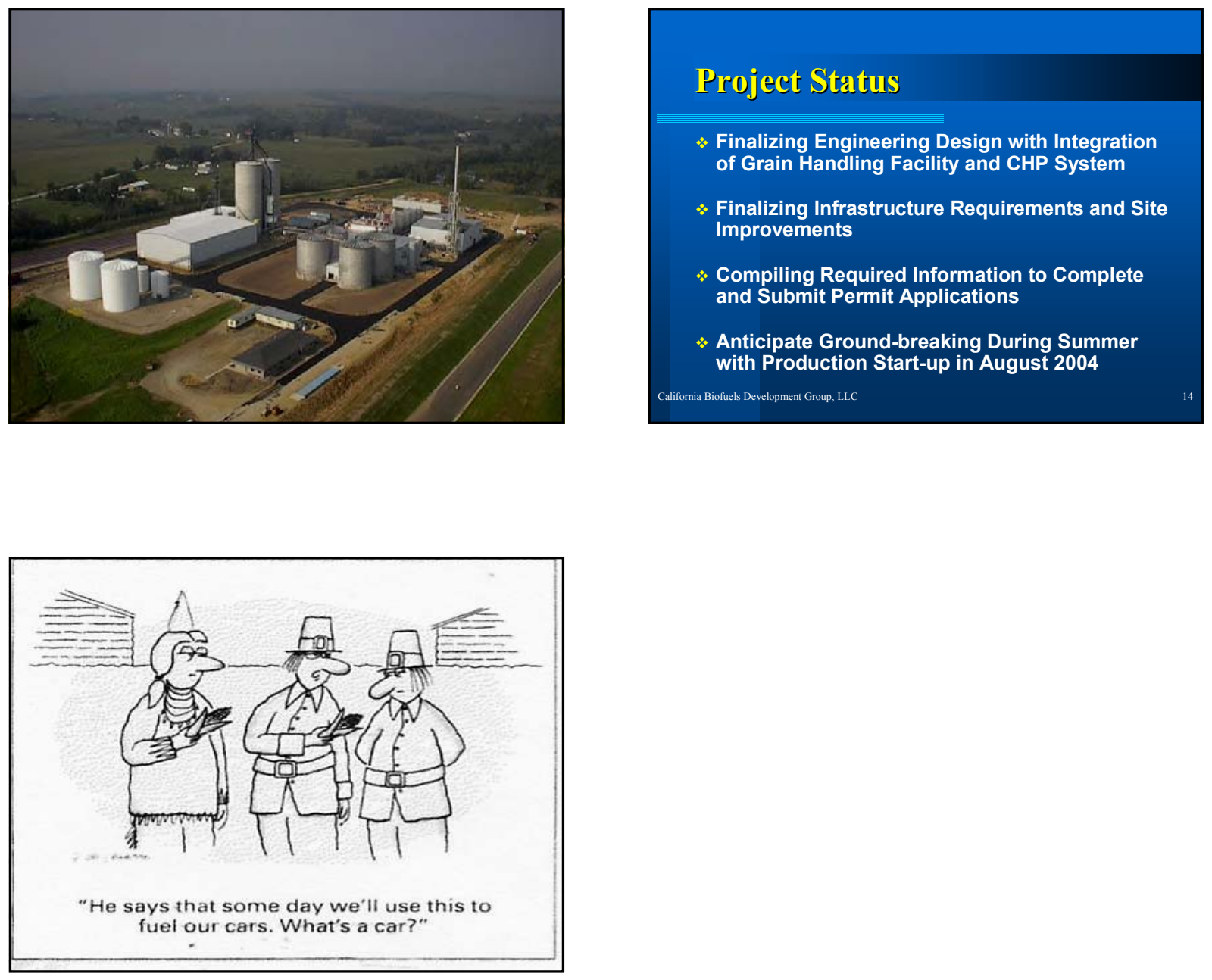

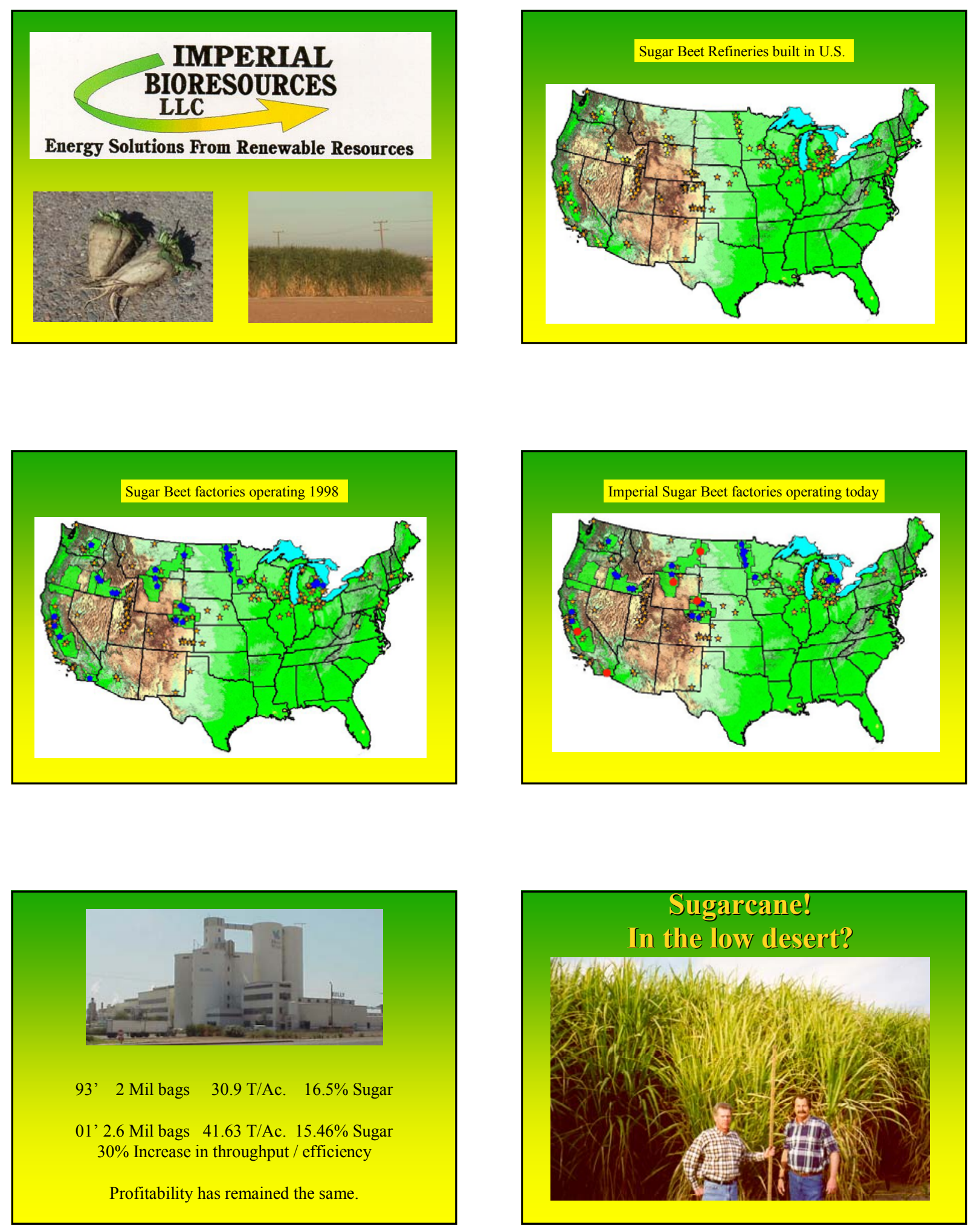

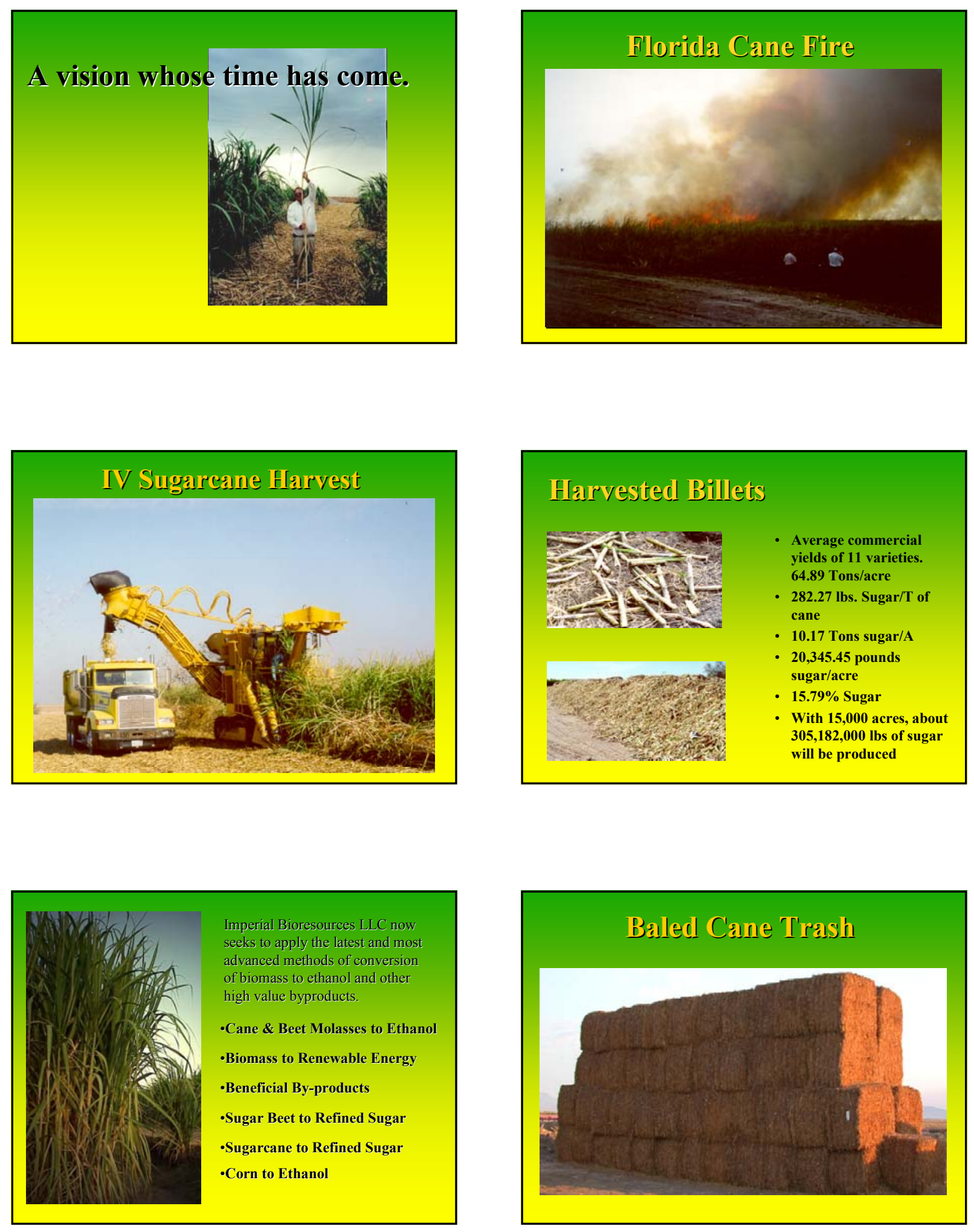

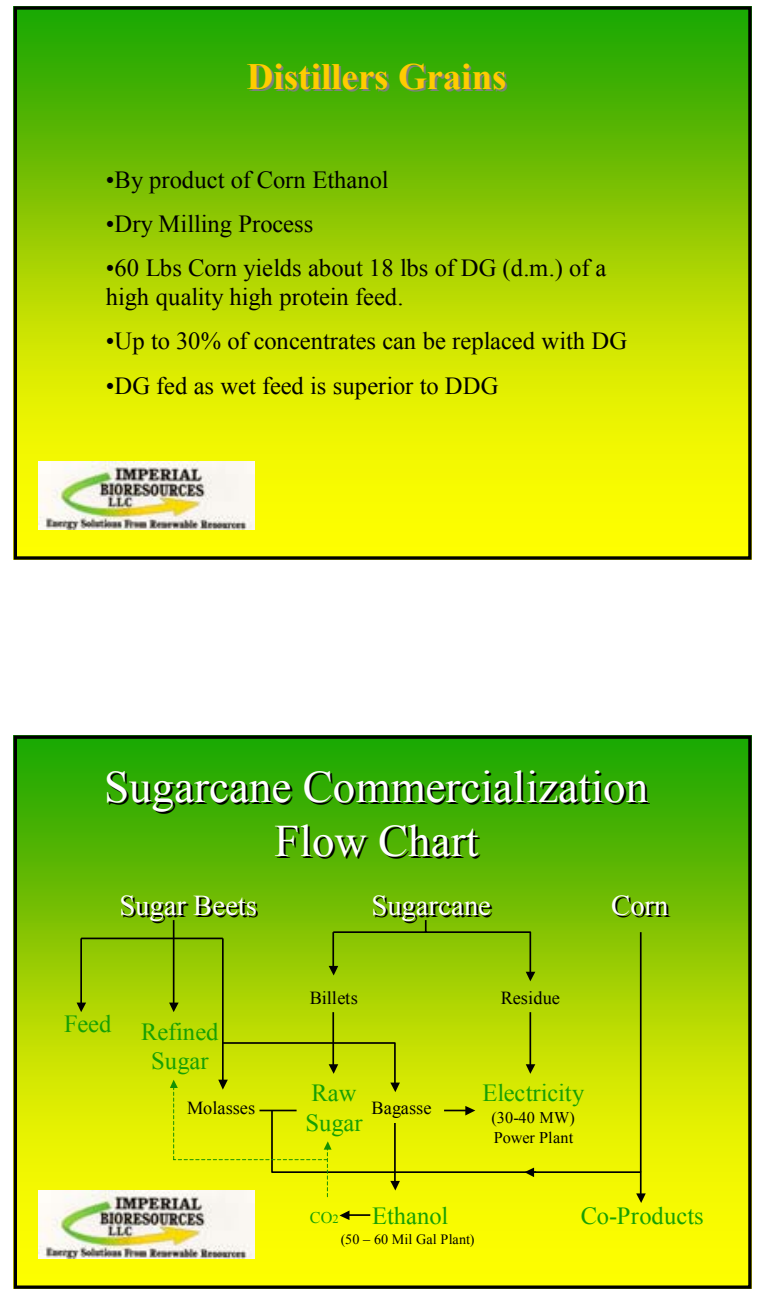

\section{Project Public Benefits}

-Adds renewable energy to California power portfolio -Helps State achieve more Energy Independence -New local energy supply helps meet new growth -Renewable fuel displaces fossil fuel - Renewable fuels burn cleaner, air quality improves -Local fuel source provides Price Stability -Plant demand is lowest in Peak Months -All sectors and rate payers benefit equally

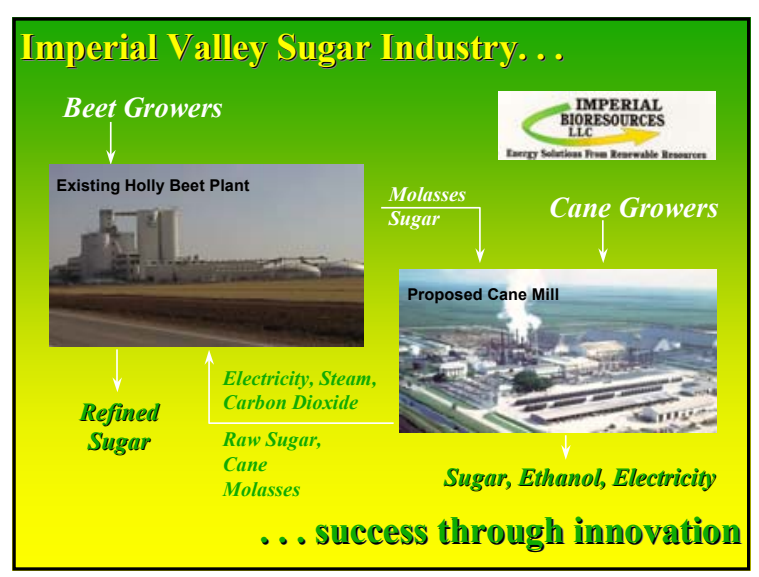

\section{Project Highlights}

- Provides California with a New Energy Crop

- Meets California's need to replace MTBE

- Improves Ambient Air Quality by replacing fossil fuel use

- Delivers substantial quantities of Low Cost Sugar

- Creates Substantial Economic and Employment Opportunities in the Imperial Valley

- Helps to keep the Sugar Beet industry here in the Imperial Valley viable

\section{What Has Been Accomplished?}

-Conducted successful preliminary growing trials on several cane varieties

-Identified an integrated project concept where the principle plant elements are optimized

-Developed project integration arrangement whereby product / co-product synergies are fully exploited

-Lobbied successfully for language in the farm bill that will allow a Cane sugar quota for California 


\section{What Has Been Accomplished?}

-Identified principle environmental concerns and developed solutions.

-No field burning of cane - yields co-generation fuel for year round generation of power

-CO2 from fermentation will be used in sugar refining process

-Solar drying of beet pulp and distillers grains reduce emissions and increases nutritional value of co-products

-Entire plant should very close to $100 \%$ renewable energy powered and $100 \%$ energy self-sufficient

\section{Where Are We Today?}

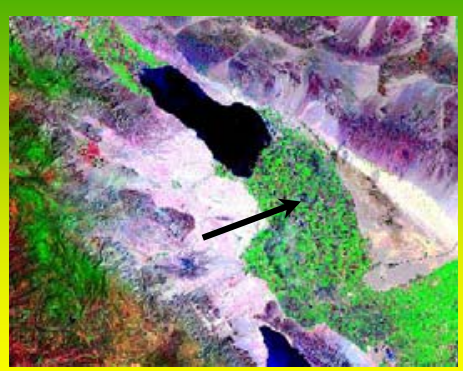

We are here.

\section{Where Are We Today?}

- Currently there are 700 acres planted in I.V.

- Field trials are being conducted

- Variety selection trials

- Fertilization optimization trial

- Seed planting rate trial

\section{What Are The Missing Pieces?}

- Financing - Corn to Ethanol Model

$-60 \%$ Owner equity required due too

- High risk, lack of long term supply contracts

- Markets must be developed

- Long term off-take contracts for co-products reduce risk, help to stabilize pricing

\section{Where Are We Today?}

- Project feasibility study about $50 \%$ complete

- Project has received grant funding from Imperial Irrigation District

- Very strong community support

\section{What Can California Do?}

- Develop a long term plan to support the growth of an in-state ethanol industry

- Support publicly, ethanol use in California 

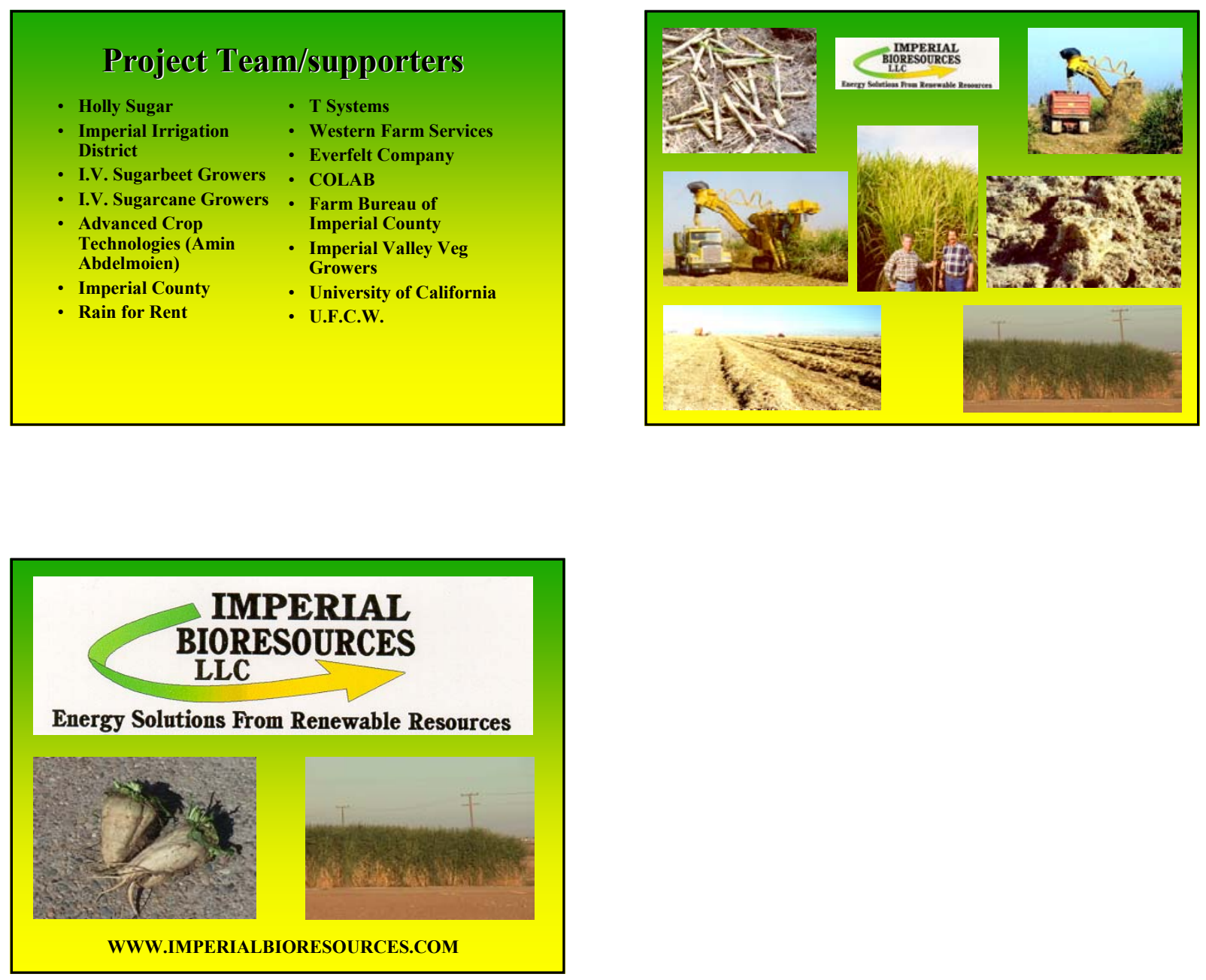


\section{San Joaquin Valley Ethanol Outlook}

Biofuels for Sustainable Transportation

April 14, 2003

Sacramento, California

Ellen I. Burnes, Ph.D.

Department of Agricultural Economics

CSU Fresno

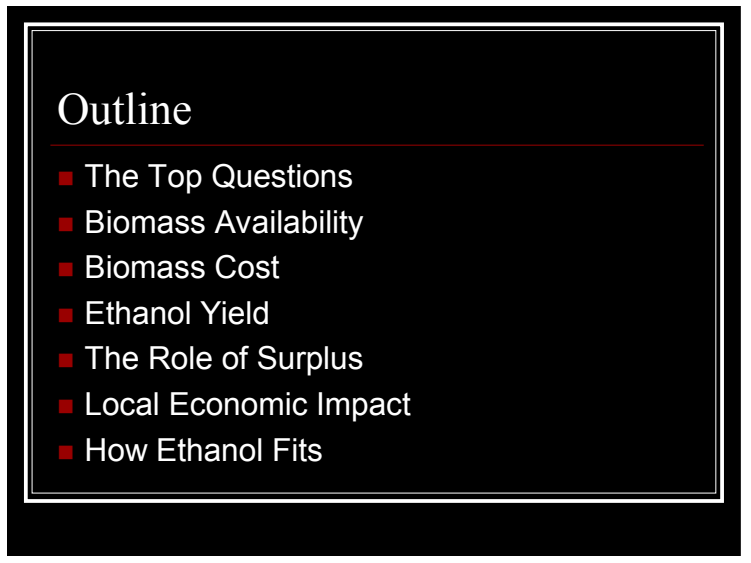

\section{The Perfect World}

A California ethanol plant that uses locally grown feedstocks, accepts multiple feedstocks, pays for transportation, bases feedstock price on comparative markets, and has no environmental impact.
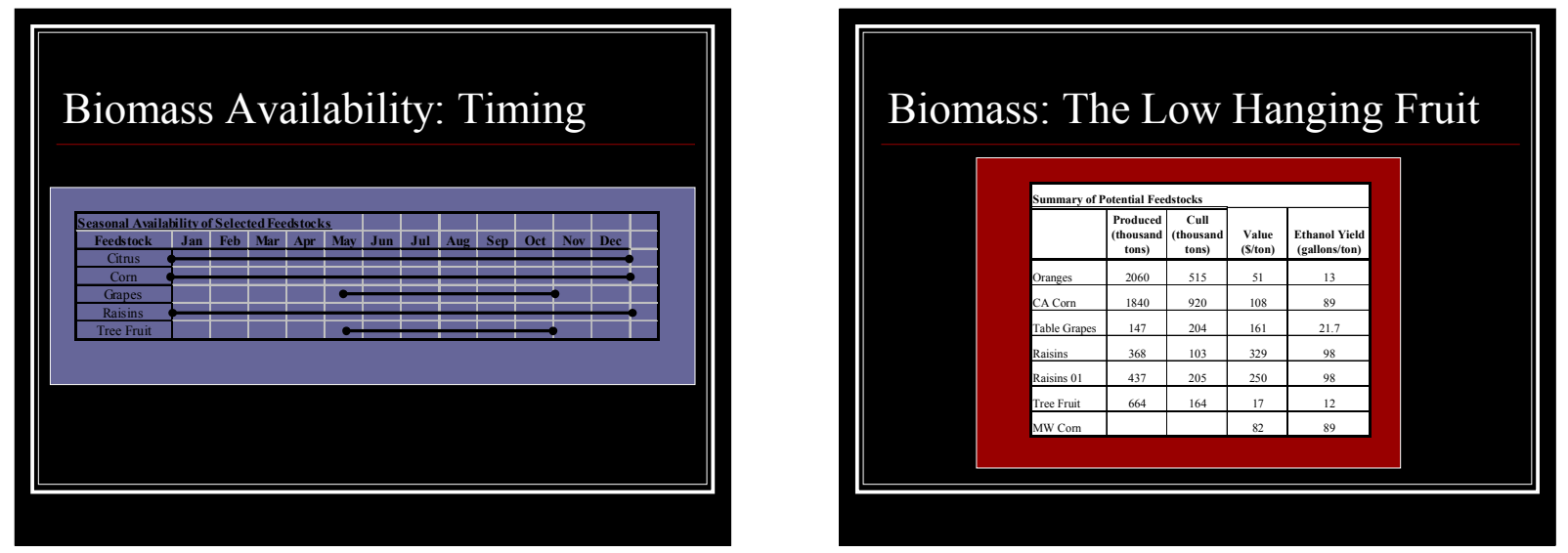

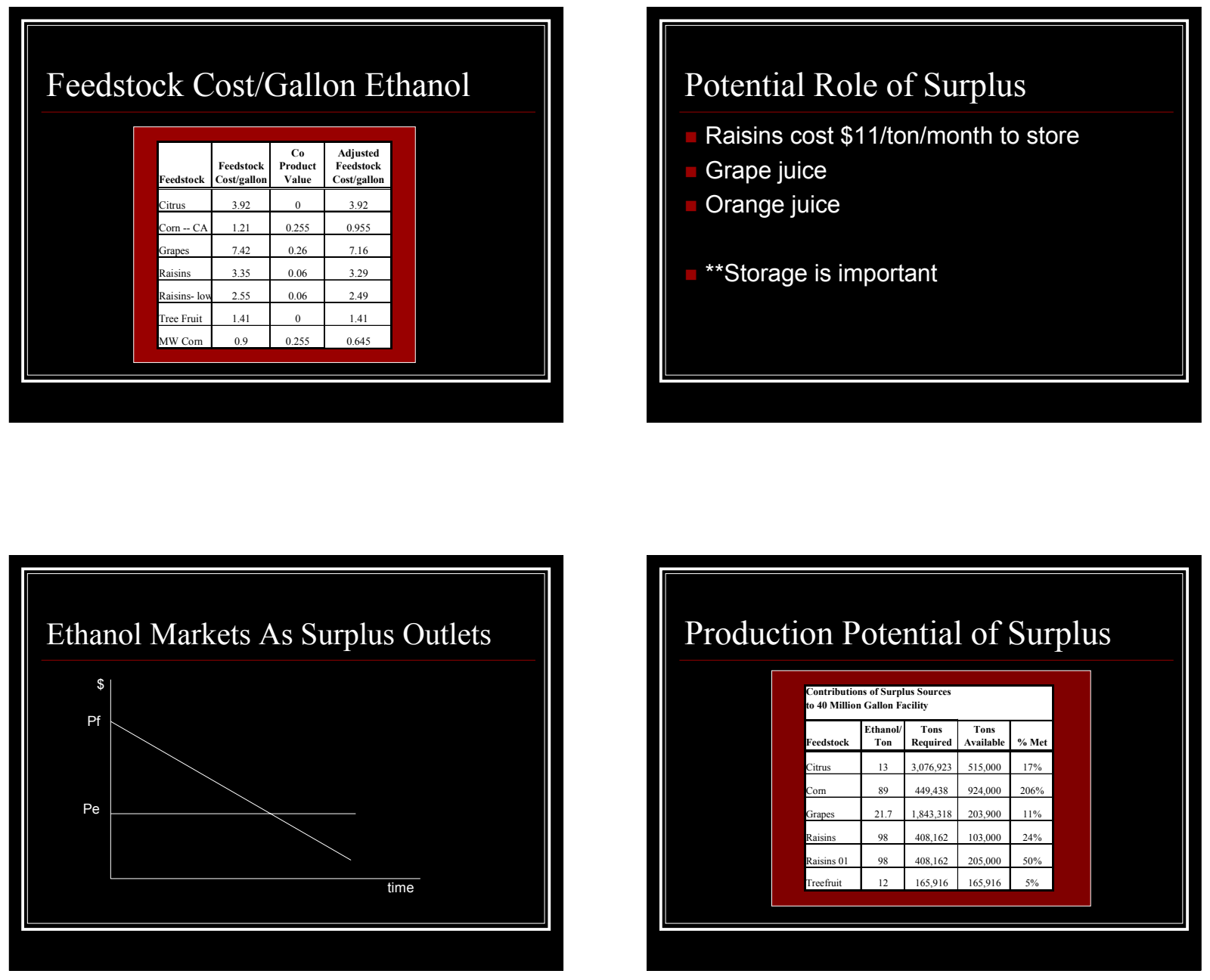

Ethanol and the Local Economy
A 40 million gallon plant
- 41 Facility Jobs
- 300 Local Jobs
- Add \$8 million to local economy

Regions of ethanol plant considerations have $16-34 \%$ year round unemployment

\section{How Ethanol Fits}

Potential Contribution to larger energy goals

Use for co-gen/biomass electric plants

Transition to other fuel types

- E85

- Fuel Cells

- Biodiesel

Strategic implications if transition to national RFS 
Acknowledgements

- CDFA, especially Steve Shaffer

- John Hagen, Department of Agricultural Economics, CSU Fresno

- Agricultural Research Initiative

- Great Valley Center, USDA Rural

Development

California Agricultural Technology Institute

- Center for Ag Business, CSU Fresno 


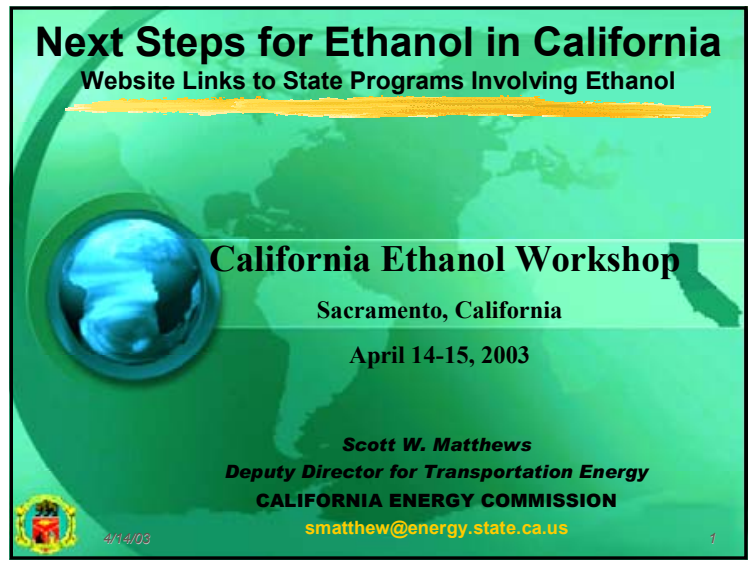

Ethanol Production Studies/PIER

\section{Energy Commission}

www.energy.ca.gov/ethanol

www.energy.ca.gov/pier/renew/ethanol
MTBE Phaseout and Ethanol Substitution

\section{Air Resources Board}

www.arb.ca.gov/cbg/cbg.htm

Energy Commission

www.energy.ca.gov/mtbe

\section{Cal EPA}

www.calepa.ca.gov/programs/mtbe

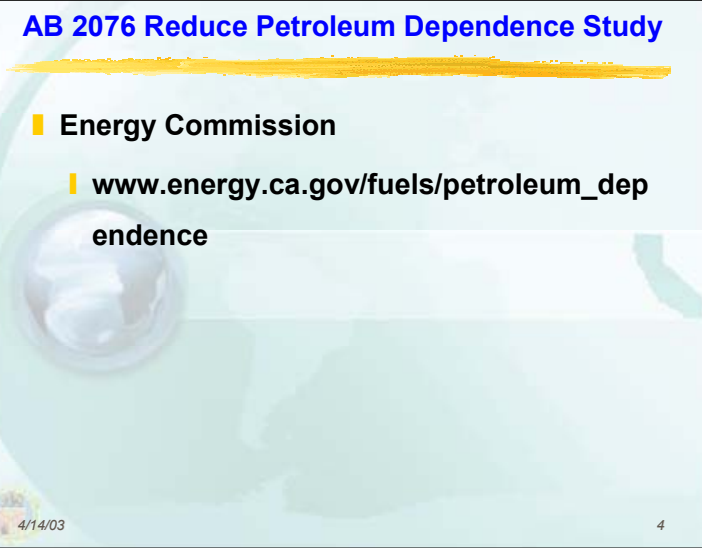

\section{AB 1493 Climate Change Initiative}

\section{Air Resources Board}

www.arb.ca.gov/gcc/gcc.htm

\section{Energy Commission}

www.energy.ca.gov/global_climate_change
Integrated Energy Policy Report

Energy Commission

www.energy.ca.gov/energypolicy 

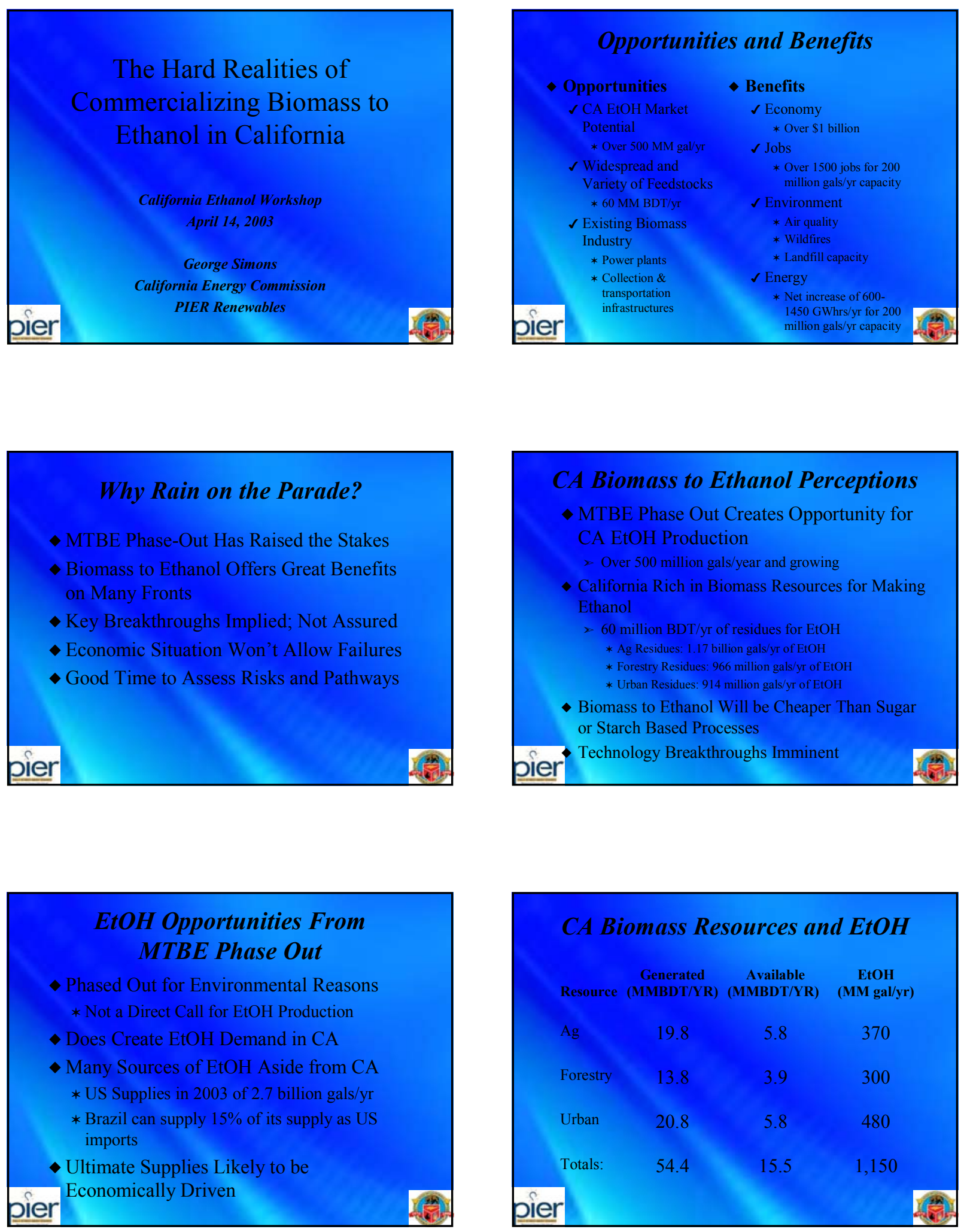

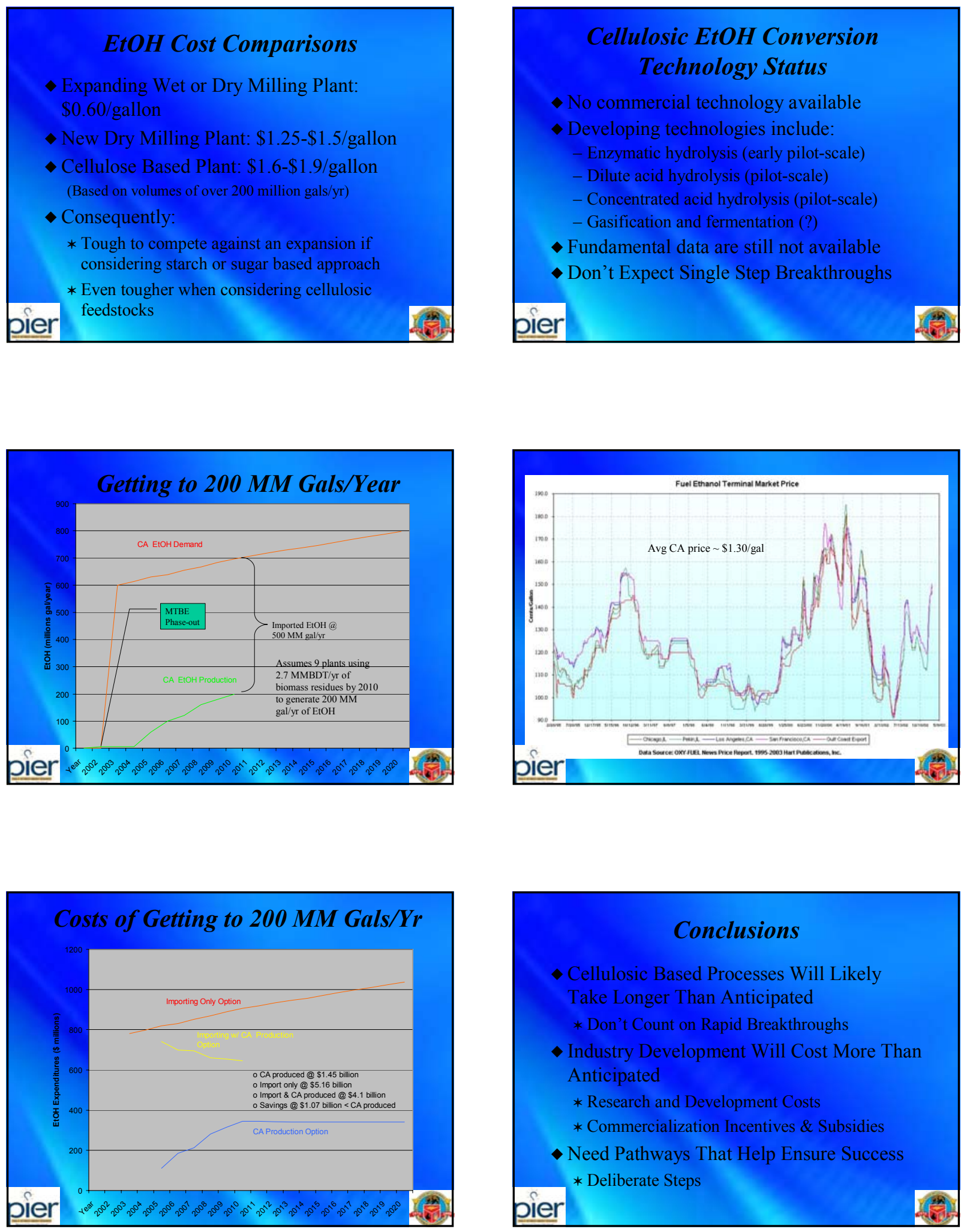


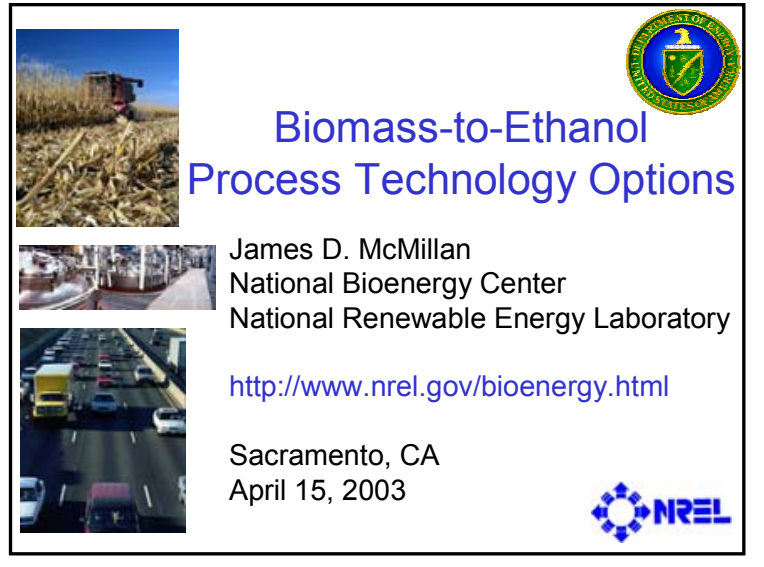

\section{Biomass Basics}

- Lignocellulosic biomass contains

- 60-70\% carbohydrates, dry basis

- Major components are cellulose, hemicellulose, and lignin

- Biomass types exhibit differences in

- Macro structure and cell wall architecture

- Types and levels of lignins and hemicelluloses

- Types and levels of minor constituents
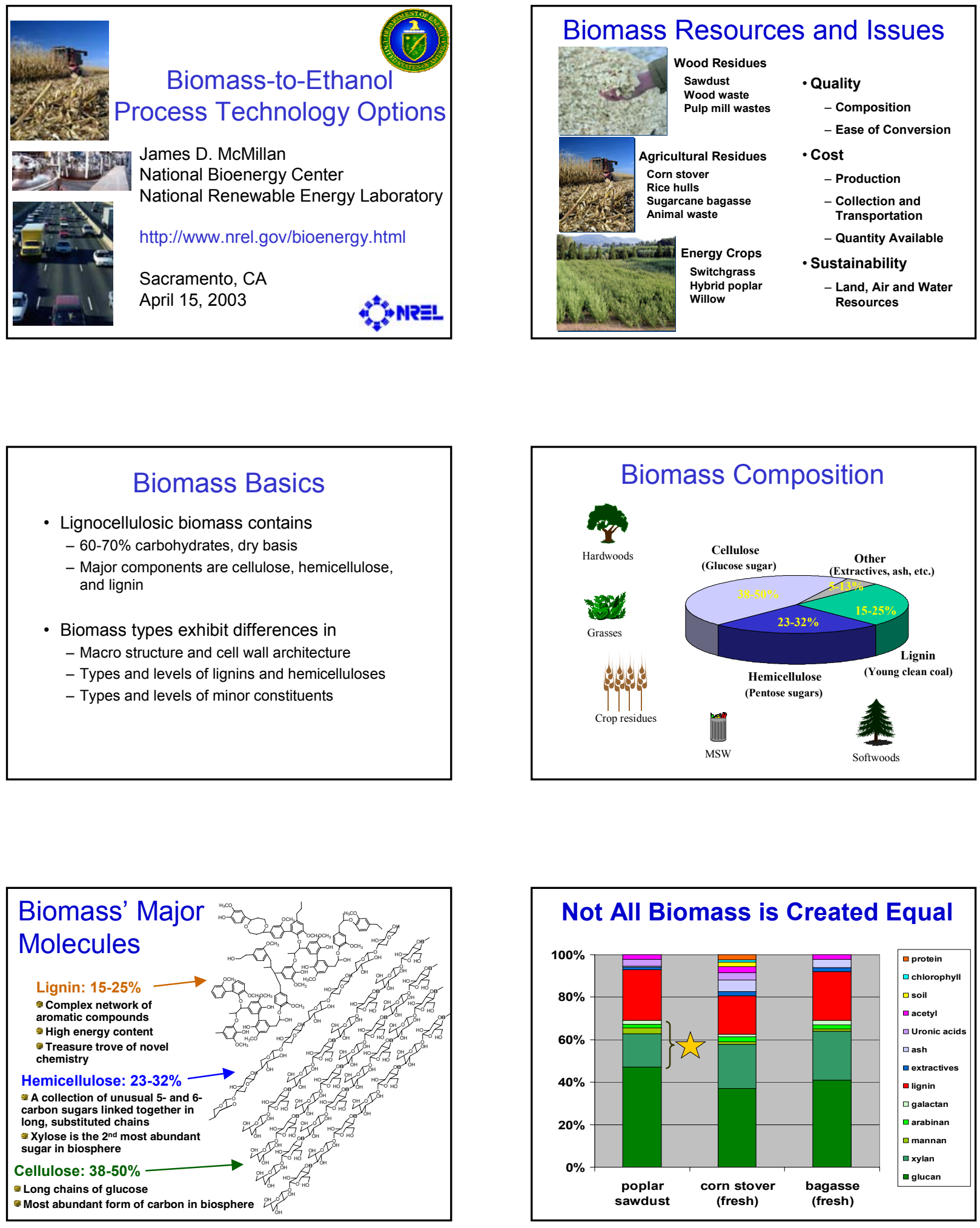

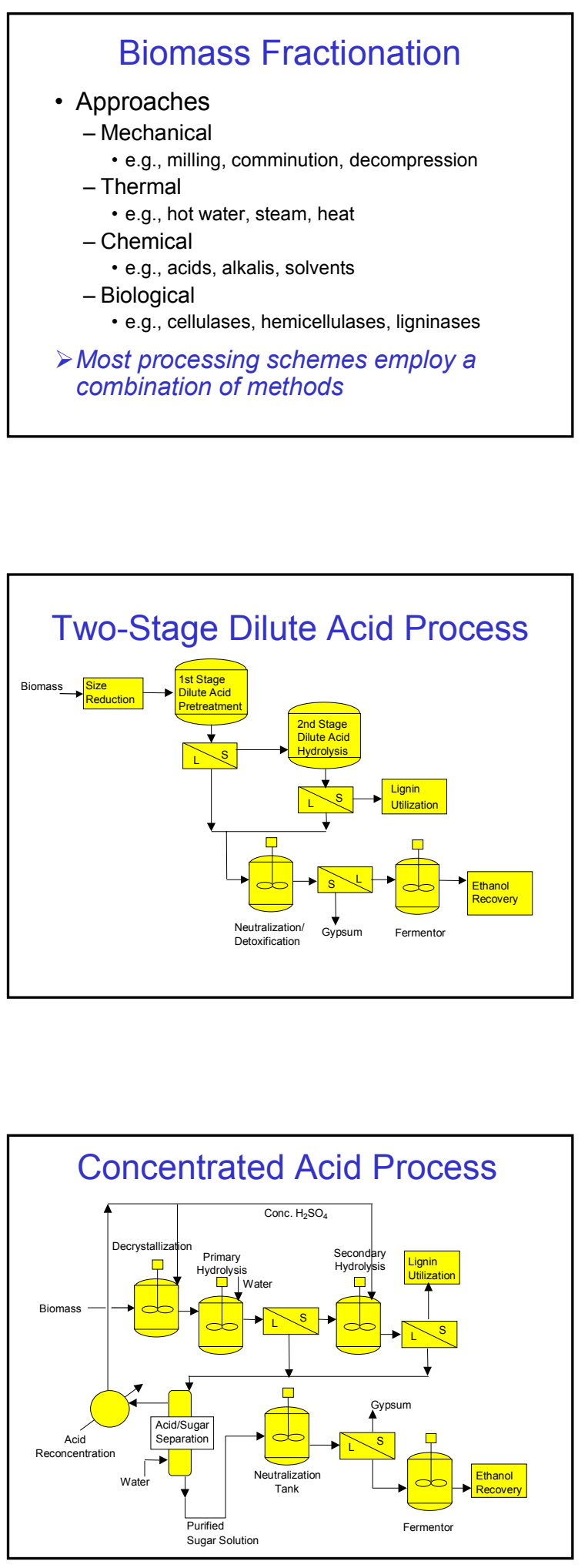

\section{Process Technology Options}

- Major categories of biomass conversion process technology

- Sugar Platform

- Dilute acid cellulose conversion

- Concentrated acid cellulose conversion

- Enzymatic cellulose conversion

- Using any of a variety of different primary fractionation or "pretreatment" methods

- Syngas Platform

- Gasification followed by synthesis gas fermentation

\section{Dilute Acid Hydrolysis}

- Driving Forces

- Adapt existing infrastructure, use recycled equip.

- Exploit recombinant fermentation technology for hexose and pentose sugar conversion

\section{- Strengths}

- Proven: oldest, most extensive history of all wood sugar processes, with the first commercial process dating back to 1898 .

- Active Companies/Institutions include

- BC International

- Swedish government

\section{Concentrated Acid Process}

- Driving Forces

- Cost effective acid/sugar separation and recovery technologies

- Tipping fees for biomass

- Strengths

- Proven: large scale experience dates back to Germany in the 1930s; plants still may be operating in Russia today.

- Robust: able to handle diverse feedstocks

- Active Companies include

- Arkenol

- Masada Resources Group 


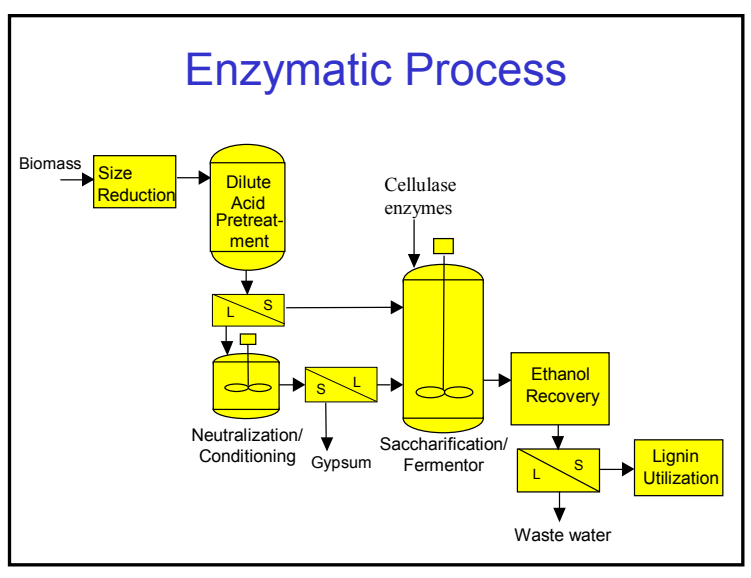

\section{Enzymatic Hydrolysis}

- Driving Forces

- Exploit lower cost cellulases under development

- Conceptually compatible with many different fractionation/pretreatment approaches

- Strengths

- Potential for higher yields due to less severe processing conditions

- Focus of USDOE's core R\&D

- Active companies include

- logen/PetroCanada, BC International, SWAN Biomass, and many others, including some of the recent Bioenergy Initiative solicitation awardees

\section{Syngas Fermentation}

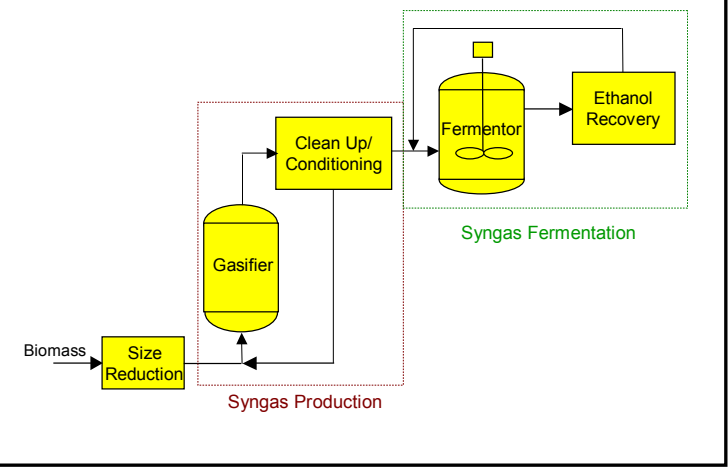

- Bacterial fermentation of $\mathrm{CO}, \mathrm{CO}_{2}$ and $\mathrm{H}_{2}$ to ethanol

$$
\begin{aligned}
& 6 \mathrm{CO}+3 \mathrm{H}_{2} \mathrm{O} \longrightarrow \mathrm{C}_{2} \mathrm{H}_{5} \mathrm{OH}+4 \mathrm{CO}_{2} \\
& 6 \mathrm{H}_{2}+2 \mathrm{CO}_{2} \longrightarrow \mathrm{C}_{2} \mathrm{H}_{5} \mathrm{OH}+3 \mathrm{H}_{2} \mathrm{O}
\end{aligned}
$$

- Syngas fermentation strains and processes remain relatively poorly characterized compared to other routes; many issues need to be resolved

- Overall process economics

-Required performance targets for

- Gasification, e.g., yield = f(gas mixture)

-Syngas fermentation, e.g., ethanol prod. yield, titer, and rate

\section{Syngas Fermentation Process}

- Driving Forces

- While unproven, may enable higher yields through conversion of non-carbohydrate fractions (e.g., lignin) to syngas components

- Strengths

- Build off previous gasification/clean up knowledge

- Ability to process a diverse range of feedstocks to a common syngas intermediate

- Active groups include

- Bioresource Engineering Inc.

- Oklahoma State, Mississippi State

\section{Challenges to Efficient Process Development}

- Processing at high solids levels

- Understanding process chemistries

- Closing carbon, mass \& energy balances

- Requires accurate measurement/analysis methods

- Identifying critical process interactions

- Integration efforts must focus on key issues

- Producing realistic intermediates and residues

- Essential to evaluate potential coproduct values 

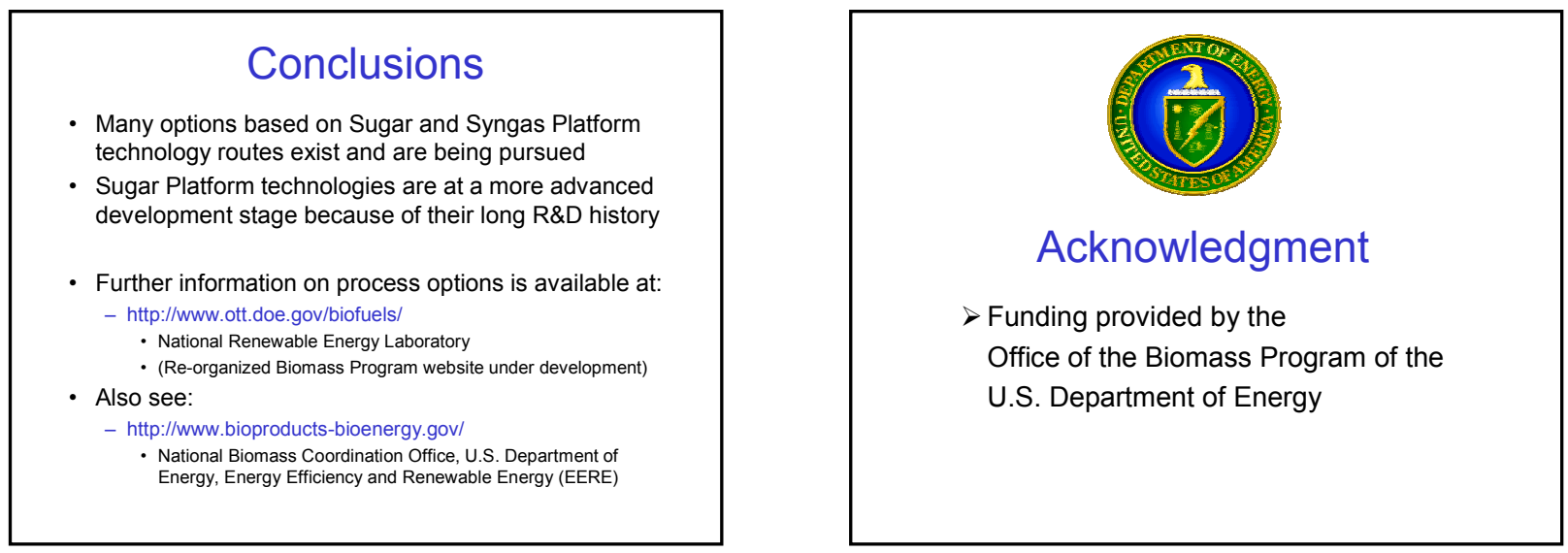

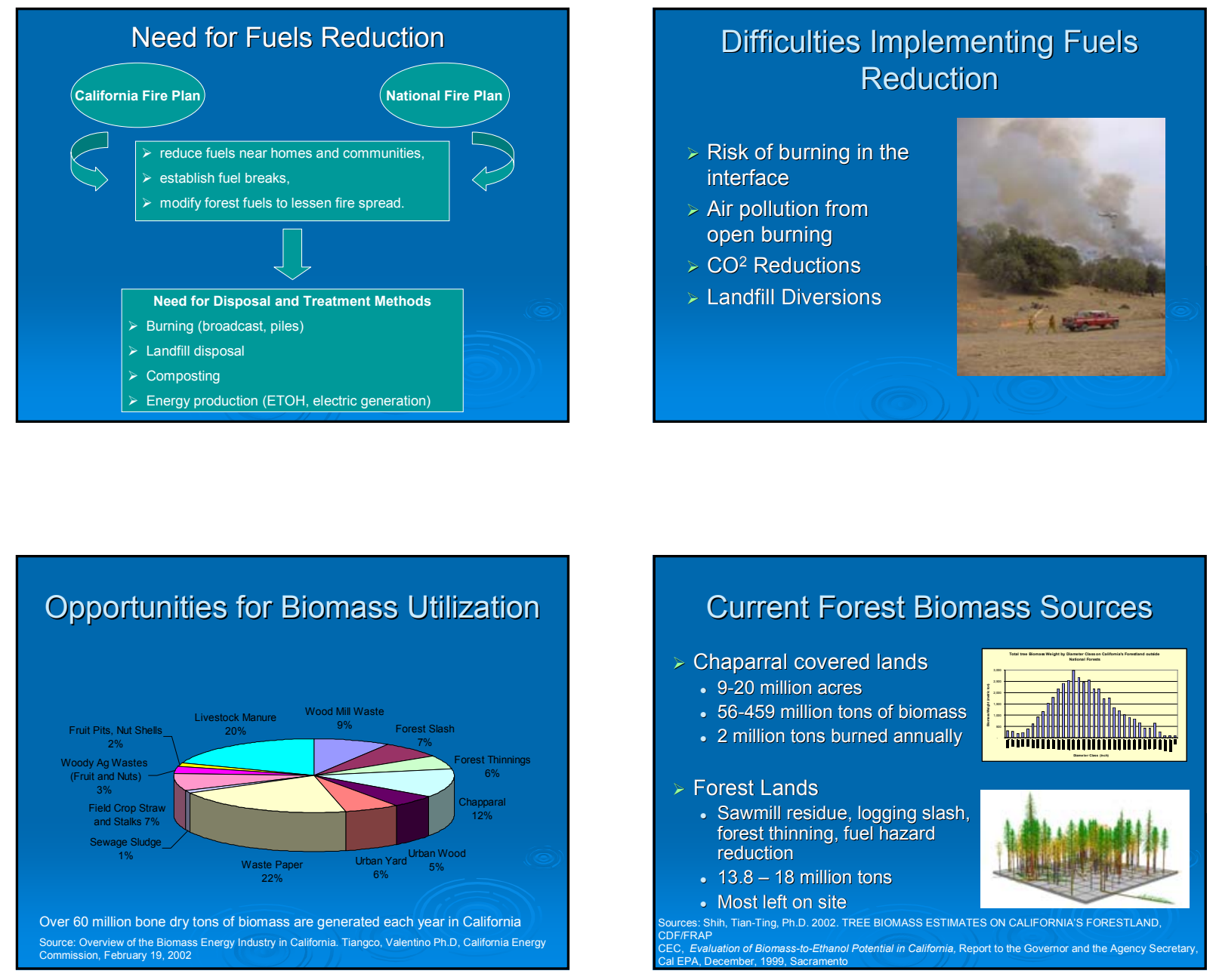

\section{Opportunities for Fuels Reduction}

> Timber Harvest Residues

- From timber harvesting

- Low potential for burning due to current high level of utilization

$>$ In-forest Residues

- From fuels reduction

- High potential for increased usage as biomass

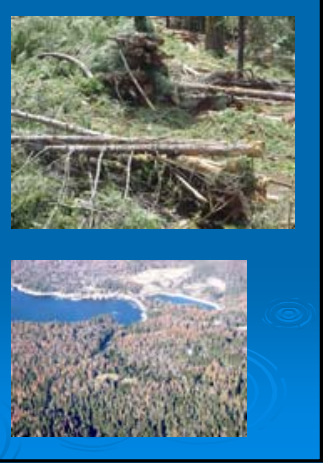

Current CA Woody Biomass Supply and Use

\begin{tabular}{c|c|c|c|c|}
$\begin{array}{c}\text { Waste } \\
\text { Source }\end{array}$ & $\begin{array}{c}\text { Gross } \\
\text { Production } \\
\text { (MM BDT/yr) }\end{array}$ & $\begin{array}{c}\text { Current Use } \\
\text { (MM BDT/yr) }\end{array}$ & $\begin{array}{c}\text { Est. } \\
\text { Fuailable } \\
\text { (MM BDT/yr) }\end{array}$ \\
\end{tabular}

\begin{tabular}{|l|c|c|c|c|}
\hline Lumber Mill & 5.5 & 1.75 & 3.25 & 0 \\
\hline Forest Slash & 4.5 & 0.25 & & 2.5 \\
\hline Forest Thin. & 3.8 & 0.25 & & 1.4 \\
\hline Urban Wood & 3.2 & 1.0 & 0.5 & 0.7 \\
\hline Urban Yard & 3.9 & 0.2 & 0.5 & 1.2 \\
\hline
\end{tabular}




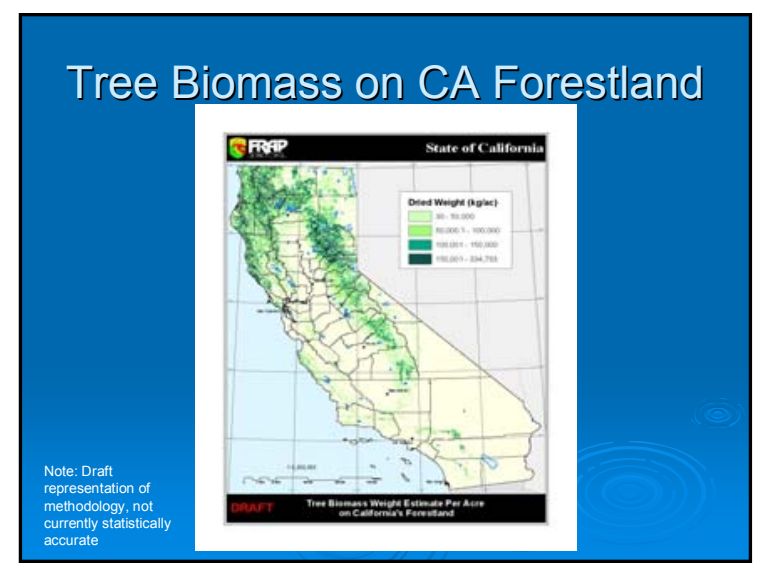

\section{Barriers to Fuels Reduction}

Technological Barriers:

Cost to chip, deliver, store, and

handle woody biomass

Efficiencies of DE equipment

Institutional Barriers:

> Non-standardized grid access

Monopoly practices by utilities

Emissions standards

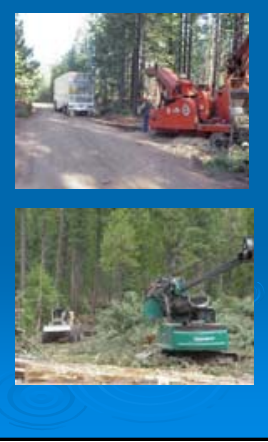

State Renewable Energy Legislation

State Renewable Energy Goals

SB 1078 Renewable Energy Portfolio Standard - Mandates 20\% renewables by 2017

SB 1038 - Funding of Renewable Portfolio

Standard and Public Interest Energy Research

- Funding existing and emerging renewable resource technologies

$>$ AB 58 - Net metering interconnection deadlines - Extend net metering terms to installations completed by $9 / 30 / 2003$

\section{Biomass Energy Capacity}

$>$ Large Scale Generators

- 35 plants $-685 \mathrm{MW}$ generating capacity

- Many under short-term contracts, thru 2002

- No long-term security

Small Scale Generators

- Distributed Generation

- Typically $5 \mathrm{KW}-5 \mathrm{MW}$
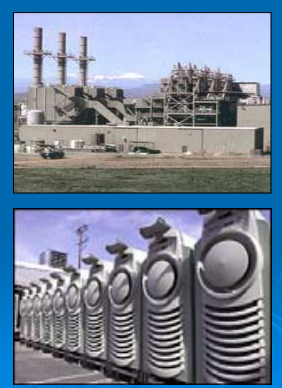

Ethanol as an Gasoline Oxygenate

$>$ MTBE to be phased out as an oxygenate in 2003

December 31, 2003 ethanol will be only approved oxygenate per ARB

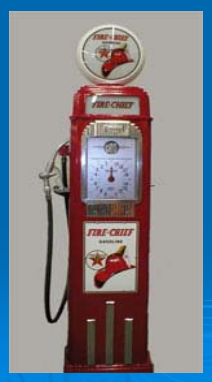




\section{Washington Ridge Bio-Energy Project}

... will construct, install operate and maintain

innovative biomass/energy

conversion equipment so as

to economically and

environmentally

demonstrate that the

utilization of forest fuels can

provide employment and

business opportunities

through the appropriately

scaled production of energy.

Public Cooperators

- Sierra Economic Development Distric

CA Department of Forestry \& Protection

$>$ Califomia Youth Authority

- USDA Forest Service

N. Sierra Air Quality Management District

County of Nevada

Dire Safe Council of Nevada County

Private Cooperators

Chiptec Wood Energy Systems

Capstone Turbine Corporation

Foresters Co-op
Washington Ridge Bio-Energy Project

Location: Washington Ridge Conservation Camp Nevada County, California

Specs: $\quad$ 5MM-BTU/Hr Chiptec Gassifier

Three $30 \mathrm{~kW}$ Capstone Turbines

Fuel: $\quad 3000$ BDTs Biomass

Goal: For the Camp to operate independent of the grid

Offset: $\quad \$ 50,000$ Electricity (annually) $\$ 17,000$ Propane

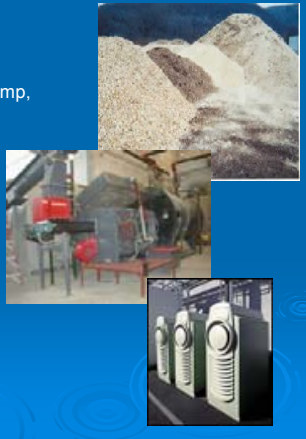

Washington Ridge Bio-Energy Project

Future opportunities

Over forty conservation camps

in California

Typically in rural setting near biomass supply

Generally reliant on a costly and oftentimes unreliable energy supply

> Workforce available on site

Fleet of 229 Engines, and an equal amount of administrative vehicles.

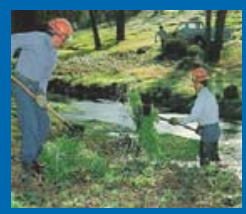

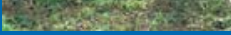

Bio-Energy or Ashes

Whether Ethanol, Biodiesel, Minor Products, or Biomass to Electricity -

Forest biomass must be managed to maintain Forest Health and reduce Fire Hazard.

Utilization of forest wood waste adds to the local economy (jobs - product)

Co-benefits such as water quality, wildlife habitat biodiversity, and recreational opportunities depend on maintaining good forest health

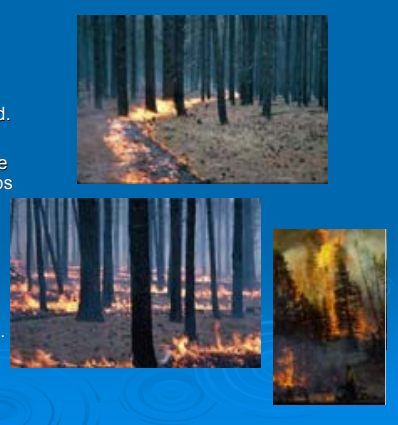




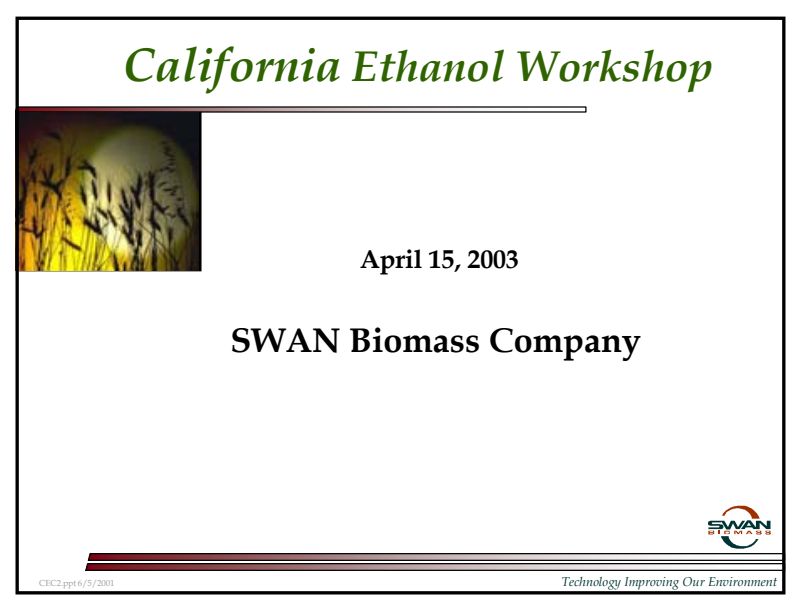

\section{SWAN Business Model}

- Licensing of Technology Package

- Internally developed technology

- Predictive process modeling

- Sublicensing of third party technology

- Structure to Support Concurrent Projects

\section{Project Stakeholder Groups}

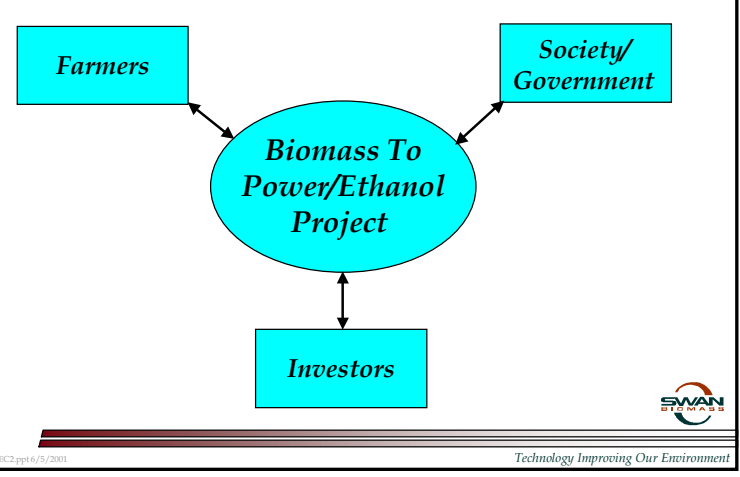

\section{Acknowledgments}

- Examples, analyses based on Imperial Valley energy crops, biomass wastes

- Information on wastes applicable to most of California

- Valuable contributions from:

- Trisha Ferrand, Imperial Valley Economic Development

- Paul Sebesta, UC Desert Research Extension Center

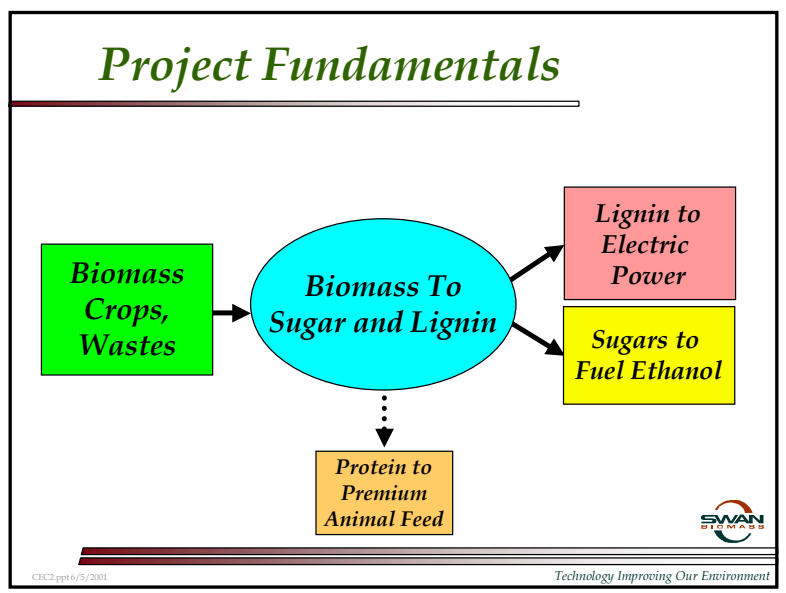

\section{Stakeholder Satisfaction}

\section{- Investors}

- Rates of return matching financial risks

- Large investments, lower transaction costs

- Availability of facility management services

- Public benefit element in projects

- Defined exit strategy

- Biomass to Power/Ethanol Facilities

- SWAN restructuring business strategy to meet investor needs 

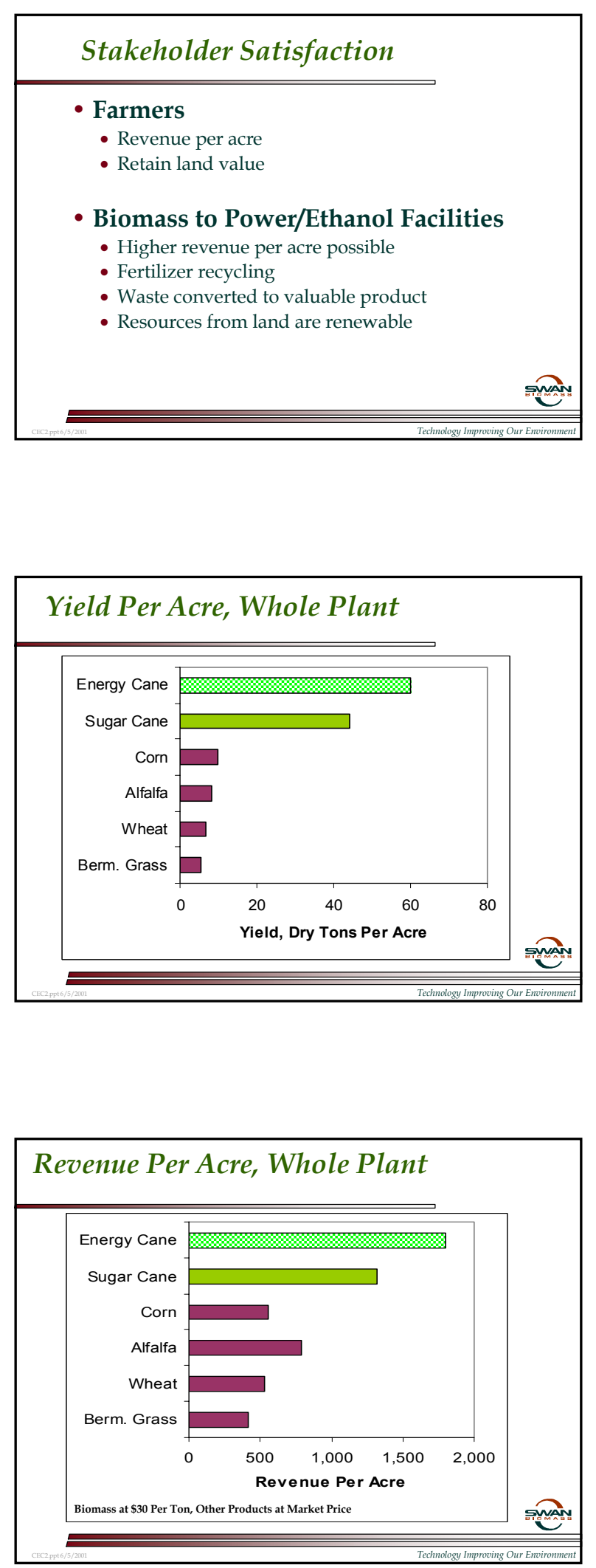
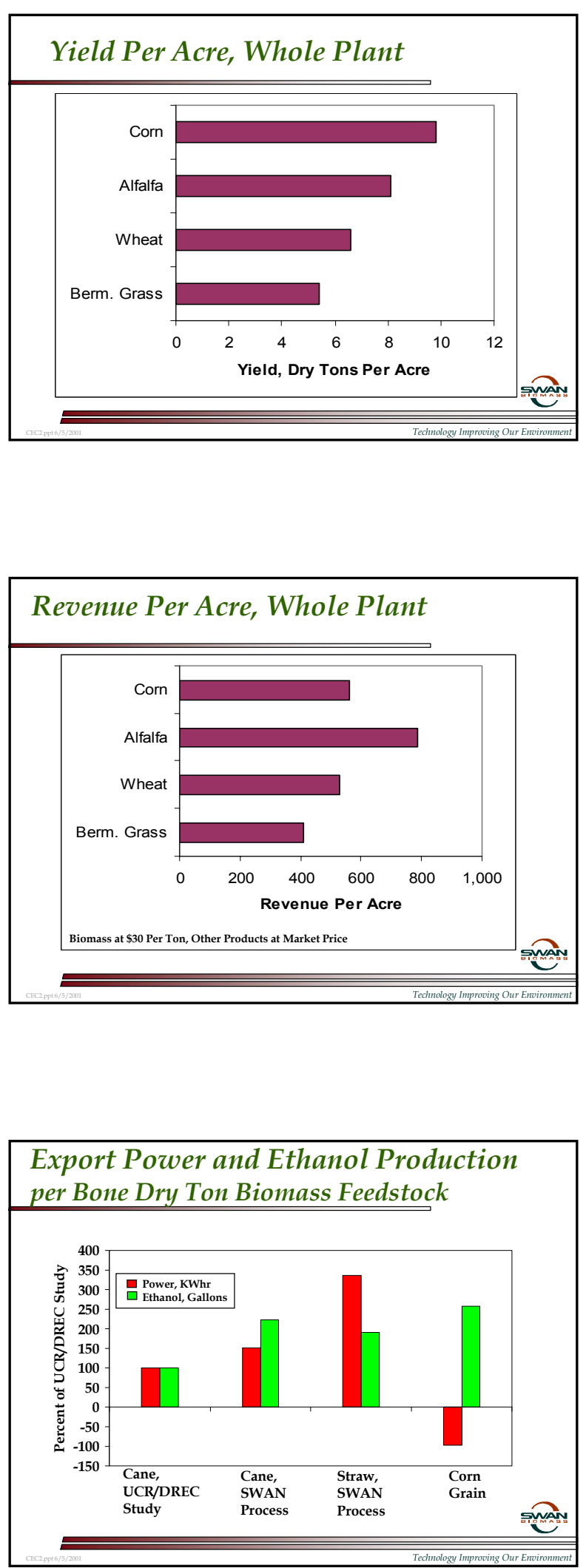


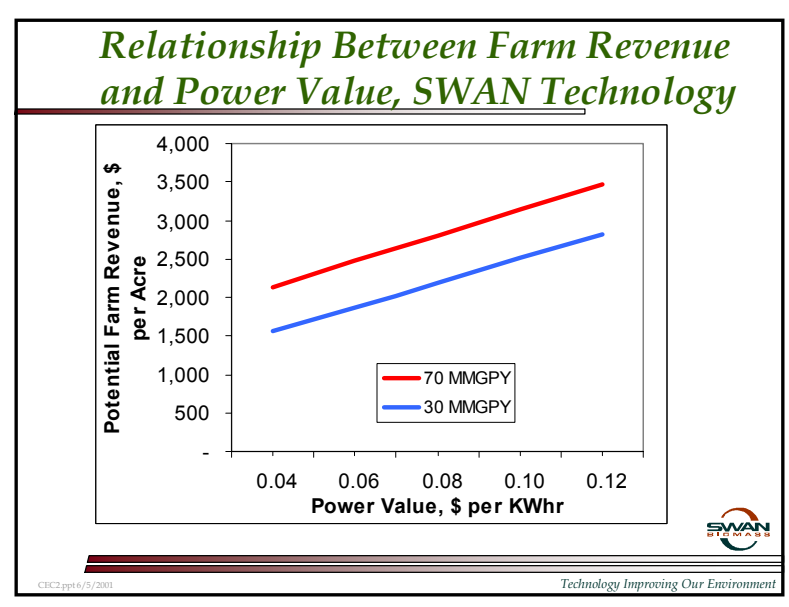

\section{California Potential -- Imperial Valley}

- Industry Producing

- 2.2 Billion gallons per year fuel ethanol

- 1,500 Megawatts export power capacity

- 12,800 Gigawatt-hrs generated power

- Economic Development

- \$6 Billion investment

- 12,400 new jobs

- \$8 Billion per year economic activity

Water Productivity, Export Power and Fuel Ethanol Co-Products

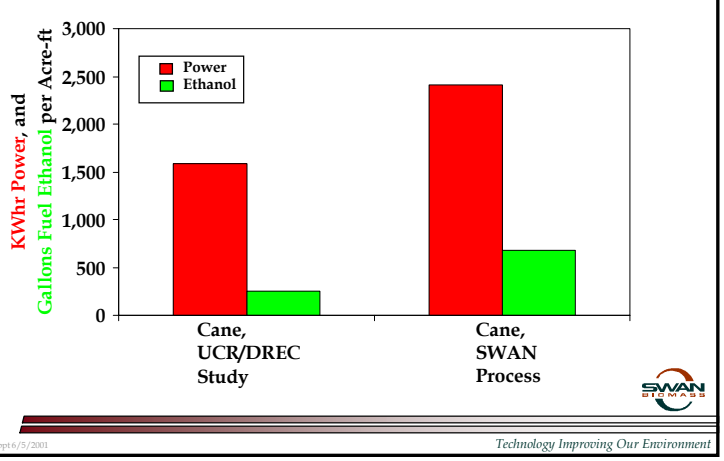

\section{Stakeholder Satisfaction}

- Society/Government

- Improved air, water quality

- Increased power supplies, lower cost

- Increased employment, economic development

- Increased use of local, renewable resources

- Biomass to Power/Ethanol Facilities

- Meet these society/government needs

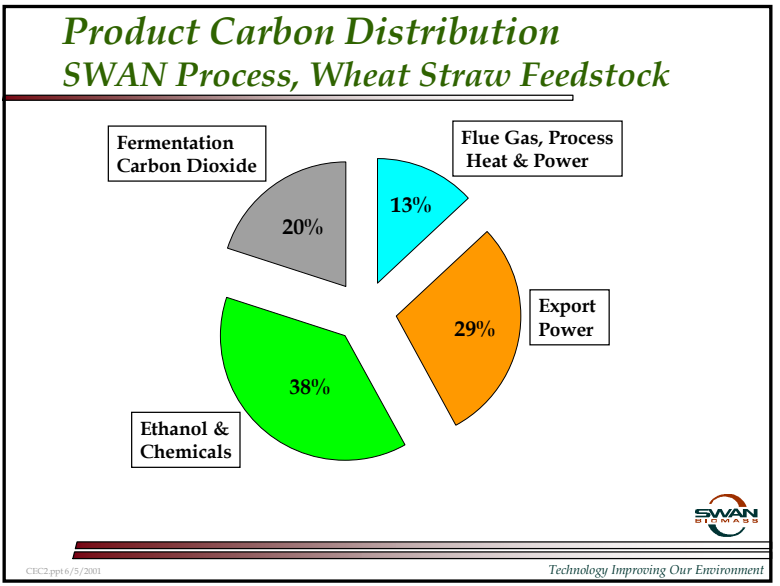

Power Value Effect on Project Profits SWAN Technology

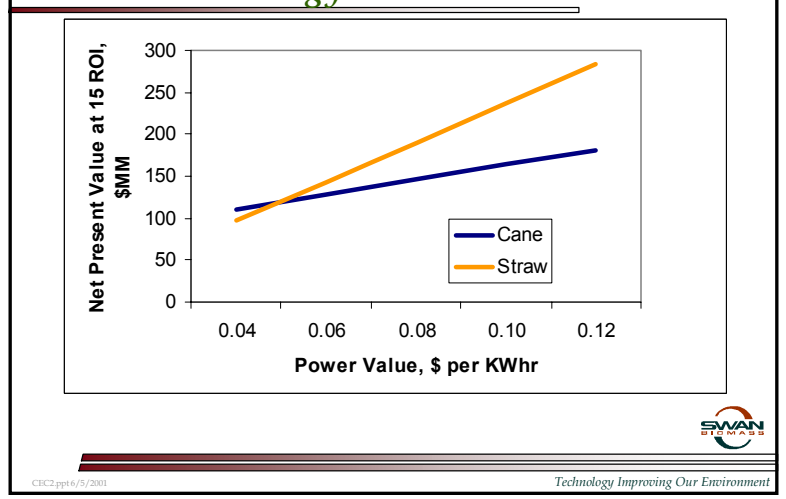



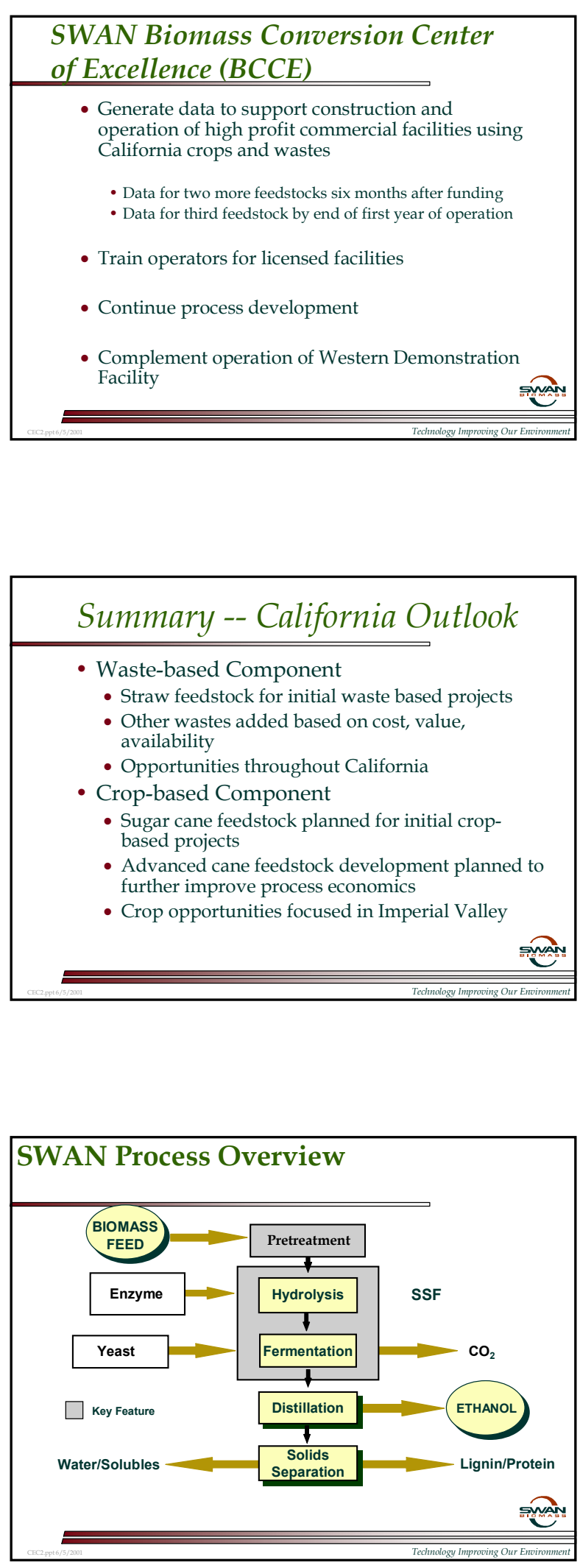

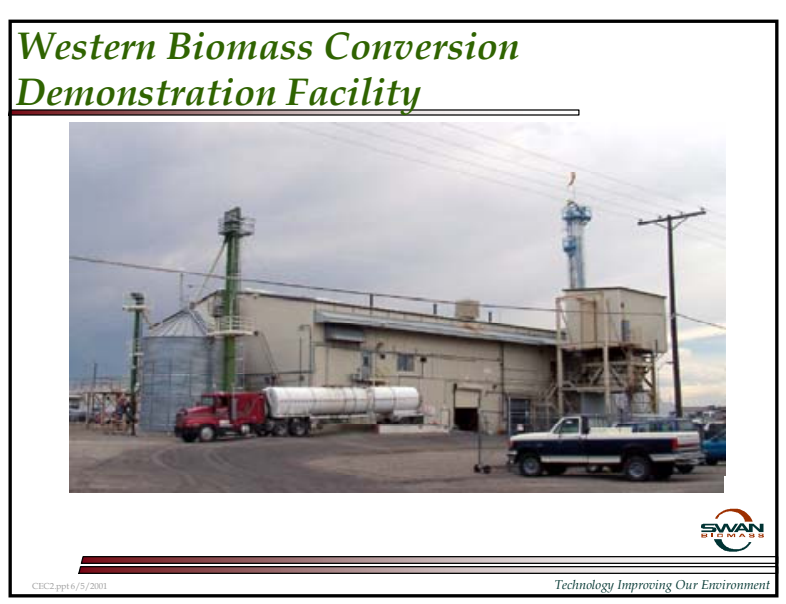

Backup Slides

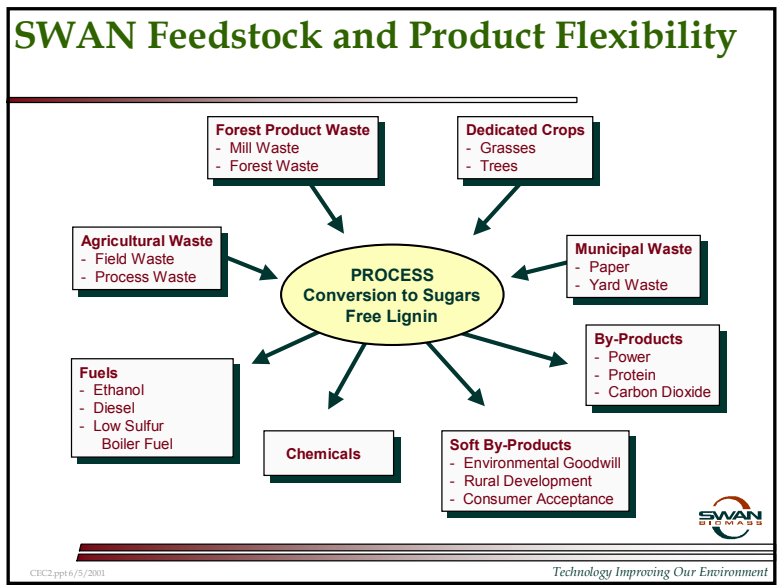



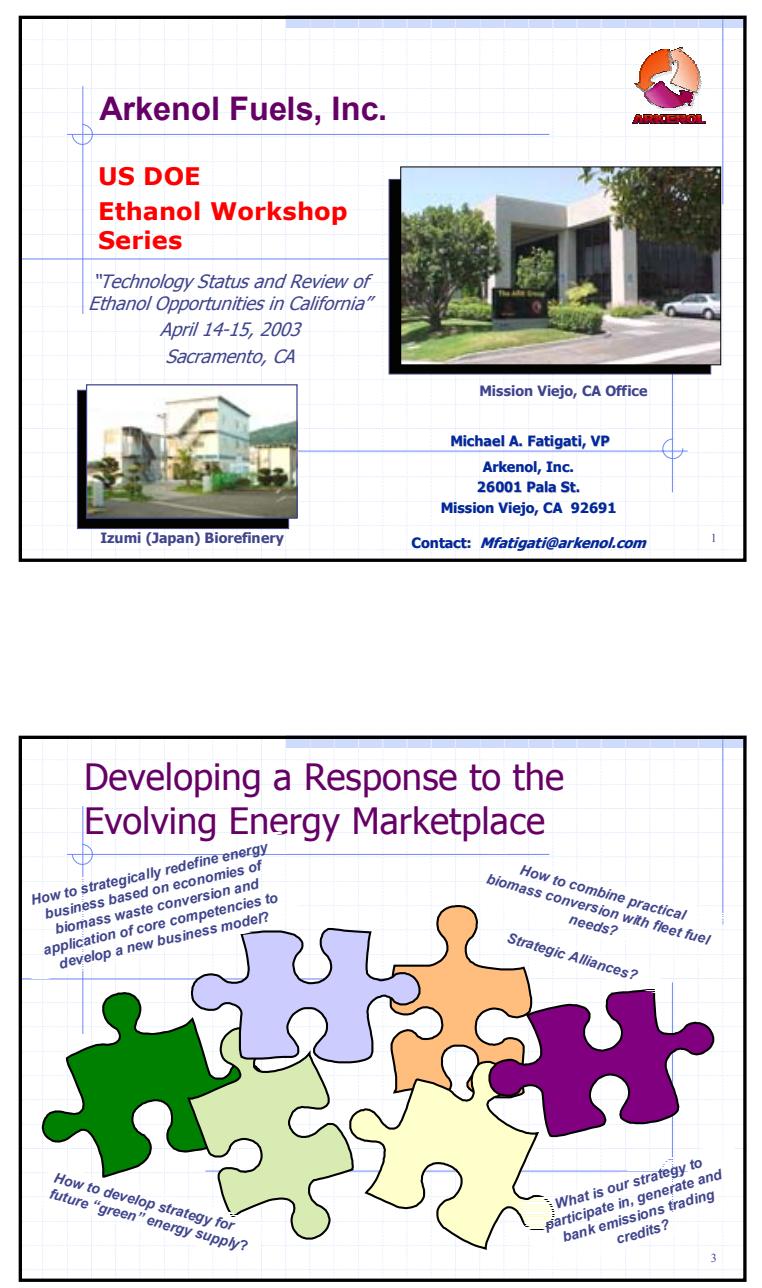

A solution......

"Arkenol Fuels, LLC."

Vision Statement

"To become a world-class producer and supplier of renewable liquid fuels by the production of ethano from opportunist
generated by utility and municipal sources."

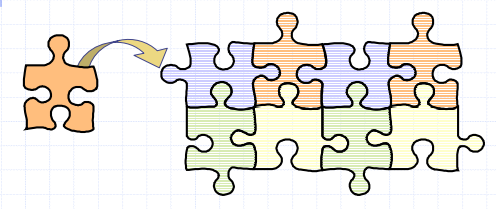

The Opportunity for Ethanol Production a Basis for a Business

State Level

- Large transportation fuel market (some estimates for demand at 900 MGPY of

ethanol!)

- Current in-state ethanol production limited, dependency upon imports

Grain feedstock production limited - tied to total livestock available - Traditional grain-to-ethanol depends upon sale of DDG's - Current pricing level of DDG's in CA can offset costs of transportation of Midwest grain. Displacement of grain blends for beef, dairy, swine, poultry suggests upper level of

- In-state production opportunities exist from use of indigenous biomass waste In-state p pd

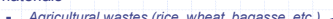
Agricultural wastes (rice, wheat, bagasse, etc.) — Available, but not financeable Forest thinnings

Sorted MSW

Note: 17,000 TPD of sorted MSW and green waste are dumped into the Puente Hills landfill (operated by LA Sanitation District), representing the potential production of $650 \mathrm{MGPY}$ of fuel ethanol from this resource alone.
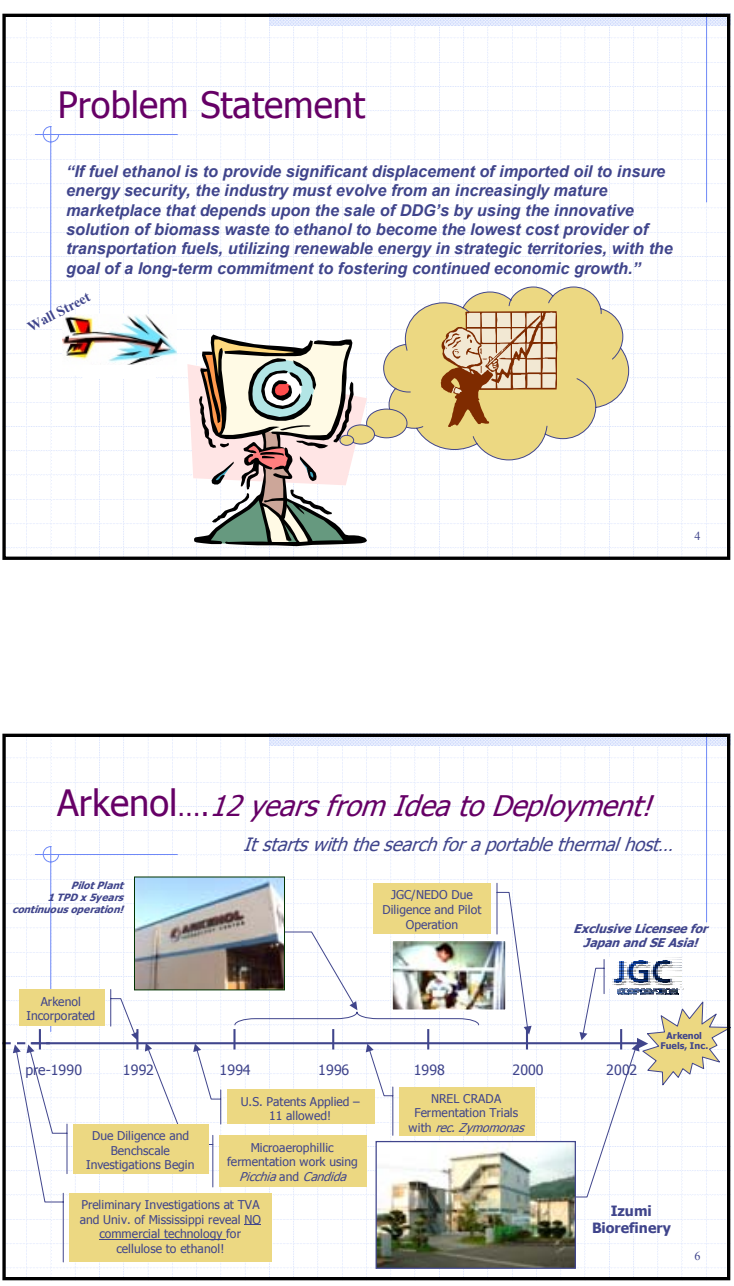

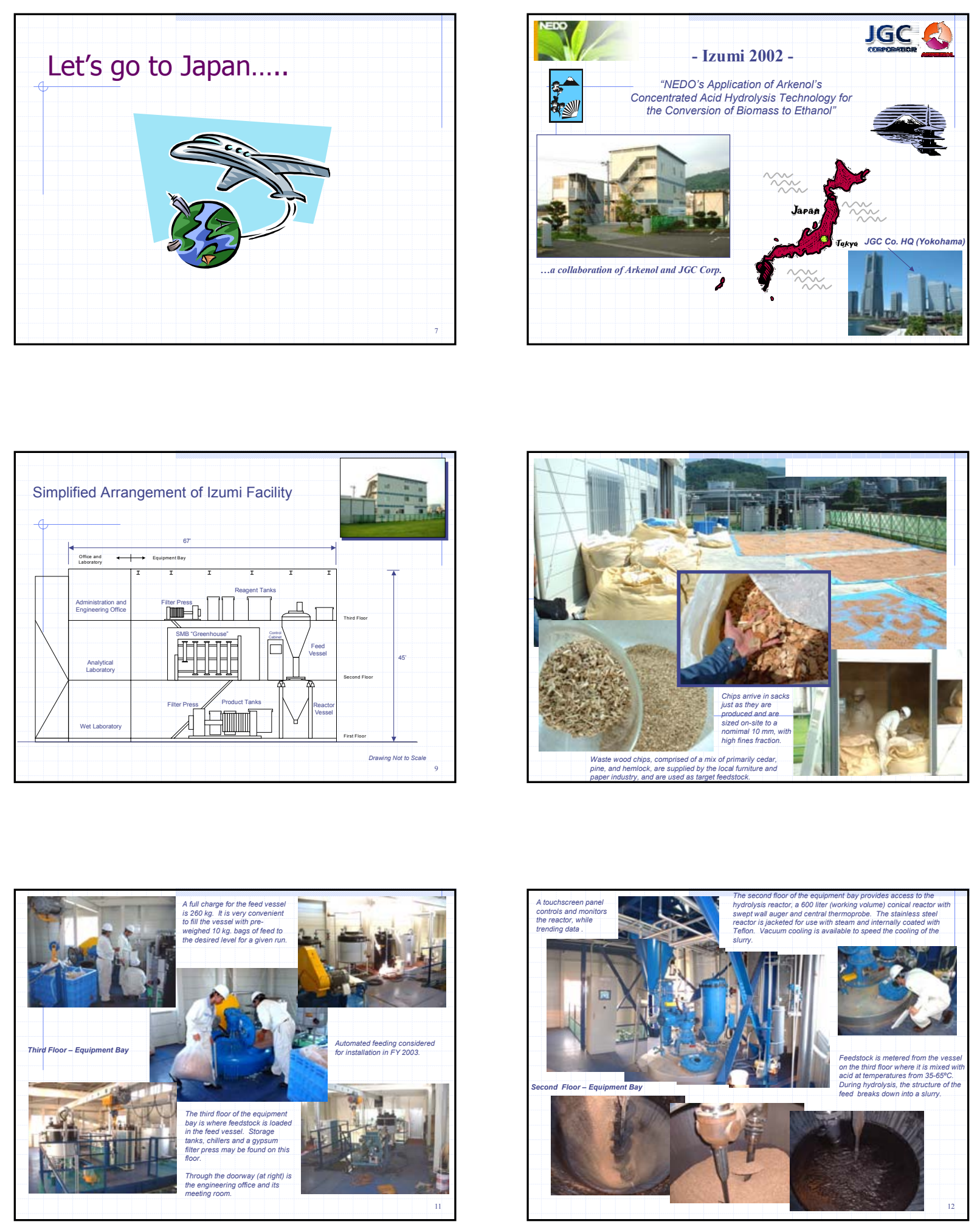

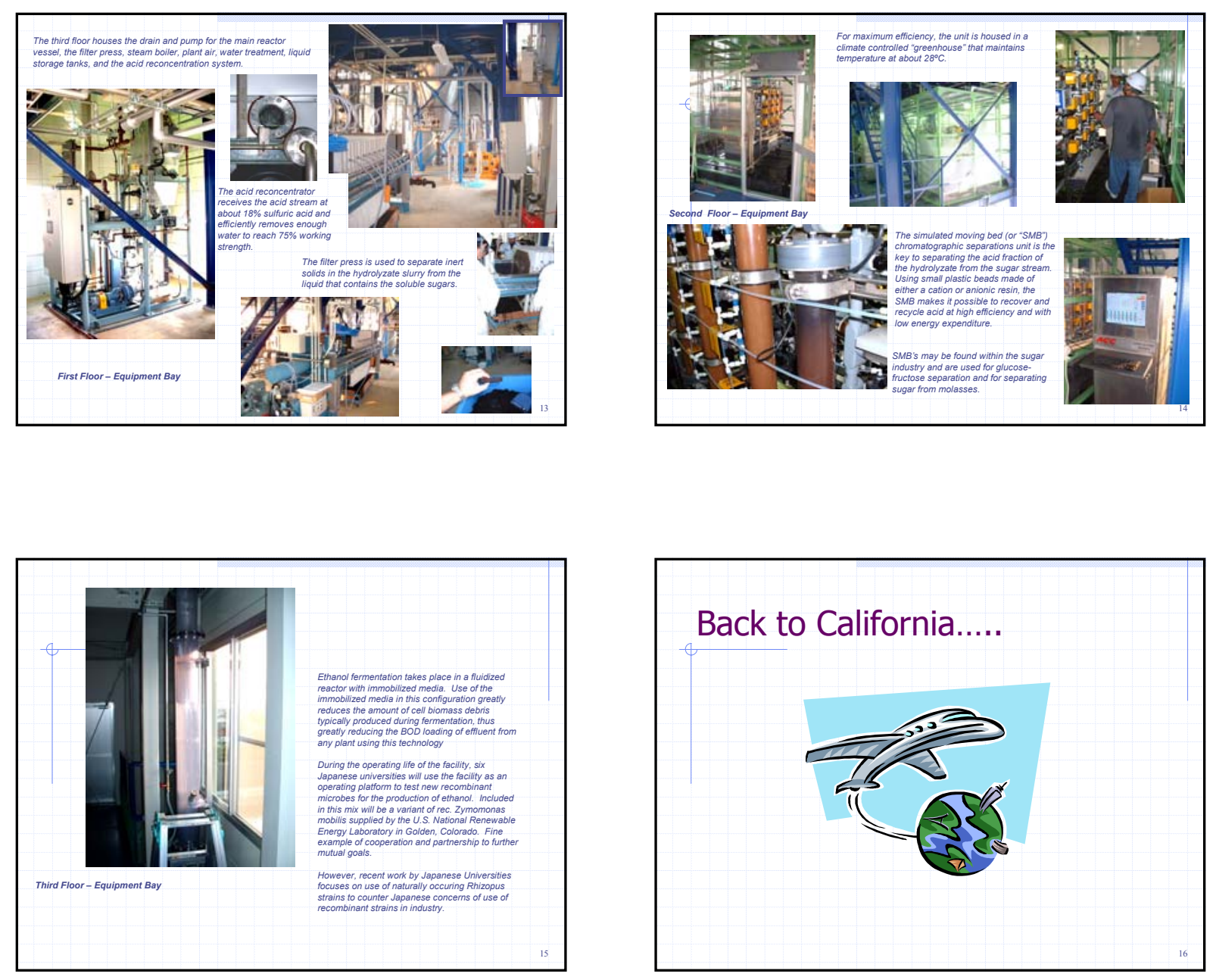

\section{Back to California.....}

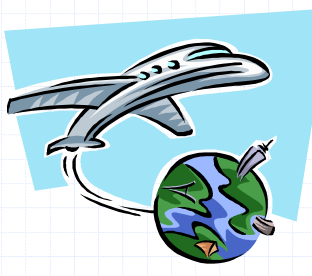

Project Development Considerations for Future Ethanol Production in California

- Air Quality Offsets

- Little to no availability of NOx and VOC credits in most jurisdictions. - Estimated costs of offsets for a typical 40 MGPY grain-to-ethanol plant is \$5-7 million for TO, else at risk from farmers for DDG pricing

- Costs for offsets in Colusa County for a proposed 15 MGPY ethanol facility is in excess of $\$ 3$ million - for TO, else same DDG risk.

- Zoning

- Risk of challenge if project seen as controversial $=$ time $=$ money!

- Potential need to rezone to M1 even for ag-related uses in ag zones.

- Requirement for rezoning possible if MRF-related uses within MRF boundaries.

- Time (...is money!)

roval process requires outlay of capital at risk for preliminary engineering and processing of permit approvals well in advance any significant project financing.
Our History of Ethanol Project Development Experience in California

- Permitted a rice straw-to-ethanol plant (1995) - Reviewed and approved by the CEC as part of a gas-fired cogeneration - Sunk costs for permitting in excess of $\$ 15$ million : Swenson havku biome e reservation.
: Vernal pools, fairy shrimp mitigation : Vernal pools, fairy shrimp miti - Emissions offsets purchases

- Funded county requests for expansions to infrastructure such as park and fire Plant not built - economics of building the combined facility were overwhelmed by
cost of conditions imposed by State and County. Inability to satisfy requirements of funding sources for feedstock contracts

- Contracts/LOl's for commitments with individual farmers to supply $120 \%$ of required rice straw deemed worthless after "investing" over $\$ 1$ million with ag consultants - not considered financeable by banking institutions. - Existing product off-take terms for ethanol not considered sufficient for project financing by non-grain, non-Midwest 


\section{Improve the process....}

Prefer single-point contact for permitting, coordination state and local requirements.

- Coordinated zoning designation for ethanol facilities - in 1995, the proposed rice straw-to-ethanol facility, adjoining a power plant, was characterized as a 'heavier' industrial use requiring additional time/money for rezoning.

- Infrastructure needs of facility require proximity to natural gas, water, power, transportation modes.

- Studies show that typical feedstock transportation costs become unattractive at a 15 mile radius from the plant, and untenable at a 50 mile radius.

- Joint powers authority formation to insure credit worthiness of feedstock supplier.

\section{Where Are Project Siting Opportunities?}

Locations in territories with abundant feedstocks, particularly those associated with tip fees.

Locally produced fuel ethanol in major transportation fuel markets outside cornbelt!

Any city or country with a population of 250,000 or more sustains feedstock demand.
Some Recommendations for Consideration by State officials*

State MUST play a more active role in developing enabling strategies!

- Possible areas of exploration...

- Capital Gains Tax Cut-establish legislation targeting individuals and institutions making venture capital investments in early stage CA technolog companies.

- Seed Capital Tax Credit- encourage angel investment through tax incentives

- Unused Tax Credits and Losses - establish legislations allowing transfer of unused tax credits and losses from early stage technology companies or investors to other state taxpayers in exchange for funds used for R\&D.

- Establish A Callfornia Seed Fund - many states have already established seed and early stage funding programs economic development purposes,
given the dynamics of the venture capital market.

\section{Summary of First Biorefinery Sizing, Costs, and Potential Returns}

260 TPD Biomass (green waste and waste wood).

6.4 MGPY Ethanol for fuel, with potential for upsizing.

5 to 10 acres (including feedstock storage on site).

- Capex estimated at \$6.50/installed gallon ethanol.

Ethanol produced for sale at \$1.11/gallon.

Tip Fees for greenwaste at \$10+/ton.

$12 \%$ ROE, 10 years

\section{Biorefinery Layout - Plant \#1}

$\sim 260$ TPD of post-recycled MSW processed to 6.4 MGPY fuel ethanol

Competitive tip fees: at or below landfill!

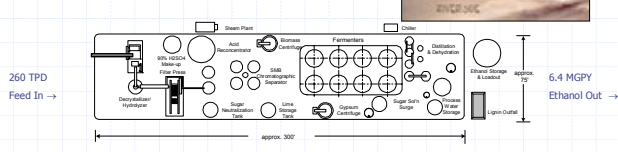

$\sim$ total of 22,500 sq.ft. (not inclusive of tip floors and product loadout)

$\sim$ 3,000 sq. ft. required for admininistrative and labs
Follow-on Biorefinery Sizing \& Costs (suitable as Cogeneration Thermal Host)

500 \& 2000 TPD Biomass (green waste, waste wood and MSW).

- 17 \& 52 MGPY Ethanol for fuel.

5 to 20 acres (including feedstock storage on site).

Cost estimated at between $\$ 3.50$ to $\$ 4.50$ /installed gallon ethanol.

Investment grade returns 


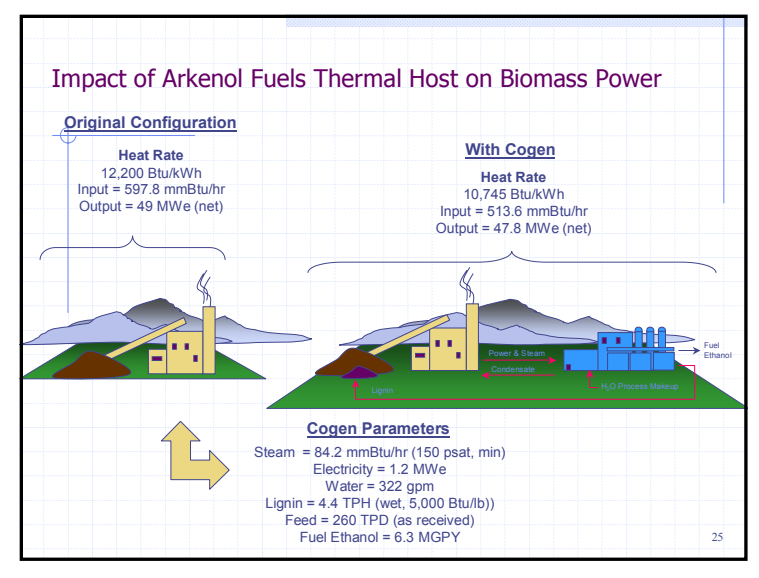

Improvements in Cost of Deployment due to Economies of Scale

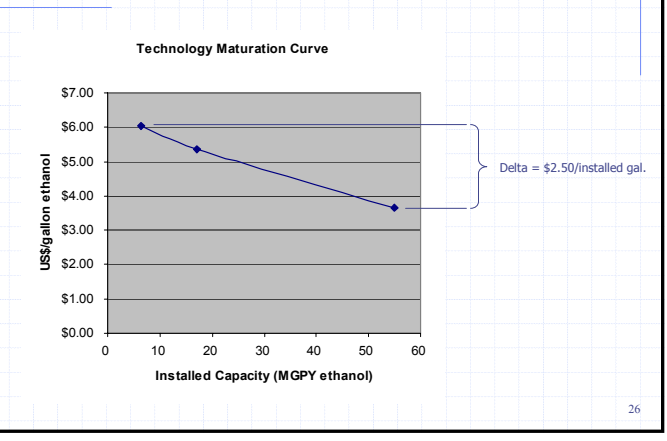

\section{Status of Arkenol Technology}

Ready for commercial deployment.

- Transitioned from batch to continuous mode.

- Exclusive licensee in Japan \& SE Asia - JGC Corporation.

Ongoing discussions with local jurisdictions regarding eco-industrial park concepts in urban setting.

- First commercial plant in Japan scheduled to start construction in March 2004.

13 plants x 5 years at 50 TPD feed planned in Japan.

\section{Special thanks to:}

US Department of Energy

- California Energy Commission

$\diamond$ Clean Fuels Partnership

$\diamond$ BBI Ethanol

Michael A. Fatigati, VP

Arkenol, Inc.

26001 Pala St.
Mssion Viejo, CA 92691

Contact: Mfatigati@arkenol.com 

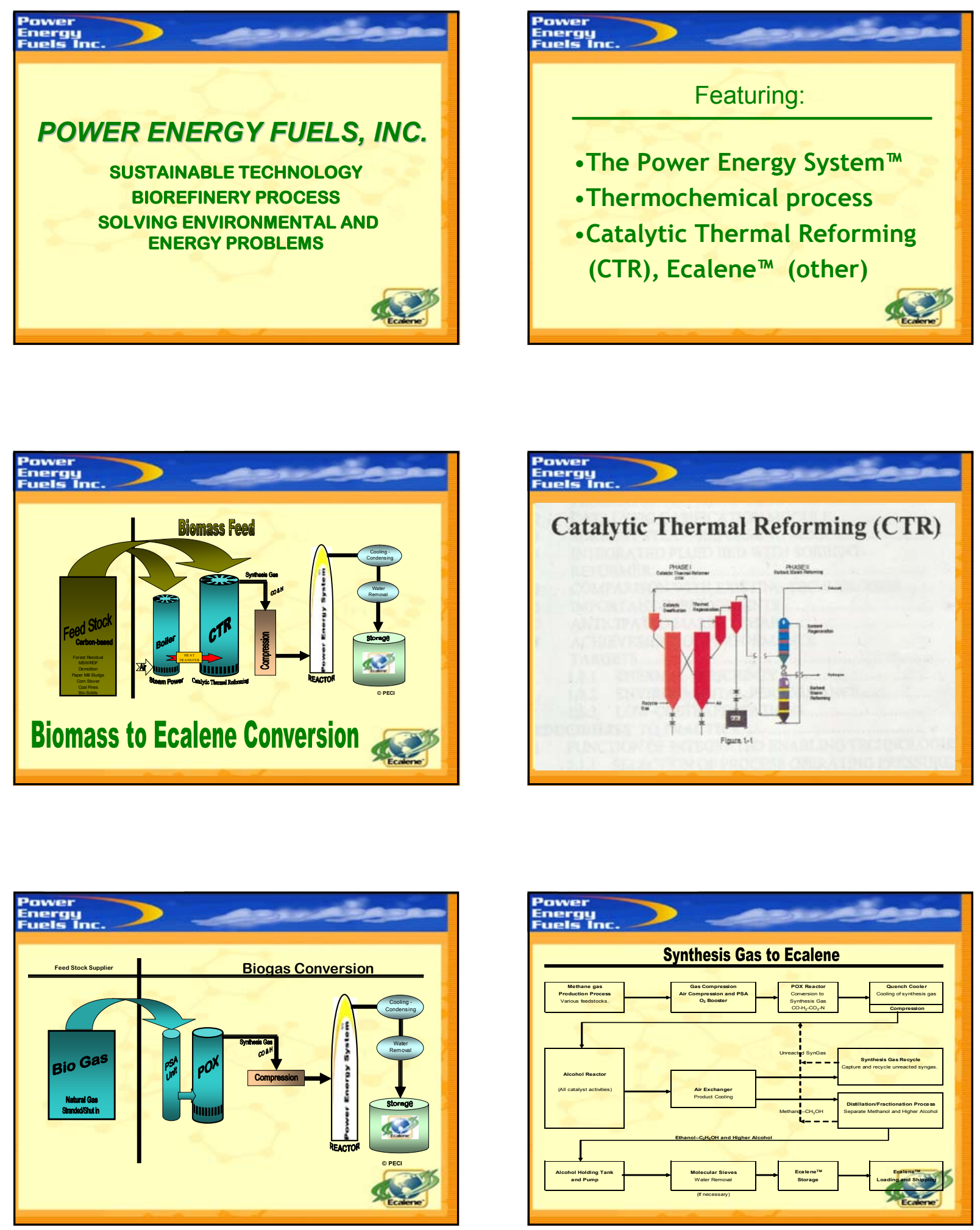

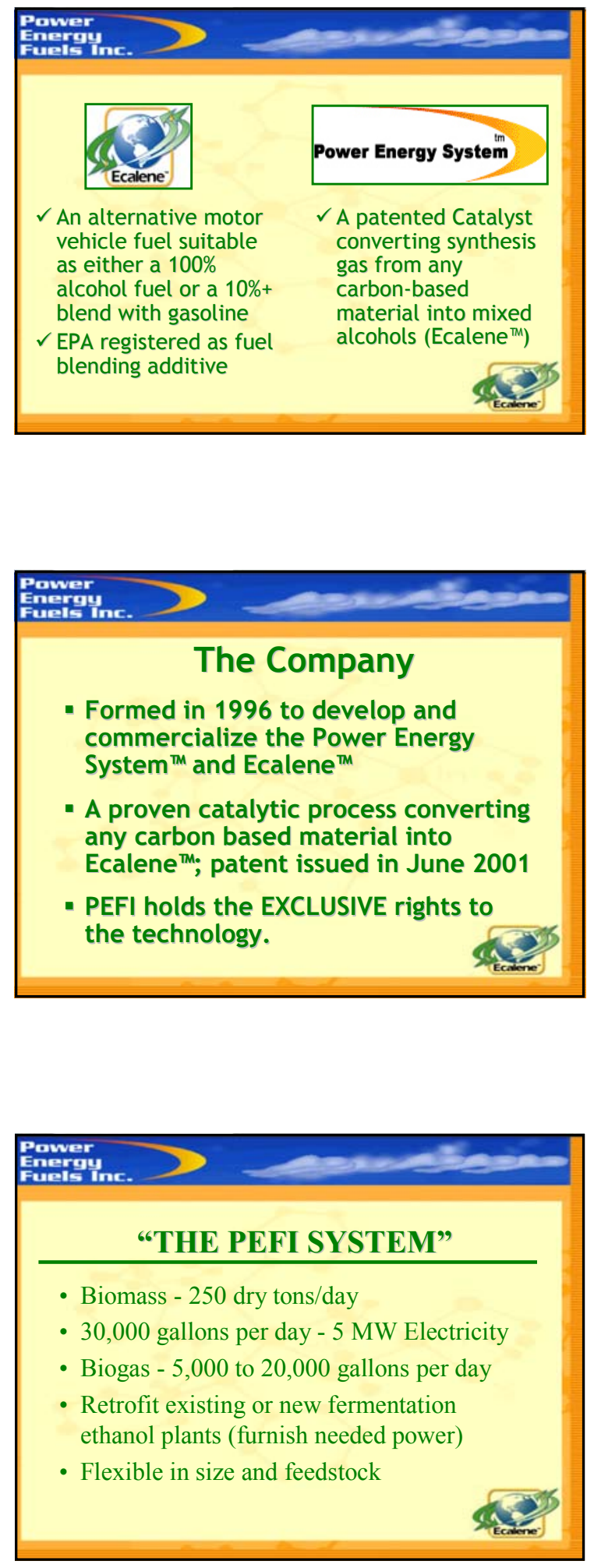
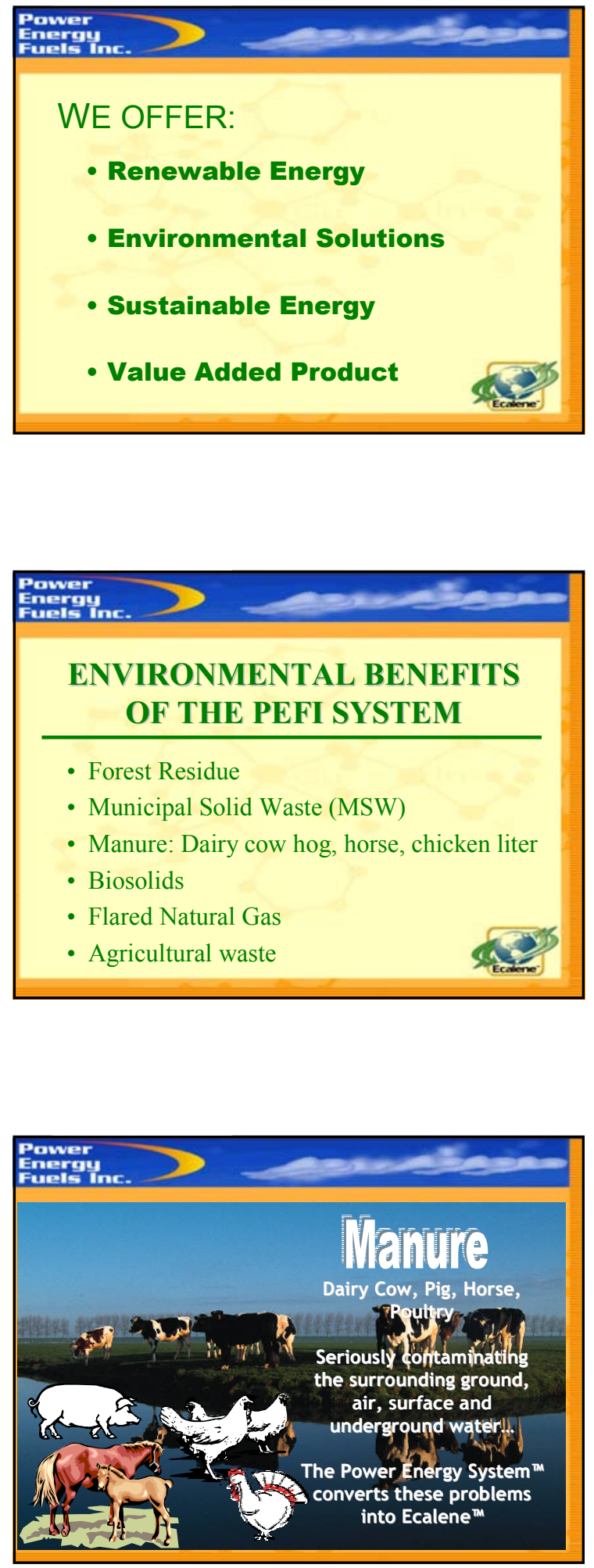

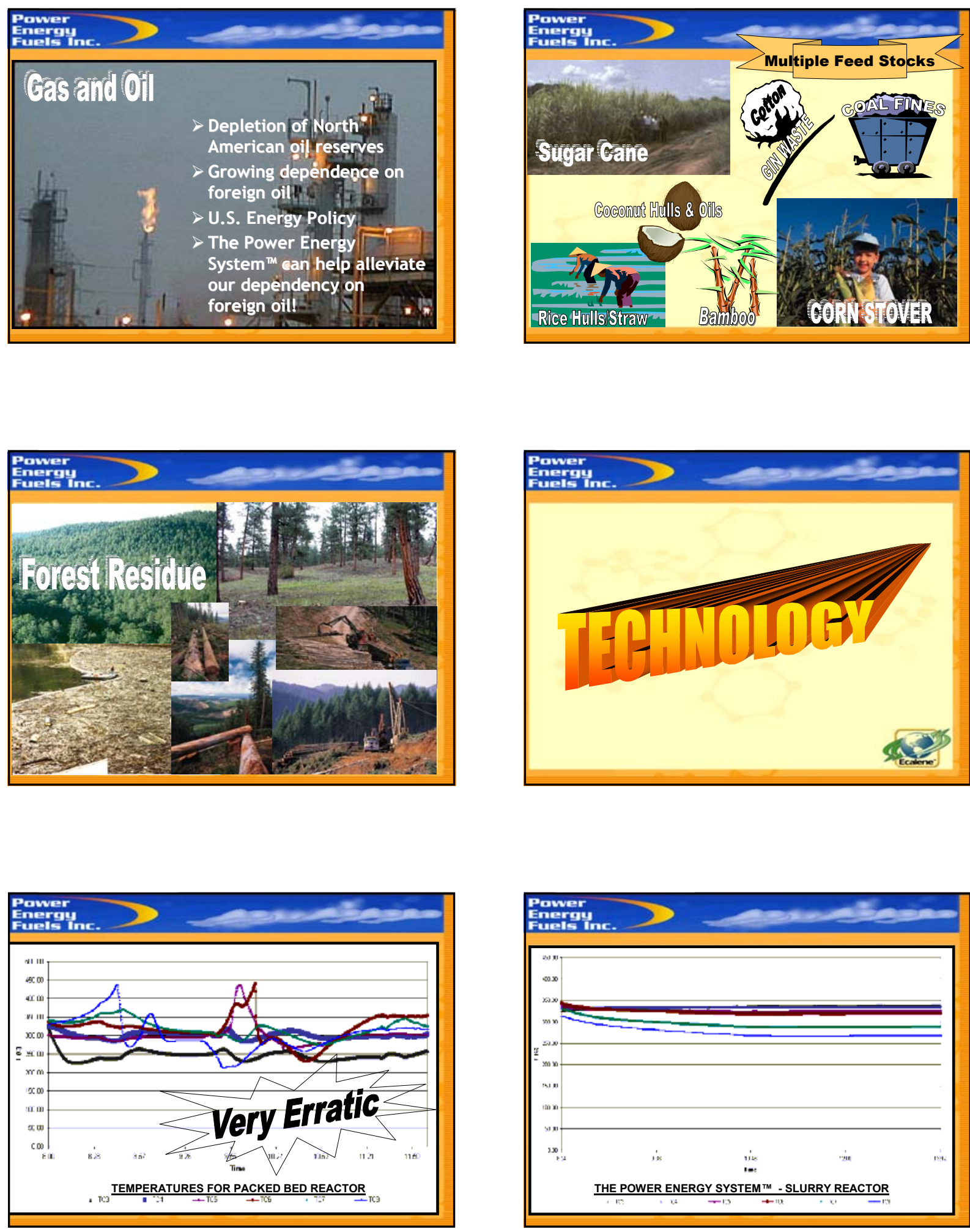


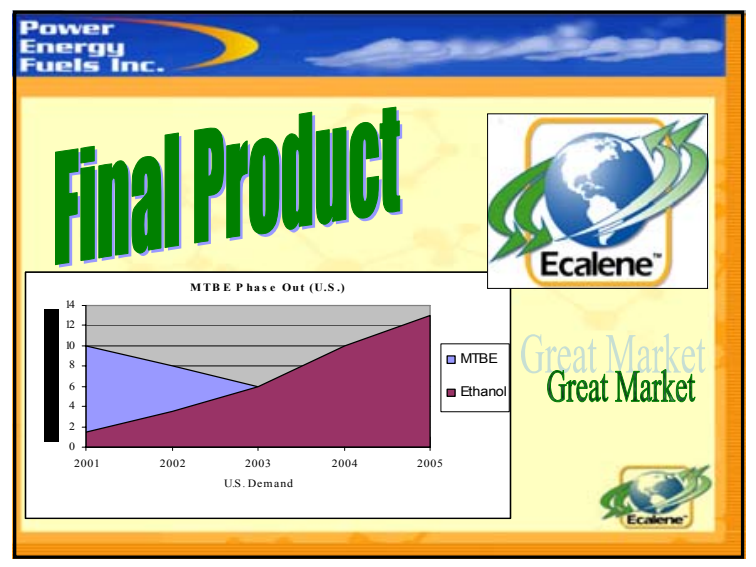

\begin{tabular}{|l|}
\hline Power \\
\hline Energy \\
Fuels Inc. \\
Ecalene \\
- Registered with EPA as fuel additive per 40 CFR 79.23 \\
- Federal registration permits the blending with gasoline in all \\
50 States \\
- Octane rating of 124+ \\
- Adds all oxygen required by Federal law \\
- Can be blended with gasoline or used as straight fuel (E100) \\
- Is an effective replacement for MTBE \\
\end{tabular}

\begin{tabular}{l} 
Pawer \\
Energy \\
Fuers Inc. \\
\begin{tabular}{|l|c|}
\hline \multicolumn{2}{|c|}{ Ecalene $^{\text {TM }}$} \\
\hline Component & Weight \\
\hline Methanol & $25-30 \%$ \\
\hline Ethanol & $45-50 \%$ \\
\hline Propanol & $15 \%$ \\
\hline Butanol & $5 \%$ \\
\hline Pentanol & $3 \%$ \\
\hline Hexanol + & $2 \%$ \\
\hline
\end{tabular} \\
\hline
\end{tabular}
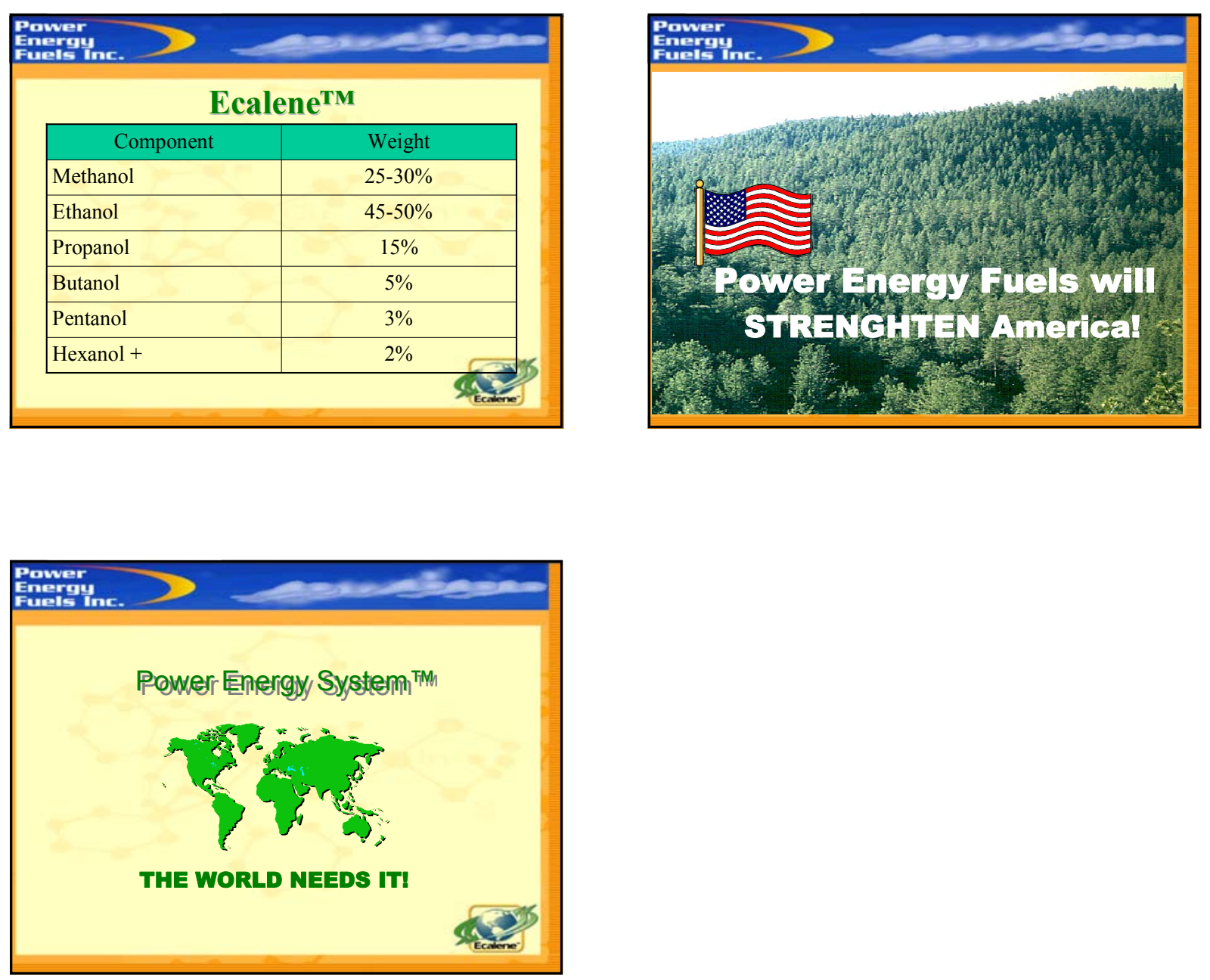

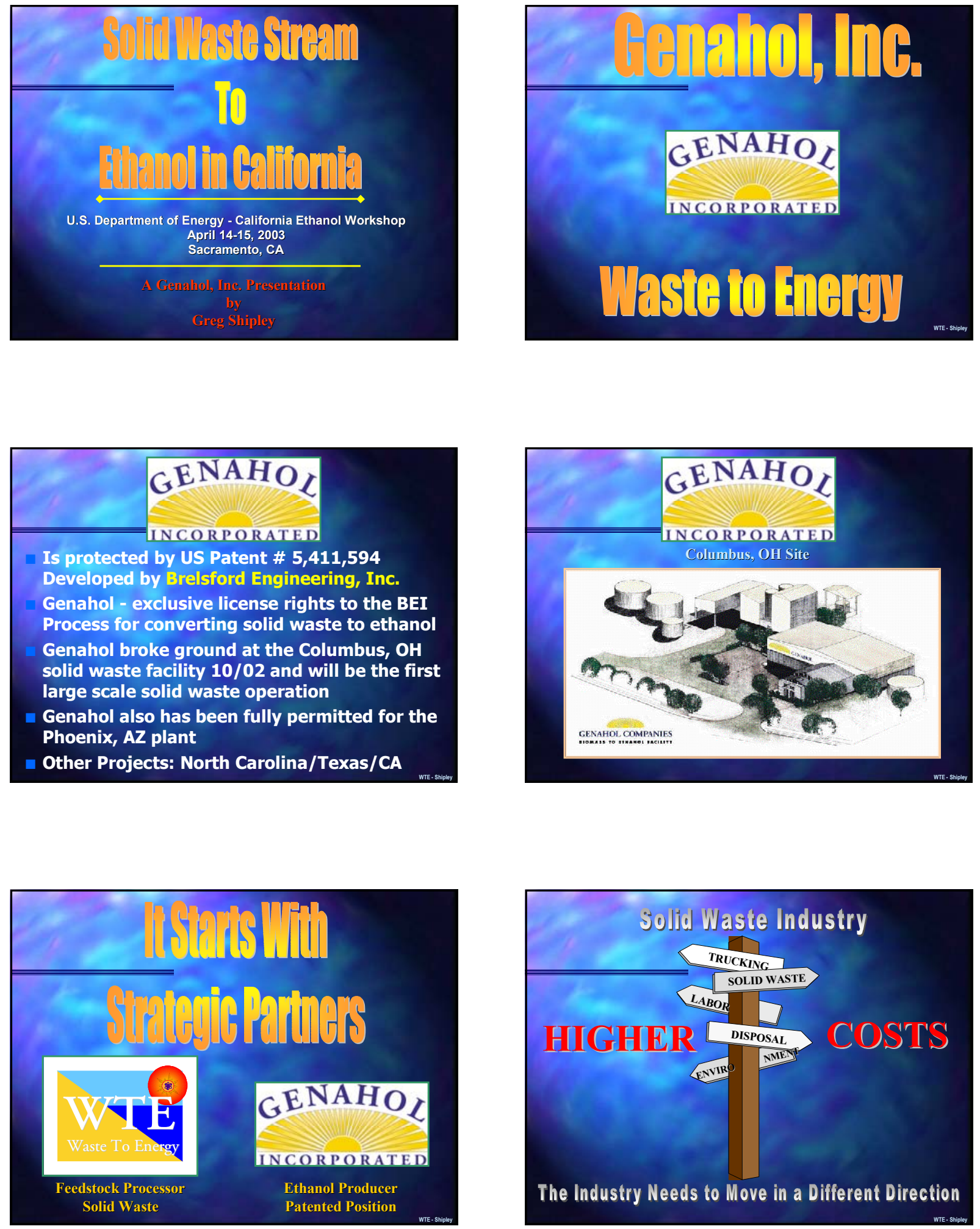

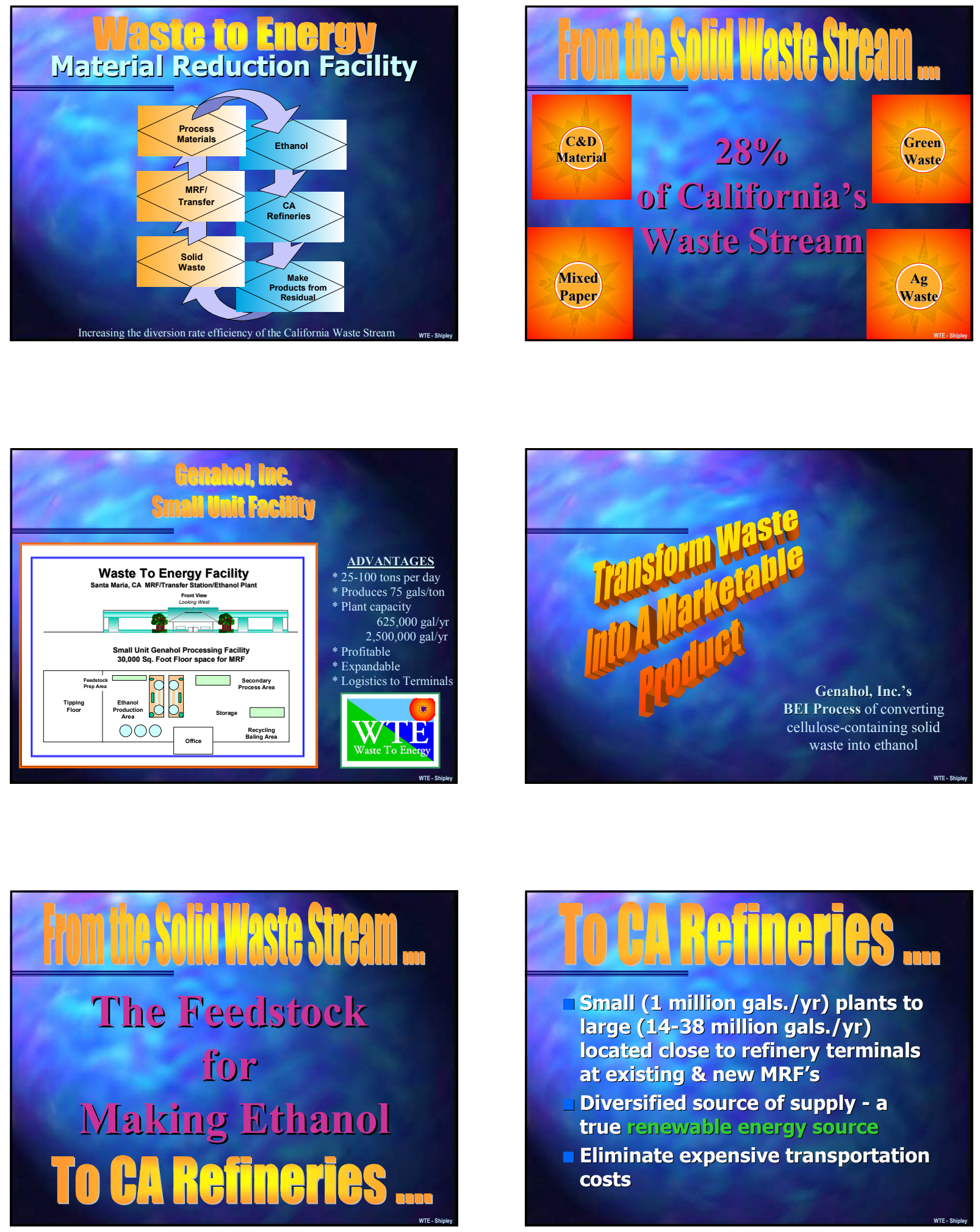

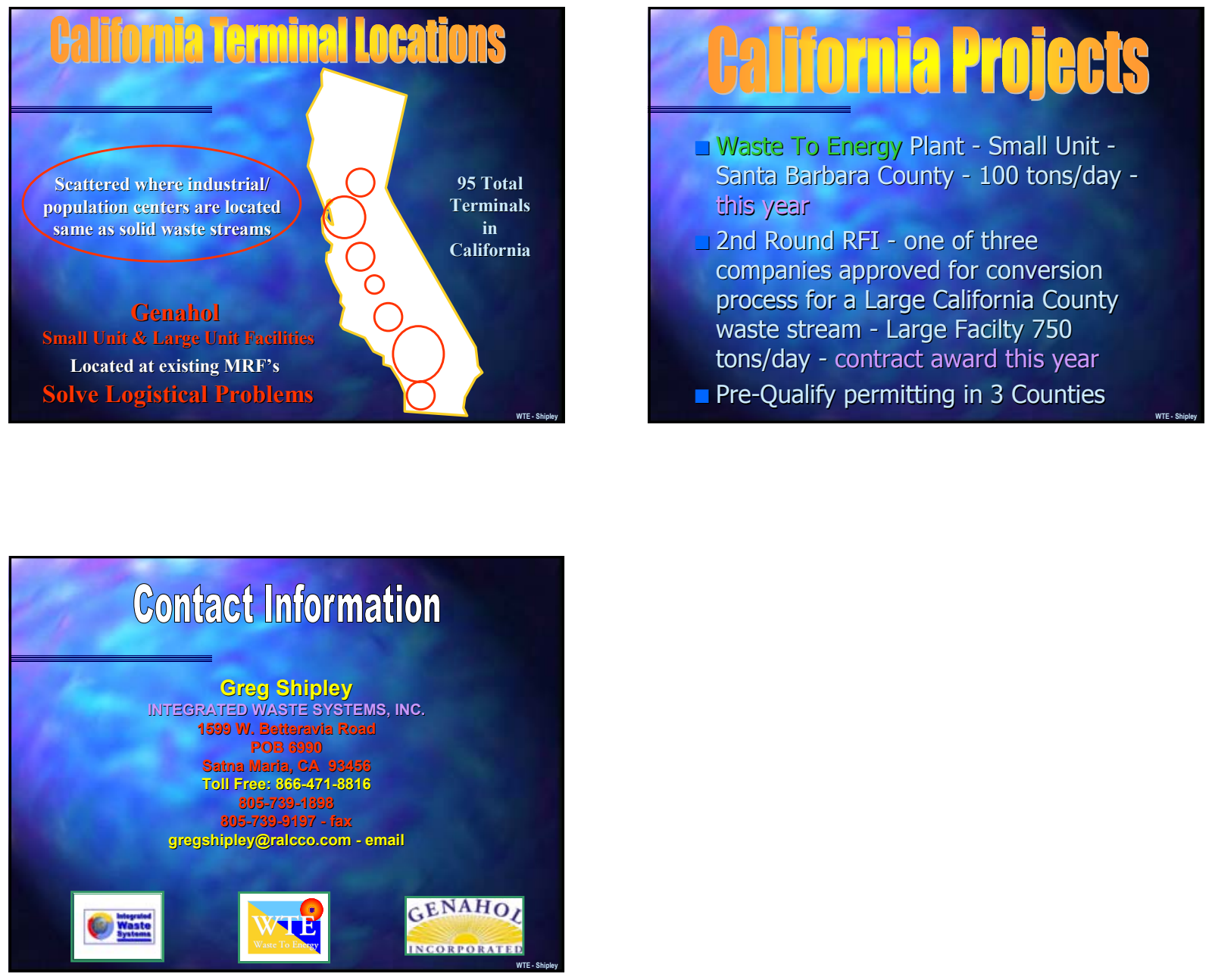


\begin{tabular}{|c|} 
HFTA \\
A Technology Development and Licensing Firm \\
offering \\
Dilute Nitric Acid Biomass \\
Hydrolysis \\
Lee M. MacLean \\
President \\
\\
\\
2424 Covey Way \\
Livermore CA, 94550 \\
\\
Phone: $925-292-5260$ \\
Fax: $925-292-5262$ \\
e-mail: Immaclean@attbi.com
\end{tabular}

HFTA - Dilute Nitric Acid Hydrolysis

Patented Process for the recovery of Sugar from Lignocellulosic material utilizing Dilute $(<0.2 \mathrm{wt}$.\%) Nitric Acid

- Recovers $-85-90 \%$ of Sugars in Hemicellulose (First Stage) $-40-50 \%$ of Sugars in Cellulose (Second Stage)
$-55-60$ gallons ethanol/BDT (mixed softwood feedstock)

- High Throughput-Residence times of 5-10 minutes in each

- High Throughput - Residence times of
reactor stage

- Benign Acid Neutralization -Ammonia, produces ammonium nitrate (highly

- Clean Lignin By-product soluble nutrient for fermentation

- Standard Materials of Construction-Stainless steels are satisfactory

- Process suitable either as a single-stage pretreatment for enzymatic hydrolysis or for two-stage total hydrolysis 

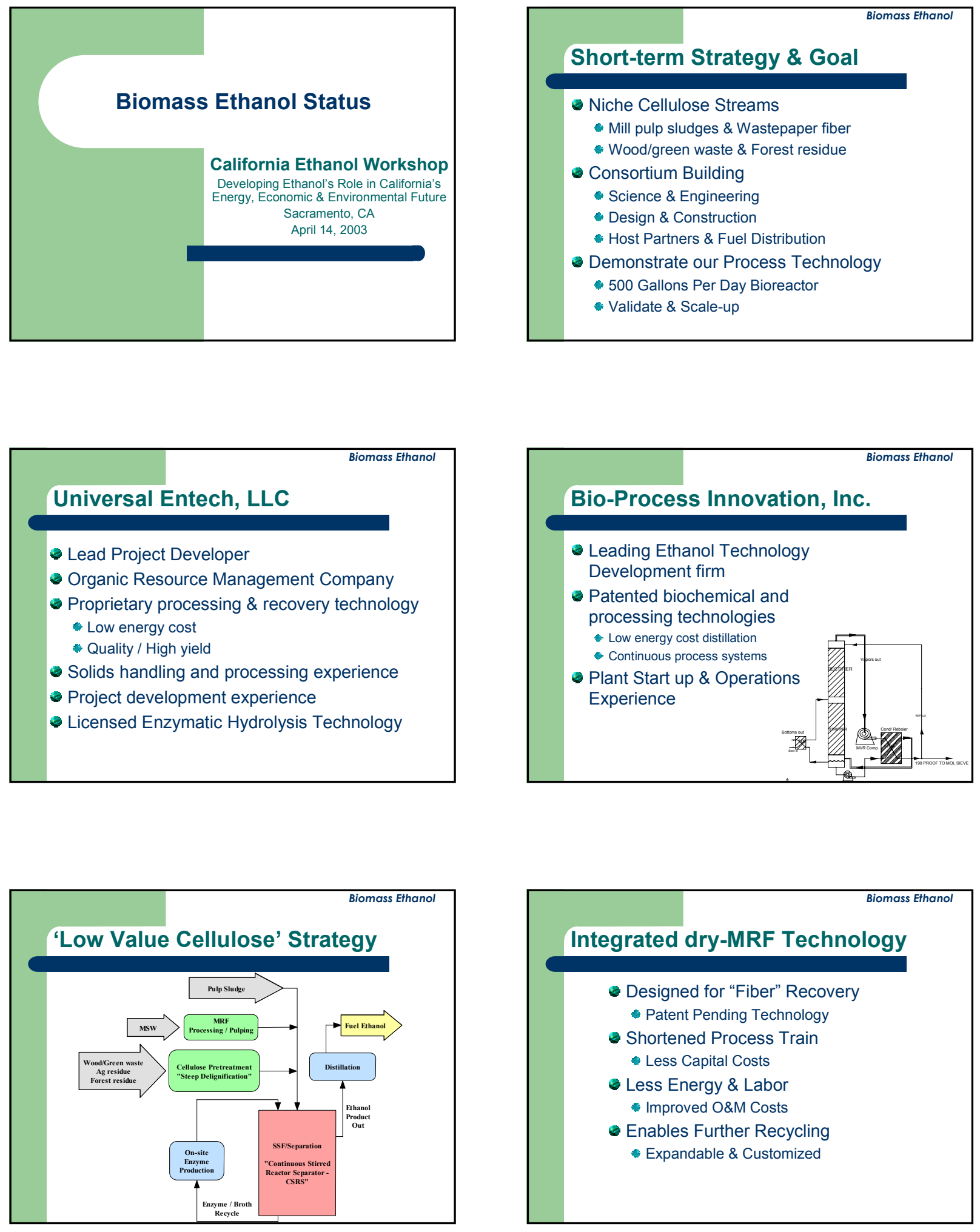

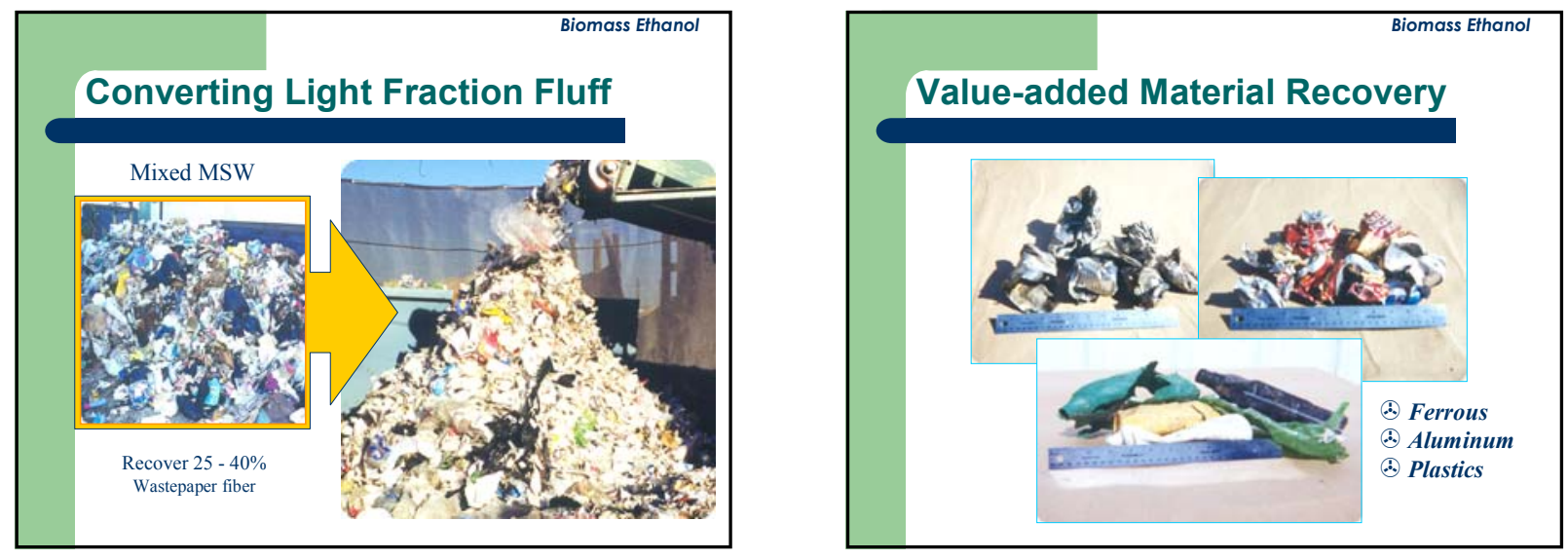

\begin{tabular}{|c|c|}
\hline \multicolumn{2}{|l|}{ Pre-commercial Timeline } \\
\hline $\begin{array}{l}\text { Design \& engineering of R\&D } \\
\text { Pilot Plant }\end{array}$ & May 2003 \\
\hline - Host site selection process & Sept 2003 \\
\hline - Permitting \& construction of Pilot & $1^{\text {st }} Q \operatorname{tr} 2004$ \\
\hline - Operation \& validation & $2004-2005$ \\
\hline $\begin{array}{l}\text { - Pre-commercial demonstration } \\
(1-2 \text { mmgpy level })\end{array}$ & $2005-2006$ \\
\hline
\end{tabular}
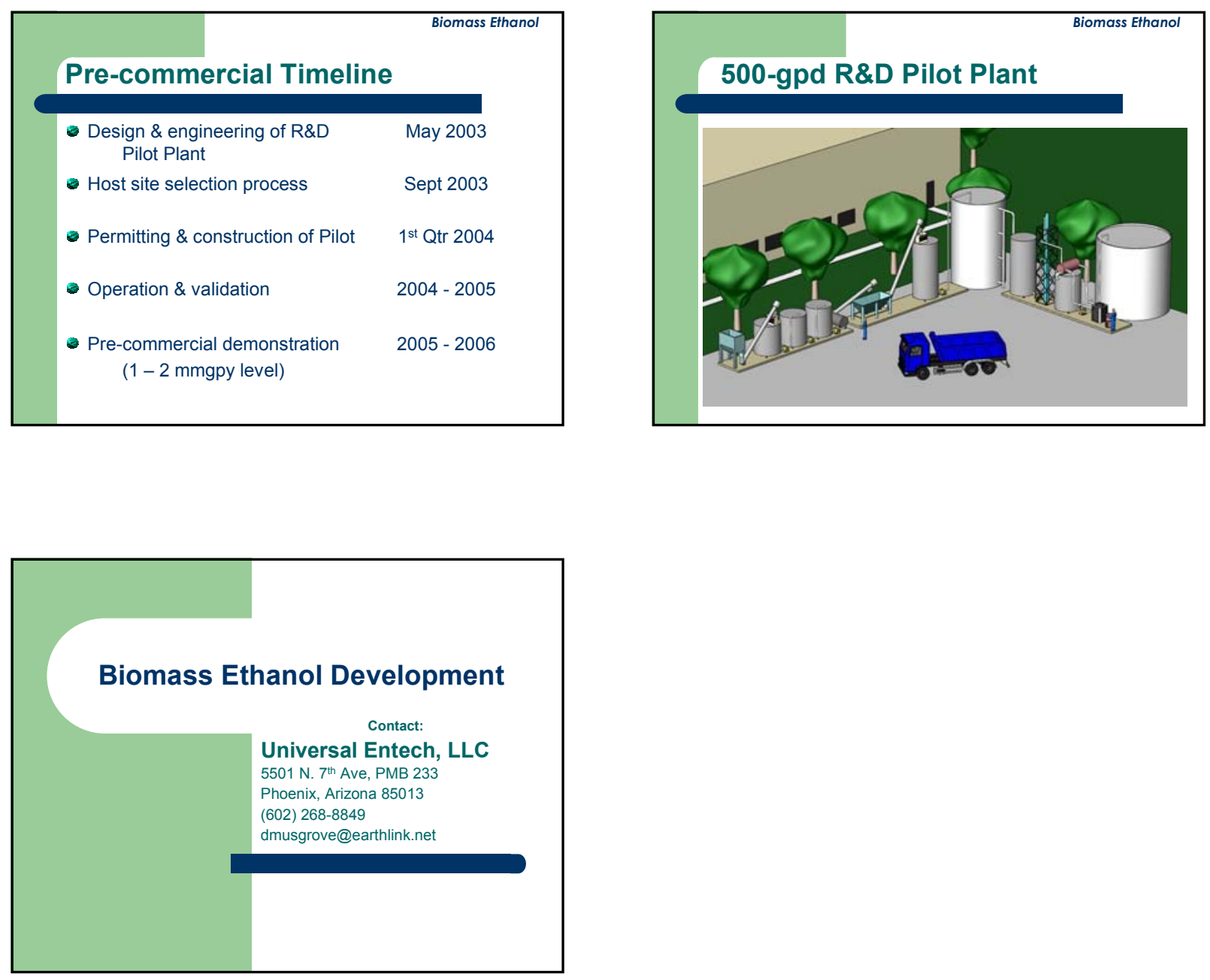


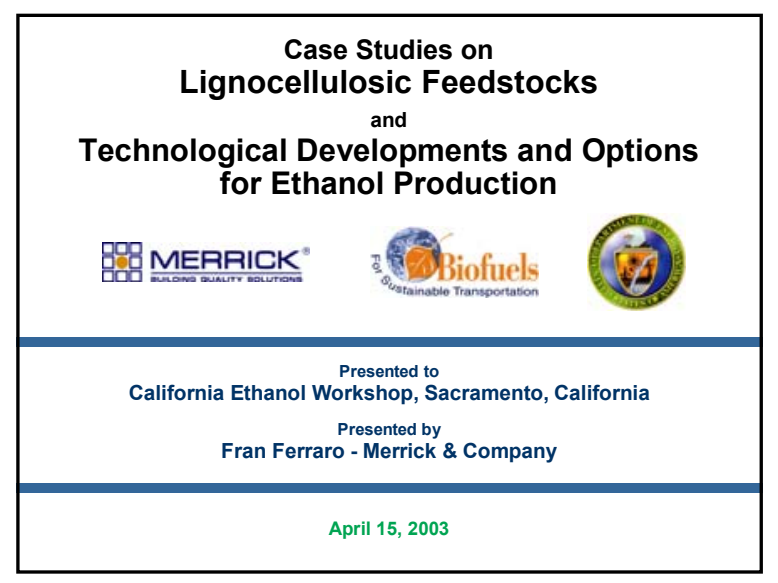

\section{Example Lignocellulosic Feedstocks for Conversion to Ethanol}

- Barky Wood Residues

- MSW - Paper Rich Trash and Green Waste

- Corn Stover

\section{Project Evaluations}

- Feed Material

- Project Location

- Project Markets

- Process Technologies

- Economic Feasibility

\section{Feed Materials \\ - Cellulose Content \\ - Moisture Level \\ - Contaminants}

\section{Project Location}

- State and Local Incentives

- Locations of Feed Sources

- Locations of Product Markets

\section{Project Markets}

- Ethanol or Mixed Alcohols

- Electricity

- Other 


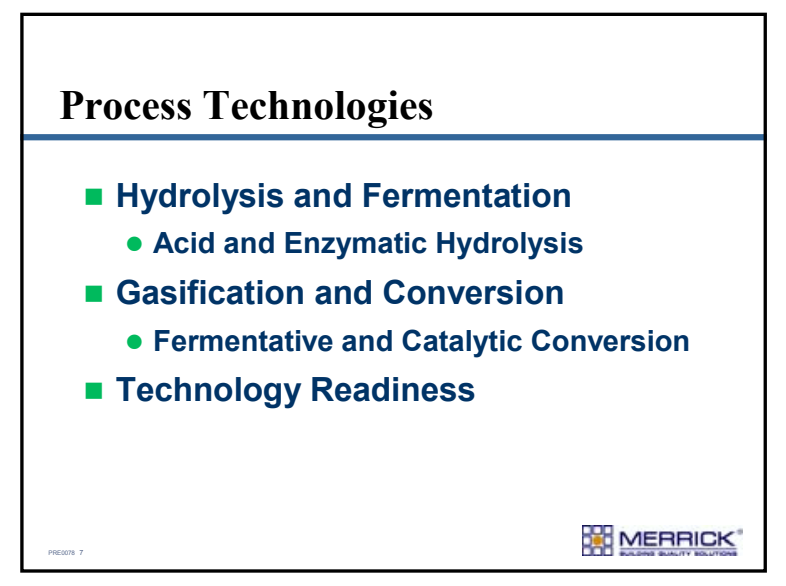

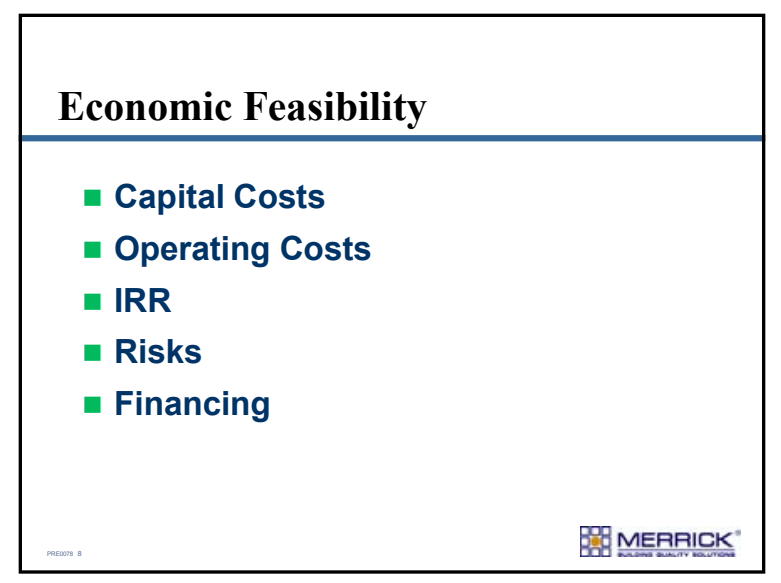

\begin{tabular}{|l|}
\hline Economic Feasibility \\
\hline A biomass-to-ethanol plant can be \\
economically attractive \\
- Low cost Feedstock \\
- Suitable project location \\
- Appropriate project markets \\
- Available process technology \\
\end{tabular}

\section{Contact Info}

Francis (Fran) Ferraro

Senior Technical Specialist

Merrick \& Company

2450 South Peoria Street

Aurora, CO 80014-5472

Phone: (303) 751-0741

Fax: (303) 368-1299

E-mail: fran.ferraro@merrick.com

www.merrick.com 


\section{Steps to Commercialization}

\section{Haird Realities (George Simons)}

ऽ $\$ 5$ billion State deficit

Huge benefits associated with ethanol

DTIBE phase out created demand for ethanol-high stakes, benefits need to

2 Hear all the time about breakthroughs, but not ensured, situation won't
tolerate failures

tolerate fallures

MTBE-great opportunity for ethanol
CTlic

Cellulosic ethanol cheaper than sugar/starch

to create market for ethanol

Ethanol production will be economically driven
Available resources do not support $3-4$ billion gallons

Midwest relatively cheap source of ethanol
Cellulosic ethanol $\$ 1$ gallon more expensive

No commercially available technologies for cellulosic ethanol

Don't expect single step breakthroughs
- Don't take things from the bench scale directly to commercial processes

- Cellulosic based processes will take longer than anticipated, development

- Need deliberate pathways to ensure success in California

\section{The Future is Uncertain}

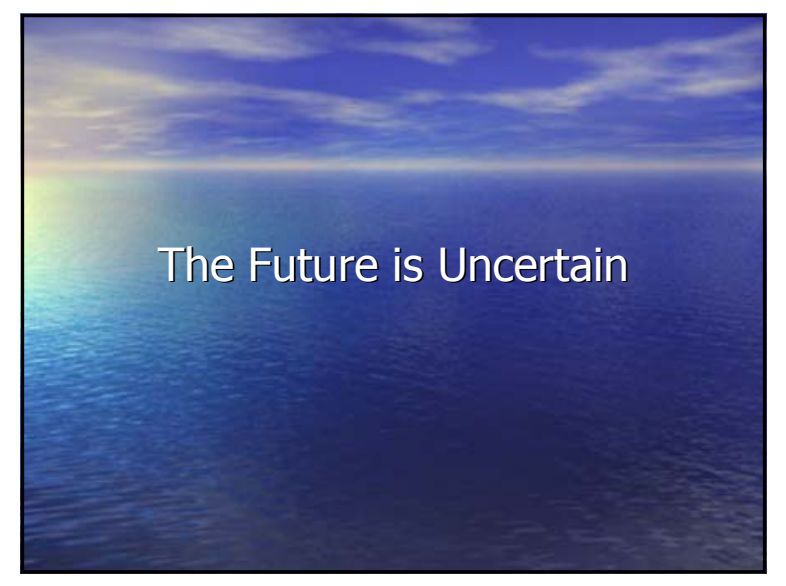

Technology Options (Jim McMillan)

, NREL trying to develop high quality data for scale-up

- Need to look at biomass resource itself

- Consentrated acid processes are working (Arkenol,

Masada, Russian facilities)

, Good progress being made in reducing costs of enzymes

, Thermo-biochemical least studied system, gasification

costs and gas quality may be limiting

challenges:

- Processing solids

- Understanding chemistry

- Chicken-egg on co-products (need materials for research)

\section{History (Loyd Forrest)}

To date none of proposed projects has been commercialized What are deal killing issues?

Siting of facility (logistics)

Technology (economically efficient?)

Market (long term purchase agreement as basis for financing) - Development team ( $95 \%$ of expertise needed for business deal) , Need to provide ethanol from biomass at price less than corn ethanc

What is longevity?

- Does technology work in practice?

Complex job to build industrial plant with off-the-shelf technology

- Complex job to build industrial plant with new technology

- Greater risk demands greater margin

- Don't assume you can sell product at current market price

- Close to commercialization (biodiesel, cellulosic ethanol, biomass to
hydrogen)

- Only technology in our short time frame (3 years) is gasification

- Biogas not Syngas (sorry Loyd--biogas is still digester gas)

\section{Forestry Supply (Doug Wickizer)}

Reduce costs and losses from damaging fires Need for fuels reduction

Options

- Composting

- Energy production

Difficulties implementing fuels reduction (air quality, structural

Large public benefits in finding uses for this material Barriers:

Technological

Driving Green-fleet markets for fuel

- Dispersed Generation-smaller facilities (Washington Ridge)

- Bioenergy or Ashes?

- Don't forget co-benefits that add benefits for public 

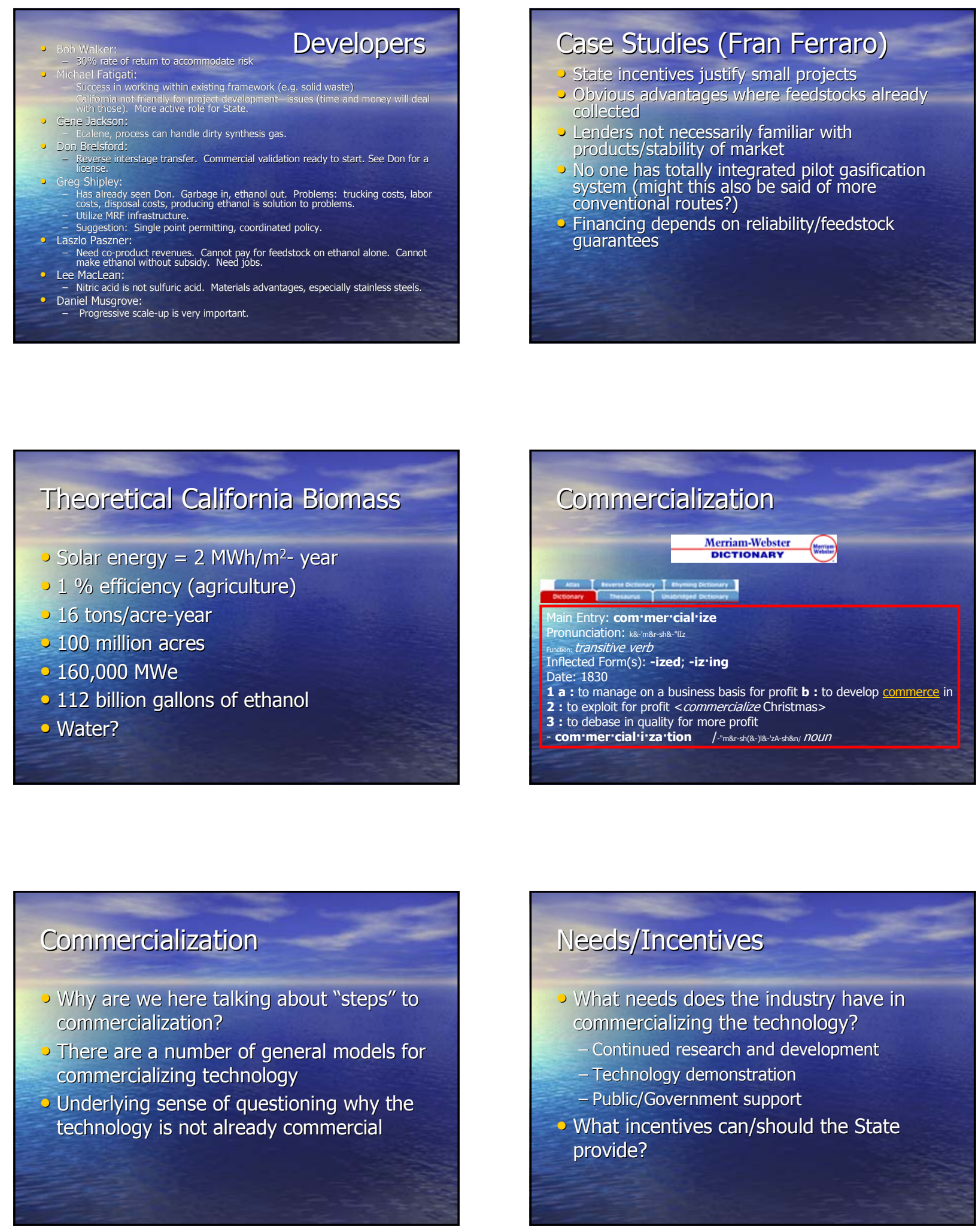

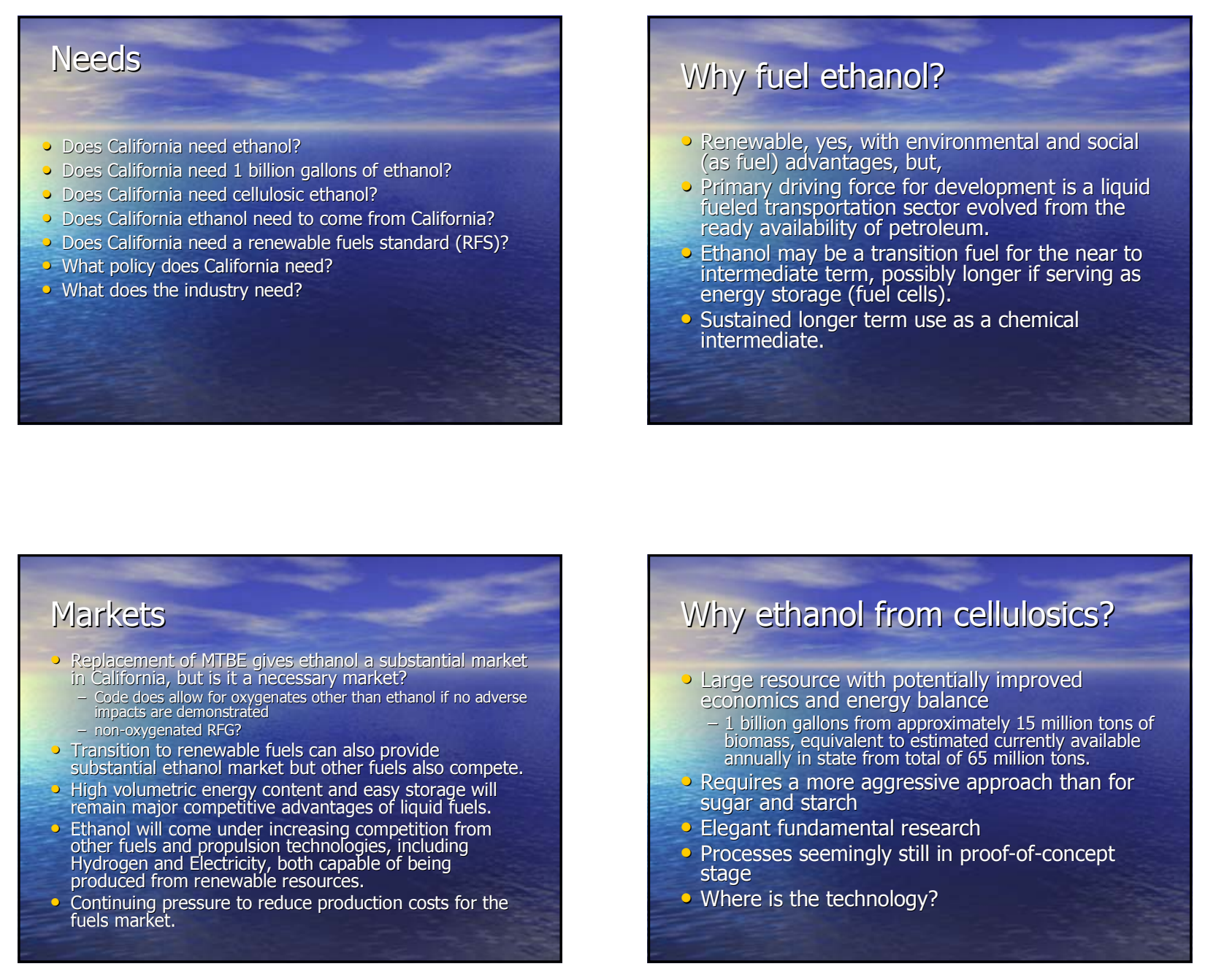

\section{Where is the technology?}

"The conversion of cellulose to ethanol is not, ait this point, rocket science."

David Morris, Institute for Local Self-Reliance

"...the world's most commercially advanced enzymatic process for making ethanol from biomass (bioethanol).

Iogen Corporation Corporate Info
http://www.iogen.ca/2100

"Both units of the facility, the material recycling facility and the ethanol production plant, employ "proven" technologies with existing commercial operations. In fact, about 400 Material Recycling Facilities (MRF's) are currently operating in the United States, and more than 1.5 billion gallons of ethanol was produced in 1996."

\section{Energy Grails?}

Tarr-firee gasifier

Low-cost PV

- Effective hydrogen storage (is ethanol it?)

, Safe disposal/transformation of nuclear waste

Fusion

, Sustainable carbon sequestration

- Paperless office

- US adoption of SI units and an end to the MMBtu

- Exergy (2nd Law) based energy policies

- Cellulosic ethanol? 


\section{What incentives from the State?}

What responsibility does the State have for developing and demonstrating technology?

, Should the State encourage/dictate fuel/energy types and strategies or simply set the standards for protecting human health and welfare and the environment, leaving the industry to develop within that context?

\section{Needs Driven Approach}

Identify needs and seek solutions

- Weighted on potential industry capability to address perceived needs of State while sinultaneously satisfying shorter term needs of industry for development funding.

- May become resource, process, or technology

driven rather than result focused

- e.g., Renewable Portfolio Standard Renewable Fuels Standard AB 939/AB 2770 definitions affecting conversion options Commodity specific credits/taxes

\section{Incentives Driven Approach}

Provide incentives consistent with social value to (needs

Economic incentives for actual benefits generated.

State has no particular role in technology.

- Industry proves technology for the purposes of obtaining financing and access to markets.

Economic incentives intended for a sufficient period to justify commercial investment.

$\checkmark$ Appropriate incentive mechanisms based on results e.g., production/producer credits based on perceived

- Economic subsidies should inherently decrease as industry need declines

e.g. production/producer credits paid from carbon taxes if environmental issues predominate.

\section{Remajining Steps to Achieving}

Commercial Biomass-to-Ethanol

\section{Process Technology}

Deliver on the promise

Demonstrate the technology

- Technica

- Economic

- Financial

- Social

- Environmental

\section{Steps to Commercialization}

- What is State policy?

What are industry needs?

- Determine role, if any, of government in supporting development

- Support fundamental research.

Motivate through regulation/incentives aimed at public/industry

goals.

Can provide markets as appropriate to meet State goals (e.g.
fleet fueling provisions).

Education and Training th

personnel demands. - For public support and financing, credible and
independently verifiable information is critical. demonstration to confirm technology and develop credible cost estimates for scale-up.

\section{Remaining Steps to Achieving}

Commercial Biomass-to-Ethanol Process Technology

Clear policies and well-informed legislation

Well-defined needs

Public education

Collaborative infrastructure development planning

Continued government and industry support of basic research

- Successful industry demonstration of integrated

technology backed up by commercial financing

- Equitable production incentives to meet public objectives 

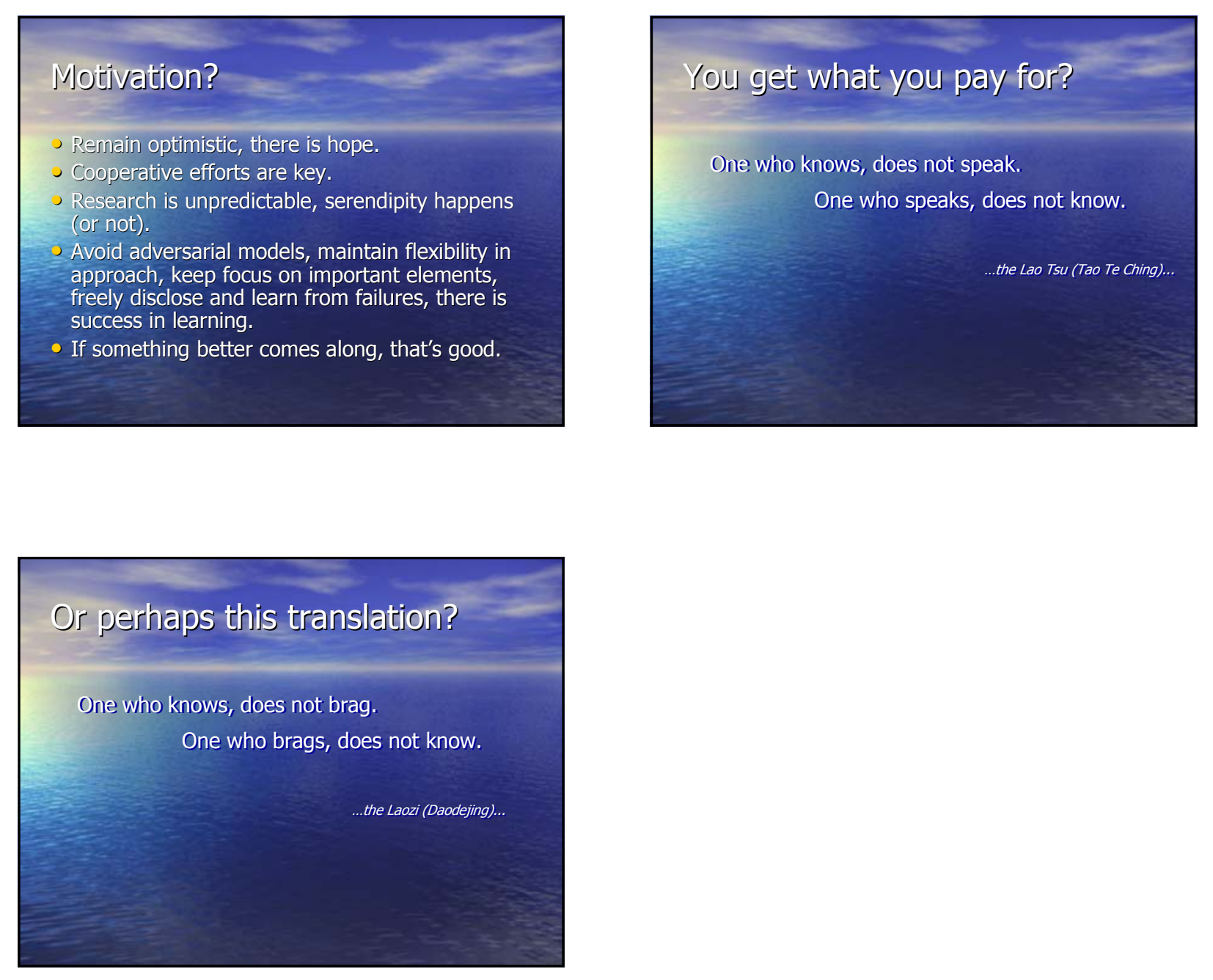


\section{REPORT DOCUMENTATION PAGE}

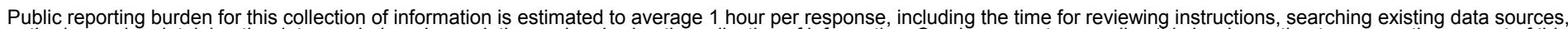

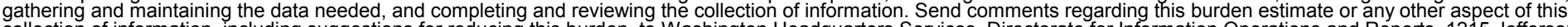

In Headquarters Services, Directorate for Information Operations and Reports, 1215 Jefferson

Davis Highway, Suite 1204, Arlington, VA 22202-4302, and to the Office of Management and Budget, Paperwork Reduction Project (0704-0188), Washington, DC 20503.
1. AGENCY USE ONLY (Leave blank)
2. REPORT DATE January 2004
3. REPORT TYPE AND DATES COVERED Subcontractor Report

4. TITLE AND SUBTITLE State-Level Workshops on Ethanol for Transportation: Final Report

5. FUNDING NUMBERS ACO-2-32052-01

6. AUTHOR(S) Angela Graf

7. PERFORMING ORGANIZATION NAME(S) AND ADDRESS(ES)

$\mathrm{BBI}$ International

8. PERFORMING ORGANIZATION

PO Box 159

Cotopaxi, Colorado 81223

9. SPONSORING/MONITORING AGENCY NAME(S) AND ADDRESS(ES) National Renewable Energy Laboratory 1617 Cole Blvd. Golden, CO 80401-3393 BB04.7120

11. SUPPLEMENTARY NOTES

NREL Technical Monitor: H. Brown

12a. DISTRIBUTION/AVAILABILITY STATEMENT National Technical Information Service

U.S. Department of Commerce

5285 Port Royal Road

Springfield, VA 22161

13. ABSTRACT (Maximum 200 words)

Final report on subcontract for holding four state-level workshops (Hawaii, Kentucky, Nevada, California) to facilitate development of ethanol production facilities in those states.

14. SUBJECT TERMS

15. NUMBER OF PAGES

biofuels; ethanol; states; workshops

16. PRICE CODE

17. SECURITY CLASSIFICATION OF REPORT Unclassified
18. SECURITY CLASSIFICATION OF THIS PAGE Unclassified
19. SECURITY CLASSIFICATION OF ABSTRACT Unclassified
20. LIMITATION OF ABSTRACT

UL 